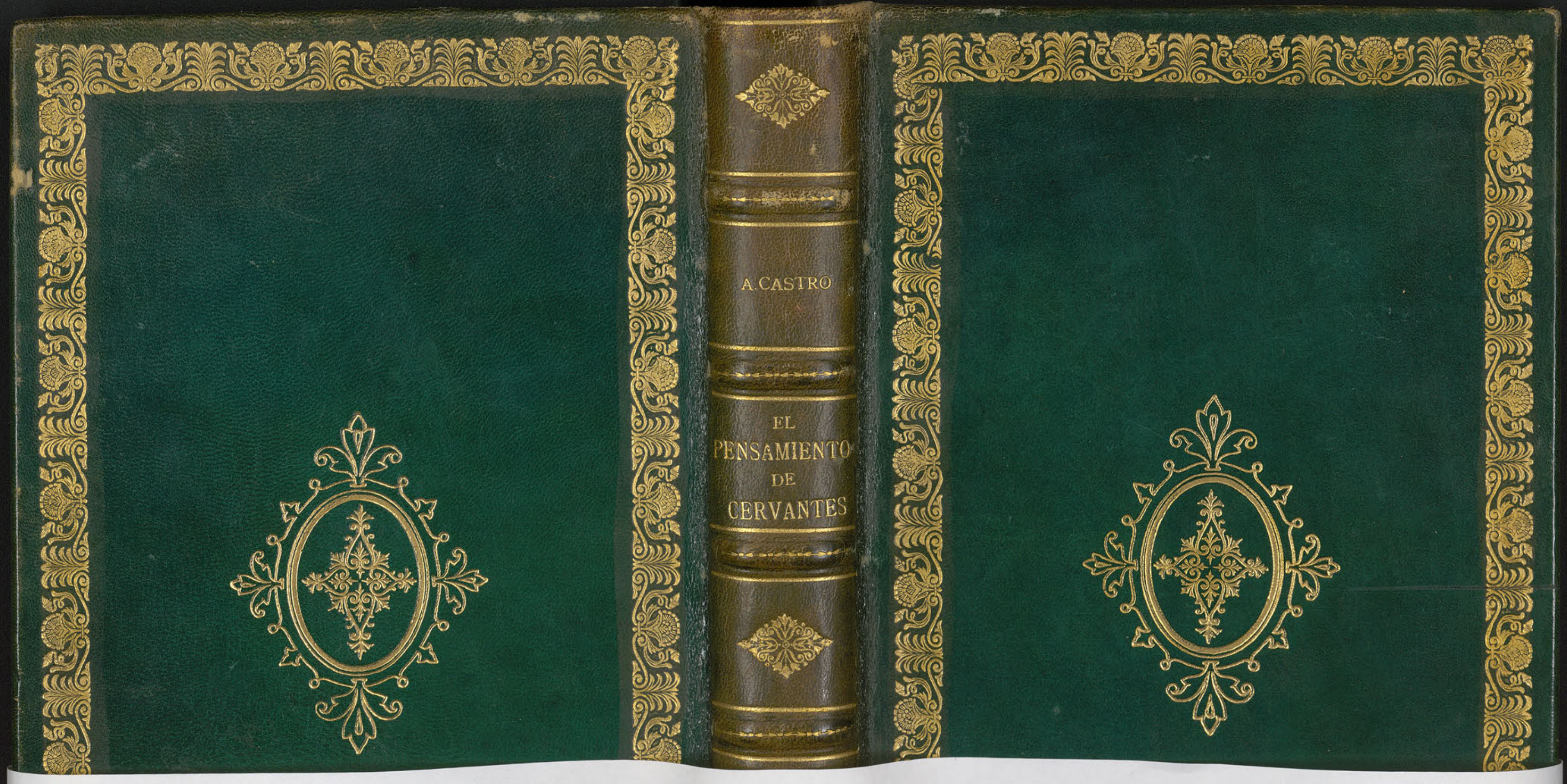


FL DRTS FAlOUEO 0500763382
Para ßus, ir contial ente. 

ANEJOS

DE LA «REVISTA DE FILOLOGÍA ESPAÑOLA»

VOLÚMENES PUBLICADOS:

ORÍGENES DE LA LENGUA ESPAÑOLA, POR R. MENÉNDEZ PIDAL. - Esta obra, que aparecerá en breve, tendrá unas 400 páginas. Lleva varios mapas e ilustraciones que esclarecen la geografía linguústica primitiva de la Península Ibérica.

$$
\text { II }
$$

CONTRIBUCIÓN AL DICCIONARIO HISPÁNICO ETIMOLÓGICO, POR v. García DE DIEGo. - Un vol. en $4 .^{\circ}$ de 209 págs., ro ptas.

III

INFLEXIÓN DE LAS VOCALES EN ESPAÑOL, POR IAX KREPINSKY, - TRADUCCIÓN Y NOTAS DE V. GARCía DE DIEGO, Un vol. en $4 .^{\circ}$ de 15 I págs., 13 ptas.

IV

EL DIALECTO DE SAN CIPRIÁN DE SANABRIA, POR FRITZ KRÜGER. - Un vol. en $4 .^{\circ}$ de 132 págs., I 2 ptas.

$\mathrm{V}$

OBSERVACIONES SOBRE LAS FUENTES LITERARIAS DE "LA CELESTINA", POR F. CASTRO GUISASOLA. - Un vol. en $4^{\circ}$ de 194 págs., Io ptas.

VI

EL PENSAMIENTO DE CERVANTES, POR AMÉRTCO CASTRO.

$$
\text { EN PRENSA: }
$$

LOS TEXTOS ESPAÑOLES Y GALLEGO-PORTUGUESES DE LA DEMANDA DEL SANTO GRIAL, POR P. BOHIGAS.
jUNTA PARA AMPLIACión DE estudios. - CENTKO DE ESTUdios históRICOS REVISTA DE FILOLOGÍA ESPAÑOLA. - ANEIO VI

\section{EL PENSAMIENTO DE CERVANTES}

POR

\author{
AMÉRICO CASTRO
}

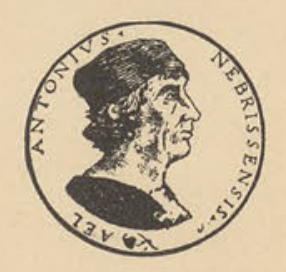

MADRID

IMPRENTA DE LA IIBRERÍA Y CASA EDITORIAL HERNANDO (s. A.) Calle de Quintana, núm. 33.

1925 


\section{RAMÓN MENÉNDEZ PIDAL}

en su XXV año de profesorado universitario. 


\section{INTRODUCCIÓN}

\section{CORRECCIONES}

\begin{tabular}{|c|c|c|c|}
\hline 'ág. & Lín. & Dice. & Léase. \\
\hline 80 & 4 & en el valor & acerca del valor \\
\hline 123 & 4 & Narciso & Nicolás \\
\hline 139 & 6 & mucho más esencial que & tan esencial como \\
\hline 164 & 18 & neoplatonismo & $\left\{\begin{array}{c}\text { neoplatonismo y el estoi- } \\
\text { cismo }\end{array}\right.$ \\
\hline 188 & 10 & en León & $\left\{\begin{array}{c}\text { en Valencia de Don Juan, } \\
\text { junto a León. }\end{array}\right.$ \\
\hline 189 & 37 & estragadaos & estragados \\
\hline & 7 & Asistimos, & Asistimos \\
\hline & 20 & y el «miles gloriosus» & $\left\{\begin{array}{c}\text { y la jactancia del } \\
\text { gloriosus }\end{array}\right.$ \\
\hline & 14 & este & tal \\
\hline
\end{tabular}

Deben tenerse en cuenta las adiciones de las páginas 389-395.

a todo ensayo de situar a Cervantes en una zona de clara concienci intelectual. He hablado en

ñola y anglosajona acerca de Cervantes, tal coso puede hacerse

ol

conferencia, sin plenitud de datos ni de aspectos. Pues bien, un crítico español que me oyó en Filadelfia ha escrito, con rara celeridad, nada menos que un libro para rebatir mi tesis de la modernidad del pensamiento de Cervantes; según ese autor, en el Quijote no hay más filosofía que la de sla fe en el ideal... sobre las ruindades de la vidas. Esperemos que ahora se comprenderá menos mal lo que digo, y que se me harán objeciones menos vehementes y más aprovechables. 
Me parece que podría resumirse así la opinión del término medio de los críticos e historiadores: el valor artístico y, en general, la grandeza íntima de las obras de Cervantes están ya conocidos merced a la labor de varias generaciones de estudiosos; lo unico que cabría sería aclarar algunos puntos concretos mal determinados, en el lenguaje y en el estilo sobre todo, y ampliar lo sabido respecto de las obras menores, puesto que respecto del Quijote todo lo esencial está ya visto.

Un hecho curioso es que siendo esto así, no surja en España ningún libro de conjunto sobre Cervantes ${ }^{1}$. Los que existen son extranjeros. Hay un estimable libro francés de Emile Chasles (I866), y otros dos modernos de carácter claro y elemental, los de Savj-Lopes (I9I4) y Schevill (I9I9). Tampoco ha sido renovada fundamentalmente la vida de Cervantes que escribio Navarrete (I8I9); entre tanto satisface la curiosidad del público la biografía del benemérito Fitzmaurice-Kelly.

Otro hecho que siempre sorprende es que Menéndez Pelayo no se ocupara de Cervantes sino ocasionalmente: en un discurso de centenario (1905), en la Historia de las ideas estéticas, con motivo del Quijote de Avellaneda, en contestaciones académicas, un poco en los Origenes de la Novela, y nada más. Muchas de sus apreciaciones han sido inspiradas por lo que la crítica nacional y extranjera dijo a lo largo del siglo xix, opiniones que en cómodo despliegue figuran en el tomo III de la Bibliografía de Ríus ${ }^{2}$, si bien es innegable que en esos trabajos de ocasión hay observaciones bellas y exactas.

Además de estos trabajos de Menéndez Pelayo quedan pocas investigaciones mencionables, en los últimos treinta años, desde el punto de vista de la técnica literaria, es decir, que hayan influído en el concepto del Quijote. Sólo recuerdo a Morel-Fatio, L'Espagne de Don Quichotte (1895) ${ }^{3}$;

El de Márnez, Cervantes y su tiempo, 190I, es obra de aficionado que no responde a las exigencias modernas.

a

3 Hay tel Sr. Juliá en Semana Cervantina, Castellón, 1920.
J. Ortega Gasset, Meditaciones del Quijote (I9I4); un capítulo de Toffanin en La fine del Umanesimo (I920), y R. Menéndez Pidal, Un aspecto en la elaboración del Quijote (I920, y edición aumentada en I924). Desde el punto de vista de la mejor inteligencia del texto, es muy valioso el comentario de F. Rodríguez Marín (I9I6) ${ }^{1}$, aunque en modo alguno evita tener presente las magníficas notas de Clemencín.

Esta verdadera penuria de trabajo científico en torno a Cervantes, aunque ello sea paradójico, procede del ambiente fetichista que se ha ido formando alrededor de aquél; y al mismo tiempo, del temor a incurrir en el pecado de esoterismo. Hay una guardia celosa que vigila para que nadie ose traspasar el límite del canon crítico permitido, so pena de ser motejado de esoterista. El principio del ne varietur es hoy el más difundido entre quienes se ocupan de estos asuntos.

A principios del siglo pasado se juzgaba el Quijote según normas neoclásicas, según puede verse en las notas de Clemencín: la imitación, la fábula y sus reglas, la verosimilitud, etc. Tal punto de vista pareció insuficiente a la crítica romántica en el extranjero, que vislumbró en la gran novela hondo valor humano y sentido profundo, que se imponía a los tiempos y a las diferencias de gentes. Surgen entonces en España lucubraciones como las de D. Nicolás Díaz de Benjumea $^{2} \mathrm{y}$ las de quienes con menor ingenio han hallado en el Quijote claves y magias de toda clase. Si el desarrollo de nuestra crítica literaria hubiese sido normal, todo eso se habría desvanecido al averiguarse que, en efecto, Cervantes formulaba graves problemas, artística y filosóficamente, sólo que de índole comprensible y perfectamente explicables dentro de la historia de España. Alguna vez apuntó esa razonable

1 La prueba de que mi elección bibliográfica no está arbitrariamente reducida, es que Rodríguez Marín, al querer citar estudios funmente redida, es que Rodiguez Marn, al querer citar estudios fundamentales sobre el Quijote, en su edición de 1916 (VI, 448), no halla a mano sino el discurso de Menéndez Pelayo y un estudio de A. SALCEDo Ruiz, Estado social que refleja el Quijote, a todas luces inferior al de Morel-Fatio.

2 Véase Ríus, III, 66 y sigs. 
pretensión: «Si bien en Cervantes no aparece la filosofía como indagación ordenada y sistemática, lucen en sus obras rasgos que deben ser recogidos para conocer el sentido filosófico de su edad» ${ }^{1}$. Para hacer ese estudio habría hecho falta conocer los escritores españoles del siglo xvi, desde el punto de vista del pensamiento, de su relación con escritores extranjeros; en suma, seguir la huella de los trabajos que en todas partes comenzaban a hacerse sobre Goethe, Shakespeare, etc. No se estudió tal aspecto, y la crítica siguió alimentándose de las ideas que buenamente desprendía el ocio o de los ecos que llegaban de tal página que a algún hombre de genio inspiró el goce estético de la internacional novela (Heine, Turguenef, etc.) ${ }^{2}$. El detritus de la crítica romántica (mal conocida) lo hallamos en quienes se afanan hoy por presentarnos un Quijote anticlerical, evangélico o anagramático. Esos ardientes cervantistas, sin duda, habrían procedido con más malicia de existir obras estructuradas, cuya mera existencia hubiera hecho imposible tales ingenuidades, que no son sino travesuras de chico sin maestro, y que no merecían haber ocupado tanto la atención de los doctos.

Lo realmente importante es que la crítica esotérica con su puerilidad ha influído por reacción en el tono de las apreciaciones sobre Cervantes, no suscitando análisis estrictamente objetivos en que se investigue, por ejemplo, el sentido religioso de Cervantes en relación con el de otros europeos de la época, sino determinando la formación de un verdadero cuadro protector, cuya misión es mantener el statu quo cervantino y alejar toda sospecha de misterio e incluso de insospechada profundidad. La tendencia de la crítica ha sido, en efecto, suprimir la busca de problemas en Cervantes; su con-

1 F. de Paula Canalejas, Estudio de la historia de la filosofía española, 1 869 (Ríus, III, 103).

Realmente no ha tenido bastante reflejo en España la crítica cervantina de Tieck y otros románticos, por no haber sido traducidos al francés o español los correspondientes textos alemanes, que hoy pueden verse en el utilísimo libro de J.-J. A. Bertrand, y antes, incompletamente, en Ríus, III, 1904. signa parece ser: "Aquí no pasa nada.» El móvil era, sin duda, plausible; pero la reacción ha sido tan enérgica, que ha invalidado no sólo las fantasías de los esoteristas, sino que ha apocado el ánimo de quienes modestamente habrían ido a espigar por el haza, de no oír una y otra vez que en ella nada podía recolectarse.

"Tomémosle como fué - dice Fitzmaurece-Kelly - ${ }^{1}$ : como un artista mejor en la práctica que en la teoría, grande por sus facultades naturales más bien que por las adquiridas... Tiene a menudo la hermosa sencillez y la fresca lozanía de la Naturaleza. Este es su carácter: la naturalidad..., de ahí el carácter humano y universal de su obra.» Rodríguez Marín ${ }^{2}$ alude con ironía a quienes «se dedican a destilar por la fina alquitara filosófica la quinta esencia de la significación del Quijote, invectiva contra los libros de caballerías - el mismo Cervantes lo dice - , de quien nunca se acordó Aristóteles, ni dijo nada San Basilio, ni alcanzó Cicerón». Ya se ve cómo la consigna es negar que en el Quijote haya posibilidad de estudio íntimo de ninguna suerte. Para el sabio comentarista - lo es, sin duda - el Quijote es esencialmente un antídoto contra la melancolía (I, xxvir).

El antecedente inmediato de tal actitud lo hallamos en Menéndez Pelayo: «Por lo mismo que algunos se obstinan en considerar el Quijote, no como la novela más digna de admiración entre cuantas ha producido el ingenio humano, sino como una especie de evangelio... ${ }^{3}$, conviene darle su tanto de culpa en la rencilla con Lope de Vega.» «En vano se les dice y predica a los inventores de tales novedades que las ideas científicas de Cervantes, si es que tal nombre merecen, casi nunca traspasan los límites del buen sentido, ni se elevan un punto sobre el nivel (ciertamente muy alto) de la cultura española del siglo xvi, como puede probarse por innumera-

1 Historia de la literatura española, 1921, pág. $21 \mathrm{I}$

2 Quijote, RM, I, xxvi. Citaré así su edición extensa del Quijote, seis tomos, 1916, poniendo primero el número de la parte y el capítulo.

3 Ideas estéticas, II, 1884 , pág. 424 
bles libros anteriores a él y de contemporáneos suyos, en los cuales están dichas las mismas cosas con mejor orden y método, con más trabazón científica y de manera más profunda $\mathrm{y}$ radical» 1 .

Si Menéndez Pelayo hubiese intentado ese trabajo de coordinación es probable que hubiera cambiado de parecer, y en lugar de preocuparse de las «ideas científicas» superpuestas al fondo artístico, que en realidad no se sabe lo que son, habría examinado la cuestión más general de cómo se representaba Cervantes el arte y la vida; mas para eso habría sido necesario a su vez desechar el lamentable prejuicio de que Cervantes era un hombre de la calle, apto sólo para percibir, intelectualmente, vulgaridades e insignificancias. Pero dejémosle la palabra : «Cervantes era poeta y sólo poeta, «ingenio lego» como en su tiempo se decía. Sus nociones científicas no podían ser otras que las de la sociedad en que vivía. $\mathrm{Y}$ aun dentro de éstas no podían ser las más peregrinas, las del menor número, sino las del número mayor, las ideas oficiales, digámoslo así, puesto que no había tenido tiempo ni afición para formarse otras» ${ }^{2}$. "Cervantes es grande por ser un gran novelista, o lo que es lo mismo, un gran poeta, un grande artífice de obras de imaginación, y que no necesita más que esto para que su gloria llene el mundo... La intuición que el artista tiene no es la intuición de las verdades científicas, sino la intuición de las formas, que es el mundo intelectual en que él vive» ${ }^{3}$.

Algo parecido había dicho en I895 A. Morel-Fatio: «Basta abrir Don Quijote para encontrar debilidades de razonamiento, ideas mal expresadas y confusas, siempre que el relato se interrumpe y que el autor se remonta arriesgándose a tomar el tono del filósofo o del moralista. Él mismo no se ha engañado con ello $\mathrm{y}$ ha definido perfectamente lo propio

1 Ideas estéticas, $1896, \mathrm{III}, 389$.

2 Ibid., pág. 391. Lo mismo vuelve a leerse en Cultura literaria de Cervantes, 1905, pág. 31 .

3 Ibid., págs. 89 y 90. de su talento, y no se ha vanagloriado ingenuamente más que de una sola superioridad incontestable: del poder creador, del don de la invención: "Yo soy aquél que en la invención excede A muchos...» (Viaje del Parnaso, IV). No vayamos, pues, a convertir a Cervantes en un genio universal, en ser excepcional casi sobrehumano... En lugar de desnaturalizarlo, esforcémonos en comprenderlo, amémosle por lo que ha sido: un habilísimo novelista y un honnête homme $>1$.

El positivismo del siglo xIx se cebaba en Cervantes. A fuerza de querer dar claridad física a las obras de cultura, se las convertía en realidades ingenuas y desustanciadas.

Menéndez Pelayo descansaba tranquilo sobre el alegre y rápido razonamiento de $\mathrm{D}$. Juan Valera: «Las indicaciones de D. Juan Valera, que es a mi juicio el español que mejor ha hablado del Quijote, aunque en pocas páginas, son lo que más se acerca a este ideal de crítica que yo concibo" ${ }^{2}$ (véase Ríus, III, IOO a IO2) ${ }^{3}$. Mas decía con harta discreción don Luis Vidart en I878: "Parécenos que el Sr. Valera exageró un poco la defensa de la tesis que sostenía, al afirmar que las máximas del autor del Quijote sobre la política, moral y poesía nunca traspasaron los límites del vulgar aunque recto juicio» (Ríus, III, 398).

Citemos además la opinión de Ángel Ganivet (I865-I898): «No existe en el arte español nada que sobrepuje al Quijote. Cuando Cervantes empieza a idear su obra tiene dentro de sí un genio portentoso; pero fuera de él no hay más que figuras que se mueven como divinas intuiciones; después coge esas

1 A. Morel-Fatio, Etudes sur l'Espagne, 1895, I. Traducción de E. Juliá, Semana Cervantina, Castellón, 1920, págs. 117 y sigs.

2 Critica literaria, cuarta serie, pág. 126.

3 Compárese: «El otro género de comentario, el filosófico, es e que resueltamente no puedo aprobar, si por él se trata de persuadirnos de que un libro tan claro, en el que nada hay que dificultar, que hasta los niños entienden, encierra una doctrina esotérica. Cerque ha los niños entience vantes no ha descieto ningua verdad. Cervantes era poeta $\mathrm{y}$ ha creado la hermosura... Otras máximas sobre política, moral y poesía..., nunca traspasan los límites del vulgar aunque recto juicio, etc. J. VAlera, en Memorias Academia Española, V, 155 
figuras y las arrea, pudiera decirse, hacia delante, como un arriero arrea sus borricos, animándolos con frases desaliñadas de amor, mezcladas con palos equitativos y oportunos. No busquéis más artificio en el Quijote. Está escrito en prosa y es como esas raras poesías de los místicos en las que igual da comenzar a leer por el fin que por el principio, porque cada verso es una sensación pura y desligada, como una idea platónica» ${ }^{1}$.

Por los textos alegados, y por otros que no se citan por amor de la brevedad, se ve con precisión que, en Valera, Menéndez Pelayo y otros, se funden la enemiga a las interpretaciones arbitrarias de esoteristas y partidarios de la omnisciencia de Cervantes, con la afirmación de que nuestro autor es la cosa más natural del mundo, un gran novelista, y que no hay que calentarse mucho la cabeza para calar su sentido. Es un español más de su época, no de los más cultos, sino de los más vulgares, que no tuvo tiempo de instruirse mucho, y que por milagro del genio tutelar de los grandes vates, produjo una maravillosa obra de fantasía, que no necesitaba para su elaboración sino eso, fantasía. De aquí al tema de la inconsciencia de Cervantes no hay más que un breve salto.

Pero antes veamos más citas de críticos modernos para que se note la amplitud que alcanza hoy la doctrina incubada en el siglo xix. Dice Savj-Lopes: «No se encuentra en él ninguna elevada interpretación del mundo, ningún sólido pensamiento, religioso o moral, sigue la fe de sus mayores, respeta el orden establecido y las verdades reconocidas: el trono y el altar, etc.» ${ }^{2}$. Schevill : «Su mente no era especulativa y su actitud hacia los dogmas políticos y religiosos de la época era tan poco crítica como la de cualquier hombre del pueblo» ${ }^{3}$ Es curioso que incluso alguien que ha estudiado a Cervantes

1 Idearium, 1897, pág. 71.

2 Cervantes, traducc. esp., pág. 38.

3 Cervantes, pág. 168 . En cambio, sin desarrollar bastante su pensamiento, añade: «En la actitud de Cervantes, en su concepción de la vida $\mathrm{y}$ en la interpretación de los pensamientos y acciones humanos, se separa sensiblemente de las direcciones intelectuales de su tiempo, con propósito filosófico, diga vaga y confusamente que «lejos de ser un esprit fort o un revolucionario o un vidente, no va como pensador más allá de su época [¿pues adónde iba a ir?], vive de ella y se limita a reflejarla» ${ }^{1}$

«Leamos las líneas y no las entrelíneas. Las obras de arte no son misterios sólo accesibles a los iniciados. Al contrario, son expresiones de emociones comunes y corrientes. Procuremos ser aún algo más niños de lo que realmente somos», dice Ramiro de Maeztu ${ }^{2}$. Y por su parte nota Azorín : «El mayor daño que se puede hacer al Quijote es seguir laborando sobre ese misticismo cervantista, etc.» ${ }^{3}$.

De este estado de opinión, del que podría allegar más textos, ha ido desprendiéndose paulatinamente la idea de que Cervantes, frente al Quijote, es un testigo de mayor excepción. Ante esa obra capital, apenas si cabe en el lector otro estado que el emocional, ya que de antemano se nos dice que en el orden intelectual nada puede revelarnos que no sepamos mejor por otros conductos. Unamuno cae de lleno en esta deducción: « ¿No hemos de tener nosotros por el milagro mayor de Don Quijote el que hubiese hecho escribir la historia de su vida a un hombre que como Cervantes, mostró en sus demás trabajos la endeblez de su ingenio?» ${ }^{4}$. Y Rodríguez Marín, siguiendo sus huellas, dirá: «Para no ver en Don Quijote las sublimidades que vemos ahora, Cervantes fué uno de tantos hombres de su tiempo. En esto se parecen Cervantes y Colón; ambos murieron sin darse clara y cabal cuenta del valor de sus invenciones. Es tal y tan profunda la creación de Don Quijote que no acertó a calar hasta su fondo su padre

T. Carreras Artau, La filosofía del derecho en el Quijote, 1905. pág. 379.

2 Ap. ICAzA, El Quijote durante tres siglos, 1918, pág. $22 \mathrm{r}$.

3 Ibid., pág. 222.

4Vida de Don Quijote, 1905, pág. 4 18. Este libro, bello y sugeridor como pocos, no pierde su hondo sentido por esta afirmación, de carácter más simbólico que científico. Quienes la han tomado al pie de la letra, en España y en Italia, han incurrido en un seco error. 
mismo» ${ }^{1}$. El tema, por otra parte, tiene antigua resonancia. Ya Heine escribía en el prólogo de la traducción alemana de I837 que «la pluma del genio es siempre más grande que el mismo genio... Sin que de ello se hubiese dado clara cuenta, escribió Cervantes la más grande de las sátiras contra el entusiasmo humano» (Ríus, III, 264). Y glosaba Menéndez $\mathrm{Pe}-$ layo, "precisamente porque el Quijote es obra de genio, y porque toda obra de genio sugiere más de lo que expresamente dice, son posibles esas interpretaciones, etc.» ${ }^{2}$. Últimamente, nuestro eminente crítico se complacía en representarse a Cervantes como una especie de niño grande, más bien como un niño prodigio, que en medio del rasgo de genio se entregaba a bulliciosas expansiones: "Se conoce que Cervantes, con el alma cándida y buena que suelen tener los hombres verdaderamente grandes, sentía cierto infantil regocijo con la lectura de disparates que a un lector vulgar hubieran infundido tedio» 3

Nos hallamos, pues, ante un Cervantes vulgar en cuanto al intelecto o a la cultura, pero inconscientemente genial ${ }^{4}$.

1 IV, 303.

2 Critica literaria, quinta serie, pág. 209. Manuel de la Revilla decía en $1875: \propto E l$ Quijote, que no pensó ni presintió, pero que in conscientemente escribió Cervantes, el Quijote eterno es una altísima y profunda concepción» (Ríus, III, I23).

3 Origenes de la Novela, I, 495. Se trata de La fortuna de amor, de Antonio de Lofraso, elogiada por Cervantes. La observación de MeÁn 7 Pelayo es precipin nendez Pel Lo es precipitada. caballerías de segundo y tercer orden $y$, sin embargo, interesaron a nuestro novelista, como interesaron a lectores vulgares, que no sentían tedio leyéndolos, sino reiterados placeres.

4 Cabe dentro de esta fórmula, escrita antes de conocerlo, el reciente libro de C. DE LoLLIs, Cervantes reazionario, 1924: «Teágenes y Cariclea no era propiamente un libro clásico, pero tal parecía a los ojos de Cervantes a causa de su escasa doctrinas (pág. 140). (Véase

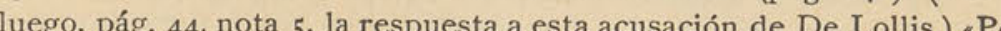
quísimo dado como fue con placer que también Schevill admite, satisfecho, un Cervantes muy poco seguro de su latín, y, de modo general, buen conocedor de mundo y no de los libros» (pág. 184). «En un certamen de gigantes de

Con tal prejuicio, destacado el Quijote de las restantes obra cervantinas, era realmente difícil darse cuenta de si en efecto el autor tenía alguna concepción peculiar de la vida, tal cual suele hallarse incluso en personalidades de menos relieve histórico ${ }^{1}$. ¿No sería hora de intentar un estudio concordado de las obras de Cervantes, serenamente, sin prejuicios, con propósito muy circunscrito? No ignoro cuanta laguna ha de hallarse en este libro; pero era preciso afrontar todos los inconvenientes. Un estudio exhaustivo de las fuentes de Cervantes habría supuesto aplazar sine die mi trabajo. Confío en que el lector de buena fe habrá de señalar omisiones e imperfecciones que en lo futuro podrían corregirse. Ahora me he arriesgado a tentar el vado.

su talla, Cervantes podría jactarse, precisamente enfrontado con Dante, de haber hecho la misma obra maestra sin saber cómo ni por qués (pág. 233; comp. 231 y passim).

1 Hasta a pequeños detalles de interpretación filológica trasciende la falta de respeto por la inteligencia y la reflexión de Cervantes. Comentando el final del capítulo VIII de la I parte del Quijote dice Clemencín, y lo acepta con aprobación R. Marín: «Pero Cervantes escribía tan sin plan ni preparación, que en el capítulo inmediato dió por supuesto que el f́ico autor habra sido Cide Hamete Benenpor Gili, Filología, 1925, pág. 18I, que cuando Cervantes escribe «el segundo autor de esta obra», se refiere claramente a sí mismo. Tratemos, pues, a Cervantes con alguna mayor mesura. 
mente importante sería, en nuestro caso, el ángulo vital del autor, la perspectiva que él escogió para sí, merced a lo cual las cosas reciben típica existencia y se transforman en esa realidad maravillosa que se llama mundo cervantino. Habría, pues, que proceder de dentro a fuera, y no al revés. La cultura de Cervantes es elemento funcional y constituyente dentro de su obra; para este hombre, tildado de espíritu mediocre y vulgar, tachado de poseer naturaleza análoga a quienes le circundaban, no hay aspecto y detalle que no hayan sido esencialmente pensados. La labor de selección y de preferencia es visible a cada paso. Decir que acierta genialmente, «sin saber cómo ni por qué», según ha escrito hace poco un crítico italiano, equivale a pensar que del posarse la abeja en los frágiles cálices pudo salir cualquier cosa, y que la miel es un bello imprevisto. Tiene mucha razón B. Croce al rechazar, como método de investigación literaria, la búsqueda desesperadamente minuciosa de cuanto pudo ver, leer o sentir el artista en torno a sí, como si esas cosas fuesen la materia del arte, cuando la verdadera materia del arte «no son las cosas, sino los sentimientos [yo añadiría «y las ideas»] del poeta, y éstos determinan y explican aquéllas, o sea cómo y por qué razón él se torna a quellas cosas y no a otras, a aquellas cosas más que a otras» (Ariosto, Shakespeare e Corneille, I920, página 33). Por lo demás, la discusión sería ociosa, ya que Cervantes, según veremos, nos ha dejado el plano de sus construcciones. En obras como el Quijote o Persiles, el mismo módulo ideal se nos muestra a cada paso, así como cualquier sección de la esfera nos presenta un círculo.

Páginas espléndidas han sido escritas sobre Don Quijote, mas no sobre su autor. La escasa información que en el extranjero se tenía del detalle de la civilización española, el poco cuidado con que entre nosotros seguimos nuestra historia intelectual (a veces sobrepreciada, a veces negada) ha hecho que se soslayen los problemas de esa índole que ofrece Cervantes. Sus obras han sido más saboreadas que meditadas; el trabajo de la sensibilidad ha sido tal vez mayor que el de la serena reflexión. Por otra parte, a los extranjeros que tanto

1 Comp.: «Comprobar a conciencia si Cervantes inventó o copió en su Rinconete... aquilatar en este último caso el mérito del artista, por el mayor o menor parecido que hubiese entrela pintura y el original» (R. MARín, Rinconete, 1920, pág. 186). Hablé de esto en Revista de Filologia, 1917, IV, 399. 
han contribuído a la formación de las ideas sobre Cervantes, puros literatos muy a menudo, sería improcedente pedirles una visión de lo que representa Cervantes dentro de nuestra historia, cuando los mismos españoles no hemos hecho todavía el análisis de lo que en nuestro siglo xvi responde a cultura y pensamiento modernos. Así acontece que aún no se ha producido un libro sobre las fuentes de Cervantes; el ensayo de Menéndez Pelayo, por brillante y valioso que fuera para aquella época, dista de ser lo que hay derecho a pedir en vista de los esfuerzos realizados sobre Montaigne, Rabelais, Shakespeare, etc. (Villey, Plattard, etc.) ${ }^{1}$.

Cervantes no compuso el Quijote con personalidad distinta de la que revelan las Novelas, el teatro o Persiles. Conviene olvidar por ahora el desigual valor artístico de esas producciones para meditar algo sobre la visión ideal de Cervantes, sobre su actitud ante la realidad que le cerca, sobre el sentido moral que proyecte en las personas que nacieron de su fantasía. El que estas preguntas puedan formularse legítimamente es independiente del hecho que Cervantes no sea un sabio como Galileo, ni un filósofo como Descartes. Rabelais, Shakespeare o Molière tampoco lo eran, $\mathrm{y}$, sin embargo, gentes tes curiosas han abordado el estudio de su pensamiento y de su moral, sin los cuales ni su obra ni la de Cervantes serían lo que son.

ARMONIA Y DISONANCIA

El Viaje del Parnaso, como es sabido, ya estaba escrito en I6I 3 y salió impreso en I6I $4{ }^{2}$. Los editores e historiadores se han detenido, sobre todo, en el aspecto erudito de este inventario poético, y han notado «la poca maña del catalogador», "lo deshilvanado de la traza» ${ }^{3}$. Pero hállase en este

1 Sería ya materia de satisfacción que poseyéramos en este punto un libro como el de F. Castro Guisasola sobre Las fuentes de la Celestina, amplio, claro y metódico.

2 Véase la excelente edición de Schevill-Bonilla, Madrid, 1922.

3 Edic. cit., pág. x. poema un pasaje importante en que Cervantes resume su credo intelectual y artístico, reflexionando sobre el curso de su vida literaria, presta ya a extinguirse:

Que a las cosas que tienen de imposibles, siempre mi pluma se ha mostrado esquiva;

las que tienen vislumbre de posibles,

de dulces, de suaves y de ciertas

explican mis borrones apacibles.

Nunca a disparidad abre las puertas

mi corto ingenio, $y$ hállalas contino

de par en par la consonancia abiertas.

¿Cómo puede agradar un desatino,

sino es que de propósito se hace,

mostrándole el donaire su camino?

Que entonces la mentira satisface

cuando verdad parece, y esté escrita

con gracia, que al discreto y simple aplace ${ }^{1}$.

Análoga idea aparece en la comedia La Entretenida:

$$
\begin{aligned}
& \text { El discreto es concordancia } \\
& \text { que engendra la habilidad; } \\
& \text { el necio, disparidad } \\
& \text { que no hace consonancia }{ }^{2} \text {. }
\end{aligned}
$$

Henos ante un programa de razón y de lógica. ¿Cómo lo cumple el autor? Antes de intentar responder a esta pregunta hemos de ver cómo venían planteándose los problemas literarios que más de cerca afectan a Cervantes. Previamente digamos lo que opinaron otros sobre la actitud de nuestro autor a ese respecto.

Menéndez Pelayo juzgaba especioso considerar a Cervantes como un «maestro de preceptiva literaria» ${ }^{3}$. Añadía, sin

1 Edic. cit., págs. $84-85$. Rodríguez Marín, Quijote, III, 383 , cita este texto parai lustrar lo que se dice en el Quijote sobre la verosimilitud. SAvJ-Lopes, Cervantes, pág. 35 , interpreta también este texto de modo literal: $« \mathrm{El}$ arte entendido como imitación de la realidad.,

2 Edic Schevill-Bonilla III 27 . Citác sionpre el teatro de Cervantes por esta edición, mediante un número romano que se refiere al tomo correspondiente de las Comedias y entremeses.

s Ideas estéticas, $188_{4}, \mathrm{II}, 405$. 
embargo, aquel sabio: "Claro es que una producción tan noble no ha podido ser nunca irracional o irreflexiva..., pero la iluminación estética es tan rápida, que la mayor parte de los artistas no sabrían decirnos por qué han seguido un camino con preferencia a otro. Todo pasa en el augusto laboratorio de la mente por reacciones que todavía no han sorprendido los ojos de los mortales» (Ibid.). Me parece que se combinan aquí cosas distintas: la calidad estética de la obra cervantina y su estructura intelectual, la cual es pensable con independencia de aquélla. Habría sido preciso examinar en conjunto la doctrina literaria de Cervantes para ver qué elementos actuaban manifiestamente sobre la disposición arquitectónica de sus creaciones. Prosigue, empero, Menéndez Pelayo analizando el concepto de poesía en Cervantes, a la que éste concede valor cultural y científico, siguiendo - según nuestro crítico - el error del marqués de Santillana y otros autores del siglo xv; error que se refleja «en sus ideas acerca del teatro y la novela; géneros que quiere someter a una reglamentación y disciplina rígidas» ${ }^{1}$.

El concepto del libro de caballerías, como epopeya en prosa, "es vulgarísimo en nuestros preceptistas del siglo xvI», que consideraban a Heliodoro y al autor del Amadís como poetas épicos. Es contradictoria la crítica que Cervantes hace de la comedia lopesca y sus propias obras, lo que lleva a la palinodia del Rufián dichoso, en que el autor se responde a sí mismo. Menéndez Pelayo reproduce, aceptándolas, las razones de Schack para explicar tal contradicción (respeto a la tradición, defensa de la escuela de Cueva y Virués a la que Cervantes pertenecía, protesta contra el excesivo desorden del teatro, preocupación por la finalidad moral). Concluye Menéndez Pelayo que no debe tomarse a Cervantes y sus esparcidas indicaciones como medida del saber estético de los. españoles del siglo xvi, sino a León Hebreo, el Pinciano y Cascales ${ }^{2}$, observación que es réplica a quienes consideraban

1 Ideas estéticas, pág. 409.

2 Obr. cit., pág. 412 a Cervantes como pozo de ciencia. En conjunto, lo que $\mathrm{Me}$ néndez Pelayo dice de Cervantes en su Historia de las ideas estéticas es hoy demasiado elemental e insuficiente.

A. Bonilla pensó primeramente ${ }^{1}$ estudiar «su especial manera de comprender y expresar el arte, inferida del estudio paciente, directo y comparativo de sus obras. Esto no se ha hecho aún respecto de Cervantes, y valdría la pena de hacerlo»; pero el docto crítico prefirió referirse sólo «a las doctrinas estéticas cervantinas, dejando para otra ocasión lo que respecta a esa segunda manera de su estudio artístico». Amplía Bonilla lo hecho por Menéndez Pelayo, añadiendo algún otro dato de la Filosofía antigua poética del Pinciano y de León Hebreo. En resumen: no considera originales las ideas estéticas de Cervantes, pero sí la insistencia sobre algunos puntos: imitación de la Naturaleza, verosimilitud, poesía como suma y compendio de todas las ciencias.

Por nuestra parte querríamos considerar el asunto desde punto de vista algo diferente. Cervantes ha leído la literatura de su siglo, los tratadistas de poética y tal vez libros de carácter filosófico o ideológico. Sus ideas literarias no son, como veremos, elemento adventicio que se superponga a la labor de su fantasía y de su sensibilidad, sino al contrario, parte constitutiva de la misma orientación que le guiaba en a selección y construcción de su propia senda. La teoría y la práctica son inseparables aquí; en Lope de Vega podemos, en cambio, distinguir muy a menudo la exornación erudita del cauce central por donde va lo típico y originalmente lopesco.

\section{LO UNIVERSAL POÉTICO Y LO PARTICULAR HISTÓRICO}

Cervantes se halla situado en el centro del problema literario que afecta a la íntima estructura del siglo. El Renacimiento había labrado formas características para las dos tendencias que venían señaladas desde la Edad Media: literatura

\footnotetext{
1 Cervantes y su obra, 1916, págs. £6-87.
} 
idealista (serie heroicotrágica) y literatura con inclinación hacia la materia (lo cómico, lo picaresco, lo que con mayor o menor precisión se llama realismo y que a veces es simple naturalismo $)^{1} . \mathrm{Al}$ acentuar el Renacimien to, con intensidad no vista antes, el poder de la razón y del ideal de una parte, y la propensión a los valores más inmediatos y terrenos de otra, ambas téndencias adquieren vida nueva e intensa dentro de los nuevos géneros literarios que surgen del siglo xv al xvr. Cuando Cervantes llama a $L a$ Celestina libro a la vez divino y humano, expresa claramente lo que pensamos en este caso. $\mathrm{El}$ arte heroico (caballeresco o de amor idealizado) se sitúa frente a lo picaresco, a la farsa cómica, etc. Visión del mundo de Calixto, visión del mundo de Sempronio. León Hebreo nos habla de que nuestra alma tiene dos caras: «La primera cara hacia el entendimiento es la razón intelectiva, con la cual discurre con universal y espiritual conocimiento, sacando fuera las formas y esencias intelectuales de los particulares y sensibles cuerpos, convirtiendo siempre el mundo corpóreo en el intelectual. La segunda cara, que tiene hacia el cuerpo, es el sentido, que es el conocimiento particular de las cosas corpóreas... Conforme a cada uno de estos dos conocimientos de las hermosuras corpóreas, se causa en el ánima el amor de ellos que es amor sensual por conocimiento sensible, y $\checkmark$ amor espiritual por el conocimiento racional» 2 .

La Italia del siglo xv había conocido muy destacadamente ambas formas de arte, representadas en las derivaciones del platonismo de Ficino (por ejemplo, en La Arcadia, de Sannazaro) y en Pulci y su Morgante. Ambas actitudes hubieron de ponerse en contacto; y así aconteció que la visión crítica y materialista de la vida lanzó sus garras sobre la visión mágicamente supraterrena. El ideal se precipita por la vertiente de lo cómico, y esa función de plano inclinado es la que realizan, por ejemplo, la novela picaresca, iniciada con el Lazarillo, las obras de Horozco y sus afines. Erasmo conoce esta acti-

1 Recuérdese la comedia a noticia y a fantasía en Torres Naharro. 2 Diálogos de amor, en M. PrLayo, Orígenes de la Novela, IV, 430. tud. Con maligna complacencia nos dice en el Elogio de la locura que «el mismo padre de los dioses y rey de los hombres, ante quien tiembla el Olimpo, ha de deponer su rayo trisulco.., y como un buen cómico se enmascara el pobrecillo bajo muy otras formas cuando le entran ganas de ejercitar aquella función que a menudo practica, quiero decir procrear pequeños Joves... Creo, señores míos, que el instrumento propagador del género humano es aquella cosa... Aquella, aque1la, y no el número cuaternario de los pitagóricos es propiamente la sacra fuente de donde sacan su vida todas las cosas» 1 . Oímos la risotada picaresca ante tal derrumbamiento del Olimpo. Todos somos unos. Este aspecto del erasmismo influye en la gestación de la novela picaresca; y juzgo eso más importante que el influjo de la crítica anticlerical de Erasmo sobre varios episodios del Lazarillo.

Luciano, conocido y precisamente muy amado de Erasmo, ha enseñado algo de este tirar de los pies a las excelsas figuras. Dice Micillo al Gallo: "Te ruego que digas si aquellas cosas que pasaron en el cerco de Troya son de la misma manera que las escribió Homero. Gallo: Créime que en aquel tiempo no había cosa señalada ni excelente: ni Aiace fué tan grande, ni Helena de tan extremada hermosura como muchos piensan» ${ }^{2}$. ¿Y no refleja idéntico espíritu el sensual y despreocupado Ariosto? Recuérdese el pasaje:

Non si pietoso Enea, nè forte Achille

$\mathrm{Fu}$, come è fama, nè si fiero Ettorre...

Non fu si santo nè benigno Augusto, Come la tuba di Virgilio suona ${ }^{3}$.

Mas otro grave peligro amenazaba a la literatura idealista. Era evidente que el incremento adquirido por el arte en el siglo xvr iba derechamente a crear una zona autónoma en que

1 Edic. Croce, pág. 16

2 Diálogos, Lyon, 1550 , fol. $88 \mathrm{v}$

3 Orlando furioso, XXXV, 25 y 26. Clemencín, IV, 1835, pág. 55 , cita estos versos con otra finalidad, pero refiere por errata al canto III del Orlando. 
los espíritus no tenían más estímulos que los puramente terrenos y humanos. La literatura hacía verdadera competencia a la religión, tanto más peligrosa cuanto que la forma en que se envolvía estaba ungida por el prestigio de las gracias antiguas y por el genio de los más egregios espíritus contemporáneos. La literatura encaminaba francamente hacia el mundo, con manifiesto olvido de las aspiraciones ultraterrenas. Esa es la causa de que pasada la primera embriaguez ante el triunfo vital que representó el Renacimiento, una franca reacción se dibuje, al acercarse I550, de acuerdo con el repliegue general que en otros órdenes realiza la Iglesia católica. El Concilio de Trento vigilará enérgicamente la literatura: «Libri qui res lascivas seu obscoenas ex professo tractant, narrant aut docent» ${ }^{1}$. Desde luego, el concepto de lo lascivo era bastante más amplio para los padres y moralistas del que hoy tendríamos, y así nos parecen incomprensibles las declamaciones contra las ingenuas novelas pastoriles, en las que los confesores veían toda clase de peligros para la honestidad de las doncellas. A lo que se aspiraba era a poner trabas al cultivo de la sensibilidad y fantasía puramente mundanas. Ese es el sentido de las censuras de los libros de caballerías que tomaron incremento durante la «Contrarreforma ${ }^{2}$. Pónese entonces de moda vol-

1 Véase De LoLlis, Cervantes reazionario, pág. 187.

2 Las críticas de los libros de caballerías, de que hay ejemplos ya en el primer tercio del siglo xvi, aumentan a mediados del siglo. MENÉNDEZ PeLayo, Origenes de la novela, I, 282 y sigs., ha citado muchos testimonios; añado dos más y los pongo por orden cronológico:

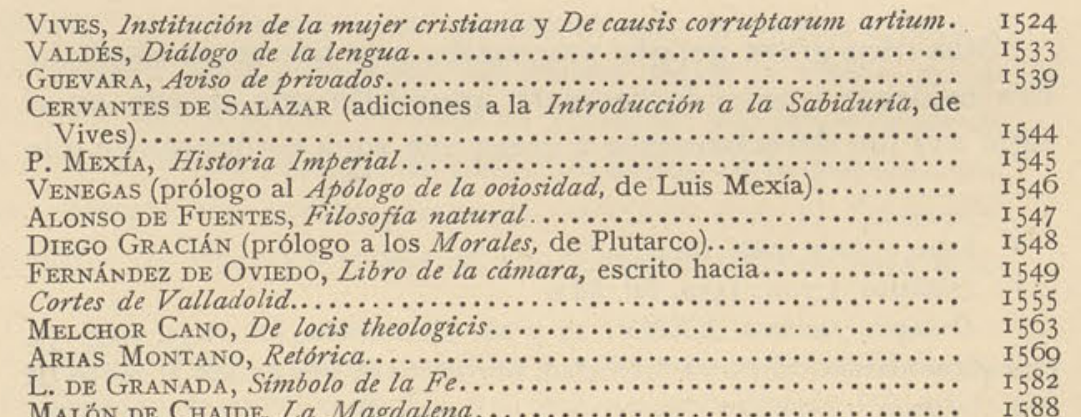

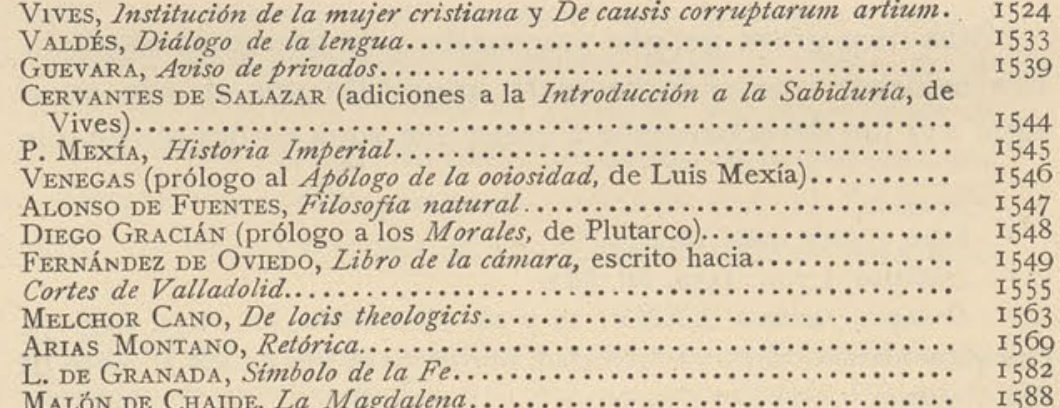

ver a lo divino las obras profanas, y no sólo los libros de caballerías, más también autores de espiritualidad tan depurada como Boscán y Garcilaso ${ }^{1}$.

La Contrarreforma, que estudiaremos más ampliamente en el capítulo VII, afectará, pues, a la técnica misma de la obra literaria, y en ese sentido conviene ahora tener presente su influjo dentro del siglo xvi. Los tratadistas procurarán definir y justificar moralmente el juego de la fantasía y de la sensibilidad en las obras profanas, a fin de salvarlas.

Dentro de este rumbo general de la literatura viene a situarse un aspecto concreto, que ha sido admirablemente ilustrado por Toffanin en su libro La fine del Umanesimo, I920: ha concedido atención especial a Cervantes, y relaciona su obra mayor con las discusiones a que se entregaron los tratadistas de poética en Italia, justamente en la época en que nuestro autor se hallaba por aquellas tierras. Parece esto fuera de duda. Conviene, sin embargo, que acentuemos en seguida que la gran originalidad de Cervantes, lo que forma la clave de sus más altas producciones, es, con el sistema de la doble verdad, ese despeñarse el ideal por la vertiente de lo cómico, cosa que naturalmente habría escandalizado a los tratadistas. Los lejanos orígenes de tal disposición de espíritu vienen más bien de las fuentes antes indicadas, y, sobre todo, del especial sesgo cervantino, irreductible a ninguna fuente. Pero es de alto interés considerar el plano doctrinal sobre que se proyecta tan singular visión de la materia artística.

La lista es seguramente muy incompleta, pero sirve para notar la frecuencia de las críticas en el momento de la Contrarreforma de Trento (el Concilio empieza en 1545). Muchas de estas censuras acentúan más que la inmoralidad, la falta de veracidad. Oviedo quiere que haya en la cámara del príncipe, libros no sapócrifos y vanos como Amadis y otros tales, sino de historias veras». Diego Gracián habla de «estos libros de mentiras y patrañas que llaman de caballerías... Nadie puede ni debe imitar lo patriroso. Que cierto, como dice Plato inguna cosa hay tan surve al buen entendi iento como decir y of ninguna cosa

1 Sebastí́n de Córdoba, Las obras de Boscán y Garcilaso traslada das en materias christianas y religiosas, Granada, 1575 . 
«Las fuentes teóricas de Cervantes - dice Toffanin fueron las mismas que atormentaron al Tasso: uno y otro tuvieron a mano los mismos libros, oyeron hablar de las mismas cosas, frecuentaron tal vez los mismos hombres. Los años de la estancia de Cervantes en Italia van de I 569 a I 575 , época en que aparecieron las poéticas de Castelvetro y Piccolomini años capitales en que se constituye el gran problema de la historia y la poesía, que hemos ilustrado» (pág. 2I3). «El problema de las relaciones entre historia y poesía... sobre e cual meditó estérilmente el Tasso, hizo florecer la sublime inspiración de Cervantes» (pág. 172).

Por primera vez intenta Toffanin deducir consecuencias metódicas del hecho de la influencia italiana sobre Cervantes. Mas digamos previamente unas palabras para que esto se entienda. Como es sabido, el Renacimiento propiamente dicho (fines del siglo $\mathrm{xv}$ y primera mitad del $\mathrm{xvI}$ ) no tiene en cuenta la Poética de Aristóteles, mal conocida por las traducciones latinas de Lorenzo Valla y Pazzi; la poesía se desarrollaba separada de la vida, y nadie aspiraba a encauzar la literatura en provecho de la mejora de las costumbres. La literatura seguía su camino, y a la objeción de inmoralidad podía responderse con Marcial: «lasciva est nobis lingua, sed vita proba» ${ }^{1}$. Tal situación en el orden artístico podría compararse con la doctrina de la doble verdad: verdad de razón y verdad de fe, que lleva al dualismo característico del Renacimiento, con un entender distinto del creer (Pomponazzi).

Pero, como vimos antes, hacia 1550 las cosas varían radicalmente. La reacción antiplatónica se acentúa; Aristóteles se torna casi un doctor de la Iglesia, y la literatura, infiltrada del espíritu de la Contrarreforma, tendrá que armonizarse con finalidades éticas y racionales. En I 548 surge con Robortelli

1 Contra ello reaccionaba Mal Lara: «Si puede ser que un hombre que escribe deshonestamente en las palabras, puede ser casto en el corazón, y que la vida pueda ser diferente de las palabras, como lo quieren probar Marcial y Ausonio, cuando hartos de desbocarse en todo lo que se puede decir, vienen con un dicho sin fuerza a probar que son de limpio corazón.) (Filosofía Vulgar, 1568 , preámbulos.) la primera edición crítica de la Poética de Aristóteles, y de esa suerte el preceptismo neoclásico aparece como un fenómeno en conexión con Trento, al intentar restablecer la síntesis medieval mediante la unión del arte con la vida, y por tanto con la moral. Fermento para tal cambio era la insatisfacción que el Renacimiento dejaba en los ánimos egregios; el final del siglo xvi estará matizado por cierta melancolía, que en forma diversa hallamos en Tasso, Mateo Alemán o Cervantes.

El problema de las relaciones entre la historia y la poesía, que no preocupó al primer Renacimiento, adquiere, pues, en la segunda mitad del siglo particular acuidad entre los tratadistas italianos ${ }^{1}$. Los moralistas censuraban la literatura pura. mente imaginativa, de arte autónomo. Hacía falta una literatura verdadera ${ }^{2}$, y al mismo tiempo ejemplar, para la que Aristóteles prestaba base sólida con su Poética: «No es el oficio del poeta contar las cosas como sucedieron, sino como debrían haber sucedido, o como fuese necesario o verisímil. Porque no está la diferencia entre el poeta y el historiador en que el uno escriba en verso y el otro en prosa, pues la Historia de Herodoto fácilmente se podría poner en verso, y no por eso dejaría de ser historia como antes lo era sin el verso; pero diferéncianse en que el uno escribe las cosas como han sucedido, y el otro como debrían haber sucedido. De donde es, que la poesía tiene más de lo filósofo y de agudeza que la historia, porque la poesía trata las cosas más en lo universal, y la historia las trata en particular» ${ }^{3}$. Ese mundo de la verdad posible o de lo verosímil, podía convertirse fácilmente en el paradigma del deber ser, de lo ejemplarmente moral. Maggi (edic. de la Poética, I 550), Varchi (Lezioni sulla Poesía, I 553) y Escalígero (Poética, I 56I), para armonizar la falsedad inevitable de la fantasía poética con la «verdad», habían tratado de ennoblecer el arte considerando escolásticamente su fin y obligándolo a reflejarse

1 Véase el capítulo XIII del citado libro de Toffanin.

2 Recuérdense las críticas de los libros de caballerías, pág. 26, nota 2.

3 Traducción de D. Alonso Ordóñez, Madrid, 1626, fol. 23. 
en la abstracción del Bien absoluto, haciendo de los personajes poéticos otros tantos ejemplares de virtud, a despecho de la realidad y de la historia. Piccolomini ${ }^{1}$, en cambio, dirá en el prefacio de su libro que el objeto de la poesía es lo verdadero; pero lo que el poeta ve con sus ojos de poeta es «la conversione di esso vero col dovuto e col verisimile». Según este comentarista de Aristóteles ${ }^{2}$, lo verosímil poético tiene más alcance que la verdad, porque es un aspecto eterno de aquello que, tomado (según diríamos hoy) en su fugacidad fenoménica, puede ser inverosímil y, por tanto, antipoético. «Pero el poeta - dice Toffanin - , mucho más vidente que el historiador, ve aquello en forma inmutable. Es decir, la verdad vista por éste se escribe con minúscula; la vista por aquél, con mayúscula, y se llama "verosímil»: un verosími sobre el cual brilla confirmándolo la luz divina, y que se llama lo «debido».

En medio de tal problema se sitúa Cervantes con plena conciencia de su alcance; para el caso es indiferente que su informaciones procedan de los tratadistas italianos de poética o del Pinciano que los sigue paso a paso ${ }^{3}$. Pienso que de ambas fuentes. En el capítulo III de la segunda parte del Quijot dialogan el Hidalgo, su Escudero y el Bachiller acerca de la primera parte del Quijote y de la forma en que han sido con cebidos los personajes principales. Lo genial de Cervantes se revela en el arte con que ha introducido en lo más íntimo de la vida de sus héroes el problema teórico que inquietaba a los preceptistas; el autor ha colocado a Don Quijote en la vertiente poética y a Sancho en la histórica; pero serán ellos $\mathrm{y}$ no el autor quienes pugnen por defender sus posiciones respectivas, y lo que es árida disquisición en los libros se torna conflicto vital, moderno, henchido de posibilidades. Don Qui-

\footnotetext{
1 Annotationi nel libro della Poetica d' Aristotele, Venecia, 1575.

2 Cfr. Toffanin, págs. I89-191.

Cfr. Toffanin, págs. I89-19r.
Ideas originales e importantes acerca de la literatura se encuen tran, por ejemplo, en Vives; pero las poéticas propiamente aristotélica de fines del siglo xvi y comienzos del xvir son mero calco de las italianas. Véase SpINGARN, La critica letteraria nel Rinascimento, pag. 139.
}

jote hablará en nombre de la verdad universal y verosímil Sancho defenderá la verdad sensible y particular ${ }^{1}$. La oposición, como es natural y cervantino, no se resuelve, sino que queda patente, como problema abierto. El ejemplo es magnífico para quienes tozudamente siguen hablando de la inconsciencia de Cervantes y de lo vulgar de sus conocimientos.

Dice Don Quijote: «Una de las cosas que más debe de dar contento a un hombre virtuoso y eminente es verse, viviendo, andar con buen nombre por las lenguas de las gentes, impreso y en estampa. Dije con buen nombre, porque siendo al contrario, ninguna muerte se le igualaría.» El Bachiller satisface cumplidamente la inquietud del caballero: «Si por buena fama y si por buen nombre va, sólo v. m. lleva la palma a todos los caballeros andantes; porque el moro en su lengua y el cristiano en la suya tuvieron cuidado de pintarnos muy al vivo la gallardía de v. m., el ánimo grande en acometer los peligros, la paciencia en las adversidades..., la honestidad y continencia en los amores tan platónicos de v. m. y de mi señora Doña Dulcinea del Toboso.»

El Bachiller conoce bien los requisitos del personaje del poema heroico, tan bien como Don Quijote, y hacia este norte van sus anhelos. Personaje perfecto, idealizado, ejemplar. Veamos, por ejemplo, el tratado Della vera Poetica (I 558 ) de Giovanni Pietro Capriano: «Variando el poema y representando las acciones humanas en el modo que deban haber ocurrido y razonablemente sucedido y reduciéndolas a ideas universales de acciones y de costumbres (que esta es una de las principales diferencias entre el historiador y el poeta), instruye y amaestra el ánimo y la vida nuestra... por la vía del verdadero bien y del vivir beato.» Mas para lograr el personaje "ab omni parte absolutus», con que soñaban los preceptistas, había que desechar los paladines extravagantes y elegir lo épico, tomando «acciones ilustres e ilustrísimas». Razón por la cual Aristóteles debió comprender que el poema épico es

Recuérdese la cita de León Hebreo, hecha en la página 24. 
siempre preferible a la tragedia, porque tras los bastidores obrará siempre la iniquidad ${ }^{1}$.

Don Quijote se cree «virtuoso y eminente» (ilustre e ilustrísimo), y sin dificultad le da la razón el Bachiller. Pero allí está Sancho, ojo avizor y garras agudas, presto a saltar sobre tan encantadora y aristotélica suposición: «Nunca he oído llamar con don a mi señora Dulcinea, sino solamente la señora Dulcinea del Toboso, y ya en esto anda errada la historia.» La historia, lo particular, el vero sensible no pueden ir parejos con la pura y universal noción del héroe; lo del don "no es objeción de importancia», dice Sansón Carrasco. ¿Pero qué hacemos con «los infinitos palos que en diferentes encuentros dieron al señor Don Quijote?» No hay héroe ilustrísimo que resista. Nuestro Hidalgo acude a su manual poético, e intenta una última y dolorosa defensa: «También pudieran callarlo por equidad, pues las acciones que ni mudan ni alteran la verdad de la historia no hay para qué escribirlas, si han de redundar en menosprecio del señor de la historia. A fee que no fué tan piadoso Eneas como Virgilio le pinta, ni tan prudente Ulises como le describe Homero.» Así con esas palabras hallo que lo había dicho Robortelli en I548: «Poetam versari in una unius personae actione describenda: in ea tamen describenda versari circa universale, quod nihil aliud est quod respicere ad generale quoddam, et commune ut si sit effingendus prudens in rebus agendis Ulysses, non qualis ipse sit esse considerandum, sed, relicta circunstantia [es decir, los palos], transeundum ad universale, et effingendum esse qualis prudens, callidusque, ab omni parte absolutus describi solet a philosophis. Hinc Plato in Sophista de pictoribus ait, oportere illos semper ad Ideam respicere, et pulchriora omnia pingere quam sint... Refert Porphirius Platonis dictum, qui jubebat quiescere, cum deventum esset ad individua et singularia: cum enim sint innumerabilia, scientia non possunt complecti» ${ }^{2}$.

1 Cfr. Toffanin, págs. 55-56.

2 Francisco Robortrlu, In librum Aristotelis de Arte Poetica expli-
El Bachiller entonces saca de dudas al Hidalgo, con una aclaración literalmente aristotélica (véase antes pág. 29): «Así es; pero uno es escribir como poeta y otro como historiador; el poeta puede contar o cantar ${ }^{1}$ las cosas no como fueran, sino como debían ser, y el historiador las ha de escribir no como debían ser, sino como fueran, sin añadir ni quitar a la verdad cosa alguna.»

Mas Don Quijote ha de defenderse de la interpretación histórica, particularista; él ha de vivir "relicta circunstantia» ${ }^{2}$, y Cervantes ha colocado a sus flancos esa tremenda «circunstantia» de Sancho, con voraz apetencia de lo

cationes, Basilee, per Ioannem Hervagium Iuniorem, 1555, pág. 79 [Bibl. Nac., 3-2165. El texto cervantino recuerda más a Robortelli que al Ariosto antes citado, pág. 25. Que la fuente directa de Cervantes sea Robortelli o alguna adaptación en vulgar de su Poética es cosa que no puedo decidir, por no disponer en Madrid de suficientes libros

La forma métrica no se juzgaba esencial para la poesía (véase antes pág. 29). De ahí que Don Quijote pida al libro de sus aventuras ancondiciones del poema heroico. El Pinciano $(1596)$ repite lo "No la prosa y el metro diferencian a la histo porque ésta imita y aquélla nos (Filosof. aut. Pótia, poética, sino gina I16). Al gina I16). Al final del capítulo XLVII de la primera parte leemos: \&La épica también puede escrebirse en prosa como en verso.» 2 Sin este concepto de la «relicta circunstantia» y de lo «universal
poético» no se pueden entender pasajes como este: «Aquí pinta el autor todas las circunstancias de la casa de D. Diego, pintá nos en ellas lo que contiene una casa de un caballero y lobrintándopero al traductor de esta historia le pareció pasar estas y otro menudencias en silencio, pósito general de la histo porque no venían bien con el proverdad me cuerza en la está que que las frías digresiones» (II, 18; RM, IV, 358). Claro está que la palabra «historias está aquí no sin misterio. Compárese lo que dice el Pinciano, pág. 176: «Imaginad que un autor compone un volumen en España de obra y acción, que en el tiempo que ella hace $y$ finge suceda realmente en la Persia escribiese en España sería poeta, y el que en la India, o do que la teció, histórico, Ahora bien: como la ficción del Qüjotende aconacaecida en Fspañ y se escribe en Espaín del Quyjote se supone por shistorias. en españa, puede pasar entonce 
que él entiende por verdad, la cual por sí sola es incapaz de poesía ${ }^{1}$.

En el capítulo II de la segunda parte, Don Quijote trata de anular la intervención histórica de Sancho, acallando sus habladurías y recabando para sí la parte mayor de dolores y sinsabores: «¿Querrás tú decir agora, Sancho, que no me dolía yo cuando a tí te manteaban? Y si lo dices, no lo digas, ni lo pienses. " Sobre todo, callar, no complicar la épica heroica con la historia cotidiana. De haber conocido el poema de Fernán González, Don Quijote habría recordado aquellos versos

Non cuentan d'Alexandre las noches nin los días, Tus callerías ${ }^{2}$,

Don Quijote, el pobre, aspira a la existencia mítica; mas Sancho, al tirarle de los pies, lo introduce violentamente en su realidad, gracias a la cual surgió el nuevo género de la novela. Esto era conocido ${ }^{3}$; pero ahora podemos seguir con alguna mayor precisión la trayectoria de semejante proceso ente de Cervantes. Genialmente supo nuestro escritor dominar el estricto problema que le ofrecían los preceptistas

1 Conviene recordar cómo el Pinciano reflejaba en España estas doctrinas aristotélico-italianas: «-¿Qué entendéis por lo que habéis dicho que el poeta se ejercita en lo universal y el histórico en lo particular? - ... El blanco adonde tiran las saetas es muy pequeño, y lo que no es blanco es tan grande como todo el mundo; así la verdad est en un punto y la mentira es todo lo que no es este punto de verdad. El historida ver y el poeta, como antes se

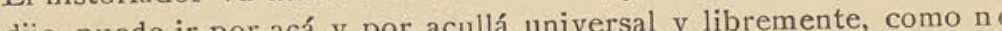
dijo, puede ir por acá y por acullá universal y librimilitud... A mí me repugne a las fábulas recibidas ni a la verisimilitud... A mi me parece que la verisimilitud es lo más intrínseco de la imitación, y aunque Aristóteles no decide esta cuestión, se debe tener que lo ve risímil es lo más importante...; mas advertid si el mandar el filósofo que no se alteren las fábulas recibidas, es a fin que se guarde la verisimilitud, de manera que debajo de uno se incluye lo otro» (edic. cit., págs. 1 $53^{-1}$ 54).

págs. $\left.153^{-1} 54\right)$.

3 Véase J. Ortrga Gasset, Meditaciones, 1914, págs. 158-159. Véase también antes pág. 25 de la Contrarreforma, tomando los preceptos aristotélicos como medio y no como meta ${ }^{1}$, elevándose a más altas esferas.

El Tasso, en cambio, cayó ingenuamente en el lazo poético, y se halló triste y desilusionado ante sus héroes de las Cruzadas por no poder elevarlos a aquel summum de perfección que exigían las poéticas: «Si hemos de creer a los historiadores, muchos de aquellos príncipes no sólo estuvieron manchados por la incontinencia, sino también afeados por la malicia y la ferocidad» 2 .

Después de lo dicho, se comprende mucho mejor el alcance de los versos iniciales del Quijote acerca de la Celestina ( «Libro en mi opinión divino, Si encubriera más lo humano»). Como crítico, Cervantes procede llevado por sus teóricas inquietudes; hay en la Celestina elementos para dar vida al personaje «ilustre e ilustrísimo», pero el elemento "particular» (el hecho bruto y la menuda circunstancia) priva al conjunto de este tono ejemplar y moralizador que pedía la Contrarreforma: «El buen poeta o ha de tocar la filosolía moral o natural en su obra», exigía el Pinciano ${ }^{3}$, y más adelante: «Limpiar las pasiones del ánimo es el fin universal de la poesía» ${ }^{4}$.

1 De Lollis (págs. 79-80) sigue en cierto modo la huella de Toffanin al interpretar el diálogo entre Don Quijote, el Bachiller y Sancho (II, 3); pero cree que esa sátira del poema heroico le permite cultivar el desorden y la frondosidad de la naturaleza «y acercarse a Lope de Vega en el seno del común origen español». No comprendo bien. Cervantes posee una visión del mundo dian. de Lope. Todas estas concomitancias con la cienci litenesta a la época sirven a aquél de base para discurir sobre el ser y el a de las cosas; y ya de las cosas; y ya sabemos que Lope se caracteriza por no plantearos, en serio al menos, cuestiones de esa índole.

Lettere, II, 403 (véase Toffanin, pág. 203).

Obr. cit., pág. 123.

4 Ibid., pág. 318. Téngase presente que la cátarsis de la tragedia se había extendido por estos preceptistas igualmente a lo épico, dentro de lo cual cabían narraciones como la Historia etiópica, de Heliodoro (Pinciano, págs. 117 y 318 ). 
LO VEROSÍMIL

La preceptiva enseñó a Cervantes a definir claramente el área del arte universal o idealista frente a la del particular o naturalista. Y una vez delimitado el perímetro, se complace en abrirle brechas y en hacer ver lo imposible de tal limitación. Donde más notoriamente se practica tal forma de agresión entre esos dos mundos es en el Quijote, y ha muchoque ruedan por los libros fáciles observaciones acerca de ello. Lo que no se ha notado es que fuera del Quijote haya muestras de la misma técnica; intentos, si se quiere, estéticamente fallidos, pero de alta importancia como reveladores de la vida que en el espíritu del autor ostenta una manera de contraposición artística que sólo en su obra magna llegó a pleno desarrollo.

Es extraño que la gran finura crítica de Menéndez Pelayo. no percibiera la perfecta armonía que hay entre la oposición Don Quijote-Sancho de un lado, y la de Galatea y la autocrítica cervantina de otro: «Tampoco le satisfacen las pastorales, comenzando por la de Montemayor ${ }^{1}$ y terminando por la suya. Si salva a Gil Polo y a Gálvez Montalvo es, sin duda, por méritos poéticos [?]. Nadie ha visto con tan serena crítica como Cervantes los vicios radicales de estas églogas... No puedo omitir la crítica mucho más punzante y desapiadada que de aquel falso ideal poético hizo Cervantes por boca de Berganza.» En el Coloquio de los perros leemos, en efecto: «Entre otras. cosas consideraba que no debía de ser verdad lo que había oído contar de la vida de los pastores, diciendo que se les pasaba toda la vida cantando y tañendo con gaitas, zampoñas, rabeles y chirumbelas.»

Los pastores que conoce Berganza «si cantaban, no eran canciones acordadas y bien compuestas, sino un «cata el lobo do va Juanica»... Lo más del día se les pasaba espulgándose o

1 Más adelante explico el sentido de la crítica de un detalle que hace Cervantes a la Diana, que nada prueba contra la admiración que sentía por novela tan leída e imitada por él. remendando sus abarcas, mientras ellos se nombraban Amarilis, Fílidas, Galateas, Dianas... Por donde vine a entender lo que pienso que deben de creer todos, que todos aquellos libros son cosas soñadas y bien escritas [es decir, arte idealista o universal] para entretenimiento de los ociosos, y no verdad [histórica o particular] alguna» 1 .

Ante todo, es inadmisible la idea de que Cervantes no gustara de su Galatea, y que lo anteriormente transcrito fuese "crítica punzante y desapiadada de aquel falso ideal poético». De ser esto así, habría para considerar a Cervantes como un débil mental o un perturbado, ya que repetidas veces en su vida habla con tanta seriedad como entusiasmo de la Galate y de su continuación ${ }^{2}$. Pero ¿en qué consiste la crítica «desapiadada»? En decir sencillamente que los pastores de la realidad que se ven son sucios, se cosen las abarcas, etc., es decir, no son como los de los libros. Berganza, según Menéndez Pelayo, «hallaba gran distancia de la realidad a la ficción»; y medrado saldría el Arte, pensamos nosotros, si no aconteciera así realmente. Los últimos editores de la Galatea, los señores Schevill y Bonilla, aciertan al decir que «Cervantes tenía la profunda convicción de que había escrito una obra inmortal»; pero inciden en la huella de Menéndez Pelayo al interpretar lo que Cervantes dice sobre las pastorales: «Nadie mejor que él formuló los defectos de semejante género literario al advertir que esas descripciones poéticas de la vida bucólica no debían de ser verdad" (pág. xiv). Y volvemos a preguntarnos

1 Apud Origenes de la novela, I, $516-518$.

2 "Yo corté con mi ingenio aquel vestido Con que al mundo la hermosa Galatea Salió para librarse del olvidos (Viaje del Parnaso, Rivad, I, 687). Promete la continuación al final de la Galatea («la segunda parte... tendrá atrevimiento de salir con brevedad a ser vista y ju\% gada de los ojos y entendimiento de las gentes»); en el Quijote («e. menester esperar la segunda parte que promete, I, 6); en la dedicatoria de sus comedias (aluego... iń la segunda parte de la Galater); en el prólogo de la (dug saleas): cirte que esperes de cirte que esperes el Persiles, que ya estoy acabando, y la segunda parte de la Galateas); en la dedicatoria de Persiles («si a dicha... me diese el cielo vida, las verá y con ellas fin de la Galatea»). 
por el sentido que esto tenga: Persiles no es «verdad», ef Viaje del Parnaso tampoco, las comedias tampoco. ¿Se divertiría Cervantes en escribir «mentiras» para hacer luego el payaso diciendo que eran, en efecto, mentiras? Creo que esa senda no lleva a ningún lugar.

Cervantes opone en este caso, como en el diálogo de Don Quijote y Sancho (II, 3), la verdad universal y la particular, el pastor "relicta circunstantia», y el pastor que se ata las abarcas; su genio le llevaba hacia el mundo de la verdad inteligible con pleno amor, con atracción incontrastable, y de ahí la dilección por Galatea, por Don Quijote (por cuya boca habla cien veces Cervantes), por Persiles, etc., etc.; mas su genio era prismático, y hacía que esa verdad inteligible se tornara en verdad sensible. ¿Pastor de zampoña? ¿Pastor de abarcas astrosas? ¿Yelmo? ¿Bacía de barbero? La única y esencial diferencia en el caso de lo pastoril es que el conflicto entre ambas verdades no se resuelve en maravillosa síntesis como en el Quijote; pero por el espíritu de Cervantes, al pensar en $L a$ Galatea, ambulaban los fragmentos del artístico problema.

Dada la metódica organización de las ideas del autor, nos será posible citar manifestaciones del mismo procedimiento literario, inherente a su técnica. En La casa de los celos (I, 207) Reinaldos pregunta al pastor Corinto por Angélica:

$$
\begin{aligned}
& \text { ¿Has visto unos ojos bellos } \\
& \text { que dos estrellas semejan? }
\end{aligned}
$$

$\mathrm{Y}$ replica Corinto:$$
\text { ¿Tiene por dicha, señor, }
$$

Esa visión irónica del ideal puede tomar otros aspectos. El personaje abstracto la «Mala Fama» realiza aquella función en La casa de los celos (I, I95):

La mala fama soy, que tiene cuenta con las torpezas de excelentes hombres.. Aquí está el grande Alcides, no cortando de la hidra Lernea las cabezas, sino a los pies de Deyanira hilando sino a los pies de Deyanos y ternezas, etc.

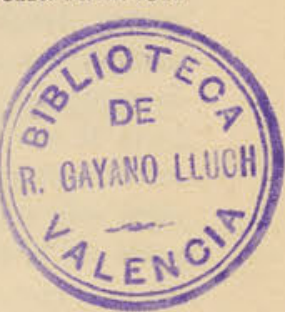

Hay un asomo de picarismo en esta actitud: recuérdense las fuentes que en las piernas tiene la Duquesa, las trampas del Duque (II, 48). Pero aquí, en realidad, es Doña Rodríguez la que nos da el apicarado escorzo de sus señores ${ }^{1}$. A Cervantes mismo lo que le preocupa, en cuanto a lo pastoril, es el tema de la doble verdad: "Porque aunque suele decirse que por las selvas y campos se hallan pastores de voces extremadas, más son encarecimiento de poetas que verdades» ${ }^{2}$.

El elogio de Tirante el Blanco se basa en que allí "comen los caballeros y duermen y mueren en sus camas y hacen testamento antes de su muerte, etc.» $(I, 6)$.

En algún caso, el héroe mismo cervantino es, por decir así, quien se tira de los pies. Cervantes hace entonces como el prestidigitador que descubre su ardid. Don Quijote contesta a las observaciones de Sancho acerca de Dulcinea: «Píntola en mi imaginación como la deseo, así en la belleza como en la principalidad, y ni la llega Elena, ni la alcanza Lucrecia» ${ }^{3}$. Y para los futuros críticos de la novela pastoril dice el gran Hidalgo: «Piensas tú que las Amarilis, las Filis, las Silvias, las Dianas, las Galateas, las Fílidas... fueron verdaderamente damas de carne y hueso?» ${ }^{4}$. Don Quijote recaba para sus dominios de puro personaje universal a estas heroínas no menos «ilustres e ilustrísimas» que el «señor de la historia» heroica. La verdad de Don Quijote es solidaria de la de Galatea y de la de Persiles.

1 Compárese el duelo por la muerte de Don Quijote: «Pero con todo, comía la sobrina, brindaba el ama y se regocijaba Sancho Panza, que esto del heredar algo borra o templa en el heredero la memoria de la pena, que es razón que deje el muerto» (II, 77).

2 I, 27 ; RM, II, 347.

3 I, $25 ;$ RM, II, 3 II.

4 I, 25; RM, II, 309. Es notable que Luis Gálvez de Montalvo, en El Pastor de Fílida $\left(158_{2}\right)$ haya notado el carácter de mera verdad poética de su novela: Entre estos amores y desdenes. jónde pacen poética de su novela: cEntre estos amores y desdenes..., zdónde pacen las ovejas? ¿A qué hora se ordeñan? (edic. MENENDEZ PELAYO, Origenes de la Novela, III, 464 a). Gentilmente responde Gálvez de Montalvo a esos posibles reparos. 
Retrocedamos ahora a nuestro punto de partida. Decíanos Cervantes (v. pág. 2I) que siempre su ingenio se había orientado en el sentido de la armonía y la consonancia, y nunca en el de la disparidad y disonancia. Esta consonancia puede darse objetivamente en la realidad, y ella es la base de lo que el autor entiende por belleza, siguiendo, como es sabido, las doctrinas neoplatónicas de León Hebreo: «Muéstrase - dice en la $G a$ latea - una parte de la belleza corporal en cuerpos vivos de varones y de hembras, y ésta consiste en que todas las partes del cuerpo sean de por sí buenas, y que todas juntas hagan un todo perfecto, y formen un cuerpo proporcionado de miembros y suavidad de colores» 1 .

Tal idea es, en efecto, un lugar común, corriente entre los lectores de los Diálogos de amor. Pero ya no es lugar común que Cervantes tome la idea de armonía y disonancia y la lleve, no al mundo objetivo, sino a la relación del sujeto y el objeto. Las distinciones que hemos visto hacer a los tratadistas de poética en Italia entre las diversas clases de verdad, se combinan en Cervantes con elementos psicológicos, y la verdad será, en último término, armonía con el punto de vista de quien la considere. Hay que poner, por tanto, mucho cuidado en la interpretación de lo que Cervantes entiende por verdad y mentira. Recuérdese el importante pasaje acerca de los libros de caballerías: "Y si a esto se me respondiese que los que tales libros componen los escriben como cosa de mentira, y que así no están obligados a mirar en delicadezas ni verdades, responderles hía yo que tanto la mentira es mejor cuanto más parece verdadera, y tanto más agrada cuanto tiene más de dudoso y posible. Hanse de casar las fábulas mentirosas con el entendimiento de los que las leyeren, escribiéndose de suerte que, facilitando los imposibles..., anden a un mismo paso la admiración y la alegría juntas, y todas estas cosas no podrá hacer el que huyere de la verisimilitud y de la imitación, en quien consiste la perfección de lo que se escribes ${ }^{2}$.

1 Ya notado en Ideas estéticas, 1884 , II, 108.

2 I, 47, RM, III, 383.
Sobre este texto suelen darse explicaciones demasiado literales, sin tener en cuenta el sentido histórico de las palabras de Cervantes. Bonilla ${ }^{1}$ observa: «Que la fábula sea verisimil, quiere decir, según Cervantes, que, sin ser verdad, «tire lo más que fuere posible a ella»; en cuanto a la imitación, quiere decir seguramente en Cervantes, lo mismo que en su guía el Pinciano: "remedo de la naturaleza». No muy preciso es tampoco lo dicho por Menéndez Pelayo ${ }^{2}$ sobre el pasaje en cuestión: «No quiere encerrar en estrechos moldes realistas [las leyes de la novela], como algunos le achacan, sino que ampliamente la dilata por todos los campos de la vida y del espíritu» ${ }^{3}$.

Recordemos, empero, la cita hecha del Viaje del Parnaso (pág. 2I):

que a las cosas que tienen de imposibles,

siempre mi pluma se ha mostrado esquiva;

las que tienen vislumbre de posibles...

explican mis borrones apacibles.

Y véase además este otro capital texto que se halla en Persiles $^{4}:$ "Es excelencia de la historia, que cualquiera cosa que en ella se escriba puede pasar al sabor de la verdad que trae consigo, lo que no tiene la fábula, a quien conviene guisar sus acciones con tanta puntualidad y gusto, y con tanta verisimilitud, que a despecho y pesar de la mentira, que hace disonancia en el entendimiento, forme una verdadera armonía.

Es decir, la verdad de la historia está garantizada en cualquier caso por la realidad objetiva de los hechos; la verdad ideal de lo inventado requiere trabazón y armonía subjetivas.

Para nuestro autor, lo posible y lo imposible, lo verosímil y lo inverosímil, no son algo meramente objetivo, sino que

1 Cervantes y su obra, 1916, pág. 107.

2 Ideas Estéticas, 1884 , II, 410 .

3 Bien es verdad que Menéndez Pelayo no concedía mayor importancia a lo que Cervantes opinara en este punto: alas esparcidas indicaciones de Cervantes, que sólo deben su mayor realce y perdurable vida a la prosa inmortal en que se hallans (Ibid., pág. 4I2).

vida a la prosa inmortal en que
4 Lib. III, cap. X, principio. 
depende de la relación del objeto con el sujeto, es decir, de un elemento ideal y subjetivo: "hanse de casar las fábulas mentirosas con el entendimiento» (Quijote); «la mentira hace disonancia en el entendimiento» (Persiles). Coordinado con esto, es forzoso interpretar el pasaje del Viaje del Parnaso, en que Cervantes afirma que siempre buscó en sus obras la «consonancia» y rechazó la «disparidad», como el programa consciente de un arte basado en idealismo renacentista. La armonía y el acuerdo no es sólo una cualidad objetiva ${ }^{1}$, sino un proceso activo de conocimiento ${ }^{2}$.

De esta suerte vamos viendo más claramente cuál sea en este punto el pensamiento de Cervantes ${ }^{3}$. Los Sres. Schevill y Bonilla, en la docta introducción que precede a su excelente edición de Persiles (pág. xvır), dicen, refiriéndose a lo mismo: "Todo esto sería de perlas si lo entendiésemos; pero desgraciadamente no tenemos el mismo concepto que Cervantes de lo que es "verisímil» y "puede pasar al sabor de la verdad».

La fuente de esta teoría de la doble verdad ${ }^{4}$ (la épicopoé-

1 \&Y puesto que el principal intento de semejantes libros sea el deleitar, no sé yo cómo puedan conseguirle, yendo llenos de tantos y tan desaforados disparates: que el deleite que en el alma se concibe ha de ser de la hermosura y concordancia que ve o contempla en las cosas que la vista o la imaginación le ponen delante; y toda cosa que tiene en sí fealdad y descompostura no nos puede causar contento alguno. Pues ¿qué hermosura puede haber, o qué proporción de partes con el todo?», etc. (Quijote, I, 47; RM, pág. 380).

2 "Otra vez se ha dicho que no todas las acciones verisímiles ni probables se han de contar en las historias, porque si no se les da crédito pierden su valor» (Persiles, III, 18; Rivad., I, 656 a).

Que la cosa no estaba clara lo revelan frases como éstas de un erudito habituado al discurso filosófico: «̨ $\mathrm{Y}$ qué decir de aquel continuo alegato de verisimilitud que el propio Cervantes hace en el Persiles, obra de las más inverisímiles que imaginarse pueden?» (BoniLLA, Cervantes y su obra, 1916, pág. 105).

En teoría, Cervantes admite la posibilidad de una verdad absoluta: «Me sucedió un caso, que si lo creyéredes, haréis mucho, y si no, no importa nada, puesto que la verdad ha de tener siempre su asiento, aunque sea en si misma» (Persiles, Rivad., I, 634 b). «La verdad bien puede enfermar, pero no morir del todo» (Ibíd., pág. $648 a$ ). tica y la histórica) está en L. Hebreo y en los preceptistas italianos, según hemos establecido. Nada más inexacto que hablar de la espontánea sencillez de Cervantes, de la imitación de la naturaleza, tal como vulgarmente se entienden dichos conceptos. Lo que la fábula pretende imitar no es la naturaleza que nos circunda, regida por las leyes objetivas de lo probable y lo necesario, sino una realidad ideal en la que se suponen vigentes (en virtud de un paralogismo) leyes análogas a las que rigen la realidad ${ }^{1}$. Lo decía muy claro en $\mathrm{I} 55 \mathrm{I}$ el poeta Girolamo Muzio en sus Rime diverse:

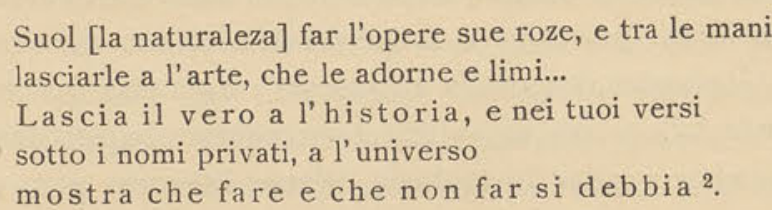

Tales ideas estaban claramente expuestas por el Pinciano: «En doctrina de Aristóteles, el poeta debe dejar lo posible no verisímil, y seguir lo verisímil aunque imposible» (pág. 206). «El poeta no es obligado a la verdad más de cuanto le parece que conviene para la verisimilitud» (pág. 22 I). S6́lo que Cervantes tuvo, al hacer el Quijote, la genial ocurrencia de presentar en dramática pugna ambas maneras de verdad, caso que a Robortelli y al Pinciano les habría causado espanto; y en Persiles insiste una y otra vez sobre el carácter de mera verdad poética que él quiso dar a su «verosímil» relato,

1 DDuplici modo fingere, et mentiri poetas, aut in rebus secundum naturam, aut in rebus praeter naturam. Si in rebus praeter naturam, id quoque duplici modo, aut in iis rebus, quae receptae jam sunt in opinionem vulgi, aut in rebus non ante unquam auditis aut narratis $\mathrm{ab}$ alio. $\mathrm{Si}$ is fiat secundum naturam, hoc est in omnium qui scribunt, uoluntate, arbitrioque positum... Si praeter naturam fiat, hoc non est cuiusvis: neque licet omnino, sed ex paralogis mo tantum figment

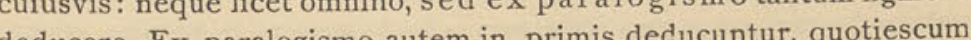
deducere. Ex paralogismo autem in primis deducuntur, quotescumque falsa pro veris sumuntur, quod declarabimus postea copiose (Roвor trill, Poética, edic. cit., pág. 76).

2 Comp. Spingarn, La critica letteraria nel Rinascimento, páginas $32-46$. 
que por ironía denominó Historia septentrional, a imitación de la Historia etiópica de Heliodoro ${ }^{1}$.

Es exacto ver en el esbozo de novela que se traza en el capítulo XLVII de la primera parte del Quijote, un plan de lo que iba a ser luego el Persiles ${ }^{2}$, "que se atreve a competir con Heliodoro», según dice el autor en el prólogo en sus come dias $^{3}$. Es innegable que Cervantes aspiró a hacer en este caso una obra conformada a los más estrictos cánones poéticos; quiso glorificar en ella «todas aquellas acciones que puedan hacer perfecto a un varón ilustre» ${ }^{4}$. Ya sabemos, por las poéticas de Italia, el sentido de este varón ilustre, depurado en sus costumbres, próximo a la perfección suma. Al escribir Persiles, Cervantes respondía a diversas exigencias que simultáneamente laboraban su espíritu; en primer lugar, darse el gusto de echar a volar la fantasía, placer literario para él de orden eminente ( «tal vez le vendrá ocasión de mostrarse nigromante, si quisiere»: ¡qué maravilla!). Además, la exigencia racional, de reglamentación, tan importante para Cervantes como el gusto de mecerse en el éter de la aventura: aquí del código literario de Aristóteles con sus escoliastas. Estamos en una época que ya no reconoce fueros al instinto. No sé si se ha notado bastante toda la importancia que el Pinciano concede a la Historia etiópica de Heliodoro ${ }^{5}$, modelo de Persiles:

Dice el Pinciano: «Tampoco la Historia de Etiopia es historia, sino que los autores, para autorizar sus escritos, les dan el nombre que se les antojas (pág. 122).

2. Schevill-Bonilla, edic. de Persiles, pág. vII.

3 Es muy interesante el estudio de Persiles en De Loliss, Cervantes reasionario, págs. ${ }_{11} 4-236$; pero el tono irónico o malhumorado del crítico lo priva de objetividad, y no vemos aquella importante obra bajo la luz que más le conviene.

4 I, 47 ; RM, III, 386.

5 «He caído en la cuenta que la Historia de Etiopia es un poema muy loado, mas en prosa» (pág. 107). «Será perfecta la heroica, cuanto a la materia, la que se funda en historia más que la que no se funda en alguna verdad mas la que carece de verdadero fundamento, puede tener mucho pinor y perfeción en su obra, y que en otras cosas aventaje a las que en verdad se fundamentan; yo, a lo menos, más
«Fué prudentísimo Heliodoro, que puso reyes de tierra incógnita y de quienes se puede mal averiguar la verdad o falsedad de su argumento ${ }^{1}$. Tengan esto en cuenta los críticos que tanto se enfadan con la fantástica geografía de Persiles. En fin, esta novela es obra de Contrarreforma: llena de moralidades, de pureza quimérica y, conociendo en conjunto a Cervantes, llena también de hipocresía, elemento esencial de la Contrarreforma cuando se trata de personajes como Cervantes, Campanella, Descartes, etc. A su hora lo veremos.

Un punto que ha dado lugar a discusión es el concepto que Cervantes tiene de la Poesía: "Una doncella tierna... a quien tienen cuidado de enriquecer, pulir y adornar otras muchas doncellas, que son todas las otras ciencias» ${ }^{2}$. En forma análoga se expresa en La Gitanilla y en el Viaje del Parnaso, lo que demuestra que estaba convencido de la excelencia científica de la poesía. Menéndez Pelayo vió en esto un error (véase antes pág. 22) que tenía sus orígenes en Santillana; Bonilla, con mejor acuerdo ${ }^{3}$, estima que se trata de «ideas dominantes en algunos preceptistas de la época», y cita al Pinciano, para quien la Poesía «comprende y trata de toda cosa que cabe debajo de la imitación, y por el consiguiente todas las ciencias especulativas». Pero conviene ahora

quisiera haber sido autor de la Historia de Heliodoro, que no de la Farsalia de Lucano» (pág. 444). Se citan juntas la Odisea, la Eneida y la Historia etiópica (dos veces en la pág. 465); iy De Lollis (pág. 140) atribuye a ignorancia de Cervantes el considerar como libro clásico Teágenes y Cariclea! (v. antes pág. 16.) Otras analogías hay entre Cervantes y el Pinciano, por ejemplo, la defensa de Amadis, no observada por los comentaristas al anotar el famoso escrutinio: «No hablo de un Amadis de Gaula ni aun del de Grecia y otros pocos, los cuales tienen mucho de bueno, sino de los demás, que no tienen verisimilitud ni doctrina, ni aun estilo grave, y por esto las decía un amigo mío salmas sin cuerpo» (pág. 45 I). Un caballero se desmaya leyendo «en Amadís la nueva que de su muerte trujo Archelaus» (pág. 95). «Toda comparación es odiosas (pág. 90)

1 Obr. cit., pág. 459.

2 II, I6; RM, IV, 326 , nota.

2 II, 16; RM, IV, 326, nota.
3 Cervantes y su obra, pág. 9 I. 
precisar algo más este punto, no vaya a pensarse que tal idea es un aditamento de erudición que ha venido a Cervantes por arrastre mecánico, siendo así que ello forma parte de sus doctrinas humanísticas, que no son en él ciertamente originales, como no son tampoco en el Pinciano; son, sí, reveladoras de su cultura y de su estado de espíritu. Considerar la Poesía como una disciplina de docencia, siquiera fuera del aspecto «universal» o idealizado de la realidad, es consecuencia necesaria de la reacción contra la poesía renacentista del arte por el arte: "Officium poetae ac finem esse apposita dicere ad admirationem» ${ }^{1}$. La Poesía, como conjunto de ciencias, respondía, de una parte, a la idea renacentista de no separar la erudición del genio; de otra, al propósito didáctico y moralizador de la Contrarreforma, dentro de la cual ha de ser situado Cervantes.

REGULACIÓN LITERARIA Y RACIONALISMO

De lo dicho hasta ahora sobre el pensamiento literario de nuestro escritor puede inferirse que una de sus máximas preocupaciones es lo que yo llamaría la regulación; aun las más frondosas fantasías se nos ofrecen acotadas por una línea ideal que las limita y define. Cervantes pugna por descubrir el módulo que rija la vida de los seres desde fuera a dentro, a manera de ley o norma; o de dentro a fuera, a manera de impulso vital y místico. Su obra consiste esencialmente en ofrecernos el poema de la armonía o el drama de la incongruencia: plegarse a la norma, adaptarse y comprender el impulso vital que rige a los demás son hechos que brotan en la gama armónica; salirse de la norma, errar en la conducta o en el pensar son resultado de no comprender, de no colocarse en la inclinación necesaria para que el destello de lo real llegue debidamente a nuestra retina. En el fondo, Cervantes está impregnado del amor a la divina razón, conquista suprema del Renacimiento.

Él no construye ciencia nueva, como Galileo o Descartes, porque su genio es de otra índole; pero conscientemente lleva

\footnotetext{
1 Véase Spingarn, Op. cit., pág. 46; Toffanin, Op. cit., pág. 23.
}

a su obra, como elementos creadores, los supuestos primarios de la cultura de su tiempo ${ }^{1}$.

De ese afán de regulación racional nace su teoría sobre el drama, todo lo inadmisible que se quiera, en oposición con sus mismas comedias, pero que estimo pueril seguir explicando como mero reflejo de la rivalidad entre Cervantes y Lope de Vega. Que esa animosidad matizase con más o menos viveza sus ataques a las comedias al uso, es muy probable; la teoría en sí es, sin embargo, netamente cervantina, en vista de las concordancias que estableceremos con otras zonas, muy ajenas al teatro y a Lope de Vega. Es frecuente en Cervantes el intento de encajar en normas y reglas formas muy varias de la actividad humana, dentro de la cual es un aspecto la literaria. Quiere regular el libro de caballería: «Si me fuera lícito... [dice el Cura] yo dijera cosas de lo que han de tener los libros de caballerías para ser buenos, que quizá fueran de provecho y aun de gusto para algunos» ${ }^{2}$.

El concepto de poesía, anteriormente analizado, forma parte de un intento de regulación: «Hala de tener, el que la tuviere, a raya, no dejándola correr en torpes sátiras ni en

\footnotetext{
1 Me produce contento hallar estas líneas de G. Lanson, ocasionalmente escritas sobre Don Quijote, pero que están plenamente a tono con mi manera de ver: «Je n'ai jamais fait une sétude» à proprement parler du symbolisme de Don Quichotte, et je me contente, sans pré tendre y rien apercevir que d'autres n' je me cont mieux vu, d'y tendre y rien apercevir que d'autres n'aient vu, et mie, wa, d'y recueillir ça et là ce qui est à mon usage, selon ma direction du moment, et pour ma nourriture intellectuelle. Je me plais d'y voir - cela n'a rien de nouveau - les dures leçons qu'inflige la réalité aux idéalistes qui se flattent de la dominer sans la connaitre. J'y entends une voix de poète faisant écho à la parole du philosophe: «Pour l'homme, sujet en même temps qu'interprète de la nature, le savoir est la mesure du pouvoir; on ne commande à la nature qu'en lui obéissant, Pendant qu'au Nord, Bacon définissat en ces formules abstraites l'a'au Nord, Bacon definissait en ces formules abstraites lattitude qui rend lactivite humaine efficace dans le domaine des sciences, au Midi, dans le même instant, Cervantès, par ses folies symboliques, faisait apparaître que la même condition s'impose à l'effort humain dans l'ordre moral et pratiques (en Don Quichotte à Paris. Une enquête littéraire, de V. García Calderón, 1916, pág. 53).
}

2 I, 32; RM, II, 496. 
desalmados sonetos», etc. ${ }^{1}$. El poeta ha de contar, sin duda, con el numen primario: «Posible cosa es que un oficial sea poeta, porque la poesía no está en las manos, sino en el entendimiento..., el poeta nascitur» ${ }^{2}$. Pero esa aptitud elemental, sin duda rara ${ }^{3}$, ha de combinarse con reflexión, experiencia y arte. En el Licenciado Vidriera ${ }^{4}$ se burla de "un poeta, de estos de la primera impresión»; y también en el Viaje del Parnaso ${ }^{5}$ : "Antes que el escuadrón vulgar acuda, De más de siete mil sietemesinos Poetas».

El espíritu preceptista nos trae como previos efluvios del siglo xviri. En El rufián dichoso recitan un deslavazado romance:

$$
\begin{aligned}
& \text { Lugo. } \quad \text { ¿Y este es el romance bravo } \\
& \begin{array}{l}
\text { Lugo. ¿Y este es el } \\
\text { que decías? }
\end{array} \\
& \text { Lagartija. Sullaneza } \\
& \text { y su buen decir alabo; } \\
& \text { y más, que muestra agudeza } \\
& \text { en llegar tan presto al cabo. } \\
& \text { Lugo. ¿Quién le compuso? } \\
& \text { Lagartija. } \\
& \text { Tristán, } \\
& \text { que gobierna en San Román } \\
& \text { la bendita sacristía, } \\
& \text { que excede en la poesía } \\
& \text { a Garcilaso y Boscán }{ }^{6} \text {. }
\end{aligned}
$$

¿No parece ya que habla el Moratín de La derrota de los pedantes?

El espíritu de reglamentación es marcadísimo en las ideas cervantinas sobre el teatro, que se han vulgarizado mucho por el fácil contraste que se nota entre la teoría y la práctica del

\footnotetext{
1 II, 16; RM, IV, 328

2 Persiles, Rivad., I, 5836 Bonilla, pág. 92).

4 Edic. cit., pág. 93

5 Edic. cit., pág. 20.
}

3 -Del infinito número de poetas que había eran tan pocos los buenos que casi no hacían número» (Licenciado Vidriera, edic. Schevill-

6 Edic. cit., pág. 14. autor ${ }^{1}$. Antes (pág. 22) cité la opinión de Schack, reproducida por Menéndez Pelayo. Cánovas del Castillo pensaba ${ }^{2}$ que Cervantes censuró el teatro por razones análogas a las que esgrime contra los libros de caballerías: «Entre la honda percepción de la realidad de Cervantes, y el casuísmo idealista del honor y el amor en la nueva dramática, hay un foso poco menos ancho que entre el Quijote y los libros de caballerías». Si escribe comedias es "por remediar la pobreza, sometiéndose por ganar dinero a la corriente del vulgo». Klein cree que esta claudicación de su doctrina dramática es análoga a la que representa Persiles respecto del Quijote ${ }^{3}$. La contradicción es, sin duda, evidente, y como es natural, sólo puede explicarse por vía psicológica, no meramente lógica, mostrando el camino que vaya de una a otra actitud.

Cervantes es refractario al arte vulgar. Su crítica de las comedias ${ }^{4}$ va precedida de esta declaración: «Puesto que es mejor ser loado de los pocos sabios que loado de los muchos necios, no quiero sujetarme al confuso juicio del desvanecido vulgo.» Cervantes habría comprendido el exabrupto de don Juan Ruiz de Alarcón en el prólogo a sus comedias: «Contigo hablo, bestia fiera.» Ahora bien: al teatro hay que ir contando con el público y su concepción de la vida, al menos cuando se trata de la sociedad en que surgió la comedia de Lope de Vega ${ }^{5}$, y Cervantes veía muy bien que él no era hombre para lanzarse ingenua y gallardamente al canto heroico de los ideales que integran el drama, ni para organizar un diálogo

1 «La musa teatral no hacía buenas migas con su ingenio, y de ahí que no pasara del noble propósito de componer comedias «que fuesen las mejores del mundo, o al menos razonables . No podrá menos de sonreír el lector moderno al tropezar con semejante frase y al pensar en que fué Cervantes quien la escribió. Y no es fácil de explicar lo que este último entendió por «razonable», porque poco de ello tienen las páginas del tomo de 1615'3 (Schevill-Bonilia, Comedias, VI, 67).

2 Véase Ríus, III, 165

3 Geschichte des span. Dramas, Ríus, III, 326.

4 II, 48 ; RM, III, 390 .

5 Véase el estudio sobre el teatro español al frente de mi edición de Tirso de Molina, 1922. ("Clásicos Castellanos».)

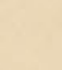

(1)


amoroso en forma directa y arrebatada. Veía en ello demasiados problemas intelectuales y literarios, y había de tomar garantías alejando de sí el asunto mediante la actitud crítica (ironía, sátira, contraposición de elementos), o usando una técnica inhibitoria (forma narrativa, sublimación de los sentimientos hasta lo irreal como en la Galatea y Persiles) ${ }^{1}$. No nos representamos a Cervantes escribiendo un diálogo de amor lopescamente:

$$
\text { - ¿Cómo estáis? }
$$

por vivir os vengo a ver ${ }^{2}$.

Esta incompatibilidad primaria con la técnica de la comedia lopesca se combina en nuestro escritor con las críticas que desde el punto de vista racional podían hacerse al teatro y que el mismo Lope formulaba: inobservancia de los precep tos y halago excesivo de la sensibilidad vulgar. Y de ello sale la diatriba antilopesca. Pero Cervantes es vanidoso y necesita fama; además en la comedia hay posibilidades que le encantan, lo mismo que en el libro de caballerías; él hubo de soñar con una comedia que fuese a las de Lope lo que Persiles a los Amadises, y quién sabe si con una sátira ${ }^{3}$.

En El rufián dichoso (II, 52 ), al condescender Cervantes obligadamente con el teatro lopesco, hace decir a la sComedia»:

$$
\begin{aligned}
& \text { Yo represento mil cosas } \\
& \text { no en relacioni, como de antes, } \\
& \text { sino en hecho, y así es fuerza } \\
& \text { que haya de mudar lugares. }
\end{aligned}
$$

Véase más adelante pág. 53

2 Caballero de Olmedo, Rivad., xxxiv, ${ }_{3} 8 \mathrm{r} a$. En la comedia $L a$ Entretenida (III, 73), Cervantes satiriza las actitudes sentimentales :

$$
\begin{aligned}
& \text { iLleve el diablo } \\
& \text { Que un hombre con sus amantes } \\
& \text { y con su espada al lado, } \\
& \text { que puede alzar en peso } \\
& \text { tere gima y se muestre de sardinas, } \\
& \text { más manso y más humilde } \\
& \text { que un santo capuchin }
\end{aligned}
$$

3 La brumosa e inquietante comedia La Entretenida debe consi-
Mas no pudo conseguirlo. La comedia que acabamos de analizar en nota revela cómo luchó Cervantes por salirse de los moldes usuales, y cómo fracasó. El teatro cervantino, dejando fuera los entremeses, es duro de leer en la actualidad, salvando algún que otro pasaje aislado.

derarse como un ensayo fracasado de parodia; ya lo notó Klein (en Ríus, III, 338): Así habría un grano de verdad en el cúmulo de neceCervantes, $\gg$ Al final de la obra dice Marcela algo que no ha sido comentado:

$$
\begin{aligned}
& \text { Yo quedaré en mi entereza, } \\
& \text { no procurando imposibles, } \\
& \text { sino casos conventibles } \\
& \text { a nuestra naturaleza. }
\end{aligned}
$$

Tenemos aquí el tema, antes señalado (pág. 46), de la armonía y conveniencia. ¿Pero en qué ha faltado Marcela a la naturaleza? Difícil es decirlo. Quién sabe lo que Cervantes proyectó y no desarrolló. He aquí brevemente el asunto central de la pieza: D. Antonio está enamorado de Marcela de Osorio, dama evanescente, que no aparece en la comedi. Su padre la tiene clasurada en un convento. Ahora bien: Tarcela de Almer a la otra Marcela, lo que añadido a la ignaldad del nombre, produce en D. Antonio actitudes equívocas, lindantes con el amor incestuoso, que Marcela observa inquieta y, al mismo tiempo, con morbosa complacencia:

$$
\begin{aligned}
& \text { Marcela. isiquiera no me dirás } \\
& \text { D. Antonio. Como te llamas, se llama. } \\
& \text { Marcela. ¿Como yo? Y ín tiene más, } \\
& \begin{array}{ll}
\text { Marcela. } & \text { que se te parece mucho. } \\
\text { [Ap.] iVálame Dios! :Qué es aquesto? } \\
\text { ¿Si es amor este de incesto? }
\end{array} \\
& \text { Con varias sospechas lucho. } \\
& \text { D. Antonio. } \\
& \begin{array}{r}
\text { Como vos, } \\
\text { Y está bien encarecido. }
\end{array} \\
& \text { Marcela. } \quad[A p \cdot] \text { El seso tiene perdido }
\end{aligned}
$$

Pero con malsana curiosidad, Marcela observaba a su hermano, y alguna desilusión se entera de ser otra mujer el objeto de su amor:

Y yo, simple, imaginaba
ser yo la hermosa Marcela

a quien mi hermano llamaba 
Cervantes percibió la inferioridad de su arte dramático y la ineficacia de las normas racionales que él soñaba aplicar. Er prólogo de las comedias de I6I 5 revela que no le contentaban demasiado aquellas producciones. Compárese el tono. firme que usa en el Quijote ante las objeciones de sus adversarios, sus réplicas seguras e irónicas, con las tristes razones de este prólogo: «... si un autor de título no le hubiera dicho que de mi prosa se podía esperar mucho, pero que del verso, nada». "Querría que fuesen las mejores del mundo, o a lo

$$
\begin{array}{ll} 
& \text { a las manos le miraba, } \\
\text { a los ojos y a la boca, } \\
\text { y con no advertencia poca } \\
\text { ponderaba sus razones, } \\
\text { sus movimientos y acciones. } \\
\text { Dorotea. } \\
\text { Curiosidad simple y loca. } \\
\text { Marcela. } \\
\begin{array}{l}
\text { Píele perdón. No quiero, } \\
\text { pues nunca arraigó en mi pecho } \\
\text { el pensamiento primero. }
\end{array}
\end{array}
$$

Lo extraordinario es que Marcela cuenta esto a su prometido Car denio; el pensamiento incestuoso surgió en ella, aunque no arraigó en su pecho. Poco antes, en esta misma segunda jornada, Marcela dice hablando de Cardenio (que aspira a casarse con ella, fingiendo ser el primo indiano que aguardaban):

$$
\begin{aligned}
& \text { Este primo no me agrada } \\
& \text { dulce amiga Dorotea. }
\end{aligned}
$$

Más adelante (pág. II 2 ), cuando aparece el verdadero primo (D. Silvestre) y la boda fracasa por no conceder el Papa la dispensa del parentesco, Marcela se limita a decir:

$$
\begin{aligned}
& \text { Casamientos de parientes } \\
& \text { tienen mil inconvenientes. }
\end{aligned}
$$

Y se queda soltera. Lo único que parece haber estremecido a esta dama frívola y espectral es la emoción equívoca que creyó hallar en su hermano. Sólo como alusión a ésto se pueden explicar los versos:

$$
\begin{aligned}
& \text { No procurando imposibles, } \\
& \text { si no casos convenibles } \\
& \text { a nuestra naturaleza. }
\end{aligned}
$$

Y la declaración final:

$$
\begin{aligned}
& \text { Que acaba sin matrimonio } \\
& \text { la comedia Entretenida. }
\end{aligned}
$$

es una manifiesta crítica de las comedias al uso. menos razonables; tú lo verás, lector mío.» Y que estaba lejos de haber logrado su aspiración se desprende de las últimas palabras: "para enmienda de todo esto le ofrezco una comedia que estoy componiendo, y la intitulo El engaño a los ojos, que, si no me engaño, le ha de dar contento». Ni con reglas ni sin reglas llegaba Cervantes a componer comedias al gusto de la época y de acuerdo con sus exigencias íntimas. En la segunda jornada de El rufián dichoso dialogan la « $\mathrm{Cu}$ riosidad" y la "Comedia», y dice ésta:

$$
\begin{aligned}
& \text { Los tiempos mudan las cosas } \\
& \text { y perficcionan las artes, } \\
& \text { y añadir a lo inventado } \\
& \text { no es dificultad notable. } \\
& \text { Buena fuí pasados tiempos, } \\
& \text { y en estos, si los mirares, } \\
& \text { no soy mala, aunque desdigo } \\
& \text { de aquellos preceptos graves } \\
& \text { que me dieron y dejaron } \\
& \text { en sus obras admirables } \\
& \text { Séneca, Terencio y Plauto. }
\end{aligned}
$$

¿Palinodia? Más bien desilusionada claudicación. El racionalismo de Cervantes, al salir del plano estético, se convertía en política pedagógica: "Todos estos inconvenientes cesarían... con que hubiese en la Corte una persona inteligente y discreta que examinase todas las comedias antes que se representasen; no sólo aquellas que se hiciesen en la Corte, sino todas las que se quisiesen representar en España, sin la cual aprobación, sello y firma ninguna justicia en su lugar dejase representar comedia alguna» ${ }^{1}$. Cervantes debí ver que más arduo que el establecimiento de este artilugio policíaco era el dar con el criterio artístico que habría de imponerse a obras cuyo sentido consistía ante todo en agradar al público. Él no podía competir con el «Monstruo de la Naturaleza», no por deficiencia de fantasía, sino por carencia de lirismo y exceso de ironía y de crítica. Y entonces aquel espíritu elástico, ducho en hipócritas artimañas, se replegó. En el prólogo a sus co-

1 I, 48 ; RM, III, 402 
medias (I6I 5) canoniza a Lope; en La guarda cuidadosa (I6I I), se asocia al coro de lopófilos: «Poco se me entiende de trovas; pero éstas me han sonado tan bien, que me parecen de Lope, como lo son todas las cosas que son o parecen buenas» ${ }^{1}$; en El. rufián dichoso (posterior a 1609) entona el elogio de la "comedia nueva». La cual no impide que al final de Pedro de Urdemalas (I6IO-I6I I) se diga de la comedia al uso:

\section{Parió la dama esta jornada,}

$y$ en otra tiene el niño ya sus barbas,

y es valiente y feroz, y mata y hiende, etc.

En la segunda parte del Quijote ${ }^{2}$ vuelve a la carga: « ¿No se representan por ahí, casi de ordinario, mil comedias llenas de mil disparates? ... Prosigue, muchacho, y deja decir; que como yo llene mi talego, siquiera represente más impropiedades que tiene átomos el Sol.» El dardo va certero a Lope de Vega.

En Persiles ${ }^{3}$ un poeta querría hacer una comedia con las aventuras de Periandro: «Pero no acertaba en qué nombre la pondría, si la llamaría comedia o tragedia, o tragicomedia, porque si sabía el principio, ignoraba el medio y el fin, pues aún iban corriendo las vidas de Periandro y Auristela...; pero lo que más le fatigaba era pensar cómo podía encajar un lacayo consejero y gracioso en el mar y entre tantas islas, fuego y nieves, y con todo esto no se desesperó de hacer la comedia y de encajar el tal lacayo, a pesar de todas las reglas de la poesía y a despecho del arte cómico.» Finalmente, el poeta desiste de su intento: «Miróse a los pies de su ignorancia, y deshizo la rueda de su vanidad y locura.»

Cervantes, no obstante la rectificación de El rufián di-

1 Edic. cit., IV, 69; Comp. Rennert y Caśtro, Vida de Lope de Vega, pág. 380 .

2 Cap. XXVI, RM, V, 63

3 Rivad., I, 626 choso, sigue, en efecto, donde antes ${ }^{1}$. El afán preceptista y antivulgar tenía raíces muy hondas en su pensamiento. La vacilación que hemos notado en sus opiniones se explica por la necesidad de justificar sus comedias, que por fuerza aspiraban a seguir la corriente, aunque no llegaran a gozar del favor público. La estructura misma de la mente cervantina impidió que su teatro rebasara aquel mediocre nivel ${ }^{2}$.

Los intentos de regulación literaria que acabo de analizar no son sino un aspecto de la actitud racional que caracteriza el conjunto del pensar cervantino ${ }^{3}$. La preocupación de cómo deban ser las cosas es en él obsesionante. Si le restáramos la fantasía poética, nos hallaríamos frente a un posible moralista del Renacimiento. Reunidas todas las sentencias y máximas de las distintas obras, forman un buen manual de moralidad.

He aquí ejemplos de esa preocupación racional: «Verá el mundo que tiene contigo más fuerza la razón que el apetito» ${ }^{4}$. «Sin que en la compra hayan intervenido pujas, que

1 En El coloquio de los perros (edic. Clás. Cast., 321 y 326 ) presenta a esto de la poesia, me pareció que la había compuesto el mismo Satanás.» En El relablo de las maravillas ya había presentado a un grotesco lincenciado Gomecillos (lindo precedente del D. Eleuterio de Moratín): «Pícome de la farándula y de la carátula; veinte y dos comedias tengo, todas nuevas, que se ven las unas a las otras, y estoy aguardando coyuntura para ir a la corte y enriquecer con ellas media docena de autores, (edic. cit., IV, I II)

2 Creo un eror la idea de Meńn Pelayo: «Nadie menos improvisador que él, excepto en su teatros (Cultura literaria de Cervantes, pág. 29). No hay aquí más improvisación que en sus novelas. 3 Que yo sepa, no ha sido examinado en conjunto y en detalle este aspecto de Cervantes; sólo conozco observaciones imprecisas. Compárese: «Cervantes era un verdadero español; pero el espíritu crítico que en él se albergaba, el genio reformador que le animaba eran ajenos a su patria. En esto es único, pero justamente en esto se fundaban la lionalista de su juiban la universad le su poesía (K. Roswawn Die Poesie und ihre Geschichte, 1855; Ríus, III, 287).

Geschichte, I855; Ríus, I
4 I, $36 ;$ RM, III, 126. 
se fundan más en rencor y fantasías que en razón» ${ }^{1}$. «Vieron mil diferentes géneros de muertes, de quien la cólera, sinrazón y enojo, suelen ser inventores» ${ }^{2}$.

$\mathrm{La}$ ponderación y la medida se manifiestan en viejas fórmulas aristotélicas, muy del gusto del autor: «No seas siempre riguroso, ni siempre blando, y escoge el medio entre estos dos extremos, que en esto está el punto de la discreción» ${ }^{3}$. "Bien sé lo que es valentía, que es una virtud que está puesta entre dos extremos viciosos, como son la cobardía y la temeridad» ${ }^{4}$. «El que le llevaba a cargo era un mayordomo del Duque, muy discreto y muy gracioso (que no puede haber gracia donde no hay discreción)» ${ }^{5}$ «No son burlas las que redundan en desprecio ajeno» ${ }^{6}$. «No es buena la murmuración, aunque haga reír a muchos, si mata a uno»?

Cálculo y reflexión piden constantemente los más representativos personajes ${ }^{8}$. Recuérdese la aparición imprevista de aquella zagala que dispara a los viajeros del Persiles esta enigmática pregunta: «Señores, \{pedirlos he o darlos he?» Periandro, entendiendo que son celos, le contesta : «Ni los pidas ni los des; porque si los pides, menoscabas tu estimación, y si los das, tu crédito; y si es que el que te ama tiene entendimiento, conociendo tu valor, te estimará y querrá bien; y si no le tiene, ¿para qué quieres que te quiera?» ${ }^{9}$. La joven Constanza, casada in articulo mortis con el Conde,

1 Persiles, Rivad., I, 671 a.

2 Ibid., $570 b$.

3 II, 5 I; RM, VI, 46.

4 II, I7; RM, IV, 352. - Comp.: :Siempre los medios fueron alabados en todas las cosas, como vituperados los extremos; que si abrazamos la virtud más de aquello que basta, el sabio granjeará nombre de loco y el justo de inicuo» (Galatea, II, 66).

5 II, 44 ; RM, V, 379 .

6 Viscaino fingido, IV, $8 \mathrm{r}$.

7 Coloquio, edic. Clás. Cast., pág. 224.

sLos gustos de los discretos hanse de medir con la razón, y no con los mismos gustos» (Persiles, Rivad., I, 593 a).

9 Rivad., I, $646 b$. dice: "Yo hago voto...» Pero apenas dijo esta palabra, cuando Auristela la atajó: «¿Qué voto queréis hacer, señora?» «De ser monja», respondió la Condesa. "Sedlo y no le hagáis - replicó Auristela - , que las obras de servir a Dios no han de ser precipitadas, ni que parezcan que las muevan accidentes» ${ }^{1}$. «Señor - respondió Sancho - , que el retirar no es huir, ni el esperar es cordura, cuando el peligro sobrepuja a la esperanza, y de sabios es guardarse hoy para mañana y no aventurarse todo en un día” ${ }^{2}$.

En Pedro de Urdemalas (III, I20) se dice que

$$
\text { es razón }
$$

que se lleve el corazón

tras sí de cualquier mujer,

no el querer, sino el tener

del oro la posesión.

Es curioso que Cervantes sobreponga la reflexión y el razonamiento al sentimentalismo patriótico tan de moda entonces. Véase cómo discurre acerca de la pérdida de la Goleta : "A muchos les pareció, y así me pareció a mí, que fué particular gracia y merced que el cielo hizo a España en permitir que se asolase aquella oficina y capa de maldades, y aquella gomia o esponja y polilla de la infinidad de dineros que allí sin provecho gastaban, sin servir de otra cosa que de conservar la memoria de haberla ganado la felicísima del invictísimo Carlos $\mathrm{V}{ }^{3}$.

Con frecuencia aparecen reflejos de la vigilancia que el autor ejerce sobre el estilo de su obra: "Con menos palabras y más sucintos discursos pudiera Periandro contar los de su vida..., porque los episodios que para ornato de la historia se ponen, no han de ser tan grandes como la misma historia» 4 .

\footnotetext{
1 Rivad., $641 \mathrm{I} a$.

2 I, 23 ; RM, II, 225.

3 I, 39; RM, III, 18 r.

4 Persiles, pág $6 \mathrm{I} b$. La preocupación por la forma que deba ir dando a su obra es obsesionante en Persiles: «Por abreviar mi histo-
} 
Resultado de esta continua valoración y crítica de los actos humanos es la excogitación de reglas y fórmulas a las cuales deban amoldarse las actividades y profesión de cada uno. "Cuando algún pintor quiere salir famoso en su arte, procura imitar los originales de los más únicos pintores que sabe; y esta mesma regla corre por todos los más oficios o ejercicios de cuenta que sirven para adorno de las repúblicas» ${ }^{1}$

He aquí cómo se forma el actor de comedias:

$$
\begin{aligned}
& \quad \text { Pues claro se entiende } \\
& \text { que el recitar es oficio } \\
& \text { que a enseñar, en su ejercicio, } \\
& \text { y a deleitar sólo atiende, } \\
& \text { y para esto es menester } \\
& \text { grandísima habilidad, } \\
& \text { trabajo y curiosidad, } \\
& \text { saber gastar y tener, } \\
& \text { que ninguno no le haga } \\
& \text { que las partes no tuviere, } \\
& \text { que este ejercicio requiere... } \\
& \text { Preceda examen primero } \\
& \text { o muestra de compañía, } \\
& \text { y no por su fantasía } \\
& \text { se haga autor un pandero }{ }^{2} \text {. }
\end{aligned}
$$

ria, pues no hay razonamiento que, aunque sea bueno, lo parezca $(572 a)$. $« \mathrm{El}$ autor de esta historia... a este segundo capítulo le dió cuatro o cinco principios, casi dudando qué fin en él tomarías (59ic). Temor a aburrir al lector: Mauricio y Ladislao juzgan la plática de Periandro caloo larga y traída no muy a propósitos (607 a). cPerindro amigo, que puesto que the no te canses de contar tus desgacias, a nosotros nos fatiga el oirlas, por ser tantas $(609 b)$. Las razones, ecuando son largas, aunque sean buenas, antes enfadan que alegrans (6I $4 a$ ). * De cuán poco gusto son las digresiones en cualquiera narración cuando ha de ser sucinta y no dilatada» $(614 b)$. «Pues las menudencias no piden ni sufren relaciones largas, se dejarán de contar las que allí pasaron» $(618 b)$. «Algunos de los más oyentes se holgaron de que Periandro pusiese fin en su plática, porque las más veces las que son isc, an lo mismo en el Quijote: sLas cules no digo yo ahora, porque de la proijidad se suele engendrar el fastidio» (II, 26; RM, IV, 60).

1 I, $25 ;$ RM, II, 28 r.

2 Pedro de Urdemalas, III, 225.

Esta idea del examen vuelve a aparecer en otras obras:

Algarroba. Pues se hace examen de barberos,

de herradores, de sastres y se haz

de cirujanos y otras zarandajas,

también se examinasen para alcaldes,

$\mathrm{y}$ al que se hallase suficiente y hábil

para tal menester, que se le diese

carta de examen ${ }^{1}$.

Cervantes no podía admitir que cualquier sujeto desempeñara cargos de autoridad. El gobierno de Sancho es una sátira, pero llena de complicaciones, por cruzarse aquí dos temas: el de la necesidad de regular racionalmente las profesiones y el de la justicia, como virtud espontánea, que a su hora analizaré. En principio hace falta que el gobernador sea instruído: "Por muchas experiencias sabemos que no es menester ni mucha habilidad ni muchas letras para ser uno gobernador, pues hay por ahí ciento que apenas saben leer y gobiernan como unos girifaltes» ${ }^{2}$, y Sancho acabará por declarar: "Yo no nací para ser gobernador» ${ }^{3}$. Tan amarga confesión debe conexionarse con este pasaje del Laberinto de amor (II, 265):

Hay algunos tan simplones,

que desde su mulada:

se ponen a gobernar

mil reinos y mil naciones:

dan trazas, forman estados

y repúblicas sin tasa,

y no saben en su casa

gobernar a dos criados ${ }^{4}$.

1 Alcaldes de Daganzo, IV, 46

2 II, $32 ; \mathrm{RM}, \mathrm{V},{ }_{175}$.

3 II, $53 ;$ RM, VI, 85

4 Compárese la respuesta de Don Quijote al Canónigo: «̨̨No hay más sino a troche moche entrarse por las casas ajenas a gobernar sus más sino a troche moche entrarse por las casas ajenas a gobernar sus dueños, y habiéndose criado algunos en la estrechez de algún pupila-
je...?3, etc. (II, 32; RM, V , I52). Cervantes coincide aquí con la docje...3s, etc. (II, $32 ; \mathrm{RM}, \mathrm{V}, \mathrm{I}_{2}$ ). Cervantes coincide aquí con la doctrina humanista, representada por sujeto tan calificado como Pedro dos a los que estudian, sin que primero hubiesen hecho muchos actos 
Cervantes da a Sancho un curso de moral antes de ponerlo de gobernador: "Nunca te guíes por la ley del encaje, que suele tener mucha cabida con los ignorantes que presumen de agudos» ${ }^{1}$. El lector recuerda los restantes consejos. Menos divulgados están rasgos parecidos dispersos en otras obras:

Nunca deshonraría al miserable que ante mí le trujesen sus delitos: que suele lastimar una palabra de un juez arrojado, de afrentosa,

mucho más que lastima su sentencia

aunque en ella se intime cruel castigo ${ }^{2}$.

En dominio muy distinto hallamos reacción análoga en la mente cervantina. Son frecuentes las referencias a la esgrima ${ }^{3}$ y en el Quijote se declara el autor partidario de la esgrima por reglas, tal como la enseñaban Carranza y sus secuaces: "Mirad, Bachiller - respondió el Licenciado - : vos estáis en la más errada opinión del mundo acerca de la destreza de la espada, teniéndola por vana.» ${ }^{4}$ Corchuelo se vale de treza moderna y zafia», pero queda lamentablemente vencido por el diestro matemático, de lo que sacaron testimonio «para que se conozca y vea con toda verdad cómo la fuerza vencida del arte».

y demostraciones de cómo han estudiado muy bien esta parte de filosofía, y no solamente se debía hacer esto en las Universidades y públicas escuelas, sino también en los demás pueblos granados, y no en lenguas extrañas, sino en la propia, para que en ellos se criasen muchos hombres de gobierno..., porque de aquí sucedería os que sirviesen a Vuestra Majestad en materia de bierno, entenderían en qué consiste el bien go de y no irían a una cosa de tanto peso y momento, tan fatos debernar, como van a etc. (Apuntamientos de como se deberina Como van", etc. (Apuntamientos de cómo se deben reformar las doctrinas, Rivad., LXV, 296 b)

1 II, $42 ; \mathrm{RM}, \mathrm{V}, 35^{2}$.

2 Alcaldes de Daganzo, IV, 50.

3 Certamen de esgrima en Persiles, pág. $5^{89} a$; enseñan una treta

de esgrima en el Rufián dichoso, II, 93.

4 II, I9; RM, IV, 391-394.
Tal doctrina es típica del Renacimiento, y la hallamos en el Cortesano, de Castiglione, repertorio maravilloso de temas renacientes, cuya acción sobre Cervantes fué muy sensible, aunque nadie la haya estudiado. «El que fuere más diestro — dice el Conde ${ }^{1}$ - estará más cerca de llevar lo mejor y con menos peligro. $\mathrm{Y}$ lo que algunos dicen que en las afrentas, donde más es menester, allí todo el artificio y toda la destreza se olvidan, no lo apruebo, porque, ciertamente, los que en tal tiempo pierden el arte, de creer es que ya de miedo tenían perdido el corazón y el seso.»

Ahora bien: Cervantes no es sólo un portador de temas de su época; por característico que esto sea de su pensamien to, no es en él menos esencial la reelaboración crítica de los puntos de vista que su época le ofrece. Ante el exceso racionalista surge la reacción de lo vital y espontáneo, en cierto modo, como lo particular se oponía a lo universal en el plano de la fantasía. Bien está la esgrima racional; pero el loco de Vidriera, que no deja descansar el magín, dijo de los diestros que «eran maestros de una ciencia o arte que, cuando la habían menester, no la sabían, y que tocaban algo en presuntuosos, pues querían reducir a demostraciones matemáticas, que son infalibles, los movimientos y pensamientos coléricos de sus contrarios ${ }^{2}$. ¿Cabe más fina observación acerca de la diferencia entre lo racional y lo emotivo? Cervantes es un racionalista que nos da los límites de lo racionalmente estructurable: «Arremetieron el uno contra el otro, $y$, sin mirar reglas, movimientos, entradas, salidas y compases, a los primeros golpes, el uno quedó pasado el corazón de parte a parte, y el otro abierta la cabeza por medio» ${ }^{3}$.

Este vaivén entre lo que «debe ser» y lo que «es» o "puede ser», explica esas posturas, a veces antagónicas, del pensar cervantesco que actúa como un inmenso péndulo. Al

1. Edic. «Libros de antaño», pág. 64 . Es lamentable que la Casa Calleja haya reeditado este importantísimo libro con supresión de uno de sus capítulos.

2 Edic. Clás. Cast., pág. 66

Persiles, pág. $586 b$. 
comprobar esta manera suya en uno y otro caso, hay que prescindir de buscar explicaciones casuísticas, como las ideadas con motivo de sus contradictorias doctrinas acerca del teatro. El lector irá viendo que las opiniones dramáticas se incluyen dentro de un sistema más amplio. Tomemos, en efecto, otro ejemplo. La razón dice a Cervantes que «esto que el vulgo suele llamar comúnmente agüeros, que no se fundan sobre natural razón alguna, del que es discreto han de ser tenidos y juzgados por buenos acontecimientos. Levántase uno destos agoreros por la mañana, sale de su casa, encuéntrase con un fraile de la orden del bienaventurado San Francisco, y como si hubiera encontrado con un grifo, vuelve las espaldas, y vuélvese a su casa..., como si estuviese obligada la Naturaleza a dar señales de las venideras desgracias con cosas de tan poco momento como las referidas. El discreto y cristiano no ha de andar en puntillos con lo que quiere hacer el cielo» ${ }^{1}$.

Esto está muy bien; no hay que intentar adivinar el porvenir, sobre todo a base de pequeñeces, porque ello no se funda sobre «natural razón»; ¿pero y el atractivo de la astrología?, dy si hubiera posibilidad de que fuera una ciencia? Más adelante (pág. 94) examinamos lo que Cervantes pensara sobre ese punto, aunque desde ahora podemos considerarlo como una de esas oposiciones características en la mente del autor.

El prurito de preceptismo es tal que llega hasta detalles minúsculos. ¿Cómo se debe casar el rey? $\mathrm{He}$ aquí la fórmula: «Si, por ventura, te dieren lugar de que discurras por el camino de la razón, quiero que tal vez consideres quién eres..., mira que los reyes están obligados a casarse, no con la hermosura, sino con el linaje.» ${ }^{2}$ ¿Cuándo hay que desenvainar la espada poniendo en peligro las vidas y haciendas? Por cinco cosas: «La primera, por defender la fe católica; la segun$\mathrm{da}$, por defender su vida...; la tercera, en defensa de su honra...;

1 II, 58; RM, VI, $16 \mathrm{I}$

2 Persiles, pág. 595 a. la cuarta, en servicio de su rey...; la quinta..., en defensa de su patria». ¡Y aún admite Don Quijote otras causas más! Parece que glosamos un código ${ }^{1}$.

¿Cuándo debemos llorar? «Por tres cosas es lícito que llore el varón prudente: la una, por haber pecado; la segunda, por alcanzar perdón dél; la tercera, por estar celoso; las demás lágrimas no dicen bien en un rostro grave» ${ }^{2}$. ¿Cómo debe ser la mujer principal? «Ha de ser anejo a la mujer principal el ser grave, el ser compuesta y recatada, sin que por esto sea soberbia, desabrida y descuidada» ${ }^{3}$. ¿Y el consejero? «El que lo ha de ser requiere tener tres calidades: la primera, autoridad; la segunda, prudencia, y la tercera, ser llamado" ${ }^{4}$, etc.

Ascendamos, sin abandonar este dominio, a puntos de vista más amplios. La vida marcha para Cervantes como un acompasado mecanismo, en cuyo ritmo no debería caber perturbación. No hay que contar con el milagro que rompe la serie encadenada de la causalidad. La fórmula de enmienda que Don Quijote propone a Roque Guinart refleja ese modo racional de encararse con los procesos de la conducta: «El prin cipio de la salud está en conocer la enfermedad y en querer tomar el enfermo las medicinas que el médico le ordena..., el cielo o Dios, por mejor decir, que es nuestro médico, le aplicará medicinas que le sanen, las cuales suelen sanar poco a poco, y no de repente y por milagro; y más que los pecadores discretos están más cerca de enmendarse que los simples» ${ }^{5}$. A la virtud se va, pues, mediante el conocimiento ${ }^{6}$ y la acción natural de las fuerzas que actúan sobre nuestra conducta; el cielo, o Dios, significan en este caso la naturaleza, la

\footnotetext{
1 II, 27 ; RM, V, 87.

2 Persiles, pág, 596 a

3 Ibid., pág. 599 a.

4 Ibid., pág. $599 a$.

$\begin{array}{ll}4 & \text { Ibid., pág. } 595 a \text {. } \\ 5 & \text { II, 6o; RM, VI, } 227\end{array}$

II, 6o; RM, VI, 227.
6 Vibran aquí los ecos de Erasmo: «Aquella sentencia de Sócrates no va muy fuera de camino, aunque reprehendida de Aristóteles. Dice él que no es otra cosa virtud, sino una ciencia o verdadero conocimiento de las cosas..., Enquiridion, Amberes, 1555, fol. 109.
} 
cual, en efecto, no obra sobre la voluntad «de repente y por milagro». En Persiles ${ }^{1}$ leemos «que los milagros suceden fuera del orden de la naturaleza, y los misterios son aquellos que parecen milagros y no lo son, sino casos que acontecen raras veces».

Esto último es de gran importancia. Al paso, sin detenerse en ello, revela Cervantes conocer la doctrina, moderna en su tiempo, acerca de los milagros, según la cual éstos no son más que hechos insólitos, cuya causa natural se ignora. Tal idea, propagada en el Renacimiento, sobre todo por Pomponazzi en De incantationibus ( 1556 ), toma su origen en el $D e$ divinatione de Cicerón: "La ignorancia de las causas en un hecho nuevo produce admiración; pero esa misma ignorancia no nos causa maravilla cuando se refiera a hechos acostumbrados» ${ }^{2}$. Cierto es que Cervantes admite que «los milagros suceden fuera del orden de la naturaleza»; pero introduce esa categoría del misterio, del milagro aparente, cuyo carácter milagroso procede sencillamente de que «acontecen raras veces», «insueta et rarissima facta», como decía Pomponazzi, uno de los patriarcas del racionalismo moderno. Aceptado el punto de vista de Cervantes, ¿dónde trazar la raya entre milagros de verdad y milagros de apariencia? ${ }^{3}$. ¿No convienen

1 Rivad., 591 $b$.

2 II, 22: «Causarum enim ignoratio in re nova mirationem facit: eadem ignoratio si in rebus usitatis est non miramur.s Antes dice: «Mulae partus prolatus est a te, res mirabilis propterea quia non saepe fit; sed si fieri non potuisset facta non esset. Atque hoc contra omnia ostenta valeat, nunquam quod fieri non potuerit esse factums ('valga esto contra todos los prodigios: nunca acaece lo que no pudo ser hecho'). Pomponazi dirá: Non sunt autem miracula qua no puo ('va heso'). Ponpo sint totaiter contra naturam sed pro tanto dicuntur miracula quia insueta et rarissima facta, et non secundum communem naturae cursum , (De incantationibus, XII, 293). Véase Busson, Les sources et le développement du rationalisme, I922, pág. 44.

3 La cosa preocupaba a Cervantes. Una de las disposiciones de Sancho en su gobierno fué sque ningún ciego cantase milagro en coplas, sino trujese testimonio auténtico de serverdadero, porparecerle que los más que los ciegos cantan son fingidos, en perjuicio de ambos en ser raros acaecimientos, fuera de las leyes conocidas de la naturaleza? La solución para Cervantes será, como para Montaigne y tantos otros hombres del Renacimiento, confiarse al criterio de la Iglesia, por definición indiscutible. La mole dogmática quedará allá, muy respetada; tanto, que lo mejor es no acercarse mucho a ella y abandonarla a su severa inmutabilidad. La obra humana continuará su camino, apoyada en el delicado báculo de la razón. Se construye asî la doble verdad: la de la fe y la de la razón, fórmula de Pomponazzi, que hará suya la Contrarreforma como el medio más seguro de eludir compromisos. Pero luego volveremos sobre este aspecto, al que aludo ahora, para delimitar el concepto del racionalismo cervantino.

Como la historia de nuestro racionalismo está por escribir, es difícil citar muchos precedentes españoles de la mencionada doctrina acerca de los milagros. Antes de Pomponazzi, encontramos entre nosotros observaciones de aire muy moderno, fruto, sin duda, del erasmismo y del influjo de los italianos del siglo xv, de cuya acción intelectual sobre los españoles tan poco sabemos. Dice, por ejemplo, Fr. Martín de Castañega en su Tratado muy sotil y bien fundado de las supersticiones y hechicerias ${ }^{1}$ : "Las virtudes naturales son tan ocultas en la vida presente a los entendimientos humanos, que muchas veces vemos la experiencia y obras maravillosas y no sabemos dar la razón dellas, salvo que es tal la propiedad de las cosas naturales y que a nosotros es oculta,

los verdaderos», II, 5 I; RM, VI, 56. En El rufián dichoso insisten las acotaciones, con persistencia que sorprende, sobre la autenticidad histórica de los milagros allí representados: «Todo esto es verdad de la historia... Todo esto desta máscara y visión fué verdad, que assí lo cuenta la historia del Santo... Todo esto fué assí, que no es visión supuesta, apócrifa ni mentirosa... Esta visión fué verdadera, que ansí se cuenta en su historia... Todo fué ansí, (IV, 66, 69,70, 89, 94) Puede ser que me engañe; pero mi impresión es que el autor, muy ladinamente, 1irso o Calderón? 
como es la propiedad natural y virtud oculta de la piedra ymán.» Cita otros cuerpos que calentándolos por frotación atraen materias leves, y prosigue: "Otramente a cada passo terníamos necessidad de atribuir tales obras a miraglo. Lo qual es contra los dotores católicos, que nunca jamás avemos de dezir que sea miraglo cosa que naturalmente (aunque por virtudes a nosotros ocultas) se pueda produzir: porque el miraglo es obra que la virtud natural no tiene fuerças para la obrar, ni lo hemos de otorgar sino fuéremos costreñidos por necessidad, faltando la potencia y virtud natural» ${ }^{1}$. Los saludadores, por ejemplo, pueden ejercer su acción curativa sin poseer virtud alguna sobrenatural, mediante acciones físicas que no se conocen ${ }^{2}$.

En esa tradición está Cervantes al decir: «Efectos vemos en la naturaleza, de quien ignoramos las causas; adormécense o entorpécense a uno los dientes de ver cortar con un cuchillo un paño" (Persiles, 595b). El pasaje es humorístico, pero la idea es que estamos lejos de conocer hasta dónde llegan las causas naturales, con lo cual se hacía difícil trazar la raya entre milagro y misterio.

En conclusión, podemos afirmar ahora que Cervantes practica de modo consciente el análisis racional de la realidad, y que muy a menudo ha intentado someter las formas de la actividad y de la cultura humanas a normas estrictas, que para él eran reflejo de la íntima e ideal esencia de las cosas. Las teorías sobre el teatro no podrán atribuirse en adelante a motivos ocasionales de rivalidad con Lope de Vega, sin que yo niegue, empero, que esta circunstancia pudiese avivar su espíritu reglamentista; aquellas teorías forman parte de un amplio conjunto. Pero también hemos ob-

1 Fols. Cjji y Cjijj.

Que en la naturaleza había fuerzas desconocidas para el hombre, era doctrina antigua (ya en Plinio); Alberto Magno la desarrolla en sus Mineralium libri $V$, editado a fines del siglo $x v$; Marsilio Ficino igualmente en su Theologia platonica, IV, 3. En esta dirección renacentista se halla nuestro inteligente Castaňega. Compárese, además, Busson, Obr. cit., pág. 46 . servado en las páginas precedentes cómo frente a la razón esquemática se erguía enérgicamente lo vital y espontáneo, así como lo real (lo particular) se oponía a lo ideal (universal). Tan complejo dualismo lleva el arte de Cervantes por caminos nuevos y extraordinarios, pero es innegable que su punto de partida vamos hallándolo en zonas bien conocidas del pensamiento renacentista. El lector, sin prejuicios, irá notando que sería por extremo peligroso tomar en serio la zumbona frase del prólogo a la primera parte del Quijote: "Todo él es una invectiva contra los libros de caballerías, de quien nunca se acordo Aristóteles, ni dijo nada San Basilio, ni alcanzó Cicerón.» 
no sea necesario dar alguna particular satisfacción a los que, siguiendo el diverso gusto de su inclinación natural, todo lo que es diferente de él estiman por trabajo y tiempo perdido» 1.

Mucho se ha escrito, naturalmente, sobre la profundidad psicológica de Don Quijote y los restantes personajes ${ }^{2}$. Pero ahora no quiero valorar la profundidad de la psicología cervantina, sino señalar meramente la estructura de ese movimiento psíquico y el valor de aquellos momentos subrayados por el autor, en los que vemos reflejarse o refractarse la realidad al cruzar el alma del personaje, y en que esa realidad va siendo dada a luz subjetivamente: «No se podrá contar buenamente los pensamientos que los dos hermanos llevaban, ni con cuán diferentes ánimos los dos iban mirando a

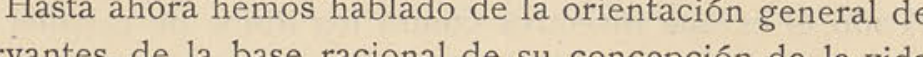
y de la doctrina literaria que de ella se desprende. Conviene considerar inmediatamente aspectos más concretos: ante todo, la actitud psicológica y la crítica de la realidad.

EL PUNTO DE VISTA EN LOS PERSONAJES

"Has de poner los ojos en quién eres, procurando conocerte a ti mismo, que es el más difícil conocimiento que puede imaginarse. Del conocerte saldrá el no hincharte como la rana que quiso igualarse con el buey» ${ }^{1}$. En efecto; está en nosotros mismos la raíz del acierto o del desatino, no sólo en lo atañadero a nosotros mismos (como objeto de conocimiento), sino también acerca de cualquier otra realidad. Cervantes no puede por menos de colocarse en el fondo de la conciencia de cuantos individuos salgan de su pluma, ya que en el sujeto radica el observatorio y fábrica de la realidad ${ }^{2}$. Las primeras líneas del prólogo de su primera obra ya nos lo presentan, esforzándose por entrar en el punto de vista de los demás: «La ocupación de escrebir églogas en tiempo que, en general, la poesía anda tan desfavorecida, bien recelo que no será tenido por ejercicio tan loable que

1 II, $42 ; \mathrm{RM}, \mathrm{V}, 347$.

2 Don Quijote dirige una larga plática a los bandidos de Roque Guinart: «Pero como los más eran gascones, gente rústica y desbaratada, no les entraba bien la plática de Don Quijotes (II, 60; RM, VI, 225).

1 Galatea, edic. Schevill-Bonilla, I, xıvII. Esta preparación del ajen punto de vista es, en su técnica, igual a esta otra: «Así que, seño gentil hombre, ni este caballo, esta lanza, ni este escudo ni escudero. ni la amarillez de mi rostro, ni mi atenuada flaveza, os podrci adnorde aquí adelante, habientb ya sabido quien soy y la profesion que hagos

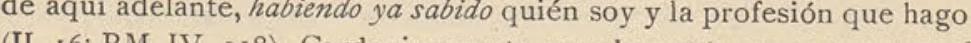
(II, I6; RM, IV, 3I8). Cardenio cuenta sus desventuras «a cuantos oí la quisieren, porque viendo los cuerdos cuál es la causa, no se maraviIlarán de los efetos》 (I, 27 ; RM, II, 35I).

2 No comprendo cómo Cesare de Lollis (Cervantes reazionario, págs. I $5^{2-1}$ 53) puede escribir esto: «En la novela francesa heroicogalante [del siglo xVII] se dibuja ya límpido el arte de la individuación psicológica que conśtituye aún la grandeza de la novela fancesa. Los retratos interiores y exteriores de los personajes estin mancos Lén lo interiores y exteriores de los personjes estén matizado observada con sutil y profunda experiencia mundana. Es lo que le falt completamente a Cervantes, y no podía venirle del modelo de Helio doro.» El crítico se refiere a Persiles; pero no piensa, como punto de referencia, en otras obras cervantinas mejor acabadas que Persiles, acude a Mme. de La Fayette. ¿Pero qué más individuación psicológic que haber creado todo un género literario en el Quijotes? Cree de Iolli que La Princesse de Clìnes, de Mme de I a Fayette es psicológicamente superior al Puijote o a las Noulas Fjemplares Io psicalogicamente superior al Qujole o a las Nobelas Ejemplarest Lo pue ocure es qu Cervantes no practica el método de la morosa delectación en el auto análisis reflexivo; pero en cuanto seres vivos, cualquier personaje de sus obras mejor logradas supone una complejidad interior no supe rada por nadie. Flaubert, como novelista, debe su existencia antes a Cervantes que a $L a$ Princesse de Clèves. 
Leocadia, deseándole Teodosia la muerte, Don Rafael la. vida» ${ }^{1}$. "Recaredo... con presteza se pasó a la capitana, donde halló que unos lloraban por el general muerto y otros se alegraban con el vivo» ${ }^{2}$.

Hay estados de ánimo que imposibilitan ciertas percepciones: «No hay cosa más excusada y aun perdida que contar el miserable sus desdichas a quien tiene el pecho colmo de contentos» ${ }^{3}$. «¿Dormís, señor? Y no sería malo que durmiésedes, porque el apasionado que cuenta sus desdichas a quien no las siente, bien es que cause, en quien las escucha, más sueño que lástima» ${ }^{4}$. Pero el apenado no se fijará en esa coordinación con el ánimo ajeno: «Propia condición de afligidos que, llevados de sus imaginaciones, hacen y dicen cosas ajenas a toda razón y buen juicio» 5 .

Sumamente importantes son esas manifestaciones del punto de vista de cada uno, prisma de la realidad, que se ofrece así con muy diversas facetas. Acumulemos ejemplos para probar que el hecho es característico de Cervantes, ya que ningún otro de nuestros clásicos ${ }^{6}$ organiza así el desarrollo vital de sus personajes. Una persona frente a otra representa un problema: «En tanto que Auristela esto decía, la miraba Periandro con tanta atención, que no movía las pestañas de los ojos, corría muy apriesa con el discurso de su entendimiento para hallar dónde podrían ir encaminadas aquellas razones»?

1 Dos doncellas, Rivad., I, 206 a.

2 Española inglesa, edic. Schevill-Bonilla, pág. 2 I.

3 Galatea, edic. cit., I, 2 I.

Galatea, edic. cit., I, 2 1.
Dos doncellas, Rivad., I, 20 I $b$.

4 Dos doncellas, Rivad., I, 201 $b$.
5 Amante liberal, edic. Schevill-Bonilla, pág. 134.

6 Claro está que existen indicaciones sueltas sobre lo psicológico: véase este pasaje de la Diana de Montemayor: „Decir que te aproveches de tu juicio y discreción, bien sé que no le tienes tan libre que puedas hacerlor, etc. (Orígenes de la Novela, II, 288 a). Pero ni a puedas he jor etc. (Origenes de la Novela, II, 288 a). Pero ni aqu ni en el Guaman, ni ho Le hallamos nunca la reiterada constancia de este procedimiento, ni, sobre todo, su intensa vivificación e el ánimo de los personajes.

7 Persiles, Rivad., I, 595
Más a menudo, según ya indiqué, el observador percibirá aquella faceta que cae dentro de su ángulo visual: "Auristela miraba con celos, y Sinforosa con sencilla benevolencia» ${ }^{1}$. «Para los que tenían [noticia] del humor de Don Quijote, era

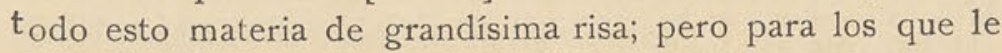
ignoraban, les parecía el mayor disparate del mundo» ${ }^{2}$.

Conocemos, a veces, el motivo de la actitud interna del personaje: "Paréceme que si no se arrimara la paciencia al gusto que tenían Arnaldo y Policarpo de mirar a Auristela, y Sinforosa de ver a Periandro, ya la hubieran perdido escuchando su larga plática» ${ }^{3}$. «El Oidor, si no estuviera tan pensativo con el negocio de Don Luis, ayudara por su parte a la burla» ${ }^{4}$.

En armonía con esta observación del fondo de la conciencia, el obrar de la persona se nos presenta como consecuencia de esa actitud inicial: el camino viene trazado por la psique. "A vuestra consideración discreta dejo el imaginar lo que podía sentir un corazón a quien de una parte combatían las leyes de la amistad y de otra las inviolables de Cupido» ${ }^{5}$. He aquí una escena de Persiles ${ }^{6}$. La hermosa Rafaela entra alborozada en la iglesia, después del saqueo por los moriscos : «Hizo oración a las imágenes, y luego se abrazó, besando primero las manos al cura; el escribano, ni adoró, ni besó las manos a nadie, porque le tenía ocupada el alma el sentimiento de la pérdida de su hacienda.» Cada uno a lo suyo, podría ser el lema de Cervantes: «Señor - respondió Sancho - , cada uno ha de hablar de su menester donde quiera que estuviere» ? Cuando más engolfados nos hallamos en aquel mar de historias que nos brinda la venta, y querríamos que las cosas vinieran a servir a nuestra excitada curio-

\footnotetext{
1 Persiles, 5926 .

2 I, 45; RM, IV, 323

Persiles, Rivad., I, 606 b.

4 I, $45 ; \mathrm{RM}, \mathrm{III}, 322$.

5. $, 45, \mathrm{RM}, \mathrm{III}, 322$

6 Galatea, 1,136

II, 3 i; RM, V, 136
} 
sidad, un nuevo tirón vital nos arrastra en otro sentido. Dos huéspedes, aprovechando el revuelto ambiente, quieren irse sin pagar; van a lo suyo: «Mas el ventero, que atendía más a su negocio que a los ajenos, les asió al salir de la puerta» ${ }^{1}$. Muy interesante es la plática entre Don Quijote y el Caballero del Verde Gabán; nosotros querríamos que no se interrumpiese; "pero a la mitad de esta plática, Sancho, por no ser muy de su gusto, se había desviado del camino a pedir un poco de leche a unos pastores que allí junto estaban ordeñando unas ovejas» ${ }^{2}$. Para la ventera, maldita la gracia que tiene Don Quijote: «En mal punto y en hora menguada entró en mi casa este caballero andante, que nunca mis ojos le hubieran visto, que tan caro me cuesta» ${ }^{3}$. En La señora Cornelia hay un momento en que el amo y Cornelia tiemblan de terror, y «solos Don Antonio y Don Juan estaban en sí, y muy bien puestos en lo que habían de hacer» ${ }^{4}$. En fin, en Cipión y Berganza hay una advertencia enérgica para quienes olvidan la adecuación que debe existir entre el ser íntimo y el hacer: «Paréceme que en esta fábula se nos dió a entender que las gracias y donaires de algunos no están bien en otros: apode el truhán, juegue de manos y voltee el histrión, rebuzne el pícaro... y no lo quiera hacer el hombre principal», etc. ${ }^{5}$. Nótese cómo Cervantes nos da aquí su parecer dogmáticamente, y que éste coincide en un todo con el desarrollo vital de los personajes. La reflexiva conciencia de lo que va realizando artísticamente no le abandona un solo momento.

El caso de Rosamunda, en Persiles, es ejemplo típico de la armonía psíquica entre el ser y el obrar: «Desde el punto que tuve uso de razón, no la tuve, porque siempre fuí mala con los años verdes y con la hermosura mucha; con la libertad demasiada y con la riqueza abundante se fueron apoderando de mí los vicios de tal manera, que han

\footnotetext{
1 I, 44; RM, III, 307.

2 II, 16 ; RM, IV, 33 .

3 I, $35 ;$ RM, III, 99.

4 Rivad I, 275 b.

5 Edic. Clás. Cast., pág. 237 .
}

sido y son en mí como accidentes inseparables... Como los vicios tienen asiento en el alma que no envejece, no quieren dejarme» ${ }^{1}$. Esto podría tomarse como un rasgo de moral, que en otra parte fácilmente hallaríamos; pero lo que es cervantino es la conexión entre ese estado íntimo, tan finamente analizado, y los concertados razonamientos de Rosamunda, perfectos desde su punto de vista. Es ella partidaria de que las jóvenes vayan al matrimonio avezadas a la práctica del amor: "La experiencia en todas las cosas es la mejor muestra de las artes, y así mejor te fuera entrar experimentada en la compañía de tu esposo que rústica e inculta» ${ }^{2}$. Su acompañante llama a Rosamunda "rosa inmunda», porque aquella se coloca en el plano de la moral corriente; pero Rosamunda sigue el norte que le señala su estrella psicológica. El valor moral de sus actos, será apreciado desde fuera, y esta apreciación valdrá como elemento exterior que nada influye en la determinación vital del personaje.

No es necesario aducir más ejemplos para que se perciba con claridad este esencial aspecto de la técnica cervantina. De esa suerte, el personaje máximo y más conocido, Don Quijote, se presenta, estructurado inicialmente, como otros a que he aludido: «Del poco dormir y del mucho leer se le secó el celebro, de manera que vino a perder el juicio», etc. La génesis del punto de vista de nuestro héroe queda señalada, lo mismo que acontece en Anselmo (Curioso impertinente) y en otros, que nos interesará sorprender en momentos decisivos de su determinación vital ${ }^{3}$. El hilo interno de

\footnotetext{
1 Rivad., I, 587 a.

2 Rivad., I, $579 a$.

3 Véase cómo analiza Cardenio el acto de Lucinda, que ha entregado su mano a Don Fernando: «Me resolví en que poco amor, poco juicio, mucha ambición y deseos de grandeza hicieron que se olvidase de las palabras con que me había engañado, entretenido y sustentado en mis firmes cosperion rable de un estado de in vantes a prestado de incertidumbre y atonía del ánimo nos da Cervantes al presentar a Dorotea, después de entregarse a Don Fernando: «Él se fué y yo quedé, ni sé si triste o alegre; esto sé bien decir: que
} 
que dependen las andanzas y decires de estas figuras está, pues, manifiesto; no hay arbitrariedad posible; de esa conexión dependen el realismo y la verosimilitud, entendidos en el sentido relativo que antes expuse. La significación interna, en cuanto motivación psicológica, será, además, uno de los recursos técnicos del autor para presentarnos muchos hechos en planos sucesivos de lejanía y perspectiva. Cuando la reina de Inglaterra ofrece silla a Ricardo, que le trae rico cargamento de especiería, alguien observa: «Ricardo no se sienta hoy sobre la silla que le han dado, sino sobre la pimienta que él trujo" (Española inglesa).

Tan prodigiosa perspicacia, su adaptación al arte, es floración típica del Renacimiento ${ }^{1}$, que iremos viendo reflejarse en Cervantes en formas mucho más complicadas de 10 que suele admitirse.

quedé confusa y pensativa y casi fuera de mí con el nuevo acaecimiento, y no tuve ánimo o no se me acordó de reñir a mi doncella por la traicín cometid de encerar a Don Féna de en mi mismo apose to, porque aun no me deter to, porque aun no me deterninaba si era bien o mal el que me había sucedido» (I, 28; RM, II, 398). Comp.: "Toda esta tardanza del cuento de Periandro se declaraba tan en contrario del gusto de Policarpo que ni podía estar atento para escucharle, ni le daba lugar a pensa maduramente lo que debía hacer para quedarse con Auristela» (Persiles, Rivad., I, 615b). Otras observaciones, igualmente finas, acerca de funcionamiento psíquico. Dice Cardenio: «Aunque pusieron silencio a las lenguas no le pudieron poner a las plumas, las cuales, con mis liberta que las lenguas, suelen da a entender a quen quieren libertad que la lenguas, suelen dar a entender a quien quieren lo que en el alma está encerrado; que muchas veces la presencia de la cosa amada turba y enmudece la intención más determinada y la lengua más atrevida» (I, $24 ; \mathrm{RM}, \mathrm{II}, 256)$ ). «No era mucho que quien llevaba $\tan$ atadas las manos tuviese algún tanto suelta la lengua» (I, 22; RM, II, 209). «Si no callamos nuestros secretos, çcómo extraña que los descubran aquellos a quienes los contamos» (Persiles, Rivad., I, 597 a).

1 Comp.: $\varangle \mathrm{El}$ mundo antiguo parece una pura corporeidad sin moradas y secretos interiores. El Renacimiento descubre en toda su vasta amplitud el mundo interno, el me ipsum, la conciencia, lo subjetivo (J. Ortega Gasser, Meditaciones del Quijote, 1914, pág. 195).

Este mundo de variadas personas, que así nos descubre su ser íntimo, no permanece en estática contemplación ante el Universo. Cervantes no es un lírico ni un místico. Cada uno de esos individuos aparece dotado de dinámica finalidad, y se pondrá muy luego a desarrollar la épica curva de su órbita, engarzando en ella cosas y personas. ¿Cómo son estas realidades objetivas con que se enfrontan los personajes? Si antes veíamos que la acción o el ademán surgían en conexión con un susbstratum íntimo, ahora veremos cómo se analizan las condiciones en que se produce el contacto con la realidad.

No muestres que tienes poca ciencia en creer desconciertos: que poco cuidan los muertos de lo que a los vivos toca ${ }^{1}$

dice un personaje de la Numancia con motivo de una aparición fantástica; esta postura crítica es la que reiteradamente hallaremos, en forma o directa o irónica.

Empeñado De Lollis, como tantos otros, en hacer de Cervantes un bobalicón rendido a los jesuítas y a los inquisidores, genial por un azar, llega a escribir cosas como ésta: «Dudo que Cervantes reuniese en sí todos aquellos rasgos humanísticos con que tan hábilmente lo engalana Menéndez Pelayo; de cualquier forma es cierto que careció absolutamente ( in tutto e per tutto») del principal rasgo humanístico: la crítica» (pág. I84) ${ }^{2}$. Según De Lollis, Cervantes cree las patrañas de ese mundo irregular que describe, y precisamente por eso lo ha escogido como escenario de sus obras. Ya veremos en adelante el valor que deba concederse a la intervención de la astrología y de las brujerías en Per-

1 Numancia, V, 148

2 De Lollis sigue aquí a su compatriota Savj-Lopes: «Cervantes supo malamente el latín: sabido es cómo se le reprochó su pobre cultura y cómo es profundamente antihumanista la naturaleza de su genio» (Cervantes, traduc. esp. de A. G. Solalinde, pág. 234). 
siles y el Coloquio; pero desde luego ocurre reaccionar contra esa acusación de que la crítica está ausente de la cabeza de Cervantes, si se entiende por crítica el análisis y valoración de los juicios humanos, y no confundimos la crítica con los contenidos históricos de cultura. Ya hemos dicho y tendremos ocasión de repetir, que nuestro autor no es ni filosofo ni hombre de ciencia; pero es innegable - lo vamos probando - que se sitúa frente a la vida que le circunda de manera muy definida y muy consciente.

Ahora lo que nos interesa es justamente el punto de vista crítico, que es distinto de la extensión de la cultura, y que es asimismo cosa muy diversa del poder de fantasear a los efectos del juego del arte; de haber sido deslindados estos aspectos, no se habrían escrito páginas tan cargadas de injusticia contra Cervantes. Éste sabe fantasear, qué duda cabe:

\section{Yo también, que soy un leño, \\ príncipe y papa me sueño, \\ emperador y monarca, \\ y aun mi fantasía abarca \\ de todo el mundo a ser dueño. \\ ¡Oh imaginación, que alcanzas \\ las cosas más imposibles! 1.}

Cervantes sabe que el mundo es un espléndido muro de rebote para la fantasía, y a veces se ha deleitado algo mórbidamente en ese juego de abolengo oriental ${ }^{2}$. Pero felizmente para él y para nosotros, la crítica forma parte de su espíritu en igual medida que el afán aventurero. De Lollis piensa que el Quijote fué escrito «senza saper come e perchè» (pág. 233); fué escrito, digo yo, aplicando a la facultad fantaseadora la reducción crítica ${ }^{3}$. Así lo vemos en el Quijote, en las nove-

\footnotetext{
1 Pedro de Urdemalas, III, 173 y 226.

2 Es curioso el interés de Cervantes por su comedia La Confusa, que se creía perdida, pero que debe ser El laberinto de amor, como hábilmente sugieren Schevill-Bonilla, Comedias, VI, I16, 122-123.

3 \& - No ves aquel caballero que trae puesto en la cabeza un yelmo de oro? - Lo que veo y columbro no es sino un hombre... que trae so-
} bre la cabeza una cosa que reluce» $(I, 21)$. las (sobre todo en el Coloquio, en el El celoso extremeño, en El Licenciado Vidriera y parcialmente en otras, lo mismo que parcialmente también en Persiles y en el teatro). Y que la crítica era innata en Cervantes, resulta de multitud de pasajes extraquijotescos que nos aseguran que aquella obra maestra no le fué inspirada por el genio de las inconsciencias ${ }^{1}$.

No es realizar un descubrimiento decir que Cervantes creó el Quijote y con él la novela moderna, haciendo que las fantasías de los libros caballerescos se despeñen por la vertiente de la ironía, la forma más aguda de la crítica. Ya lo vió así el romanticismo alemán. Herder llama al Quijote «epopeya cómica» (Bertrand, pág. 349); para Novalis, la novela (es decir, el Quijote) tiene por tema resolver la antítesis entre la realidad y el sueño (Ibíd., pág. 209); más precisamente, Bouterwek se representará el Quijote como el conflicto de la naturaleza y la razón contra la "Unnatur» y la «Unvernunft»: «Por eso es el primer modelo clásico de la novela moderna; gracias a Cervantes, el libro de caballerías, bastardo equívoco, fruto del genio y el mal gusto, se convirtió en la verdadera novela para los modernos» (Ibíd., pág. 369). Menéndez Pelayo refleja la misma manera de ver: los libros de caballerías «se proyectan como espléndida visión ideal, y, muertos en sí mismos, continúan viviendo enaltecidos y transfigurados por el Quijote» ${ }^{2}$. Mal puede ser, quien así

1 Comp. «Entra un mozo con su caja y ropa verde, como estos que piden limosna para alguna imagen.

\Mozo. - Den, por Dios, para la lámpara del aceite de Señora Santa Lucía, que les guarde la vista de los ojos.

»Soldado. - ¡Hola, amigo Santa Lucía! ¡Venid acá!... ¿Pedís para la lámpara o para el aceite de la lámpara? Que como decís limosna para la lámpara del aceite, parece que la lámpara es del aceite y no el aceite de la lámpara» (La guarda cuidadosa, IV, 64).

2 Cultura literaria de Cervantes, en Estudios de critica literaria, página to. Tal punto de vista ha sido renovado y combinado con otros sugestivos problemas por J. Ortega Gasset, en Meditaciones del Quijote, 1914: «De suerte que no es sólo el Quijote quien fué escrito contra los libros de caballerías, y, en consecuencia, lleva a éstos dentro, sino que el género literario «novelas consiste esencialmente en aquella intususcepción» (pág. 176). 
procedio, un temperamento inconsciente y anticrítico. Si alguna vez nos da esta impresión, no será por causas sencilla e ingenuamente perceptibles.

He aquí algunos ejemplos de cómo se ejerce la función crítica, prescindiendo de los conocidos casos de oposición entre Don Quijote y Sancho:

Algarroba. El cielo puede hacer lo que él quisiere, sin que nadie le pueda ir a la mano, especial cuando llueve.

Panduro. De las nubes, Algarroba, cae el agua, no del cielo ${ }^{1}$

Veamos otro pasaje lleno de alusiones y de intenciones: Bachiller. ¿Sabéis leer, Humillos? Humillos. No, por cierto,

ni tal se probará que en mi linaje haya persona tan de poco asiento, que se ponga a aprender esas quimeras que llevan a los hombres al brasero y a las mujeres a la casa llana ${ }^{2}$.

El saber leer podía, pues, llevar a los hombres al quemadero inquisitorial y a las mujeres al prostíbulo. Tremenda ironía, ya que Cervantes ha dicho en otros lugares: «El que

1 Alcaldes de Daganzo, IV, 42 . Comp.: «Aquel año habían las nubes negado su rocío a la tierra, y por todos los lugares de aquella comarca se hacían procesiones, rogativas y disciplinas pidiendo a Dios abriese las manos de su misericordia y les lloviese, $\left(I_{5} 5^{\circ}, \mathrm{RM}, \mathrm{UII}, 4{ }_{3}\right)$. En este aso el espitu de la Contrarreforma ba hecho divimur la ironi tan che sutilmente deslizada en Los alcaldes de Daganso, Cervantes sabia que no era el cielo sino las nubes quien mandaba el agua. Luis de Granada (Simbolo de la fe, Rivad, VI, 609b) comentando a Mateo, V, 45: «Vuestro padre llueve sobre justos e injustos», dice: «Demás destos beneficios... encarece el Salvador otros dos que recebimos del sol y del agua lluvia que cae del cielo » Punto de vista este distinto del de Cervantes. Pomponazzi habla largamente sobre la dificultad de admitir influjo de los rezos sobre las lluvias; véase Busson, Sources du rationalisme, pág. $5 \mathrm{I}$.

2 Alcaldes de Daganzo, IV, 47 lee mucho y anda mucho, vee mucho y sabe mucho" ${ }^{1} \mathrm{y}$ "e ver mucho y el leer mucho aviva los ingenios de los hombres» ${ }^{2}$.

\section{«EL ENGAÑO A LOS OJOS»}

Mas el problema fundamental, en este caso, arranca de una región superior a aquella en que se dibuja concretamente cada género literario. Si hay en Cervantes una preocupación general, previa a las demás, es la de cómo sea la realidad objetiva. Al final del prólogo a las comedias, uno de esos prólogos en que el autor dice cosas esenciales y muy pensadas, leemos: "Para enmienda de todo esto le ofrezco una comedia que estoy componiendo y la intitulo El engaño a los ojos, que, si no me engaño, le ha de dar contento" ${ }^{3}$. Cervantes daba así nombre, en I6I5, a una dirección de su pensamiento y de su arte, que había sido la preocupación de toda su vida artística: "Renovóse la admiración en todos. en Don Quijote por no poder asegurarse si era verdad o no lo que le había pasado en la cueva de Montesinos» 4 .

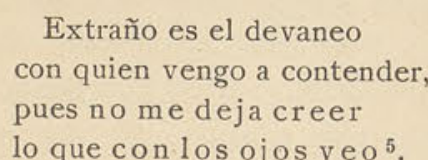

Extraño es el devaneo

con quien vengo a contender,

pues no me deja creer

lo que con los ojos

Selvas de encantos llenas, ¿qué es aquesto que veo?

¿Qué figuras son estas que se ofrecen

¿Son malas o son buenas?

Entre creo y no creo,

me tienen estas sombras que parecen ${ }^{6}$.

1 II, $25 ; \mathrm{RM}, \mathrm{V}, 4 \mathrm{I}$

2 Persiles, Rivad., I, 5986.

3 Véase Schevill-Bonilla, Comedias, VI, 15 ; A. Cotarelo, Teatro de Cervantes, pág. 684.

4 II, 34; RM, V, 220.

5 Gallardo español, I, I 15 ; véase pág. 122.

6 La casa de los celos, I, 226; comp. pág. 2 I2. 
Don Quijote es el depositario mayor del tema de la realidad oscilante: "Como a nuestro aventurero todo cuanto pensaba, veía o imaginaba le parecía ser hecho y pasar al modo de lo que había leído» ${ }^{1}$. Esa inseguridad en el valor absoluto de lo que vemos, a veces se da plenamente en Don Quijote; aunque lo más frecuente sea que él vea un aspecto y nosotros, con los demás personajes, otro distinto. El Hidalgo sabe que las cosas poseen muchos modos de realidad: "Andan entre nosotros siempre una caterva de encantadores que todas nuestras cosas mudan y truecan..., y así, eso que a ti te parece bacía de barbero me parece a mí el yelmo de Mambrino, y a otro le parecerá otra cosa» ${ }^{2}$.

Alguien podría pensar que en este caso hay encantadores y yelmo de Mambrino. Pero en los anteriores ejemplos de «engaño a los ojos» no había nada de eso, ni tampoco en los que atañen a realidades de índole puramente moral: «... Según la priesa que me daba mi alma a poner por obra ésta que a mí me parece tan buena como tú, padre amado, la juzgas por mala». Así dice Zoraida a su padre como explicación de abandonarlo en la playa y de huir con su amante ${ }^{3}$. Por otra parte, "parece que el bien y el mal distan tan poco el uno del otro, que son como dos líneas concurrentes, que aunque parten de apartados y diferentes principios, acaban en un punto" ${ }^{4}$. Todo este mundo que nos rodea está, pues, en un tris, que se trate de un yelmo o de la noción de bien $\mathrm{y} \mathrm{mal}^{5}$.

A veces esta vacilación ante la realidad no se produce espontáneamente, sino que es suscitada. Se ha advertido por

\footnotetext{
1 I, 2 ; RM, I, 114.

I, 25; RM, II, 287

I, 4 I; RM, III, 243 .

4 Persiles, Rivad., I, 675 b.

La realidad está siempre en esta doble vertiente, según desde donde se le contemple. Dulcinea huele a hombruno para Sancho, y a ámbar desleído para su amo (I, 3I; RM, II, 467). Sancho hace «el más doloroso y risueño llanto del mundos cuando cree a Don Quijote muerto por los disciplinantes (I, 52 ; RM, III, 469 ).
}

algunos que la segunda parte del Quijote gira en torno a las aventuras que los demás crean al héroe ${ }^{1}$, aventuras que en la primera parte surgen por sí mismas. Pues bien: en la serie de fenómenos que analizo ocurre también que «artificialmente» se hace que las cosas presenten una realidad fingida al lado de la verdadera. Todos recuerdan las bodas de Camacho y la ficticia muerte de Basilio; técnica análoga encontramos en la simulada riña de la comedia La Entretenida ${ }^{2}$, y en todos aquellos casos en que intencionalmente se descubre el plano verdadero en que descansaba una ilusoria apariencia, como en este pasaje de La guarda cuidadosa:

Cristina. - El sacristán me deshonró el otro día cuando fuí al Rastro..

Ella. - ¿Y dónde te llevó, traidora, para deshonrarte?

Cristina. - Alli en mitad de la calle de Toledo, a vista de Dios y de todo el mundo me llamó de sucia y de deshonesta...

Ella. - ;El alma me ha vuelto al cuerpo! 3 .

Cervantes, por consiguiente, rozó repetidas veces el problema de cómo sean las cosas que contemplamos: irealidad, apariencia? "Eso que a ti te parece bacía de barbero me parece a mí el yelmo de Mambrino y a otro le parecerá otra cosa.» Este mundo que nos cerca ‘es «el engaño a los ojos»? Nuestro autor nos envía así un eco de lo que fué tema central para los pensadores del Renacimiento. El siglo xvi está cruzado por gérmenes de lo que más tarde, desde Descartes, ha de llamarse filosofía idealista, cuyo precedente son las ideas platónicas renacentistas irradiadas desde Florencia. Todos han visto la influencia de León Hebreo en las opiniones que Cervantes formula acerca del amor, en primer lugar porque él mismo lo cita en el prólogo del Quijote y luego porque lo traduce casi literalmente en la Galatea. No causará, pues, sorpresa que hablemos de resonancias platónicas (más exac-

1 Entre otros, por Schelling; véase Bertrand, pág. 194.

2 III, 93.

3 IV, 76 
tamente renacentistas) en Cervantes, refiriéndonos a zonas de su pensamiento no observadas con ese criterio ${ }^{1}$.

Como es sabido, lo central del pensamiento renacentista consiste en variar la relación en que, según la Edad Media, se hallaban el sujeto y el objeto; para aquélla, la mente era una especie de tabla en la cual quedaban impresas las huellas de la realidad; ésta y el sujeto se correpondían exactamente. La filosofía aristotélico-escolástica llevaba esas ideas a todas las cabezas, y Cervantes conoce y aprueba esa teoría tradicional, aunque, como hemos visto y veremos aún, no la practique al realizar sus concepciones literarias: «No me maravillaría yo tanto de esto si fuese de aquella opinión del que dijo que el saber de nuestras almas era acordarse de lo que ya sabían, prosuponiendo que todas se crían enseñadas; mas cuando veo que debo seguir el otro mejor parecer del que afirmó que nuestra alma era como una tabla rasa, la cual no tenía ninguna cosa pintada, no puedo dejar de admirarme, etc.» ${ }^{2}$.

$$
\begin{aligned}
& \text { Dulcinea del Toboso, } \\
& \text { del alma en la tabla ras } \\
& \text { tengo pintada de modo }
\end{aligned}
$$$$
\text { que es imposible borrarla }{ }^{3}
$$

Pero junto a tan realista concepción del mundo *, el humanismo había comenzado a dar importancia al hombre: éste no se limitará a reflejar pasivamente la realidad, sino que se volverá su modelador ideal. Lo seguro, la base de apoyo serán los

Menḱndez Pelayo, Vicisitudes de la filosofía platónica en España (Ensayos de critica filosófica, 1892) no habla más que de la doctrina del amor platónico en Cervantes.

2 Galatea, II, 74.

3 II, $46 ;$ RM, V, 430 .

Nótese que la concepción de la equivalencia entre pensamiento y realidad podía tenerse aun viniendo del campo platónico. Dice Luis de León en los Nombres de Cristo: «Todas las cosas viven y tienen ser en nuestro entendimiento... Y lo que ellas son en sí mismas, essa misma razón de ser tienen en nosotros, si nuestras bocas y entendimientos son verdaderos» (edic. Onís, I, 30). estados de conciencia, nuestra mente; de aquí hay que partir para conocer lo que realmente sean las cosas, siendo así que el testimonio de los sentidos es falaz. La distinción platónica entre apariencia e idea ${ }^{1}$ llevará al dualismo entre aspecto y razón, cuyas máximas consecuencias sacará Descartes; pero, como decía antes, gérmenes de lo que ha de ser la doctrina idealista se encuentran a lo largo del siglo xvi. Nuestro Luis Vives decía en su De prima philosophia: "Cuando decimos que una cosa es o no es, que es de esta o de la otra manera, que tiene tales o cuales propiedades, juzgamos según la sentencia de nuestro ánimo, no según las cosas mismas, porque no es para nosotros la realidad la medida de sí misma («illae enim non sunt nobis sui mensura sed mens nostra»), sino nuestro entendimiento» ${ }^{2}$.

Mas fuera del campo de la Filosofía, que no es de mi incumbencia analizar, la literatura venía aludiendo a esa inquietud que inspiraba el aspecto cambiante de la realidad y a la importancia del propio juicio para fallar en definitiva. Ya en I 505 tocaba claramente el tema Pietro Bembo en Gli Asolani, diálogo de amor lleno de espíritu petrarquista y, sobre todo, neoplatónico, traducido anónimamente al español en I 555: "No se puede considerar sin maravilla cuán dificultoso es hallar la verdad de las cosas que caen en disputa todo el día..., ninguna paresce que se vee tan poco dubdosa sobre la cual no se pueda disputar en pro y en contra verisímilmente... Lo cual dió por ventura ocasión a algunos antiguos profesores de la filosofía a creer que de ninguna cosa se supiese lo cierto, y que ninguna certenidad se podía alcanzar de cualquier cosa, más de simple opinión y presunción... Agora ya no hallé por maravilla (a cuanto yo creo) quien la resciba; mas todavía ha quedado en las mientes de infinitos

1 Parte Aristóteles de las cosas sensibles (in sensum cadentibus), dice Fox Morcillo, y Platón, de las nociones ideales (a rebus mente perceptis). Véase Menéndez PrLayo, Crítica filosófica, 1892, pág. 166.

2 El texto fué ya citado por Menéndez Pelayo, Critica filosófica, pág. 283 , y por Bonilla, Vives, pág. 280 . 
hombres una queja callada y general contra la naturaleza por tenernos el puro tuétano de las cosas tan guardado y escondido y con mil fábulas cubierto y fajado casi con mil cortezas.»-

Pero de tales incertidumbres no se sale sino mediante la investigación racional de las cosas; quienes la han practicado "no quedaron quejosos de la naturaleza, como hacen los otros, por no habernos puesto al descubierto la verdad de las cosas conocederas, como quiera que ella tampoco puso. en descubierto la plata ni el oro» ${ }^{1}$.

Actitud crítica frente a lo real, gérmenes de subjetivismo, uso autónomo de la razón en lo profano y en lo sacro: a lo largo del siglo xvi tales ideas, incubadas por el Renacimiento, inspiraron manifestaciones exquisitas de nuestra cultura, cuya culminación representa Cervantes. Todo ello. es de elemental evidencia, y no lo diría si no vinieran rodando por muchos libros conceptos ingenuos y exteriores acerca de Cervantes, que tienen por base la idea de que humanismo quiere decir meramente estudio de autores griegos y latinos, «espíritu de la antigüedad" ${ }^{2}$; cuando, en realidad, humanismo significa valoración y ensalzamiento de lo humano, del hombre, de su razón, subordinándole todo lo demás; es un método nuevo de observar el mundo. Sobre esto se han deslizado los historiadores de nuestra literatura, por espíritu de adhesión a muy viejas rutinas; y así, cuando hablan de humanismo, tratan de "armonía», de "buen gusto», de cosas, en suma, que dejan la mente en reposo.

1 Los Asolanos, Salamanca, 1555 , sin paginar (Bibl. Nac., $R$ - 15.039 ) El pasaje citado está al comienzo del libro III.

2 Idea muy exterior de lo que es el humanismo de Cervantes hallamos en el estudio de Menéndez Pelayo sobre la Cullura literaria dt Cervantes: «El espíritu de la antigüedad había penetrado en lo más hondo de su alma, y se manifestaba en él, no por la inoportuna profusión de citas y reminiscencias clásicas, sino por otro género de in fe cite y reminiscencias clásicas, sino por otro géne de nfluencia más hondo y eficaz a Las notas humanistas serian: «Lo claro y armónico...; buen gusto...; pureza estética...; filo sofía grave, consoladora y optimista...; buen humor reflexivo...; por esto, realmente, fué humanista, más que si hubiese salido de coro toda la antigüedad griega y latinas (págs. 12-13).
La crítica del aspecto de la realidad ocurre, naturalmente, en Erasmo. Es muy característico el adagio titulado Sileni Alcibiadis ${ }^{1}$ : "Aiunt esse Silenos imagunculas quaspiam fuisse fictiles, et ita facta, ut diduci et explicari possent, quale clausae ridiculam ac monstruosam tibicinis speciem habebant.» El maestro Bernardo Pérez, en el prólogo de su traducción, explica así el sentido: «Llámase los Silenos de Alcibiades; la causa por qué, la misma obra te lo dirá; lo que yo te diré, será sólo esto: que para que veas cuán peligroso es juzgar de las cosas por lo que exteriormente vemos dellas, teniendo unas en poco y otras en mucho, con los falsos juicios que nuestros engaños concibe, es necesario que leas esta obra y por ella conozcas y sepas de aquí adelante dar a cada cosa su valor, desnudándola de lo ajeno y vistiéndola de lo que es suyo» ${ }^{2}$.

Erasmo aplica a lo religioso ${ }^{3}$ este método de superación de las apariencias, y si alude a él en general, es siempre pensando en asuntos de fe. Leemos, por ejemplo, en el Coloquio llamado de religiosos:

Timoteo. - Estas colunas... ¿̇son, por ventura, de mármol?

Eusebio.-Estas son del mesmo mármol que se hizo el arroyo [que era de argamasa].

Timoteo. - Por mi fe, hermosamente están contrahechas; yo juro que verdaderamente eran marmóreas.

1 Me sirvo de una edición abreviada: Adagiorum omnium... Erasmi..., Amberes, 1530, fol. $304 v$.

2 Amberes, 1555, fol. A2 $r$. La edición de 1529, que aún utilizaba yo en 1916 , ha desaparecido de la Biblioteca Nacional junto con otras valiosas obras.

3 ePor ventura hallarás algunos obispos, que si miras aquella solemne consagración que les hacen, aquel nuevo atavío que se ponen, aquella mitra respla que les hacen, aquel nuevo ate con aquella mitra resplandeciente con oro y con perlas preciosas, aque zapato engastado también con muchas perlas, $y$, finalmente, todo aque espiritual y misterioso arnés que le ponen de pies a cabeza, dirás que es algún varón muy excelente, y aun celestial, mucho mayor que hombre; pero abre el Sileno: no hallarás otro que un guerrero pleiteador, en suma, un tirano. Vernás a decir que todo aquel atavío no era en él sino como un entremés de burla» (Silenos de Alcibiades, Amberes, 1555 , fol. $8 v$ ). 
Eusebio.-Y aun por eso debe todo hombre vivir muy sobre aviso para no jurar ni creer ligeramente lo que les paresciere, hasta ser bien certificado de ello, pues vemos que cada día nos engañamos en las cosas miradas a sobre haz ${ }^{1}$.

En el Elogio de la locura vuelve a aludirse al mismo problema: "Todas las cosas humanas tienen dos aspectos a modo de los Silenos de Alcibíades, los cuales tenían dos caras del todo opuestas; por lo cual, muchas veces, aquello que a primera vista parece muerte..., observado atentamente es vida», etc. «Para decir la verdad, todo en este mundo no es sino una sombra y una apariencia; pero esta grande y larga comedia no puede representarse de otro modo.» «La realidad de las cosas... depende sólo de la opinión. Todo en la vida es $\tan$ oscuro, $\tan$ diverso, tan opuesto, que no podemos asegurarnos de ninguna verdad» 2 .

1 En Origenes de la Novela, IV, $18 \mathrm{I} a$.

2 Me sirvo de la bella edición italiana que ha cuidado Benedetto Croce, 1914, págs. 42-43. Al hablar de esta obra surge la pregunta de si Cervantes pudo leerla; desde luego, yo pienso que pudo verla en latín, y enterarse suficientemente de su contenido; pero hay que observar que existió traducción española, lo que facilita la suposición de que Cervantes la conociera. Dice Menéndez Pelayo (Heterod, II, 72 ) qque en los índices expurgatorios figuran un Confesionario, una Manere

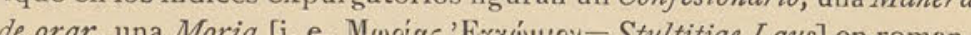
ce y un Vinda cristiana. Que no exista jemplar, no quere decice y una lecir ada, por lo mucho que se persiguieron las traducciones de Erasmo. De la primitiva traducción italiana dice Croce que sè rimasta ignota agli eruditi italiani, e che neppur io sono riuscito a vederes; peroexiste. Mi sabio amigo Marcel Bataillon me habló de un ejemplar conservado en la Biblioteca de Santa Genoveva, en París, que, como le dije, debe ser único. Lo he visto, y he aquí una somera descripción: - La Moria | d' Erasmo nova-|mente in volgare | tradotta | Con Priuileio dello Illustriss. I Senato Vinithano. I In Ven tha L'an I Con PXXIX-

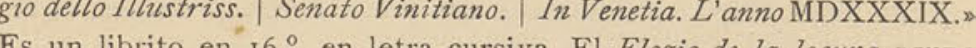
Es un librito en 82 folios. El colofón reza: «Stampata in Vinetia, per Giouanni della Chiesa Pauese, nell'anno MDXXXIX il mese di febraio.s Comienza con una dedicatoria « $\mathrm{Al}$ clarissimo M. Pietro Zeno, illustriss. capo del Consiglio de X, Antonio Pellegrini... (3 fols.). Luego: «La Moria d'Erasmo, interprete Antonio Pellegrini...» Comienza: «Comunque si uoglia che di me parlino i mortali... En el mismo volumen se encuen-
Otro escritor típico del Renacimiento, Baltasar Castiglione, alude asimismo al tema de la realidad engañosa: «En toda cosa hay tanta dificultad de conocer la verdadera perfición, que casi es imposible. Esto es por la diversidad de los juicios... No embargante esto, yo tengo por cierto que cualquier cosa tiene su perfición, la cual podrá, con razonables argumentos, ser conocida por quien de aquella tal cosa tuviere noticia.» $\mathrm{Y}$ viene a seguida una importante sentencia: "Mi opinión seguilla heis si os parece bien, y si no, aterneisos a la vuestra si fuere diferente de la mía, y en tal caso no defenderé yo mi razón porfiándola mucho, porque no solamente a vosotros os puede parecer una cosa y a mí otra, mas yo mismo puedo tener sobre un mismo caso, en diversos tiempos diferentes juicios» ${ }^{1}$.

Al comentar V. Cian este pasaje ${ }^{2}$, dice que la frase "per la varietà de' giudicii» es una verdad proverbial que se halla en Terencio: "Quot homines, tot sententias», y para el pasaje que sigue inmediatamente lo relaciona con la sátira tercera de Horacio; pero no cita antecedente para lo que juzgo decisivo en este pasaje de Castiglione: "Non solamente a voi po parer una cosa e da me un' altra, ma a me stesso poría parer or una cosa ed ora un' altra.» Trátase aquí de una cuestión de sensibilidad y de ideología que no se resuelve en fuentes; justamente lo característico de los escritores humanistas y renacentistas es esta nueva valoración de la materia antigua, contenida en los clásicos o incluso en la literatura popular. Que en este punto se trata de un sentido

tran estas otras obras: «Formaggiata di sere stentata al serenissimo tran este ot ob ob

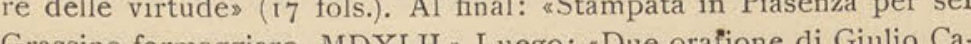
Grassino formaggiaro. MDXLIr, Luego: aDue oratione di Giulio Camillo al re Christianissimo. In Vinegia. MDXLV, (I f fols.). «Le lettere di M. Francesco Sansovino sopra le dieci giornate del Decamerone di M. Giouanni Boccaccio. MDXLIII» ( 83 fols.).

El Cortesano, trad. de Boscán, en «Libros de antaño», pág. 50. 2 Il Cortegiano, del conte Baldesar Castiglione, anotato e illustrato da Vittorio Cian, Firenze, 1910, pád. 37. 
nuevo, resulta claro de la homogeneidad de dirección que hallamos en Vives, Bembo, Erasmo y Castiglione, y del desarrollo ulterior que esta actitud crítica (en algún respecto escéptica), subjetiva, e idealista en germen, nos ofrecerá en los pensadores que plenamente construirán, a base de ella, la ciencia y la filosofía modernas. Parece inexcusable relacionar con tales precedentes los pasajes anteriormente citados de Cervantes, sobre todo el más significativo de ellos: «Eso que a ti te parece bacía de barbero, me parece a mí el yelmo de Mambrino, y a otro le parecerá otra cosa» ${ }^{1}$. Cervantes no era un filósofo, pero ha dramatizado en sus obras, sobre todo en el Quijote, uno de los problemas centrales que inquietaron el pensamiento moderno, en el alba de la formación de los grandes sistemas. El mundo en Cervantes se resuelve en puntos de vista, en representación y también en voluntad, sin que yo quiera establecer, al usar estas palabras, ambiciosas y anacrónicas correlaciones. Es bastante dar a esos términos el sentido que inmediatamente ofrecen.

\section{CRÍTICA DE LA REALIDAD}

Si Cervantes hubiese dejado inermes a sus personajes ante esa universal fantasmagoría ${ }^{2}$, no habría salido del plano de sueño irreal. Pero la novedad extraordinaria es que las cosas puedan ser al mismo tiempo yelmo y bacía, y que vivan como tales. De esa suerte, la aventura puede alzar su vuelo, pero llevando en el ala el plomo de la crítica, del espíritu científico.

¿Qué elementos intervienen en este proceso de averigua-

1 Recordemos (v. pág. 42) que Cervantes no es por esto un pirronista; la verdad para él no era una quimera, «puesto que la verdad ha de tener siempre su asiento, aunque sea en sí mismas (Persiles, página $634 b$ ); «la verdad bien puede enfermar, pero (Ibid., 648 a).

2 "Por el hábito que tengo que no sé qué me diga ni qué me piense de estas cartas y de estos presentes: por una parte veo y toco la fineza de estos corales, y por otra leo que una duquesa envía a pedir dos docenas de bellotas» (II, 50; RM, VI, r8). ción de la realidad? Ante todo la luz natural del entendimiento: «El necio en su casa ni en la ajena sabe nada a causa que sobre el cimiento de la necedad no asienta ningún discreto edificio... Buen natural tienes, sin el cual no hay ciencia que valga» 1 .

Pero lo que distingue el razonar de los personajes cervantinos al intentar aprehender lo real es el empleo de la experiencia: "La experiencia en todas las cosas es la mejor maestra de las artes» ${ }^{2}$. Han sido citadas algunas veces estas frases de Don Quijote relativas a su permanencia en la cueva de Montesinos : "Despabilé los ojos, limpiémelos, y vi que no dormía, sino que realmente estaba despierto; con todo esto, me tenté la cabeza y los pechos por certificarme si era yo mismo el que allí estaba o alguna fantasma vana y contrahecha; pero el tacto, el sentimiento, los discursos concertados que entre mí hacía me certificaron que yo era allí entonces el que soy aquí ahora» ${ }^{3}$.

Se ha dicho que en este pasaje Cervantes precede a Descartes en su "yo pienso, luego soy»; afirmación ligera, ya que Cervantes se limita a hacer constar, experimentalmente, la identidad de la persona pensante, cuya realidad se averigua como la de cualquiera otra cosa. La experiencia es, en efecto, un medio de conocimiento grato a Cervantes. No expone, claro es, ningún sistema preciso que nos permita deducir la profundidad de su saber y de su meditación en este punto; dentro de ese plano elemental se muestra, sin embargo, bastante explícito, y podemos decir sin miedo que la experiencia de los sentidos es para él fuente y garantía de conocimiento:

1 II, 43 ; RM, V, 374-375.

2 Persiles, I, 14.

3 II, 23; RM, 462. Comp. A. Bonilla, Cervantes y su obra, pág. 12. Pasajes análogos se hallan en otras obras: «Cuando yo tales razones di, de todo punto acabé de creer que soñaba, y que era alguna visión aquella que delante los ojos tenía, y que la continua imaginación, que aquella que delante los ojos tenía, y que la continua imaginación, que
de Nisida no se apartaba, era la causa que allí a los ojos viva la representase. Mil preguntas les hice, $y$ a todas ellas me satisfacieron, pri mero que pudiese sosegar el entendimiento, y enterarme que ellas eran Nisida y Blanca» (Galatea, II, 120 ). 
Descubra el hombre siempre

tal valor y tal brío,

que le muestren varón a todo trance.

No se ande con esferas,

con globos y con máquinas

de inteligencias puras;

atienda, espere, escuche, advierta y mire,

o lo que en daño suyo,

o en su pro sus amigo

quisieren descubrirle ${ }^{1}$

$\mathrm{Y}$ si lo ignoras, te advierto

que son seguras verdades

las que la experiencia apura ${ }^{2}$

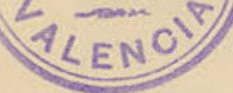

Señor, lo que yo puedo aconsejart

es que procures que la vista sea

la que de esta verdad ha de informarte ${ }^{3}$.

No le dije a vuestra merced que mirase bien lo que hacía, que no eran sino molinos de viento? 4

Recuérdese que Don Quijote compone la celada «sin querer hacer nueva experiencia de ella» (L, I). En el Vizcaino fingido ${ }^{5}$, ante el temor de que una cadena sea de alquimia, dice Solórzano: «Vaya a la platería y en el contraste se pese y toque esa cadena.

La experiencia es igualmente exigida para cimentar el juicio sobre la realidad moral: «No quiero juramentos, señor Andrés, ni quiero promesas; sólo quiero remitirlo todo a la experiencia de este noviciado, y a mí se me quedará el cargo de guardarme cuando vos le tuviéredes de ofenderme» ${ }^{6}$.

\footnotetext{
1 La Entretenida, III, 74

2 Laberinto de amor, II, 319

3 La Entretenida, III, 95.

4 I, 8; RM, I, 267.

5 IV, 88.
}

6 Gitanilla, edic. Schevill-Bonilla, pág. 83. Además: «En tanto que la experiencia y la razón no me mostraren el contrario de lo que hasta aquí me han mostrado, yo creo que mi opinión es tan verdadera cuanto la tuya falsa» (Galatea, I, 72). "Soberbia es esa, Lenio, y en ella muestras cuán fuera vas del camino de la verdad de amor, y que te riges más por el norte de tu parecer y antojo, que no por el que te debías regir, que es el de la verdad y experiencia» (Ibid., II, 42).
La experiencia no es, por otra parte, mero acto receptivo en que los sentidos y sus percepciones causan sin más la acción de conocer; hace falta el interés de la voluntad, es decir, la atención: "Las lecciones de los libros muchas veces hacen más cierta experiencia de las cosas, que no la tienen los mismos que las han visto, a causa que el que lee con atención repara una y muchas veces en lo que va leyendo, y el que mira sin ella no repara en nada, y con esto excede la lección a la vista» 1 .

En fin, para el logro de la verdad hace falta que empleemos un encadenado y congruente razonar, y tengamos cuenta de las nociones de causa y efecto: "Al doblar de una punta pareció descubierta y patente la misma causa, sin que pudiera ser otra de aquel horrísono y espantable ruido... Y eran (si no lo has, joh lector!, por pesadumbre y enojo) seis mazos de batán, que con sus alternativos golpes aquel estruendo formaban" ${ }^{2}$. "Si va a decir la verdad, yo no me puedo persuadir que los azotes de mis posaderas tengan que ver con los desencantos de los encantados, que es como si dijésemos: "si os duele la cabeza, untaos las rodillas» ${ }^{3}$. Sancho hará esfuerzos para reducir tal absurdo a límites racionales: «Yo pienso darme de manera, que sin matarme, me duela; que en esto debe consistir la sustancia de este milagro» ${ }^{4}$.

1 Persiles, Rivad., I, 638 a

2 I, 20; RM, II, 130.

3 II, 67; RM, VI, 334.

4 II, 71; RM, VI, 317. Comp.: « Tan de esencia de la historia es saber las cabras que han pasado, por extenso, que si se yerra una del número no puedes seguir adelante con la historia?» (I, 20; RM, II, rig). Nótese que aquí es Don Quijote y no Sancho quien ejercita la función crítica. Otros ejemplos: «No puede ser - respondió Sanla función crítica. Otros ejemplos: «No puede ser - respondió Sancho-, porque si fueran ladrones no se dejaran aquí este dineros (I,
23; RM, II, 231). En El trato de Argel (V, 8I) un cautivo distingue las pisadas de los moros:

\section{Porque es ancho su calzado,
el nuestro más escotado,}

y ansí son diferenciadas.

Don Quijote opina que Morgante «no debió de ser muy alto..., que muchas veces dormía debajo de techado» (II, I; RM, IV, 63). 
En la comedia La Entretenida (III 2I), Cardenio se regocija ante la idea de hacerse pasar por un rico indiano:

Gran principio a mi quimera!

Torrente. Llámala, señor, dislate,

torre fundada en palillos

como casica de naipes.

como casica de naipes.
Dime: ¿Dónde están las perlas

¿Dónde las piedras bezares

¿Adónde las catalnicas

o los papagayos grandes?

¿Dónde la práctica de Indias,

de los puertos y los mares

que se toman y navegan?

No debe, por tanto, admitirse la existencia sino de 10 que es susceptible de demostración experimental o racional. Puiede acontecer que el proceso investigatorio se detenga, ya porque salga de los límites racionales e invada la zona de lo misterioso, ya porque la facultad razonadora de Cervantes declare incapaz de resolver la dificultad. En Los baños de Argel (I, 322) se refiere un caso de espejismo. Habla un guardián turco:

Salió el sol esta mañana,

y sus rayos imprimieron

en las nubes tales formas,

que, aunque han mentido, las creo.

Una armada figuraron,

que venía a vela y remo..

Los cristianos se alucinan ante esa visión («engaño a los ojos»), creen distinguir hasta los cómitres y remeros en buques que vienen a salvarlos. Los moros se asustan

$$
\begin{aligned}
& \text { Por estas formas que el sol } \\
& \text { ha con sus rayosimpreso } \\
& \text { en las nubes, ha en nosotros }
\end{aligned}
$$$$
\text { otras mil formado el miedo. }
$$

El resultado es que los genízaros matan a muchos cristianos con

$$
\text { crueldad }
$$

igual de la necedad

mayor que jamás se ha visto.
LímITES DE LA INVESTIGACIÓN

El cadí informa al rey de Argel de tal suceso (pág. 328), y le explica que

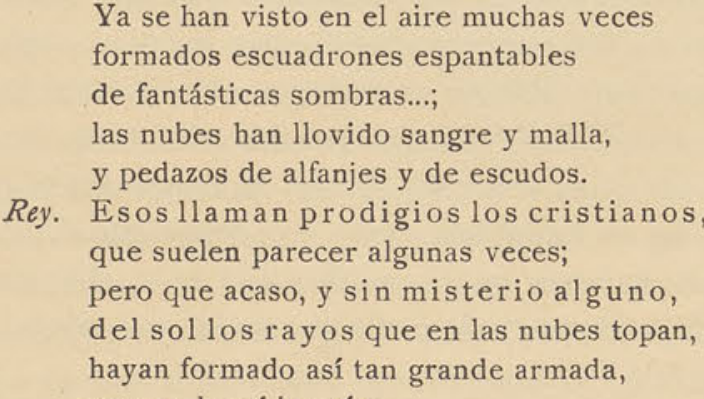

Ya se han visto en el aire muchas veces formados escuadrones espantables de fantásticas sombras...;

las nubes han llovido sangre y malla, y pedazos de alfanjes y de escudos.

Rey. Esos llaman prodigios los cristianos, que suelen parecer algunas veces; pero que acaso, y sin misterio alguno, del sol los rayos que en las nubes topan, hayan formado así tan grande armada, nunca lo oí jamás.

He aquí separados cuidadosamente el campo del prodigio y del misterio, límite de la experiencia, y por eso indiscutible, y el de los fenómenos naturales que la observación determina. El Rey se entera de que junto al «prodigio cristiano» existe la acción nada misteriosa de los rayos solares. Se ha señalado alguna analogía entre un pasaje de este episodio y otro de La libertad de Roma de Juan de la Cueva ${ }^{1}$.

$$
\begin{aligned}
& \text {... las nubes sangre sobre mí vertiendo. } \\
& \text { Esas señales y prodigios vimos... }
\end{aligned}
$$

En Cueva se cita, en efecto, un "prodigio", y bien pudo leerlo Cervantes; pero lo cervantino consiste en dar a ese prodigio valor de tal, situándolo al lado de un hecho natural y nada misterioso; es decir, en analizar críticamente la realidad, como hace Sancho y cuantos se sitúan en la serie de este tema.

La otra limitación de que hablé es de carácter subjetivo. Don Quijote se lanza a arreglar la estructura social con motivo del discurso de las armas y las letras: «Es más fácil premiar a dos mil letrados que a treinta mil soldados...; esta imposibilidad fortifica más la razón que tengo. Pero dejemos esto aparte, que es laberinto de muy dificultosa salida» ${ }^{2}$.

\footnotetext{
1 Edic. Schevill-Bonilla, VI, 8 I
}

2 I, 38 ; RM, III, 158. 
La crítica de las realidades morales da lugar a finísimos análisis, según veremos con más oportunidad al hablar del error. Aquí daremos sólo un par de ejemplos. Dice Dorotea de la condición de sus padres: "Quizá nace mi poca ventura de la que no tuvieron ellos en no haber nacido ilustres; bien es verdad que no son tan bajos que puedan afrentarse de su estado; ni tan altos que a mí me quiten la imaginación que tengo de que de su humildad viene mi desgracia» ${ }^{1}$. "Los mercaderes son mayores en su sombra que en sí mismos» ${ }^{2}$ (es decir, sus hijos tienen más prestigio social que ellos).

\section{ASTROLOGÍA Y HECHICERÍA}

Conviene ahora detenernos un poco en el análisis de los elementos fantásticos en la obra cervantina (astrología, brujería, etc.), para ver qué valor tengan desde el punto de vista crítico. El asunto es delicado, y no es posible adoptar una actitud estricta y literal. En este punto los textos vistos aisladamente se prestan a encontradas interpretaciones. Menéndez Pelayo ${ }^{3}$ pensaba que «el mismo espíritu positivo y práctico que llevó a Cervantes a enterrar bajo el peso de la parodia toda la literatura fantástica, sobrenatural y andantesca de los tiempos medios, respira en la aventura de la cabeza encantada de Barcelona... Y, sin embargo, cuando en su vejez hizo un libro de aventuras..., no dudó, sin duda por debilidad senil, en acudir a los prestigios algo pueriles de la magia, y colocó en las regiones del norte, por él libremente fantaseadas, hechiceras y licántropos.» Pero prodigios y fantasías hay también en el Coloquio y en el Quijote; lo interesante sería averiguar el valor que Cervantes conceda a todo esto. Actualmente, De Lollis ${ }^{4}$ examina el problema, y de una parte (págs. I96-197) hace observaciones tan justas como

I, $28 ;$ RM, II, 384 .

2 Coloquio, Clás. Cast., pág. 239.

3 Heterodoxos, 1880, II, 675

4 Cervantes reazionario, pág. 186 y sigs. éstas: «Es vano pedir a Cervantes que llegue a una sistematización en este punto... Su curiosidad era de artista. Su genio realista, con que preludiaba lo mejor del romanticismo, le hacía buscar las expresiones extremas de lo característico, y lo atraía hacia lo anómalo... Con los locos van las brujas y los brujos... El poder alucinador del artista busca en la superstición un modo de ampliar los confines de la realidad (recuérdense algunas novelas de Balzac)»; pero, no obstante tales ideas, De Lollis afirma (pág. 203) que Cervantes cree realmente en el vuelo de Rutilio, desde Siena a Noruega, subido en una manta, cual otro licenciado Torralba; la salvedad de Rutilio: «como cristiano bien enseñado, tenía por burla todas estas hechicerías (como es razón que se tengan) " ${ }^{1}$, sería - según De Lollis - una concesión que Cervantes hacía al espíritu inquisitorial para evitarse complicaciones.

Por mi parte no pienso que Cervantes, en Persiles, se nos ofrezca sometido a las creencias brujeriles, ni por senilidad ni por otra causa. El volar en manta no es en sí más extraordinario que cualquiera de las otras cosas que acontecen en esta historia septentrional, conscientemente inverosímil de la cruz a la fecha ${ }^{2}$. Lo que acontece, si no lo han por enojo, es que Cervantes, enamorado de la aventura en sí, abre la puerta a los temas bizantinos y a las fantasías más peregrinas que él, "raro inventor», gustaba tanto de fraguar; pero, al mismo tiempo, no podía resistir al vehemente deseo de poner a la aventura un comentario crítico, a manera de marco que delimitara su extensión. En el Quijote, obra genial, la caída de la aventura caballeresca se verifica dentro de una unidad estética, y el vaivén e interferencia Quijote-Sancho constituye la medula artística del procedimiento novelesco (véase pág. 77); en Persiles, obra imperfecta, la aventura aspira a vivir ple-

1 Persiles, Rivad., I, $572 a$.

2 «El Persiles nos garantiza que Cervantes quiso la inverosimilitud como tal inverosimilitud» (J. ORTEGA Gassét, Meditaciones, pág. 145). ¿Pero no dijo el canónigo al trazar el plan de un libro de caballerías ideal: «tal vez le vendrá ocasión de mostrarse nigromante si quisiere?» (Quijote, I, 47). Véase antes pág. 44. 
namente, y si se reduce y limita su significación es por procedimientos intelectuales, realmente extraestéticos. Para esto acude el autor a observaciones morales, religiosas o científicas, cuyo principal interés es que nos definen la cultura y el pensamiento del autor. En ningún caso, empero, es lícito afirmar que Cervantes cree seriamente que un individuo va en una manta desde Siena a Noruega, o que la licantropía es algo que acontece realmente. A Cervantes le divertían sobremanera todas esas cosas, como lo demuestra su enorme lectura de libros de caballerías, inexplicable si pensamos que lo hizo sólo para irritarse contra tamaños desatinos; de haber sido así, con leer un par de ellos le habría sobrado documentación.

Se impone, pues, distinguir dentro de ese complejo de fantasías, cuáles lo eran realmente para Cervantes y cuáles no. Dentro de la imaginación literaria, unas y otras pueden aparecer mezcladas, pues aquélla no reconoce límites (véase pág. 76); pero en la reacción crítica descubriremos el ámbito del pensamiento cervantino.

Grisóstomo «sabía la ciencia de las estrellas, y de lo que pasan allá en el cielo el sol y la luna, porque puntualmente nos decía el cris del sol y la luna... Adevinaba cuándo había de ser el año abundante o estil (estéril)... Esa ciencia se llama astrología, dijo Don Quijote» (I, I2). En Persiles (I, I8): «Mauricio sabe por la astrología un mal suceso que les avino en el mar... Puso los ojos en el cielo Mauricio, y de nuevo tornó a mirar en su imaginación las señales de la figura que había levantado... Confiaba de la salud de todos por haber hallado, como se ha dicho, en la figura que había levantado, que aquel suceso no amenazaba muerte, sino descomodidades casi mortales» (Rivad., I, $583 a, 585$ ). «Mauricio... acudió a su ciencia, y halló en ella que grandes dificultades habían de impedir su partida» (Ibid., 60I b). Más adelante hallamos otro astrólogo, Soldino: «No soy mago ni adivino, sino judiciario, cuya ciencia, si bien se sabe, casi enseña a adivinar... Aquí he dado fin al estudio de las matemáticas, he contemplado el curso de las estrellas y el movimiento del sol y de la luna; aquí he hallado causas para alegrarme, y causas para entristecerme, que aunque están por venir, están ciertas» (Ibid., $655 b, 656$ b); y, en efecto, Soldino adivina con acierto cosas que luego acaecen.

La hechicera Cenotia, de Alhama de Granada, salió huyendo de la Inquisición, y se encuentra en los países nórdicos; hace una interesante distinción entre la hechicería y la magia de encantos: "Las que son hechiceras nunca hacen cosa que para alguna cosa sea de provecho: ejercitan sus burlerías, con cosas, al parecer, de burlas, como son habas mordidas, agujas sin puntas..., y si algo alcanzan, tal vez, de lo que pretenden, es, no en virtud de sus simplicidades, sino porque Dios permite, para mayor condenación suya, que el demonio las engañe; pero nosotras, las que tenemos nombres de magas y encantadoras, somos gente de mayor cuantía: tratamos con las estrellas, contemplamos el movimiento de los cielos, sabemos la virtud de las yerbas, de las plantas, de las piedras, de las palabras...» ${ }^{1}$. Esta Cenotia logra, con sus hechizos, poner en trance mortal al joven Antonio; el padre la amenaza de muerte: «Mira si tienes su vida envuelta en algún envoltorio de agujas sin ojos o de alfileres sin cabezas; mira, joh pérfida!, si la tienes escondida en algún quicio de puerta.» $Y$, en efecto, "sacó del quicio de una puerta los hechizos que había preparado para consumir la vida poco a poco del riguroso mozo» y «salió la salud perdida de Antonio a plaza» (Ibid., 607 a). Más adelante, Cervantes califica a Cenotia de «embaidora» (Ibid., 6I6 a).

De este episodio parece resultar que Cervantes pensó primero en que la acción hechiceril de la bruja fuese de tipo algo «elevado», análoga a la desarrollada por los astrólogos; pero o se olvidó de su propósito o cambió de parecer, y hace que Cenotia actúe con artes de menor calidad, mediante un envoltijo oculto en el quicio de una puerta. Acaba llamándola embaidora, no obstante el éxito de sus misteriosos

1 Persiles, Rivad., I, 602 b. 
procedimientos. Lo único que al autor le preocupa es obtener efectos que suspendan el ánimo, dando previamente al lector una base cualquiera para que surja en su fantasía la impresión de maravilla. Recordemos que Cervantes ha dicho esto muy claramente en el Quijote, I, 47: "Hanse de casar las fábulas mentirosas con el entendimiento de los que las leyeren, escribiéndose de suerte que, facilitando los im posibles..., admiren, suspendan, alborocen y entretengan.» ¿Por qué, pues, hablar en estos casos de senilidad, de reaccionarismo, de credulidad vulgarísima en Cervantes? Al final de Persiles vuelve a producirse otro de estos encantamentos, y los hechizos de la judía, mujer de Zabulón, hacen enfermar gravemente a Auristela : «Pero Dios, por nuestros mismos pecados, para castigo de ellos, permite que pueda quitar la salud ajena esto que llaman hechicería, con que lo hacen las hechiceras, usando mezclas y venenos, que con tiempo limitado quitan la vida a la persona que quierens (Ibid., 673 b).

carácter puramente literario de este tema brujeril resulta aún más patente si se tiene en cuenta que, antes de Cervantes, las judías de Roma aparecen practicando sus hechicerías en un «ragionamento» del Aretino, y puede ser que en otras obras: «Se per aventura [las cortesanas de Roma] le veggono [al amante] allentar del donare, subito ricorrono a le giudee maliarde e incantantrice... E se con un' altra ti fermi, o parli, le ti vogliono far gli incanti, e vanno presto a cimiteri e a le sepolture: quivi trovano le forze, e quivi l' esche con che ti legano e ti lusingano... E le ho scontrate al lume della incantata luna hor scapigliate, hor nude, co piu strani gesti e modi di streghe... e dove chiamano il diavolo», etc. ${ }^{1}$.

Si las artes de hechicería no hubiesen dado lugar a persecuciones inquisitoriales, por la fácil credulidad de muchos, Cervantes no habría tenido empeño en señalar el carácter de «embaidoras» de las brujas.

1 Il ragionamento del Zoppino, s. 1., I 584, pág. 306 y sigs.
En cuanto a la astrología, la cuestión es distinta. Intentemos poner de acuerdo textos y actitudes al parecer contradictorios. Si se limitara Cervantes a utilizar esas fantasías como un procedimiento de complicar la fábula novelesca, no habría que dar al asunto más importancia, y asimilaríamos este caso al de la hechicería; pero veamos los textos.

El astrólogo Mauricio, en Persiles, habla de un sueño présago que ha tenido: "Ni el sueño que a mí me turbó cae debajo de la observación de la astrología, porque sin guardar puntos ni observar astros, señalar rumbos ni mirar imágenes, me parecio ver visiblemente que en un gran palacio de madera, donde estábamos todos los que aquí vamos, llovían rayos del cielo que lo abrían todo..., y como sé que no hay más cierta astrología que la prudencia, de quien nacen los acertados discursos, ¿qué mucho que yendo navegando en un navío de madera, tema rayos del cielo, nubes del aire y aguas de la mar?» $(584 b)$.

"Ninguna ciencia, en cuanto a ciencia engaña; el engaño está en quien no la sabe, principalmente la de la astrología, por la velocidad de los cielos, que se lleva tras sí todas las estrellas... Y así el astrólogo judiciario, si acierta alguna vez en sus juicios es por arrimarse a 10 más probado y a lo más experimentado; y el mejor astrólogo del mundo, puesto que muchas veces se engaña, es el demonio..., como ha tanto tiempo que tiene experiencia de los casos pasados» ${ }^{1}$.

1 Persiles, Rivad., I, 578 b. - Esta era doctrina muy corriente a la sazón. A. G. de Aмrzúa, El casamiento engañoso, pág. 623 , comentando el pasaje del Coloquio: «Él [el demonio], no sabe nada de lo por venir ciertamente, sino por conjeturass, cita este oportuno texto del fardin de fores curiosas, de Antonio DE Torquemada: «El demonio, fardin de fores curiosas, de ANTonio DE Torquemada: «El demonio,
como más astuto y sagaz que ninguno de los hombres y por la larga experiencia que tiene y por algunas conjeturas, puede saber lo que está por venir... en algunas cosas.s - Según Vives, los vaticinios eran artes diabólicas: «Huye, pues, de aquellas artes, que son contrarias a virtud, como son las que por lo que hay en las rayas de las manos en el fuego o en el agua o por cuerpos muertos o por las estrellas, 
En otro pasaje del Quijote volvemos a hallar la idea de que la astrología es ciencia, y que no puede servirse de ella cualquier advenedizo: «Este mono no es astrólogo, ni su amo ni él alzan, ni saben alzar, estas figuras que llaman judiciarias, que tanto ahora se usan en España, que no hay mujercilla ni paje, ni zapatero de viejo que no presuma de alzar una figura, como si fuera una sota de naipes, del suelo, echando a perder, con sus mentiras e ignorancias, la verdad maravillosa de la ciencia» 1

En la comedia La Entretenida ${ }^{2}$ nuevamente encontramos el mismo punto de vista:

\section{Antonio. Si podrá la astrología judiciaria declarallo?}

D. Francisco. Yo no pienso interrogallo: que tengo por fruslería a ciencia, no en cuanto a ciencia,

e profieren a adevinar lo que está por venir: porque hay en todas ellas una dañosa vanidad, hallado por nuestro enemigo el demonio engañador. Y se tractan y profieren a cosas que reservó Dios para sí solo, que es el conocimiento de cosas ascondidas y venideras ( Introducción a la sabiduria, Amberes, $155 \mathrm{t}$, fol. 14 v). Conviene tener en cuenta que en la época del Renacinier oncepto del demonio con el de la mítica das y consejas, y en el cual se piensa al hablar de estas fábulas cervantescas. No puedo analizar aquí el asunto, y sólo diré que el demonio representa, a veces, la acción de las fuerzas ocultas e incognoscibles, combinadas con el personaje de la teología católica. He aquí una cita de Polidoro Virgilio, autor practicado por Cervantes, a un en sus. obras latinas (según veremos luego): «Plato in Epinomide, eorum Datura sic descipit: Daenoses gens aerum in terra medique re(a) ione collocas colere debenus. int, nunquam tamen nobis manifeste apparent: prudentiae mirabilis participes, sunt, acuto quippe ingenio, tenacique memoria, cogitationes nostras omnes cognoscunt... sciunt quae ipsi machinaturi sunt et futura quaedam, utpote quasi in procinctu non autem longo post tempore eventuras (De prodigiis, Lugduni, 1589, fols. I13115). Este poder de vaticinio lo ejercen los demonios con motivo del saco de Roma (Tbid., fol, 1 16).

1 II, $25 ; \mathrm{RM}, \mathrm{V}, 43$.

2 III, 13. sino en cuanto al usar dell

el simple que se entra en ella

sin estudio ni experiencia.

Por consiguiente, si las razones de Don Quijote las encontramos repetidas en lugares tan distintos y en forma tan concorde, parece prudente decir con Clemencín ${ }^{1}$, que Cervantes «no estuvo enteramente exento de las preocupaciones comunes de su siglo en esta materia, y que los disparates y falsos vaticinios de los astrólogos los atribuía a su ignorancia y ruindad personal, y no a la vanidad de la ciencia que profesaban».

En cambio parece enteramente clara su actitud respecto de las brujerías. Dice la bruja del Coloquio: «Hay opinión que no vamos a estos convites sino con la fantasía, en la cual nos representa el demonio las imágenes de todas aquellas cosas que después contamos que nos han sucedido...» ${ }^{2}$. «Las unturas... son tan frías, que nos privan de todos los sentidos, en untándonos con ellas, y quedamos tendidas y desnudas en el suelo, y entonces dicen que, en la fantasía, pasamos todo aquello que nos parece pasar verdaderamente» ${ }^{3}$. "Todas estas cosas y las semejantes son embelecos, mentiras o apariencias del demonio» ${ }^{4}$.

Así, pues, las visiones de las brujas son producidas por menjurjes y drogas; sus alucinaciones son análogas a las que hoy causan el opio o la cocaína; la explicación no puede ser más clara ni científica. Ahora podemos separar con precisión

1 Edic. Bibl. Clás., VI, 153. Creo que los textos aducidos son evidentes, y por eso discrepo de A. G. DB AMEZÚA, El casamiento engañoso..., pág. 199, que piensa que Cervantes negó «su crédito ciencia tan generalizada y universal entonces como la astrología judi-

2 Clás. Cast., pág. 296.

lbíd., pág. 302. En estos menjurjes entraban la cicuta, el beleño, el solano y la mandrágora (véase el comentario de A. G. de Amezúa al Coloquio de los perros, pág. 637 ).

Ibíd., pág. 309 (véase, además, pág. 3 Io). 
la fábula brujeril, con función fantasmagórica dentro de la. obra, y la opinión del autor ${ }^{1}$.

Y lo mismo acontece con la licantropía: «Eso de convertirse en lobas y lobos algunas gentes de estas septentrionales, es un error grandísimo - dijo Mauricio - , aunque admitido de muchos... Lo que se ha de entender de esto, es que hay una. enfermedad, a quien llaman los médicos manía lupina, que es. de calidad, que al que la padece, le parece que se ha convertido en lobo, y aúlla como lobo...» ${ }^{2}$. «Todo esto se ha de tener por mentira, y si algo hay, pasa en la imaginación y no realmente... La fuerza de los hechizos de los maléficos y encantadores, que los hay, nos hace ver una cosa por otra; y quede desde aquí asentado que no hay gente alguna que mude en otra su primera naturaleza» 3

Acerca de los sueños, Cervantes les da una explicación natural, aunque, como en el caso de la astrología, piensa que quién sabe si no hay en ellos materia para la ciencia divinatoria: «Dice Dios en el Levítico: «No seáis agoreros, ni deis

1 A. G. de Amezúa, en su sabio comentario del Coloquio de los perros (pág. 198), piensa que Cervantes no creía en absoluto que fuese fantain lo de las brujas, al escribir: aentrambas opiniones tengo para mí fra lo de las brujas, al escribir: centranbas opiniones tengo para mí ue son veraderas, refriéndose a si aquells ibn a sus convites eal o imaginativamente. Pero yo no comparto la duda de Amezúa. Téngase en cuenta que, en este caso, habla la bruja Camacha, y ya es mucho que, desde su punto de vista, admita la influencia de la fantasía en sus andanzas.

2 Persiles, Rivad., I, $583 b$ (véase edic. Schevill-Bonilla, I, 340).

Ibid., $584 b$. De Loulss, Cervantes reazionario, pág. 192, cita este pasaje y lo comenta irónicamente: «Hacer parecer, pero no transforpasaje y lo coll De mar. Una sutil d obsesionado con el reaccionarismo de Cervantes. Éste no niega la existencia de las alucinaciones; lo que niega es que tengan correspondencia con la realidad. Lo que confunde a De Lollis (pág. 193), es que la hechicera Cenotia quite la salud al joven Antonio con sus hechizos, y piensa así que Cervantes, lo mismo que Antonio de Torquemada, Fardin de fores curiosas, cree en las brujas. Ya he dicho antes lo necesario sobre la brujerí como tema literario. Por ese camino serín tos en la fábula artística; también Racine. crédito a los sueños», porque no a todos es dado el entenderlos... ${ }^{1}$. Los sueños, que cuando no son revelaciones divinas, o ilusiones del demonio, proceden, o de los muchos manjares que suben vapores al cerebro, con que turban el sentido común, o ya de aquello que el hombre trata más de día» ${ }^{2}$.

Qué relación guarda todo esto con las ideas de la época? -Está Cervantes retrasadísimo al hablar de la existencia de demonio? ${ }^{3}$. De Lollis se burla de las ideas de Cervantes sobre los sueños: "Au choix, entre los dos extremos de la mala digestión o de la revelación divina» (pág. I99). Pero esta posición es antihistórica, porque un científico como Descartes "tuvo tres sueños consecutivos en una sola noche, que imaginó no podían venir sino de lo alto». "A malo spiritu ad templum propellebar», decía Descartes; entonces se volvió del lado derecho y rezó, ya que Dios no había permitido «que se dejase arrastrar, ni aun a un lugar santo, por un espíritu que no había enviado» 4 .

Es curiosa la actitud de los historiadores con nuestro Cervantes; tendría éste que haber sido lo que fué, y además Galileo y Descartes en una pieza, para no producir esa impresión de un pobre y vulgar ignorante, víctima de las supersticiones más burdas ${ }^{5}$. Cervantes admitía la posibilidad de la astrología,

1 Los Sres. Schevill y Bonilla, en su edición de Persiles, I, 120 hacen llegar las comillas de la cita del Levitico hasta entenderlos», con lo que parece que esa frase última es bíblica y no de Cervantes, siendo así que es locontario. En Le tico, XIX, 26, se dice sólo: Non augurabimini, nec observabitis somnia.

augurabimini, nec observabitis somnia.»
2 Rivad., I, 584 b. Explicación análoga se da a los sueños en el Viaje $\begin{aligned} & 2 \text { Rivad., I, } 584 b \text {. Explicación análoga se da a los sueños en el Viaje } \\ & \text { del Parnaso, principio del capítulo VI, Rivad., I, } 693 a \text {. P. Ciruelo, Re- }\end{aligned}$ probación de supersticiones (1556), da también estas causas: «Alguna alteración del cuerpo del hombre..., revelación de Dios, o de algún ángel bueno o malo» (edic. Barcelona, 1628, págs. 77-78).

3 Véase antes, pág. 99, nota.

4 Véase G. Munaud, Une arise mystigue chez Descartes, en Revue de Méthaphysigue, I916, pág. 6I I. Comp. J. Chevaluer, Descartes, I921, pág. $4 \mathrm{I}$.

5 Al citar SAvj-Lopes, Cervantes, pág. 258, la frase de Persiles "Quiero que entiendas por verdad infalible que la tierra es el centro del cielo», añade como comentario: «No es precisamente un discípulo 
como muchos esclarecidos ingenios de aquella época. Piénsese que esa disciplina abarcaba, en monstruosa mezcolanza, lo que hoy es astronomía y meteorología, juntamente con la astrología judiciaria propiamente dicha. Son notables los esfuerzos por separar ambas zonas (la exacta y la fantástica) dentro de la astrología. Nuestro Pedro Ciruelo, en su Reprobación de las supersticiones ( 1556 ), intenta, como puede, esa delimita ción: "Concuerdan la verdadera y la falsa astrología, no solamente en el nombre, más también en la obra, que entrambas juzgan de las cosas que están aún por venir, y esto juzga por los cielos y estrellas... ${ }^{1}$. Y porque los cielos y estrellas, alte-

de Galileo Galilei.» La cultura de Cervantes en estas materias era la admitida en el Sur de Italia durante su permanencia allá hasta pudo, por ejemplo, tener noticia de Bernardino Telesio, cuyas obs daban que hablar a la saźn. En este flósofo habia marcada mezcla de lo antiguo y lo moderno, como en tantos otros espirius de fnes del cilo antiguo y lo moderno, cono en tantos otros espiritus de fines del siglo xvi; y, no obstante, Telesio es uno de los fundadores de la ciencia moderna. Pues bien: en La philosophia di Bernardino Telesio, ristretta in verità... (Nápoles, 1589 , pág. 107) leo esto: «Falla [Aristóteles] gravemente, percioche, se egli havesse mirato le cose in viso, havrebbe senza fallo conosciuto e veduto con gli occhi, la terra essere pe sua natura inmobile.s Galileo enseña en Pisa, y en 1597 escribe Keplero que el sistema de Coperico era objeto de geneal hillidad (ch. Charbonnel, La pensée it alienne an XVI. siecle, 1919, pág. ${ }^{67} 7$ ). Y se quiere que Cervantes, desde su rincón madrileño, viviendo de la cultura que almacenó hacía treinta o cuarenta años, nos dé en $P$ er siles la última nota de la ciencia del día, cuando Campanella, aun en 1613 , se resistía a admitir el movimiento de la tierra, que más tarde aceptó (Blanchet, Campanella, pág. 24I).

1 Página 61 de la edición de Barcelona, 1628 , con adiciones de un Pedro Antonio Jofreu, abogado barcelonés. El ejemplar que manejo, de nuestra biblioteca universitaria, tiene algunas curiosas anotaciones de un lector de 1780 : sEste libro es muy digno de aquellos tiempos en que se escribió e imprimió; en esta última mitad del siglo $18 .^{\circ}$ la España no es tan ignorante, crédula ni supersticiosa; así, por pasatiempo, se pueden passar los ojos por este libro y reírse a carcajadas. 1780.» El adicionador Jofreu es un fanático bárbaro, que escribe en su prólogo: «Hasta el perverso Calvino hizo justicia de Miguel Servet, porque era herege ; bolvamos los ojos solamente al rejno de Francia que despús que por nustros pecados se ab io enno de fran-

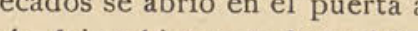

rando el aire y la tierra, también alteran a los hombres y a los otros animales..., el verdadero filósofo que conoce las virtudes y propiedades de las estrellas, podrá por ellas conocer los efectos sobredichos en los elementos y en los hombres, aves y animales... Y aunque estos buenos astrólogos, en sus juicios no siempre acierten, no es maravilla por dos razones. La una es por parte de la ciencia en sí, que trata de cosas muy altas y dificultosas de saber por su mucha diversidad. La otra razón es por parte del astrólogo, que muchas veces no sabe tan bien la ciencia como sería menester... Y ansí de los otros sabios en sus artes y ciencias que no siempre aciertan, no porque la ciencia no sea buena, mas por la dificultad de la materia, y o por falta de saber en el letrado» ${ }^{1}$. Es lo mismo que antes (pág. IOO) notábamos en Cervantes:

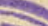

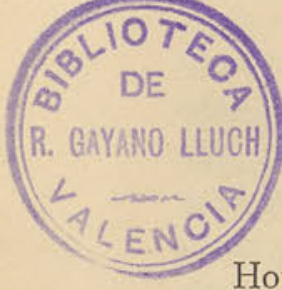

Que tengo por fruslería

la ciencia, no en cuanto a ciencia

sino en cuanto al usar della

el simple que se entra en ella

sin estudio ni experiencia.

Hoy es fácil calificar de inocente tal actitud mental; pero una serie de lógicos supuestos y de hechos ignorados, junto con la idea de la causalidad universal, llevaba necesariamente

razón de estado se permitió a los hereges y supersticiosos predicar y hazer los ejercicios de su falsa religión... Y además de castigar Dios a los príncipes malos con desastrados fines..," Al llegar aquí, el lector de 1780 glosa enojado: «Calla, que la fanática superstición fué la que acabó con el mejor de los reyes, Henrique $4{ }^{\circ}{ }^{\circ}$ En la página 49 , glosa acabó con el mejor de los reyes, Henrique $4^{\circ} \gg$ En la página 49 , glosa
así las ingenuidades de Ciruelo acerca del demonio: \&Voy viendo que de pies a cabeza este libro está lleno de credulidades y niñerías, y algo más dijera si me instaran.» En la página 98 nuestro lector se irrita deci. didamente leyendo las insanias del Jofreu, y escribe: « $\star_{i}$ Pobres teólogos, si son como tú! ¡Majadero!s Y al llegar aquí se conoce que arrojó el libro, que no tiene más anotaciones ni huella de uso. Es interesante esta ano qua nota de clariad deciochista, que para pero que tal vez no posera el arte de leer entre lineas; el libro pasado, pero que tal vez no poséa el arte de leer entre linas, el libro de Ciruelo (sin las glosas de Jofreu) merecía más atenta observación. Pág. 62. 
a tales consecuencias, con mucha más facilidad tratándose de personas curiosas e inquietas intelectualmente ${ }^{1}$.

Cervantes censura a quienes entran en la ciencia astrológica «sin estudio ni experiencia». La magia y el ocultismo habían mantenido, en efecto, a través de la Edad Media, la tradición de observar los fenómenos experimentalmente ${ }^{2}$, y en el siglo xvi, los conocedores de estas artes (Paracelso, Agripa de Nettesheim) se presentan como partidarios de la experiencia contra las abstracciones de la escolástica medieval. Nettesheim piensa que si las propiedades ocultas de origen celeste pueden ser descubiertas, será mediante experiencias y conjeturas, no por la dialéctica de Aristóteles. Por este camino se establece una notable concordancia entre los alegatos de Telesio en pro del método experimental y las tendencias que eran tradicionales en el ocultismo.

Otra base para el desarrollo de la filosofía oculta es lo que se ha llamado el pampsiquismo, deducido del cuasi panteísmo de Telesio ${ }^{3}$. Admitida el alma del mundo, hay que reconocérsela a los astros y a los elementos, que prestan alma y vida a los seres singulares. Campanella dirá en De sensu rerum: "Lo que existe en los efectos y en el todo debe existir también en las causas y en las partes» ${ }^{4}$

Campanella, como Agripa de Nettesheim, admite que el móvil principal de la actividad oculta de los seres es la repul-

1 Lo veía muy bien Juan Martí en su continuación del Guzmán de Alfarache (Rivad., III, $4 \mathrm{IO}$ a): «Aunque esta ciencia en sus principios es clara y cierta, pero, como es negocio de tan lejos, principios es clara y cierta, pero, como es negocio de tan lejos, pocos la saben... La raíz de este vicio está en el apetito que reina en los hombres de cosas nuevas., Y el bárbaro adicionador del libro de Ciruelo antes citado observa que sla libertad de los hereges y supersticiosos desahoga, a su parecer, el entendimiento, y le libra del jugo de la escuridad que tienen los misterios de la fes (Prólogo).

2 Un excelente exposición se halla en L. Blanchet, Campanella, I920, págs. 193 y sigs.

3 E. Troilo, B. Telesio, 1924, pág. 60

4 "Quidquid est in effectibus esse et in causis: ideoque elementa ac mundum sentire» (lib. I, cap. I). De sensu rerum se escribía en 1604 , aunque se publicó en 1620 (véase Blanchrt, Campanella, pág. 196). sión de los contrarios y la atracción de los semejantes. Tal principio, en relación con el ocultismo, había sido formulado ya en $\mathrm{I} 560$ por el napolitano Della Porta ${ }^{1}$; la atracción entre los semejantes es la ley del universo físico, y, desde luego, la química, la medicina, todas las ciencias aplicadas, deben deducir de esa ley sus principios generales y particulares. $\mathrm{He}$ aquí, pues, un nuevo portillo para la aceptación del ocultismo astrológico por quienes pensaban que la vida física y moral era, ante todo, armonía y concordancia.

Situémonos, pues, en la historia y no decretemos que Cervantes era un pobre ignorante al aceptar la posibilidad del vaticinio astrológico; su contemporáneo Campanella pensaba en forma análoga, partiendo de ideas que habían de ser fecun das para la ciencia posterior, aunque su aplicación a la astrología hoy nos parezca pueril. Hacia I6I 3 escribía Campanella sus Astrologicorum libri VI, publicado en I629, algunos de cuyos pasajes he anotado para dar al lector un punto de referencia ${ }^{2}$. La teoría astrológica del hado admite que los hechos relativos al porvenir están preformados en sus causas desde el origen del mundo; pueden, por tanto, ser previstos por el hombre que conozca la acción de esas causas, siempre contingentes si se trata de acontecimientos humanos, pero que determinan en la conformación de los caracteres individuales ciertas predisposiciones generales que la ocasión desarrolla y precisa. A las ideas astrológicas de Cervantes podríamos aplicarles estas justas palabras de Blanchet sobre Campanella: «El error de Campanella no tiene, pues, como origen los principios

1 Magia naturalis, lib. I, cap. XIV.

2 eNil mirum si et sydera, quae causae sunt manifestae omnium

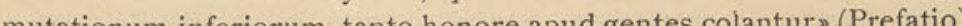
mutationum inferiorum, tanto honore apud gentes colantura(Prefatio). «Propterea astrologiam scribere decrevi juxta physicas regulas, quae possint in ecclesia Dei absque suspicione legi (pág. 3). "Quamvis Deus inferiora mutet, non tamen sine secundis causis... mutationes rerum humanarum, etsi sint a Deo, non sine causis naturalibus fieri censendum est... Ergo nec sine stellarum actionibus res nostrae mutantur: neque, illis non mutatis, istae mutenturs (pág. 66). Para el detalle de los horóscopos, véase, Ibid., I 99 [Bibl. Nac., 3-45603]. 
lógicos colocados en la base de la astrología; el error procede de su conocimiento insuficiente de las relaciones efectivas entre nuestro mundo y el mundo sideral; de la ligereza con que infringe (por imaginación o por apego a la tradición) las reglas que ha establecido; en fin, de la ausencia total de rigor que caracteriza su razonamiento por analogía» 1 .

Siendo Campanella huésped del rey de Francia predice que el eclipse de Sol anunciado para el I de junio de 1639 le sería funesto; para conjurar el peligro recurrió a todos las artes de la astrología (colgar tapices blancos, poner plantas verdes en su celda, etc.); no obstante lo cual, murió el 2 I de mayo de 1639.

Hemos visto a Cervantes mostrarse sumamente cauto (páginas 99-100) y postular gran caudal de experiencia para que los pronósticos astrológicos fuesen respetables; tal vez juzgaba, como en el caso de los médicos, que el progreso humano aún no permitía la realidad de esa ciencia, posible en teoría (en el estado de los conocimientos sobre la naturaleza a fines del siglo xvi, un ingenio crítico no vería mucha diferencia entre e pronóstico de un médico y el de un astrólogo) ${ }^{2}$. Dada la correlación que, en efecto, existe entre los astros y la vida terrena (estaciones, climas, mareas), siendo vaticinables los eclipses, ¿dónde podía ponerse realmente el límite entre astronomía y

1 Blanchet, Campanella, pág. 216.

2 De hecho la medicina y la astrología iban juntas muchas veces; véase Charbonnel, La pensée italienne, pág. 199. Y criticando los absurdos de médicos y astrólogos, al mismo tiempo que negaba el criterio de autoridad representado por Aristóteles, comienza Petrarca a abrir la vía por donde han de caminar la razón y la experiencia del Renacimiento (v. De Nolbac, Pétrarque et l'Humanisme, 1907, pág. 4). Pero entre la turba de charlatanes, contra quienes se yerguen Petrarca Montaigne - e igualmente Cervantes - bullían los gérmenes de nueva ciencia; así como en la alquimia se ballan contenidos precele tes de la quica. Ardloo proble para los hombres de 1600 era leslinde de esos camos recubiertos de brum; porque no deslinde de esos campos recubiertos de bruma; porque no bastaba con la elegante abstención de un Montaigne; su inteligente escepticismo, por fecundo que fuese, necesitaba ir seguido de tesis muy afirmativas astrología? ${ }^{1}$. ¿Cómo rechazar la previsión de los acontecimientos humanos, por observación de los astros, en una época en que las ciencias físicas y biológicas eran verdaderos arcanos? La curiosidad y el afán racional de los hombres del Renacimiento les impidió encerrarse siempre en un discreto «nescio»: : ppor qué ensañarse entonces contra Cervantes, que después de todo no había hecho del pensar exacto menester central de su actividad? Por otra parte, la verdad le era revelada a la época moderna envuelta entre los más extraños errores y confusiones. De no considerar así el final del siglo xvi, formularemos sobre Cervantes juicios desprovistos de sentido histórico ${ }^{2}$.

En conclusión, Cervantes se halla, en lo que atañe al contenido de una parte de su cultura, en la misma ambigua postura que muchos pensadores preclaros de fines del siglo xvi y aun de principios del xvir. Y digo de una parte, porque ya tendremos lugar de ver cómo sus ideas morales revelan una posición decididamente moderna. Pero lo que hay que destacar fundamentalmente es la disposición formal de su espíritu, que no se explica porque utilizara estas o las otras fuentes; es el uso continuo de la crítica, la fe en la experiencia y en la razón, el afirmar que las cosas nos ofrecen múltiples aspectos, y que a las discusiones de los hombres toca averiguar qué sea, en último término, lo verdadero. En Persiles refiere el protagonista un salto prodigioso que dió con su caballo desde una eminente roca sobre el mar helado, sin que ambos sufriesen el menor daño; y añade Cervantes ${ }^{3}$ : «Duro se le hizo a Mauricio el terrible salto del caballo tan sin lisión; que quisiera él, por lo menos, que se hubiera quebrado tres o cuatro piernas, porque no dejara Periandro tan a la cortesía de los que le

1 "De allí a poco rato, levantándose un alterado viento, se comenzaron a ver algunas negras nubes... señales por donde algunos pastores que allí estaban, en la rústica astrología maestros, algún venidero turbión y borrasca esperabans (Galatea, II, 205).

2 Deben consultarse además: Charbonnel, Ob. cit., págs. 192 y siguientes; Vilı.Ex, Sources des Essais de Montaigne, II, 344 y sigs.

3 Rivad., I, 62I $a$. 
escuchaban la creencia de tan desaforado salto; pero el crédito que todos tenían de Periandro les hizo no pasa adelante con la duda del no creerle, que así como es pena del mentiroso que cuando diga verdad no se le crea, así es gloria del bien acreditado el ser creído cuando diga mentira.»

La reducción irónica de la fantasía engañosa está finamente realizada. El lector atento sonríe ante la malicia cervantina, y sabe a qué atenerse. Periandro goza de nuestra simpatía, y no merece que se le obligue a confesar una mentirilla de mayor o menor bulto. $\mathrm{Ni}$ quiso Cervantes que Periandro pusiera él mismo en duda lo verídico de su relato, como hubo de hacer Don Quijote con las fantasías de la cueva de Montesinos. No hace falta; la actitud crítica del autor queda aquí patente ${ }^{1}$ como en cien casos más.

La alquimia y el afán crisopéyico, la matemática de los cuadradores del círculo, el arbitrismo tan en moda a la sazón, el poeta que escribe un suplemento de la Historia del Santo $\mathrm{Brial}^{2}$, brindan cuatro nuevos puntos de rebote para la crítica irónica de Cervantes: no creo que haya sombra de duda acerca de cuál sea su pensamiento.

1 Siento tener que citar otra vez a De Lollis para disentir de su opinión; pero el eminente hispanista ha publicado un libro que a cada paso roza puntos que yo he examinado, y sobre los que tenemos, por lo que veo, opiniones opuestas. Así, por ejemplo, este pasaje de Persiles, para mí característico del sentido delicadamente cítico de vantes, es para él una prueba de incapacidad y cas de bober de Cerque Perianto es el protagoista de la novela, y Cervato que Periandro es el protagonista de la novela, y Cervantes le concede toda su simpatía..., no creo que quiera reírse ni hacer que se rían de el... [¿y Don Quijote?] Siempre una moral relativa, de contrarreforma, que admite gloria alli donde hay mentira. Parece como si a quellas pobres conciencias, puesto que ya no eran dueñas de sí, renunciasen a todo punto fijo de orientación " (Cervantes reasionario, pág. 185). En la página I 86 añade: «Cervantes, el buen hombre que todos conocen", (cil buon uomo que tutti san el ). Pero es posible que no se vea a primera vista lo que Cervantes dice y piensa escribir ese pasaje? Sólo un prejuicio tan arraigado como el que inspira libro pudo llevar a De Lollis a expresarse de esta suerte.

2 Coloquio de los perros, edic. Clás. Cast., págs. 33 r-332.
OTRAS MANIFESTACIONES DE LA CULTURA CERVANTINA

Lo dicho acerca de la facultad crítica del autor nos presenta algunos de los límites de su cultura; mas conviene ahora examinar cuál sea la actitud de Cervantes frente a ciertas formas del saber, sin que ello signifique designio de analizar en conjunto el contenido de sus conocimientos ${ }^{1}$. Sólo me interesan aquellas manifestaciones de cultura que impliquen orientación determinada frente a los varios caminos que la vida de entonces presentaba a un espíritu activamente curioso. Un inventario metódico de todo el saber cervantino requeriría, por otra parte, la previa determinación de sus fuentes, sólo en parte $y$, a veces, inexactamente conocidas; he renunciado a esa tarea para no alargar este estudio más de lo que me convenía.

Dice Cipión que filosofía «se compone de dos nombres griegos, que son filos y sofia: filos quiere decir amor, y sofía, la ciencia; así que filosofía significa amor de la ciencia, y filósofo, amador de la ciencia». "Mucho sabes, Cipión», replica su compañero Berganza; «qquién diablos te enseñó a ti nombres griegos?» "Verdaderamente, Berganza, que eres simple, pues de esto haces caso; porque estas son cosas que las saben los niños de la escuela, y también hay quien presuma saber la lengua griega, sin saberla, como la latina, ignorándola» ${ }^{2}$.

Es evidente que si nuestro autor no hubiera estado decidido a eliminar de su obra cuanto juzgó inesencial, fácil le

1 La índole de este trabajo me obligó a exponer en el capítulo I las ideas literarias de Cervantes.

2 Coloquio de los perros, edic. Clás. Cast., pág. 254. Recuérdese el prólogo al Quijote: «Y con estos latinicos y otros tales os tendrán siprólogo al Quijote: $\mathrm{Y}$ con estos latinicos y otros tales os tentrí siquiera por gramáticos (RM, I, 35). Lo que debecompararse con Erasmo: *Maravillosa cosa estiman insertar y mezclar, aun fuera de propósito, palabritas griegas, con las cuales acaban por formar hermosísimos mosaicos» (Elogio de la locura, edic. Croce, pág. 12). En la Galatea hay, a veces, aparato de erudición mitológica (edic. Schevill-Bonilla, II, 28-29); pero felizmente el autor renunció a este fácil camino, que para algunos habría significado mucha doctrina. 
habría sido acumular sacra y profana sabiduría; pero la preocupación por la sobriedad y la delimitación del área artística era en él sentimiento más fuerte que el sinsabor que pudiera ocasionarle la actitud del vulgo docto o seudodocto. Magníficamente lo declara: "Y pues se contiene y cierra en los estrechos límites de la narración, teniendo habilidad, suficiencia y entendimiento para tratar del universo todo, pide no se desprecie su trabajo, y se le den alabanzas, no por lo que escribe, sino por lo que ha dejado de escribir» ${ }^{1}$.

Esta ausencia de pedantería no ha sido bien apreciada por algunos cervantistas, que no se han percatado de que era rasgo esencial del autor ese propósito de no brindarnos sino sustancias incandescentes, que no dejasen aparecer sus orígenes rudimentarios, como acontece tan a menudo en Lope de Vega. El lector irá viendo que, en conjunto, la obra de Cervantes supone lecturas vastísimas, y grave meditación sobre problemas esenciales de la cultura contemporánea; pero él pensaba que la mayoría de las noticias y nociones que circulaban por los libros «son cosas que las.saben los niños de la escuela».

¿Sabía latín? Se pone en duda generalmente; un gran conocedor de la materia lo presenta poco seguro en esa lengua ${ }^{2}$, lo que complace a De Lollis ${ }^{3}$. Mas, cosa curiosa, el mismo De Lollis ha de reconocer pocas páginas más adelante: «Es posible que el mismo Polidoro fuese la fuente de Cervantes, tanto más cuanto que en su obra se encuentra el detalle, señalado también por Cervantes, de la ausencia de animales venenosos en Inglaterra» ${ }^{4}$. Se trata de las Anglicae Historiae, de Polidoro Virgilio, no traducidas al romance, y en las que se habla de Rosamunda Clifford, la manceba del rey Enrique II

1 II, $44 ; \mathrm{RM}, \mathrm{V}, 378$.

2 Schevilt, Studies in Cervantes, en Transactions of the Connecticut Academy, 1908, XIII, 498.

3 «Veo con placer que también Schevill se satisface con la idea de un Cervantes peor que mal seguro de su latín» (Loc. cit., pág. I84.)

4 Loc. cit., pág. 228. de Inglaterra, que aparece en Persiles. Cervantes hasta hace el juego de palabras "Rosamunda: rosa inmunda» ${ }^{1}$; es decir, que leía el latín, lo cual no quiere decir que lo supiera como Vives o Quevedo, y que no equivocara una cita al reproducirla de memoria ${ }^{2}$. Creo que es conveniente ir abandonando el dogma de Cervantes «ingenio lego ${ }^{3}$ en el sentido de persona inculta y algo sandia en cuanto al intelecto. Puede ser agradable,

\footnotetext{
1 Cfr. Persiles, edic. Schevill-Bonilla, I, 338.

2 Decir «aliquando bonus dormitat Homerus» en vez de «quandoque bonus»; atribuir a Catón el edonec eris felix ovidiano, etc. Pero tampoco Montaigne citó siempre con absoluta exactitud tc. Pero latinos: véase $E$ sais, latinos; véase Essais, III, 6, donde el texto de Cicerón «Si intermina um in omnes partes..., ha sufrido importante alteración.

3 Ríus, Bibliografía, III, 386 , dice que "Tomás Tamayo de Vargas 11 amó a Cervantes «ingenio lego», sin decir dónde. Seguramente había tomado el dato de la Vida de Cervantes, de M. FerRández de NAVArreTE, 1819, pág. 32: "No era mucho, pues, que varios de sus émulos rivales, ufanos con tan pomposos títulos, logrados tal vez a poca costa le tratasen de ignorante y de envidioso, y le desprecisen por costa, de iguales requisitos, ni que por esta fala le lamasen por carecer como dice el cronista D. Tú cono dice el cronista D. Tomás Tamayo de Vargas, habiendo apellidado del mismo modo al marqués de Santillana, D. Íñigo López de Mendoza, a Felipe de Comines, a D. Antonio Hurtado de Mendoza, a Rodrigo Méndez de Silva, y a otros que no necesitaron, sin embargo, de aquellas distinciones para ser alabados de los varones más sabios de nuestra nación, como lo advirtió oportunamente D. Alonso Núñ de Castro» Quiere, pues, decirse con eingennio lego», que no bu obtenido titulos universitarios. Don Toḿs Tamajo de Vargas lanzo famosa frase en su Funta de libros, la major gue Espana ha sistonzó la lenguga hasta el año de Ib de libros, la major que España ha visto en su lengua, hasta el año de 1624, Bibl. Nac., ms. 9753, tomo II: «Miguel de Cervantes Saavedra, ingenio, aunque lego, el más festivo de España; de Esquivias.s Menéndez Pelayo, Icaza y otros han explicado bien lo de "ingenio lego». Pero en un reciente artículo (Künstlerische Berïhrungspunkte zwischen Cervantes und Rabelais en Fahrbuch für Philologie, 1925 pág. 355), dice H. Hatzfeld: «Ambos (Cervantes y Rabelais) han introducido el Renacimiento italiano en (Cu pati soldado y católico, apontó tarde la elegante for a resuantes, uum y catolco, aporto tarde la elegante forma renacentista, el humanista Rabelais, monje y excéptico, introdujo temprano su espíritu crítico.s Sigue, pues, Hatzfeld, que tan importantes estudios está publicando sobre Cervantes, en la idea de que «lego» supone 'persona sin cultura', que se queda en la forma y no va al fondo.
} 
románticamente, esa hipótesis brumosa del genio inconsciente; pero preferimos, frente a ella, unos cuantos adarmes de prosaica claridad.

Todos recuerdan la frase: "Como yo soy aficionado a leer aunque sean los papeles rotos de las calles» $(I, 9)$, expresión de la ilimitada curiosidad con que Cervantes enfrontaba la vida, curiosidad que transmitió a su amigo Don Ouijote: "Como él era algo curioso, y siempre le fatigaban deseos de saber cosas nuevas» ${ }^{1}$. "Si estos pensamientos caballerescos no me llevasen tras sí todos los sentidos, que no habría cos que yo no hiciese, ni curiosidad que no saliese de mis manos, especialmente jaulas y palillos de dientes» ${ }^{2}$. Aquí el tema de la curiosidad da un quiebro cómico, mas el afán por penetrar en las cosas es efectivo, y esto convierte a Don Quijote en un insaciable preguntón: "Yo os suplico que me digáis quién sois y la causa que os ha traído a vivir y a morir entre estas soledades» ${ }^{3}$; y Sancho advierte que "no hay cosa donde no pique y deje de meter su cucharada» ${ }^{4}$. Cervantes nos ha dejado una de las primeras observaciones acerca del turismo extranjero en España: andar, ver, observar por doquiera el curso inexorable de la vida; he ahí uno de los grandes móviles de su afán espiritual. «Vine a Lisboa y me embarqué en una nave que estaba con la vela en alto para partir a Inglaterra, en la cual iban algunos caballeros ingleses que habían venido, llevados de su curiosidad, a ver a España, y habiéndola visto toda, o por lo menos las mejores ciudades, se volvían a su patria» ${ }^{5}$.

1 II, 24; RM, V, 15

2 II, $6 ;$ RM, IV, 150

3 I, $24 ;$ RM, II, 252.

II, 22; RM, IV, 445

5 Persiles, Rivad., I, $567 b$. Véase en Pedro de Urdemalas, esta nota de inquietud vital:

$$
\text { En fin, con la variedad }
$$$$
\text { se muda la voluntad }
$$

$$
\text { (III, 2Ir.) }
$$

Cfr. el elogio de los comediantes en la página $2 \mathrm{I} 7$.
La física y la astronomía de Cervantes eran las naturales en un escritor nacido en I 547. Él admite los cuatro elementos ${ }^{1}$, los once cielos y el sistema de Tolomeo ${ }^{2}$ como era corriente en su tiempo, no sólo en «ingenios legos», sino en personas muy doctas y latinizadas ${ }^{3}$. Pero, como he dicho, no aspiro a hacer labor de enciclopedia cervantina, sino a mencionar algunos puntos que juzgo característicos.

La medicina, por ejemplo, no es para Cervantes una ciencia absurda, como lo era para Montaigne ${ }^{4}$; pero prácticamente dudaba de que hubiese médicos capaces: «La medicina yo alabo, Pero los médicos no, Porque ninguno llegó Con lo que es la ciencia al cabo» ${ }^{5}$. Sancho quiere echar a todos los médicos de la ínsula, menos a los «sabios, prudentes y discretos» ${ }^{6}$. Más adelante se desea la muerte a todos los médicos, y hay la misma corrección: «Los buenos, lauros y palmas merecen» ". "La medicina mal compuesta obraba al revés de lo que había de obrar la bien ordenada», se dice en El Licenciado Vidriera, juntamente con que «los médicos nos matan sin desenvainar otra espada que la de un récipe» ${ }^{8}$. Un mal médico mató a una mujer porque «la purgó estando preñada» ${ }^{9}$. "La buena opinión califica la acertada medicina, y así suele haber médicos venturosos como soldados bien

1 I, 27 ; RM, II, 369, nota.

2 «Por los once cielos que dicen que hay , Persiles, Rivad., I, $6+4 a$, 597a, 61 $3 a$; cfr. La ilustre Fregona, Rivad., I, 190; Quijote, II, 4I RM, V, 326. Comp. mi estudio de Rojas Zorrilla en Teatro Antiguo Español, I917, II, 260.

3 Véase antes pág. 104

4 ¿Ce n'est pas à eux que j'en veux, c'est à leur arts, Essais, II, 37

5 Rufián dichoso, IV, 67. Es la misma idea de Lope de Vega, según ya notó Clemencín, VII, 178 :

$$
\begin{aligned}
& \text { Que no desprecio yo la medicina, } \\
& \text { sino en quien la ejercita la ignoranci }
\end{aligned}
$$

(Hermosura de Angélica, II.)

6 II, $47 ; \mathrm{RM}, \mathrm{V}, 445$

II, 49 ; RM, V, 480

8 Edic. Schevill-Bonilla, págs. $98-99$

9 II, 47 ; RM, V, 453 . 
afortunados» ${ }^{1}$; con lo que parece decirse que la fortuna, más que el propio valer, determina la capacidad del médico ${ }^{2}$.

Cervantes, aquí como en otros casos, no se muestra fundamentalmente escéptico; cree en la eficacia de la ciencia y de la razón, pero duda de que realmente esa eficacia se haga manifiesta. Había sólo la teórica posibilidad de llegar a penetrar en la ciencia médica; esa es la nota que Cervantes pone al tema tradicional de la desconfianza en la pericia del médico y del miedo a morir a sus manos ${ }^{3}$.

\section{Persiles, Rivad., I, $672 b$.}

2 Un médico prevé la muerte de la gran pecadora $\mathrm{D}^{\mathrm{a}}$ Ana en el Rufián dichoso (Edic. cit., págs. 66 y 84), mas procede, en realidad, como un astrólogo vaticinador.

3 Confróntese, por ejemplo, MaL LARA, Filosofía vulgar, II, 60 : "Quien a médicos no cata, o escapa o Dios le mata. Quien a ellos se ha entregado, un verdugo y bien pagado.» Pero Mexía era partidario de la medicina simple y natural, a base de hierbas, sno de los compuestos y ponzoñas de agora, que en lugar de curar nos matan y enflaquecen» (Silva de varia lección, cho cura noturistamente una herida de su amo conérdese cómo SanI , I. RY, I, 356). En ascado I, I I; RM, I, 356). En su interesante «Diálogo de los médicos», Pero Mexía concluye que si bay salgunos indiscretos médicos o malos artífices, no por eso habemos de reprobar a los buenos» (Diálogos eruditos, Sevilla, 1570 , pág. 55), lo que supone mucha menos desconfianza que la demostrada por Cervantes. 
rando $\tan$ tremenda verdad rompe la ecuación vital representada en el amor concorde. Cervantes es en tales casos tan implacable (ya lo veremos) como es magnánimo cuando se trata de dos voluntades dispuestas a fundirse naturalmente. Tragedia del desacuerdo (error), exaltación épica de lo. armónico y concorde en el amor recíprocamente logrado: por estas opuestas vertientes discurren en último término las más de las fábulas cervantinas (serie errónea: Celoso extremeño, Grisóstomo, etc.; serie armónica: El Cautivo, Persiles, etc.)

Examinemos la serie errónea. Leemos en Persiles (623a) que el mejor pensamiento es el más sosegado, "cuando no se mezcle con error de entendimiento». El error puede consistir en la falsa interpretación de una realidad física (venta - casti1lo; molino - gigantes; carneros - ejército; río Ebro - Océano, etc., etc.); sus resultados, en fin de cuentas, se sitúan siempre en la gama de lo cómico (ridículo, humorismo, etc.). Puede asimismo consistir el error en mala interpretación de una realidad moral (típico ejemplo es Anselmo, creyendo que la virtud de Camila es como oro que puede ponerse al fuego para probar su pureza); las consecuencias de tales errores no suelen ser cómicas, sino trágicas, y a m enudo tales yerros se castigan con la muerte.

Los errores más interesantes, desde el punto de vista de la ideología del autor, son, por consiguiente, los de este último tipo. En ellos se percibe la oposición y desarmonía entre dos puntos de vista. Además, el mero y constante error sobre las apariencias físicas supone ser francamente loco, como lo son Quijana ${ }^{1}$, Tomás Rodaja y sus congéneres; el error moral, en cambio, se aloja fácilmente en quienes pas por cuerdos, ya que sus raíces, siendo más amplias e intrincadas que las de las perturbaciones meramente sensoriales, pueden envolverse en aparente discreción. Hay un número considerable de personajes que se engañan moralmente, fue-

1 eSiendo, pues, loco como lo es; y de locura que las más veces toma unas cosas por otras..., II, ro; RM, IV, 208. ra de los del Quijote, lo cual prueba que se trata de una tendencia en el autor, de la que es caso máximo su obra maestra. Y tal tendencia es de índole más amplia que la estructura misma de los personajes, ya que hemos de ver que muchos de ellos ni se equivocan ni aciertan siempre de modo sistemático. Don Quijote está en lo firme más de una vez; Sancho suele desbarrar, pese a su evidente buen sentido. Hemos de ir viendo cómo las series de la desarmonía (error) y de la concordancia (atracción vital, sobre todo en el amor) son caminos reales por los que discurren unos u otros personajes cervantinos, o alternativamente, un mismo personaje.

Cómo son estos errores morales? Tomemos el caso de Juan Haldudo (Quijote, I, 4). El Hidalgo piensa que un simple mandato suyo tendrá la virtud de modificar en lo sucesivo la conducta del cruel labrador del Quintanar. Don Quijote no ha intentado reformar los motivos que determinaban a Haldudo a maltratar al niño Andrés, sino que suspende mecánicamente la acción de aquellos motivos con la amenaza de su lanza. Desaparecida la amenaza, la realidad moral de Haldudo vuelve a ser lo que naturalmente era: impulso cruel.

Más adelante ${ }^{1}$ reaparece el muchacho para hacer bien patente el error del Caballero: «Como v. m. le deshonró tan sin propósito..., encendiósele la cólera, y como no la pudo vengar en v. m., cuando se vió solo descargó sobre mí el nublado... Si otra vez me encontrare, aunque vea que me hacen pedazos, no me socorra ni ayude.» El esquema es sencillo: una realidad moral y un alucinado observador; como consecuencia, una trágica catástrofe para el mozo sin ventura que, maltrecho y pobre, marcha a Sevilla, dejando corrido a Don Quijote y triste al lector. El generoso Hidalgo no ha soportado esta vez la consecuencia de su yerro; la víctima es un niño. El hecho es único en el Quijote, y deja en el ánimo infinita melancolía.

Pero hay otros casos de profunda complicación en que

1 I, 3 I; RM, II, 479-482. 
los planos del acierto y el error se intersectan. Así, en los galeotes. Cervantes intenta hacernos ver que aquellos sujetos no deben ir a galeras; no hay justa consecuencia entre los delitos y sus penas («el torcido juicio del juez», etc.). La sociedad y la justicia no debieron, moralmente, imponer aquellos castigos, juzgados arbitrarios por Don Quijote y por Cervantes; henos ante un primero y fundamental error. Pero los guardas están obligados, por su función, a no soltar a los galeotes, punto de vista explicable, pero que Don Quijote, por altos designios, cree de su deber violentar: - segundo error. Los galeotes están libres y aspiran a correr por el ancho mundo; su libertador quiere que vayan con las cadenas a hacer pleitesía a Dulcinea. Nueva incongruencia de dos puntos de vista: - tercer error. Debe, dos puntos de vista :- tercer error. Debe, sin embargo, tenerse en cuenta, que al decir en este caso "error», no podemos coincidir enteramente con el concepto usual aplicable a otros casos de sencilla confusión, que suponen una realidad firme, evidente y fácilmente perceptible. La realidad moral, para nuestro novelista, es aquí ondulante y tornasolada. Con ciertas reservas hay, pues, que hablar de error en este episodio, ya que lo erróneo confina con lo problemático. ¿Tiene razón la justicia al condenar a los galeotes? ¿La tienen los guardas? ¿O los galeotes? ¿O Don Quijote mandándoles ir con sus cadenas a los pies de Dulcinea? ¿Yelmo? ¿Bacía? ¿Baciyelmo? La técnica es la misma ${ }^{1}$

No tendría interés prolongar el análisis de los errores de Don Quijote, muy presentes en la memoria del lector; realizar un estudio especial del Quijote es, además, un fin que no persigo. El héroe comienza enganándose sobre sí mismo y sigue equivocándose hasta el final, con intervalos de mara-

No es tampoco pequeña la complejidad de la aventura del rebuano (II, 27). Don Quijote demuestra lo a del rebuzofenda porque le llamen «del rebuzno, jue mote; pero no es menos a cualquier otro armas e irritado, en poco descripciones reglamentarias y un poco de evangelio. La demostración nos la trae Sancho al soltar su estentóreo rebuzno $(\mathrm{RM}, \mathrm{V}, 88)$. villoso acierto, incluso para defender con éxito su derecho a ser loco frente a los audaces como Sansón Carrasco. Pero dejemos al magno personaje, para examinar otros de menor trascendencia estética, que al coincidir con aquél en ciertos rasgos formales descubren un esquema común que sirve de molde a muy varios tipos humanos.

Reparemos en El Curioso impertinente. Ya en tiempos de Cervantes se ha censurado la intercalación de esta novela en el Quijote, «no por mala ni por mal razonada, sino por no ser de aquel lugar» ${ }^{1}$. Cervantes se excusa en el capítulo XLIV: «escribir de un solo sujeto y hablar por las bocas de pocas personas era un trabajo incomportable...; por huir deste inconveniente había usado en la primera parte del artificio de algunas novelas, etc. ${ }^{2}$. Muchos han opinado sobre el sentido que tenga esta intercalación de El Curioso; no voy a citarlos a todos, pero sí a algunos. El debate parece que ha perdido actualidad; Rodríguez Marín no analiza la cuestión en su comentario; el asunto es, sin embargo, importante, porque va unido al concepto mismo de la técnica de Cervantes.

Opiniones adversas a la intercalación. - Clemencín: "Cervantes no se empeñó en defender lo que no podía defenderse ${ }^{3}$. Creo que influyen aquí las mismas razones de poética neoclásica que orientan todo el comentario de Clemencín.

Grillparzer censura no tanto el hecho de la intercalación, como las novelas mismas, y no sólo las de El Curioso y El Cautivo sino los demás episodios: "Es en ellos el autor sumamente afectado y amanerado.» El Curioso es «muy débil novela: lo interesante está tratado en un momento; en cambio, las partes indiferentes están desarrolladas más de lo justo» ${ }^{4}$.

1 II, 3 ; RM, IV, 93.

2 RM, V, 378.

3 Quijote, edic. Bibl.Clás., V, 64. Vuelve a criticar duramente tal intercalación en VII, 106.

4 Sämtliche Werke, 1842, XIII, I94. Véase Bertrand, Cervantes et le romantisme allemand, pág. 589 . 
Bertrand ${ }^{1}$ no emite opinión categórica, pero pregunta con desconfianza: «En qué refleja El Curioso impertinente la vida o siquiera los sentimientos del autor?» El distinguido erudito no intenta defender la intercalación.

Schevill ${ }^{2}$ : «Cervantes reconoció más tarde que, dejando a un lado el interés de la novela, la forma de insertarla fué un error inartístico.»

Máine ${ }^{3}$ reconoce en este caso que «las narraciones tanto mejor se leen, cuanto más se guarda en ellas la unidad de acción»; pero no juzga explicable «la severidad con que se ha censurado a Cervantes».

Unamuno ${ }^{4}$ mira "El Curioso impertinente como novela por entero impertinente a la acción de la historia».

Opiniones favorables. - G. de Schlegel ${ }^{5}$ : «No recordamos que ningún crítico haya calificado de extraña a la conexión y de violentamente introducida en la Odisea la historia de los galanteos entre Marte y Venus; y, sin embargo, no tiene más de común con la suerte de Ulises que El Curioso impertinente con la de Don Quijote... En la verdadera novela, o todo es episodio o no lo es nada.»

Tieck: "Anselmo quiere tener en la mano el amor invisible... Por su impertinente curiosidad destruye la nobleza y la castidad de su mujer; su esfuerzo para realizar el ideal destruye el ideal mismo del tesoro moral... La novela hace juego profundamente con la acción principal de Don Quijote...; expresa en otra forma la acción general de la filosofía cervantina» 6 . En 1829 escribía Solger ${ }^{7}$ : «Las novelas intercaladas [en el

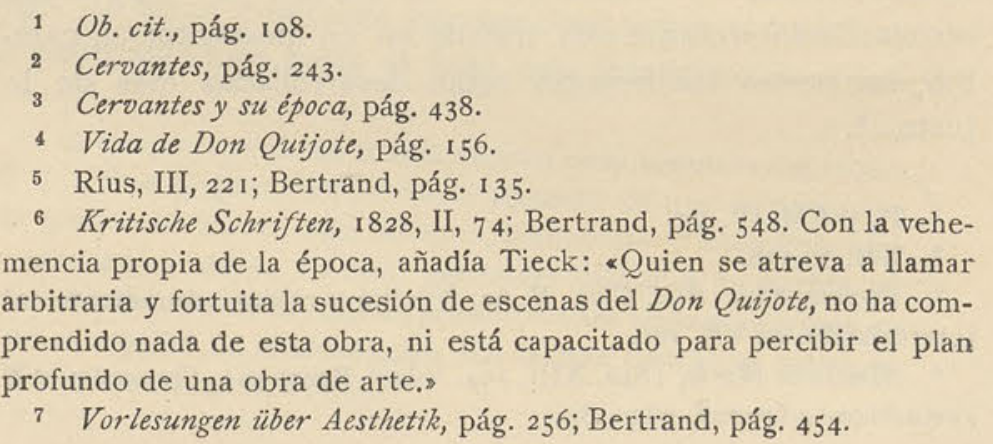

Quijote] son de una importancia esencial para el poema, y tienen siempre una relación alegórica con el pensamiento general de la obra entera.»

Narciso Díaz de Benjumea ${ }^{1}$, a vueltas de sus descosidas interpretaciones, tiene juicios para mí aceptables: El Curioso impertinente "no es episodio pegadizo... Anselmo tiene notable analogía con Don Quijote... y se une estrechamente con la idea fundamental». Benjumea conocía tal vez las ideas de los románticos alemanes.

R. Renier ${ }^{2}$ pensaba que «entre estas novelas entremezcladas y las aventuras del protagonista, hay, examinándolas atentamente, la misma antinomia que existe entre la realidad y la imaginación».

De los anteriores datos, que no necesitan ser exhaustivos, se ve que hay dos grupos de pareceres: unos que, por razones de armonía, de preceptiva o meramente de condensación del interés en torno al protagonista, rechazan la intercalación de las novelas (su fuente, en último término, sería la crítica neoclásica); otros que, obedeciendo a una concepción romántica del arte, buscan conexión interna entre los diversos episodios y el conjunto. Yo creo que estos últimos se acercan más a la verdad, y podrían apoyarse incluso en el pensamiento del autor: "Los cuentos y episodios de [el Quijote], que, en parte, no son menos agradables y artificiosos y verdaderos que la misma historia» ${ }^{3}$.

Me represento la relación de los episodios con la acción central del Quijote como una consecuencia de cierta concepción moral y psicológica, que no se proyecta sólo sobre el personaje excelso, sino que rebasa su ámbito y anima figuras secundarias en torno a él. Que esa actitud moral y psicológica se combine con temas varios en la frondosa figura de Don Quijote es cuestión distinta, y en este momento secundaria; lo interesante para mí es señalar la existencia dentro de la

Comentarios al Quijote, 1859; Ríus, III, 74.

2 Ariosto e Cervantes, 1878 ; Ríus, III, $35^{2}$.

3 I, 28 ; RM, II, 375 
máxima novela de una similitud en la disposición psicologica y vital de los personajes principales y secundarios. De ahí surge la armonía entre los episodios y la fábula mayor; en esos episodios interviene a veces Don Quijote (Grisóstomo, Cardenio, Camacho, etc.); en otros (Celoso y Cautivo) asiste a su relato. Más alcance que esa nimia cuestión de forma tiene el hecho de que el Celoso esté en la misma serie ideal que el episodio de Grisóstomo, y los demás casos de inarmónica incongruencia debida al error; y que el Cautivo rime con el de D. Fernando y Dorotea, y los restantes casos de urgente y armoniosa convergencia operada por el amor. Coronando tal variedad, definiendo su esencia, aparece el héroe majestuoso, como síntesis inefable que armoniza los contrarios, al presentarnos la verdad y el error, lo que es y lo que no es, en recíproca fluencia, en esencial oscilación, como problema infinito para el espíritu.

Por eso es útil, admitiendo esta idea, salir de Don Quijote para estudiar el tema del error y de su expiación, que aparece más escueto y asequible en personajes de segundo orden. Siendo ello así, todas las obras de Cervantes sirven al propósito, sin que estorbe a mi finalidad (que es analizar el pensamiento del artista egregio) intercalar algunos personajes accesorios del Quijote con otros de las restantes obras. Convienen todos ellos en ofrecernos como germen de su carácter un enfoque erróneo de su punto de vista, sin tener en cuenta la manera de ver y sentir del prójimo; o una equivocación sobre la naturaleza de las cosas, pidiendo a la vida más de lo que puede dar (lubricidad insaciable de Rosamunda), o queriendo comprimirla en los límites escasos de nuestra poquedad (el anciano Carrizales, marido de una lozana muchacha). La virtud de la realidad es, sin embargo, de tal índole, que aquella se dispara contra el infractor de su ley inmanente; se produce así una expiación demostrativa de que el error ha existido, lo que es altamente cervantino. Veámoslo.

Cervantes, en El Curioso impertinente, se sitúa frente a la opinión vulgar expresada en el refrán: «Esa es buena, que está al fuego y no se quema» ${ }^{1}$. Anselmo dice: «No es una mujer más buena de cuanto es o no es solicitada» ${ }^{2}$. Pero la novelita hace ver que un elemento esencial para la virtud femenina es la atmósfera que la cerca, uno de cuyos esenciales componentes es la conducta del esposo. Obsérvese que en los adulterios que Cervantes presenta en sus obras, los maridos llevan el peso principal de la responsabilidad (Celoso extremeño, el polaco en Persiles, etc.). Petrarca había hecho decir a la Razón: «Muchas veces, por cierto, el marido es guía y ejemplo de la deshonestidad de su mujer» ${ }^{3}$. Mal Lara ${ }^{4}$ reproduce la misma idea: «Ciertamente que en la necedad de muchos está la maldad de sus mujeres, y en el poco mirar por su honra.» El Pinciano nos dice que «muchas de esas impertinencias son causadas de la poca prudencia de los maridos» ${ }^{5}$. No son tales autores los únicos en sostener la doctrina que Cervantes refleja en este caso. Aunque debe ser notado que esas máximas morales son excesivamente vagas; y que en el Curioso impertinente no se trata de mal ejemplo del marido, conducta disoluta, etc., sino de una audaz experiencia para ver cómo florecería el corazón de Camila al mudar de clima moral y afectivo.

Anselmo quiere probar la virtud de Camila, como si la virtud fuese un metal: "Que la prueba manifieste los quilates de su bondad, como el fuego muestra los del oro» ${ }^{6}$. Pero la virtud no es un objeto físico como el oro, cuya esencia es independiente de las circunstancias; la virtud se forma o se deforma por motivos sociales, es algo relativo. Además la

\footnotetext{
1 MAL LARA, Filosofía vulgar, 1568 , folio 84 , cent. IV, refr. 33 .

2 I, 33; RM, II, 15
}

3 De los remedios contra próspera y adversa fortuna, Sevilla, I 534, fo. $195 \mathrm{v}$.

4 Ob. cit., fol. $9 \mathrm{I} v$.

5 Filosof. ant. poética, pág. 60.

6 La comparación (ya en la Biblia) había sido hecha también por Castiglione: «Doña Isabel de Aragón... ha mostrado su virtud y esfuerzo, como suele el oro mostrar en el fuego su valor (Cortesano, pág. 340). 
mujer "es animal imperfecto» ${ }^{1}$, y requiere ser alejada de las ocasiones.

El error de Anselmo es doble. Piensa que su mujer es un ser abstracto que guardará la honestidad, sabiendo que él consiente en hacerla convivir con el amigo que la corteja, no. obstante decir ella en una carta : «Creo que [Lotario] mira más por su gusto que por lo que a vos os toca.» Pero Anselmo pretende que la mesa se sostenga quitándole las patas.

Rodríguez Marín, III. 27, anota que «esta nada lisonjera calificación no es debida a Anselmo ni a Cervantes». Pero más adelante (I, 5 I; III, 452) dice Cervantes, no un personaje: : La natural inclinación delas mujeres, que, por la mayor parte, suele ser desatinada y mal compuesta." En qué se basa, pues, la afirmán de Rodríguez Marín?

El tema venía debatiéndose durante el Renacimiento. Uno de los dialogadores del Cortesano, de Castiglione, sostiene la misma tesis («siendo las mujeres animales imperfectísimos», Libros de antaño, páginas $273,302,304$ ), para dar lugar a la interesante defensa de la mujer que viene luego. Véase la edición italiana de Cian, 19ı0, pág. 309. Cervantes ha creado tipos adorables de mujer; basta hojear sus obras; pero ha emitido opiniones muy desfavorables sobre su caŕcter, lo

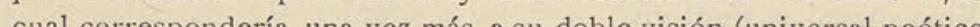
y particular prosaico). Fuera del campo de la sublimación artística, parece como si no estimara mucho a la mujer al analizarla críticamente: «Bien así como mujer, cuya naturaleza es fácil y arrojadiza para todo aquello que es de su gusto» (Amante liberal, pág. ' 77, edic. SchevillBonilla). «El menor vituperio que dellas dijo fué llamarlas antojadizas» (Persiles, Rivad., I, 655b). «Parienta es la confusión Del discurso de mujer» (Gallardo Español, I, 43). «Que deseos de mujer Se mudan a cada paso (Ibid, 5I). Es accidental y vano Tal deseo en la mijers (Ibid, 75$)$. The (Ibid, 5 r) Pe «Oh mujeres, mujeres, todas o las más mudables y antojadizas!s (Guar. da cuidadosa, IV, 63). «Ha dado la palabra de ser esposa de Artandro y agora, por cumplir con la condición mudable de mujer, la ha nega do (Galatea, II, I52). [Compárese: «Oh constancia, oh firmeza, y cuántas pocas veces hacéis asiento sobre corazón de hembra» (Montema yor, Diana, en Orígenes de la Novela, II, 257a)]. «No os acuciéis en volver tan presto esa cabra a su rebaňo; que pues ella es hembra.. ba de seguir su natural di quequien las mujeres que las respeten sus maridos porque son castas y honestas, como si en sólo esto consistiese de todo en todo su per-
Trróneo es también su concepto de la amistad: Lotario, obligado por Anselmo a decir amores a una dama bella y joven, ha de permanecer en el plano abstracto del respeto amistoso. La naturaleza vital sigue su camino, y Anselmo hace girar su mente en el vacío. Bien es verdad que está loco: «Yo padezco ahora la enfermedad que suelen tener algunas mujeres que se les antoja comer tierra, yeso, carbón y otras cosas peores, aun asquerosas» ${ }^{1}$. Cervantes, implacable, le hace caer

fección, y no echan de ver los desaguaderos por donde desaguan la fineza de otras mil virtudes que les falta n..., etc." (Fuez Divorcios, IV, 14). "Quieren do han de aborrecer, Vanse de adonde han de estar, Temen donde han de esperar, Esperan do han de temers ( $L a-$ berinto de auror, II, 295). aLas mujeres somos naturalmente vengatiberinto de allor, II 295 . aL vas $($ Persiles, 6o7 a). “Las mujeres, que por naturaleza las más, son codiciosas, como las más son altivas y soberbias» (Ibid., 598 a). Cervantes no exige gran talento a la mujer: "Como una mujer no sea necia, tonta o boba, bástale que ni por aguda despunte ni por boba no aproveche" (Ilustre fregona, Rivad., I, I 7 I $a$ ). Su contemporáneo Montaigne pensaba que «le rôle de la femme dans la société, c'est de plaire et de se faire aimer» (Villey, Sources des Essais, II, 477). Como no pueden oponerse a estas apreciaciones otras contrarias, se impone la conclusion de que Cervantes tén no muy buena la opinion de la mujer; para lograr tipos femeninos deliciosos y encantadores te nía que forjarlos mediante el arte, y ponerlos fuera del alcance de la crítica. Y entonces se convertirá en ardiente paladín de sus derechos.

I, 33; RM, 34. Como es sabido, el cuento procede del Orlando furioso, XLIII, 1-476. Schevill señaló (RHi, XXII, 447) la coincidencia con un pasaje del Crotalón, sin afirmar, claro está, que tal obra fuera la fuente, por no haberse publica Plis otro relato parecido al del Crotalón en cualquier libro que no conocemos, en el que se añadan detalles al episodio del Orlando. El cura dice de esta historia que pudo ocurrir entre un galán y una dama; pero centre marido y mujer algo tiene del imposible» (RM, III, I09). Es el juicio de un espectador; el autor ya se cuidó de hacer loco a Anselmo; y además el concepto de la imitación admitía que la de un relato literario ya existente tuviese tanta fuerza como la de la misma naturaleza (v. antes pág. $34, \mathrm{n}, \mathrm{I})$. No creo, por otra parte, ni que esta

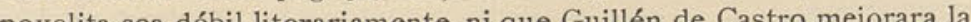
f́bula el Curioso impertinente (véase Revista de Filologia Española, 1916, III, pág. ${ }^{660}$ ). 
muerto sobre el desatino de su vida: «un necio e impertinene deseo me quitó la vida...» ${ }^{1}$.

No creo que haya sido notada esta manera cervantina de poner sistemáticamente término a las vidas de quienes han metido un fundamental disparate. ¿Expiación? ¿Demostración de que el iluso, el que pide a la vida más de lo que puede dar, es inapto para permanecer en ella? El comentario es menos interesante que el hecho mismo de esta muerte post errorem. Muere así Carrizales, el viejo, en El Celoso extremeño ( no te culpo, niña mal aconsejada...; le sobrevino un desmayo...; el dolor le apretó de manera que, al seteno día, le llevaron a la sepultura»).

El tema aparece igualmente en un pequeño episodio del Quijote $^{2}$ : el marido de D. ${ }^{a}$ Rodrígu a D. ${ }^{2}$ Casilda; llevando le ocurre dar le ocurre dar escolta de honor a un alcalde de Corte; ante tal inconveniencia, la señora le dice por lo bajo: "¿Qué hacéis desventurado? ¿No veis que voy aquí?» El alcalde, caballero avisado, insinúa que él debería en todo caso acompaña D. ${ }^{\text {a }}$ Casilda; mas el con la gorra en Doña Casild acompañando al alcalde. largo alfiler. largo alfiler. La mula se alborota, cae la dama y la puerta de Guadalajara tuvo mucho que reír. Doña Casilda despide al menguado servidor, los chicos se burlan de él de pesar, sin duda alguna, tengo para mí que se le causó el mal de la muerte».

Hay otros notables casos que convienen aquí. El portugués Manuel de Sousạ Coutiño (en el Persiles) cierta bella vecina "con una (enamora de cierta dequepodría una esperanza más dudosa que cierta, que podría ser viniese a ser mi esposa. Consulta a los padres, no a ella. Después de varias peripecias, la bella Leonora se hace monja, porque nunca pensó en tomar como esposo sino a Jesucristo. Coutiño dice

1 I, $35 ;$ RM, III, 107

2 II, $48 ; \mathrm{RM}, \mathrm{V}, 470-47 \mathrm{I}$. perder el juicio, y ahora, por la misma causa, vengo a perder la vida» ${ }^{1}$. El caso guarda relación con el de Grisóstomo y Marcela; recuérdese la admirable defensa que la gentil pastora hace de la libertad de amar: "Yo nací libre, y para poder vivir libre escogí la soledad de los campos... Fuego soy apartado y espada puesta lejos... Si a Grisóstomo mató su impaciencia y arrojado deseo, ¿por qué se ha de culpar mi honesto proceder y recato?» ${ }^{2}$. Ni un solo momento olvida Cervantes ese dogma del amor libremente correspondido; sus mujeres están protegidas por los más violentos rayos de su pluma contra quienes se empeñan en forzarles la voluntad. El obstinado perece en la demanda; y lo mismo acaece a quien, usando la fuerza de la autoridad paterna, logra realizar un casamiento desacorde. Así, Carrizales y sus demás compañeros de insania matrimonial. Con firmeza maravillosa lo dice Marcela: "Bien se puede decir que antes le mató su porfía que mi crueldad ${ }^{3}$. Don Quijote usando el fuero de su sublime sentido, decreta que «ninguna persona, de cual estado y condición que sea, se atreva a seguir a la hermosa Marcela, so pena de caer en la furiosa indignación mía». Cervantes y su héroe, como tantas otras veces, van aquí al unísono. Y los manes del espíritu renacentista exultarían. Al frente de ellos Erasmo: "Como sea en libertad del hombre no amar, zno te parece que de sí mismo es homicida el que pone sus amores, subjeta su libertad e solicita con mucha impor-

1 Rivad., I, 575 b.

2 I, I4; RM, I, 425-427.

3 En La Galatea, libro III (edic. Schevill-Bonilla, I, 125-126), se exponen ya los argumentos de Marcela: «Quejarse el nuevo amante de la dureza del rebelde pecho de su señora, va fuera de todo razonable término; porque como el amor sea $\mathrm{y}$ ha de ser voluntario y no forzoso, no debo yo quejarme de no ser querido de quien quiero. mil enamorados importunos habria que, por su solicitud, alcanzasen lo que quiź no se les debia de derecho. No debe el desder̆a do jarse de su amada sino de su ventura, que le nego las gra jarse de su amada, sino de su ventura, que le negó las gracia que al conocimiento de su señora pudieran mover a bien querer le, etc.s 
tunidad a una donzella para querer de ella por ventura más de lo que es lícito y honesto?» ${ }^{1}$.

Ortel Banedre, polaco de nación, descubre en una posada de Talavera a cierta linda moza ${ }^{2}$. Llevado de su gusto, de su punto de vista, hace que los padres le entreguen a la hermosa doncella. Cervantes nos presenta al Banedre repleto de deseos: "Tomé el pulso a mi gusto, y halléle tal, que a no casarme con ella, en poco espacio de tiempo había de perder perdiendo el gusto, la vida.» Mas Luisa, labradora inquieta y sensual, ha puesto su alma en Alonso, de condición proporcionada a la suya. El polaco rompe esa armonía de manera violenta, enseñando perlas y dineros. Se lleva a la rapaza; pero... recordemos el programa ideal de Cervantes:

\section{El discreto es concordancia...}

el necio, disparidad.

Ortel Banedre va neciamente a la disparidad, y Cervantes se complacerá en acosarlo a lo largo de la novela. Luisa lo abandona y huye con su amante; el polaco quiere vengarse, pero Periandro lo disuade ${ }^{3}$.

En diversas ocasiones reaparecen la moza talaverana, el marido y un amante de aquélla; el polaco apalea a este último, y Luisa "no hizo más de echar mano a un cuchillo..., se le clavó por los riñones, haciéndole tales heridas que no tuvieran necesidad de maestro...» ${ }^{4}$. «La muerte del polaco puso en libertad a Luisa, y a él le trajo su destino a venir peregrino a Roma: antes de llegar a su patria halló en Roma a quien no traía intención de buscar, acordándose de los consejos que en España le había dado Periandro; pero no pudo estorbar su destino, aunque no le fabricó por su voluntad» ${ }^{5}$. La homicida acaba casándose con su nuevo amante.

1 Colloquio del matrimonio, en Origenes de la Novela, IV, 166.

2 Persiles, Rivad., I, 636.

3 Véase mi estudio sobre el honor en Revista de Filologia Española, 1916,1 III, 357 .

4 Rivad., I, $666 b$.

5 Ibid, $671 b$.
La historia citada muestra con qué pertinacia se aferraba Cervantes a la idea de lo que llamo muerte post errorem. Muy bien podía haber renunciado a desenlazar el incidente del polaco, en medio de aquel dédalo de aventuras, tanto más cuanto que ya aparecía bastante castigado Banedre con la fuga de la moza y la pérdida de sus dineros. Juzgó, empero, necesario encerrar el episodio dentro de líneas aún más inexorables.

Recibe asimismo muerte expiatoria la sensual Rosamunda, que se abrasa en amores por el bárbaro Antonio: «Me dejo ir con la corriente de mis gustos, heme ido ahora con el que me da el ver siquiera a este bárbaro muchacho, el cual, aunque le he descubierto mi voluntad, no corresponde a la mía, que es de fuego, con la suya, que es de helada nieve...; golpes que no se pueden resistir con poca paciencia y con mucho deseo. $\mathrm{Ya}$, ya la muerte me va pisando las faldas...» ${ }^{1}$. Rosamunda, en cierto modo, semeja a Grisóstomo 2.

Encuéntranse en Persiles otras expiaciones por motivos más o menos análogos; así Cenotia la bruja, que muere colgada 3 ; o Clodio, pasado por la flecha de Antonio, «castigo merecido a sus muchas culpas» ${ }^{4}$.

¿Y qué decir ahora de la muerte de Don Quijote? Es forzoso reconocer que en algo semeja a las de Anselmo y Carrizales, es decir, que recuerda esa fórmula de expiación máxima tan grata a Cervantes; sólo que aquí el tema se sublima, y aparece irisado a la luz de otros motivos. Don Ouijote se arrepiente de sus errores: "Yo tengo juicio ya, libre y claro, sin las sombras caliginosas de la ignorancia» 5 . Pero la diferencia esencial con los restantes citados casos es

1 Persiles, $587 a$.

2 No es este el único caso en que un hombre repele el amor de una mujer; en el Laberinto de amor, II, 287, Manfredo rechaza a Julia: -Que un torpe amor esta paga, $\mathrm{Y}$ aun otra peor requiere.»

3 Pág. $616 b$.

4 Pág. $603 a$.

5 II, 74; RM, VI, 437 
que sentimos una inmensa piedad al ver pasar de este mundo al genial Hidalgo, y con nosotros se afligen quienes le rodean: "La mayor locura que puede hacer un hombre es dejarse morir, sin más ni más, sin que nadie le mate, ni otras manos le acaben que las de la melancolía». Así dice Sancho; al hablar de "melancolía» roza el tema de la vida malograda pero como ningún aspecto de lo quijotil cabe en las usuales tres dimensiones, sino que se nos proyecta en espacios de más compleja estructura, sería tan irrespetuoso como frívolo equiparar la muerte de este héroe único con la de seres de calidad mucho menos imponderable.

Mas no siempre el yerro va seguido de muerte, ni aun cuando se trata del máximo pecado de la incongruencia amorosa. Conviene detenernos en este punto importante de la ideología cervantina. Como en tantas ocasiones más, Cervantes recoge ahora temas tradicionales, vulgarizados incluso en el folklore, y les da sentido y alcance intensos, conforme a la disposición de su pensamiento. Que se detenga en esos temas para elaborar sobre ellos sus fábulas, no indica ni que sus ideas carezcan de interés ni que sean debidas al azar de las lecturas: en materias de esta índole se encuentra lo que se busca ${ }^{1}$. No hará falta que vayamos a épocas remotas para investigar el origen de ese sentimiento de la concordancia amorosa y de la adecuada proporción del hombre y la mujer; basta decir que el Renacimiento acentuó la importancia del problema por motivos tanto de razón como de emoción vital En cualquier escritor tocado del espíritu de la época encontramos alusiones características; por ejemplo, en Pero Mejía: "Como dice Aristóteles en su Economica, la diversidad de las costumbres y condiciones no deja hacer amistad ni amor verdadero... En lo que toca al linaje y riquezas de la mujer, refrán era antiguo, contado entre los dichos notables de los siete sabios de Grecia: «Busca mujer que sea tu igual.» Cuyo autor dicen que fué uno de los dichos siete, llamado Pitaco.

\footnotetext{
1 Véase antes pág. 19
}

Declarando Erasmo esta sentencia, lo entiende también por la igualdad de las edades...» ${ }^{1}$.

Juan de Mal Lara trae varios refranes pertinentes: "Casa tu hijo con tu igual, y no dirán de ti mal» ${ }^{2}$; «todas las aves con sus pares» ${ }^{3}$; «no conforma con el viejo la moza» ${ }^{4}$, a reserva de haber justificado antes la tesis contraria al glosar: «Bien parece la moza lozana cabe la barba cana ${ }^{5}$, porque, como dice el autor, «si algunos refranes se contradicen, no es maravilla, porque habiendo nacido de diversos hombres, traen diversos sentidos».

Cervantes tiene sobre el particular una opinión cerrada «El comer y el casar ha de ser a gusto propio» ${ }^{6}$. Esa es la primer condición para la conformidad matrimonial: «Era bien dejar a la voluntad de su querida hija el escoger a su gusto cosa digna de imitar de todos los padres que a sus hijos quieren poner en estado» ? Mauricio busca marido a su hija «to-

1 Silva de varia Lección, Lyon, 1556, págs. 234-235. Erasmo dice,

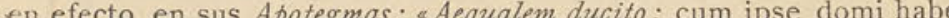

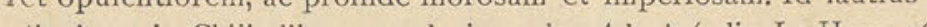
plicuimus in Chiliadibus», es decir, en los Adagia (edic. La Haya, 1641 pág. 503). Hay, en efecto, un adagio de Erasmo: «Aequalem uxorem quaere.» (Chiliada I, Centuria VIII, I.) Lo curioso es que, según

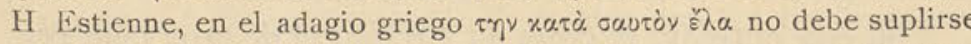
rovraixa 'mujer', y que, por lo tanto, el sentido es muy distinto (Adagiorum... chiliades... quibus adjectae sunt Henrice Stephani, París, 1579, col. 242). Pero gre problema de filolo a no nos interesa; cue Eraso inste pobre la necesidad de la igualdad matim que Erasmo insiste sobre la necesidad de la igualdad matrimonial, y que otros lo siguen en la doctrina; y es igual que la haya sacado de los griegos o de su cabeza. Compárese Coloquios, en Origenes de la Novela, IV, $168 a, b$.

2 \&Esta sentencia paresce haver nacido de todos los filósofos antiguos y más de Plutarco, en el tratado De liberis educandis” (Filosofía vulgar, edic. ${ }_{15} 62$, fol. $63 r$ ).

3 Centuria V, núm. 9 .

4 V, 34, edic. 1568 , fol. 113 .

$5 \mathrm{~V}, 35$.

- Guarda cuidadosa, IV, 77 . Comp. Galatea, ed. Sch.-Bon., II, I46: «El

rostro que no se alegra Del no conocido esposo»; ibíd., págs. 142-1 43. 7 I, 5 I; RM, III, 445. 
mando [su] consentimiento primero..., por parecerme acertado» ${ }^{1}$. Recuérdense aquellas dos parejas trocadas en sus gustos, "por querer todos cuatro obedecer a nuestros padres» ${ }^{2}$. El tío de Marcela, cura del pueblo, no quería casarla «sin su consentimiento. $\mathrm{Y}$ a fe que se dijo esto en más de un corrillo en el pueblo en alabanza del buen sacerdote» ${ }^{3}$. Ha de haber además paridad de condición, porque «nunca los desiguales casamientos se gozan ni duran mucho en aquel gusto con que se comienzan» ${ }^{4}$. Por eso se excusa el viejo rey Policarpo cuando piensa tomar por esposa a una niña de diez y siete años: «Puesto que tus pocos años no están obligados a sentir qué cosa sea esto que llaman amor, ni los muchos míos estén ya sujetos a su jurisdicción, todavía ['sin embargo'] tal vez sale de su curso la naturaleza, y se abrasan las niñas verdes, y se secan y consumen los viejos ancianos» ${ }^{5}$. Eso piensa él desde su punto de vista; pero Cervantes desde el suyo declara que «entre todos estos disinios no tomaba el pulso a su edad, ni igualaba con discreción la disparidad que hay de diez y siete años a setenta, y cuando fueran sesenta es también grande la distancia» ${ }^{6}$. En conclusión, el rey fracasa ${ }^{7}$, y Cervantes se contenta con privarle del trono; si se llega a casar, quién sabe si no habría ido al sepulcro con sus compañeros en infringir los mandatos de la natural armonía.

Con este episodio se cruza en Persiles el de otro viejo rey (Leopoldio de Danea), que para alegrar su viudez toma por

1 Persiles, 5776 .

2 Persiles, Rivad., I, 605 b. Recuérdese que Luscinda dió el «sís a Cardenio spor no salir de la obediencia de sus padres» (I, 28; RM, II, 40I). Las consecuencias fueron desastrosas: huída de Cardenio, etc. Tocar a la libertad de amar es, para Cervantes, poner fuego a la santabárbara. Se dice en la Galatea (edic. Schevill-Bonilla, I, 185): «Si ella tuviera amor, poco inconveniente era la obligación de los padres para dejar de cumplir con lo que al amor debía.

3 I, I2; RM, I, 370

3 I, I2; RM, I, 370.
4 I, $28 ; \mathrm{RM}, \mathrm{II}, 393$.

5 Persiles, $596 a$.

- Ibid., Goo a.

7 Ibid., $616 b$ mujer a una dama de la reina, a la cual no pareció "ser injusto anteponer los rizos de un criado mío a mis canas» ${ }^{1}$. Los adúlteros fraguan matar al rey, pero son descubiertos y metidos en un cepo. El rey los lleva a Danea para ajusticiarlos; mas Periandro, que ha apresado la nave del rey, procede entonces como en el caso del polaco; promete al rey la libertad a cambio del perdón de los adúlteros, a lo que Leopoldio accede. Como se ve, Cervantes no conoce límites para la libertad de quienes mutuamente se aman, lo que resalta más frente a su ensañamiento con tanto viejo sandio, a quienes convendrían las palabras que Rutilio dice a Clodio, cuando desatentadamente aspira al amor de Auristela: «Verdaderamente nosotros estamos faltos de juicio, pues nos queremos persuadir que podemos subir al cielo sin alas, pues las que nos da nuestra pretensión son las de la hormiga» ${ }^{2}$.

Resulta, pues, que dentro del tema del casamiento incongruente puede señalarse como subtema el de «el viejo y la niña», que culmina en El Celoso extremeño, pero que, comn hemos visto, tiene otras ramificaciones. $\mathrm{Ha}$ de añadirse el entremés del Viejo celoso, en que se trata el asunto cómiçamente, como es propio del entremés, pero con idéntica doctrina: «El setentón que se casa con quince, o carece de entendimiento, o tiene gana de visitar el otro mundo lo más presto que le sea posible» ${ }^{3}$. Nunca ha escrito Cervantes con tan desvergonzado cinismo como en esta deliciosa obrita: D. ${ }^{a}$ Lorencica ayúntase con un lindo galán que le ha traído su vecina Hortigosa, y va contando a su marido (de quien sólo la separa una puerta) las impresiones nuevas que experimenta: "Ahora echo de ver quien eres, viejo maldito; que hasta aquí he vivido engañada contigo!» ${ }^{4}$. Tengan eso en cuenta quienes toman en serio la

1 Pág. 6r r. Recuérdese con qué astucia se libra una doncella de casarse con un viejo que le imponían sus padres, en El Licenciado $V_{i}$ driera, Rivad., I, 1646 .

2 Pág. 5ogb. Ya vimos antes cómo acabó Clodio (pág. 13I). Ténganse además en cuenta estos lugares de Persiles: $598 b, 638 b, 662 a, b 678 b$.

3 IV, I5I.

4 IV, I6I. 
«ejemplaridad» de las novelas, y no sospechan el grado de maliciosa hipocresía de que podía ser capaz el autor. Lorencica salva su responsabilidad diciendo que ella no tomó por esposo al viejo Cañizares: «Diómele quien pudo, y yo, como muchacha, fuí más presta al obedecer que al contradecir. Pero si yo tuviera tanta experiencia de estas cosas, antes me tarazara la lengua con los dientes, que pronunciar aquel sí» ${ }^{1}$.

Cervantes se complace en poner de relieve lo inútil de querer por fuerza guardar a una mujer: "Si yo no me guardo, mal me guardaréis» ${ }^{2}$. Leonora, encerrada bárbaramente por su celoso guardián, ve a Loaysa por un agujero del torno; en El laberinto de amor, Julia «encerrada do el sol entraba apenas» por un padre severísimo, logra ver a Manfredo ( $E n$ fin, yo, de curiosa, Un agujero hice en una puerta»), se prenda de él, "y al cabo el entregarme fué forzoso» ${ }^{3}$. ¿Y la deliciosa criatura que Sancho encuentra rondando la ínsula, fatigada del aislamiento a que su padre la condena, y que sale de noche en traje de hombre para ver algo de ese mundo que le ocultan?

La literatura y el folklore han tratado el asunto antes de Cervantes. Mal Lara glosa el refrán «Piénsase mi madre que me tiene muy guardada, y otro dame cantonada», diciendo: "No faltaba quien a hurto gozaba de ella..., si ella, la hija, no estaba también en guardarse» 4 . Pero mucho antes hallamos expuesto el mismo pensamiento, en forma menos vulgar, en El Cortesano, tan manejado por nuestro novelista: "Sabé otra cosa, que ningún freno las aprieta ni

1 IV, 146.

2 El mismo cantar de El Celoso extremeño aparece en La Entretenida, III, 88 , con glosa muy expresiva de la idea cervantina: $₫$ Dicen que está escrito, Y con gran razón, Que es la privación Causa de apetito. Por eso es mejor Que no me encerréis", etc. Comp. "Guard́́balo su padre, y guardábase ella que no hay candados, giardas nicerra que mejor guarden a una doncella que las del recato propios (I, $5 \mathrm{I}$ M, III, 444).

3 II, 279-284

4 VIII, 80 ; edic. 1565 , fol. 230 . las sojuzga, sino el que ellas mismas se ponen, y veréislo en esto, que las más de las que son guardadas con grandes estrechezas o maltratadas de sus maridos o padres son menos buenas que las que viven con más libertad ${ }^{1}$. Castiglione llega a tolerar el adulterio de las mujeres que «casaron sus padres por fuerza con hombres viejos, dolientes, asquerosos, que las hacen vivir en perpetua desventura... ¿Por qué no consentiréis vos que a esta mujer que está en tan duro estado le sea permitido buscar algún alivio para tantos trabajos, y dar a otro aquello que del marido es no solamente despreciado, más aún, aborrecido?» ${ }^{2}$. Pero ¿y la moral católica? ¿Y el sacramento del matrimonio? La moral del Renacimiento, conocida y asimilada por Cervantes (según demuestran los hechos allegados), pensaba, a veces, en otras normas y en otros fines.

No nos apartemos, sin embargo, de nuestra ruta. En esta serie del error amoroso han de situarse las fracasadas bodas de Camacho el rico ${ }^{3}$ con la bella y pobre Quiteria, intentando saltar por el amor de Basilio. Sancho, al saberlo, formula la sabida doctrina cervantina: "A mi mujer con esol..., la cual no quiere sino que cada uno case con su igual, ateniéndose al refrán que dice «Cada oveja con su pareja.» Irónicamente hace Cervantes decir a Don Quijote: «Si todos los que bien se quieren se hubiesen de casar, quitaríase la elección y jurisdicción a los padres de casar sus hijos con quien y cuando deben» ${ }^{4}$. A la hora de la verdad, cuando muchas

1 Edic. Libros de antaño, pág. 348.

2 Pág. 376.

3 De tal modo se hallaba Cervantes obsesionado con esta idea, que la proyecta incluso sobre Rocinante! Se divierte el autor en hacer que tan respetable rocín incida en el error de incongruencia amorosa "Sucedió, pues, que a Rocinante le vino en deseo de refocilarse con las señoras facas..., mas ellas, que a lo que pareció, debían de tener más ganas de pacer que de al, recebiéronle con las herraduras y con dientess (I, I5). En la segunda parte, recuerda Sancho el lacon los des yangüeses cuando a mestro buen Rocinante se le antojó pedir cotufas en el golfo?? (II, 3 ; nuestro buen
RM, IV, 88).

4 II, $19 ;$ IV, 384 
espadas acometen a Basilio, Don Quijote, como antes para defender a Marcela, requiere su lanza y declara a grandes voces que no se puede tomar «venganza de los agravios que el amor nos hace... a los dos que Dios junta, no podrá separar el hombre, y el que lo intentare, primero ha de pasar por la punta de esta lanza ${ }^{1}$. Camacho se resigna, reflexionando «que si Quiteria quería bien a Basilio doncella, también le quisiera casada, y que debía dar gracias al Cielo más por habérsela quitado que por habérsela dado» ${ }^{2}$. Basilio triunfa, pero Don Quijote completa su intervención con consejos de un buen sentido casi aburguesado; bien está que Basilio y Quiteria se amen y se casen, que prescinda la doncella de la riqueza de Camacho, pero Basilio debe abandonar su vida de bohemio romántico: "Todo esto decía [Don Quijote] con intención de que se dejase el señor Basilio de ejercitar las habilidades que sabe, que aunque le daban fama no le daban dinero ${ }^{3}$. El racionalismo preceptista de Cervantes aparece aquí templando sus audacias a favor del amor espontáneo y aun extralegal; vislumbramos un hogar apacible y bien reglado: «Si traes buena mujer a tu casa, fácil cosa te sería conservarla.» Mas en este punto declara Sancho que su amo podría tomar dos púlpitos en cada dedo *. No sabemos realmente hasta dónde pueda llegar el mar insondable de la ironía cervantina; cada actitud espiritual es criticada y reducida por la contraria.

Según observamos ya, el ámbito de los temas en el Quijote no coincide a veces con el área psicológica de los personajes; así acontece que Sancho se nos mete donde menos lo esperaríamos; por ejemplo, a defender, frente a su oíslo Teresa Panza, la posibilidad de un matrimonio desigual: "Tengo de casar, mujer mía, a Mari Sancha tan altamente, que no

1 II, 21; RM, IV, 437.

2 Cfr. El Licenciado Vidriera: «Dile que dé gracias a Dios por haber permitido le llevasen de casa a su enemigos (Rivad, I I I b). Se rata de un marido entristecido porque su mujer huyó con su amante.

3 II, $22 ; \mathrm{RM}, \mathrm{IV}, 442$.

4 Ibid., 444. la alcancen sino con llamarla señora» ${ }^{1}$. Mas he aquí que automáticamente ocupa su mujer el hueco que él deja al marcharse del buen sentido: «Eso no, Sancho; casadla con su igual, que es lo más acertado; que si de los zuecos la sacáis a chapines... Ahí está Lope Tocho...; con éste, que es nuestro igual, estará bien casada.» Es decir: mucho más esencial que la esquemática rigidez del carácter, es para el autor ese vasto plano en que dos actitudes ante la vida se confrontan y pugnan.

Una forma especial de error, en la relación de hombre y mujer, representan los casos de engaño apicarado. Aquí entrarían El casamiento engañoso, donde el fraude es mutuo, y la expiación de la falta del alférez Campuzano, consecuencia directa de su imprudente cálculo. Recordemos también el episodio de Laura, malamente deslumbrada por el aparente esplendor de Vicente de la Roca, soldado bravucón; el castigo de su falta de perspicacia y de su aturdimiento es verse robada, abandonada, «desnuda en camisa» ${ }^{2}$.

Aunque el error en materia erótica sea el que solicita con más vehemencia la pluma de Cervantes, hay ejemplos de yerros morales de otra clase, no menos significativos para la investigación del pensamiento cervantino. Así acontece que la orgánica estructura de las ideas en el Quijote se percibe claramente aun tratándose de episodios insignificantes. El Ventero, fiel a su punto de vista, está atento a que sus huéspedes no se marchen sin pagar; esa es su misión y no interesarse por la feroz contienda que ha planteado Don Quijote en torno al yelmo de Mambrino. Dos sujetos intentan excusar la paga; «mas el Ventero, que atendía más a su negocio que a los ajenos..., les afeó su mala intención, con

1 II, 5 ; RM, IV, 126.

2 I, 5 I; RM, III, 45 Caso de bobería, tratado en estilo de farsa, es (a el de Pancracio de la virtud de su mujer (ano ha Laco que se le iguale; la honestidad y el recogimiento han 
tales palabras que les movió a que le respondiesen con los puños» ${ }^{1}$. La descortesía es algo que irrita siempre Don Quijote (y a Cervantes); reclamar la paga puede hacerse sin injuriar. El Ventero ha creído, sin embargo, que podía decir malas palabras a dos hombres, por lo visto bastante arriscados; y entonces la mecánica moral de Cervantes hace que vengan sobre él golpes sin cuento. Quién sabe si no matiza algo esta escena la actitud personal de Cervantes hacia los venteros, y se combinan así las ideas con el «patos» individual. Don Quijote, requerido para proteger al golpeado, contesta "muy de espacio y con mucha flema», que ha de pedir licencia a la princesa Micomicona. Pero concedida licencia, resulta que se trata de una pendencia de gente escuderil, más bien de la competencia de Sancho. Lo importante, empero, es la declaración del autor: «Pero dejémosle aquí, que no faltará quien le socorra, o si no, sufra y calle el que se atreve a más de a lo que sus fuerzas le prometen.» He aquí una idea capital, cuya aplicación vamos viendo, tanto en las aventuras mayores como en los pequeños incidentes; por eso decía antes que así como la sección de cualquier parte de la esfera nos da el círculo, así el examen de los más pequeños detalles del Quijote descubre la misma uniforme y orgánica estructura. Crece la admiración ante la genialidad del autor al ver cómo pudo, sin monotonía, repetir una y otra vez la misma moralizadora tesis.

Indicaba antes cómo abandona Sancho a las veces la senda discreta para aventurarse en la del absurdo; pues bien: ahora nos hallaremos con que Don Quijote es piedra de toque para la impertinencia ajena. Don Quijote, en sí mismo, es un complejo vital que obedece en su existencia a quién sabe qué causas naturales y necesarias; podremos decir que está loco, que no cuadran sus juicios con el que nosotros formamos acerca de las cosas que juntamente con él estamos viendo; pero él, loco o lo que sea, tiene su ley y su órbita, por la que discurre merced a altos e inescrutables motivos. Su

\footnotetext{
I I, 44 ; RM, III, 307 .
}

género de vida no es menos respetable, en el fondo, que la independencia sentimental a que aspiraba Marcela. Ahora bien: unos cuantos desocupados, conterráneos de Don Quijote, se hallan a mal traer con la vida que a éste place seguir a costa de su brazo, de su esfuerzo y de sus costillas: «Dice, pues, la historia que cuando el bachiller Sansón Carrasco aconsejó a Don Quijote que volviese a proseguir sus dejadas caballerías, fué por haber entrado primero en bureo con el Cura y el Barbero sobre qué medio se podría tomar para reducir a Don Quijote a que se estuviese en su casa quieto y sosegado, sin que le alborotasen sus mal buscadas aventuras; de cuyo consejo salió, por voto común de todos y parecer particular de Carrasco, que dejasen salir a Don Quijote, pues el detenerlo parecía imposible, y que Sansón le saliese al camino como caballero andante... y le venciese, teniéndolo por cosa fácil» ${ }^{1}$. Y henos en presencia de un personaje que se aventura en la que he llamado serie quijotesca, frente a Don Quijote! El resultado es el conocido: el Bachiller conserva su vida, gracias a "los pensamientos extraordinarios de Don Quijote, que se dió a entender que el Bachiller no era el Bachiller»; de otro modo «el señor Bachiller quedara imposibilitado para siempre de graduarse de licenciado, por no haber hallado nidos donde pensó hallar pájaros». Tomé Cecial, que vió cuán mal había logrado sus deseos y el mal paradero que había tenido su camino, dijo al Bachiller: "Por cierto, señor Sansón Carrasco, que tenemos nuestro merecido: con facilidad se piensa y se acomete una empresa; pero con dificultad las más veces se sale de ella. Don Quijote loco, nosotros cuerdos, él se va sano y riendo; vuesa merced queda molido y triste. Sepamos, pues, ahora, ¿cuál es más loco: el que lo es por no poder menos o el que lo es por su voluntad?»

Algunos cervantistas tachan de inverosímil la intervención del bachiller Carrasco ${ }^{2}$; tal suceso no aspira a la vero-

1 II, ${ }_{15}, \mathrm{RM}, \mathrm{IV}, 306$.

2. Véase Cienercín, Bibl. Clás., V, 290. 
similitud, sino a hacer manifiesto el derecho de Don Quijote a seguir el camino que su especial naturaleza le señala, y el error de quienes trataban de contrariar su rumbo de él. Nótese que Don Quijote abandona el menester caballeresco por motivos orgánicamente enlazados con su anomalía mental; y si las mecánicas intervenciones de sus familiares y amigos llegan a triunfar, eso acontece para que la historia pueda tener fin. $\mathrm{Su}$ sanidad mental coincide con su muerte. Don Quijote se yergue siempre en su quijotismo, y repele a Carrasco lo mismo que al clérigo de los duques, y para eso cuenta con el máximo apoyo del autor. Nuestro héroe se resiste a creer que Carrasco y el Caballero de los Espejos sean una misma persona, y con gran razón: «He sido yo su enemigo por ventura? ¿̇Hele dado yo jamás ocasión para tenerme ojeriza?» Nobles palabras disparadas contra la frivolidad. En sujetos como Carrasco pensaba Cervantes al escribir: «Mira, Berganza, nadie se ha de meter donde no le llaman ni ha de querer usar del oficio que por ningun caso le toca” ${ }^{1}$. O estas otras frases de El laberinto de amor, expresivas de la misma doctrina:

Necio llamaré del todo, o curioso, al que se mete en lo que no le compete ni toca por algún modo 2

De los hechos aducidos resalta claramente el papel metódico que desempeña el error en las obras de Cervantes. De la disparatada conducta de todos esos personajes - dentro y fuera del Quijote - se siguen consecuencias funestas o, en todo caso, muy enojosas para quienes torcieron su vía ${ }^{3}$.

\begin{abstract}
Coloquio, edic. Clás. Cast., pág. 337 .
2 II, 265.

3 No es necesario agotar todos los ejemplos que nos ofrece el autor; por su curiosidad añadiré, sin embargo, que en El Vizcaino fingido fracasa la pedante y marisabida Cristina; creyendo poder engañar a los demás, queda ella misma burlada por el falso vizcaíno Quiñones y por Solórzano. He aqui la moraleja:
\end{abstract}

$$
\begin{aligned}
& \text { La que se fia en su ingenio, } \\
& \text { lleno de fingidas trazas, }
\end{aligned}
$$

La figura de Don Quijote, en uno de sus mayores aspectos, no es sino la magnificación de un tema que corre por toda la obra cervantina ${ }^{1}$, y no invalida esta manera de ver 1a inmortal figura el que esa desarmonía inicial se torne luego armonía inefable, según ya hubimos de indicar ${ }^{2}$. Los demás personajes quedan, en cambio, mucho más apegados a la concepción doctrinaria de la moral cervantina.

Contemplando en conjunto la doctrina del error llegamos al siguiente resultado. El error es una ruptura de las acordadas armonías de la naturaleza, idea que ya poseía el autor al escribir su primera obra: «Hermosa Galatea, en fe de la razón que he dicho y de la que tengo de adorarte, te hago este ofrecimiento, el cual te ha de obligar a que tu voluntad me descubra, para que yo no caiga en error de ir contra ella en cosa alguna» ${ }^{3}$.

\section{fundadas en interés, y en voluntades tiranas; cual dicen, del guardarse, y se arroja a las corrientes} que ligeramente pasan,
o sabe poco o nonad

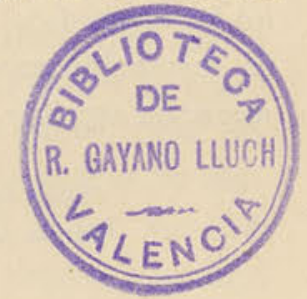

$$
\text { (Edic. cit,, pág. 103.) }
$$

En fin, como en el caso del error erótico, también se proyecta sobre Rocinante el tema del error en general en la forma cómica que puede imaginarse. En la aventura de las Cortes de la Muerte, el caballejo «dió a correr por el campo con más ligereza que jamás prometieron los huesos de su notomía... Con su amo vino suelo; ordinario fin y paradero de las lozanías de Rocinante y de sus atrevimientos» (II, 11 ; RM, IV, 237).

:Que, con todo esto, dé en una ceguera tan grande y en una sandez tan conocida que se dé a entender que es valiente siendo viejo, que tiene fuerzas estando enfermo», etc. (II, 6). Creo falsa la idea de E. Chasles, Cervantes, 1866 , pág. 280 , de que el error criticado en el Quijote sea el causado por la literatura culta y galante.

2 Mrnéndez Pidal, Un aspecto en la elaboración del \&Quijote», 1924 pág. 52, observa que en el capítulo VII, es donde comienza el auto a mirar la fantasa del loco como un ideal que merece respeto, es cuando se decide a pintarlo grande en sus propósitos, pero fallido en ellos».

Edic. Schevill-Bonilla, II, 150. 
Ese acuerdo de las voluntades es un aspecto del unido ritmo del universo, idea neoplatónica que Cervantes toma de escritores como Castiglione y León Hebreo, muy imitados por él ${ }^{1}$. El error es, pues, una infracción del orden natural, y el castigo que Cervantes da a los infractores revela que la misma naturaleza es la encargada de aplicar automáticamente las sanciones, y no los poderes extranaturales. En suma, esta justicia cervantina va implícita en la culpa, es inmanente. Ello nada tiene de extraño en una época en que doctrinas parecidas se formulaban en otras partes. Tomás Campanella expone en su Philosophia realis la tesis de que «naturalis est punitio culpae»; todo vicio es una violación de la ley de naturaleza, y se castiga en sus consecuencias por la misma naturaleza, la cual no puede ser violada ${ }^{2}$. Cervantes no ha aprendido en Campanella su doctrina moral, porque su formación espiritual está hecha cuando Campanella comienza a escribir. El soneto

\section{Seco ogni colpa è doglia, e trae la pena} nella mente o nel corpo o nella fama,

aunque escrito antes de 1607 , no se publica hasta 1622 . Cervantes recibiría tales ideas en Italia, en el ambiente en que se formaban los grandes pensadores del momento. Al hablar de la moral de nuestro autor, veremos el sentido de esta

1 .Todo el universo es un individuo... Tanto el todo $\mathrm{y}$ las partes son perfectas y felices, cuanto rectamente y enteramente consiguen los oficios a que son enderezados por el sumo Opífice. El fin del todo la unida perfeción de todo el universo, etc. (Dichlogos de antor, The en Origenes de la Novela, IV, 354). Una clara exposición de la doctria neoplatónica en el Renacimiento trae R. HonigSWALD, Giordano Bruno, edics. Revista de Occidente, 1925. Véase, por ejemplo: «El pensamiento de que la divinidad infinita lo llena todo con su ser y lo funde todo en sí misma, formando así una unidad armónica..., la teoría de la llamada coincidentia oppositorum, son ideas que hallamos constantemente en G. Bruno» (pág. 83).

2 G. Gentile, Giordano Bruno e il pensiero del Rinascimento, 1920, págs. II 4 y 116 . concepción del castigo como secuela de la misma naturaleza, como principio inmanente y humano ${ }^{1}$.

\section{LA ARMONÍA Y EL ACIERTO}

Mas no todo es equivocarse en el ámbito de la ciudad cervantina. Junto a los inhábiles arqueros, como marco preciso que hace destacar su impericia, ha situado Cervantes casos de plena armonía vital, de comprensión perfecta con lujo de coincidencias. Si el amor incongruente es motivo de absurdos y desdichas, el amor compartido nos lleva a gloriosas adecuaciones. El joven D. Luis refiere al Oidor su impresión luego que vió a $\mathrm{D}$. ${ }^{\mathrm{a}}$ Clara: «La hice dueño de mi voluntad..., por ella dejé la casa de mi padre, y por ella me puse en este traje, para seguirla dondequiera que fuera, como la saeta al blanco o como el marinero al norte» ${ }^{2}$. Y la gentil D. ${ }^{a}$ Clara afirma por su parte: «En mi vida le he hablado palabra, y con todo eso le quiero de manera que no he de poder vivir sin él» ${ }^{3}$. El Oidor, "como discreto, ya había conocido cuán bien le estaba a su hija aquel matrimonio».

Las metáforas son características ${ }^{4}$; aluden a fuerzas in-

1 La crítica del hidalguismo, aunque debiera entrar aquí como análisis de otro error moral, he preferido tratarla más adelante como opinión de Cervantes sobre los españoles.

$\begin{array}{ll}2 & \text { I, } 44 ; \text { RM, III, } 309 . \\ 3 & \text { I, } 43 ; \text { RM, III, } 283 .\end{array}$

$4.43 ; 111,283$. se va tras la lumbre» (La Entretenida, pág. 88). Todo ello es reminiscencia neoplatónica: «Píntanle [al amor] tirando saetas, porque hiere de lejos y tira al corazón como a propio blanco... Los cuerpos inferiores son guiados de la naturaleza derechamente a conocer su fin y sus propios lugares..., como la saeta va derechamente al blanco, no por su propio conocimiento, sino por conocimiento del ballesteros

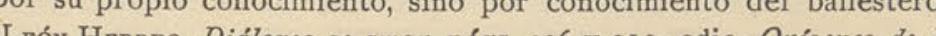
(Lín H IV). A A Novela, IV). «Aquellos vivos espíritus que salen por los ojos, por se engendrados cerca del corazón, también cuando entran en los ojos donde son enderezados como saeta al blanco..., y no solamente 
contrastables que salvan obstáculos y escollos de toda suerte, que emplean cualquier medio para lograr el destino final. En las bodas de Camacho, Basilio acude a la artimaña que todos recuerdan para hacerse dueño de Quiteria, y Don Quijote decreta que «en las contiendas y competencias amorosas se tienen por buenos los embustes y marañas que se hacen para conseguir el fin que se desea» 1 .

En Persiles ${ }^{2}$, Isabela Castrucho se finge endemoniada, y, gracias a esa treta, logra casarse con Andrea Marulo. En El Amante liberal, Ricardo y Leonisa salvan inverosímiles obstáculos hasta poder lograr el triunfo de amor; junto a ellos fracasan y pierden la vida, según la consabida fórmula, Alí, Hazán y el Cadí, que torpemente aspiraban al goce de Leonisa.

La historia del Cautivo, inserta en el Quijote, es asimismo ejemplo de cómo se cumple el proceso de armonía entre dos

descubren los pensamientos, más aún, suelen encender amor en el corazón de la persona amada» (Castiglione, El Cortesano, pág. 389). Montemayor, en la Diana, ha copiado literalmente a León Hebreo: «Píntanlo ansi mismo flechando su arco, porque tira derecho al corazón», etc. (Origenes de la Novela, II, 304 b).

1 II, 2 I; IV, 437. Comp.: «Advierte, Sancho, que el amor ni mira respetos ni guarda términos de razón en sus discursos» (II, ${ }_{58}$ ). «Las culpas que comete el enamorado en razón de cumplir su deseo, no l, son en razón de que no es suyo, ni es él el que las comete, sino el amor que manda su voluntad (Persiles, $610 a$ ). \&No les parecieron tan traidores [los designios], que no hallase en ellos disculpa el haber sido por el amor forjados (Ibid., 616b) « «El amor, sutil maestro de encaminar los pensamientos, a los más turbados ofrece lugar y coyuntura de mosparlos, trarlos, sin mescabo de sucreditos (Ibid. 594 ). usticia, Pretende castigar secretas culpas, Teniendo las de amor tantas disculpas" (El laberinto de amor, II, 227). «El amoroso [deseo] que Artandro tiene - dijo Galatea - fué el que le movió a tal descomedimiento, y así conmigo en parte queda desculpados (Galatea, edic. cit., II, 153). Igualmente en El Corlesano, de Castiglione: «Con ninguna otra cosa puede Beatriz excusarse de culpa, sino con haber errado por amor, el cual ya veis si se debe perdonar en los hombres como las mujeres. En verdad, respondió Micer Bernardo, las pasones de amor gran desculpa traen consigo de cualquier yerros (págia 276). Véase más adelante pág. 149

$2659 b$. seres concordados. La diferencia de religión en Zoraida añade un matiz dramático al bellísimo relato; quiere ella hacerse cristiana, pero a través del amor del Caballero cautivo: «Muchos cristianos he visto por esta ventana, y ninguno me ha parecido caballero sino tú. Yo soy muy hermosa y muchacha..., mira tú si puedes hacer cómo nos vamos y serás allá mi marido.» La primera vez que el cristiano ve a la mora cree tener ante sí «una deidad del cielo, venida a la tierra para mi gusto y para mi remedio». Cuando se despiden, «ella arrancándosele el alma al parecer, se fué con su padre»1. Amor y religión (ésta como envoltura de aquél) llevan a $Z_{0}$ raida tras su cautivo, con violencia no igualada por ningún otro episodio cervantino. La bella argelina pudo marcharse de su hogar sin otros incidentes; pero Cervantes hace intervenir al padre, arrebatado en la huída de los cristianos y abandonado luego por los fugitivos. Quizá no hay más trágico momento en el Quijote. El anciano clama, maldice, ruega, suplica, arrastrando su miseria por la playa solitaria: "Vuelve, amada hija, vuelve a tierra, que todo te lo perdono!» ${ }^{2}$. Pero se yerguen sus brazos contra lo ineluctable; su triste figura nos descubre abismos de lo humano, la lejana perspectiva de un destino inexorable. El pesimismo cervantino se refleja en este dolor irremediable, tan siniestro como el del mal aventurado niño, azotado por Juan Haldudo, labrador del Quintanar.

Casi creo ocioso llamar la atención acerca de la dependencia íntima de esta novelita con el resto del Quijote; si $E$ l Curioso impertinente era la tragedia del desatino, El Cautivo representa el drama de la armonía vital. Ambas obras se sitúan en las dos opuestas vertientes que integran la concepción cervantina del mundo. Tomando ese punto de mira, podría decirse que El Cautivo es al Curioso impertinente lo que Persiles es al Quijote. En Persiles el amor aparece estilizado, dos personajes son seres ingrávidos que suelen discurrir por

1 I, 4 I; RM, III, 227. 
el plano de la quimera; pero en su más esquemático diseño, Persiles es el relato de cómo Periandro había de afincarse en el corazón de Auristela, porque ella es su blanco, su norte y su destino, en virtud de un preestablecido proceso de armonías y concordancias. Para esta finalidad, la novela bizantina ofrecía a nuestro autor excelentes modelos de peripecias, del mismo modo que la literatura caballeresca con sus despropósitos, o el mero espectáculo de la demencia (cuentos de locos, Entremés de los romances ${ }^{1}$, etc.), satisfacían su opuesta inclinación, que le atraía hacia ese mundo donde no imperaban la razón y el buen acuerdo.

Este aspecto del pensamiento cervantino tiene fácil engrane con ideas muy corrientes en su época. Más de una vez se ha citado y comentado la referencia que hace Cervantes a los Diálogos de León Hebreo en el prólogo al Quijote, y la doctrina del amor que figura en el libro IV de la Galatea, tan apegada al texto de los Diálogos; pero se ha dado a esa relación alcance meramente externo, y tal doctrina se ha considerado como simple lugar común que corría por los libros de Cervantes como por otros muchos ${ }^{2}$. Pero esta es una opinión por demás inexacta en nuestro caso; la verdad es que Cervantes utilizó los Diálogos, El Cortesano y otros libros.

1 Véase MenÉNDez Pidal, Un aspecto en la elaboración del "Quijotes, 1924 .

2 «Para la mayor parte de los poetas y hombres de letras no era el platonismo otra cosa que un recurso semejante a la mitología: un florilegio de frases hechas y de lugares comunes, medio paganos y medio cristianos, sobre el Bien Sumo y la belleza una en Dios, y derramada difusamente en las criaturas.. La verdad la buscaban pocos, aun dando por supuesto que fuera el platonismo el camino de enconth innegables: lo que de ella queda flotando en la atmósfera es el concepto del gran Cosmos, físico y moral, creado por el amor divino, e imagen del Dios que lo habita» (Menéndez Pelayo, Ideas estéticas, III, 90) $\mathrm{Y}$ añade en Vicisitudes de la Teoria platónica en España, I892, pág. I I 9 : sPero el solo hecho de insertar tales teorías, como Cervantes lo hizo en una pastoral, en un libro de ameno entretenimiento demuestra cuán vigoroso era el empuje de la corriente platónica en el siglo xvı.. análogos, no de manera superficial, sino incorporando a su obra el sentido de su doctrina. ¿Por qué ha de ser neoplatónica la doctrina del amor del libro IV de la Galatea y no lo ha de ser la concepción del amor, que se desprende de los citados casos de armonía erótica, en que con insistencia se revela el mismo punto de vista? No sería una razón el que haya podido establecerse con facilidad el parangón entre el texto de la Galatea y el de los Diálogos, y este otro aspecto no ofrezca un medio de prueba tan material. Aunque son bastante explícitas las analogías entre los textos de León Hebreo y las ideas de Cervantes: "La concordia y correspondencia mutua y recíproca que se halla en los cuerpos celestiales más aina me parece efecto y señal de su amor que causa de él» ${ }^{1}$. Esa imperiosa necesidad de congruencia que venimos observando en nuestro autor, recuerda ideas de este tipo: «La forma que informa mejor la materia hace las partes del cuerpo entre sí mismas con el todo proporcionadas y ordenadas intelectualmente...» ${ }^{2}$. Una de las causas del amor «es la conformidad de la naturaleza y complisión..., una cierta similitud y correpondencia armonial de la una complisión a la otra ${ }^{3}$.

Ahora bien, si el amor es la base de la armonía humana y universal, es comprensible que a los infractores de esa armonía acaezcan las más desastradas peripecias. Y por la misma causa habrá que conceder la máxima libertad (véase pág. I46), a los bienhadados amantes para lograr su fin, "porque el verdadero amor a la razón y a la persona que ama hace fuerza con admirable violencia e increíble furor, y más que otro impedimento humano perturba la mente -donde está el juicio...» *. Que es lo mismo que dice Don

1 Diálogos, pág. 32

2 Diálogos, 425 a.

3 Ibid., $311 a$.

4. Ibid., 307 a. Comp.: «Las fuerzas poderosas de amor suelen turbar los ingenios más entendidos» (Persiles, $6_{32} b$ ). "Calla, hija Auristela..., que en ningunas otras acciones de la naturaleza se ven mayores milagros ni más continuos que en las del amor..., el amor junta los 
Quijote: "Advierte, Sancho, que el amor ni mira respetos ni guarda términos de razón en sus discursos» ${ }^{1}$.

A la luz de la anterior doctrina del amor hay que interpretar la censura que se hace de la Diana de Montemayor en el Quijote ${ }^{2}$, la cual a Clemencín, Menéndez Pelayo y Rodríguez Marín pareció demasiado severa. Pide Cervantes «que se le quite todo aquello que trata de la sabia Felicia y de la agua encantada». Menéndez Pelayo ${ }^{3}$ nota que «los encantamientos de la sabia Felicia y el agua maravillosa, que infundiendo dulce sueño en los amantes trocaba sus respectivas inclinaciones, son una máquina poética no más fantástica e inverosímil que la mayor parte de las aventuras de los primeros libros del Persiles...» Pero esta observación es improcedente, y es una prueba más de la ligereza con que se interpretan las palabras de Cervantes, por juzgarlo caprichoso razonador. A Cervantes no le molesta lo inverosímil (ya sa-

cetros con los cayados...> (Persiles, 597b). «Amor, como otro Marte nos desvelas, Furia y rigor en sus entrañas mora, Hasta las religiosas almas dañas, Y fundas en traiciones tus hazañas" (Gallardo español, I, 85). «Dijeron a voces muchos: Cupido vence, el amor es invenñol, I, 85). «Dijeron a voces muchos: Cupido vence, el amor es inven-
cible» (Persiles, 606 b). «Sólo se vence la pasión amorosa con huílla... cible» (Persiles, $606 \mathrm{~b}$ ). «Sólo se vence la pasión amorosa con huílla..., porque es menester fuerzas divinas para vencer las suyas humanas,
(I, 34; RM, III, 54). La mujer siente aún con más vehemencia el amor: rCómo a su centro camina, Esté cerca o apartado, Lo leve o lo que es pesado, Y a procuralle se inclina, Tal la hembra y el varón $\mathrm{El}$ uno al otro apetece, Y a veces más se parece En ella esta incling

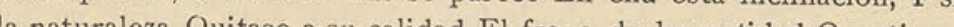
la naturaleza Quitase a su calidad El freno de honestidad Que tiempla su ligereza, Correría a rienda suelta Por do más se le antojase, Sin que la razón bastara A hacerle dar la vueltas (El laberinto de amor, II, 262). He aquí otros datos de carácter distinto para que se vea cuán amplia era la preocupación por este tema: «Las condiciones de amor son tan diferentes como injustas, y sus leyes tan muchas como variables» (Persiles, $590 a$ ). «;Oh fuerzas poderosas de amor; de amor, digo, inconsiderado, presuroso y lascivo y malintencion con cuntalionado, y con cuánta đacilld atropella distinios buenos...... (Persiles, $636 \mathrm{a}$ ). $\times \mathrm{Y}$ nunca en la poca edad Tiene firme asiento amor, $Y$ siempre el mozo amador Huye la dificultad, (Rufián dichoso, II, 2 I). Véase antes pág. 146. II, 58 .

2 I, 6; RM, I, 229

3 Origenes de la Novela, I, 460 . bemos lo que eso significa para él), porque entonces habría condenado en bloque la Diana y no habría escrito la $G a$ latea; lo que condena es la frivolidad del autor, para quien el impulso erótico, la esencia vital más poderosa, según Cervantes, puede cambiar de carácter y rumbo mediante un trago de agua: "¿Qué os parece si el agua sabe desatar los nudos que este perverso de amor hace?... Jamás pudiera creer yo que la ciencia de una persona humana pudiera llegar a tanto como esto» ${ }^{1}$.

Antes de alejarme de este tema querría parangonar otros textos de Cervantes con algunos de León Hebreo. No afirmo en absoluto que la fuente sean los mismos Diálogos, porque éstos fueron muy copiados e imitados durante el siglo xvi pero de una u otra forma, tales concordancias son muy elocuentes:
«DIÁLOGOS DE AMOR»

«El verdadero amor... hácele enemigo de placer y de compañía, amigo de soledad, melancólico, lleno de pasiones, rodeado de penas, atormentado de aflición, martiriado de deseos, susto gado de desesperación, etc., etc.» (pág. 307 a).

«Lo que yo hallo de mayor admiración es que, siendo tan intolerable y extremo de crueldades $y$ de tribulaciones, la mente no espera apartarse de ella, antes a quien se lo aconseja y lesoco quien se lo aconseja y le soco(pág. 307a). (pág. 307a).

\section{CERVANTES}

¿Y en mil partes nos cuentan [mil autores al miserable amante no enten[dido, poco premiado y menos conocido (El laberinto de amor, II, 244.)

\&Y nunca a los amantes a con[sejes cuando tienen por gloria a sus que es como quien predica a los [herejes, en sus vanos errores obstinados

(El laberinto de amor, 245) ${ }^{2}$. cien mil varios dolores que ator-

1 Edic. Origenes de la Novela, II, $315 b$.

$2 \mathrm{El}$ que ambos pensamientos se sucedan inmediatamente en Cervantes y Lén Hebreo habla muy a favor de la imitación. Casi literal mente reproduce estos pasajes de León Hebreo la Diana de Montemayor (Origenes de la Novela, II, 305 a). 
«El uso de este vocablo hermoso, acerca del vulgo, es según el conocimiento que los tienen de la hermosura; que cosa sólida es que ellos no pueden com prehender otra hermosura que la que los ojos corporales y los oído comprehenden; por lo cual creen, fuera de ésta, no haber otra hermosura, sino que es alguna cos ingida, soñada o imaginadas (página $423 a$ ).

"DIÁLOGOS DE AMOR》

Aquellos cuyos entendimientos tienen ojos claros..., conocen mucho más de la hermosura incorpórea que los carnales de la corpórea (pág. 423a). «Las mayores hermosuras consisten en las partes del ánima en la imagintiva en a fina con las lindas fantasis.., hermo os estudios..., hábitos virtuosos y ciẹncias, y más perfectamente en el entendimiento abstracto» (pág. 422b). «La hermosura viene en los cuerpos por la participación de los incorpóreos, sus superiores; y tanto cuanto fatta la participacion de ellos, tan on deformes. Sofía!, no te bastan los ojos corporales para ver las cosas hermosas» (pág. 423 b).

«Pero no puedo pensar qué es lo que vió esta doncella en v. m. que así la rindiese y avasallase: qué gala, qué brío..., qué rostro...; muchas veces me paro a mirar a v. m. desde la punta del pie hasta el último cabello de la cabeza, y que veo más cosas para espantar que para enamorar; y habiendo yo también oído decir que la hermosura es la prinera y principal prosincipal parte que enamora, no teniendo v. m. ninguna, no sé yo de qué se enamoró la pobre» (II, 58 ; RM, VI, 169). Sancho refleja, pues, el concepto vulgar de hermosura; a lo que replica Don Quijote:

$$
\text { CERVANTES }
$$

Advierte Sancho - respondi Don Quijote -, que hay dos ma neras de hermosura, una del alma y otra del cuerpo, la del alma campea y se muestra en el en tendimiento, en la honestidad, en buen proceder, en la libera. en el buen proceder, en la libera. lidad, en la buena crianza, $y$ toda estas partes caben y pueden esta en un hombre feo; y cuando se pone la mira en esta hermosura, y no en la del cuerpo, suele nace el amor con ímpetu y con ventajas. Yo, Sancho, bien veo que no soy hermoso; pero también co ay ber mo pero th foén co. bástale a un hombre de bien , para ser bien queser monstruo, para ser bien querido, como tenga los dotes de alma que te he dichos 1 .

La misma tesis en Persiles, pág. 605 b: «Yo adoro a Leoncia, que es la fea, sin poder ser parte a hacer otra cosa...; a los ojos de mi alma, por las virtudes que en la de Leoncia descubro, ella es la más hermos mujer del mundo.» En La española inglesa: «Isabela, desde el punto \&latón difine el amor ser apetito de la cosa buena para poseerla» (pág. 374b).

Es el amor, cuando bueno, deseo de lo mejor;

si esto falta, no es amor sino apetito $\sin$ freno.s

(El laberinto de amor, II, 287.)

"Dí́LOGOS DE AMOR"

\section{CERVANTES}

«Lo deleitable no es amado después que se alcanza, porque todas las cosas que deleitan nues tros sentidos materiales, de su naturaleza, cuando son poseldas, son madas (pas. 285b). El hombre (pág. 285 ). «Ll hombre desea y ama la mujer antes que la haya, y la mujer al varón. Tienen asimismo estas cosas deleitables tal propiedad, que, habidas que son, así como cesa el deseo de ellas, cesa también las más reces el amor, y muchas veces se vierte en fastidio y aborrecimiento» (pág. 289 ; ; comp. 303 b)

que te quise, fué con otro amor de aquel que tiene su fin y paradero que te quise fue en el cumplimiento del sensual apetito..., tus in muise, fea te adoro." (edic. Schevill-Bonilla, V, $49 \mathrm{I}$ ). En el conocido discurso de Lenio en la Galatea se contraponen también la belleza corpórea y la incorpórea (II, 45); pero la particularidad del citado pasaje del Quijote es en primer lugar seguir más de cerca a los Diálogos, y además hacer expre-

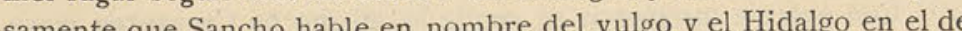
samente que Sancho ha puramente ideal de Lenio, pastor desamorado. Don Quijote, en realidad, intenta, como puede, una armonía de ambas tendencias.

1 Se repite la idea más adelante: «Después de cumplido aquello que el apetito pide, el mayor gusto que puede venir es apartarse de donde le alcanzaron» (I, 28; RM, II, 397). Rodríguez Marín piensa que weste penamiento conforme a lo que la experiencia muestra lis positivista, que tra cada dia, podf́ ochrrite liteno se resigna a aceptar que la literatura se hice, y puntos de vista del autor. Cervantes repite en La fuerza de la sangre: «Un ímpetu lascivo, del cual nunca 
«La hermosura corporal, que \&Que esta fuerza tiene la heres sombra de la espiritual, deleita mosura, que en un punto, en un tanto a quien la ve, que se lo roba, momento lleva tras sí el deseo de y le convierte en sí, y le quita la quien la mira y la conoce" (Dos libertad y le hace su aficionador (pág. $423 b$ ).

"DIÁLOGOS DE AMOR»

doncellas, Rivad., I, 205b) 1 .

1 fuego es el más sutil, ligero y purificado de todos los elementos, y con ninguno dellos tiene amor sino con el aire, cuya vecindad le place; empero ba de estar sobre él; an al cielo y no estar sobre el; ana al cielo y no reposa jamás, donde quiera que está, hasta que se le acerca» (página $313 b)$.

\section{CERVANTES}

«Si al fuego natural no se le pone materia que en la tierralesustente. volveráse a su esfera fácilmente, que asín Y a laturaleza lo dispone.

$$
\begin{array}{r}
\mathrm{Y} \text { al amante que quiere que se } \\
\text { [abone }
\end{array}
$$

su fe con afirmar que no consiente en su alma esperanza, poco siente de amor.»

(Laberinto de amor, II, 264.).

Cervantes, habremos de reconocer que el neoplatonismo se halla en la base de su manera de concebir la vida, sencillamente porque las doctrinas que los neoplatónicos del siglo xy difunden por Europa son el sostén del edificio ideológico del Renacimiento. Ese sistema de armonías naturales, cuyo nexo esencial es el amor, supone previamente la idea de la naturaleza como realidad divina, que Lorenzo Valla, Nicolás de Cusa, Marsilio Ficino, Pico de la Mirándola - e inspirados en ellos León Hebreo y Baltasar Castiglione - infundieron en el pensamiento y en el arte del siglo xvi.

Aparte de estas directas conexiones con León Hebreo, si reflexionamos sobre la tonalidad general del pensamiento de

nace el verdadero amor que permaneces (Rivad., I, $167 b$, y $166 b$ ). Reproduce el mismo pensamiento Castiglione en $\mathrm{El}$ Cortesamo: Aque1 los enamorados que cumplen sus carnales deseos con sus amigasen llegando al fin deseado, no solamente quedan hartos y enhas..., mas a mas aborrecenlas...; o verdaderamente quedan en el mismo deseo, como aquellos que aún no han llegado al fin verdadero» (pág. 485). León Hebreo complica algo más su teoría (pág. 304 a) admitiendo. que los deleites del gusto y el tacto son los que causan fastidio, no los del ver, oír y oler.

1 Con notable insistencia se repite lo mismo en Cervantes, claro ndicio de lo muy presente que tenía estas ideas del amor y la belle za: «Privilegio de la hermosura que trae al redopelo y por la melea sus pies a la voluntad más exentas (Gitarilla, Clás. Cast, pag 81) Es privilegio de la heros. pág. 8I Es privilegio de la hermosura rendir las voluntades y atraer los coraones» (Persiles, $590 \mathrm{~b}$ ). «La hermosa presencia del mozo arrebató la vista y aun los corazones de cuantos le miraron" (Ibid., $588 b$ ). «Por ser prerrogativa de la hermosura que siempre se le tenga respetos (Coloquio, Clás. Cast., pág. 220). "Que también la hermosura tiene fuerza de despertar la caridad dormida (Gitanilla, edic. cit pág. If). Ruperta va a matar a Croriano, dormido, pero abllo tat her. 
$\mathrm{Y}$ antes (pág. 134) ya hemos notado que «tal vez sale de su curso la naturaleza, y se abrasan las niñas verdes, y se secan y consumen los viejos ancianos» ${ }^{1}$. Sería ingenuamente anacrónico interpretar el sentido de esas frases poniendo bajo el vocablo «naturaleza» el significado vulgar e impreciso que solemos darle en la conversación corriente. Basta ordenar los textos cervantinos para percibir la importancia de tal idea, que plenamente figura en la mente del autor al escribir su primera obra y que aparece asimismo en la última. Este y otros hechos análogos ${ }^{2}$ permiten suponer que cuando Cervantes escribe la Galatea (de I58I a I583), alrededor de los treinta y cinco años, tiene completo el bagaje ideológico que irá sirviendo de sostén - o si se quiere, de reverso - a ese arte suyo, tan vario y $\tan$ complicado. No me ha sido posible notar en ese punto entre su primera y sus últimas obras diferencias importantes que supongan crisis perceptible de su pensamiento.

Tomemos ahora el tema de la naturaleza tal como aparece en la Galatea (1585): «En todas las obras hechas por el mayordomo de Dios, naturaleza, ninguna es de tanto primor ni que más nos descubra la grandeza y sabiduría de su hacedor [como] la compostura del hombre, $\tan$ ordenada, $\tan$ perfecta y $\tan$ hermosa, que le vinieron a llamar mundo abreviado ${ }^{3}$. Treinta años más tarde aparece en Persiles idéntica idea: "Como a nosotros el cielo que ves nos cubre, asimismo cubre a los antípodas, que dicen, sin estorbo alguno y como naturalmente lo ordenó la naturaleza, mayordoma del verdadero Dios» ${ }^{4}$. de 1604: "Como este género de poesía no lleva el cuidado de las imitaciones y adorno de los antiguos, tiene en ella el artificio y rigor rethórico poca parte, y mucha el movimiento del ingenio elevado, e cual no excluye a la arte, sino que la excede, pues lo que la naturaleza acierta sin ella es lo perfecto...» «Nótese - a ñade Menén dez Pelayo - que las palabras del anónimo prologuista son casi mismas que usó Montaigne en los Ensayos al tratar i Pare Parece como si Menéndez Pelayo tomase como manifestación espo rádica lo que nosotros consideramos como tema del arte y la naturaleza, ideas esencialmente renacentistas y que en España tienen su tradición, como en Francia la suya. La analogía con Montaigne se debe a ser comunes las fuentes de esa idea en España y en Francia. Véanse págs. $182-183$.

2 Pág. 583 .

1 Persiles, $596 a$.

2 La teoría de la concordancia natural y del desacuerdo erróneo. está en la Galatea, según antes fué notado.

está en la
3 II, 63.

3 II, 63.

4 Pág. $644 a$. Además: «Harás que mis ojos vean El grande poder de Dios O de la naturaleza, A quien Alá dió poder Para que pudiese hacer Milagros en su belleza» (Gran Sultana, II, 159). Compárese cuán categóricamente opuesto es Luis de Granada: «El hombre es como una breve mapa que aquel Soberano Artífice trazó... Lo crió 
Parece extraño que la Inquisición dejara estampar proposiciones como la de que el hombre y sus perfecciones (y su alma) habían sido creadas "por el mayordomo de Dios, naturaleza»; en ello no verían sino un lugar común literario ${ }^{1}$; pero sin gran esfuerzo descubrimos en esta afirmación cervantina, concordada con las que ahora se citarán, un reflejo del pensamiento naturalista del Renacimiento, con ricos precedentes antiguos y modernos, y que a la sazón daba sus frutos en Italia, en Francia y en España.

La valoración de la naturaleza, como principio autónomo e inmanente, comienza en realidad para la época moderna con Nicolás de Cusa († I464), autor de De docta ignorantia (la ignorancia consciente). Según él, Dios es el maximum absolutum y el mundo creado por Él es el maximum contractum, que contendrá «explícitamente» (desarrollado) lo que Dios contiene «complicadamente» (comprimidamente) ${ }^{2}$ : "Le singole cose sono Dio stesso, sono un Dio creato, secondo 1' energica frase del Cusano» ${ }^{3}$. Con ese estado de espíri-

Dios en el sexto día..., queriendo hacer en él un sumario de todo que había fabricados (Símbolo de la fe, Rivad., VI, 243b).

1 Compárese el soneto de Barahona de Soto a doña Blanca de Guzmán :

$$
\begin{aligned}
& \text { Al tiempo que os formó naturaleza, } \\
& \text { os dieron éstos de su ser la cumbre: } \\
& \text { Minerva, su saber; el Sol, su lumbre; } \\
& \text { Diana, su virtud, y Amor, su alteza. }
\end{aligned}
$$

Apud Rodríguez MARín, Luis Barahona, pág. 42. Barahona era fino humanista en su cultura; poseía en su librería el Nuevo Testamento en romance, las obras de Cardano, Averroes, Castiglione, León Hebreo, las Apotegmas de Erasmo, sus Adagia, Lorenzo Valla, etc., etc. Véase
la lista de sus libros en R. MARín, Ob.

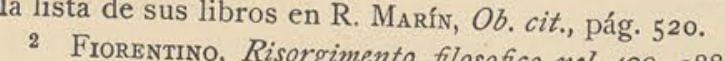

2 Frorentino, Risorgimento filosofico nel 400, 1885 , caps. I-II; Bernardino Telesio, 1872 , pág. 73.

3 No puedo trazar aquí la historia del concepto de naturaleza a través de la literatura del Renacimiento, entre otras a tendríamos que acudir a precedentes medievales, y acanes, porque bir un libro distinto de éste. Pocos torisugestivos que la din embargo, más cómo va reflejando la lite. ratura, al pasar de la Edad Media a la Moderna, al problema de las relaciones entre Dios y la naturaleza, al hilo del desarrollo de las tu, el Renacimiento se lanza sobre autores como Plinio, cuya Historia Natural fué uno de los mayores arsenales de hechos $\mathrm{y}$, sobre todo, de ideas nuevas. Se registran 38 ediciones de I469 a I532. En ella se leen pensamientos como este: «El mundo... es de creer que sea una Deidad eterna, inmensa, ni engendrada, ni que jamás se podrá corromper» ${ }^{1}$.

El poder de Dios se confunde con el de la naturaleza, cuya apoteosis constituye la religión de muchas gentes del Renacimiento ${ }^{2}$, entre quienes ha de contarse al autor de la Celestina, que la inicia ex abrupto y maravillosamente con las conocidas palabras: «En esto veo, Melibea, la grandeza de Dios... En dar poder a natura que de tan perfecta hermosura te dotase.» La naturaleza es aquí un apoderado («un mayordomo», el oixovópos áratós de Aristóteles) de la Divinidad; pero prácticamente es un demiurgo que hace de Dios, lo cual, si a la letra, y en este caso, puede aun parecer ortodoxo, no lo es en cuanto al sentido íntimo. A seguida de esto dirá Calixto: «Por cierto los gloriosos santos que se deleitan en la visión divina, no gozan más que yo agora en el acatamiento tuyo... Si Dios me diese en el cielo la silla sobre sus santos, no lo ternía por tanta felicidad» ${ }^{3}$.

ideas filosóficas. Comienzan los primeros destellos con San Francisco ( $\dagger$ 1226), que canta dulcemente en sus Laudes creaturarum: «Laudatu si, mi signore, cum tucte le tue creature specialmente messer lu frate sole, e ello è bellu e radiante cum grande splendore; de te, altissimu, porta significatione... Per sor aqua, la quale è multo utile $e$ humele e pretiosa e castan, etc. Dante y Petrarca son más tarde los avivado e los en petrarca progresan la visión mística, y a la vez racional, del universo; se descubren insospechados valores. Lorenzo Valla dirá en la primera mitad del siglo xv: «Idem est natura quod Deus, aut fere idem» (De Voluptate, I, I3). Nicolás de Cusa dará el paso decisivo en el campo del puro pensar filosófico, y la literatura seguirá afanosa las vicisitudes del trascendental problema.

1 II, I (traduc. de Gerónimo de Huerta, 1599 ).

2 Véase Busson, Les sources du rationalisme, pág. 24.

3 El bueno de Aribau, en su edición (Rivad., III, 5), altera el texto,

y anota con angélico candor: «Aquí se encuentra una blasfemia en las ediciones más antiguas.» - «La falta de fe... es la conclusión defini- 
Hacía notar antes que la base de esta doctrina era el neoplatonismo, tal como había sido interpretado por el Renacimiento. Para fijar claramente esa idea es útil citar las palabras de un profundo conocedor de la historia de la filosofía renacentista: «Sólo en una época cuyos intereses intelectuales estaban dominados por el afán de conocer el mundo, pudo el neoplatonismo verificar por completo ese giro hacia el naturalismo. En las edades Antigua y Media faltábale base suficiente para ello; el espíritu del Renacimiento fué quien desató, aquí también, las tendencias hasta entonces germinantes» 1 . El neoplatonismo tenía un concepto «negativo» de Dios; Dios era lo que no era el mundo, y sólo mística, no racionalmente, podía ser contemplado por algunos elegidos. Pero poco a poco el concepto de la infinitud de ese Dios ignoto se va refiriendo al mundo, a la naturaleza, como realidad secundaria, derivada de la de la divinidad; el afán de conocimiento, de glorificación de la realidad, hizo dar al neoplatonismo esa vuelta importante dentro del pensar renacentista: "Sólo un mundo infinito es creación digna de un Dios infinito. Sólo en un mundo infinito puede "actuar» un Dios infinito. Por dependencia de Dios, ya era el mundo finito concebido como divino. Ahora [en Giordano Bruno] es divino el mundo virtud de su propia infinitud, igual a la infinitud divina: Dios está en el mundo, y el mundo es infinito, pues es por Dios y en Dios. Así como el neoplatonismo, superó la teoría de «negatividad» de las determinaciones de Dios, por medio del desarrollo gradual de sus propios motivos ideológicos, asî también superó la tesis de la finitud del mundo. Habíase,

tiva y el jugo de las doctrinas de todos los pensadores del siglo xvI... Averroístas y alejandristas, por diversos caminos, tienden todos a la misma meta: la explicación pos a la a la naturaleza; los artion a la naturaleza; los artistas, llámense Ariosto o Folengo, no conocen más mundo que el natural y humano...; negaban a Dios porque afirmaban el valor absoluto de la naturaleza y el hombre» (Grestne, Bernardino Telesio, I9I I, pág. $3 \mathrm{I}$ ). Les precede históricamente el autor de La Celestina.

R. Honigswald, Giordano Bruno, pág. 80. pues, llegado al punto en el que la teoría neoplatónica tenía que chocar con la obstinada resistencia de la tradición aristotélica y eclesiástica, aferrada a la idea de un mundo finito. $\mathrm{Y}$ este es uno de los puntos centrales en donde comienza la oposición de Bruno frente a la tradición científica» ${ }^{1}$.

Tal concepción del mundo, que Honigswald analiza con ocasión de Giordano Bruno († I600), y cuyo resultado será más tarde el panteísmo de Spinoza, ya hemos visto que tiene antiguos precedentes. Resumiendo la doctrina de Nicolás de Cusa, Marsilio Ficino y Pico de la Mirándola, dice Blanchet ${ }^{2}$ : "Sea cual fuere la afición por la especulación trascendente, que esos filósofos hayan sacado del neoplatonismo, es manifiesto que su ardiente deseo de conciliar todos los dogmas y todos los sistemas en la unidad de la religión natural, y de otra parte la misma adopción de las ideas de Plotino sobre el origen divino del alma, condujeron a aquéllos a admitir la inmanencia de lo divino en la criatura humana y en el universo, y la realidad de un movimiento de conversión por el cual todo ser tiende a volver a su principio: lo uno eterno y absoluto. En este punto preparan la vía a las enseñanzas de Giordano Bruno y de Campanella» ${ }^{3}$.

R. Honigswald, Ob. cit., págs. $8 \mathrm{I}-82$.

2 Campanella, 1920, pág. 427.

En los Lectionum antiquarum libri triginta (1542), de Ludovico Celio Rhodigino, enciclopedia consultadísima durante el siglo $\mathrm{x}$ habla así de la naturaleza: „Naturam esse Aristoteles censet, principium motus, et quietis, in quo primo est et non per accidens. At napiuma turam erficientem, inprovpros vocavit, hoc est opificem» (Edic. 1599, col. 16). «Praesto tamen sunt, qui nomina quidem esse fateantur plura, Deum tamen unum. Sic non aliud esse naturam, quam Deum ipsum interpretantur: hoc est, toti mundo et partibus eius insertam divinitatis» (Col. 1027). Concordando con esto leemos en Benedetto Varchi: «Fra tutte le cose naturali, cioe che hanno dentro se il principio del movimento e quiete loro... ni una se ne ritruova in luogo cruno.. la quale non habia in se (come liceva il Filosofo nel pi醇 mo libro delle parti degli Animali) alcuna cosa di divino.s (B. VARCH a prima parte delle Lezzioni, Fiorenza, 1560, proemio.)

Cabe en lo probable que Cervantes manejara estos autores por- 
Traer estas nociones al dominio de nuestra historia literaria del siglo xvi parece exigencia elemental. De no hacerlo, nos encontraremos con temas y con indicaciones que en sí mismos carecen de pleno sentido y que lo adquieren llevándolos al cauce general del pensamiento coetáneo, del que son regueros. Fernando de Rojas, Garcilaso o Cervantes son artistas ante todo, pero eran varones discretos y disertos que labraron su materia artística de cara a los afanes más vehementes de la época. Entre las historias de las literaturas modernas, la española es probablemente una de las más frívola y superficialmente tratadas. Hasta en manuales elementales puede leerse que la novela naturalista de los franceses guarda honda conexión con el giro positivista del siglo xıx y, sin embargo, no quieren los historiadores españoles ahondar en el siglo xvi, una de las épocas más densas de la historia del mundo, para ver si nuestra literatura se ha estremecido al contacto de aquella formidable vibración espiritual; se contentan con explicar las llamadas bellas letras autónomamente, como mero juego de la sensibilidad y la fantasía, aislada de las otras zonas de la cultura por la "fermosa cobertura del estilo ${ }^{1}$. La literatura del siglo xvi, y Cervantes en grado muy subido, aparecen tocados por el pensamiento filosófico

que en ambos pudo leer un detalle que figura en La gran Sultana: Si de bien tendrás me e... Esse qui dicant, se au- ¿Gl'auguri antichi, eApol-
dire sermonem animalium at- lonio Tianeo, non intendeporque no es posible menos, que intelligere... nuper vero vano le voci degli uccelli?

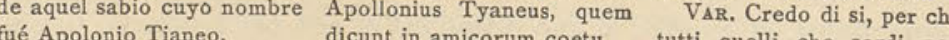
el cual, según que lo sabes..., quum audiret hirundinem sono, le intendono; ma supo entender de las aves aliis nuntiare, asinum prope significazioni delle voci, creurbem onustum cecidisse, do di no, se non in quel Esto dicen, $\rightarrow Y$ esto es cierto. declarasse audita, idque ita pra.? (L'Hercoletto di soOra cantase el canario, fuisse comperta (Criro RHо- di messer Benedetto Varch, ora trinase el jilguero..., Drerro, Ob. cit., col. 784). Vinetia, 1570, pág. 27.) de sus cantos entendia
los escondidos secretos.

(II, ז43.)

1 Se dirá que ahí está la Historia de las ideas estéticas de Menéndez Pelayo; mas no obstante su enorme interés, se trata de un estudio de índole distinta del que echo de menos. Véase, por ejemplo, el tomo II I884, págs. 96-108. del Renacimiento. Esta idea de naturaleza, la cual con tanta finura como habilidad es llamada «mayordomo de Dios», y cuyo sentido histórico apunté, es un eco de los admirables esfuerzos realizados durante los siglos xv y xvi para situar los valores supremos de la vida en el seno mismo del devenir natural, con lo cual la trascendencia medieval era sustituída por la inmanencia, según dicen los filósofos: lo divino no trasciende de este mundo y de esta humanidad, sino que está inmanente en ellos ${ }^{1}$. El naturalismo inmanentista que en una u otra forma aparece en Marsilio Ficino, Pico de la Mirándola y Pomponazzi, culmina en el filósofo de Cosenza, Bernardino Telesio ${ }^{2}$, maestro de Campanella. Hay un hecho curioso, y es que Cervantes cita un Telesio en la Galatea ${ }^{3}$, que nada de extraño tiene se refiera al filósofo que ya en I 565 había publicado el De rerum natura juxta propria principia, y cuyo nombre y cuyas ideas daban que hablar durante la estancia de Cervantes en Italia (véase pág. I04).

No poseo prueba concluyente de que Cervantes haya leído a Telesio, ya que en el ambiente mismo de España se hallaban ideas naturalistas impregnadas de carácter inmanente (traducciones de Erasmo, León Hebreo, Castiglione, P. Mexía y Mal Lara); la novedad importante que caracteriza a Telesio, su teoría acerca del calor y el frío como «propria principia» de la naturaleza, no aparece en Cervantes; pero merece ser indicado, de todas maneras, que la doctrina telesiana pudo influir en él para confirmar y dar unidad a cuanto por otra parte hubiese aprendido sobre el particular, tanto más cuanto que

1 Véase Blanchet, Campanella, 1920, págs. 129-132 (libro fino y preciso).

2 Véase Gentile, Telesio, i911; Tronlo, Telesio, 1924; Blanchet, Campanella, habla a menudo de Telesio.

3 "Un antiguo sacerdote, que luego conocieron ser el anciano The lesios (lib. V, edic. Schevill-Bonilla, II, I76). Los editores notan en el Prólogo (pág. xxxıI) que «Thelesio es tal vez reminiscencia del poeta y humanista italiano de ese nombres, Antonio Telesio (I482-1534) a quien Garcilaso dedicó una oda latina (véase Flamins, Il Cinquecento, pág. 122). Pero me parece más probable que Cervantes pensar en el Telesio, contemporáneo suyo. 
hay notables analogías entre la moral naturalista de Cervantes y la de Telesio: "Despreciar esta vida, las fuerzas y los bienes de la naturaleza, apartarse, sobre todo, de la naturaleza, sería dar muestras no sólo de impiedad e incultura, sino de sandez y locura...» ${ }^{1}$. "Aunque creada por Dios, la naturaleza no está dotada de existencia puramente accidental y contingente..., cada ser tiene poderes propios y una aptitud especial para realizar sus operaciones particulares... Todo ser dotado de actividad posee también la facultad de velar por su conservación, su desarrollo individual...» ${ }^{2}$. «El hombre, como las demás cosas de la naturaleza, tienden a perseverar en su propio ser, no habiendo metas extrínsecas a ese proceso natural» 3 .

Todas estas ideas zumban en el oído cuando leemos atentamente a Cervantes; abundantes ejemplos hemos aducido y aduciremos aún; pero por características de Telesio que sean tales ideas, como afirmaciones parecidas ocurren en otros autores influídos por el neoplatonismo (con matiz e intensidad varios), nada puede resolverse con certeza. Porque desde hacía un siglo el ambiente estaba cargado de sugestiones análogas, más o menos precisas, provinientes de las zonas más diversas. Por entre los resquicios de la lucha entre ortodoxia y heterodoxia se filtraba, incoercible, la doctrina del naturalismo cuasi panteísta, a favor del bello pliegue del arte, o disimulada por semejanzas verbales con el lenguaje tradicional. Así, acontecía que Erasmo, basándose en el espiritualismo de San Pablo, venía a coincidir con las deducciones del racionalismo anticristiano: tan frondosa y compleja es la ideología humanístico-renacentista. Leemos, en efecto, en los prolegomena a los Adagia: "¿Qué otra cosa aconseja la caridad sino que sean comunes todas las cosas de todos? Unidos. nosotros en amistad con Cristo, en virtud ciertamente del mismo aglutinante (sic: glutino) que le hace estar unido al Padre,

1 Véase Blanchet, Campanella, pág. 393

2. Ít., Ibid., pág. 151

3 Gentrie, Telesio, pág. 75 e imitando hasta donde se puede aquella perfectísima comunión por la cual Él y el Padre son uno mismo, no hay duda que nosotros seamos también uno mismo con Cristo, y que, como dice San Pablo, formemos con Él un espíritu y una carne. Así, por ley de amistad, todas las cosas son comunes a Él con nosotros, a nosotros con Él; y además, estamos unidos unos con otros por iguales lazos de amistad, como miembros de una misma cabeza, como un uno y mismo cuerpo, para que un mismo espíritu nos anime: para que suframos y gocemos con las mismas cosas. (Esto es lo que significa aquel pan místico, formado de muchos granos contenidos en la misma harina, y la bebida de aquel vino, en el que muchas uvas están fundidas en el mismo licor.) Finalmente, para que así como la suma de las cosas creadas está en Dios, y Dios a su vez en todas, del mismo modo sea vuelta en unidad la universalidad de todas las cosas» ${ }^{1}$.

Tales son las bases ideológicas de la doctrina naturalista que en varia forma refleja la literatura. Mucho antes de Cervantes había dicho Garcilaso:

Una obra sola quiso la natura

hacer como esta, y rompió luego apriesa la estampa do fué hecha tal figura ${ }^{2}$.

1 «Aut quid aliud hortatur charitas, quam ut omnium omnia sint communia? Videlicet, ut amicitia coagmentati cum Christo, glutino nimirum eodem quo ille cum Patre cohaeret absolutissimam illam communionem quod licet imitantes, per quam ille et pater idem sunt: munionen quoad licet initantes, per qu nos item iden cum illo simus: et, at ait Paulus, anus spiritus et una caro cum eo efficiamur: iamque amicitiae iure omnia illi nobiscum, omnia nobis cum illo sint communia, deinde paribus amicitiae vinculis alii cum aliis inter nos copulati, velut eiusdem capitis membra tamquam idem et unum corpus, eodem animemur spiritu: iisdem doleamus, iisdem gaudeamus. Id quod etiam mysticus ille panis e pluribus granis in eandem coactus farinam, et vini potus e multis racemis in eundem liquorem confusus, admonet. Postremo, ut quum summa in eunden liquorem confusus, ad onierrm catan gomena, col. 5).

2 Égloga, II, edic. Navarro Tomás (1924), pág. 63. 
Pensamiento tomado, según creo, del Ariosto:

Natura il fece, e poi ruppe la stampa ${ }^{1}$.

Cervantes, siguiéndolos, desarrolla más la idea:

$$
\begin{aligned}
& \text { Robó la naturaleza } \\
& \text { lo mejor de cada cosa } \\
& \text { para formar esta pieza, } \\
& \text { y así la sacó hermosa } \\
& \text { sobre la humana belleza... } \\
& \text { Tal jamás la ha visto el sol, } \\
& \text { ni otra fundió en su cristal } \\
& \text { el cielo que la compuso }{ }^{2} \text {. }
\end{aligned}
$$

El mismo concepto aparece en forma distinta: «Yo he oído decir [habla Sancho] que esto que llaman naturaleza es como un alcaller que hace vasos de barro, y el que hace un vaso hermoso, también puede hacer dos y tres y ciento» ${ }^{3}$. «La naturaleza había hecho iguales y formado en la misma turquesa a él y a Auristela» 4 .

Cervantes, empero, presenta, junto a la naturaleza inmanente, o que se basta a sí misma, acciones sobrenaturales o. divinas, y en algún caso nos explica que el poder de Dios hace variar el curso natural de las cosas «cuando a nuestros ojos quiere hacer alguna maravilla» ${ }^{5}$. Tal dualidad, que se

\footnotetext{
1 Orlando, X, 84 . He preguntado al mejor conocedor del Orlando, al maestro Pío Rajna, por el origen de este verso, y ha tenido la bondad de contestarme: "Il verso Natura il fece è dal Bolza, Manuale ariostesco, 1866, p. $40 \mathrm{I}$, ricondotto ad uno "La fe' natura e poi ruppe la stampa» che si da come contenuto in Petrarca, son. VIII. Ma trarca questo verso non appartiene; e puo darsi che esso stesso emanato da quello dell' Ariosto, rispetto al quale nalla trovo ne ecchi commentatori, nulla ni moderniso

2 Gran Sultana, II, I24. Además: «Auristela, a quien no quiso da igual naturaleza» (Persiles, 628a).

3 II, $30 ;$ RM, 'V, I 24

4 Persiles, 669.

5 sPero Dios, que así lo tenía ordenado, tomando por medio e instrumento de sus obras (cuando a nuestros ojos quiere hacer a inun maravilla) lo que la misma natura na no alcosa, orlé que a ana y poco silencio que larco Antonio habra yejoco parte mejorarle» (Dos Doncellas, Rivad., I, 209 b).
}

da incluso en obras de puro pensamiento ${ }^{1}$, son perfectamente explicables dentro de la época, mucho más en producciones de índole artística; no hay que olvidar, sin embargo, que la intima estructura de la obra cervantina se acomoda, según hemos demostrado, a puntos de vista sacados de la inmanencia natural.

En principio, la naturaleza es "perfecta» ${ }^{2}$, si bien ha distribuído el bien y el mal entre los mortales ${ }^{3}$; «como el hacer mal viene de natural cosecha, fácilmente se aprende el hacelle» ${ }^{4}$. Llegado el caso, el autor admitirá, por espíritu de Contrarreforma, la doctrina del pecado original: «El hacer y decir mal lo heredamos de nuestros primeros padres» ${ }^{5}$; 10 que está en contradicción con la hipótesis de la perfección natural de todos los humanos que, como veremos, exigen el tema de la Edad de Oro y sus afines. Y cuando Cervantes sonría melancólico ante la imposibilidad de la perfección natural, no irá guiado por motivos teológicos.

En cualquier caso, sin embargo, Cervantes posee la firme

1 Compárese Cardano que ora revela un sentimiento profundo de 1 Comón la en misma sus . Para Carano, vesterna (BLANCHE? Campanella, 1920, pág. 130). Para Cardano, véase Charbonnel, La pensée italienne au XVI eiècle, 1919, $274 \mathrm{y}$ sigs.

2 "Condición de la naturaleza humana, que puesto que Dios la crió perfecta, nosotros por nuestra culpa la hallamos siempre falta, la cua falta siempre la ha de haber, mientras no dejáremos de desear» (Persiles, 595 b). El estilo - ambiquamente hipócrita - es típico de la Contrarreforma; véase un excelente ejemplo en BıANCHET, Campanella, I920, pág. 218.

1920, pág. 218 . 3 "Naturaleza compuso La suerte de los mortales Entre bienes y
entre males, Como nos lo muestra el uso» (La Entretenida, pág. 71). entre males, Como nos lo muestra el uso» (La Entrelenida, pág. 71). 4 Coloquio, Clás. Cast., pág. 215.

5 Ibid., pág. 240. Comp. sAl culpado que cayere debajo de tu jurisdicción, considérale hombre miserable, sujeto a las condiciones de la depravada naturaleza nuestras (II, 42; RM, V, 355). Erasmo, como es a duralmente es sabido, admith la antiction res honestas res honestas» (Coloquio De pueris... instituendis. Véase Prneav, Erasme: sa pensée religieuse, pág. II.) 
convicción de que cada ser está dotado por la naturaleza de una mística esencia, que fatalmente se cumple: «No he podido yo contravenir al orden de naturaleza, que en ella cada cosa engendra su semejante» ${ }^{1}$. «La encina da bellotas, el pero, peras; la parra, uvas, y el honrado, honra, sin poder hacer otra cosa” ${ }^{2}$. $Y$ es interesante ver cómo el determinismo biológico se transporta al mundo moral: que Clodio fuere callado, seré yo buena; porque en mí la torpeza y en él la murmuración son naturales * ${ }^{3}$. «La moza es más del suelo que del cielo, y quiere seguir su inclinación a despecho y pesar de vuestros consejos» ${ }^{4}$. Respecto de la mujer, Cervantes señala sus naturales e incorregibles caracteres (véase pág. I 26) ${ }^{5}$. Y difícilmente podrá la educación o el rango social cambiar los indelebles rasgos impresos sobre cada uno: "Los que nacen de padres humildes, si no los ayuda demasiadamente el cielo, ellos por sí sólos pocas veces se levantan» 6 .

De esa suerte el nacimiento y la condición heredada constituyen una verdadera naturaleza, que muy difícilmente

1 Prólogo Quijote, I. Aunque esto fuera lugar común, lo noto por ser significativo. Comp.: «Como dice Aristóteles en los F́sicos, y lo ter Lucrecio, poeta antiguo, todo animl LARA, Filosofía vular, 2 El retablo de las maravillas, IV, 10

El retablo de las maravillas, IV, 107. Añade Benito: :Sentencia ciceronianca sin quitar ni poner un punto. - Capacho. Ciceroniana quiso decir el señor alcalde Benito Repollo.»

3 Persiles, $584 a$. Determinismo análogo hallamos en Erasmo, con la importante diferencia, ya notada antes, que aquél no admite la natural inclinación al mal: «Quemandmodum canis nascitur ad la naavis ad volatum - ita homo nascitur ad philosophim et honestum, tiones» (Coloquio De pueris instituendis).

dad; véa ad; véanse págs. $65_{2} b, 653 a, 6{ }_{5} 6 a$.

5 En El laberinto de amor, II, 269, se dice de alguien: «Debe de ser de vil naturaleza, $\mathrm{O}$ a quien soberbia natural inclina $\mathrm{A} \tan$ infames he chos de bajeza.s

- Persiles, 597 b. Comp. : «... si tras las mañas ligeras Del vulgo no quieres irte, En el cual si alguno hubo $\mathrm{O}$ hay humilde en rica Siempre queda la bajeza, De aquel prinipio que tuvos (Pedro de Urdemalas, pág. 224). podrá contrarrestarse por la costumbre y práctica de otra vida ${ }^{1}$. La idea de lo natural se aplica así para justificar la rígida división de las clases sociales, y más aún para combatir el intento de elevarse a mayores en las gentes de condición media. Como todo espíritu esencialmente cómico y crítico, Cervantes da a veces la impresión de ser algo reaccionario (también Molière); si nuestra postura en el mundo está determinada por la naturaleza, que ha trazado el área por donde debemos discurrir; si la razón, aguda e implacable, vigila para que en ningún caso rebasemos los límites de nuestro dominio, es evidente que hacemos la vida imposible al sandio y al mixtificador; pero puede ser que al barrerlos, arrastremos también gérmenes de heroicas aunque insanas actividades. La complejidad del problema fué considerada por el genio de Cervantes, que se detuvo reverente ante la alta demencia del Hidalgo de la Mancha. Pero fuera de aquél, todos los demás casos de "quiero y no puedo» fueron tratados despiadadamente. Así, el grave eclesiástico de casa de los duques, «de estos que gobiernan las casas de los príncipes; de estos que como no nacen príncipes, no aciertan a enseñar cómo lo han de ser los que lo son; de estos que quieren que la grandeza de los grandes se mida con la estrechez de sus ánimos..., habiéndose criado algunos en la estrecheza de algún pupilaje...» ${ }^{2}$. La idea hállase en términos parecidos en Erasmo, lo que constituye una importante indicación en este caso: «El príncipe secular cuando ya llega al imperio está bien ejercitado y criado para aquello tal; el eclesiástico, a las veces, le viene, sin lo haber jamás pensado, la gobernación del mundo, y acaece que el que natura no hizo sino para un reino, el juego de la fortuna le sube al sumo imperio» ${ }^{3}$. Erasmo piensa en el Papa, rey improvisado, y Cervantes habla del eclesiástico que «sin haber

1 Para el mal, nota Cervantes que la costumbre hace naturaleza: La costumbre del vicio se vuelve en naturaleza» (Coloquio, Clás. Cast., pág. 301).

2 II, 3 I y 32 ; RM, V, 140 y 152

Silenos de Alcibiades, Amberes, 1555 , fol. $19 r$. 
visto más mundo que el que puede contenerse en veinte o treinta leguas de distrito», se mete "de rondón a dar leyes a la caballería». Esa es la diferencia.

El que las personas deban perseverar en su propia condición procede de la idea de que naturalmente no puede ser de otra manera: «Si acaso viniere a verte cuando estés en tu ínsula alguno de tus parientes, no le deseches...; con esto satisfarás al Cielo... y corresponderás a lo que debes a la naturaleza bien concertada» ${ }^{1}$. En este punto hallamos observaciones casuísticas, como la contenida en El Vizcaíno fingido ${ }^{2}$ acerca de los coches. Brígida los elogia porque yendo en ellos se "desvanecía tanto, que creía bien y verdaderamente que era mujer principal, y que más de cuatro señores de título pudieran ser mis criados». Cristina replica que "no era bien que un coche igualase a los no tales con las tales, pues viendo los ojos extranjeros a una persona en un coche... echaría a perder la cortesía, haciéndosela a ella, como si fuera a una principal señora». La lección de armonía y buen acuerdo aprovecha, porque Brígida responde: «Dios te lo pague, amiga, porque me has consolado con tus advertimientos» ${ }^{3}$. Reservemos los honores y preeminencias. para los que naturalmente son grandes, como aquella «hermosísima Segismunda, reina por naturaleza, bellísima por privilegio y por merced de la misma naturaleza» 4

Los efectos de la virtud natural son inexcusables tanto física ${ }^{5}$ como moralmente; en este último caso aquella fuerza

1 II, 42 ; RM, V, 35I. « ¿Puede por dicha la pobreza Ouitar lo que nos da naturaleza?? (Casa de los celos, I, I36).

2 IV, 85.

En otros casos también se nos dice que el consejo ha sido aprovechado; es una fórmula cervantina. Compárese la respuesta del polaco a Periandro, que le ha disuadido de vengarse de su mujer: «Un ángel te ha movido la lengua, con la cual has ablandado mi voluntad (Persiles, $637 b$ ).

4 Persiles, 675 a y $676 a$.

5 sLas acciones naturales Son forzosas, y el comer Una dellas viene a ser» (La Entretenida, pág. ${ }_{5}$ ). «Me quedé dormido, tales son fuerzas de lo que pide $\mathrm{y}$ ha menester nuestra naturaleza» (Persiles. obra como impulso místico ${ }^{1}$, que determina las anagnórisis en La fuerza de la sangre, La Gitanilla, La española ingle$s a$, etc., acompañadas de una inconsciente y previa atracción.

En conjunto, la doctrina naturalista en Cervantes podría resumirse así: la naturaleza, mayordomo de Dios, ha formado los seres, poniendo en ellos virtudes o defectos, que imprimen en cada individuo huellas imborrables y determinadoras de su carácter, cuya realización será el tema de la vida de cada cual. Esa varia condición establece afinidades y disconformidades, dentro del individuo mismo ante todo, ya que la voluntad o la razón pueden favorecer o contrariar esa originaria disposición de la persona. Cada uno ha de conocerse a sí mismo, y no intentar romper su sino natural, su inmanente finalidad ${ }^{2}$. En la relación con los demás, los afines se atraen con energía invencible, guiados fundamentalmente por el amor (neoplatonismo); los dispares, se estrellan trágicamente procurando armonías vedadas por la naturaleza, alta deidad.

Decía antes (pág. I64) que en realidad Cervantes no habría necesitado aprender estas doctrinas en Italia, siendo así que Erasmo y los italianos nos las habían traído a nuestra

568a). Hasta en un relato tan inmaterial como el de la Galatea, encontramos: «Será bien que visitéis vuestros zurrones, y cumpláis con lo que naturaleza os obliga» (II, 205).

«Daba señales de ser de algún noble padre engendrado» ( $L a$ fuerza de la sangre, Rivad., I, 168 a). «Muchas veces la nobleza del linaje pone alas y esuerza el ́́nimo a levantar los ojos adonde la humilde pone alo y exte

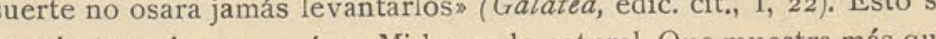
convierte en lugar común: «Mi honrado natural, Que muestra más que hay en mís (TrRso, Vergonzoso, edic. Clás. Cast., 1922, pág. 76). En Los baños de Argel, I, 332, alguien se decide a ver a su hijo martirizado ¿Vamos; que no teme encuentro Piedra que naturalmente Va presurosa a su centro.» El carácter místico se nota claramente en esta declaración de la Gitanilla: «Alcanzo más de aquello que mi edad promete más por mi buen natural que por la experiencias (Rivad. I, I05a).

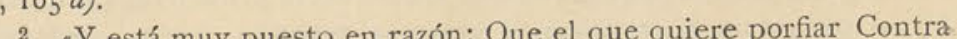
su estrella, ha de dar Coces contra el aguijón» (La Entretenida, página 29). 
casa, y se habían ramificado entre ciertos escritores españoles. Lo que nuestro autor pudo tal vez lograr en Italia fué la noción del extremado valor de tales doctrinas. La relación con el cardenal Acquaviva y su ambiente, si la conociéramo a fondo, habría de iluminar esencialmente la cuestión.

Mas vengamos a hechos precisos. La doctrina naturalista se halla en el Elogio de la locura, de Erasmo (I5 I) puesta en italiano desde I 539 (véase pág. 86) y probablemente en español, aunque no se conserven ejemplares. He aquí uno cuantos ejemplos claros: «Me parece cosa muy ridícu padecer a un ser porque se encuentra en su estado natural. ¿Lamentaríais la suerte de un hermoso caballo porque no ha aprendido la gramática?» ${ }^{1}$. «Habiéndoos naturaleza, la verdadera prudencia exige que no os alcéis sobre la condición humana» ${ }^{2}$. «La naturaleza, esta madre y productora del género humano» ${ }^{3}$. "Todo aquel que yendo contra la naturaleza se cubrecon "lodo a manto manto de la virmultiplica multiplicar sus defectos. Por cuyo motivo, según el adagio griego, la mona es siempre mona, aunque se vista de púrpura” ${ }^{4}$. Si los alquimistas son locos por excelencia, es porque aspiran «nada menos que a confundir, a mezclar, a cambiar la naturaleza» 5 .

Alusiones a parecidas ideas se hallan en León Hebreo. La naturaleza es para él unà codeidad, que ha puesto en el hombre estímulos de acuerdo con su esencia racional: «Dios ni la naturaleza no ponen en criatura alguna entero amor, ni deseo, o inclinación o inherencia sino para alcanzar o para ser cosa posible, y no para el vero manifiesto imposible; y

1 Edic. Croce, pág. 49

2 Pág. 44 .

3 Pág. 26.

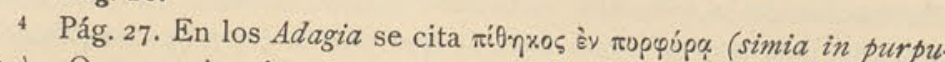
ra): "Quam multos id genus simios videre est in principum aulis; quibus si purpuram, si torquem, si gemmas detrahas, meros eerdones deprehendes.

Pág. 63. por esto verás que un hombre no desea subir por su pie al cielo, o volar con alas, o ser una estrella» 1 .

Para Castiglione, el mundo "no es otra cosa sino una milagrosa y gran pintura, por las manos de la natura y de Dios compuesta» ${ }^{2}$. Pero, en general, la naturaleza como codeidad se convierte francamente en poder autónomo: «La natura, en aquella secreta simiente que en toda cosa está mezclada, ha puesto y engerido una cierta fuerza y propiedad de su principio para todo aquello que dél procede, por manera que lo que nace tiene semejanza a aquello de donde nace» ${ }^{3}$

Castiglione admite que esa naturaleza es un poder que obra por delegación divina, que tiene facultad creadora; sólo excepcionalmente se admite como hipótesis la intervención divina y no natural en la marcha del mundo: «Verdad es que o por la buena constelación o por la buena naturaleza nacen algunos acompañados de tantas gracias, que parece que no nacieron, sino que fueron hechos por la propia mano de Dios, puramente sin otro medio, y ennoblecidos de todos los bienes del alma y del cuerpo. Al contrario de éstos se ven otros tan necios y desconcertados, que no se ha de creer sino que la natura por despecho o por burla los echó en el mundo. Estos... ni por mucho trabajo que en ello pongan ni por muy buena crianza que reciban pueden llevar buen fruto" ${ }^{4}$. "Creo yo luego que las pasiones y las enfermedades sean dadas a los hombres por la natura» ${ }^{5}$. Y ahora la armonía basada en la naturaleza: "Naturalmente se hace juntarse fácilmente cada cosa con otra semejante a ella» ${ }^{6}$. "Cada uno me parece que se debe aplicar a su natural instinto y desto pienso que habla Cicerón..., y así no tengo por bien

1 Diálogos, edic. cit., pág. $405 a$.

2 El Cortesano, edic Libros de antaño, pág. 122.

3 Pág. 51.

4 Pág. 52 .

Pág. 140

6 Pág. 184 
que un colérico y arrebatado se ponga a escribir cosas mansas y sosegadas» 1 .

A Mal Lara llega el naturalismo por imitación de Erasmo; pero no encontramos en él las audaces afirmaciones de su modelo, ni siquiera las de Cervantes. Leyendo la Filosofía vulgar se percibe con cuánta precaución maneja el autor las sustancias erasmistas. No obstante, hallamos indicaciones interesantes, en las que se transparenta el espíritu humanista. "La naturaleza es amiga de conservarse en gran manera; y ya que no puede ser inmortal, procura por generación res taurar la pérdida que la muerte hace» ${ }^{2}$. Por naturaleza «conforman unos hombres con otros, que somos participantes de razón todos [tema del común denominador humano a base de razón], y en aquella excelencia que tenemos llevando ventaja en esto a todas las bestias [tema de la dignidad del hombre, por razones humanas]... Y en esta parte hay cierta cosa en que todos nos parecemos. Así hay otra especial, que cada uno tiene por su natural inclinación... Pues para escoger la manera de vivir, es menester que cada uno mire por su natural... Si uno nació aficionado a la teología, que no le hagan estudiar leyes, porque es negocio más honrado y más provechoso...; el que es grave no entienda en cosas de burlas... Cada uno huyendo de su natural, y era el consejo de toda la vida» ${ }^{3}$.

¿No vienen súbitamente al recuerdo aquellas elegantes razones de Don Quijote: "En lo de forzarles [a los hijos] que estudien esta o aquella ciencia, no lo tengo por acertado, aunque el persuadirles no será dañoso... V. m. deje caminar a su hijo por donde su estrella le llamas? 4.

Según Mal Lara, la bondad y la honestidad son naturales; por eso suprime los refranes lascivos que salen de la «regla que nos puso la naturaleza de ser buenos y honestos (según

1 Pág. 99. Para más detalles sobre la noción de naturaleza en $E$

Cortesano, véanse págs. $38,39,76,98,120,124,206,207,304$.

Edic. 1568 , fol. 149 .

IX, 14 ; edic. ${ }_{5} 68$, fols. $236 v-237$.

II, I6; RM, IV, 325,330 . dice Tullio en los Oficios), que nos enseñó a cubrir y descubrir el cuerpo en aquellas partes que merece ser visto» ${ }^{1}$. ¿Y la explicación bíblica? Mal Lara no pensó en esa dificultad; tratándose de la naturaleza, el humanista de buena cepa se dejaba arrebatar por el más ingenuo entusiasmo: «Si bien miramos por qué la naturaleza dió los hermanos, hallaremos que es y fué para que no hubiésemos menester buscar amistades» ${ }^{2}$.

Basta con lo dicho para darse cuenta del rumbo que llevaba en España este concepto de la naturaleza, como fuerza codivina, mística e ineludible, cuando Cervantes formaba su espíritu; citar más autores sería inútil para mi propósito ${ }^{3}$.

\section{Edic. I 568; Preámbulo, parte 6.}

2 VII, 28 ; edic. I 568 , fol. 193 v.

3 Prescindo de otro aspecto importante que ofrece la evolución histórica del concepto de naturaleza dentro de la literatura española. Los autores ascéticos y místicos, sobre todo los de inspiración franciscana, acogen el culto a las manifestaciones de lo natural, en las que ven reflejos divinos; mas para ellos esa naturaleza no posee personalidad, no es «mayordomo de Dios", sino espejo de sus glorias; no es fuente de energ y de actividad que impulsa al hombre por ser ál uno abjo de austa contenplacón y as lo que de sus productos sino objeto de nuestra contemplación y ast lo que para el humanista se resuelve en acción objetiva e ineluctable, es para el místico puro éxtasis. Dice Santa Teresa: «Aprovechábame a mí también ver agua, campos, flores; en estas cosas hallaba yo memoria del Criador; digo que me despertaban y recogían y servían de libro.> (Vida, Rivad., LIII, 40 b). Mas el carácter de puro medio que para la Santa ostenta la naturaleza se nota en este pasaje de las Relaciomes, en el que lo objetivo aprece ya suprimido, así como se sacan los nes, en el que lo objetivo aparece ya supeinido, as como se sacan los hilos del cañamazo, luego de estar hecho el bordado: «Cuando veo alguna cosa hermosa, rica, como agua, campo, flores, olores, músicas, etc., paréceme no lo querría ver ni oír; ;tanta es la diferencia de ello a lo que yo suelo ver! Y ansí se me quita la gana de ellas. Y de aquí he venido a dárseme tan poco por estas cosas» (Rivad., LIII, ${ }_{14} 6 b$ ). Si lo divino venía a aposentarse en el alma del místico, no había que buscarlo fuera de aquella recatada infinitud: ${ }_{\alpha} \mathfrak{N}_{\mathrm{N}}$ To habéis oído muy muchas veces decir que está Dios en sus criaturas por potencia, premuchas veces decir que esta Dios en sus critus por potenia, presencia y por esencia? Pues así habeis de entender que esencialmente bida con vos, con su ser divino, eterno" (BERNARDINO DE LAREDO, Su- 
Es, en cambio, inexcusable internarnos nuevamente por la obra cervantina para ver cómo de esta idea central de naturaleza arrancan temas literarios que a su luz reciben explicación y sentido. De esa suerte irá confirmándose que la doctrina naturalista no es en nuestro autor - como no lo era tampoco en otros escritores del siglo xvi - lugar común que el azar ingería dentro de la fábula artística.

Aunque antes de analizar esos temas naturalistas ha de hacerse una observación metódica de bastante alcance, que el lector hallará justificada después de lo escrito en el primer capítulo. No se piense en modo alguno que presentamos a Cervantes como si fuese un entusiasta humanista de principios del mil quinientos, con fe ardiente e ingenua en los valores naturales que exaltaron místicamente a un Mirándola, a un Sannazaro o a Rabelais: esto sería anacrónico y, en último término, amenguaría la poderosa originalidad de Cervantes. Cuanto llevamos dicho de la fe mística en lo natural debe

Essai sur les sources de Sainte Thérèse, 1923, pág. I48. Para el problema místico debe verse ahora el profundo libro de Jean BaruZi, Saint fean de la Croix et le problème de l'expérience mystique, 1924.)

Creo que Luis de Granada daría lugar a un estudio curioso, porque en él la posición humanista no está ahogada del todo por la meramente contemplativa. Inspirándose en Seneca, De vita beata, dirá en e Simbolo de la fe: "¿Qué cosa es Dios? Todo lo que vemos, porque en todas las cosas vemos su sabiduría y asistencias (Rivad., VI, $18_{3} a$ ). En él predominará, sin embargo, la actitud trascendente, ya que la naturaleza no será un mundo con actividad absoluta e inmanente, sino escala para ascender a Dios: «Como este mundo visible sea efecto y obra de las manos de Dios, él nos da conocimiento de su Hacedor (Ibid., I $83 b$ ). Luego veremos que Luis de Granado acepta la dotris del humanismo al reconocer que el cistianismo contina la flosofia antigu. Valut la pena analize en cristete antigua. Valdría la pena analizar en detalle la obra del P. Granada, ejemplo de cómo se disuelve el ideario renacentista en este fuerte representante del ascetismo católico. En resolución se vería que la idea de naturaleza, balbuceada por el pobrecito de Asís, sale de la Edad Media en dos direcciones divergentes: el mundo vale por reflejar a Dios y llevar a Él, y el mundo es como Dios y hay que atemperarse a sus exigencias. Fl drama moral y religioso en el siglo xurgrata en torno a esas dos formidables posiciones. coordinarse con lo observado en el capítulo I, «Orientación literaria», donde se expuso la singular técnica cervantina, profundamente crítica, negadora de principios absolutos, que presentaba una realidad siempre en función de su contrario. Vacila la fe de Cervantes al contemplar las encantadoras construcciones basadas en la pura virtud natural o en la deducción racional, que llevaban derechamente al «universal poético» o a las armonías neoplatónicas; su alma se iba tras esos ideales, pero al mismo tiempo las punzaba críticamente y deshacía el globo de ilusión. De ahí tristeza, amargura, pesimismo. Como veremos al hablar de la Contrarreforma, ese estado de espíritu era propio de las mejores sensibilidades a fines del siglo xvi; pero sólo Cervantes logró crear sobre tal base un arte nuevo, que nuestra época sigue considerando como moderno. Salvo poco numerosas excepciones, el plano del «universal poético», o de la armonía, se agrietea y se deshace al quererlo actualizar. ¿Dónde están los pastores de la novela pastoril?, se pregunta Cervantes. $Y$ en el mismo Persiles, cuyos protagonistas van discurriendo su vida a fuerza de trabajosos artificios, ¿no hallamos cien fracasos lamentables entre los personajes episódicos? Ante la peripecia vital - los puntos de vista, los deseos basados en estímulos naturales entrechocan miserablemente - , Cervantes sonríe melancólico: el humanismo no basta; pero lo kotro», la solución tradicional, tampoco. Lo admirable es que esa melancolía ha sido, a su vez, inserta y fundida dentro del Quijote como elemento dinámicamente activo.

LA EDAD DE ORO

La sensibilidad literaria no podía contentarse con los abstractos conceptos que le brindaba la filosofía. Esa naturaleza, que, según Lorenzo Valla, era igual a Dios ${ }^{1}$, no podía, en cuanto a lo humano, coincidir plenamente con la vida imperfecta que nos cerca. Al concepto de naturaleza

1 Véase antes pág. 159 , nota. 
divina que iba forjando la filosofía renacentista corresponden en el arte representaciones idealizadas de un mundo perfectamente puro y sin mácula, libre todavía de los errores y deficiencias que hoy pesan sobre él. Ese es el sentido que proyecta el Renacimiento sobre temas como la Edad de Oro, del que se apodera con avidez al hallarlo en los autores de la antigüedad. Hoy lo comprendemos difícilmente; pero si queremos acercarnos de veras a la literatura de los siglos xv y xvi, hemos de tener muy presente aquel místico fervor de los humanistas, que soñaban con un mundo que se bastase a sí mismo, libre de los malos afeites con que lo habían rebozado el tiempo, el error y las pasiones; terso y brillante como al salir del divino y natural troquel.

En dos direcciones principales se proyecta ese anhelo. Una va hacia un pasado quimérico, la edad dorada o de Saturno ${ }^{1}$; otra hacia el presente, con aspiración a hallar realmente algo que pertenezca a esa pura naturaleza. El Renacimiento idealizará los niños y sus juegos; el pueblo, sus cantares y sus sentencias, que se juzgan espontáneas y primitivas (refranes); el salvaje no adulterado por la civilización; se menospreciará la corte y se alabará la aldea ${ }^{2}$. Algunos de estos rasgos aparecen en Cervantes.

Pero veamos antes la Edad de Oro. Es muy conocido el discurso inserto en el Quijote (I, I I), al cual pone el autor, desde luego, una terrible apostilla reveladora del espíritu complejo a que antes aludí (pág. I77) : "Toda esta larga arenga, que se pudiera muy bien excusar, dijo nuestro Caballero, porque las bellotas que le dieron le trujeron a la

1 .Vita Saturnia, proverbiali tropo effertur pro beata et luxus exotici dolique ignara, qualis aureo saeculo tribuitur a poetis... Saturno regnante auream aetatem extitisse fabulantur poetaes (HADRIANI JUNII, Adagia, adicionados a los de Erasmo, París, I579, col i 103).

2 Determinaron de lavarse los hermosos rostros, pues no era Chet para acrecentales hermosura el vano y enfadoso artifio menester para acrecentaries her los (Galatea, edic. Schevillidades se tienen por más hermosas" (Galatea, edic. Schevill-BoniIla, I, 45). memoria la edad dorada, y antojósele hacer aquel inútil razonamiento a los cabreros.»

Algo menos conocido es el canto a la misma bella fantasmagoría que se encuentra en El trato de Argel:

$$
\begin{aligned}
& \text { ¡Oh santa edad, por nuestro mal pasada, } \\
& \text { a quien nuestros antiguos le pusieron } \\
& \text { el dulce nombre de la edad dorada... } \\
& \text { No sonaba en los aires la querella } \\
& \text { del mísero cautivo... } \\
& \text { Entonces libertad dulce reinaba... } \\
& \text { Pero después que sin razón, sin lumbre, } \\
& \text { ciegos de la avaricia, los mortales... } \\
& \text { descubrieron los rubios minerales } \\
& \text { del oro que en la tierra se escondía, } \\
& \text { ocasión principal de nuestros males, etc. }{ }^{1 .}
\end{aligned}
$$

La riqueza, la codicia y su secuela la guerra acabaron con el mundo perfecto; en esta fábula, la corrupción de los mortales procede de causas puramente humanas y no de castigo divino. La fábula viene de la antigüedad ${ }^{2}$, pero el sentido que ofrece es el que le da el Renacimiento, del cual es ornamentación característica.

Un autor muy leído por Cervantes, Mal Lara, alude expresamente a Ovidio ${ }^{3}$, y nota que «si todo estuviese tan concertado que fuese aquello que traen los poetas de la Edad de Oro, que guardaban sin ley, sin pena, sin algún castigo toda justicia, yo daría por no menester las penas y jueces» ${ }^{4}$. «Las guerras se inventaron pasada la edad de oro, quiero decir en comenzando la malicia» ${ }^{5}$. "Los poetas Hesíodo, Arato, Virgilio, Ovidio..., tratando de la edad de oro, decían que corrían ríos de leche y miel en todas las tierras, y esto era

1 V, 53 .

2 R. ScheviLL, Ovide and the Renascence in Spain, págs. 187,153 y 149

-Dice Ovidio que desde que comenzó la edad de plata, comenzaron los adulterios? (Filosofia vulgar, 1568 , fol. $78 r$ ).

4 Fol. $102 v$. 
porque vivían santamente; y así era a los que Dios quiere bien» ${ }^{1}$.

Por la nota anterior vemos cómo Cervantes, al pensar en el príncipe perfecto, evocaba el tema de la áurea y feliz edad; la misma asociación hallamos en Castiglione: "Esta es la buena manera de gobernar como es razón, la cual sola bastaría a hacer los hombres bienaventurados, y restituir otra vez al mundo aquella edad de oro, que fué, según se escribe, en el tiempo en que reinó Saturno» ${ }^{2}$. ¿Y no parece una reminiscencia del mismo tema aquella descripción del rey Policarpo en Persiles? El rey es un hombre perfecto, elegido «sin intervenir de por medio ruegos o negociaciones...; los pueblos viven quietos, campea la justicia y resplandece la misericordia...; no agobian la vara de la justicia las dádivas, ni la carne y sangre de los parentescos...»

Al margen de estas idealizaciones hay en Cervantes alguna idea más precisa acerca del estado natural, que fácilmente llegaría a él por medio de Erasmo. ¿Se recuerda el episodio de Feliciana de la Voz?: "Sólo dificultó el ponerla en camino estando tan recién parida, y así se lo dijo; pero el anciano pastor dijo que no había más diferencia del parto de una mujer que del de una res, y que así como la res sin otro regalo alguno después de su parto se quedaba a las inclemencias del cielo, ansí la mujer podía sin otro regalo alguno acudir a sus ejercicios, sino que el uso había introducido entre las mujeres los regalos y todas aquellas prevenciones que suelen hacer con las recién paridas» ${ }^{3}$.

1 Fol, $7 r$. En el Quijote, II, 2; RM, IV, 25, se alude a la edad de hierro junto a la dorada: «Si a los oídos de los príncipes llegase la verdad desnuda..., otras edades serían tenidas por más de hierro que la nuestra.» Comp.: «Hesíodo en la obra de Agricultura, contando de las cuatro edades, dice que en la de hierro había grandes maldades, y entre ellos cuenta las que a sus padres deshonran, (MaL LaBa, Ob.

cit., VII, 2. fol. 1 $176 v$ ).

edic. cit., pág. 434

3 Persiles, 630a. En La Señora Cornelia (Rivad., I, 214) ocurre también que una gran dama se ponga a andar por la calle en seguida de
Esto quiere decir que la civilización ha alterado el buen orden natural de las cosas, y claramente lo había dicho Erasmo: «Digamos francamente que el saber y la industria se han introducido en el mundo como las demás pestes de la vida humana, y que fueron inventados por aquellos mismos espíritus que crearon todos los males... Nada de esto conocíase en la edad de oro, y los hombres entonces, sin método, sin regla, sin instrucción, vivían felices, guiados por la naturaleza y el propio instinto ${ }^{1}$. He ahí cómo se dibuja en el siglo xvi la futura paradoja de Rousseau - el hombre de la naturaleza - que en último término remonta a Erasmo, pasando por Montaigne.

El siglo xvi, llevado por estímulos emocionales, buscará afanoso la virtud natural donde piensa que se halla; hasta reconocerá que la civilización fué un mal, porque vino a empañar el brillo prístino de los seres. Pero al mismo tiempo, el Renacimiento busca con no menor afán la cultura, que es razón, y que es lo contrario de la espontaneidad natural. De ahí el cruce de ideas, las contradicciones y los vaivenes de aquella época frondosa, de la que forma parte Cervantes. El siglo xvir vendrá luego a clasificar y precisar aquel mundo oscilante, en que lo antiguo convive con los atisbos de lo moderno. Tal momento de la civilización si no se refleja en Cervantes en forma de doctrina filosófica o científica, constituye, sin embargo, el substratum de su visión artística de mundo. Nuestro autor sabe que lo ideal sería armonizar el arte y la naturaleza, lo racional y lo vital: «Dígote, Sancho, que si como tienes buen natural tuvieras discreción, pudieras tomar un púlpito en cada mano y irte por ese mundo predicando lindezas» ${ }^{2}$. «Según es opinión verdadera,

haber dado a luz. Erasmo, en su coloquio Puerpera, había recomendado que las madres criaran a sus hijos; Mal Lara repite el consejo, *aunque las señoras no querrán oír esta filosofía... De aquí viene que no hay amor entre los hermanos, de tal manera son los hijos de los palacios> (Cent. IV; refr. 46).

1 Elogio de la locura, edic. Croce, pág. 50

2 II, 20; RM, IV, 4 I 9. 
el poeta nace; quieren decir que del vientre de su madre el poeta natural sale poeta; y con aquella inclinación que le dió el Cielo, sin más estudio ni artificio, compone cosas, que hace verdadero al que dijo: est Deus in nobis..., etc. También dijo que el natural poeta que se ayudare del arte será mucho mejor y se aventajará al poeta que sólo por saber el arte quisiere serlo; la razón es porque el arte no se aventaja a la naturaleza, sino perfecciónala; así que mezclada la naturaleza y el arte, y el arte con la naturaleza sacarán un perfectísimo poeta» ${ }^{1}$. ¿`Mas cómo armonizar lo racional y lo vital, lo poético y lo real? Ese es el magno problema que Cervantes blande ante el arte moderno.

Anteriormente (pág. 62) pudimos observar la importancia del elemento racional en Cervantes, y cómo esa noción de arte se traducía a veces en casuística reglamentación; dijimos que su genialidad literaria consistía en superar la oposición así planteada entre lo vital y lo racional, tomando una actitud dominante de tales contrastes, actitud que esencialmente consistía en presentar esa oposición como un problema de infinita amplitud. Pues bien, ahora toca examinar cómo aparecen en la obra cervantina más temas de índole naturalista o vital, opuestos a los de índole racionalista.

Decía antes que la segunda dirección en que aparecía en el siglo xvi el anhelo de perfección natural iba derechamente hacia el presente, para buscar en la vida visible lo que más se acercara a la noción de pura naturaleza: el niño, el

1 I, 16; IV, 330. Montaigne (I, 30) había escrito: «Todas las cosas, dice Platón, son producidas o por la naturaleza, o por la fortuna, por el arte; las mayores y más bellas, por una u otra de las dos primeras; las menores e imperfectas, por el último. Cervantes ha concebido a veces la armonía entre arte y naturaleza: «La industria de su moradores ha hecho tanto, que la naturaleza, encorporada con el arte, es hecha artífice y connatural del arte, y de entrambos a dos se ha hecho una tercia naturaleza, a la cual no sabré dar nombres (Galatea, edic. cit., II, I89). salvaje, el rústico, el animal incluso ${ }^{1}$; en una palabra, en las manifestaciones de mayor espontaneidad vital. Recuérdese cómo se poetiza en La Gitanilla la vida suelta de los gitanos,

1 Bastará con algún ejemplo típico. Mal Lara (Filosofía vnlgar, r 568) es sumamente representativo, y resulta extraordinario que no se haya aún notado expresamente el valor de los temas que atesora: «Aun acá los niños, guiados de la razón natural y bondad que tienen los niños, guiados de la razón natural y bondad que tien Cresca en su nueva alma, cuando veen que otro iba a hacelle mal
y tropieza y se lastima, dicen: «Dios lo vido»(fol. I $9 r$ ). Nótese, al y tropieza y se lastima, dicen: «Dios lo vido» (fol. I $r$ ). Nótese, al
paso, la influencia de Erasmo, cuyos Adagia sigue Mal Lara muy de cerca; la doctrina ésta es, en último término, anticristiana, ya que el niño debía poseer esas virtudes, no tanto por estar cerca de su natural origen, como por la redención de la culpa primera mediante el bautismo. Vé ceses pág. 67 . En cuanto a los salvajes, sabido es que los relatos de su vila y costumbres, dalo a conocer por los viajeros

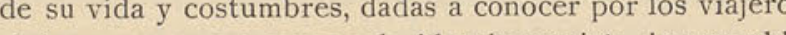
españoles, abrieron un nuevo cauce a la idea humanista, inseparable de la naturalista. Montaigne aprovechó mucho a nuestro Gómara (VILIEX, Sources, I, I37). Mas el punto de arranque está igualmente en Erasmo, máximo proveedor de temas para el siglo xvi: «No ha muchos días que posaron aquí unos huéspedes que decían haber andado muchas regiones nuevamente halladas... Contaban haber llegado a una isla de tierra muy templada, donde todos andaban desnudos, e tienen por cosa de gran vergenza chbir alguna parte de su cuerpo... Viven muy concertadamente. A rrancan unas raíces que les sirven para hacer pan en lugar de trigo... Acabado este trabajo, que todos hacen en común con el rey, vase cada uno donde quiere, y entienden en sus negocios, crían virtuosamente a sus hijos, castigan los vicios e, sobre todo, el adulterio» (Coloq., en Origenes de la Novela, IV, 232 a). Mal Lara dice: "Los indios no se casan con la hija del rico por las riquezas que tiene y la memoria de su linaje, sino con gran diligencia

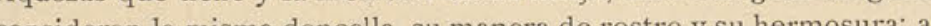

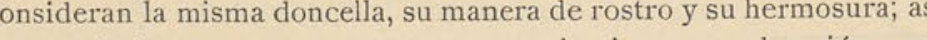
que no lo hacen como nosotros, que sin ninguna moderación arremetemos al casamiento, sino con otra prudencia y saber diferentes $(\mathrm{V}$ 24; fol. I o r r). Montaigne desarrolla posteriormente ideas análogas en el capítulo sobre los caníbales (Essais, I, 30 ): «Nous appellons sauvage les fruits que nature de soi et de son progrès ordinaire a produits tandis qu'à la vérité ce sont ceux que nous avons altérés par notre artifce et détourné de l'ordre commun, que nous devrions apelle plutôt savar. A los salvajes, ales lois naturelles leur commandent plutôt sauves.o A los encores, fort peu abatardies par les notres. $y$ sigue u a pin a vida salvaje no menos utopica que la del estalo del rey policarpo. Pero Mejía hará el panegírico de los animales: «Cómo de las aves y ani- 
en cuya descripción hay elementos del tema de la Edad de Oro: «Los montes nos ofrecen leña..., las inclemencias del cielo son oreos... Nosotros guardamos inviolablemente ley de la amistad...» ${ }^{1}$. En otras ocasiones ha vuelto Cervantes a tratar de la libre gitanería, lo que demuestra la dilección que ponía en el asunto.

En general, el elogio de la vida sencilla, rústica y solitaria lleva a su retaguardia el sueño de la pura espontaneidad natural. Ese es el acento que la época renacentista pone sobre el «Beatus ille». Don Quijote reflexiona ante Sancho dormido: « $\mathrm{Oh}$ tú, bienaventurado sobre cuantos viven sobre la haz de la tierra, pues sin tener invidia ni ser invidiado, duermes con sosegado espíritu!... $\mathrm{Ni}$ la ambición te inquieta, ni la pompa vana del mundo te fatiga, pues los límites de tus deseos no se extienden a más que a pensar tu jumento» ${ }^{2}$.

Soldino, retirado del mundo, entona análogo cántico en su retiro: "Aquí, en lugar de los príncipes y monarcas que mandaban en el mundo, a quien yo servía, he hallado a estos árboles mudos, que aunque altos y pomposos son humildes; aquí no suena en mis oídos el desdén de los emperadores, el enfado de sus ministros» ${ }^{3}$. Y antes dirá Renato, retirado en la isla de las Ermitas: "Dejarónme entregado a mi soledad, donde hallé tan buena compañía en estos árboles, en estas yerbas y plantas, en estas claras fuentes... Oh soledad, alegre compañía de los tristes! ¡Oh silencio, voz agradable a los oídos donde llegas, sin que la adulación ni la lisonja te acompañen!» 4 .

males pueden tomar ejemplo y reglas para bien y virtuosamente vivir los hombres.» \&... antes es grande confusión y vergüenza... que todos los animales sigan perfectamente sus naturalezas y hagan sus obras perfetas en su género, y que el hombre, animal racional, use $\tan$ mal de su libre albedrío» (Silva de varia lección pág. Lyon, 556). Véase tambín el capitulo XLII del libro 11.

1 Edic. Schevill Bonilla, pág. 78 .

2 II, 20; RM, IV, 398

C. 3 Persiles, Rivad., I, 6566 .

4 Ibid., $620 a$.
$\mathrm{Y}$ he aquí cómo se armoniza el menosprecio de corte con lo pastoril: "Cuando me paro a considerar, agradables pastores, la ventaja que hace al cortesano y soberbio trato el pastoral y humilde vuestro, no puedo dejar de tener lástima a mí mesmo, y a vosotros una honesta envidia... Ya se sabe bien que es una guerra vuestra vida sobre la tierra. Pero, en fin, en la pastoral hay menos que en la ciudadana, por estar más libre de ocasiones que alteren y desasosieguen el espíritu... Un pastor amigo mío..., después de haber gastado algunos años en cortesanos ejercicios, y algunos otros en los trabajosos del duro Marte, al fin se ha reducido a la pobreza de nuestra rústica vida» ${ }^{1}$. ¿Pero no se percibe aquí, además, una melancólica nota de renunciación y ascetismo?

Estas formas que reviste la sensibilidad renacentista no tienen contorno geométrico; unos temas se proyectan sobre el esfumado de otros, se combinan y entrecruzan complicadamente; pero el sentido fundamental que les afecta no deja de ser por eso menos claro. Nótese que ya en el siglo xv la Edad de Oro (visión de una época ucrónica) se funde con la idealización de la vida rústica; así en la Laude della vida rusticana de Angelo Poliziano (I454-I494):

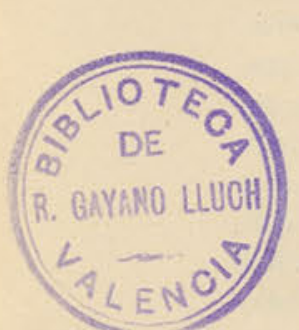

Quanto è più dolce, quanto è più sicuro

Seguir le fere fuggitive in caccia...

Or se vede il villan domar col rastro

Le dure zolle, or maneggiar la marra;

Or la contadinella scinta e scalza

Star con l' oche a filar sotto una balz.

In cotal guisa già l' antiche genti ['gentilidad']

$\mathrm{Si}$ crede esser godute al secol d' oro.

Así, pues, quienes introducen los temas de la Edad de Oro, de la vida rústica - y de la pastoril — en la literatura, lo hacen con el espíritu cargado de místico naturalismo ${ }^{2}$. La

1 Galatea, edic. cit., II, 33-35, y pág. 38 .

2 Véase cuán claramente se expresa Erasmo: «Es mucho más deseable la vida de las moscas y de los pájaros, que nacen libres y que la naturaleza se encarga de alimentar; serían perfectamente felices 
tendencia al bucolismo apunta ya en Petrarca, si bien de manera artificiosa y muy apegada a Virgilio. En pleno siglo xv, León Bautista Alberti hace el elogio de la vida rústica en Della famiglia (I44I); de ahí debe proceder, en cuanto al tema, el Menosprecio de corte, de Guevara, y creo que hasta el estilo ${ }^{1}$ : "Porge la villa utile grandissimo, onestissimo e certissimo; e pruovasi: qualunque altro esercizio s' intoppa in mille pericoli; hanno seco mille sospetti...; in comperare, cura; in condurre, paura; in serbare, pericolo; in vendere, sollecitudine; in credere, sospetto; in ritrarre ['ganar'], fatica; nel commutare, inganno. E cosi sempre degli altri esercizi ti premono infiniti affanni e agonie di mente. La villa sola sopra tutti si truova conoscente, graziosa, fidata, veridica... Neanche il verno si dimentica teco essere la villa liberale; ella ti manda la legna, l' olio, ginepri e lauri... Piace alla villa la tua opera ed esercizio pieno di diletto, il quale sia non meno alla sanità tua che alla cultura utilissimo... Ni

vivirían tranquilos si no temiesen las acechanzas de los hombres. No os imagináis cúnto pierden los pájaros de su nativa belleza, cuanto los amestran la ju los amaestran en la jula para que nos canten; tan verdad es, en todos aspectos, que las producciones de la naturaleza sobrepasan con mucho las del arte» (Elogio de la locura, 1511 , edic. cit., pág. 53). El materialismo aplicado a la historia literaria hizo decir a tan profundo pensador como Burckhardt, que las descripciones de la vida campestre comienzan en Italia, porque allí el campesino era libre y no siervo de la gleba (Civilisation en Italie, II, 86). Como si Mal Lara, Montaigne y tantos otros no hubiesen poetizado a los salvajes por el mero hecho de serlo. Se trataba de hallor hespontaid a por dogle serlo. Se trab de bal Lara, glosando el refrán, sNo hay mujer hermosa el día de la bodas (V, 38), dirá: «La hermosura verdadera..., fuera de estar en el cuerpo, está en el tratarla sencillamente.» Recuérdese que en la Edad de Oro cervantina, «su perdición [de las doncellas] nacía de su gusto y propia voluntad, (I, II)

1 Véanse sobre todo los capítulos V y VI (edic. Clásicos Castellanos). Compárese, por ejemplo: «No gozan deste privilegio los que andan en las cortes y viven en grandes pueblos; porque all les tom ropa..., hurtan la leña, talan la leña, quiebran las puertas... O cuán bienaventurado es aquel a quien cupo en suerte tener qué comer en el aldea», etc. una invidia, ni uno odio, ni una malivolenzia ti nasce dal coltivare e governare il campo» ${ }^{1}$.

Fr. Antonio de Guevara refleja igualmente el místico naturalismo del Renacimiento en aquella entusiasta fantasía de El villano del Danubio, inserta en el Reloj de Principes: «En las palabras groseras que digo, y en las vestiduras monstruosas que traigo, podéis bien adevinar que soy un muy rústico villano; pero con todo eso, no dejo de conocer quién es en lo que tiene justo y quién es en lo que posee tirano.» El elogio de la sencillez virtuosa de los germanos va envuelto en el mismo tema de la idealización de la vida natural: "Os respondo que pues no teníamos enemigos, no curábamos de ejércitos, y que, pues, era cada uno contento con su suerte, no teníamos necesidad de superbo senado que gobernase; que siendo, como éramos, todo iguales, no consentíamos haber entre nosotros príncipes» 2

\section{LO PASTORIL}

Lo rústico y aldeano fué tomado como base para proyectar desde ella cierta visión de la vida perfecta; mas como esa visión procede de una serie de deducciones racionales y esquemáticas, al moldearse dentro de un género literario forzosamente había de conservar su carácter esencialmente quimérico y racionalista. El Renacimiento ha organizado de tal modo las sustancias literarias, que los géneros han de inclinarse hacia el lado de la idea o hacia el de los sentidos; la novela pastoril es género idealista, conscientemente irreal. Su núcleo es el concepto del hombre que forjo el humanismo: un ser abstracto cuya función es ser común denominador de las variedades concretas de hombre; el elementoartísticamente decorativo procede en parte del tema de la Edad de Oro, en parte del bucolismo, utilizado como medio-

\footnotetext{
1 Della famiglia, lib. III, edic. A. Bonucci, págs. 280 y sigs.
}

2 Rivad., LXV, 161 a, 163 
para lograr ese mundo inalterable, sin ayer ni mañana, sustraído a la acción de lo concreto, de lo real, porque esto inmediatamente habría hecho saltar el marco de tan ingrávidas escenas. El pellico uniformador anula todos los gérmenes de realismo que pudieran llevar las representaciones de personajes efectivos - con alma y cuerpo - que inicialmente tuviera el autor. De ahí el casi nulo valor que ofrecen literariamente esas identificaciones con seres reales ${ }^{1}$. ¿Para qué sirve artísticamente que sepamos que la Diana de Montemayor fué una dama que aún vivía en León cuando Felipe III visitó la ciudad en 1602 ? $^{2}$. Diana pertenece a la época de Saturno, y allí hemos de ir si queremos algún trato con su quimérica belleza.

Discrepo en absoluto de la opinión que Menéndez Pelayo tenía acerca de la novela pastoril: «El bucolismo de la novela no es un hecho aislado, sino una manifestación peculiar, y sin duda alguna la más completa, de un fenómeno literario general, que no se derivó de un capricho de la moda, sino de la intención artística y deliberada de reproducir un cierto tipo de belleza antigua, vista y admirada en los poetas griegos y latinos. Ninguna razón histórica justificaba la aparición del género bucólico: era un puro dilettantismo estético» ${ }^{3}$. Si creemos que el Renacimiento, en aspecto tan importante como éste, reproduce cierto tipo de belleza antigua, por frívolo ejercicio de dilettantismo, el concepto de Renacimiento

1 Lo mismo que el prurito de explicar materialmente la creación del género. Dice Rossi (Quattrocento, pág. 370) : «Cierto es que los hombres del Renacimiento ansiaban con ardor la amenidad, la paz, la sencillez de la vida campestre, por lo cual abandonaban las ciudades por las villas oportunamente elegidas, cuando llegaba la buena estación. La Arcadia [de Sannazaro], con su ingenuo sentimentalismo idílico, acricia no produjeros romanos, y no produjeron novelas pastoriles. Hay que buscar explicaciones menos materiales y más peculiares de la época renacentista.

2 H. A. Rennert, The Spanish Pastoral Romances, Filadelfia, I912, pág. 35 .

Origenes de la Novela, I, $4 \mathrm{I}$ se nos va de entre las manos. De cuanto antecede se desprende que lo pastoril viene a su hora y sazón, guiado por motivos intensos que afectan a lo íntimo de la sensibilidad y de la ideología coetáneas. Yo insisto en ello porque aspiro a ver nuestro siglo xvi con algún orden y trabazón, a fin de explicar la trayectoria que han recorrido los temas capitales de Cervantes. ¿Se quiere ver, en efecto, cómo lo pastoril, lo rústico y el concepto de naturaleza aparecen unidos lógica y orgánicamente en una de las mentes más típicas del siglo xvr? Léase este pasaje de Mal Lara (VI, 67), el cual ninguna novela pastoril escribió:

«Acaeciónos ir una vez de Salamanca a Talavera, y antes de pasar el puerto de Arenas, en aquellos pobres lugares de Barajas y Nava Redonda, vimos una mañana que salía un viejo con unos bueyes y tras ellos una moza de quince años, con una sayuela parda corta y un calzado recio, un sayuelo alto azul, como de hombre, el gesto hermoso, de tan buenas faiciones, que si alguna de la ciudad la tomara entre manos, con muy poco blanco fuera hermosísima. Los cabellos llevaba cortados por los hombros, haciendo una coleta de tan rubios cabellos que espantó a los que la vimos. Su denuedo y aire era pastoril, y tan zahareña, que al igual de las vacas que llevaba, se apartó de la vista de los que tanto la miraban. Allí se nos representó la pastora Silvia, las Ninfas, la Enone de Paris, y no faltó quien quisiera hacer aquella media legua una jornada de muchos días. Pero la honestidad de la pastora abatió los pensamientos. Ésta era muy galana, muy hermosa y muy preciada doncella, cual dicen allá que agradó al marqués de Saluces en las tierras del Piamonte, que fué la casta Griseldis. Así las ejercitaba Licurgo, así Platón en sus Repúblicas.

»Estas muy pocas veces saben qué es adulterio, $\mathrm{y}$ en tales aldeas donde estas mujeres viven, parecen las muy compuestas ser malas mujeres. Y así huyen de ellas como de una víbora, y sienten mal de la que comienza a pararse galana. Cierto esta es edad de oro, la que se vive en tales lugares, si ya no están estragadaos; y de aquí se va con facilidad 
al cielo» ${ }^{1}$. Y a continuación refiere una anécdota de Plinio, «aquel gran inquiridor de los secretos de la naturaleza».

Se ve aquí cómo la literatura y los prejuicios ideales valoran ingenuamente las percepciones: pocos trozos hay más instructivos que el anterior para conocer la organización mental de un español versado en humanidades hacia mediado del siglo xvi. Asistimos, al despliegue de los temas de la Edad de Oro y de lo pastoril, como derivaciones de concretas ideas sobre la naturaleza; y análogo proceso se cumple en la mente de Cervantes.

No tengo para qué detallar la forma en que lo pastoril ocurre en la obra cervantina, por ser ello de sobra conocido. Fuera de la Galatea, hallamos en el Quijote una fingida Arcadia (II, 58) y un proyecto de vida bucólica para el héroe maltraído. Sin duda ofrecería interés un análisis minucioso de la influencia de las anteriores pastorales en Cervantes; mas es ese un estudio que ahora no puedo llevar a cabo ${ }^{2}$. Antes (pág. I 50) vimos con qué finura hacía Cervantes observaciones respecto de la Diana de Montemayor, y sobre todo, cómo lo pastoril era elemento esencial dentro de su mundo poético (págs. 37-38). En resolución, lo pastoril, ideológica y estéticamente, es un tema esencial en Cervantes.

Pero es importante recordar, antes de alejarnos de este tema, que Cervantes tampoco se sitúa ante él con el estado de ánimo de un quiñentista. Antes analizamos con detenimiento (pág. 37) la reducción irónica a que sometió la poética realidad de lo pastoril.

REFRANES

Cervantes introduce en sus obras muchos refranes y habla de ellos. Ya notó E. Chasles ${ }^{3}$ que nuestro autor «ha leído

1 Edic. 1568 , fol. 16 1 v.

Datos útiles y bibliografía en H. A. Rennert, The Spanish Pastoral Romances, págs, 116-125.

3 Cervantes, 1866, pág. 34 . los adagios de Erasmo, los refranes españoles y las pasquinadas italianas». Menéndez Pelayo observa que «la sabiduría popular hace del libro inmortal uno de los mayores monumentos folklóricos, algo así como el resumen de aquella filosofía vulgar que enaltecieron Erasmo y Juan de Mal Lara» ${ }^{1}$; y toca el asunto nuevamente hablando de Mal Lara «Mal Lara había pasado su vida enseñando las letras clásicas. ¿Quién se atreverá a decir que le apartasen de la estimación y comprensión de la ciencia popular, en que tanto se adelantó a su tiempo? Al contrario, de los antiguos aprendió el valor moral e histórico de los proverbios o paremias. El mismo fenómeno observamos en otros grandes humanistas, en Erasmo ante todo, que abrió por primera vez esta riquísima vena, y con ella renovó el estudio de la antigüedad; en el comendador Hernán Núñez, infatigable colector de nuestros refranes, y en Rodrigo Caro, ilustrador de los juegos de los muchachos» ${ }^{2}$.

Se nota así el hecho conocido de que Erasmo cultivó los refranes, y con él otros humanistas; que Mal Lara comprendía la ciencia popular encerrada en los proverbios; que el Quijote es un monumento folklórico. Todo ello es evidente, pero algo externo, si al mismo tiempo no indicamos el sentido de ese culto por los refranes.

El refrán nos lleva al centro de la ideología renacentista. No sin misterio es aquella época la de las grandes colecciones de proverbios, y es, en verdad, muy significativo que varones tan doctos como Hernán Núñez, Mal Lara y otros se dediquen a reunir refranes. La clave de ello nos la da Erasmo, base, con sus Adagia, de los grandes refraneros.

El humanismo concibe al hombre independientemente de tiempos y lugares, y lo provee de un sentido justo y razonable que la naturaleza puso en él. La verdad, la moralidad y la justicia, según Erasmo, no necesitaron del cristianismo para existir. Leemos en los prolegómenos a los Adagia

1 Cultura literaria, pág. II.

2 Origenes de la Novela, II, xL. 
que el adagio «satius esse injuriam admittere, quam injuriam inferre» expresa lo que Platón ha tratado de decir en varios lugares, y comenta: "Quod autem unquam dogma proditum est a philosophis... vel Christiana religione vicinius?» La doctrina moral inmanente en los proverbios es tan alta, que hace exclamar a Erasmo: "Quid aliud egit princeps nostrae religionis Christus?» ${ }^{1}$. El refrán es la expresión del fondo de verdad, eterno y universal, que la naturaleza buena puso en el hombre. Lo popular adquiere así un sentido nuevo merced al racionalismo humanista. Prosigue Erasmo: «Inest in his parœmiis nativa quaedam et genuina vis veritatis. Alioquin qui fieri potuit ut eandem plerumque sententiam in centum dimanasse populos, in centum videamus transfusam linguas: quae ne tot quidem saeculis, quibus nec pyramides obstiterunt, vel interierit, vel consenuerit?» ${ }^{2}$ :

Nos hallamos, pues, donde antes: en el reino de la espontaneidad, de la virtud natural. En la Edad de Oro, en la vida rústica y pastoril, se buscaba la pureza de las costumbres naturales; en el refrán se busca la expresión de la sabiduría inmanente, por modo místico, en el ser humano.

Esta doctrina erasmista fué difundida en España por Mal Lara en su Filosofía vulgar (I568), que paso a paso sigue los Adagia $^{3}$. He aquí cómo se da a los refranes valor natural "¿Qué más verisímil argumento que el que por tantos años han aprobado tantas naciones, tantos pueblos... y de los que todos en común, hasta los que en los campos apacientan las ovejas, saben...? De tal manera que estoy por decir que los refranes significan, en cierta manera, naturalmente» 4 Y continúa parafraseando a Erasmo: «Es grande maravilla

1 Adagiorum Erasmi... Chiliades, Parisiis, 1579, col. 5. (La primer edición es de 1500 .

2 Ibid., col. 6.

3 *No hay cosa que en estos refranes yo ponga que no la vea en sus originales griegos y latinos», fol. 109 $r$. No insisto aquí en ello por tratar en otra parte de Fuan de Mal Lara y su "Filosofia vulgar (véase Homenaje a Menéndez Pidal, tomo III).

4 Filos. vulg., edic. 1568 , preámbulo 9. que se acaben los superbos edificios, las populosas ciudades, las bárbaras pirámides, los más poderosos reinos, y que la filosofía vulgar siempre tenga su reino dividido en todas las provincias del mundo... El refrán corre por todo el mundo de boca en boca, según moneda... Los refranes aprovechan para el ornato de nuestra lengua y escritura. Son como piedras preciosas salteadas por las ropas de gran precio, y la disposición da a los oyentes gran contento; y como son de notar, quédanse en la memoria» ${ }^{1}$. Los refranes son anteriores a la civilización: «España había menester en los tiempos pasados este trato honestísimo de la labor del campo; fué apurando las verdades en ella de tal manera, que las dejó todas escritas en el libro natural con grande copia de refranes. Habemos de entender que antes que hubiese filósofos en Grecia, tenía España fundada la antigüedad de sus refranes» ${ }^{2}$. El humanismo erasmista pierde sus filos al pasar a Mal Lara, pero encontramos el eco de su pensamiento cuando el folklorista sevillano, a propósito de los refranes religiosos, dice que «por ellos se verá cuán bien sintieron los antiguos de Dios» ${ }^{3}$. La razón ${ }^{4}$ es más antigua que Platón, "y como ésta está en los ánimos de los hombres, señala lo que es justo, aunque sea por boca de un aldeano». $Y$ he aquí cómo mediante el humanismo se alcanzan nociones de justicia y de moral, naturales y espontáneas: "Aun de los niños de nuestra lengua podemos aprender doctrina grande sin ser filosofos» ${ }^{5}$.

De esta suerte se llega a la dignificación de lo popular en una época que desprecia soberanamente al vulgo, como incapaz de juicio y razonar propio. El Renacimiento rinde culto a lo popular, como objeto de reflexión, pero lo desde-

1 Ibid., preámbulo 9.

Ibid., preámbulo 8.

3 Ibid. Comp.: «Los refranes, a los cuales, no sin causa, agudamente el portugués llama evangelios pequeños» (Pinciano, Filosofía antigua poética, edic. 1893 , pág. 27 ).

4 Cent. VII, refr, II, fol, $86 v$

5 Fol. $42 r$. 
como sujeto operante. De todos modos, en España, por el sesgo especial de nuestra historia, el humanismo pone fuerte acento en esta rehabilitación del espíritu vulgar: «Habiendo estos refranes nacido de todas maneras de gentes, hay algunos que se pueden decir de la hez del pueblo, y de lo más bajo. Que dado que se trate de filosofía moral, la tra$\tan$ en comparaciones bajas, de aquellas digo que ellos saben y traen entre manos; y aun esto no lleva mucha sinrazón, porque así introduce Platón a Sócrates; traer comparaciones bajas y razones groseras que se pueden palpar» 1

Con tales ideas previas debemos considerar lo que Cervantes dice de los refranes, $y$, sobre todo, el hecho de que los proverbios sean elemento de tal importancia en su obra. Por bajo de su función literaria, de los efectos múltiples y oportunos que desempeñan en el estilo cervantino, hay que considerar lo que el autor piensa sobre esas «sentencias breves, sacadas de la experiencia y especulación de nues tros antiguos sabios» ${ }^{2}$. Traduciendo a Erasmo había dicho Mal Lara: «Es, pues, el refrán, según dice Sinesio, una razón que tiene dignidad, que sacada de los misterios de 1 filosofía, representa cuanto sabía la antiguiedad» ${ }^{3}$. En otros lugares dirá Cervantes que todos los refranes son «sentencias breves sacadas de la luenga y discreta experiencia» (I, 39), $\mathrm{y}$ «sentencias sacadas de la mesma experiencia, madre de las ciencias todas» (I, 2I). Mal Lara había dicho: «Grande fué el saber de los antiguos que en todas las cosas enseñan cuanto fué el valor de su experiencia, y como de ella sacamos ciencia» ${ }^{4}$. Dirá Don Quijote: «Paréceme, Sancho, que no hay refrán que no sea verdadero» (I, 2I), y Mal Lara dice también : "No hay refrán que no sea verdadero" ${ }^{5}$. Critica Don Quijote, como es conocido, el abuso que Sancho hace de los refranes: «Muchas veces los traes tan por los cabellos, que

1 Fol. $66 r$.

II, $67 ;$ RM, VI, 344 .

3 Filosof. vulg., preámbulos.

4 Ibid., fol. $128 r$.

5 Ibid., preámbulos. más parecen disparates que sentencias...; y cargar y ensartar refranes a trochemoche hace la plática desmayada y baja» ${ }^{1}$. Igualmente había precavido Mal Lara contra tal exceso: «S toda nuestra habla y escritura es toda de refranes, pierde su gracia con la demasiada lumbre... Téngase juicio en esto porque darán en cara los muchos refranes» ${ }^{2}$.

En resolución, los refranes están en Cervantes como un tema legado por el humanismo, en relación con los que venimos examinando, e igualmente influído por un concepto básico sobre la naturaleza. La conexión con Mal Lara, eco de Erasmo, subraya el sentido con que aquí aparece esa manifestación de la natural sabiduría de los pueblos. Dése hoy el valor que se quiera a los refranes, es lo cierto que su significación en Cervantes ha de percibirse históricamente y a la luz de las características generales de su pensamiento, ya bastante claras para nosotros. Los proverbios no aparecen aquí amontonados como en los refraneros, ni artificiosamente engarzados como en La Dorotea, de Lope de Vega, sino que surgen como emanación espontánea del espíritu de Sancho. Frente a ese tema, Don Quijote se hará portavoz de la crítica : «̨Dónde los hallas, ignorante, o cómo los aplicas mentecato, que para decir yo uno y aplicarle bien, sudo y trabajo como si cavase?» (II, 43).

LA LENGUA VULGAR

El Renacimiento dignifica el refrán por ser expresión de la natural y mística sabiduría ínsita en la conciencia; avalora los romances que canta el vulgo por tradición, que se reunen en colecciones poéticamente tituladas (Primavera, Rosa gentil, etc.), y en los que se vería quién sabe qué místicos ecos de la belleza natural; en fin, el Renacimiento ha de dignificar la lengua hablada, la vulgar y usadera, considerándola como el más inmediato instrumento de expresión, en

\footnotetext{
1 II, $43 ;$ RM, V, $363-364$
}

2 Filosof. vulg., fol. bii 
contacto directo con ese fondo misterioso de lo humano, fuente del espíritu. El principio metafísico se aliaba con el estímulo vital, que iba afanosamente tras de cuanto era vida y energía; el lenguaje hablado fué en seguida objeto de amor para los más egregios entre los renacentistas. Además, la conciencia nacional buscó un punto de apoyo en las hablas locales, frente al latín, abstractamente internacional.

Cervantes se ha ocupado en varias ocasiones de la lengua vulgar, en forma no desprovista de interés. Conoce, por supuesto, las polémicas entre latinistas y romancistas, y toma partido a favor de los últimos. En el Coloquio dice Cipión «que hay algunos que no les excusa el ser latinos de ser asnos». A lo que asiente Berganza, "pues cuando en tiempos de los romanos hablaban todos latín, como lengua materna suya, algún majadero había entre ellos, a quien no excusaría el hablar latín dejar de ser necio» ${ }^{1}$. El tema se funde aquí con la crítica de la afectación y la pedantería, pero en el Quijote lo hallamos expuesto con serena claridad: $" Y$ a lo que decís, señor, que vuestro hijo no estima mucho la poesía de romance, doime a entender que no anda muy acertado en ello, y la razón es esta: el grande Homero no escribió en latín, porque era griego, ni Virgilio no escribió en griego, porque era latino. En resolución, todos los poetas antiguos escribieron en la lengua que mamaron en la leche, y no fueron a buscar las extranjeras para declarar la alteza de sus conceptos; y siendo esto así, razón sería se extendiese esta costumbre por todas las naciones, y que no se desestimase el poeta alemán porque escribe en su lengua, ni el castellano, ni aun el vizcaíno que escribe en la suya» ${ }^{2}$.

Clemencín glosó este pasaje citando a algunos de los que antes de Cervantes defendieron el uso del romance ${ }^{3}$. Conviene, empero, aplicar a la cuestión el método que hemos

1 Edic. Clás. Cast., pág. 250.

2 II, 16; RM, IV, 328.

3 Hay un artículo, bibliográficamente valioso, de M. Gutiérrez, sobre la defensa de la lengua vulgar frente a la latina en el siglo xvi, en La ciudal de Dios, $1912, \mathrm{XC}, 428$ y sigs. usado en los demás casos. La fuente inmediata de Cervantes debe ser el prólogo al libro III de los Nombres de Cristo; allí trae Luis de León la frase: «Su lengua materna griega, que, cuando ellos vivían, la mamaban con la leche los niños.» Antes lo había dicho Juan de Valdés en el Diálogo de la lengua, cuyo manuscrito no creo conocieran León ni Cervantes: «Todos los hombres somos más obligados a ilustrar y enriquecer la lengua que nos es natural y que mamamos en las tetas de nuestras madres, que no la que nos es pegadiza y que aprendemos en libros» ${ }^{1}$. La idea se halla también en Bembo, Della volgar lingua ${ }^{2}$ ( 1525 ): «Si come a Romani huomini era ne buoni tempi più vicina la latina favella che la greca, conciosiache nella latina essi tutti nascevano et quella insieme col latte dalle nutrici loro beeano et in essa dimoravano tutti gli anni loro comunemente» ${ }^{3}$.

Erasmo, que nunca escribió en vulgar, expresa su entusiasmo por el habla popular, aunque refiriéndose a la antigüedad. En el comentario a su adagio «Sileni Alcibiadis» dice de Sócrates: «Su habla era sencilla, popular y ratera, como de aquel que siempre traía en la boca estos vocablos carreteros, carpinteros, zapateros, porque a éstos y con éstos hacía él aquellas sus pláticas, que llamaba introducciones» ${ }^{4}$. El erasmista Cristóbal de Villalón defiende así la lengua vulgar en El Escolástico: «No es escripta la presente obra en latín, sino en nuestra castellana lengua, porque más fácilmente dice el hombre lo que quiere en su propia lengua que en la peregrina...; aliende que 1 a lengua que Dios y naturaleza nos ha dado, no nos debe ser menos apacible que la latina, griega y hebrea ${ }^{5}$. Como en el pasaje antes citado de Valdés,

1 Edic. Böhmer, pág. 342 .

Citado por Valdés: «̨Pareceos a vos que el Bembo perdió su tiempo en el libro que hizo sobre la lengua toscana?», pág. 342 .

3 Prose, Firenze, 1548 , pág. 7.

Silenos de Alcibiades, Amberes, ${ }^{1555}$, fol. $3 v$. La primera edición de la traducción española es de 1529 ; el ejemplar que poseía aún en 1916 nuestra Biblioteca Nacional, ha desaparecido.

5 Edic. Bibliófilos Madrileños, pág. I6. 
se ve claramente que la rehabilitación del lenguaje vulgar va unido a la ideología naturalista del siglo. El cultivo de la gramática castellana se da a menudo entre erasmistas; el caso de Juan de Valdés es clásico; Juan Martín Cordero, traductor de Erasmo ${ }^{1}$, compuso La manera de escrevir en castellano ${ }^{2}$; Cristóbal de Villalón es autor de una Gramática castellana (I558) ${ }^{3}$. Y en cuyo proemio dice: «Estamos en edad... que se precisa en todas las naciones muy sabios varones escrebir en sus lenguas muy vulgares»; y, en efecto, hombres muy sabios, como Pedro Simón Abril, propugnan la enseñanza en vulgar y no en lengua extraña, "porque en los tiempos antiguos no hubo nación tan bárbara que tal hiciese..., sino que enseñaron los caldeos en caldeo y los hebreos en hebreo, y lo mismo hicieron las demás naciones..., de donde resultaba que los díscípulos entendían a sus maestros con gran facilidad» ${ }^{4}$. Con la corriente erasmista podría relacionarse también la actividad gramatical de Francisco Thámara, traductor de los Apotegmas de Erasmo ${ }^{5}$; de Alejo Vanegas, autor de una curiosa Ortografía, y que en I 537 publicó en romance libro de asunto tan grave como la Agonía del tránsito de la muerte; añadióle como epílogo una declaración de las sentencias y vocablos oscuros, en la que dice: «Este vicio de menospreciar la propia lengua se extendió tanto cuasi por todo el mundo, que hasta hoy queda arraigado en la opinión de muchos vulgares; mas los prudentes que miran la cosa de dentro, hablan ser verdad lo que escribió el mismo Marco

1 Véase Bonilla, Revue Hispanique, 1907, XVII, pág. 502.

2 Fols. 107 a 127 del volumen en que se halla la traducción de Erasmo, Las quexas y llanto de Pompeyo, Amberes, ${ }_{15} 56$.

3 LA VIÑaZA, Bibliografía histórica de la Filologia castellana, col. 48 r. 4 Thuntamientos de cimo se deben reformar las doctrinas, Rivad. LXV, 293. Simón Abril escribió una Gramática, hoy perdida.

5 Cuando se haga la historia del erasmismo español, mediante ideas claras y metódicas, habrá que tener en cuenta cómo confluyen en sus representantes más característicos diversos puntos de vista acerca de lo humano, de la concepción del hombre y de la vida. Fran cisco Thámara tradujo El libro de las costumbres de todas las gentes [de Boëmus y Giglio], Amberes, 1556 .
Tulio, que debajo de capa vieja, muchas veces habita la sapiencia. Es lo mismo que dice el refrán: «Debajo del sayal, hay al.»

Podrían añadirse aún los nombres de Vergara, Palmireno $\mathrm{y}$ otros erasmistas, pero un estudio cabal de este punto incumbe a quien escriba la historia de la filología española en el siglo $\mathrm{Xvi}^{1}$. Comienza ésta propiamente con Nebrija, como claro producto del Renacimiento - una de cuyas facetas era la exaltación de la gloria nacional $-{ }^{2}$, y sigue prosperando al calor del humanismo (en el sentido que damos a esta palabra), uno de cuyos esenciales factores es Erasmo ${ }^{3}$.

Tornando a Cervantes, notaremos que su pensamiento acerca del lenguaje no se limita a reconocer la conveniencia y legitimidad del uso del vulgar: "Los poetas antiguos escribieron en la lengua que mamaron en la leche» Por ese camino del ingenuo naturalismo se dignifica por igual toda for-

1 He aquí cómo se expresa el erasmista Pedro Mejía: «Pues la lengua castellana no tiene, si bien se considera, por qué reconozca ventaja a otra ninguna, no sé por qué no osaremos en ella tomar las invencion a fortianos y otras naciones lo hacen en las suyas, pues no faltan en España agudos y altos ingenios. Por lo cual yo, preciándome tanto de la lengua que aprendi de mis padres como de la que me mostraran preceptores, quise dar estas vigilias a los que no entienden los libros latinos» (Silva de varia lección, Lyon, 1556, Prólogo).

2 Confróntese:

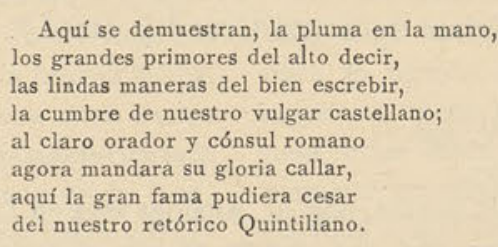
(Coplas de Alonso de Proaza, puestas al final de Las Sergas de Esplandiän del regi-
dor Montalvo, 15 10; M. PEraxo, Origenes de la Novela, III, VII-VIII.)

3 Para Nebrija véase mi libro Lengua, enseñansa y literatura, 1924, págs. $144-145$. Debería estudiarse la formación espiritual de Nebrija en el ambiente italiano y en relación con León Bautista Alberti († 1472), que escribe en vulgar el diálogo Teogenio, con ofensa, según algunos, de la "maestà letteraria» que exigía tratar "materia si eloquente in lingua latina» (Rossi, Il Quatrocento, pág. 93). 
ma de expresión vulgar por el hecho de serlo, y Cervantes sabe que por ahí se va a la negación de la cultura y del arte literario. Por eso proyecta sobre el idioma no sólo la idea de naturaleza, sino también la de arte en este pasaje admirable: «El lenguaje puro, el propio, el elegante y claro está en los discretos cortesanos, aunque hayan nacido en Majalahonda; dije discretos porque hay muchos que no lo son, y la discreción es la gramática del buen lenguaje, que se acompaña con el uso» ${ }^{1}$. Es decir, el lenguaje natural ha de ser refinado por la cultura y las buenas maneras, idea que el Renacimiento concibe, y que es la nuestra en la actualidad. Sancho dice: "Pues sabe que no me he criado en la corte, ni he estudiado en Salamanca para saber si añado o quito alguna letra a mis vocablos..., no hay para qué obligar al sayagués a que hable como el toledano, y toledanos puede haber que no las corten en el aire en esto del hablar polido» ${ }^{2}$. De suerte que, en principio, el toledano es para el autor un habla modelo. En esto seguía la opinión formada en torno a la capitalidad imperial de Toledo. Dice en el Viaje del Parnaso:

\section{En propio toledano y buen romance,}

les dió los buenos días cortésmente ${ }^{3}$.

La misma idea se halla en Juan de Valdés: "Como a hombre criado en el reino de Toledo y en la corte de España, os preguntaremos de la lengua que se usa en la corte» ${ }^{4}$; también en Melchor de Santa Cruz ${ }^{5}$ y otros ${ }^{6}$.

1 II, 19; RM, IV, 390

2 Ibíd., pág. 387.

3 Edic. Schevill-Bonilla, pág. or. Análoga idea en La ilustre fregona.

4 Edic. Böhmer, pág. 355, donde se cita el proemio del Amadís, Venecia, 1533: ‘Hijo es más elegante por ser toledano, y fijo está bien por ser sacado del latín.*

5 Menéndez Pelayo, Origenes de la Novela, II, Lxvi.

No ha sido citado un pasaje interesante de G. Fernández DE Ovikdo, Quincuagenas, pág. 510: «Que el intérprete de la lengua castellana sea de Toledo. porque allí es donde se habla mejor nuestra lengun $\mathrm{E}$ dole mejor que Toledo se habla es la casa real de los reyes, nuestro señores, así porque allí acuden todos los principales

Ahora bien: por encima del toledano y del hablar cortesano, Cervantes coloca la discreción, la cual falta a veces a los cortesanos, del mismo modo que hay toledanos que no son modelo de hablar pulido. Rasgo de fina crítica, de análisis racional, que nos lleva a otros campos ya familiares para nosotros del pensamiento cervantino. La fuente inmediata me parece que será también ahora el citado Prólogo de los Nombres de Cristo: "Piensan que hablar romance es hablar como se habla en el vulgo, y no conocen que el bien hablar no es común, sino negocio de particular juicio, así en lo que se dice como en la manera como se dice.» Tal doctrina viene señalada por Ambrosio de Morales, que censura a los que exigen cuidado y esmero sólo en el uso de las lenguas sabias: «Yerran mucho sin duda... Tomemos sólo una parte, y no de las más principales, de un lenguaje, que es la propiedad de los vocablos: ¿cómo es posible que sola naturaleza con el uso la enseñe?... Según esto, no habría diferencia entre un hombre criado desde su niñez entre rústicos, y otro que se crió en una gran ciudad o en la corte... Muy diferentes cosas son en el castellano, como en cualquier otro lenguaje, hablar bien y hablar con afectación, y en todos el hablar bien es diferente del común.» La analogía sigue aún más estrecha entre ambos autores:

AMBROSIO DE MORALES

«Tulio... hace que sea muy diferente su habla, no en los vocablos y propiedades de la lengua latina, que todos son unos, sino en saberlos escoger y juntarlos con más gracia en el orden y en la com. posición... en la melodía y dulZura con que suenan las palabras mezclad
rezas 1.

e bien criados señores, e gente noble, como porque allí es la escuela e toque de la buena crianza.s

1 Prólogo al Diálogo de la dignidad del hombre, de H. Pérez de Oliva, Rivad., LXV, $38 \mathrm{r}-382$.
LUIS DE LEÓN

De las palabras que todos ha lan elige las que convienen, $y$ mira el sonido de ellas, y aun cuenta a veces las letras, y la pesa y las mide y las compone, para que no solamente digan con claridad lo que se pretende decir, sino también con armonía dulzura, 
Mucho antes que por los autores mencionados había sido dicha la misma cosa por Castiglione, cuyo libro era lectura obligada para todos los cultos de la época. Júzguese: «Lo que más importa y es más necesario al cortesano para hablar y escribir bien, es saber mucho... Tras esto cumple asentar con buena orden lo que se dice o se escribe, después esprimillo distintamente con palabras que sean propias, escogidas, llenas, bien compuestas, y sobre todo usadas hasta de vulgo, por que éstas son las que hacen la grandeza y la majestad del hablar, si quien habla tiene buen juicio y diligencia, y sabe tomar aquellas que más propiamente esprimen la significación de lo que se ha de decir, y es diestro en levantallas, y dándoles a su placer forma como a cera 1

Castiglione escribe para Italia, país políticamente dividido, y no tiene tan fuerte idea de la unidad de la lengua ${ }^{2}$ como los españoles, que poseen un centro cortesano a que referirse; de ahí que aquél acentúe mucho la importancia del elemento psicológico, de cultura individual, para regular el so idiomático: "La buena costumbre de hablar... nace de los hombres de ingenio, los cuales con la dotrina y esperiencia han alcanzado a tener buen juicio, y con él concurren y consienten todos a una mano en acetar los vocablos que les parecen buenos, los cuales se conocen por una cierta estimativa natural, no por arte o regla alguna» ${ }^{3}$. No viendo clara una norma objetiva de autoridad, Castiglione se refugia en un criterio naturalista, algo vago y rústico, apoyado en psicología y estética.

Así se entendía en el siglo xvr la cuestión del bien hablar, más como asunto de razón que de instinto, una vez sentado

Edic. cit., pág. 88. Castiglione parafraseó muy libremente la Epist. ad Pis. de Horacio, en lo que atañe a la exigencia de saber: eScribendi recte sapere est et principium et fonss $(v, 309)$. Véase edición del Cortegiano, por Cian, $1910, \mathrm{p}$ g. 80 . En aconej voces de la lengua bablada, Castigione discrepa del Benbo Castion comendaba la imitación de los autores (Ciav, Ibid).

2 Págs. 90-91.

8 Pág. 93. el principio de que la lengua materna ha de usarse por motivos naturales. Cervantes dirá que no importa haber nacido en Majadahonda para hablar bien; en I 556 decía el erasmista valenciano Juan Martín Cordero, acerca del castellano: "Aunque sea yo muy aficionado a esta lengua, todavía no me es natural... No debe darse alguno a entender, que por no ser uno de Castilla, no pueda saber la manera de escrebir mejor que muchos que lo son» ${ }^{1}$.

En fin, notemos que Cervantes se interesa por cuestiones de lenguaje de índole más concreta. No era él partidario del angostamiento e inmovilidad del idioma. En el prólogo de la Galatea atribuye al poeta la facultad de enriquecer «su propia lengua... y abrir camino para que, a su imitación, los ánimos estrechos que en la brevedad del lenguaje antiguo quieren que se acabe la abundancia de la lengua castellana, entiendan que tienen campo abierto, fértil y espacioso.» En el Coloquio censura «el error que tuvo el que dijo que no era torpedad ni vicio nombrar las cosas por sus propios nombres, como si no fuese mejor, ya que sea forzoso nombrarlas, decirlas por circunloquios y rodeos que templen la asquerosidad que causa el oírlas por sus mismos nombres» ${ }^{2}$. Hay algunas observaciones lexicográficas en el Quijote: «La gente curiosa se ha acogido al latín, y al regoldar dice erutar, y a los regüeldos, erutaciones; y cuando algunos no entienden estos términos, importa poco; que el uso los irá introduciendo con el tiempo, que con facilidad se entiendan; y esto es enriquecer la lengua, sobre quien tiene poder el vulgo y el uso» ${ }^{3}$.

1 La manera de escrevir en castellano, Amberes, 1556 , págs. 107 y 111 . 2 A. G. Amezúa, en su erudita edición (pág. 507), trae un pasaje del Galateo (1601), de Gracián Dantisco, muy parecido: «Se pueden decir por rodeos y términos limpios y honestos sin nombrar clara ${ }^{-}$ mente cosas semejantes.

${ }_{3}$ II, $43 ;$ RM, V, ${ }_{362}$. En II, 67, Don Quijote se interesa por las palabras de or i mujer dige de aprender la lengua castellana (vénse edic Schevillni mujer deja de aprender la lengua castellana (vén Bonilla, II, 3 I I y nota): un eco de las antiguas alusiones al imperialismo del idioma 
Se alude aquí a la conocida doctrina de Horacio, y se da un toque nuevamente al aspecto popular y espontáneo del idioma.

LA JUSTICIA

La noción de justicia se relaciona asimismo con el concepto de la natural virtud del hombre.

Montaigne había escrito: «La justice en soi, naturelle et universelle, est autrement reglée, et plus noblement, que n'est cette autre justice spéciale, nationale, contrainte au besoin de nos polices... Pour autoriser et seconder [les lois], la vraie vertu a beaucoup à se demettre de sa vigueur originale» (III, I). Pierre Charron, en De la Sagesse (I60I) considera igualmente la justicia como virtud natural ${ }^{1}$, lo que es muy razonable deducción dado el concepto humanista del hombre y la naturaleza. Mal Lara (I568) nos hablaba antes (pág. I83) de «los niños, guiados de la razón natural y bondad que tienen fresca en su nueva alma». El orden y la jerarquía sociales son asimismo frutos instintivos: «Nació con el hombre, como dice Tulio en los Officios, lib. I, un deseo de ser el principal; y que el ánimo, bien instruído de la misma naturaleza, no quiere obedecer si no es a persona que lo merece» ${ }^{2}$.

Cervantes se complace en oponer la justicia espontánea, sencilla, equitativa, en suma, místicamente natural, a la legal y estatuída; no se formula dogmáticamente esa doctrina en ninguna parte, pero los hechos la presuponen con la mayor elocuencia. Roque Guinart, el bandolero, se opone con su legalidad propia a la ley oficial; reparte el dinero a su compañía "con tanta legalidad y prudencia, que no pasó un punto ni defraudó nada de la justicia distributiva» ${ }^{3}$. De sí mismo

1 Véase SABRIÉ, De l'humanisme au rationalisme. P. Charron, 1913, págs. 326 y sigs.

2 Filosofia vulgar, 1568 , fol. $17 v$. Véase la cita hecha al hablar de la Edad de Oro, pág. I 79.

3 II, 6o; RM, VI, 225. dice: «Yo, de mi natural, soy compasivo y bien intencionado»; pertrechos morales que le sirven para ordenar la trascendental equidad de su existencia. Roque Guinart penetra en el Quijote envuelto en ese tema de la justicia supralegal ${ }^{1}$, $y$ en el de la aventura por la aventura ${ }^{2}$.

Sentido análogo nos brindan las maravillosas sentencias de Sancho como gobernador de la ínsula. No hay que insistir en su análisis, por estar aquéllas en la memoria de todos. La demostración de que nos encontramos realmente en zona preparada por el humanismo, la hallamos en el elogio de la sencilla justicia de los musulmanes, poetizada por Cervantes, de la misma suerte que Mal Lara o Gómara idealizan las costumbres de los indios americanos, por más próximos a lo natural. Demostración esto a su vez de que el humanismo renacentista parte de sí mismo, y busca materia que alimente su especial ideología en la antiguiedad, en los salvajes, en los moros, o en cualquier otra zona de lo humano. Es célebre el pasaje de El Amante liberal ${ }^{3}$ : «Las más [de las causas] despachó el cadí, sin dar traslado a las partes, sin auto, demandas ni respuestas, que todas las causas, si no son las matrimoniales, se despachan en pie, y en un punto, más a juicio de buen varón que por ley alguna. Y entrẻ aquellos bárbaros si lo son en esto, el cadí es el juez competente de todas las causas.»

En el Quijote vuelve a hallarse el mismo elogio: «Entre moros no hay traslado a la parte, ni «a prueba estése», como entre nosotros» ${ }^{4}$. Y que lo importante aquí es el pensamiento del autor, resulta de que también se alaba una justicia simple y $\sin$ fórmulas de la reina de Inglaterra: «Sin acuerdo de letrados, y sin poner a su camarera en tela de juicio, la con-

1 \&Es tan buena la justicia, que es necesario que se use aun entre los mismos ladrones» (Ibid., pág. 226).

2 «Aquí amanecían; acullá comían; unas veces huían, sin saber de quién, y otras esperaban, sin saber a quién» (Ibid., pág. 234).

3 Edic Schevill-Bonilla, pág. 150 .

II, 26; RM, V, 57. Véase el comentario de Clemencín, Bibl. Clás., VI, 169 . 
denó en que no sirviese más su oficio, y en 10.000 escudos de oro para Isabela» ${ }^{1}$.

Así creo que se suprime la sorpresa que causaba a MorelFatio este elogio de la justicia musulmana: «No es chocante que este enemigo de los infieles se vea obligado a reconocer noblemente la superioridad de ciertas instituciones de los adeptos de Mahoma?» Y pensaba el ilustre hispanista que esto "habría debido servir para amortiguar un tanto su feroz falta de tolerancia " ${ }^{2}$. Actitud completamente inadecuada al caso, y en la que resalta el error metódico de interpretar la obra cervantina como una ecuación con la realidad que le cercaba, y no como una proyección de la manera de ver el mundo que poseía el autor. De nada sirvió que Clemencín señalara ya los conocidos versos de Juan de Mena (que él atribuye a Fr. Juan Martínez de Burgos):

\section{En tierra de moros un solo alcalde} libra lo cevil e lo criminal... ${ }^{3}$,

lo cual señalaba el carácter de tema literario en tal elogio; la rutina positivista, satisfecha con el hecho material y desgranado, fué incapaz de ver que lo esencial era aquí el molde cervantino de la justicia, al que se ajustaban los moros, la reina de Inglaterra, Sancho, Roque Guinart, etc. Ninguna falta hacía que Cervantes conociera "por vista de ojos el enjuiciamiento de los mahometanos»; tal detalle es en todo caso secundario. Lo que no es secundario es que Cervantes reciba de la tradición renacentista un concepto de justicia que hallamos en Montaigne y otros pensadores del siglo xvI, en estrecha conexión con la doctrina de la moral natural.

1 La española inglesa, edic. Schevill-Bonilla, pág. 52. «Vino Tozuelo cun el parecer de la moza, diéronse las manos los donceles, acabóse el pleito, y pasó el baile adelante; que si con esta brevedad se acabaran todos los pleitos, secas y peladas èstuvieran las solícitas plumas de los escribanos» (Persiles, Rivad., I, 6386).

2 L'Espagne de Don Quichotte, trad. esp., pág. 142.

3 Rodríguez Marín $(\mathrm{V}, 57)$ no ve en esto sino una preferencia por la justicia mora, más pronta que la nuestra, «que zozobra y se pierde en un mar de trámites.
A las alabanzas de la justicia sencilla y razonable corresponde la violenta reprobación de la justicia de la época, lo más opuesto a razón y equidad que pudiera imaginar Cervantes; personalmente, tenía sobre ello experiencia amarga. La tiranía, la despótica barbarie de jueces y alcaldes fortificaba por contraste la idea transmitida por el Renacimiento de una sociedad pura, regida por criterios tan exactos como ingenuos. Aquel conde de Puñonrostro, que en Sevilla anticipaba inhumanos procedimientos de nuestros días, hace decir a Cervantes, a través de un personaje: "Cuántos pobretes están mascando barro no más de por la cólera de un juez absoluto, de un corregidor, o mal informado o bien apasionado! Más ven muchos ojos que dos» ${ }^{1}$. Palabras admirables, de un noble espíritu que sentía afanes análogos a los nuestros en los días aciagos porque España atraviesa.

La justicia de la época está descrita con la mayor severidad: "Coheche v. m., señor tiniente, coheche y tendrá dineros, y no haga usos nuevos, que morirá de hambre» ${ }^{2}$. «Habrá favor tan bueno que llegue a la oreja del juez y del escribano, como estos escudos, si llegan a su bolsa?» ${ }^{3}$. "Que no falt ungüento para untar a todos los ministros de la justicia; porque si no están untados, gruñen más que carretas de bueyes» ${ }^{4}$. «Ricla, la tesorera, que sabía muy poco o nada de la condición de escribanos y procuradores, ofreció a uno... no sé que cantidad de dineros... Lo echó a perder del todo, porque en oliendo los sátrapas de la pluma que tenían lana los peregrinos, quisieron trasquilarlos, como es uso y costumbre, hasta los huesos» ${ }^{5}$.

1 Ilustre fregona, Clás. Cast., pág. 250

2 Gitanilla, Rivad., I, pág. 104

3 Ibid., pág. $106 a$.

4 Ilustre fregona, Clás. Cast., pág. 276.

5 Persiles, Rivad., I, pág. 631 . Véase, además, el verdugo que pega de recio por no estar (Coloquio, Clás. Cast., pág. 303). Ios de recio por no elu

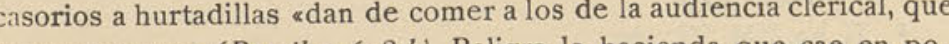


Las sentencias son a veces crueles y desmesuradas: «Me acuerdo haber tenido un amigo, que en una comisión criminal que tuvo, dió una sentencia tan exorbitante, que excedía en muchos quilates a la culpa de los delincuentes...», porque "pensaba otorgar la apelación, y que con esto dejaba el campo abierto a los señores del Consejo para mostrar su misericordia» 1 . Otro caso: "Con atestiguar los demás presos que aquél no era el que pensaban, contando la verdad de todo el caso, pudo tanto la malicia en el pecho de los jueces, que, sin más averiguaciones, le sentenciaron a muerte» ${ }^{2}$. Y Cervantes aspira a un régimen de razón y humanidad: «Los jueces discretos castigan, pero no toman venganza de los delitos; los prudentes y los piadosos mezclan la equidad con la justicia, y entre el rigor y la clemencia dan luz de buen entendimiento» ${ }^{3}$.

Tal cúmulo de razones explican de sobra que Don Quijote dé suelta a los galeotes. Estaba convencido de cuán absurda era la justicia al uso, y hace prevalecer un criterio de moralidad superior, basada en estímulos inmanentes. Ha de compararse con el episodio de los galeotes la tremenda pregunta formulada, en otro lugar de la novela, durante la visita a las galeras surtas en Barcelona: «¿Qué han hecho estos desdichados, que ansí los azotan, y cómo este hombre solo, que anda por aquí silbando, tiene atrevimiento para azotar a tanta gente?» ${ }^{4}$. Sublime e irónica ingenuidad. Comprendemos bien la reacción de simpatía hacia el delincuente, hacia el colocado al margen de la ley: Roque Guinart, galeotes, gitanos, el que se va de la venta sin pagar, etc., etc.

En resolución, Cervantes ha establecido en este caso el

habitual contraste entre un mundo ideal y universal y la concreta realidad que le cercaba; pero por tratarse de asunto tan vitalmente próximo a él, de contornos tan dolorosos, no hallamos el menor intento de sátira, de crítica de la fantasía con que soñaba su alma noble. No hay aquí lugar para el escorzo humorístico como acontecía con la Edad de Oro, lo pastoril, lo caballeresco o la esgrima científica. Cervantes toma la grave posición del moralista. Dice un alcalde en $P e$ dro de Urdemalas (I, I24):

Véala yo en poder de mi enemigo,

vara que es por presentes adquirid

No obstante, la justicia pura, como tantas otras construcciones de la razón o del anhelo, cuando llegamos realmente a asirlas, se nos van de las manos. La justicia encantadora, prometida por el humanismo, queda maltrecha y abollada por la nube de pedradas que los galeotes arrojan sobre su libertador. Hay cosas que no son para este mundo, no obstante no tener sentido sino dentro de este mundo. He ahí la tragedia cervantina.

(Coto la justicia (Ibid., 668 b). Latrocinio en ministros de la justicin (Coloquio, Clás. Cast., págs. 262-268). Crítica de los escriban Justicia cenciado Vidriera, pág. 107).

1 Licenciado Vidriera, pág. Iо1. Otro castigo arbitrariamente bárbaro en Persiles, $643 a$, final.

2 Galatea, edic. cit., 1, 126

Persiles, $463 b$.

4 II, 63; RM, VI, 280. 
rota de livianas ocasiones... Las pendencias del vulgo traen consigo a la misma confusión... Lo que dirá el vulgo casi siempre malintencionado» ${ }^{1}$. «No soy tan frágil que me deje ir con la corriente del vulgo, las más veces engañado» ${ }^{2}$. «La honra... la dejó al vano discurso del vulgo, casi siempre engañado» ${ }^{3}$. En otros lugares se califica al vulgo de «ignorante» ${ }^{4}$, de «bajo y grosero» ${ }^{5}$, de «insolente y libre» ${ }^{6}$. La función de la plebe es meramente la de llenar la tierra: «Del linaje plebeyo no tengo que decir sino que sirve sólo de acrecentar el número de los que viven, sin que merezcan otra fama ni otro elogio sus grandezas»?

El desdén por el vulgo se halla atestiguado en forma razonada en los más característicos escritores del Renacimiento. En la Celestina se dice, traduciendo a Petrarca: «Ninguna cosa es más lejos de verdad que la vulgar opinión ${ }^{8}$. Erasmo, en el Enquiridion: «La verdad es que el juicio común de la gente nunca jamás fué ni es regla muy cierta ni muy derecha para regirse hombre por ella» ${ }^{9}$. En otras obras erasmianas ocurren análogos juicios: «La gente vulgar, ciega y tarda de ingenio, como juzga al revés y torcidamente de las cosas, no tomando dellas sino aquella corteza exterior que se ofrece a los sentidos, cae y desvara a cada paso, se adapta esta otra forma de despotismo de la inteligencia de lo que un día será, en efecto, ilustrado despotismo.

El tema llega a Cervantes, como a otros muchos escritores, en los que no es raro se disuelva en lugar común y anodino. En nuestro autor, por el contrario, considerado el clima ideal e histórico en que florece, no hay motivo para mirar la actitud ante el vulgo como un accidente retórico, sino como consecuencia de precedentes cargados de sentido como los demás que venimos hallando. "[La poesía] no se ha de dejar tratar de los truhanes ni del ignorante vulgo, incapaz de conocer ni estimar los tesoros que en ella se encierran. Y no penséis, señor, que yo llamo aquí vulgo solamente a la gente plebeya y humilde; que todo aquel que no sabe, aunque sea señor y príncipe, puede y debe entrar en número de vulgo» ${ }^{1}$. «El pueblo, el cual por la mayor parte se albo-

\footnotetext{
1 II, I6; RM, IV, 328.
}

1 Persiles, $640 a b, 641 a$.

2 Licenciado Vidriera, edic. Schevill-Bonilla, pág. 107

3 Persiles, 620 a.

4 Viaje del Parnaso, edic. Schevill-Bonilla, pág. I II.

5 Laberinto de amor, II, 302.

6 Rufian dichoso, II, 23.

7 II, 6; RM, IV, I47. Como la incultura es lo que determina al vulgo, cuando aquélla se atenúa, puede menguar su indiscreción; de ahí que diga Cervantes: «Porque es discreto el vulgo de la corte, Aunque le toca la común miserias (Viaje del Parnaso, pág. 103).

8 "Nihil est a virtute vel a veritate remotius quam vulgaris opinios (V. Castro Guisasola, Fuentes literarias de la Celestina, 1924, pág. 124). Séneca había dicho: «Argumentum pessimi, turba est» (De vita beata, II).

9 Edic. Amberes, 1555, fol, rogv. Compárese Revista de Filología Española, 1916, pág. 381. 
recibiendo engaño con falsas imágenes de lo que llaman bienes y con más falsas de lo que llaman males» ${ }^{1}$. En uno de los Coloquios $^{2}$ se explica el apartamiento de los «astrólogos, poetas e otros semejantes" por parecerles "que no podían acabarse en medio del vulgo las cosas grandes y que salen de la medida o capacidad del vulgo». Para León Hebreo los secretos de la naturaleza deben ser conocidos sólo por unos pocos, "porque declarar demasiadamente la verdadera y profunda ciencia es echarla a los inhábiles della, en cuyas mentes ella se corrompe y adultera» ${ }^{3}$. Luis Vives opina que "son dañosas las opiniones del vulgo, que con grandísimo desatino juzgan de las cosas» ${ }^{4}$. Pero Mejía «quiere contradecir esa otra sentencia en que afirmáis que habemos de seguir las comunes opiniones, porque parece que es contra buena filosofía y aun contra las escripturas, pues es cierto que habemos de tener ['opinar'] lo que tienen los sabios» ${ }^{5}$. Y justamente cuando Cervantes escribía, A. Velázquez de Velasco dice en La Lena (I602): «Si bien conozco que el ciego vulgo recibe con más voluntad el mal (por serle como natural) que la utilidad de una sabia providencia ( $\tan$ ajena dél) ${ }^{6}$.

En Italia también ocupó tal opinión las mejores plumas: «Et le voci che '1 vulgo errante stolto $\mathrm{Di}$ peccato e disnor si gravi estima» 7 . Ariosto habla del "sciocco vulgo» ${ }^{8}$, y Giordano Bruno exclama violentamente: "Vi dico che la caggione è l' universitade che mi dispiace, il volgo ch' odio, la moltitudine che non mi contenta» 9 .

1 Silenos de Alcibiades, edic. 1555 , fol. $8 r$.

2 Menéndez Pelayo, Orígenes de la Novela, IV, 174. Para el Elogio de la locura, véase edic. Croce, págs. 72, 8I, 84, 128: ‘Aquella bestia grande y gorda que se llama pueblo» (pág. 39).

3 Edic. Origenes de la Novela, IV, 326.

4 Introducción a la sabiduria, Amberes, $155 \mathrm{I}$, fol. ir

6 Diálogos, Sevilla, ${ }_{5770}$, pág. 163.

6 En Orígenes de la Novela, III, 380.

P. Bzмвo, Rime, edic. Venecia, I573, pág, 147.

8 Orlando, VII, $\mathrm{I}$.

9 Opere italiane, I, 262.
LAS ARMAS Y LAS LETRAS

Pietro Bembo, uno de los interlocutores en El Cortesano, de Castiglione, responde al conde Luis de Canosa: "Yo no sé por qué queréis que este nuestro Cortesano, tiniendo letras y tantas otras buenas calidades, tenga todas estas cosas por ornamento de las armas, y no las armas, con todo lo demás, por ornamento de las letras, las cuales, por sí solas, sin otra compañía, llevan tanta ventaja a las cosas de la guerra, cuanta es la que el alma lleva al cuerpo» ${ }^{1}$. Comentando este pasaje dice Vittorio Cian, el mejor conocedor del Cortegiano: «Esta es una de tantas cuestiones ociosas, que, a partir de la antigüedad y durante el Renacimiento, fueron tratadas y agitadas con un interés y un ardor polémico, que difícilmente logramos explicarnos hoy... La más curiosa prueba de la importancia que el Renacimiento concedía a tal debate, es encontrar un reflejo en el poema novelesco de un poeta caballero y humanista, el Boyardo, en aquel bellísimo coloquio nocturno de los dos adversarios, Orlando y Agricano (Orl. inn., lib. I, cxviII)» ${ }^{2}$.

Cian piensa, por consiguiente, que el Renacimiento concedió enorme importancia a un tema "ocioso», es decir, carente de sentido. ¿Cómo sería posible, sin embargo, que una cuestión meramente verbal, sin trascendencia, hubiese excitado tanta pluma docta a intervenir en la discusión? Hasta ahora vamos observando que tras de cada tema cervantino queda una estela de pensamiento y sensibilidad, y no se ve porqué «las armas y las letras» iban a ser excepción ${ }^{3}$.

1 Lib. I, cap. IX, edic. Libros de antaño, pág. 113.

2 Edic. igro, pág. ir 2. Los versos de Boyardo dicen:

$$
\begin{aligned}
& \text { Rispose Orlando: cIo tiro teco a un segno, } \\
& \text { Che l' armi son de l' lomo 'il primo onore; } \\
& \text { Ma non già che il saper faccia men degno } \\
& \text { Anzi lo adorna com' un prato il fiore.? }
\end{aligned}
$$

3 He aquí una bibliografia de los libros más importantes, además de los textos que citaré:

Flavio Brondo, De litteris et armis comparatio, 1460 (dedicada al duque Borso de Este). 
La Edad Media ofrece precedentes de este debate en las conocidas disputas del clérigo y el caballero ${ }^{1}$, en las cuales se examinan las ventajas de cada una de esas profesiones, principalmente desde el punto de vista femenino: ellas son las que juzgan de las excelencias del amor de los clérigos o de los caballeros. Pero si formalmente hay alguna analogía entre uno y otro tema, el contenido es sumamente distinto. El hombre de letras en la Edad Media gozaba de alto prestigio social cuando era eclesiástico. Don Juan Manuel en el Libro de los Estados los llama "oradores»: "Dígovos que todos los estados del mundo que se encierran en tres: al uno llaman defensores, et al otro oradores, et al otro labradores» ${ }^{2}$. Pero la primer cosa que toca hacer al clérigo es «lidiar con armas contra los moros, que son nuestros enemigos» $(344$ b). Estas clases sociales están rigurosamente estructuradas, y no se ocurre pensar que la gloria inmortal se deba a las letras profanas y al mero ejercicio de la inteligencia. Cuando esto acontece, es que ha comenzado la nueva época del Renacimiento. Entonces se laicizan los problemas de la cultura, y a vueltas de muchos respetos, la teología acabará por

Cristororo Lafranchino, Tractatuhus seu Quaestio utrum preferendus sit miles an doctor, Brixiae, [Brescia], I497.

CASTIGlione, Il Cortegiano, Venecia, 1528.

Juan Ángel González, Pro equite conttra litteras declamatio. Alia viceversa pro litteris contra equitem, Valencia, 1549.

Muzio, Il Gentilhuomo, Venecia, I 575, págs. 230-239.

Franc. Bocchi, Sopra la lite delle armi et delle lettere, Florencia, 1580.

Domenico Mora, Il Cavaliere in risposta al Gentiliomo del Muzio, nella precedenza dell'armi e delle lettere, 1589 .

Después de salir la primera parte del Quijote, publica Francisco de Morales unos diálogos, el segundo de los cuales trata de las armas y las letras (véase Clemencín, comentario al capítulo XXXVIII de la primera parte del Quijote); Francisco NúÑez de VeLAsco, Diálogos de contención entre la milicia y la sciencia, Valladolid, $16 \mathrm{J4}$ - Una a lán encuentro en el Pinciano: «Veo una cuestión muy ren̆ida entre las armas y las letras» (Filosofia 1 . Vé le 1 Véanse Elena y Maria, edic. Menéndez Pidal, en Revista de Filologia Española, 1914, y la bibliografía citada en la pág. 69.

2 Rivad., pág. 337 b. quedar fuera de cuenta. Recuérdense las palabras de Don Quijote en el discurso de las armas y las letras: «No hablo ahora de las [letras] divinas, que tienen por blanco llevar y encaminar las almas al cielo; que a un fin tan sin fin como este ninguno otro se le puede igualar: hablo de las letras humanas» ${ }^{1}$

En el siglo xv el creciente desarrollo de la cultura crea una vida civil, y el universitario, el jurista, en ocasiones e mero literato, ascienden al primer plano de la vida social. Al mismo tiempo se abre paso la doctrina de que la nobleAl mismo tiempo se abre paso la doctrina de que de las , paccesible a quien por un esfuerzo intelectual se hace hijo de sus obras ${ }^{2}$. Y así surge el debate del valor social de las letras, es decir, de las ciencias y las artes, que persistirá mientras dure la idea de que el prestigio de un pueblo se debe exclusivamente a su política militar, y al eco de la antigua nobleza esencialmente guerrera. A medida que esta nobleza va prefiriendo las salas de palacio al campo de batalla, o se limita a vivir de su renta - se acortesana o se aburguesa - y que la cultura es cosa menos insólita, el famoso debate se vacía de sentido y de interés. Por esta razón no debe considerarse la polémica como ociosa en sí misma (pese a la frivolidad o inconsistencia de los argumentos que a veces se utilizaron), ni como un pleito que hayamos de fallar hoy en uno u otro sentido.

Antes veíamos oponerse el sabio al vulgo; ahora la cultura spira a firmar su valor social frente a instituciones que hasta entonces venían siendo el único exponente de la autoridad y del prestigio páblicos. El humanismo trae la conciencia de que el saber no es mero deleite y pasatiempo, sino elemento activo para la vida de la colectividad, y entabla discusión sobre ello. La novedad sorprende, no todos estarán de acuerdo, y frente a los ensayos de armonía, habrá afirmaciones apasionadas en uno u otro sentido. Don Quijote, que se juzga brazo armado de la justicia trascendental, ha de

1 I, 37 ; RM, III, 150.

It $1,37, \mathrm{RM}, \mathrm{II}, 15 \mathrm{O}$. 
sostener cálidamente el valor de las armas en su ardiente peroración; pero Cervantes conoce la amplitud del problema al aludir a él en otras ocasiones.

Pero veamos antes algunos precedentes que nuestro autor pudo conocer. He aquí la opinión de Erasmo en el Elogio de la locura, en la cual vibra el fervor que exaltaba a aquel paladín de la inteligencia: "Me diréis que la guerra exige suma prudencia. Os lo concedo, pero en los generales; y luego ésta no es sino una prudencia particular, relativa al oficio de las armas, y que no tiene ninguna relación con la sabiduría filosófica. Por lo cual los parásitos..., toda la hez del vulgo puede aspirar a la inmortalidad de la guerra mucho mejor que los hombres. que viven día y noche absortos en la contemplación» 1 .

Mal Lara, más templadamente, predica la armonía: «Ha venido la cosa a tales extremos, que aun es señal de nobleza de linaje no saber escrebir su nombre; que cierto no es digno de escrebirse no parando en la escuela, y sabiendo que la pluma no embota la lanza; aunque otros señores, mirándolo mejor se han dado a las letras y ejercicios dellas» ${ }^{2}$.

Pero Mejía titula así el capítulo X del libro III de la Silva de varia lección: "En el cual, por muchas historias y ejemplos, se prueba ser las letras y doctrinas muy provechosas y necesarias a los reyes y príncipes, y también a los capitanes que siguen el ejercicio y arte militar» 3 .

1 Edic. Croce, pág. 35. La fuente remota de la actitud renacentista se hallaría en Cicerón, que alude a este pleito en varias ocasiones, se hallaría en Cicerón, que alude a este pleito en varias ocasiones,
por ejemplo, en $D e$ Officiis, I, $23:$ :Omnino illud honestum, animo excelso magnificoque quaerimus, animi efficitur, non quod ex viribus. Exercendum tamen corpus et ita afficiendum non corporis. consilio rationique possit in exsequendis negotiis et in utabore rando. Honestum autem id, exod exquirimus, totum est positure animi cura et cogitatione: in quo non minorem uttlitatenostum in qui togation afferunt qui togati reipublicae praesunt, quam qui bellum gerunt. Itaque eorum consilio saepe aut non suscepta aut confecta bella sunt, nonnunquam etiam illata: ut M. Catonis bellum tertium Punicum, in quo etiam mortui valuit auctoritas.»

2 Filosofia vulgar, VI, 6ı; edic. 1568 , fol. $157 v$.

3 Edic. Lyon, ${ }_{1556}$, pág. 409.
Lo más frecuente es que se aspire a la armonía entre ambos. órdenes, en la forma que Castiglione la presenta: «Yo condeno, respondió el Conde, a los franceses, porque piensan que las letras estorban las armas, y tengo por cierto que a nadie conviene más la dotrina que a un caballero que ande en cosas de guerra, y por eso estas dos calidades asidas y ayudadas la una con la otra, quiero que se hallen en nuestro Cortesano... Los hombres dotos, cuanclo escriben, casi nunca se ponen en alabar sino los varones famosos en guerra y sus hazañas maravillosas, las cuales de suyo merecen gloria por la propia y esencial virtud de donde nacen» ${ }^{1}$.

Parece, pues, como si se llegara al resultado de que el guerrero suministra la materia de lo heroico, que adquiere luego valor y sentido gracias a las letras: Aquiles y Homero no son pensables sino conjuntamente.

Para Cervantes, familiarizado con el debate, el hombre puede tomar uno de ambos rumbos, el heroico o el intelectual: «Dos caminos hay, hijas, por donde pueden ir los hombres a llegar a ser ricos y honrados: el uno es el de las letras: otro, el de las armas» ${ }^{2}$. En Persiles se nos habla de un "varón insigne y famoso, así en armas como en letras» ${ }^{3}$. "Mis padres me criaron en los estudios, así de las armas como de las letras, si se puede decir que las armas se estudian» ${ }^{4}$. Recuérdese además aquel curioso peregrino que surge en un mesón cercano a Roma: «Yo, señores, soy un hombre curioso; sobre la mitad de mi alma predomina Marte, y sobre la otra mitad Mercurio y Apolo; algunos años me he dado al ejercicio de la guerra, y algunos otros y los más maduros en el de las letras ${ }^{5}$. En fin, se encuentra igualmente dividido entre ambos afanes aquel bárbaro español de Persiles: «Echáronme al mundo padres medianamente nobles, criáronme como ricos, llegué a

\footnotetext{
1 Edic. cit., pág. II 4.

2 II, 6; RM, IV, 148.

3 Rivad., I, 588 a.

4 I, ז2; edic. Schevill-Bonilla, I, 85 .

5 Ibid., 661 b.
} 
las puertas de la gramática, que son aquellas por donde se entra a las demás ciencias, inclinóme mi estrella, si bien en parte a las letras, mucho más a las armas» (Persiles, 567 a).

Cervantes había experimentado en su propia vida esas dos sendas mayores que la época ofrecía ${ }^{1}$ y que él valoraba a su modo. La guerra era el sueño heroico. El curioso Peregrino del Persiles, dotado como Cervantes de «un no sé qué de fantástico e inventivo», está formando un libro, Flor de aforismos, con las sentencias que recoge acá y acullá, en el que algunos de los personajes de Persiles (662 a) notan: «Más hermoso parece el soldado muerto en la batalla que sano en la huída. Dichoso es el soldado que cuando está peleando sabe que le está mirando su príncipe. La honra que se alcanza por la guerra, como se graba en láminas de bronce y con puntas de acero, es más firme que las demás honras.» Pero frente a eso se halla la gloria que confiere los libros, como los del Peregrino ${ }^{2}$, y en la que también cree Cervantes, porque sabe que su libro será inmortal y dará la vuelta al mundo puesto en todas las lenguas. Volvemos así a encontrarnos frente al esencial dualismo cervantino: fantasía épicoheroica, razón, crítica reflexiva. En un momento de su discurso, Don Quijote exclama: «Pero dejemos esto aparte, que es laberinto de muy dificultosa salida.» Del mismo modo sería también para nosotros laberinto dificultoso tratar de razonar la preferencia de Cervantes por una u otra de esas formas de actividad humana. El vértice de su alma, en el que se cortan ambos planos (fantasía heroica y esfuerzo racional), pertenece a uno y a otro. $\mathrm{Y}$ así vive en él este tema, de índole primariamente formal, pero molde para las preocupaciones sociológicas del Renacimiento. A veces nos parece

En I, 39 se cita el refrán: «Iglesia, o mar, o casa real ; pero Cervantes, cuando habla por su cuenta, ya lo hemos visto (pág. 215), piensa en las letras profanas o en la guerra.

2 «Por los [ejercicios] de las letras he sido algún tanto estimado; algunos libros he impreso, de los ignorantes no condenados por malos, ni de los discretos han dejado de ser tenidos por buenos» (Persi.les, $66 \mathrm{I} b)$. percibir en aquel debate, a través del simétrico paralelismo de sus razones, un eco lejano de las polémicas entre el clérigo y el caballero, el alma y el cuerpo o el agua y el vino ${ }^{1}$.

\section{LOS ESPAÑOLES}

¿Qué pensó Cervantes acerca de sus connacionales? Una idea de conjunto acerca de España no la encontramos, ni creo tampoco que haya datos que permitan plantear la cuestión de si el autor escribía en vista del apogeo o decadencia de nuestro poderío, tal como hoy nos representamos ambos momentos ${ }^{2}$. Lo que sí encontramos son ciertas notas del carácter español, y justamente aquellas que respondían al interés del autor, es decir, a su especial manera de ver la vida. No nos extraña nada, por esa razón, hallar repetidas alusiones a la arrogancia tradicionalmente atribuída a nuestro pueblo. He aquí varios pasajes:

\section{Este español me atosiga;}

que siempre aquesta nación

fué arrogante y porfiada ${ }^{3}$.

*Y este nuestro bárbaro español, en cuya arrogancia debe estar cifrada la valentía del orbe» ${ }^{4}$. "Allí [en Luca] mejor que en otra parte ninguna son bien vistos y recibidos los españoles, y es la causa que en ella no mandan ellos, sino ruegan, y como en ella no hacen estancia de más de un día, no dan

1 Moret-Fatio, L'Espagne de Don Quichotte, cree que el discurso de las armas y las letras aes un trozo valiente de los que a Cervantes gustaba escribir a veces para demostrar que era capaz de arriesgarse hasta las cimas de la literatura y elevarse a las ideas generales (traducción cit., pág. 155). Pero ya hemos visto por los demás textos que no se trata de una declamación retórica, ¿Qué secá y pobre idea de Cere trata de 2 Cómo podía prever la decadencia irremediable y cercana? (Morel-Fatio, Op. cit., pág. 143).

3 Casa de los celos, I, 162 .

4 Persiles, 597 a. 
lugar a mostrar su condición tenida por a rrogante» ${ }^{1}$ "Mostrábanse con todos liberales y comedidos, y muy ajenos de la arrogancia que dicen que suelen tener los españoles" ${ }^{2}$

Es curioso que entre las indignadas palabras que un rey moro profiere contra los cristianos españoles, vuelvan a aparecer las de «porfiado» $\mathrm{y}$ «arrogante»:

\section{¿Qué mal conoces la canalla terca, \\ porfiada, feroz, fiera, arrogante, \\ pertinaz, indomable y atrevida! 3 .}

El haz de prejuicios o preocupaciones que Cervantes. proyectaba sobre España, iluminaba especialmente esas notas de desmesura que tanto habían de herir su pupila: arrogancia, gusto por la fachenda y vanagloria. Los extranjeros. habían comenzado a poner de relieve ese aspecto del carácter español, que hacen destacar luego, entre otros, Cervantes y Suárez de Figueroa en el Pasajero ${ }^{4}$. En esa zona se precisan más concretamente modalidades sociales, creadas a base de vana infatuación, y sobre cuya inanidad cae como un dardo la pluma del satírico. En ese caso se hallan el afán de hidalguismo y el «miles gloriosus». Morel-Fatio ${ }^{5}$ ha escrito que observando la condición de Don Quijote y «colocándolo exactamente en su centro, es como se llega a distinguir lo

1 Ibid., 658 a. Comp.: «Luca, ciudad pequeña, pero muy bien hecha, y en la que mejor que en otras partes de Italia son bien vistos y agasajados los españoles, (Licenciado Vidriera, edic. Schevillibonilla pág. 8o).

2 Señora Cornelia, Rivad., I, 2 I 1 a.

Baños de Argel, I, 329.

Baños de Argel, $1,329$.

4 Son populares las Rodomañtades, de Brantôme, escritas en el siglo xvi, pero no publicadas hasta 1665 . Castiglione había dicho: «irá los españoles..., decí si hallaréis muchos que no traigan consigo una soberbia y fantasía loca donde quiera que se hallen con y con mujeres.» A lo que observa otro interlocutor: No niego yo que no haya muchos españoles muy locos y llenos de una fatasi harto pesada; pero digo que los de mayor pesar pero digo que los de mayor apartan de la banda, comúnmente son mansos y blandos y bien criaS\$ (Cortesano, pág. 172; comp. págs. 18 I, 198 y 206).

5 Op. cit., pág. ${ }^{152}$ que creo constituye la principal intención del libro: la crítica del hidalguismo, la plaga de la sociedad española que Cervantes, mejor que nadie, ha sabido medir hasta lo más profundo». No creo que sea esa la intención principal del Quijote, ni sé si puede hablarse de una intención "principal». En todo caso miraríamos esta crítica del hidalguismo como aspecto de un conjunto mucho más amplio, en el cual se incluyen las numerosas formas de error que hemos analizado; y, además, sería indispensable no perder un momento de vista que el hidalguismo, como las restantes formas de error ${ }^{1}$, ocurren en Don Quijote en medio de una especial atmósfera artística que ironiza el mismo intento crítico lanzado sobre el héroe.

Morel-Fatio ${ }^{2}$ ha recogido observaciones satíricas o humorísticas acerca de hidalgos, dueñas y fanfarrones de la milicia, así como sobre el prurito de usar don. Convendría no olvidar ${ }^{3}$ aquel Antonio del Persiles (I, 5) que hubo de huir de su pueblo a causa de una riña sobre cuestión de tratamientos ${ }^{4}$ : "Yo, por ser hijo de mis obras y de padres hidalgos, merezco el merced de cualquier señoría.» Este sujeto se presenta como un impulsivo, que concede importancia a lo que no la tiene: "Sucedió, pues, que yo me revolví sobre una cosa de poca importancia con un marinero inglés, a quien fué forzoso darle un bofetón.» Cervantes aplica al español Antonio algo de la técnica punitiva que usa con los que yerran: se ve abandonado en el mar, a punto de ahogarse: "Aumenté las aguas del mar con las que derramaba de mis ojos, no de temor de la muerte, que tan cerca se me mostraba, sino por

1 Un caso, sin duda, de error moral: "Los hidalgos dicen que no conteniéndose vuesa merced en los límites de la hidalguía, se ha puesto don y se ha arremetido a caballero con cuatro cepas y dos yugadas de tierras (II, 2; RM, IV, 76).

de tierras (II, $2 ; \mathrm{RM}, 1 \mathrm{~T}, 76)$
2 Op. cit., págs. $144-158$.

2 Op. cit., págs. $144-158$. Añádase también aquel paje que prefiere servir al rey más bien
que «a un pelón de la corte»; que no pudo ni alcanzar librea con que que «a un pelón de la corte»; que no pudo ni alcanzar librea con que vestirse, porque sus amos, sacabados los negocios a que venían a la
Corte, se volvían a sus casas y recogían las libreas que por sola ostentación habían dado» (II, 24; RM, V, 19-2I).

4 Recuérdese el Escudero del Lazarillo de Tormes. 
el de la pena que mis malas obras merecían" (véase antes pág. I44). No es, pues, obra buena romper la crisma al prójimo por un vuesa merced de más o de menos.

Si las dueñas dieron tan reiterado motivo de burla a Cervantes, es porque aquéllas, como el eclesiástico de los Duques, afectaban un señorío de que estaban carentes: « $\mathrm{Oh}$, válame Dios, y cuán mal estaba con estas señoras un hidalgo. de mi lugar!» 1 .

En el modo cervantino aparecen igualmente tratados los «milites gloriosi», como Vicente de la Roca (I, 5 I), el soldado hampón de La guarda cuidadosa, y el mismo alférez Campuzano, que tan cara pagó su altisonante prestancia: «El vestido de colores, a fuer de soldado, y tan gallardo a los ojos de mi locura, que me daba a entender que las podía matar en el aire.»

Considerando ahora en conjunto los anteriores hechos, se ve que todos ellos presentan como rasgo general ser manifestación de insuficiente conocimiento de sí mismo y de deseo de afectar virtudes inexistentes. La afectación es para nuestro novelista cosa, como él diría, incomportable. La afectación saca de quicio a Cervantes. Todos conocen las palabras de maese Pedro al chico explicador del retablo «Llaneza, muchacho, no te encumbres, que toda afectación es mala!» ${ }^{2}$. El mismo pensamiento vuelve con insistencia en otros lugares: "Habla con reposo, pero no de manera que parezca que te escuchas a ti mismo: que toda afectación es mala» ${ }^{3}$ Al pedante obstinado le obliga Cervantes a situarse en el plano razonable. El zagal Clemente observa a Pedro de Urdemalas, que le habla en forma inadecuada:

$$
\begin{aligned}
& \text { Pues sabes que soy pastor, } \\
& \text { entona más bajo el punto, } \\
& \text { habla con menos primor. }
\end{aligned}
$$

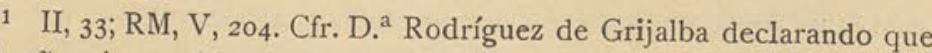
•dueñas tiene mi señora la duquesa en su servicio que pudieran ser condesas si la fortuna quisiera* (II, 37; RM, V, 266).

2 II, 26; RM, V, 6I.
Pedro. Que si eres te pregunto Amadís o Galaor.

Clem. No soy sino Antón Clemente $\mathrm{y}$ andas, Pedro, impertinente en hablar por tal camino.

Pedro. Pan por pan, vino por vino

$$
\text { se ha de hablar con esta gente }{ }^{1} \text {. }
$$

«Reponce mío, habla por tu vida a lo moderno y de modo que te entienda, y no te encarames donde no te alcance» ${ }^{2}$. "No te asotiles tanto, que te despuntarás; habla de aquello que tus años permiten, y no te metas en altanerías, que no hay ninguna que no amenace caída» ${ }^{3}$. Vidriera describe un poeta que «tuerce los labios, pone en arco las cejas y se rasca la faldriquera», que dice un soneto "con tono melifluo y alfeñicado" ${ }^{4}$. "No puedo sufrir ni llevar en paciencia oír las quejas que dan de la fortuna algunos hombres, que a mayor que tuvieron fué tener premisas y esperanzas de llegar a ser escuderos» ${ }^{5}$.

Toda esta crítica de la afectación, de la pedantería y sus derivados viene derechamente del Renacimiento; el vigilante análisis racional alumbra esos rincones de la conciencia, y obliga a valorar formas de conducta entregadas antes a la ingenuidad. Como siempre, Erasmo debe figurar aquí, no sólo por su espíritu antipedantesco, opuesto al charlatanismo. y a la suficiencia, que a cada paso se muestra en el Enquiridion y en el Elogio de la locura, sino por su adagio Ne magna lo-

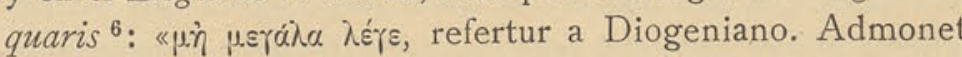
temperandum esse a magniloquentia, jactantiaque, qua nihil omnium intolerabilius». Castiglione explica con su clara elegancia: "Hallo una regla generalísima, la cual pienso que más que otra ninguna aprovecha acerca desto en

1 Pedro de Urdemalas, III, i 19. Cfr. Coloquio, Clás. Cast., pág. 249.

2 Cueva de Salamanca, IV,

C Gitanilla Rivad, I, rosa.

4 Edic. Schevill- Bonilla, pág. 93.

- Edic. Schevill- Bonilla, pág. 93.

6 Coloquio, Clás. Cast., pág. 
todas las cosas humanas que se hagan o que se digan, y es huir cuanto sea posible el vicio que de los latinos es llamado afetación; nosotros, aunque en esto no tenemos vocablo proprio, podremos llamarle curiosidad o demasiada diligencia y codicia de parecer mejor que todos» ${ }^{1}$.

La literatura cómica del siglo xvi se apodera de algunos de esos temas, y trata, a modo de sátira o farsa, personajes como el «miles gloriosus» ${ }^{2}$, que Cervantes recibe muy elaborado por su siglo. Mal Lara ${ }^{3}$, glosando el refrán «Más vale viejo que me honre que galán que me asombre», habla de un cortejador mancebo que se llegó a su dama, "y el Dios os salve que le dió fué que si mandaba que cortase y hen. diese a todo el mundo por ella; y sacada su espada, le comenzó a contar desgarros y campos de Italia, que no dejó cosa que se diga de García de Paredes ${ }^{4}$ que no la atribuyese a sí, rodeando de tal manera su espada, y embraveciéndose tan de veras, que comenzó la mujer a dar gritos y pedir favor de gente». Por eso la dama prefiere al viejo y no al galán, y nota Mal Lara que «parte de esto se cuenta en $E l$ Cortesano». Es verdad. No quiere Castiglione que el caballero "se muestre tan fiero que continuamente traiga braveza en el rostro y en las palabras, haciéndose león, y diciendo que sus arreos son las armas y su descanso el pelear, y amenazando al mundo", porque pudiera acontecerle recibir la respuesta que una gentil dama dió a un bravucón: «Díjole ella entonces, con una buena risa: pues luego agora que no hay guerra ni hay para qué seáis, yo sería de parecer que os con-

1 Cortesano, edic. cit., pág. 73

2 J. P. Wickhersham Crawford, The braggart soldier and the rufian in the spanish drama of the sixteenth century, en Romanic Review, $191 \mathrm{I}$,

3 Filosofia vulgar, IV, 98.

4 Obsérvense las concomitancias con Vicente de la Roca: «Vicente venía de las Italias y de otras diversas partes de ser soldado...; había muerto más moros que tiene Marruecos y Túnez, y entrado en más singulares desafíos, según él decía, que Gante y Luna, Di ego García de Paredes y otros mils (I, 5 I; RM, III, 445-447). certasen y os untasen bien, y, puesto en vuestra funda, os guardasen con los otros arneses para cuando fuésedes menester ${ }^{1}$. Y es imposible dejar de asociar todo esto con el desenlace del entremés de La guarda cuidadosa, en que Cristina concede su amor a un manso sacristán y no a un fiero soldado ${ }^{2}$.

En cuanto a la crítica del hidalguismo, además del conocido escudero del Lazarillo de Tormes, conviene citar nuevamente a Mal Lara, donde hallamos referencias al don y al hidalguismo ${ }^{3}$ : $« \mathrm{El}$ don requiere sostenerse en un rango social muy elevado, y vale más trabajar sin don que querer sostenerlo sin medios; la pequeña y pobre hidalguía sólo da cuidados» ${ }^{4}$. Sancho, que aspira a vivir feliz, dirá: "Que yo no tengo don, ni en todo mi linaje lo ha habido» (II, 44).

\section{Obr. cit., pág. 59.}

2 sacristán. - Como es propio de un soldado, Oue es sólo en los años viejo, Y se halla sin un cuarto, Porque ha dejado su tercio, Imaginar que ser puede, Pretendiente de Gaiferos, Conquistando por lo bravo Lo que yo por manso adquiero» (IV, 79). En El Cor tesano vuelve a decirse que agrada más el que hace la guerra sin alabarse, sque otro que está siempre loándose, y con bravezas y reniegos espanta al mundo» (pág. 76).

Descarto de aquí la crítica de la honra, como falsa gloria mundana, porque se trata ahora del hidalgo que, sin poder, se considera aristócrata; lo que es distinto.

4 ¿Yo no he leído de palabra ni de habla junta que tanto haya menester como un don; porque lo primero demanda linaje y lustre, ha cienda grande, renta de mayorazgo, casa conocida, familia de todas gentes, dueñas, doncellas, escuderos, lacayos, pajes, caballos, mulas... y si también quisiere, algo de virtud.» *Asimismo puede venir esta falta por hacerse el señor tener en mucho $y$ tener poco, que no llega her hacerse el seño tener en mucho y ten cía que García... Preguntado uno que era caballero, y fué a Indias vino rico: «¿Cómo ganaste de comer?», respondía: «Quitándome el don.»

-La mujer del hidalgo, poca hacienda, gran trenzado. Dicho avemo en algunos réfranes arriba cuánto trabajo tenga el que tiene estado que no lo puede mantener... La mujer del escudero, grande la bolsa poco dinero. dinero es una cosa que da muy pocas veces consonante a escudero... La mujer del escudero, tocas blancas y corazón negro...; to- 
Consideremos otros aspectos de la vida española que cayeron bajo la atención de Cervantes. Antes vimos (página 57) que él era partidario del abandono de la Goleta por razones de buen sentido. Ahora encontramos además una curiosa alusión a Flandes. Un bajá dice al Gran Turco, en La gran Sultana (II, I 5 I):

\section{Triste historia es la que leo:}

que a nosotros la Persia así nos daña,

que es lo mismo que Flandes para España.

Conviene hacer la paz, por las razone

que en este pergamino van escritas.

Sería imprudente querer ahondar en el sentido de ese pasaje, no disponiendo de bastantes datos; pero tengo la impresión que Cervantes no pensaba como Lope de Vega ${ }^{1}$. En $E$ trato de $\operatorname{Argel}(\mathrm{V}, 6 \mathrm{I})$ dice un esclavo que, a falta de D. Juan de Austria, vendría el rey mismo a liberarlos del rigor turco:

$$
\begin{aligned}
& \text { el cual, sin duda, ya venido hubiera, } \\
& \text { si la cerviz indómita y guerrera } \\
& \text { del luterano Flandes no ofendiese } \\
& \text { tan sin vergüenza a su real corona. }
\end{aligned}
$$

Quizá era partidario Cervantes de lo que llamaríamos hoy una política mediterránea, y creía que la nación no la realizaba por estar distraída en las guerras continentales: agotar las fuerzas combatiendo cristianos civilizados, en tanto que a dos pasos de nuestras costas anidaban los bárbaros, azote de nuestras villas marítimas, no demostraba mucha cordura. En la Epistola a Mateo Vázquez y en El trato de Argel exhorta al rey a combatir a los turcos argelinos:

Su gente es mucha, mas su fuerza es poca, da, mal armada, que no tien en su defensa fuerte muro o roca.

as blancas..., que no se vee hacer humo en su casa en todo el año, y de ahí le viene su tristeza grandes (Filosofía vulgar, 1568, fols. 46 , 58 y 97 ).

1

:Qué le costó de Flandes al Segundo [Felipe] no conceder la libertad injusta

(Corona trígica; véase nuestra Vida de Lope de Vega, pág. 3 r3.)
Cada uno mira si tu armada viene,

para dar a los pies el cargo y cura

de conservar la vida que sostiene ${ }^{1}$

Con gran desesperanza contemplaría Cervantes la ineficacia de su país. El rey Azán dice de los españoles en El gallardo español (I, IO7):

\author{
El socorro aprestarán \\ el mundo amenazarán, \\ y, estándole amenazando, \\ llegarán a tiempo cuando
}

yo esté en sosiego en Orán ${ }^{2}$.

Junto a esta crítica de la arrogancia española y de algún aspecto de la política exterior, hallamos textos de carácter patrítico en que brilla el orgullo nacional. Así habla Ortel Banedre: «Soy extranjero y de nación polaco; muchacho salí de mi tierra y vine a España, como a centro de extranjeros y a madre común de las naciones» ${ }^{3}$.

En La gran Sultana (I, I3 I) hay otro pasaje interesante: Andrés. Madrigal.

Español sois, sin duda

$$
\text { Y soylo, y soylo; }
$$

lo he sido y lo seré mientras que viva,

y aun después de ser muerto ochenta siglos.

En La señora Cornelia hay varios momentos en que se exaltan el valor y caballerosidad de los españoles: «Que llevando un español a mi lado, y tal como vos me parecéis, haré cuenta que llevo en mi guarda los ejércitos de Jerjes» ${ }^{4}$ «Por la cortesía que siempre suele reinar en los de vuestra nación, os suplico, señor español, que me saquéis de estas calles.» "Aquí me veo sin ti encerrada, y en poder que, a no saber que es de gentiles hombres españoles, el temor de perder mi honestidad me hubiera quitado la vida» ${ }^{5}$.

1 Edic. Schevill-Bonilla, V, 23 ; VI, 29.

2 Es lo que dirá Tirso: «Socorro de España sois, Siempre perdido por tardos (Celoso prudente, Rivad., V, 631 a).

3 Persiles, 6346 .

4 Rivad., I, $216 a$.

5 Ibid., $2 \mathrm{1} 2 b, 2 \mathrm{1} 3 b, 2 \mathrm{1} 5 a$. 
En la Galatea, el venerable Telesio ensalza la poesía española: "No penséis que es pequeño el gusto que he recibido en saber por tan verdadera relación cuán grande es el número de los divinos ingenios que en nuestra España hoy viven, porque siempre ha estado y está en opinión de todas. las naciones extranjeras que no son muchos, sino pocos» ${ }^{1}$.

Pero hay algunos elogios de países extraños que implican: el reconocimiento de deficiencias en la patria. La vida en Francia es más apacible que en España: «Francia, la cual es tan poblada, tan llana y apacible, que a cada paso se hallan casas de placer, adonde los señores dellas están casi: todo el año, sin que se les dé algo por estar en las villas ni en las ciudades» ${ }^{2}$

En dos ocasiones se recuerdan las bien provistas hosterías de Italia: «Las holguras de Palermo, la abundancia de Milán, los festines de Lombardía, las espléndidas comidas de las hosterías.» «Se partió luego, goloso de lo que había oído decir a algunos soldados de la abundancia de las hosterías de Italia y Francia. Sonábale bien aquel Eco li buoni polastri, picioni, presuto e salsicie, con otros nombres de este jaez, de quien los soldados se acuerdan cuando de aquellas partes vienen a éstas, y pasan por la estrecheza e incomodidades de las ventas y mesones de España ${ }^{3}$. Vemos dibujarse las primeras líneas de La fonda nueva, de Larra.

Algunas regiones de España han merecido elogios y apreciaciones dignos de nota. De los catalanes y de Barcelona se dice en Las dos doncellas: "Llegaron a Barcelona... Admiróles el hermoso sitio de la ciudad y la estimaron por flor de las bellas ciudades del mundo, honra de España..., amparo de los extranjeros, escuela de la caballería, ejemplo de lealtad, etc.» ${ }^{4}$. «Es condición natural y propia de la no-

1 Edic. Schevill-Bonilla, II, 237.

2 Persiles, $650 a$.

3 Licenciado Vidriera, Fuerza de la sangre, edic. Schevill-Bonilla págs. $76,128$.

Rivad., I, 206 a. bleza catalana saber ser amigos y favorecer a los extranjeros que de ellos tienen necesidad alguna» ${ }^{1}$. "Los corteses catalanes (gente enojada, terrible; pacífica, suave), gente que con facilidad da la vida por la honra, y por defenderlas entrambas se adelantan a sí mismos, que es como adelantarse a todas las naciones del mundo» ${ }^{2}$.

Valencia ha recibido también floridos y altisonantes conceptos: «La grandeza de su sitio, la excelencia de sus moradores..., todo aquello que la hace hermosa y rica sobre todas las ciudades, no sólo de España, sino de toda Europa ${ }^{3}$; y principalmente les alabaron la hermosura de las mujeres y su extremada limpieza y graciosa lengua, con quien sólo la portuguesa puede competir en ser dulce y agradable» 4 .

Los vizcaínos, nombre que se daba entonces a todos los vascongados, están mencionados con simpatía en La señora Cornelia: "Son unos benditos como no estén enojados, y en esto parecen vizcaínos, como ellos dicen que lo son; pero quizá para contigo serán gallegos, que es otra nación, según es fama, algo menos puntual y bien mirada que la viz caína» ${ }^{5}$.

Al vascuence dedica una mención especial:

\section{Vizcaína,}

que es lengua que se averigua

que lleva el lauro de antigua

a la etiopia y abisina... ${ }^{6}$.

1 Rivad., I, 2096

2 Persiles, $648 a$.

3 Algo de lugar común hay en esto, porque lo mismo se dice de Nápoles en Licenciado Vidriera, edic. Clás. Cast., pág. 28.

4 Ibid., $646 a$.

5 Rivad., I, $217 b$.

6 Gran Sultana, II, 166. En Señora Cornelia, Rivad., I, 222 b, se nota la costumbre de los vizcaínos de casarse en su país, «no por menosprecio, pues no era posible, sino por cumplir su loable costumbre y la voluntad de sus padres., Véase J. ApraIz, Cervantes vascófilo, o sea, Cervantes vindicado de su supuesto antivizcainismo, Vitoria, 1895 , donde Ce hallan mís datos y amplias discusiones sobre los juicios de otros se hallan más 
Es notable que la mayor atención de Cervantes, y su simpatía, vaya hacia las regiones no castellanas, con exclusión de Galicia, "menos puntual y bien mirada.» (¿Lugar común y tradicional? ¿Opinión fundada en propios motivos?) De castellanos y andaluces no hay juicios de conjunto como los anteriores. ¿Poetizaba el autor las regiones que menos había frecuentado?

De todas suertes, prescindiendo de estas apreciaciones, con lo que se dice sobre España y los españoles hemos podido subrayar comienzos de crítica y de enjuiciamiento discreto de los españoles y de la España contemporánea. El rasgo que con más frecuencia aparece en la pluma cervantina es la «arrogancia», la presuntuosa jactancia que hería, en primer término, el sentido escrutador del maravilloso crítico ${ }^{1}$.

\section{LO PICARESCO}

Creo que la más fina observación que Menéndez Pelaya hizo acerca de Cervantes se refiere a la infinita distancia que establece entre aquél y la novela picaresca: «Camina por otros rumbos, Cervantes no la imita nunca.» $\mathrm{Y}$ añade estas firmes palabras: «Mateo Alemán, uno de los escritores más originales y vigorosos de nuestra lengua, pero tan diverso de Cervantes, en fondo y forma, que no parece contemporáneo suyo, ni prójimo siquiera» ${ }^{2}$.

Tan discreta doctrina está lejos de ser compartida por todos los que han estudiado a Cervantes. Rodríguez Marín suscribe ciertamente las anteriores frases de Menéndez Pelayo, pero tal vez no se nota con la suficiente claridad en su docto libro ${ }^{3}$ cómo es posible que habiendo tanto pícaro en

1 A otros aspectos de la vida española hemos de aludir al tratar de la religión. A las familias de los moriscos «no las esquilmaban las religiones» (Persiles, 646 a); es decir: los conventos esquilmaban a España.

2 Cultura literaria de Cervantes, 1905, pág. 32.

3 Edición de Rinconete, 1920, págs i8
Rinconete, no sea esa novela de la clase de las picarescas. Es innegable que hay un equívoco cuando se habla de Cervantes como autor picaresco. Ese equívoco se refleja en la vaguedad de las opiniones cuando llega el momento de considerar este punto, o en el error manifiesto de aquéllas. Las resumiríamos así: Cervantes escribió novelas picarescas ${ }^{1}$; escribi6 algo parecido, pero no propiamente picaresco ${ }^{2}$, diferente de aquéllas por la perfección del estilo ${ }^{3}$; en fin, Cervantes no escribió novelas picarescas, pensó escribir una, siguiendo la moda, y fué gran lástima que no lo hiciera ${ }^{4}$.

1 «En este admirable mosaico... de ningún modo podía faltar una novela genuinamente picaresca» (J. ApraIz, Las novelas ejemplares, 190I, pág. 45).

2 Nota Savj-Lopes: «Esta es la gran diferencia que existe entre Rinconete y las novelas más propiamente picarescas, tales como Ro el tétrico Guzmán de Alfaraches el amarguísimo Lazarillo de Tormes o el tétrico Guzmán de Alfaraches (traduc. esp., pág. 153). La idea procede en parte de M. Pelayo, pero el autor llega a una conclusión de tipo sbaciyelmos: q
es novela picaresca tan propiamente como otras.

es novela picaresca tan propiam ente como otras.
3 Tratando Schevill de la diferencia entre Rinconete y otras noveas, dice: sIt is, moreover, apparent how much more skilfully the roguish features of the story are handled than in the dry and unillumined style of Lavarillo or in the heavy and inelastic manner of Guz-

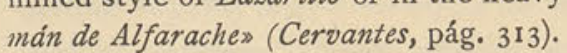

mán de Alfaraches (Cervantes, pág. 313).

4 sSi Cervantes hese tenido oportunidad de escribir su novela picaresca, no consideraríamos el Gil Blas de Lesage como padre de nuestro moderno roman de moeurss (F. DE HAaN, An Outline of the History of the nov. picar., 1903, pág. 25). "Cervantes entró a rivalizar con los autores picarescos al presentar en el Quijote a un célebre pícaro, Ginés de Pasamonte, cuya autobiografía - dice - , si la escribiera, sobrepasán los de Lazarillo y Guzmán. En sus deliciosas nobiera, sobrepare velas refere cuentos de picer, the gonas, etc. (F. W. CuANDEn, The Literature of Roguery, Lgon, I, g) «No deja de causar maravilla cómo [Cervantes] pudo renunciar a competir en este género con los autores de la novela picaresca» (CHANDLRR, La novela picaresca, s. a., pág. 214). De Lollis opina como De Haan y Chandler, al decir que nuestro autor pensó pagar tributo a la moda de la novela picaresca escribiendo una más, sla cual sabemos que de el capitu XXII de la priner parte del Ruijote: habrí side una maravilla” (Cervantes reazionario, pág. 59). 
La opinión últimamente mencionada parte del supuesto que Cervantes era un seguidor de las modas, y no un seleccionador de ellas. Tal idea es, a mi juicio, insostenible, no sólo a causa de los hechos acumulados en este libro, sino por la mera intuición de lo que, en tiempos de Cervantes, hubiera sido un escritor con temas y estilos gobernados por la inquieta onda de la moda.

Lope de Vega sería el ejemplo típico de esa clase de escritores sobre quienes el medio y el momento marcan fácilmente su impronta; recuérdese cómo pulsó confiadamente casi todas las cuerdas de la literatura contemporánea. Cervantes abarca la novela, algunas formas de la poética y la dramática, y aun así reconoce explícitamente que sus versos y sus comedias son para él actividades menores. Aun así, tampoco Lope de Vega ha escrito una novela picaresca. Contemporáneos de Alemán, Quevedo y Espinel, nuestros dos mayores clásicos se abstuvieron de enriquecer el españolísimo género. ¿Se ha pensado en las causas de este singular hecho? Lo juzgo singular porque ambos escritores han bordeado la novela picaresca repetidas veces, mas se abstuvieron cuidadosamente de penetrar en su ámbito.

Eludiendo ahora hablar de Lope de Vega, porque habríamos de alejarnos mucho de nuestra senda, meditemos brevemente sobre el no picarismo de Cervantes. Para esto echamos de menos una comprensiva definición de esa clase de novelas, que abarque no sólo sus características formales, sino además la íntima estructura de su estética ${ }^{1}$, y que destaque lo específico y diferencial respecto de otras formas novelescas. Esta clase de obras, además de tratar de pícaros, nos ofrece la visión del mundo que puede tener uno de esos

1 Véase J. ORtrga Gasset, La picardia original de la novela picaresca, en la revista La Lectura, 1915, pág. 373: $₫ \mathrm{El}$ tema del rencor a crítica madurece en la novela picaresca. En la primera novela interral que se esciben, el Qujoto, se dan un abrazo noventán en la se escribe.., el Quijote se dan un abrazo mone - en la tregua de Dios que el corazón de un genio les ofrece - amo y rencor, el mundo imaginario e ingrávido de las formas y el graviante, áspero de la materia. sujetos mal logrados, bellacos y ganosos de decir mal. De ahí que sean esenciales tanto la forma autobiográfica como la técnica naturalista. El pícaro ve la vida picarescamente, no cree en las ideas ni en los valores ideales, y se aferra, por tanto, a lo único que para él es válido y seguro: la materia y el instinto. La consecuencia emotiva de tal actitud es el desconten10, la amargura y el pesimismo (Guzmán de Alfarache), o la sorna y el sarcasmo (Pablos el Buscón). Véase cuán típicamente picarescos son estos pasajes: «Fué imposible resistirme, porque como a mujer preñada, me iban y venían eruptaciones del estómago a la boca, hasta que de todo punto no me quedó cosa en el cuerpo, y aun el día de hoy me parece que siento los pobrecitos pollos picándome acá dentro... Era el año estéril de seco, y en aquellos tiempos solía Sevilla padecer, que aun en los prósperos pasaba trabajosamente; mirad lo que pasaría en los adversos. No me está bien ahondar en esto, ni el decir el porqué, que soy hijo de aquella ciudad. Quiero callar, que todo el mundo es uno, todo corre unas parejas, ninguno compra regimiento con otra intención que para granjería, ya sea pública o secreta... Para dar medio cuarto de limosna, la examinan» ${ }^{1}$. "Y lo que es más de notar, que nunca nos enamoramos sino de pane lucrando, que veda la orden damas melindrosas, por lindas que sean; y así, siempre andamos en recuesta con una bodegonera por la comida, con la huéspeda por la posada» ${ }^{2}$.

Suele mirarse el Lazarillo de Tormes como la primer manifestación del género picaresco. Es exacto, aunque debe tenerse en cuenta un matiz importante: que el Lazarillo es fuente y punto de arranque del género picaresco, pero encierra al mismo tiempo gérmenes de una visión de la vida más compleja que la adoptada por las obras clásicas de ese género, en las que, sobre todo, pensamos al decir «novela picaresca». La figura del Escudero, algunos aspectos de Lá-

1 Guzmán, Rivad., III, 197 b, 197 a. Para la picardía de todos los oficios y profesiones, Ibid., pág. $224 a$.

2 Buscón, pág. i6g de mi edición, en la Colección «Nelson», 1917. 
zaro hacen presentir (ya lo sugirio, por primera vez si no me engaño, Navarro Ledesma) algo del maravilloso dualismo Don Quijote-Sancho. Tras de las críticas del Clérigo de Maqueda y del Buldero laten inquietudes erasmistas, que suponen ideal y afanes renovadores. En el Lazarillo falta el tono amargo, el encallecido y estático pesimismo que consideramos consustancial con el género picaresco. De esta encantadora obrita, podían derivarse novelas picarescas; pero, al mismo tiempo, algo más. Si Mateo Alemán sume en él sus. raíces, también Cervantes recoge allá elementos para su sintético realismo.

Unos sesenta años más tarde aparece el Guzmán de $\mathrm{Al}$ farache, en $1599^{1}$. Rápidamente se suceden varias obras de corte parecido, inspiradas en temas exclusivamente picares$c o s$, en el fondo de estructura diversa a la observada en $L a$ zarillo. En ellas pensamos, sobre todo, y con razón, al ha-. blar de novela picaresca. De ahí que considere que novela. picaresca es esencialmente la realizada por Mateo Alemán; es el molde fraguado para contemplar de cierta manera la vida humana; en ella son esenciales la técnica naturalista, el carácter autobiográfico y gustar la vida con mal sabor de boca. Si al decir novela picaresca pensamos otra cosa, nos salimos de la correspondiente categoría estética e histórica; y en la medida que un escritor se aleje de ese esquema, se alejará también del concepto de novela picaresca. El héroe de ésta se halla prietamente aherrojado por la fórmula literaria que le hace surgir al mundo del arte; y pegado a la tierra, por fuerza ha de contemplar la vida de abajo arriba. Cuando Mateo Alemán ha querido realzar el bajo nivel de su relato, ha tenido que abandonarlo, y sobreponerle mecánicamente largas digresiones moralizadoras: salvación artificiosa y estéticamente infecunda, desde el punto de vista del género novelesco.

Lo que resta de estas novelas, en cuanto arte, es su atractivo como narración viajera y anecdótica, la gracia un poco

1 Supongo escrito el Lazarillo a fines del primer tercio del siglo. ruda, el rasgo maligno, la abultada comicidad que a veces bordea la farsa ${ }^{1}$. Y junto a todo eso, el espectáculo de la materia, física o humana, pugnando sin éxito por dotar a sus miembros atáxicos de una imposible agilidad, u ofreciéndonos estáticamente la visión turbia de esas realidades ineficaces. El novelista picaresco ha de recortar y abstraer la realidad para obtener ese agrio escorzo que nos brinda, ya que una gentil sonrisa o un noble gesto son tan reales como los huevos podridos o la diarrea ${ }^{2}$; es un arte idealista de signo contrario. En esa reducción, a veces se producen rasgos de violencia y de sobriedad que no dejan de tener su encanto. Mas un efecto de belleza, pleno y noble, las novelas estas. no creo que lo causen nunca.

Danse en la obra cervantina, parcial y externamente, ciertos elementos de novela picaresca. Por lo pronto hay pícaros: Ginés de Pasamonte, los rufianes del teatro, la gentuza que asoma acá y allá en el Coloquio, en otras novelas, sobre todo en Rinconete y Cortadillo. Pero esos pícaros son siempre objeto de las manipulaciones artísticas del autor, que los maneja como figuras de retablo. ¿Se recuerda el maravilloso artificio de algunas escenas de Rinconete? El patio de Monipodio está silencioso; «de puro limpio y aljimifrado, parecía que vertía carmín de lo más fino». Sobre ese fondo precíso van a comenzar a destacarse unas figuras silenciosas. Rincón contempla el local, y va revelándonos detalles esenciales:

1 Concretamente, el estilo del Guzmán es muy superior al de Marcos de Obregón; hay en las glosas de Mateo Alemán trozos límpidos y de sombría belleza que es lástima no sean más leídos. El episodio de Ozmín y Daraja no pertenece al género picaresco.

2 A la señon mi ama le faltó la virtud retentiva, y aflojándosele cA la senora mi ama le faltó la virtud retentiva, y a ojóndosele los cerraderos del vientre, etc., (Guzman, Rivad., III, 228 b). «Apeeme a cierta necesidad natural... Dijo el Marqués: «Esperadme aquí, que > voy a aquella callejuela a cierta necesidad natural, (Marcos de Obre gón, Clás. Cast., I, 233; II, 6). Todos recuerdan las mal olientes escenas. del Buscón. Cervantes ha incidido una vez en este ambiente escatológico, que la grosería de las costumbres hacía tolerable; pero hay un tono de burla e ironía en la escena de los batanes que falta en el estilo seco y directo de la novela picaresca. 
«Encajada en la pared, una almofía blanca, por do coligí Rincón que la esportilla servía de cepo para limosna, y la almofía de tener agua bendita, y así era la verdad.» Van entrando otros callados personajes: dos mozos, dos de la esportilla, un ciego, "sin hablar palabra ninguno, se comenzaron a pasear por el patio». Surgen «dos viejos de bayeta, con antojos, que los hacían graves y dignos de ser respetados». La escena va haciéndose progresivamente más densa. Tácita y misteriosa aparece la vieja halduda que realiza ante una imagen ciertos actos extraordinarios: «Habiendo primero besado tres veces el suelo, y levantado los brazos y los ojos al cielo otras tantas, se levantó y echó su limosna en la esportilla.» El silencio no se ha roto. ¿Asistimos a una representación de "La Chauve-souris»? Llegado el momento, frente a esa masa callada y heteróclita se proyecta Monipodio, llevando por delante el bosque de su pelo en pecho. Todo esto es profundamente espectacular, y están sabiamente dispuestos los efectos de primero y último término. No sé cómo pueda pensarse que la fuerza artística de Rinconete resida en ser mero trasunto de esa realidad que todos ven con los ojos.

Cervantes lo ha dicho, es muy sabido, pero conviene recordarlo: «Los cuentos, unos encierran y tienen la gracia en ellos mismos; otros, en el modo de contarlos; quiero decir que algunos hay que aunque se cuenten sin preámbulos y ornamentos de palabras, dan contento; otros hay que es menester vestirlos de palabras, y con demostraciones de rostro y de las manos y con mudar la voz, se hacen algo de nonada, y de flojos y desmayados se vuelven agudos y gustosos» ${ }^{1}$. Pues bien: considerados en sí y artísticamente, los pícaros son «nonada»; espectacularmente tratados pueden tornarse interesantes. Nos hace sonreír el jaque si lo contemplamos envuelto en su ingenua bravuconería, cargado de hierro, bigotes buídos. En otros casos el ánimo inquieto del pícaro es el portillo para la posible aventura, la

\footnotetext{
1 Coloquio, edic. Clás. Cast., pág. 219.
}

vida libre y extrasocial, la crítica. Temas cervantinos para nosotros ya muy familiares.

El pícaro es, pues, un objeto en manos de Cervantes, subordinado a su compleja visión del mundo. ¿Mas cómo pensar ni un momento que él pudiera instalarse en la pupila de uno de aquellos seres, dispuesto a suscribir sus pobres juicios y a plegarse al rastrero caminar de su espíritu? De ahí que halle infundada la suposición de que Cervantes pensase escribir una novela picaresca, y no la escribiera por estas o las otras razones.

Vicente Espinel puede descansar confiado en la sensibilidad de Marcos de Obregón, que se interesa por lo que tiene en su interior un culebrón a que dió muerte: "Halláronle dentro dos muy gentiles gazapos.» $\mathrm{Y}$ con este motivo formula este hondo pensamiento: "Ordenación fué de Dios, para sujetar la soberbia del hombre y desjarretársela con la misma inmundicia y asquerosidad de la hez de la tierra, que aun muerta la vía y me daba horror ${ }^{1}$. Digno de este otro, esencialmente picaresco: "¿Qué mayor pobreza que andar bebiendo los vientos, echando trazas, acortando la vida y apresurando la muerte, viviendo sin gusto con aquella insaciable hambre y perpetua sed de buscar hacienda y honra?» ${ }^{2}$. La muerte iguala a todos, piensa el pícaro desde su ruindad, y ordena su vida al hilo de $\tan$ menguada doctrina. Y Marcos refiere la suya pausada y minuciosamente, sin selección y sin claroscuro: «Los gatos son de gran seguridad contra las sabandijas que se aparecen en las casas» ${ }^{3}$. Cervantes, vigilante siempre en lo que atañe al estilo, hará decir a Cipión: «Si en contar las condiciones de los amos

1 Edic. Gili Gaya, Clás. Cast., I, 236.

2 Ibíd., pág. I ig. El misoginismo es típico: «Maldiga Dios sus determinaciones [de las mujeres], etc.s (Ibíd., II, 29.)

3 Frente a esta rampráa, el Buscón de Ouevedo es admirable con el fondo nos da una visicin con su estilo ágil, nervioso y agrio, pero en el fondo ning plenamente picaresca de la vida: hambres, sarna, ruindad, escatología. En el prólogo a la edición publicada en la colección «Nelson» (1917) traté de analizar su rara originalidad. 
OTROS TEMAS

que has tenido y las faltas de sus oficios te has de estar, amigo Berganza, tanto como esta vez, menester será pedir al Cielo nos conceda la habla siquiera por un año» ${ }^{1}$. Y en todo el Coloquio, lo mismo que en Rinconete, el autor no nos abandona nunca en manos de ningún pícaro; Cipión y Berganza dominan los seres que tratan, moral y artísticamente. Si por su carácter autobiográfico la genial novelita recuerda la traza de la novela picaresca, la analogía no pasa de la superficie: "QQué te diría, Cipión hermano, de lo que vi en aquel matadero, y de las cosas exorbitantes que en él pasan? Ninguna cosa me admiraba más ni me parecía peor que el ver que estos jiferos con la misma facilidad matan a un hombre que a una vaca.» Berganza no se atreve a rescatar la carne que le roba una moza, "por no poner mi boca jifera y sucia en aquellas manos limpias y blancas. - Hiciste bien, por ser prerrogativa de la hermosura que siempre se le tenga respeto» ${ }^{2}$. A su hora, Berganza se erige en grave ministro de justicia y castiga al alguacil ladrón ${ }^{3}$. Y basta, para que se note la esencial diferencia entre el Coloquio y la novela picaresca, tanto estética como ideológicamente.

Observaciones parecidas podrían hacerse sobre otros as pectos de lo picaresco en Cervantes. El casamiento engañoso es, sin duda, un episodio de picardía; pero téngase en cuenta que se nos presenta la acción como ya sucedida, que la técnica punitiva del autor ha marcado su huella en el alfére Campuzano, que éste confiesa que «el gusto... me había echado grillos al entendimiento", y que el amigo interlocutor domina la acción al exclamar: "De esa manera, entre vuesa merced y la Sra. D. ${ }^{2}$ Estefanía, pata es la traviesa.» El héroe picaresco no puede abandonar su mezquina psicología; el alférez Campuzano, ofuscado un momento, vuelve al plano de la dignidad y nos refiere el elevado coloquio de Cipión y Berganza, que no habría podido ocupar la retentiva de nin-

1 Edic. cit., pág. 218

2 Ibíd., pág. 220.

3 Ibíd., pág. 277 gún Guzmán de Alfarache. No menos característico es el fina de Rinconete; los dos mozalbetes han diableado un poco, nos han puesto en contacto con aquel absurdo mundo de Monipodio, pero «era Rinconete, aunque muchacho de muy buen entendimiento, y tenía un buen natural...; propuso en sí de aconsejar a su compañero no durasen en aquella vida tan perdida».

Rasgos sueltos de apicaramiento que acá y allá se encuentran cabrían dentro de explicaciones semejantes: surgen como contraste, como detalle que da variedad a la acción ${ }^{1}$. En cuanto a Vidriera, su crítica moralizadora, irónica y clarividente en nada iguala las sombrías y amargas diatribas que contra el universo mundo lanzan los típicos héroes de la novela picaresca.

En conclusión: presentar pícaros o rozar motivos picarescos es cosa que nada tiene que ver con escribir una novela picaresca, entendida ésta en la forma antes dicha. Como vimos al hablar de la orientación literaria de nuestro egregio autor, su arte profundo le llevaba a tocar necesariamente temas ideales junto a otros sensibles, materiales. Lo típico de su genio consistía en no afincarse dogmáticamente en ninguna de esas posiciones. $\mathrm{Y}$ de querer instalarse en alguno de esos mundos exclusivos, siempre habría elegido ambientes como el de la Galatea o Persiles. El espíritu inquieto y ascendente de Cervantes no hubiera podido reposa en la visión que un mozo de muchos amos proyectaba sobre la vida. Un pícaro, ser andariego y a su hora divertido, era un tema para ser tratado como a Cervantes conviniera, bajo luz humorística o moralizadora, o sencillamente tomando como espectáculo su activa exterioridad, con gran cuidado de que nunca hable en serio y por su cuenta. Lo que el pícaro piense no interesa a Cervantes.

1 Una mujer, en La señora Cornelia, descontía del honor de los caballeros: «no es todo oro lo que en ellos reluce», etc. (Rivad., I, $217 b)$. 
el Coloquio dice la bruja: «Rezo poco y en público; murmuro mucho y en secreto: vame mejor con ser hipócrita que con ser pecadora declarada...; la santidad fingida no hace daño a ningún tercero, sino al que la usa» ${ }^{1}$. En Persiles dice, no ningún personaje, sino el autor: "Los ímpetus amorosos que suelen parecer en los ancianos, se cubren y disfrazan con la capa de la hipocresía: que no hay hipócrita, si no es conocido por tal, que dañe a nadie, sino a sí mismo» ${ }^{2}$. Además de esos textos, alegados ya por Clemencín, hay otros no menos expresivos. Dice el anciano Mauricio: "Seguí las costumbres de mi patria, a lo menos en cuanto a las que parecían ser niveladas con la razón; y en las que no, con apariencias fingidas mostraba seguirlas: que tal vez la disimulación es provechosa» ${ }^{3}$.

Otros dos al [soslayo] se llegaron, y con la risa falsa del conejo,

y con muchas zalemas me hablaron.

Yo, socarrón; yo, poetón ya viejo volvíles a lo tierno las saludes,

sin mostrar mal talante o sobrecejo.

No dudes, ;oh lector caro!, no dudes, sino que suele el disimulo a veces

servir de aumento a las demás virtudes ${ }^{4}$.

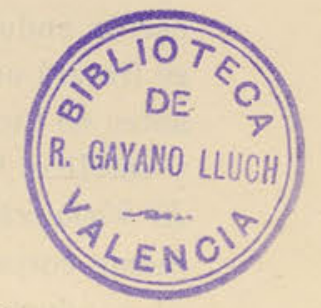
esos graves problemas, se deja guiar del complejo espíritu de fines del siglo, mezcla extraña de adhesión a la Iglesia y de criticismo racionalista. Psicología e historia han de ser aquí también nuestros guías.

No me parece escandaloso afirmar desde luego que Cervantes era un gran disimulador, que recubrió de ironía y habilidad opiniones e ideas contrarias a las usuales. En el Quijote (II, 24) consigna la máxima: «Menos mal hace el hipócrita que se finge bueno que el público pecador» ${ }^{2}$. En

1 Decía Heine: «Cervantes war ein getreuer Sohn der römischer Kirche... ein katholischer Dichter... nirgends eine Spalte des Zweifels» (Introducción a la traducción alemana de 1837, págs. LI y LVIII).

2 RM, V, I5, donde no hay ningún comentario. Clemencín cita pasajes del Coloquio y Persiles, y discute la justeza moral de la doctrina con textos de San Agustín y el Evangelio.

Cinco veces se nos hace el elogio de la hipocresía y del disimulo, y puede ser que haya dejado escapar alguna cita La última, del Viaje del Parnaso, es espléndida: "Yo, socarrón; yo, poetón ya viejo.» Llevemos, pues, un poco de cautela y desconfianza a la lectura de este genial socarrón, lleno de cautelas y disimulos ${ }^{5}$.

1 Edic. Amezúa, pág. 338, que no comenta el pasaje. Rodríguez Marín en la suya de Clásicos Castellanos, pág. 297, cita el Quijote. II, 24. Comp. además, Coloquio, Clás. Cast., pág. $255_{21-24}$.

2 II, 7; edic. Schevill-Bonilla, I, 2I I, que no comentan el pasaje.

3 Persiles, I, I 2; Rivad., I, 5776 .

4 Viaje del Parnaso, cap. VIII. Edic. Schevill-Bonilla, pág. 118.

5 Fijándose en el título de sejemplares» dado a las novelas, J. ORTEGA GASSET, Neditaciones, 1914, pág. 143, llamó la atención sobre «la 
$\mathrm{Y}$ a fin de que resulte evidente la aplicación de esa téc nica cautelosa por parte del autor, voy a citar un ejemplo indiscutible, en el que Cervantes aparece primero sin más cara, en la espontaneidad de su pensar, y luego con una faz convencional, tal como la requería el momento y el ambiente. Ya sabemos que Cervantes no ha presentado nunca un adulterio que en el fondo no apruebe o disculpe. Fué tan lejos en ello, que en El Viejo celoso, según vimos ${ }^{1}$, hace pe-

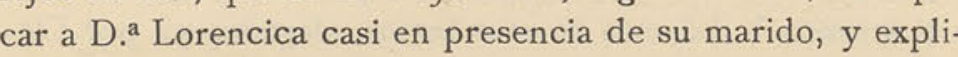
cando a éste las complacencias que experimenta, ignotas para ella hasta entonces: "A Ahora echo de ver quién eres, viejo maldito; que hasta aquí he vivido engañada contigol» Es, pues, manifiesto que a Cervantes no le asustaba contarnos en forma aprobatoria - si la ocasión lo permitía cómo se cumple un acto de adulterio.

Pero hay que escribir novelas «ejemplares». Nuestro socarrón endulzará entonces la voz, pondrá ojos humildosos y se frotará untuosamente las manos, las cuales se cortaría él antes de escribir cualquier pensamiento menos que honesto y católico. En El Celoso extremeño el cuadro es análogo al de El Viejo celoso: ¿dejaremos pecar a la dama?; ¿haremos real mente cornudo al viejo Carrizales? No hemos de dar ejemplos inductores de tentación. En todo caso mitigaremos los términos mucho más que en aquel indecente entremés, en el que por raro caso nos hubimos de permitir unas escandalosas y sinceras zapatetas. Con esta reserva redacta Cervantes la escena entre Loaysa y la niña desposada con Carrizales. Esa primera redacción queda consignada en el manuscrito (conservado por feliz azar) que fué del licenciado Porras de la Cámara, racionero de la catedral de Sevilla, quien reuní́ varias obras en un volumen para solazar con su lectura cardenal D. Fernando Niño de Guevara ${ }^{2}$, arzobispo de Sevi-

heroica hipocresía ejercitada por los hombres superiores del siglo xviI»; menciona a Galileo y Descartes.

1 Pág. 135.

Véase F. Ropriguez Marfix, El Loavsa del Celoso extremeño, roor, pág. 26.

Ila (I600-I609). El Celoso extremeño sería así leído a su Eminencia; jjuzgó éste pecaminosa la escena entre Loaysa y la damita? Quién sabe. Lo cierto del caso es que cuando $\mathrm{El} \mathrm{Ce}$ loso extremeño aparece impreso en $\mathrm{I} 6 \mathrm{I} 3$, tal escena ha sufrido extraña purificación. Los ángeles de la Contrarreforma se han cernido sobre los dos amantes, y el resultado es algo mirífico: duermen en brazos uno de otro, sin que la castidad reciba menoscabo. ¡Oh maravilla! No falta sino que el portento se exorne con la advocación de algún santo, y se nos cuente en una lápida: Siste, viator..

He aquí los dos textos ${ }^{1}$ :

REDACCIÓN DE HACIA I606

Tomó González por la mano a Isabela $\mathrm{y}$, casi por fuerza y medio arrastrando, preñados de lágrimas los ojos, la llevó al aposento donde Loaisa estaba; y, dándole la bendición con una falsa risa de la bendión con una fasa de mono, les ceró tras sí las puery los dejó solos..

Bueno fuera a esta sazón preguntar a Carrizales, si no durmiera tanto, adónde estaban sus advertidos recelos..

No estaba ya $\tan 110 \mathrm{ros}$ sabela en los brazos de Loaisa, a lo que creerse puede, ni se extendía tanto el alopiado uncüento del untado marido, que ir tanto como ellos pensaban...

$$
\text { IMPRESO DE } \quad 16 \mathrm{I} 3
$$

[Texto igual, salvo leves diferencias de estilo.] tantes a vencerla, y él se cansó en balde, $y$ ella quedó vencedora, $y$ entrambos dormidos. Y en esto ordenó el Cielo que, a pesar del ungüento, Carrizales despertase... ${ }^{2}$

1 Edic. Rodríguez Marín, en El Loaysa del Celoso extremeño, páginas $8 \mathrm{I}-83$.

2 Ocurren otros casos de esta calculada moralidad. Véanse ejemplos: "Con la intercesión de una doncella mía, en un apartado corredor nos vimos Grisaldo y yo muchas veces, sin que nuestra estada 
Vió a Isabela en brazos de Loai- Vió a Leonora en brazos de sa, durmiendo entrambos tan a Loaysa, durmiendo tan a sueño sueño suelto, cono si a ellos se suelto, como si en ellos obram la. hubiera pegado la virtud del un- virtud del ungüento güento con que él había dormido.

Me parece que el ejemplo es de alcance y trascendencia muy superior a cuanto pudiésemos decir por nuestra cuenta. Hemos cogido al autor con las manos en la masa. Enlazado con todo lo que precede y con lo que ha de seguir, presumo que quien nos lea sin prejuicios no ha de negarnos esta premisa mayor: Cervantes es un hábil hipócrita, y ha de ser leído e interpretado con suma reserva en asuntos que afecten a la religión y a la moral oficiales; posee los rasgos típicos del pensador eminente durante la Contrarreforma.

\section{CONTRARREFORNA}

Hacia mediados del siglo xvi se inicia el gran repliegue defensivo de la Iglesia católica, cuyos efectos aún se notan un siglo más tarde ${ }^{1}$. En España la reacción fué violenta, y la persecución del ideal erasmista, su más dramático episodio; en los demás países católicos la Iglesia fué tan lejos como se lo permitió la resistencia con que tropezó. En lis-

solos a más se extendiese que a vernos y a darme él la palabra que hoy... me ha tornado a dar» (Galatea, II, 20). En el Quijote (I, $5 \mathrm{I}$ ) hallan a Leandra sen una cueva de un monte, desnuda en camisas, porque aquel Vicente de la Roca, csin quitarle su hon or, le robó cuinto aquel

1 Hay un antiguo libro de Си. Dejos, De l'influence du Concile de Trente sur la littérature et les beaux-arts, $188_{4}$, interesante por al:zunos datos, pero cuyo sentido no nos sirve, por no percibir el complicado espíritu de esa época: "Cien años después de la muerte de Lutero, Francia produjo una generación de escritores que, mediante un effuerzo de genio y de virtud, volvió a hallar la perfección clásica y la piedad de tiempos de los padres de la Iglesia», etc. (Prólogo). Son, la pied de tices de en cambio, esenciales el libro de Toffanin, tantas veces citado, y los que a continuación menciono. Como orientación general es útil E. Gotнin Staat und Gesellschaft des Zeitalters der Gegenreformation, en Kultur der Gegenwart, I908, II, V, I. paña no encontró Roma prácticamente el menor obstáculo, por ser escasos y débiles los núcleos de pensamiento antipopular; y así pudo constituirse la «democracia frailuna» de que habló Menéndez Pelayo. Durante la época erasmista, cuando el arzobispo de Toledo, Fonseca († I 534), y el de Sevilla, el inquisidor general Manrique († I 538), sostenían denodadamente a Erasmo († I536), pareció posible ir hacia un cristianismo romano, y al mismo tiempo de carácter crítico y, por tanto, antipopular. Pero esto fué una ingenua ilusión, artificialmente mantenida por la energía de Manrique y sus amigos, en una época en que aún no estaban suficientemente claras las actitudes. La Reforma había brotado de dentro de la Iglesia; el erasmismo tenía mucho de común con Lutero, y hasta iba más lejos que éste en ocasiones ${ }^{1}$. Erasmo estaba sostenido por Roma, por el Emperador y por la Inquisición. Así se explican las dudas y las vacilaciones en unos y otros hasta I 538. Muerto Manrique, las Órdenes religiosas desbordaron la contenida agresividad, y se vió que el erasmismo era obra de unos cuantos «intelectuales», sin base de opinión. La Iglesia en todas partes se vió obligada a retornar al momento prerrenacentista, a sostener enérgicamente el statu quo dogmático y a reformar las costumbres, a fin de atenuar los motivos de crítica en el enemigo. Durante el Renacimiento la Iglesia había andado en coqueteos con el espíritu de novedad; los papas hicieron lo que es sabido, y se creyó con inconsciencia que el arte, la razón y la vida podían crecer sin rozar el edificio dogmático. Erasmo representaba justamente este espíritu de concordia, que no podía en modo alguno ser eficaz ni sincero, ya que el holandés minaba las bases del catolicismo. La desbandada luterana comenzó, y la Iglesia cantó en Trento su mea culpa. Repliegue general. $\mathrm{Ni}$ arte, ni razón, ni vida libres. Hay que volver al viejo redil, estrechando sus mallas. Reacción, Contrarreforma ${ }^{2}$.

Véase Prneau, Erasme: sa pensée religieuse, 1924.

2 Tuve que anticipar en las páginas $26-27$ observaciones y datos que hay que tener ahora muy presentes acerca de la Contrarrefor- 
En un moderno e interesante libro ${ }^{1}$ se caracteriza así este momento: «El optimismo en el sentimiento mundano y la conciencia de ser libre la personalidad autónoma fueron de gran importancia para la vida espiritual y la cultura del Renacimiento; pero recibieron grave sacudida con las tormentas desencadenadas sobre Italia, Roma y Europa en la primera mitad del siglo xvi. La voluntad de los hombres y a de la Iglesia contemplaban ante sí resistencias y obstácuos contra los cuales se deshacían y fracasaban. Las discordias religiosas, con las cuales el catolicismo debía renunciar de hecho a su pretensión de universalidad; las luchas dinásticas de los señores, que pasaban de uno a otro país; el saco de Roma por el ejército imperial (1527), provocaron conmociones profundas y mostraron a muchos católicos que estaba en peligro la existencia de valores esenciales y tradicionales. Bajo la impresión de acontecimientos irremediables, tornaron las gentes a buscar sostenes y apoyos en su fuero interior y en la autoridad eclesiástica. La corriente pesimista se extiende y recubre notablemente la civilización de la segunda mitad del siglo XVI.»

Creo que a esas causas, reflejadas en grandes acontecimientos de la vida pública, habría que añadir motivos que afectan directamente al ideario humanísticorrenacentista. Con entusiasmo frenético ante la vida divinizada, y con crítica negativa de los valores hasta entonces en curso, no se podía seguir indefinidamente. La ciencia está en el aire (de ahí magia y astrología, o escepticismo inteligente de Montaigne, que en sí no es solución); la moral privada y pública, ¿en qué se va a basar?; en suma, si la Edad Media ha fracasado, ¿qué se pone concretamente en lugar de ella? Una respuesta clara y pragmática, con posibilidad de generalización

a. Añádase que en el prólogo a la traducción de la Parenesis a De mónico, de Isócrates, dice Pero Mexía († $155 \mathrm{I})$ : ${ } \mathrm{Y}$ también porque Isócrates en algunos lugares habla como gentil, tuve cuidado de traducirlo cristianamente» (edic. Madrid, 1673, pág. 691).

WERNER WEISBACH, Der Barock als Kunst der Gegenreformation Berlín, 192 I, pág. social, no se pudo dar hasta el siglo xvin, y sería absurdo pedirla ni aun a las mejores cabezas del siglo xvi. La única solución es pactar con las fuerzas efectivas - la Iglesia - y trabajar como se pueda para el mañana. Entre tanto se reinstaura Aristóteles. El protestantismo-que G. Bruno ensaya - no era solución; luego veremos su juicio sobre aque1la nueva creencia. Después del estímulo inicial, que supuso libertad para el propio juicio, las consecuencias no fueron ni la soltura del pensamiento, ni la tolerancia, ni la emancipación del yugo teológico. Recuérdese el dicho protestante: "Quod illis est Papa, est nobis Scriptura.» Sin embargo, los países protestantes creían haber resuelto todos los problemas con su nueva religión, a la que sinceramente se entregaban. Pero el Renacimiento tardó más en dar fruto maduro en los países protestantes que en los católicos; la nueva fe cristiana, alumbrada por el Renacimiento, se popularizó, se hizo movimiento de masa; pero se atenuó, en cambio, la acción de las individualidades insatisfechas y curiosas. Las grandes construcciones del pensamiento renacentista, base de la ciencia y del mundo nuevos, se han hecho bajo la áspera y recelosa mirada de Roma: Telesio, Campanella, Bruno, Galileo, Descartes... En Germania, figuras de igual talla vinieron más tarde.

En el mundo católico la situación es muy complicada durante la Contrarreforma. Para el católico, abandonar la envoltura dogmática suponía quedarse sin religión. Ya en el siglo xvi comienza el movimiento de los «libertins» franceses (en realidad ateos), suscitado por influencias italianas ${ }^{1}$. Pero los más altos espíritus buscaron fórmulas para no romper abiertamente con la Iglesia. Piénsese en la actitud de Montaigne, que se adhiere en conjunto a las verdades de la religión católica; todas ellas están fuera del alcance de la

Busson, Sources et développement du rationalisme, 1922, pág. xIV «Bibliothèque de la Société d'Histoire ecclésiastique de la Frances). Nótese el hecho curioso de que aun hoy día el llamado libre pensamiento se alimente sobre todo de ex católicos y ex judíos. 
razón, fuera de la crítica y de nuestros medios de conocimiento. Ese acto de fe universal le basta y basta a la Iglesia. Su pensamiento puede entonces vagar a la ventura, y lo que diga en tal materia estará a cubierto de toda sospecha. Montaigne lo acepta todo de la Iglesia, no admite discusión sobre el menor detalle. Para Cervantes, «la reina de todas [las ciencias es] la Teología» ${ }^{1}$. La religión queda así relegada a un rincón de la conciencia, queda aparte, y toda la vida discurre sin ella ${ }^{2}$. Dice Montaigne: «La doctrine divine tient mieux son rang à part comme reine et dominatrice... Les raisons divines se considèrent plus vénérablement et révéramment seules et en leur style qu'appariées aux discours humains» ${ }^{3}$. Ahora bien: ¿̨no hay un reflejo de análogo espíritu en alguna frase del discurso de las armas y las letras? Dice Don Quijote: "No hablo ahora de las [letras] divinas, que tienen. por blanco llevar y encaminar las almas al cielo; que a un fin tan sin fin como éste ninguno otro se le puede igualar: hablo de las letras humanas» ${ }^{4}$. Cervantes, al igual de Montaigne, construye la vida de sus personajes teniendo en cuenta una moral despojada de bases teológicas, y fundada en naturaleza y razón (véase el capítulo VII).

En el ambiente histórico que analizamos acontecía justamente lo contrario que en la época actual. Hoy las religiones positivas son, para la mayoría de sus fieles, asunto atañedero al dominio privado. La religión no sale de la intimidad de la conciencia sino cuando se convierte en partidismo político, lo cual demuestra que por propia virtualidad no

1 II, $16 ;$ RM, IV, 324.

2 Villby, Sources des Essais de Montaigne, II, 329-330.

Essais, I, 56. Modernizo la ortografía, lo mismo que hago con los textos españoles.

4 I, 37; RM, III, I50. Comp. Erasmo: «No se debe llamar escritura profana la que tuviere doctrina pía e provechosa para buenas costumbres»; la cual puede traerse a cuento sin escrúpulo, porque «la Escritura sagrada en todo ha de llevar la ventaja, e con ésta ninguna se ha de comparar (Coloquios, en Origenes de la Novela, IV, 189). puede ya influir en la vida pública. A fines del siglo xvi la situación era otra; el catolicismo era antes materia de Estado que de conciencia, y entre nosotros iba ligado al honor nacional ${ }^{1}$. Así como hoy un católico actúa a menudo en la vida social y procede en su conducta sin tener presentes aquellas normas que confiesa en el terreno íntimo, de la misma suerte algunos espíritus selectos durante la Contrarreforma aspiraban a salvar la independencia del propio pensar como particulares. Por eso dirá el Tasso, según ahora veremos, que cree como cristiano y piensa como filósofo. Sería, pues, un error suponer necesaria congruencia entre el Cervantes que glosa una redondilla en alabanza de San Jacinto para las justas que en su honor celebran los padres predicadores de Zaragoza ${ }^{2}$ y el Cervantes que ejercita la crítica, la sátira o construye una moral arreligiosa, sin ánimo de que esto afecte a su catolicismo ni, sobre todo, trascienda al dominio de lo públicamente declarado. El lazo que mantiene unidas ambas actitudes es la habilidad y el disimulo de Cervantes. Lo ha dicho bien claro, y por si algo faltaba, Berganza lo completa en el Coloquio: "Ahora no van las cosas por el tenor y rigor de las antiguas: hoy se hace una ley y mañana se rompe; y quizá conviene que así sea. Ahora promete uno de enmendarse de sus vicios, y de allí a un momento cae en otros mayores. Una cosa es alabar la disciplina y otra el darse con ella; y en efecto: del dicho al hecho hay gran trecho» ${ }^{3}$.

La hipocresía consiste en este caso en encubrir hábilmente el alcance del pensamiento íntimo; en lo que tendría de crítica nociva (personalmente muy peligrosa) para esas verdades de carácter público y tradicional; pero no consiste en hablar en serio de esas verdades sin creer en ellas ${ }^{4}$. Si no

1 Vénse el importante estudio de M. Batallon, Honneur et Inquisition, en Bulletin Hispanique, 1925, XXVII, 5.

2 Rivad., I, 709.

3 Edic. Clás. Cast., pág. 255.

4 No sería admisible que Cervantes procediese como farsante en todos los actos de religión y piedad que aparecen en su vida y en su 
entendemos la hipocresía de esta manera, no alcanzaremos a penetrar el espíritu de la Contrarreforma, cuyo andamiaje está sostenido por el hábil disimulo. Como molde intelectual, la «doble verdad» sirvió a maravilla a quienes se encontraban en mala postura. En Cervantes esa «doble verdad» vino a armonizarse con el «engaño a los ojos»; y así, su mente y su sensibilidad están gobernadas también ahora por la elasticidad y la ondulación que esencialmente las informan.

Decíamos que el católico inquieto tomó ya el camino del libertinismo ateísta (en España sin manifestación perceptible), o el más flexible y difícil de la «doble verdad» : verdad de fe, verdad de razón (de origen escolástico, pero con nuevo sentido desde Pomponazzi), sin detenerse a poner de relieve la incompatibilidad de una y otra. Ya nota Höffding que «las audaces. esperanzas de los pensadores del Renacimiento se hallan aliadas en Campanella con la humildad ante la Iglesia» ${ }^{1}$. El caso. de Giordano Bruno es aún más significativo; para él las verdades de fe, la religión, son indispensables a fin de que el pueblo se mantenga dentro de la justicia civil: "Quel che è vero [es decir, la ciencia y la filosofía] è pernicioso alla civile conversazione, e contrario al fine delle leggi» ${ }^{2}$. Y comenta Gentile: «La verdad de la filosofía, en suma, es sólo para la filosofía. La verdad de la vida práctica, y de la misma religion, en cuanto institución social e iglesia educadora de los pueblos, puede, y a veces (según G. Bruno) debe ser una verdad diametralmente opuesta a la de la filosofía.» "Le vere proposizioni - dice Bruno - non son proposte da noi al volgo, ma ai sapienti soli, che possono aver accesso all' intelligenza.

obra. ¿Qué explicación tendría eso? En esos momentos sigue las costumbres y la tradición, y se adhiere a ellas con la misma evidencia que aceptaba la realeza o la organizción social de su tiempo. Otras. erían antihistóricas.

1 Hist. philosoph. moderne, I, I58; BLanchet, Campanella, págs. 415. y sigs.

2 Diálogos De l'infinito, universo e mondi. Ap. GenThe, G. Bruno, pág. 17. Para algo parecido en el P. Mariana, véase pág. 258 nota. di nostri discorsi» ${ }^{1}$. La distinción del vulgo y el sabio era, pues, importante en más de un sentido (véase antes pág. 210) Para Bruno no hay posibilidad de ley ni de estado sin religión. Como para Campanella, la religión de un país es para él como la constitución política y la ley positiva; de aquí que Bruno se aleje de los protestantes, "questi grammatici che in tempi nostri grassano per l'Europa», que causan daños, guerras y discordias. No hay, pues, que mirar la retractación de Bruno en I 592, ocho años antes de su martirio, como una baja debilidad, sino como fruto de íntima y complicada convicción. Meses antes de que interviniera el Tribunal de Venecia, Bruno había comenzado a preparar su reconciliación con Roma; estaba dispuesto «a domandare umilmente perdono al Signore Dio e alle Signorie illustrissime de tutti li errori commessi» ${ }^{2}$. Tal retractación no puede mirarse como vil flaqueza en quien dió serenamente la vida por la «otra» verdad.

Cuando Galileo expone en sus diálogos el nuevo sistema del mundo, toma la hipócrita caución de hablar hipotéticamente. Y así podía decir el cardenal Belarmino, perseguidor del gran astrónomo: «Digo que me parece que V.P. y el señor Galileo obran prudentemente contentándose con hablar ex suppositione y no absolutamente." No obstante lo cual, aquel anciano de sesenta y nueve años hubo de abjurar de rodillas, en I633, su idea de que la tierra se movía. Frente a la ciencia experimental de Galileo, se erguía Roma; y por boca de Belarmino decía algo que calificaríamos de supina idiotez, si el sentido histórico no nos obligara a ser algo más comprensivos con las rutinas tradicionales: «El Concilio prohibe exponer las Escrituras contra el común sentir de los Santos Padres... Todos convienen en exponer ad litteram que el Sol está en el cielo y gira en torno a la Tierra con gran velocidad, y que la Tierra está en el centro del mundo, inmóvil» ${ }^{3}$.

\footnotetext{
1 Opere italiane, I, 293; Gentile, Ob. cit., pág. 18.

2 Gentile, Ob. cit., pág. $3 \mathrm{I}$
}

3 Galileo, Opere, XII, 17 I 
Fenómenos de ese mismo tipo, aunque de menos dramática grandeza, podrían citarse ${ }^{1}$. Descartes estará en situación algo semejante a la de Bruno; escribe al P. Mersenne en I640: "Etant très zélé à la religion catholique, j'en révère généralement tous les chefs. Je n'ajoute point que je ne me veux pas mettre au hasard de leur censure; car croyant très fermement l'infaillibilité de l'Église, et ne doutant point aussi de mes raisons, je ne puis craindre qu'une vérité soit contraire à l'autre " ${ }^{2}$. Descartes fué menos vehemente que Bruno, y supo armonizar su respeto a la tradición popular (que íntimamente sentía) con el cultivo de la ciencia que significaba la ruina de la teología. Su biógrafo Baillet escribe: "Il ne voulait pas se départir de la résolution qu'il avait prise, de ne jamais rien produire que les théologiens pussent prétendre être sous leur juridiction» ${ }^{3}$.

1 Telesio admitiendo un alma «superaddita» por Dios a la material, a fin de tranquilizar a la Iglesia (HöfFdra, Ob. cit., I, ro7); Campanella, ya citado, entregándose a la Iglesia (Саarbonst, Pensée ita lienne au XVI' siècle, pág. 586). Véase cuán característico es este pasaje de Ouevedo acerca de Torcuato Tasso: En nuestros tie pasiguió esta opinión errada [que el alua tiene an hértos tiempos iguió esta opinión errada [que el alma tiene un género de cuerpo] el doctísimo poeta y filósofo Torcuato Tasso, en el diálogo que intitula $E l$ mensajero, en boca de su genio; habiéndose ca ut el ado en la dedicatoria con estas palabras: «Permítaseme discurrir como filósofo, creyendo como cristiano.s Pudiera discurrir mejor como filósofo cristiano" (Providencia de Dios, en Bibl. de Aut. Esp. pág. I69a).

2 Carta al P. Mersenne, Oeuvres, edic. Adam et Tannery, III, 259

3 En Oeuvres, edic. Adam et Tannery, V, 475. He aquí un pasaje muy expresivo de una carta del filósofo: «Monitis et praeceptis tuis. obtemperabo, praecipue in iis quae spectant ad sacram theologiam obtemperabo, praecipue in iis quae spectant ad sacram theologiam
et ortodoxam religionem... Restat tantum unus scrupulus, de motu et ortodoxam religionem... Restat tantum unus scrupulus, de motu est ex ea Congregatione, quae Galilaeum condemnavit» (Ibid., V, 544 ). En 1648 escribe al marqués de Newcastle: «Vous voyez ce que vous pouvez sur moi, puisque vous me faites passer les bornes de philosopher que je me suis prescites (Itd , V, 139). Vease, pues, como el espíritu de la Contrase cómo el espirtu de la Contrarreforma producía consecuencias en otros Países, y cuán instructiva es su comparación con lo que mucho antes acontecía en el ánimo de nuestro Cervantes. Como es sabido, Descar-
Esta excursión a dominios tan alejados de Cervantes tiene, sin embargo, una utilidad para nosotros. Nuestro autor es el literato que hubo en España de carácter más abierto a las influencias universales; sería absurdo pensar que Europa se apoderó ávida y permanentemente de una obra sin notas de cultura universal; se habla del localismo de Lope de Vega, que le circunscribe a España; se le contrapone la humanidad de Cervantes, y en cambio se niega a éste contacto con el pensamiento y los finos problemas de su tiempo, que están en él como están en Shakespeare, otro europeo de primera magnitud. Con fantasía y casero buen sentido no se hace un Quijote.

El lector discreto ha comprendido ya por qué cito esos casos máximos de Bruno, Campanella, Montaigne, Tasso y Descartes. A fines del siglo xvi había una especial forma de religiosidad en los hombres más egregios, creada por el conflicto de las ideas renacentistas (en el fondo ateístas o panteí :tas) con el catolicismo, representante de la tradición, del orden social, de fuertes sentimientos individuales y colectivos que en modo alguno quedaban satisfechos con las promesas del Renacimiento, trémulas y arrebatadas. Había la sospecha, en los ánimos más altos, de que las grandes construcciones estaban por hacer; frente al entusiasmo, al anhelo y al vislumbre de verdades estaba la tremenda y secular afirmación de Roma. La Contrarreforma obliga a compromisos, a arreglos ${ }^{1}$, en parte por convicción, en parte por miedo a la hoguera; pero trae también al ánimo melancolía y desengaño, muy característicos y perceptibles a principios del 1600 .

En Cervantes, visto en conexión con el momento en que vive, hallaremos reflejos de ese complicado espíritu en lo que

tes renunció a publicar su Tratado del mundo después de la condenación de Galileo (1633), y va a Loreto a dar gracias a la Virgen por el descubrimiento de su método filosófico, método que arruinará la teología como ciencia.

1 No casuísmo de los jesuítas? La Iglesia llegó ahí a su máximo de elasticidad. 
atañe al pensamiento religioso. Católico, sí, hemos de repetirlo; pero en la forma en que lo eran otros hombres de genio, preocupados de novedades. Creyente, piadoso; pero formula la doctrina de la naturaleza como poder divino que crea al hombre, lo que es esencialmente heterodoxo y anticristiano $^{1}$, y cuya consecuencia es una moral con sanciones inmanentes, que para nada tiene en cuenta la vida futura. Frente a ciertas creencias y prácticas católicas, mantiene actitudes bastante críticas. Su cristianismo, según veremos, recuerda, en ocasiones, más a Erasmo que a Trento.

\section{ALARDE DE ORTODOXIA}

En lo que se nota, desde luego, el carácter especial de este sentimiento religioso es en el alarde de ortodoxia, en el continuo curarse en salud de nuestro Cervantes. Si no pasa nada, ¿por qué insistir tanto en que no pasa? Lope, Tirso, Quevedo, Luis de León, Mateo Alemán no andan con tantas precauciones; son afirmativos en materia religiosa y no piensan que nadie pueda pensar que alguna cosa de sus escritos no está en regla. De la Primera parte del Quijote se dice en la Segunda, que «la tal historia es del más gustoso y menos

1. Blanchet, Campanella, pág. 405, dice en el capítulo titulado \&L descristianización del sentimiento religioso»: «El pensamiento filosófico del Renacimiento... descristianizaba, por decirlo así, el sentimien to religioso. Sustituía a la adoración interior de Dios vivo, personal, y al amor del Cristo salvador, la contemplación de la obra del Creador, la admiración apasionada de lo divino inmanente en el universo la confinza optimista en un destino terrestre, regulado por la misma en las armonías de Divinizando la creación y el «microcosmoss, el hombre, [véase ante pág. 157], más aún que el «macrocosmos»...; aproximando de esa suerte Dios al universo y el hombre a Dios, el pensamiento renacentista pierde poco a poco el sentimiento de la diferencia entre el reino de la naturaleza y el de la gracia...» - Debí citar antes lo que Descartes entiende por naturaleza: «Per naturam enim, generaliter spectatam, nihil nunc aliud quam vel Deumipsum, vel rerum creatarn coordinationem a Deo institutam intelligo $\sigma^{\circ}$ Méditation). perjudicial entretenimiento que hasta agora se haya visto, porque en toda ella no se descubre, ni por semejas, una palabra deshonesta, ni un pensamiento menos que católico» ${ }^{1}$. Las novelas también están católicamente reselladas: «Una cosa me atreveré a decirte: que si por algún modo alcanzara que la lección de estas novelas pudiera inducir a quien las leyere a algún mal deseo o pensamiento, antes me cortara la mano con que las escribí que sacarlas en público: mi edad no está ya para burlarse con la otra vida» (Prólogo). Aludiendo Sancho al autor de la Primera parte, sostiene «que si hubiera dicho de mí cosas que no fueran muy de cristiano viejo, como soy, que nos habían de oír los sordos» 2 .

En La española inglesa, parte de la acción transcurre en Inglaterra, tierra de herejes. Hay que tomar precauciones: "Quiso la buena suerte que todos los de la casa de Clotaldo

\section{II, 3; RM, IV, 98}

2 II, 3 ; RM, IV, 93. Parece, sin embargo, difícil no consagrar una sonrisa a las referencias a esa seminobleza que se arrogaban los cristianos viejos, doctrina anticristiana que hacía depender los beneficios de la gracia de Cristo de la conducta de los antepasados, y no de cristiano proceder de la persona: «Eso allá se ha de entender - respondió Sancho - con los que nacieron en las malvas, y no con los que tienen sobre el alma cuatro dedos de enjundia de cristianos viejos, como yo los tengo' (II, 4; RM, IV, I r 8). «Destas lágrimas y determinación tan honrada de Sancho Panza, saca el autor desta histori que debía de ser bien nacido, y por lo menos cristiano viejos (I, 20 , RM, II, 129). «Yo cristiano viejo soy, y para ser conde esto me basta. - Y aun te sobra, dijo Don Quijote» (I, 21; RM, II, 172). Los padres de Dorotea eran egente llana, sin mezcla de alguna raza mal sonante, y como suele decirse, cristianos viejos ranciosos» (I, 28; RM, II, 384). En El relablo de las maravillas el señor Benito Repollo est́́ muy seguro de que t ha de ver todas las maravillas: Puedo í seguro a

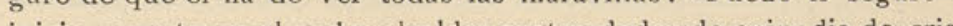
juicio, pues tengo el padre alcalde: cuatro dedos de enjundia de cristiano viejo rancioso tengo sobre los cuatro costados de mi linaje: $j \mathrm{mi}$ ren si veré el tal retablo!» (IV, I10). Leemos en el Coloquio: «Muy diferentes son los señores de la tierra del Señor del cielo: aquéllos para recibir un criado, primero le espulgan el linaje..., pero para entrar a servir a Dios, el más pobre es más rico; el más humilde, de mejor linaje» (edic. Clás. Cast., pág. 233). 
eran católicos secretos» ${ }^{1}$. En Persiles todos los habitantes de aquellas fantásticas regiones son católicos. El rey Policarpo guardó las «leyes de la viudez con toda puntualidad y recato, tanto por el crédito de mi persona como por guardar la fe católica que profeso» ${ }^{2}$. En aquel matrimonio de los gustos trocados está "ya el sacerdote a punto de darles las manos y de hacer las católicas ceremonias que se usan» ${ }^{3}$. El anciano Mauricio había nacido en una isla cercana a Ibernia, y declara: «Soy cristiano católico, y no de aquellos que andan mendigando la fe verdadera entre opiniones» ${ }^{4}$.

Sancho, en su programa de gobierno, promete «premiar a los virtuosos, $\mathrm{y}$, sobre todo, tener respeto a la religión y a la honra de los religiosos» ${ }^{5}$. El Cura del Quijote se disfraza de doncella, pero cambia de disfraz con el Barbero y se viste de escudero, "que así profanaba menos su dignidad» ${ }^{6}$. D. Antonio Moreno, en Barcelona, «temiendo no llegase [1o. de la cabeza encantada] a los oídos de las despiertas centinelas de nuestra fe, habiendo declarado el caso a los señores inquisidores, le mandaron que la deshiciese» ? Nuestro amigo Rodaja, "de los titereros decía mil males; decía que era gente vagamunda, y que trataba con indecencia de las cosas divinas, porque con las figuras que mostraban en sus retratos, volvían la devoción en risa, y que les acontecía envasar en un costal todas o las más figuras del Testamento viejo y nuevo, y sentarse sobre él a comer y beber en los bodegones y tabernas» 8 .

1 Edic. Schevill-Bonilla, pág. 6.

2 Rivad., I, 596 a.

3 Ibid., $606 a$.

4 Ibid., 577 b. En la Galatea la necesidad de colocar a los pastores en un ambiente abstracto, suniversal» y no shistórico», impide que los sacerdotes (como el venerable Telesio) pertenezcan a una religión concret.

II, 49 ; RM, V, ${ }_{484}$

I, 27 ; RM, II, 345 .

II, 62; RM, VI, 264

Licenciado Vidriera, edic. Schevill-Bonilla, pág. 103.
La piedad religiosa se ha manifestado en otras formas, que conviene no olvidar para que nuestra información sea cabal. Un Dr. Antonio de Sosa, compañero de Cervantes, dijo, en $2 \mathrm{I}$ de octubre de I580, que éste «se ocupaba muchas veces en componer versos en alabanza de nuestro Senor y de su bendita Madre, y otras cosas santas y devotas, algunas de las cuales comunicó particularmente conmigo» 1 . Justamente, en las comedias relativas a su estancia en Argel encontramos avivado el sentimiento religioso. Cristianismo representaba para Cervantes: libertad, patria y civilización, frente a la barbarie del turco argelino. En El trato de Argel V, 75) suspira por el rescate de los niños víctimas de la sodomía; en esta comedia Sayavedra perora como podría hacerlo un misionero (págs. 84-90); hay oraciones devotas (págs. IOO-IOI) ${ }^{2}$, etc. A veces parece esta obra una comedia de santos. El caso es poco frecuente en Cervantes. Creo que hay que tener en cuenta el carácter especial del género dramático de la época, que debía apoyarse en sentimientos heroico-religiosos, aptos para la emoción popular. Hay verdadera exaltación religiosa en Los baños de Argel, donde un padre cautivo dice de sus hijos (I, 282):

$$
\begin{aligned}
& \quad \text { Y si veis que se endereza } \\
& \text { de Mahoma la torpeza } \\
& \text { a procurar su caída, } \\
& \text { quitadles antes la vida } \\
& \text { que ellos pierdan su limpieza. }
\end{aligned}
$$

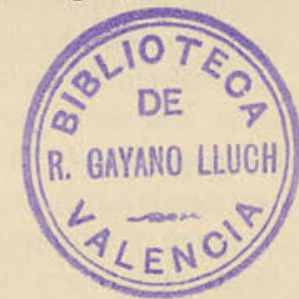

En la misma obra (págs. 268-274) un renegado mata a otro, y declara heroicamente ante el cadí que aspira a ser mártir de Cristo. El recuerdo del ambiente, realmente dramático, de la cautividad argelina y las condiciones del género hicieron que Cervantes se abandonara - sin crítica - a pulsar una nota tradicional que no hallamos en sus novelas, en las que su genialidad y su pensamiento adquieren modalidades supremas.

1 Véase Torres Lanzas, Revista de Archivos, 1905, pág. 396.

2 También en La gran Sultana, II, 173. 
Habría que tener asimismo en cuenta las poesías religiosas, de tono corriente, consagradas a San Jacinto, a Santa Teresa, a San Francisco.

Recuérdese, no obstante, que en El rufián dichoso toma actitud de franca reserva respecto de los milagros que narra, lo mismo que en el Quijote procede con tanta cautela como ironía ante las maravillas de Santiago Apóstol: «Muchas veces le han visto visiblemente..., matando los agarenos escuadrones; y desta verdad te pudiera traer muchos ejemplos que en las verdaderas historias españolas se cuentan» 1 . $\mathrm{Y}$ decía así en El rufián dichoso, como vimos en la página 65 : «Todo esto es verdad de la historia... Todo esto fué así, que no es visión supuesta, apócrifa ni mentirosa... Esta visión fué verdadera, que ansí se cuenta en su historia.»

1 II, 58; RM, Vl, 167-168. Recuérdese que Cervantes se mostró riguroso en cuanto a admitir milagros (véase pág. 64). Quevedo acepta mucho más propicio las fábulas pretéritas, y blande su espada en honor del Patrón de España: «Es de Santiago el patronato de las Españs por derecho divino; cŕpole en el repartimiento de los apóstoles, pañas por derecho propio santo Apostol. Hi djo que Cristo le habla dado el patronato de España; refiérelo así en su privilegio el rey don Ramiro [?]; confírmanlo otros muchos reyes que dicen lo propios (Quevedo, Su espada por Santiago, Rivad., XLVIII, 433b). El P. Mariana se mostró, en cambio, por demás excéptico en lo tocante a la venida a España del Apóstol Santiago, y expresa sus dudas en el típico estilo de la época de la Contrarreforma: $\mathrm{L}$ as razones con que se persuadieron ser aquel sepulcro y aquel cuerpo el del sagrado Aṕ́stol no se refieren; pero no pulcro y auel cierpo el dela cona Apóstol no se rener pero no hay duda sino que cosa tan grande no se recibió sin pruebas bastantes.» Líneas más abajo su probidad de historiadọr le hace decir abiertamente: «No dejaré de avisar, antes de pasar adelante, que algunas personas doctas y graves estos años han puesto dificultad en la venida del Apóstol Santiago a España; otros, si no los mismos, en la invención de su sagrado cuerpo por razones y textos que a ello les mueven. Sería largo cuento tratar esto de proposito, y no entiendo sea expediente con semejantes disputas y pleitos alterar las decociones del publo, ar especial tan asentados y firpleitos alterar las decocionos del pucblo, en especial tan asentadas y firmes como ésta es》 (Historia de España, I6oI, lib. VII, cap. V). ¡Cómo econtrarreformiza» nuestro gran jesuíta, y qué claramente destacan sobre este fondo las irónicas frases de Cervantes!
El santuario de Guadalupe está ensalzado en Persiles: «La santísima imagen, que es salud de las enfermedades, consuelo de los afligidos, madre de los huérfanos y reparo de las desgracias» ${ }^{1}$. Pero des absolutamente ingenuo lo que se dice de los milagros de Guadalupe?: "De tal manera hicieron aprensión estos milagrosos adornos [muletas, cadenas, etc.] en los corazones de los devotos peregrinos, que volvieron los ojos a todas las partes del templo, y les parecía ver venir por el aire volando los cautivos envueltos en sus cadenas a colgarlas de las santas murallas, y a los enfermos arrastrar las muletas, y a los muertos, mortajas, buscando lugar donde ponerlas, porque ya en el sacro templo no cabían: ta n grande es la suma que las paredes ocupan.» La impresión de que Cervantes desconfiaba un poco de tanta maravilla se confirma al leer algo análogo respecto de Nuestra Señora de Loreto, «en cuyo santo templo no vió paredes ni murallas, porque todas estaban cubiertas de muletas, de mortajas, de cadenas, de grillos, de esposas, de cabelleras, de medios bultos de cera y de pinturas y retablos que daban manifiesto indicio de las innumerables mercedes que muchos habían recebido de la mano de Dios, por intercesión de su divina Madre, que aquella sacrosanta imagen suya quiso engrandecer y autorizar con muchedumbre de milagros, en recompensa de la devoción que le tienen aquellos que con semejantes doseles tienen adornados los muros de su casa. Vió el mismo aposento y estancia donde se relató la más alta embajada y de más importancia que vieron, y no entendieron, todos los cielos y todos los ángeles y todos los moradores de las moradas sempiternas» ${ }^{2}$. El relato de tan extraordinarios prodigios debe conexionarse con la doctrina del autor sobre los milagros, con lo que sabemos de su espíritu crítico y con lo que luego hemos de decir ${ }^{3}$.

1 Rivad., I, 631 b.

2 Licenciado Vidriera, edic. Schevill-Bonilla, pág. 82

Recuérdese el texto de Trento: «Deben ser absolutamente condenados... los que afirman que no se deben honrar ni venerar las reliquias de los santos; o que es en vano la adoración que éstas y otro 
Las romerías a Santiago aparecen en Las dos doncellas; los peregrinos pasan por Montserrat, "haciendo lo que a buenos y católicos cristianos debían» ${ }^{1}$. Isabela, en La española inglesa, "no ganaba otros jubileos que aquellos que en el monasterio se ganaban. Desde su casa y desde su oratorio andaba, con el pensamiento, los viernes de cuaresma, la santísima estación de la cruz y los siete venideros del Espíritu Santo» ${ }^{2}$. Al llegar a Lisboa los peregrinos de Persiles, dice Antonio: "Agora sabrás del modo que has de servir a Dios..., los ricos templos en que es adorado..., las católicas. ceremonias con que se sirve, y notarás cómo la caridad cristiana está en su punto...: el que en [los hospitales] pierde la vida, envuelto en la eficacia de infinitas indulgencias, gana la del cielo» ${ }^{3}$. Y por si algo faltaba para hacer resaltar el fondo de severa ortodoxia que Cervantes ha querido dar sus obras, hallamos aquí (pág. 667$)^{4}$ una completa exposición de los dogmas católicos. A Auristela le explican «desde la invidia y soberbia de Lucifer» hasta «la venida de este Señor a juzgar el mundo sobre las nubes del cielo». Sancho, por su parte, cree «firme y verdaderamente en Dios y en todo aquello que tiene y cree la Santa Iglesia Católica Romana» (II, 8).

Todo ello es típico del espíritu que anima la Contrarreforma, que en Cervantes se manifiesta con rara exuberancia. Dijérase al autor preocupado - ya lo indiqué antes - por dar impresión de fidelidad absoluta, de estar fundido con las creencias de la sociedad, de participar del propósito defensivo que inspiraba a la Iglesia, y que se manifestaba en todos los órdenes de la civilización. En I594 se recubrieron las

monumentos sagrados reciben de los fieles; y que son inútiles las frecuentes visitas a las capillas dedicadas a los santos con el fin de alcanzar su socorro» (Concilio de Trento, sesión XXV, año 1563).

1 Rivad., I, pág. $210 a$

2 Edic. Schevill-Bonilla, pág. 57

3 Rivad., I, 623 b.

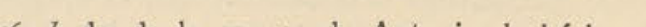
expone sus creencias religiosas según el esquema oficial. desnudeces de las figuras alegóricas con que Guglielmo della Porta había exornado el sepulcro de Paulo III. El papado se preocupaba enérgicamente de hacer servir el arte para fines religiosos. De Gregorio XIII (I 572 -I 585) se cuenta que erigió muchos edificios, no tanto para gloria suya, como por motivo de piedad; y que acostumbraba a decir que el edificar era un deber de amor público. Cuando este pontífice fundó la Academia de San Lucas (1577) lo hizo para ayuda al arte, decaído por causa de elementos innobles y paganos, a fin de utilizarlo para la propaganda cristiana ${ }^{1}$. Y Cervantes escribe novelas «ejemplares», y en Persiles nos muestra paradigmas de amores que no rozan los sentidos.

NO CONFORMISMO

Las cosas son, sin embargo, bastante más complicadas. No era posible tomar casi dos siglos, encendidos por el culto a la vida y a la razón, y enterrarlos tanto que no trascendiera alguna vez el fuego interior que seguía su obra por bajo de cuantas envolturas quisieran ponerle. Época maravi1losa esta de la Contrarreforma, llena de dualismos (sin duda efectivos y sinceros en muchos casos), pero también de hábil disimulo, de audacia contenida, de mucho tirar la piedra escondiendo muy luego la mano. A nuestro Cervantes es innegable que se le ven las costuras en más de un caso. En medio de tanta piedad, de tanta unción, a lo mejor nos hace un maligno guiño, reprimido prestamente, pero que aleja toda idea de que él admitiera en bloque y sin más ni más cuanto aceptaba el vulgo de su tiempo sobre asuntos religiosos. Sin que ello suponga que Cervantes poseía en su mente un sistema de libre pensamiento, ni que fuese un «libertin» a la francesa; Cervantes era católico, apostólico, romano..., pero, posee al mismo tiempo una ideología no cristiana (reflejada en su concepción de la naturaleza y de la

1 Véase Weisbach, Der Barock als Kunst der Gegenreformation, 1921, págs. 8-9. 
moral); además, ciertas prácticas y creencias excitan su crítica, y de vez en cuando se le escapa una malicia ${ }^{1}$. Situación que nada podrá extrañar ahora, cuando quienes se llaman católicos (y lo serán sinceramente) poseen una tabla de dogmas. para su acomodo particular, y toman y dejan de Roma-en el pensar y en el obrar - lo que a bien tienen. La diferencia es que esta actitud, hoy perfectamente frívola, era hacia I600. algo muy serio que bordeaba la tragedia, y obedecía a causas profundas, según he tratado de demostrar.

Menéndez Pelayo pasó sobre este punto como sobre brasas, y nada preciso y concreto quiso decirnos: "Si los que pierden el tiempo en atribuir a Cervantes ideas y preocupaciones de libre pensador moderno conociesen mejor la historia intelectual de nuestro gran siglo, encontrarían la verdadera filiación de Cervantes, cuando su crítica parece más. audaz, su desenfado más picante y su humor más jovial e independiente, en la literatura polémica del Renacimiento; en la influencia latente, pero siempre viva, de aquel grupo erasmista, libre, mordaz y agudo... Cervantes nació cuando el tumulto de la batalla había pasado, cuando la paz se había restablecido en las conciencias» ${ }^{2}$.

Se nos presenta aquí a Cervantes como chico travieso

1 El lector sabrá disculpar mi insistencia; pero la extremo, porque me repugnaría infinito que en un problema rigurosamente científico, como es éste, vinieran a mezclarse impropias actitudes de «derecha» de «izquierda». Siguiendo la idea de Cervantes, que la verdad es una aspiro sencillamente a obtener claridad, huyendo de viejas ingenuida-

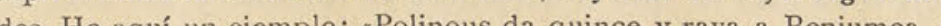
des. He aqu un jemplo: Polinous da quice y raya a Benjumea, cuantos han supuesto que el ingenio cristiano, segun frase proverbial de su contemporáneo Urbina, el teólogo católico, el esclavo de Santísimo Sacramento, el fraile terciario, el que pidió y recibió la extremaunción con sus sentidos cabales, el cuasi fanático, según cuas se aventura a calificarlo Valera, fué un miserable farsante que ocultó toda su vida sus ideas librepensadoras y antirreligiosas por miedo (ridícula especie, tratándose de Cervantes) al Tribunal de la Inquisi-

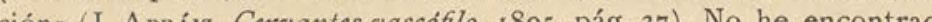

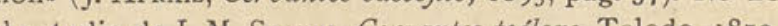
l estudio de J. M. Sbarbi, Cervantes teólogo, Toledo, 1870.

2 Cultura literaria de Cervantes, pág. 15. que a veces se permite bromas picantes y desenfadadas, merced a la influencia «latente... de aquel grupo erasmista, libre, mordaz y agudo». Menéndez Pelayo - al que tanto debemos, sean cualesquiera las diferencias que de él nos aparten hoy - cuando habla de erasmismo piensa en las críticas mordaces contra los monjes o la vida religiosa y en detalles satíricos; eso se desprende de cuanto escribí en sus Heterodoxos. Para mí, Erasmo es mucho más que eso, representa una nueva concepción religiosa, una ideología de acuerdo con las ideas humanísticas. El lector atento ha tenido ya ocasión de observarlo. Eso hace que, al encaminar yo a Cervantes hacia el erasmismo, no coincida con Menéndez Pelayo casi más que en las palabras; el erasmismo de Cervantes significó para el gran crítico mucho menos que para mí, y me atrevería a decir que significó cosa distinta. Sinceramente lamento ahora que, habiendo hablado tan a menudo de ello, nunca pensara Menéndez Pelayo en darnos una meditada apreciación de ese grupo erasmista y de sus ideas religiosas, morales y, en general, humanas. Gracias a esa laguna puede hablarse de "paz en las conciencias» a fines del siglo xvi, y tratarse, con cierto elegante descuido, del erasmismo, es decir, de algo que, con buen acuerdo, juzgó la Iglesia en el siglo xvı peligrosísimo para su existencia, tanto teológica como prácticamente.

Pero de modo concreto, ¿̨dónde están reunidas y sistematizadas esas manifestaciones "no conformistas» de nuestro autor? Se trae a cuento a menudo lo de «con la Iglesia hemos topado», lo de vivir los alemanes con libertad de conciencia, y quizá pasajes ambiguos, aducidos con ingenuo propósito de anticlericalismo, postura inútil para el historiador. $Y$ eso me parece que es todo ${ }^{1}$.

Conviene considerar, como siempre, no sólo el Quijote, sino las demás obras. En la segunda edición, publicada por

1 Es útil ver, por tratarse de algo preciso, lo que dice Rodríguez Marín $(\mathrm{V}, 248)$ sobre los expurgos inquisitoriales de que fué objeto el Quijote en 1624 y 1632 . 
Juan de la Cuesta, de la Primera parte del Quijote, en el mismo año de 1605 , aparece una variación importante:

PRIMERA EDICIÓN DE 1605

Mas ya sé que lo más que él hizo [Amadís] fué rezar y encomen darse a Dios; pero squé haré de rosario, que no le tengo? En esto le vino al pensamiento cómo le haria, y fué que rasgo una gran tira de las faldas de la camisa, que andaban colgando, y dióle once ñudos, el uno más gordo que los demis, esto le sirvio de rosario el tienso gue alli esturo, donde reso un 1 ique alli estwo, donde read un millón de Avemarias. Y lo que le fatigaba, etc.» 1 .

Se le fué la pluma a Cervantes; si el pañal astroso de Don Quijote sirve para rezar en él un millón de Avemarías, poca importancia tienen en este momento para el autor el rosario y las avemarías ${ }^{2}$. Ni Lope ni Quevedo se habrían atrevido a tal profanación. Alguien debió advertirlo, y Cuesta o, probablemente, el mismo Cervantes quitaron más que aprisa el escandaloso pasaje. La Inquisición portuguesa mandó tachar en I624 este otro texto del capítulo XVII de la primera parte: «Luego dijo sobre la alcuza más de ochenta pater nostres y otras tantas avemarías, salves y credos, y a cada palabra acompañaba una cruz a modo de bendición. Corresponde mal tanta sorna con los alardes de ortodoxia; y no es sólo esto, porque en la Segunda parte, capítulo XXIII, el héroe nos presenta así a Montesinos: «No traía arma ninguna, sino un rosario de cuentas en la mano, mayores que

1 I, 26; RM, II, 328. Casi todas las ediciones modernas traen sólo el texto de la segunda columna.

2 Después de todo había precedentes doctrinales en autores gravísimos: «Mandónos el Señor que, cuando orásemos, no hablá semos mucho, sino que multiplicásemos más la afección y amor que no las palabras» (Francisco DE Osuna, Tercer abecedario, edición Nueva Bibl. de Aut. Esp., pág. 461 ). medianas nueces, y los dieces asimismo como huevos medianos de avestruz» ${ }^{1}$. Leemos en Persiles: «Apesgábale el cuello un rosario, cuyos padrenuestros eran mayores que algunas bolas de las con que juegan los muchachos al argolla» 2 .

No mayor respeto merecen al gran novelista ciertas ceremonias eclesiásticas. Sancho cambia el mal aparejo de su burro por el bueno quitado al Barbero; y Cervantes explica: «Hizo mutatio capparum, y puso su jumento a las mil lindezas» ${ }^{3}$. La mutatio capparum era la que hacían los cardenales en Roma al acercarse el tiempo caluroso; se compara, pues, a un asno con un cardenal, todo lo en broma que se quiera, pero se compara ${ }^{4}$. Y que esta irrespetuosidad hacia los sa-

1 RM, IV, 463. Se alude también al srosario de sonadoras cuentas» en Rinconete, edic. Rodríguez Marín, I920, pág. 262.

2 Rivad., $634 a$.

3 I, 2 I; RM, II, 154

4 La explicación de este trueque de capas la da Clemencín, 1833. II, 160. Amezúa, edic. del Coloquio, pág. $66_{3}$, trae algún dato más que en nada importante varía la explicación de Clemencín; lo que debía explicarse en el Coloquio es por qué Cervantes dice: «era tiempo de mutatio capparum, en el cual los cardenales no se visten de rojo, sino de morado», siendo así que el Ceremonial Romano explica que al hacerse la mutación, en Pentecostés, los cardenales se ponen capas «cum serico rubro sive cremesino». El texto que cita Amezúa nadi pesencin ande, porque se limita a decir que los cardenales traen ala de choro morada o colorada, segin los tiemposs, es decir, morada hasta cierta época de la primavera, y luego encarnada. Amezúa se ha confundido, y en nota a la pág. 664 supone que la mutatio citada en el Quijote es distinta de la aludida en el Coloquio. Creo que debe pen. sarse sencillamente que Cervantes en el Coloquio de los perros no se acordaba de sus experiencias cardenalicias de hacía muchos años, y en lugar de escribir que los cardenales, al llegar la mutación, se vestían de encarnado, dijo que se vestín de morado - Refiriéndose al pitín de (P) que está solamente en la forma». ¿Pues en qué otra cosa podía estar Clemencín, comentarista muy objetivo y razonable, observa: «Atendiendo su genio y humor, no es imposible que esta mutación de capas, aplicada aquí a la de los aparejos de los asnos, envuelva alguna alusión maligna a personas y sucesos de aquel país y de aquella épocas, es decir, cuando servía al cardenal Aquaviva. 
grados ornamentos no era ocasional, lo demuestra otro pasaje de El retablo de las maravillas (IV, I I9): "jHideputa, y cómo que se vuelve la mochacha! Sobrino Repollo, tú, que sabes de achaque de castañetas, ayúdala y será la fiesta de cuatro capas.» Aquí se compara el lascivo baile de la hija de Herodías ${ }^{1}$ con una misa de cuatro prebendados «con cetros de plata y capas de brocado, que asisten al oficio y canturia», como explica Covarrubias.

Hablando antes del sentido crítico del autor (pág. 78) citamos dos buenos ejemplos. La lluvia es un producto natural de las nubes, no capricho celeste; las rogativas del vulgo piden, pues, una alteración de las leyes naturales. No deja de ser asimismo curioso que las dos veces que Don Quijote halla en su camino cortejos religiosos (entierro o rogativa) arremeta contra ellos, sin que Cervantes se detenga en reparos piadosos, más justificados aquí que cuando sin motivos prorrumpe en declamaciones de respeto a la Iglesia. Puede ser que esto nada tenga de particular; pero como la crítica de las procesiones es grata a Erasmo, deben recordarse aquellas «procesiones, rogativas y disciplinas, pidiendo a Dios abriese las manos de su misericordia y les lloviese» ${ }^{2}$, una de las cuales pone en gran aprieto Don Quijote - junto con lo que Erasmo dice en su Modus orandi ${ }^{3}$ : "In publicis supplicationibus ac pompis ecclesiasticis, quantum videmus apud quasdam gentes superstitionis... multa ridicula tum fiunt, tum etiam dicuntur... Sunt enim ista vestigia veteris paganismi.» Recordemos también el tremendo pasaje de Los alcaldes de Daganzo, en que Humillos dice que no sabe leer, porque eso son quimeras

que llevan a los hombres al brasero.

El medio de no caer en las garras inquisitoriales era, por tanto, permanecer en una absoluta ignorancia; así lo enten-

1 Cervantes, por descuido, dice: «La llamada Herodías, cuyo baile alcanzó en premio la cabeza del Precursor de la vida.s Comp.: Evangelio, Marcos, VI, 22.

2 I, $52 ; \mathrm{RM}$, III.

3 Opera Omnia, t. V, col. 1120 dería el vulgo, atento a los peligros de las lecturas, y Cervantes lo repite Dios sabe con qué sorna o con qué amargura.

Don Quijote comenta el rasgo de San Martín partiendo su capa con el pobre, tan celebrado, y tan a menudo representado por escultores y pintores: "Creo que fué más liberal que valiente, como lo puedes echar de ver, Sancho, en que está partiendo la capa con el pobre, y le da la mitad; y, sin duda, debía de ser entonces invierno; que si no, él se la diera toda, según era de caritativo» ${ }^{1}$. Al hilo de esta crítica socarrona, jadónde llegaría el autor en su comentario íntimo?

Algo hay también sobre los santos milagreros. En la comedia La Entretenida, D. Antonio, desesperado, busca a su dama, encerrada no se sabe en qué lugar. Desechan el recurso de la astrología, y añade su amigo D. Francisco:

$$
\begin{aligned}
& \text { Si acaso Marcela fuera } \\
& \text { alguna joya perdida, } \\
& \text { yo buscara otra salida, } \\
& \text { que buena en esto la diera. } \\
& \text { Santos hay auxiliadores, } \\
& \text { veinte o más, o no sé cuántos; } \\
& \text { pero no querrán los santos } \\
& \text { curarnos de mal de amores }{ }^{2} \text {. }
\end{aligned}
$$

Con el espíritu de la nota anterior ha de relacionarse la recomendación de Sansón Carrasco al ama del Ingenioso Hidalgo: «Téngame aderezado de almorzar alguna cosa caliente, y de camino vaya rezando la oración de Santa Apolonia, si es que la sabe; que yo iré luego allá y verá maravillas... - ¿La oración de Santa Apolonia dice vuestra merced

1 II, 58; RM, VI, 155 . Véase pág. 310.

2 III, en el cielo su protector, su santo tutelar..., y que se encuentran distribuídas entre estos grandes y poderosos señores de la corte celestial las diversas incumbencias del protectorado. Uno cura el dolo de muelas, otro ayuda a las parturientas; otro, a encontrar las cosas perdidas; este vela por la seguridad y prosperidad de los ganados... Dejo los demás porque no acabaría nunca» (Erasmo, Elogio de la locura, edic. cit., pág. 67 ). 
que rece? Eso fuera si mi amo lo hubiera de las muelas; pero no lo ha sino de los cascos. - Yo sé lo que digo, señora ama», replica el guasón del Bachiller ${ }^{1}$.

No hay modo de tomar tampoco en serio el encargo que Cristóbal de Lugo da a un ciego en El rufián dichoso (II, 29):

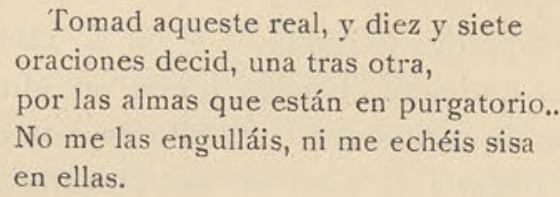

En la comedia La Entretenida el viejo escudero Muñoz deja a su señora en la iglesia y se sale a la calle. Tranquiliza así su conciencia:

\author{
Viejo en pie, largo sermón, \\ temblores de puro frío, \\ y el estómago vacío, \\ no llaman la devoción.
}

1 II, 7; RM, IV, 153 y 161. Erasmo censura a los que supersticiosamente rezan a San Cristóbal para librarse de mala muerte; a San Roque, para evitar la peste; a Santa Bárbara y San Jorge, para no caer en mano de enemigos. Hay quien ayuna a Santa Apolonia, para que no le duelan las muelas; etc. Los paranos hacín lo mismo bon pio y Neptuno. Cito texto latino: Sunt qui certos Divos, caltau quibusdam colunt ceninonis. Alins Christophorum singulis salutat diebus, sed non nisi conspecta ejus imagine, quo tandem spectans? Nempe huc, quod sibi persuaserit, sese eo die a mala morte tutum fore. Alius Rochum quemdam adorat, sed cur? Quod illum credat pestem a corpore depellere. Alius Barbaræ, aut Georgio certas preculas admurmurat ne in manus hostium veniat. Hic jejunat Apollonix, ne doleant dentes...; Hieroni cereolus accenditur, ut res que periit recipiatur. Oure quiddem pietas nisi a respectu commodo perit incomode noom non est ut non ita multum absit a superstitione eorum, qui quondam Herculi decimam bonorum partem, vovebant ut ditescerent, aut Assculapio gallum, ut a morbo revalesce:ent, aut qui Neptuno taurum cædebant, ut feliciter navigarent. Nomina quidem commutat sunt sed finis utrisque communis, (ERAsmo, Enchiridion, en Opera Omnia, 1704, V, colums. 26-27). Volveré sobre este punto al hablar del cristianismo de nuestro autor.
Aquíal sol estaré, en tanto que se quiebra la cabez este fraile, rica pieza, que todos tienen por santo ${ }^{1}$.

CRÍTICA HUMANISTA

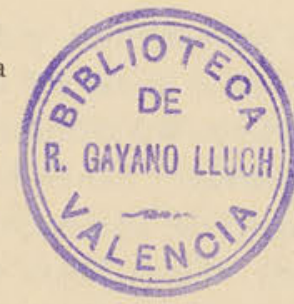

Hay un diálogo en el Ouijote lleno de complicadas ironías. Sancho tiene algunas dudas acerca de dónde paran las almas de «esos Julios o Agostos, y todos esos caballeros hazañosos que ha dicho». Don Quijote responde gravemente: «Los gentiles, sin duda, están en el infierno; los cristianos, si fueron buenos cristianos, o están en el purgatorio o en el cielo.» Mas slo pensaba Cervantes? A Sancho ${ }^{2}$ se le ocurre la endiablada idea de separar los grandes hombres de la antigüedad y los santos, según el ornato de sus tumbas respectivas: "¿Tienen delante de sí lámparas de plata, o están adornadas las paredes de sus capillas de muletas, de mortajas, de cabelleras, de piernas y de ojos de cera?» $\mathrm{Y}$ así, sale otra vez aquí la misma observación hecha con motivo de los santuarios de Guadalupe y de Loreto (pág. 259), cuya reiteración confirma la malicia con que siempre ocurre. Sancho insiste en que es superior «la fama del que resucita muertos, da vista a los ciegos, endereza los cojos y da salud

1 Ibid., pág. 98. Dice Erasmo de los predicadores en el Elogio de la locura (edic. cit., pág. 108): «Observad cómo gesticulan.... cómo hacen retumbar toda la iglesia con el estrépito de sus voces. En el silencio del claustro es donde aprenden esta vehemente manera de evangelizar que cada hermanuco transmite a otro, como secreto de suma importancia.» Y en los Coloquios (Origenes de la Novela, VI, 153): Escojo los [sermones] que he de oír, porque hay algunos que es mejor no haberlos of́do.s

2 A Sancho, que ha dicho poco antes con infinito cinismo: $\&$ Verdad que soy algo malicioso, y que tengo mis ciertos asomos de bellaco; pero todo lo cubre y tapa la gran capa de la simpleza mía, siempre natural y nunca artificiosa; y cuando otra cosa no tuviese, sino el creer, como siempre creo, firme y verdaderamente, en Dios y en todo aquello que tiene y cree la santa Iglesia Católica Romana...) (II, 8; RM, IV, 175 ). 
a los enfermos, y delante de sus sepulturas arden lámparas, y están llenas sus capillas de gentes devotas que de rodillas adoran sus reliquias... Esta fama, estas gracias, estas prerrogativas..., tienen los cuerpos y las reliquias de los santos, que, con aprobación y licencia de nuestra santa madre Iglesia, tienen [jotra vez!] lámparas, velas, mortajas, muletas, pinturas, cabelleras, ojos, piernas, con que aumentan la devoción y engrandecen su cristiana fama ${ }^{1}$.

Es imposible no asociar tal sátira de la superticiosa piedad que reflejaban los santuarios con las críticas análogas de Erasmo, difundidas por toda su obra, pero concentradas en los Diálogos, traducidos íntegramente al italiano, y de modo parcial al español ${ }^{2}$. Así, por ejemplo, en el titulado Peregrinatio religionis erga ("Il peregrinaggio per voto») dicen a los peregrinos que «il latte della beata Vergine, il quale in altri luoghi si mostra, è venerabile; ma che questo è più da onorare, perchè è stillato del petto della beata Vergine... $\mathrm{Ci}$ furono mostrate assai reliquie, teste, denti, mani $e$ intere braccia, etc. ${ }^{3}$. En la traducción española del Coloquio de religiosos se alude a menudo a temas afines: "Estando en Bretaña, vi el sepulcro de Santo Tomás de Conturbel cargado de perlas infinitas e de piedras de gran valor, allen-

II, 8; RM, IV, 182-183. Véase con qué diferente espíritu alude al mismo tema Lope de Vega :

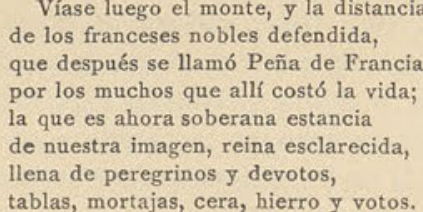

(La hermosura de Angelica, 1604, canto II, edic. Obras sueltas, $\times 776, \mathrm{II}, 23$.

2 Colloqui familiari di Desiderio Erasmo, Vinegia, 1 549, traducción de Pietro Lauro Modonese, Han sido reproducidos en parte por B. Croce, 1914. La traducción espanola del siglo xvi puede verse B. Croce, rer4. La traduecion espola los Origenes de la Novela, de Menéndez Pelayo, tomo IV. Entre am. bas, Cervantes tenía muy a su alcance todos los Diálogos de Erasmo. 3 Edic. cit., págs. 172 y 179 . Todo el coloquio es una crítica mordaz de los santuarios. de de otras maravillosas riquezas que tenía. Yo más querría que de todas estas cosas se quitase lo superfluo e se repartiese a pobres» ${ }^{1}$. En el coloquio el Naufragio se relatan las promesas que formulan los amenazados de naufragio: «Un inglés prometía montes de oro a Nuestra Señora de Walsingham si llegaba a tierra vivo. Otros prometían cien otras cosas al lignum crucis que se venera en tal lugar, otros al mismo lignum que se venera en tal otro. Lo mismo acontecía con la Virgen María, que reina en muchas partes; porque el voto se considera nulo si se calla el lugar.-Antonio. ¿Qué tontería!; como si los santos no habitaran en el cielo» ${ }^{2}$.

Hemos visto que Don Quijote piensa que «los gentiles, sin duda, están en el infierno», y que dudábamos en atribuir seriamente tal idea a Cervantes. Erasmo había dicho: "Con dificultad me atiento de no creer determinadamente que Sócrates está en el número de los santos que en ley de natura sirvieron a Dios; ca no se debe dudar que hobo algunos ante del advenimiento de Cristo, cuyos nombres no sabemos. ¡Oh cuántos cristianos vemos morir, no con aquel ardor e verdadera confianza que Sócrates moría...., haciendo confianza en las cosas de que no debría tanto fiarse, como son treintanarios, misas del conde, oraciones peculiares e otras semejantes invenciones casi supersticiosas!», etc. ${ }^{3}$. Y aún más explícitamente: «Yo muchas veces hallo algunas cosas que los antiguos dijeron, o los gentiles escribieron, hasta los poetas, las cuales son tan puras, tan santas, tan divinas, que no puedo creer sino que cuando las escribían alguna gracia especial de Dios regía sus corazones para ello; e por ventura a más se extendió el espíritu de Dios en repartirsu doctrina de lo que nosotros pensamos, e aun en la vida, pienso haber muchos en la compañía de los santos, que acá no sabemos» ${ }^{4}$

1 Origenes de la Novela, IV, 195 a.

2 Edic. Croce, pág. 230.

3. Coloquio de religiosos, en Origenes de la Novela, IV, 192

4 Ibid., pág. $189 b$. 
«Este libro es griego: tiene algunas obras morales de Plutarco..., en las cuales hay $\tan$ santa doctrina, que me parece cosa maravillosa haber entrado sentencias tan evangélicas en corazón de hombre gentil» ${ }^{1}$. Multitud de otros textos podrían citarse sobre esta esencial manera de ver del humanismo, según el cual el cristianismo continúa sencillamente la más elevada filosofía de los gentiles egregios. Mal Lara se refiere a ello a cada paso: «Los gentiles tenían que ninguna cosa se hacía sin voluntad divina; nosotros tenemos que aquello se hace que a Dios aplace» ${ }^{2}$. Y Luis de Granada, refiriéndose a la doctrina platónica del amor, exclama : «Pues ¿qué cristiano habrá que no se espante de ver en estas palabras de gentiles resumida la principal parte de la filosofía cristiana, pues aquí se declara el fin de nuestra vida, que consiste en la contemplación y amor de la hermosura divina?» ${ }^{3}$. «Y porque en este ejercicio concuerdan los filósofos con los cristianos, parecióme engerir aquí la manera en que este gran filósofo [Séneca] se ejercitaba en este oficio. Lo cual servirá para confusión de muchos cristianos, que ni tienen ojos para saber mirar las maravillas que Dios ha obrado en este mundo, ni les pasa por pensamiento lo que este filósofo gentil siempre hacía» ${ }^{4}$.

La cuestión aquí implicada, es decir el destino último para las almas de los gentiles ilustres, es de las más difíciles dentro de la teología cristiana, y el lector disculpará que trate brevemente de ella en forma digresiva. Realmente Don Quijote al decretar que «los gentiles, sin duda, están en el infierno", hizo una afirmación por demás atrevida. Es realmente extraño que los comentaristas hayan pasado sin detenerse en este punto, cuando tanta importancia han sabido conceder a nimios detalles. Me parece que Cervantes ironiza, y pone en boca del Hidalgo una opinión vul-

Coloquio de religiosos, en Orígenes de la Novela, IV, 200 a.

2 Filosofia vulgar, 1568 , fol. $26 \mathrm{v}$.

Adiciones al memorial de la vida cristiana, Rivad., VIII, ${ }_{4} 8 \mathrm{I} a$.

4 Luis de Granada, Simbolo de la fe, Rivad., VI, i8z a. $\operatorname{gar}^{1}$ y extremada, que correría como válida. Prueba de ello es que la Inquisición, en los dos minuciosos expurgos que hizo del Quijote, no se creyó obligada a enmendar ese categórico aserto. Cervantes no pensaba en serio en la fatal condenación de los gentiles, como no lo pensaban otros escritores coetáneos, ni, sobre todo, la misma Iglesia, cuando tenía que enfrontarse con el grave problema, dogmática y teológicamente ${ }^{2}$.

No voy a exponer en detalle la complicadísima cuestión teológica que durante siglos, desde los primeros momentos del cristianismo hasta hoy, hace cavilar a católicos y protestantes ${ }^{3}$. En la actualidad es excusado decir que el asunto sólo

1 Recuérdese que Dante deja en un lugar especial del Infierno a los gentiles ilustres, que no verán a Dios, por no haber sido bautizados (Inf., IV, 25 y sigs.). De ese limbo salieron, sacados por Cristo, Adam, Abel, Noé, Moisés, Abraham, David, Israel, sed altri moltis Adam, Abel, Noé, M
pero no los paganos.

2 Me sirvo del excelente estudio de L. CAPÉran, Le problème du sahut des infideles, 1912, dos vols. ( Bibliothèque de Théologie Historique publiée sous la direction des professeurs de Théologie à l'Institut Catholique de Paris»). Capéran examina tanto el aspecto histórico como el teológico.

3 He aquí sólo un breve resumen. Cristo murió por salvar a toda la humanidad, dice el cristianismo desde San Pablo. Los primeros cristianos saben, sin embargo, que hace falta el bautismo para la salvación. Hay quien se preocupa por la suerte de sus padres, muertos sin conocer la nueva creencia. De ese terreno afectivo, la cuestión se eleva de plano por los apologistas más doctos. San Justino admite que Cristo, o sea el Verbo, actuó siempre, y todos participaron de la rán divin, a cristianismo sería una filosofía superior, que encierra toda la verdad, que parcialmente conocen las filosofías anteriores. Sócrates es como un profeta (Capéran, págs. 51-53). Otros padres en los primeros tiempos admiten que la verdad de la filosofía antigua procede de influjos bíblicos. La escuela alejandrina admitirá, en suma, que el espíritu de Dios actuó siempre sobre el hombre. Así responde Orígenes a Celso, que pregunta cómo Dios dejó pasar tantos siglos sin acordarse de que tenía que traer a la justicia los hombres: aEs qué antes no le pre(Ibíd., pág. 62).

El pueblo necesitó, sin embargo, explicaciones más concretas y materiales: Cristo baja a los infiernos a continuar allá su evangeliza- 
preocupa a las escuelas de teología; los católicos no teólogos suelen ignorar el alcance del problema. Mas en tiempo de Cervantes el humanismo, el protestantismo, el descubrimiento

ción. La primera Epistola de San Pedro dice: «Propter hoc enim et mortuis evangelizatum est $=$ sporque por esto también ha sido predicado el Evangelio a los muertos; (IV, 6). Y antes dice que Cristo «fué en espíritu a predicar a los espíritus encarcelados» (III, I9). Sobre esta base descansa el dogma de la bajada a los infiernos, que se interpretaba en los primeros siglos como predicación a las alas se erpretaba el inferno. Los a de Migne, S. G., IX, 265) admiten que la evangelización se extendió a todas las almas de buena voluntad, y no sólo a los que esperaban la venida de Cristo. La predicación en los infiernos la continúan los apóstoles. Contra Celso (que objetaba excéptico: «Supongo que no diréis que no habiendo convencido a los vivos, fué al infierno a convencer a los muertos»), Orígenes dirá que Cristo después de muerto fué a convertir a cuantos quisieron oirle. La teolón griega conergoza de gran favor entre los protestantes (Caperán, págs. 66 y 496). San Agustín admitirá que Cristo salvó en los infiernos a quien él quiso: «quos esse solvendos oculta nobis sua justitia judicabat» ( $D e G e$ nesi ad litteram, XXXIII, 63); considera como una herejía que Cristo salvase a todos los habitantes del infierno, y juzga un profundo misterio las palabras de San Pedro relativas a la evangelización de los muertos; acaba por negar la bajada a los infiernos interpretando los textos de manera tris orignale a los in textos de manera crics. 109). Dogmáticamente la Iglesia nunca ha dicho lo que Cristo hiciese en los infiernos; se limita a consignar el dogma «descendit ad inferos» 0 «ad infernos", como uno de los smysteria Christis (Concilio Lateranense IV, año 1215); me sirvo del Enchiridion symbolorum de rebus fidei, de Denzinger, Friburgo, 1913. No parece que a la Iglesià le haya interesado analizar dogmáticamente el famoso texto de la Epístola de San Pedro. La doctrina vulgar y consuetudinaria en la Iglesia occidental ha variado bastante las cosas al olvidar la evangelización del inferno ha variado buterno $y$ al sutitur el difernos por el a Luis de Granada: «Su sacratísima ánima bajó a aquel lugar del infierno, llamado el limbo de los santos padres, adonde estaban de tenid as las ánimas de todos los fieles que habían muerto y pasado desta vida en la fe y esperanza deste Redentor (que era el sacrificio que había de abrir el cielo, y hacer libre y franca la entrada a la vista de Dios), y que de allí los sacó, etc.s. (Compendio y explicación de la Doctrina Cristiana, Rivad., XI, 73 b.) de gentes no cristianas por españoles y portugueses concedieron a ese tema rango preeminente.

En la historia de este complicado asunto nos interesa destacar, que desviada por San Agustín la solución alejandrina de la evangelización póstuma, sólo quedaba abierta la vía mística, que Santo Tomás establece doctrinalmente con la teoría de la fe implícita (Capéran, Ob. cit., pág. 194), contenida en la noción de providencia; de ahí puede pasarse a la creencia en el mediador Cristo, esencial para la salvación. La escolástica acabará por admitir este principio: facienti quod in se est, Deus non denegat gratiam.

$\mathrm{Y}$ vengamos al humanismo, que es lo que principalmente ofrece interés para nosotros. La necesidad de salvar a los gentiles ilustres se siente con gran vehemencia desde el siglo xv. No podía caber duda acerca del destino final de quienes eran mirados como el coronamiento de toda sabiduría y virtud. Erasmo, como hemos visto, convertirá en santos a Cicerón y a Sócrates: «Sancte Socrates, ora pro nobis.» Es curioso notar que ya en nuestro Alfonso el Tostado (I 400 (?)-I 455 ) aparezcan atenuadas aquellas condiciones de fe implícita en el mediador Cristo que Santo Tomás exigía; supone, en cambio, que las almas de Sócrates, Platón y Aristóteles fueron sacadas por Cristo del limbo de los Santos Padres, gracias a la pureza de su conducta ${ }^{1}$; y no exige a tales filósofos ni el conocimiento del Dios de los judíos, ni noción del pecado original. El famoso obispo de Ávila lleva a este problema teológico la fe entusiasta del humanismo.

No ha tenido en cuenta Capéran a Pico de la Mirándola, que inclinado a hacer buena la suerte ulterior de los gentiles, no olvida las dificultades teológicas sobre que saltan el Tostado y Erasmo. Dice así: "La luz verdadera que tal vez ilumina a todo hombre que viene a este mundo, llegó a conocimiento de algunos de los que vivían en esa forma [amando el nombre de la religión y adorando a Dios]; y habiendo recibido y con-

1 Alphonsi Tostati, Upera Omnia, Venetiis, 1 596, XII, 107 $b$. Véanse otros textos en Capéran, Ob. cit., pág. 215. 
servado aquella luz, lograron la bienaventuranza. Nuestros más ilustres teólogos están firmemente conformes en aceptar que la verdad lució para todos los que, antes de la venida de Cristo, vivieron según la ley de naturaleza esculpida en sus mentes; y quienes fueron fieles a aquélla, se salvaron. Lo mismo puede aplicarse a los que, después del advenimiento de Cristo, nacieron en lugares adonde no llegó noticia de la ley cristiana, admitiendo que hayan existido, como algunos creen, quienes conservaran intactos los dones de la naturaleza. A pesar de ello consta que aquéllos, de quienes tan bien opinan (a saber, Sócrates, Platón y otros) sacrificaron a los dioses; lo cual, como todos los teólogos admiten, nunca puede hacerse sin. gran ofensa para Dios. Pero no nos apartemos demasiado de nuestro propósito. Cabe admitir, en todo caso, que la luz natural imbuída y congénita en cada hombre por obra de Dios, iluminó a aquéllos, para que conociesen la obligación de guardar buenas costumbres y adorar a Dios. Así fué que Sócrates (como él dice) sacó del cielo su filosofía y la situó en las ciudades, etc. ${ }^{1}$.

El conflicto, como se ve, era bastante agudo, y otros textos pudieran allegarse que lo manifiestan. ¿¿́ómo podía decre-

1 J. Pico de la Mirándola, De studio divinae et humanae philosophiae, en Opera Omnia, Basilea, 1557, II, 15 . He aquí el original latino: ${ }_{4} \mathrm{Et}$ forte eorum aliqu forte eorm alifibus qui scilicet tali instituto vitam degebant lux vera quae illuminat omnen hominen venientem in hunc mundum innotuit: qua recepta et custodita, beatitate donati sunt. Nostrorum enim theologorum qui celebriores habentur firmus consensus est, eis omnibus qui ante Christi adventum vixere, secundum insculptam quorumlibet mentibus naturae legem veritate illuxisse: quam agnitam secuti salvati sunt: pari pacto si qui post Christi adventum aliquibus in locis nati ad quos Christianae legis fama non perveniat, an vero tales liqui extiterint qui natirae dona illibatacustodient non le dere. Los tamen de quibus bene ipsi opinantur, videlicet Socrates, Plato et alii diis sacrificasse memoriae proditum est. Quod nullo pacto unquam fieri absque magna Dei offensa omnes theologi consentiunt. Sed ne a proposito nimis divertamus, hoc saltem liquet naturale lumen cuilibet homini consertum congenitumque a Deo eis illuxisse, ut mores componendos censerent Deumque colendum. Sic Socrates philosophiam (ut ille inquit) evocavit e caelo, et in urbibus collocavit.» tarse sin gran cautela la salvación de los gentiles eminentes que habían sacrificado a otros dioses? Porque entonces no habría razón para que también no se salvaran quienes después de Cristo descollaron en ciencia y virtudes, no obstante practicar otras religiones; se comprende que Pico pensara en la armonía de todas las creencias. Pero de otra parte, ¿cómo mandar al infierno a espíritus que revelaban poseer ideas esenciales para el cristianismo?

La Iglesia, en este punto, ha procedido con prudencia y habilidad. Los humanistas, y aun los teólogos, han mandado a la gloria o al infierno a determinados filósofos, según sus personales preferencias. Ya vimos cómo procedieron el Tostado y Erasmo. Ginés de Sepúlveda quiere salvar a Aristóteles ${ }^{1}$; el jesuíta Pereyra declaró impíos a Sócrates, Platón, Séneca y Mercurio Trismegisto ${ }^{2}$; la Sorbona juzgó temerarios los entusiasmos de Erasmo; mas la Iglesia no decreta «ni un implacable ostracismo ni una escandalosa amnistía» ${ }^{3}$. Roma habría salido de su tradicional cautela si hubiese entrado a decretar la salvación concreta de este o el otro gentil; dejó que la tradición popular - ironizada por Cervantes - man- . dase al infierno al mundo precristiano; pero tuvo cuidado de no negar la posibilidad de que fuese al cielo el elegido por Dios en cualquier momento de la historia. La Iglesia no ha salido de su reserva dogmática más que en un caso, en el de la Virgen María, declarada libre del pecado original antes de venir Cristo al mundo; y aun así, mil ochocientos años tardó Roma en declarar dogma lo que tradicionalmente venía siendo creencia popular, no obstante la opinión de Santo Tomás y otros insignes teólogos ${ }^{4}$.

La doctrina de Trento, en cuanto a los gentiles, no da soluciones concretas ni terminantes. El lector corriente, no iniciado en los retorcimientos teológicos, sacaría, en tiempos

\footnotetext{
1 Opera omnia, Coloniae, 1602, lib. VII, epíst. 91.

2 Selectae Disputationes, Lugduni, 1604, 1I, 97.

3 Capéran, págs. 248-250.

4 Véase L. Coulange, La Vierge Marie, París, 1925.
} 
de Cervantes, la impresión de que era poco menos que imposible salvarse antes de Cristo. El Concilio decretó en la Sesión VI (1 547): «Habiendo perdido todos los hombres la inocencia en la prevaricación de Adán; hechos inmundos y, como el Apóstol dice, hijos de ira por naturaleza..., en tanto grado eran esclavos del pecado y estaban bajo el imperio del demonio, que no sólo los gentiles, por las fuerzas de la naturaleza, pero ni aun los judios por la misma letra de la ley de Moisés podían levantarse o lograr la libertad («inde liberari aut surgere possent»), aunque no estuviese extinguido en ellos el libre albedrío, pero sí debilitado en su fuerza, e inclinado al mal.» El libre albedrío no estaba destruído, pero. sí muy enfermo; pero tampoco permite el Concilio que se diga que ese libre albedrío no puede cooperar a la acción divina, «a Deo motum et excitatum». En suma, el Concilio ni comparte la doctrina protestante de que los gentiles van al infierno (contradicha por Zwinglio que los salva sin dificultad), ni acepta el entusiasmo erasmiano que canoniza a Sócrates y a Cicerón.

Por nuestra parte nos guardaremos mucho de terciar en $\tan$ espinosa controversia. Si me he detenido en ello, ha sido únicamente para que se perciba el amplio horizonte sobre que se proyectan muchas frases de Cervantes. La falta de estudios previos sobre la historia de los problemas teológicos en España y su conexión con la literatura me ha hecho extenderme tal vez más de lo debido; pero no me atrevía a decir nada que no estuviese bien fundado en autoridades irrecusables. Así se juzgarán mejor los entusiasmos de algunos de nuestros escritores clásicos respecto de los grandes varones de la gentilidad.

Ya vimos como Luis de Granada exaltaba el alto sentido cristiano de Platón y Séneca. Quevedo, ardiente senequista, explica así el problema: «Por esta y otras cláusulas me persuado que Séneca comunicó a San Pablo; no por las cartas que del uno al otro se leen con sus nombres sin su estilo» ${ }^{1}$.

1 Providencia de Dios, Rivad., XLVIII, 195.
Séneca fué en verdad contemporáneo de San Pablo; pero pensar que hubo relación entre ambos, es pura ilusión. Lo que a Quevedo le maravilla en Séneca se encuentra también en filósofos griegos que nada tuvieron que hacer con los apóstoles. Pero era preciso para Quevedo evangelizar un tanto a aquel escritor pagano, ya que "San Jerónimo le colocó en el catálogo de los escritores eclesiásticos, y San Agustín frecuentemente le citó, y otros gravísimos escritores católicos» ${ }^{1}$.

Cervantes sabe, y lo dice claramente, que hay aspectos fundamentales de la religión cristiana que son mero trasunto de la pagana: «Aquel famoso templo de la Rotunda, que en la antigüedad se llamó el templo de todos los dioses, y ahora, con mejor vocación, se llama de todos los santos» ${ }^{2}$. Está dicho al paso, sin insistir; pero el autor sabía lo que decía. Compárese si no este otro texto sobre la fiesta de las Mondas en Talavera: «Se preparaba para celebrar la gran fiesta de la Monda, que trae su origen de muchos años antes que Cristo naciese, reducida por los cristianos a tan buen punto y término, que si entonces se celebraba en honra de la diosa Venus por la gentilidad, ahora se celebra en honra y alabanza de la Virgen de las vírgenes» ${ }^{3}$. El culto a la Virgen, ‘guarda, pues, relación con el de Venus, como el de los santos con el de los dioses? Así lo creía el humanismo, en su afán de buscar un común denominador que uniese el mundo pre- y postcristiano. Erasmo, en el coloquio Naufragium, dice que «antes era Venus quien velaba por los marineros, porque se pensaba que había nacido del mar; y cuando cesó en tal cargo, reempla-

\footnotetext{
1 Providencia de Dios, Rivad., XLVIII, 195.
}

2 II, 8: RM, IV, 178. Erasmo, en el Enquiridion, compara los sacrificios que se hacin a los dioses con los favores que se solicitan de ficios que se hach a los doses con los favores que se solicitan de los santos a trueque de ofrendas: "Nomina quiden con suta sed finis utrisque communis» («Los nombres han variado, pero la finalidad es igual en ambos casos»). Véase Pinbav, Erasme: sa pensée religieuse, pág. 127.

3 Persiles, Rivad., I, 633 b. «Las pasadas fiestas de la gentilidad, a quien imita la de la Monda de Talaveras (634a). 
zaron esta madre que no era virgen por una Virgen que es Madre» ${ }^{1}$. Erasmo fué lejos en esta senda. Véase el adagio Panem ne frangito: «En la antigüedad con pan se sellaba la amistad. Unde et Christus princeps noster, distributo pane, perpetuam inter suos amicitiam consecrabat $=$ Así Cristo nuestro jefe, al distribuir el pan, consagraba amistad eterna entre los suyos.» En las ediciones posteriores de los Adagia no figura tan atrevida interpretación, que afecta a la esencia eucarística ${ }^{2}$. Y es que una vez comenzada la coordinación del mundo antiguo con el cristiano, era difícil trazar la raya de la prudencia. Erasmo llega a decir - y eso lo dejaron circular en romance-: «Si tomas el Testamento viejo y no miras otro que la historia y corteza de la letra, cuando cuenta que Adán fué formado del limo de la tierra..., çno te parece que es una fábula sacada de las ficciones de Homero?» 3

La postura humanista lleva a Cervantes a admitir que no hace falta la lumbre de la fe cristiana como base de ciertas creencias. Cide Hamete dice al principio del capítulo LIII de la Segunda parte: "Sola la vida humana corre a su fin, ligera más que el viento, sin esperar a renovarse si no es en

1 Edic. Croce, pág. 23o. Este pasaje, sin duda irrespetuoso para la «Sancta Maris Stella», dice así en el original latino: «Olim Venus agebat curam nautarum, quia nata credebatur ex mari: ea quoniam desiit curare, suffecta est huic matri non virgini Virgo Mater.s

2 No figura el adagio en la edición abreviada por Teodorico Cortehoevius, Amberes, 1530; en la edición de París, I 599, con com rios de Henri Etienne, figura el adagio (

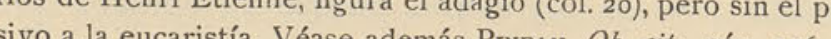
sivo a la eucaristía. Véase además Pingau, Ob. cit., pág. 156

3 Silenos de Alcibiades, traducción de Bernardo Pérez, Amberes, ${ }^{555}$, fol. $7 v$. No entro a discutir, claro está, la justeza histórica de las apreciaciones erasmistas. Los estudios de religión comparada llevan hoy otros derroteros. Se duda actualmente de que los santos cristianos correspondan a los dioses paganos; pero se admite por muchas plumas discretas que el paganismo tenía más puntos de contacto con el cristianismo que el mismo judaísmo. La prueba es que los pagas e cristianizaron, y los judios coos se cristianizaron, y los judios conservan aún su religión. Debe verse el estudio de Тн. ZigLinsкi, La Sybille (trois essais sur la religion antique et le christianisme), París, Rieder, 1924; es libro lleno de mesuada doctrina. la otra, que no tiene términos que la limiten.» Esto dice Cide Hamete, filósofo mahomético; porque esto de entender la ligereza e instabilidad de la vida presente y de la duración de la eterna que se espera, muchos sin lumbre de fe, sino con la luz natural, lo han entendido" ${ }^{1}$. Ahora veremos que Julio César, al preferir la muerte súbita, «aun que respondió como gentil y ajeno del conocimiento del verdadero Dios, con todo eso dijo bien». ¿Pero y la preparación deseable para disponer el alma? A César no le interesó ese detalle, como gentil que era; ‘pero y a Cervantes?

Cervantes, sin darle importancia, roza la zona peligrosa del erasmismo, que, repito, no puede considerarse con el elegante descuido que en este caso usó Menéndez Pelayo. No se trata meramente de bromas joviales. Los santos recuerdan a los dioses; la Virgen, a Venus; los gentiles pensaron bien sin tener fe; y Cervantes pensaría - digámoslo con un giro suyo - : «Vean a Erasmo, donde más largamente se contiene.» Hasta dónde fuera internamente nuestro autor por esa vía del humanismo racionalista, yo no lo sé; sin la base de sus textos, no me interesan las conjeturas. Pero tenía el deber de precisar la filiación histórica de las cosas que concretamente dice, para que nadie piense que son ocurrencias del azar. Tanto más cuanto que es innegable que Cervantes estaba directamente influído por Erasmo, según demuestra e siguiente cotejo. $\mathrm{Y}$ estoy seguro que un estudio más amplio del que he podido hacer revelará otras imitaciones:

\section{CERVANTES}

No andes, Sancho, desceñido y flojo; que el vestido descompuesto da indicios de ánimo des mazalado, si ya la descompostura y flojedad no cae debajo de socarronería, como se juzoó en la de Julio César» (II, 43; RM, V, 539).

\section{ERASMO}

Después de la victoria de César, siendo preguntado Cicerón que cómo había errado en el elegir las partes, le respondió Cicerón diciendo que la cintura le ha. bía engañado. Dando a entender que no pensaba que un hombre
1 Comp.: «La suerte fatal, que, según opinión de los que no tienen lumbre de la verdadera fe, todo lo guía, guisa y compone a su modo» (I, 23; RM, II, 226) 
Clemencín cita a Macrobio, que efeminado había de vencer. Pores la fuente de Erasmo en este que César se ceñía la ropa a la ral pensar en el accesible texto hombres, de adonde solía amode los Apotegmas. Pompeyo que se guardase de muchacho mal ceñidos (Apotegmas, Amberes, 1549 . fol. $172 v)$.

•Preguntáronle a Julio César, aquel valeroso emperador romano, cuál era la mejor muerte. Respondió que la impensada, la de repente $\mathrm{y}$ no prevista; $y$ aunque respondió como gentil y ajeno del conocimiento del verdadero Dios, con todo eso dijo bien» (II, 24; RM, IV, 23). Clemencín cita a Suetonio, que es fuente de Erasmo, pero no de Cervantes.

« ₹̊No has visto tú representar alguna comedia adonde se introducen reyes, emperadores y pontífices, caballeros, damas y otro diversos personajes? Uno hace el rufián, otro el embustero, este el mercader, aquel el soldado..., acabada la comedia... quedan to dos los recitantes iguales... Pues lo mesmo acontece en la co media y trato de este muno, donde unos hacen los emperadores, otros los pontifices. pontífices. pero en llegando al fin, que es cuando se acaba la vida..., queda guales en la sepultura» (II, 12 ; RM, IV, 247). La idea y hasta el movimiento estilístico son análogos; pero Cervantes, shipócritamente», suprime el sentido que Erasmo da a su comparación 1 .

"Como entre cena se fuese leantada una plática, que cuál género de muerte era el muy bueno, sin pensar respondió [César] que el de subito y sin pensar; y que juagó por muy bueno le conteció a él» (Apotegmas, folio ${ }_{1} 58 r$ ). [Véase en nuestras Adiciones finales la correspondiente a esta página, por ser importante.]

«Hipócritas [='enmascarados'] e podrán llamar todos aquellos que no son que parecen, bien como en las comedias que se representan, los que parecen reyes no son reyes, ni los que parecen obispos son obispos, porque las personas que debajo de aquellas insignias reales o pontificales se cubren son hombres vulgares o bajosos, tomados de las heces del pueblo. Pues desta misma manera acaesce muchas ve ces en los reyes e prochas vese tien por verncipes que se tienen por verdaderos... Acabada la farsa de este mundo, muchos que dejan acá la máscara de las muestras exteriores no serán conocidos de Dios quios, en Orivenes de la Noocla, IV. 185-186).

1 La fuente remota de esta comparación está en Séneca, epístolas LXXVI y LXXVII; comp. A. VALBUENA, Los autos sacramentales de
No tuve amistad en mis verNo co, y así, en mí siempre estuvo Venus frías (Persiles, edic. Schevill-Bonilla, I, 32).

Sine Cerere et Baccho friget Venus» (Adagia, chil. II, cent. III, núm. 97). Procede de Terencio (Eunuchus), que lo trae con alguna variación: «Sine Cerere Libero, friget Venus.s La forma de Erasmo es la que ha debido influir en Cervantes; si directa o indirectamente, no puedo a ismarlo.

Acuérdome que cuando estudiaba oí deciral precetor un efrán latino, que ellos llaman adagio, que decía: Habet bo vem in linguam...) (Coloquio, Clás. Cast., págs. 256-257)

Bos in lingua... Atheniensium

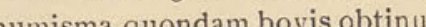
figram four... Qui pecunia corsupt loqui non auderent, bovem in lingua dicebantur haberes (Adagia, chil. I, cent. VII, núm. I8). Amezúa (edic. Coloquio, pág. 515) refirió ya a Erasmo.

«No hay libro tan malo que no "Plinio el mayor solía decir que tenga algo bueno» (II, 3; RM, IV, no había libro por muy malo que fuese que no aprovechase en alguna cosa, pero entiéndese cuando el lector sabe sacar dél fruto, porque hay algunos que no leen sino para reprehender mas, Amberes, 1549, fol. 34I).

Queda, pues, patente que, además de en contenidos eruditos, el humanismo de Cervantes también se refleja en alusiones y en ironías, que deben analizarse con gran prudencia, en vista de muchos otros datos, a fin de no incurrir en arbitrariedades. En este capítulo VIII de la Segunda parte del Quijote surgen en oposición los conceptos de gloria humana y de gloria celestial, al formular Sancho la tremenda pregunta : «Cuál es más: resucitar a un muerto o matar a un gigan-

Calderón 1924 pác. 63, para otros reflejos de la misma idea en Lope y Calderón. Pero la fuente de Cervantes no es Séneca, sino Erasmo; basta coroj. Pero la fuente de Cervantes no es el de los Coloquios.

1 Añádanse a estos paralelos los correspondientes a las páginas indicadas en negrilla en el índice de personas. 
te?» Don Quijote ha de reconocer que vale mucho más resucitar a un muerto; Sancho, con su infrangible lógica, propone "que nos demos a ser santos, y alcanzaremos más brevemente la buena fama que pretendemos». Es decir: contribuyamos a aumentar el caudal de reliquias que «llevan lo reyes sobre sus hombros, besan los pedazos de sus huesos, adornan y enriquecen con ellos sus oratorios y sus más preciados altares... ${ }^{1}$. Y advierta, señor, que ayer o antes de ayer... canonizaron o beatificaron dos frailecitos descalzos, cuyas cadenas de hierro [!] con que ceñían y atormentaban sus cuerpos se tiene ahora a gran ventura el besarlas y tocarlas... Así que, señor mío, más vale ser humilde fraileci. to de cualquier Orden que sea, que valiente y andante caballero». Don Quijote replica que «religión es la caballería; caballeros santos hay en la gloria». Y Sancho, implacable: «Pero yo he oído decir que hay más frailes en el cielo que caballeros andantes.» Fama humana y fama divina: ‘cuál de las dos? La ironía carga sobre la segunda. Recordemos que la gloria para Cervantes gravitaba hacia las armas o las letras. La sátira de las reliquias - y de los frailes - es ahora una contraprueba.

Ya notó Morel-Fatio que Cervantes trata con deferente respeto al Cura, al que ejerce la cura de almas ${ }^{2}$, y, en cam-

En los últimos años del siglo xvr y primeros del siguiente se desarrolló en España una verdadera locura supersticiosa en tore a reliquias y cuerpos de santos. Es la época de los plomos del Sacro Monte de Granada. El P. Mariana acude al Rey y a Papa con icro to de contener la demencin to de contener la demencia del vulgo, fomentada por las autoridade eclesiásticas. Véase G. Ствот, Mariana historien, 1905, págs. 45 y sig. L'Espagne de Don Quichotte, traducción española, págs. $127 \cdot 128$. «os señores clérigos del difunto, que pocas veces se dejan mal pasar» (I, I 9; RM, II, 94); ya notó Clemencín (II, I I I) que «el dictado que se les da de señores es enfático y maligno». Todo ese capítulo estu lleno de punzadas (el entierro aparatoso, las excomuniones, la vida

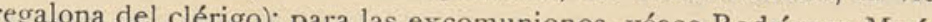
I, 9o. La zumba ladina apar 1, 90. La zumba ladina aparece en la frase: «o no pensé que ofendía a sacerdotes ni a cosas de la Iglesia, a quien respeto y adoro como católico y fiel cristiano que soy.» bio, fustigó al eclesiástico que no vive en medio de sus ovejas. Creo que hay que añadir que el fraile no le inspiró excesivo respeto:

\author{
Mientras el fraile no llega \\ a ser sacerdote, pasa \\ vida pobre, estrecha, escasa, \\ de quien a veces reniega. \\ Tiene allá el predicador \\ sus devotas y sus botas, \\ y el presentado echa gotas, \\ y suda con el prior; \\ mas el novicio y corista, \\ en el coro y en la escoba \\ sus apetitos adoba, \\ diciendo con el Salmista : \\ Et potum meum cum fletu miscebam. \\ Pero bien será callar, \\ Pero bien será callar,
pues sé que muchos convienen \\ en que las paredes tienen \\ oídos para escuchar ${ }^{1}$.
}

Todos conocen el cuento de la viuda: "Hermosa, moza libre y rica, y, sobre todo, desenfadada, se enamoró de un mozo motilón, rollizo y de buen tomo; alcanzólo a saber su mayor $^{2}$, y un día dijo a la buena viuda, por vía de fraternal

\footnotetext{
Rufín dichoso, II, 68. Aquí tenemos otro caso de cautela confe1 Rufán dichoso, 11, sada, que hay que añadir a los de la página 241 . Es conocida la acerbá crítica que Erasmo hizo de los religiosos (véase Pineav, Ob. cit., pá-
gina 214). He aquí una muestra tomada de la traducción española de los Coloquios (1532): «Pamphiro. Ninguna cosa hay más religiosa que las Órdenes de los mendicantes; mas no hay cosa más semejante a la negociación ['comercio]... Negocian en casa de ciudadanos e nobles, $c$ también en las de los poderosos. - Eusebio. Mas no comen ni beben.Pamphiro. Por qué no? No son hombres como nosotros'-Eusebio. Y Pampliro. ipor que no? destos, ‘que linaje escogiste? - Payphro. Todas las for experimenté. - Eusebio. ¿Ninguna te contentó? - Pamphiro. Antes me hubieran mucho agradado todas si supiera luego negociar; mas veí que antes que me encomendasen la negociación, había por mucho tiempo de sudar en el coros(Origenes de la Novela, IV, 162). 2 I, 25. Es decir, 'el prior del convento'; pero Cervantes, cautamente, emplea un sustitutivo, para no escandalizar. Lo cómico es que
} 
reprehensión: "-Maravillado estoy, señora..., de que una mujer tan principal, tan hermosa y tan rica como vuestra merced se haya enamorado de un hombre $\tan$ soez, tan bajo y tan idiota como Fulano, habiendo en esta casa tantos maestros, tantos presentados y tantos teólogos, en quien vuestra merced pudiera escoger como entre peras, y decir: "Este quiero, aqueste no quiero». E1 lector recuerda la respuesta de la viuda: "Para lo que yo le quiero, tanta filosofía sabe, y más, que Aristóteles.»

En el entremés de El Viejo celoso, Cristinica, la sobrina de D. ${ }^{2}$ Lorenza, quería imitar a su tía, y pide a la vecina, señora Hortigosa: "Hágame merced de traerme a mí un frailecico pequeñito con quien yo me huelgue.» $\mathrm{Y}$ al acabar repite "Si mi vecina me hubiera traído mi frailecico, yo la tuviera por mejor vecina» 1

Después de esto, ¿̇cómo no sentir la tremenda ironía de un pasaje de El Licenciado Vidriera, alegado muy a menudo

hubo comentarista que dió a «mayor s otro sentido; y otros que para no reconocer que se trataba de un convento de frailes, forzaron el no reconocer que se trataba de un convento de fralles, forzaron el valor de las palabras. Rodríguez Marín, II, 307, interpreta bien el tex to. Después de todo, que en los conventos la religión y la moral an duviesen por los suelos, era cosa dicha y redicha. Santa Teresa se expresa con claridad, y eso que ya había sido hecha la tan decantada reforma de Cisneros: «En un monesterio hay dos caminos: de virtud y religión, y falta de religión... Úsase tan poco el de la verdadera religión, que más ha de temer el fraile y la monja que ha de comenar de veras a siguir del todo su llamamiento, a los mese da de comus co vera a sigir del todo su todos los denonios y más cautela y disimulacion ha de tener para hablar en la amistad que desea de tener con Dios, que en otras amistades y voluntades que el demonio ordena en los monesterios" (Libro de su vida, Rivad., LIII, 35 a).

IV, ${ }_{150}$ y 165 . Comp.: $\varangle$ Soldado. Dejas, Cristina, a esta flor, a este jardín de la soldadesca, y acomódaste con el muladar de un sotasacristán, pudiendo acomodarte con un sacristán entero y aun con un canónigo" (Guarda cuidadosa, IV, 63). Todo esto, en efecto, es de traaición (Grarda aidacosa, IV, 63). Todo esto, en efecto, es de unos cuantos pasajes: la monja que no grita al acercársele nocturnamente el fraile, para no infringir la regla del silencio; no hay mujeres estérilestonde los monjes acuden con asiduidad; etc. para probar la piedad del autor, si recordamos además e coloquio de Don Quijote y Sancho antes mencionado? Helo aquí : «Pasando acaso un religioso muy gordo por donde él estaba, dijo uno de sus oyentes: "De ético no se puede mover el padre.» Enojóse Vidriera, y dijo: "Nadie se olvide de lo que dice el Espíritu Santo: Nolite tangere Christos meos." $\mathrm{Y}$ subiéndose más en cólera, dijo que mirasen en ello, y verían que de muchos santos que de pocos años a esta parte había canonizado la Iglesia..., ninguno se llamaba el capitán don Fulano, ni el secretario don Tal de don Tales, ni el conde, marqués o duque de tal parte, sino Fr. Diego, Fr. Jacinto, Fr. Raimundo, todos frailes y religiosos; porque las religiones son los Aranjueces del cielo, cuyos frutos de ordinario se ponen en la mesa de Dios» ${ }^{1}$.

No hay pues, ataques a creencias fundamentales, pero sí punzadas a la vida eclesiástica, a los rezos, a los santos, a los milagros debidos a la superstición, a lo que es, en suma, obra esencialmente humana. Muchas ideas cristianas no eran, según los humanistas, divino privilegio del catolicismo, sino construcciones de la humana razón. Esa fué la huella de Eras mo en los más altos espíritus de España.

Veamos todavía más hechos de esta índole. La vida eclesiástica brindaba apacibles maneras de vivir. Un sacristán nos dirá :

$$
\begin{aligned}
& \text { Como persona aplicada } \\
& \text { a la Iglesia, y no al trabajo, } \\
& \text { mejor meneo el badajo } \\
& \text { que desenvaino la espada } 2
\end{aligned}
$$

Gentes industriosas utilizan las prácticas religiosas para provechos muy de este mundo. En El gallardo español, Buitrago pide para las ánimas cuando no tiene

$$
\begin{aligned}
& \text { A la parte voy con ellas, } \\
& \text { remediando sus querellas } \\
& \text { a fuerza de avemarías, }
\end{aligned}
$$

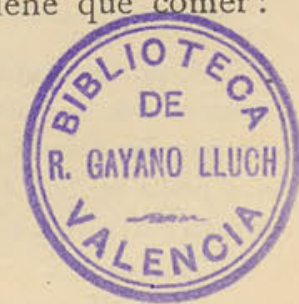

1 Edic. Clás. Cast., pág. 76

2 Baños de Argel, I, 238. 
$\mathrm{y}$ mis hambrientas porfías con lo que me dan para ellas ${ }^{1}$

En Pedro de Urdemalas ${ }^{2}$, un Ciego y Urdemalas luchan a portía por liberar las ánimas benditas :

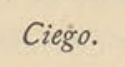

Toda esta farsa de Pedro de Urdemalas afecta no sólo a los que comercian con las ánimas, sino un poco también a las mismas ánimas. No hay tal vez que ir tan lejos como Klein: «२Podría una comedia luterana que se titulase «Caja de indulgencias de Tetzel», burlarse peor de ello?» ${ }^{3}$. Pero es

1 I, 64. Cervantes presenta así el personaje: «Trae una tablilla, con demanda de las ánimas de purgatorio, y pide para ellas. $\mathrm{Y}$ esto de pedir para las ánimas es cuento verdadero, que yo lo vi. Y la razón por qué pedía se dice adelantes $(\mathrm{I}, 37)$. «Le ha dado el Conde esta demanda porque pueda sustentarse con ella, (38)

2 III, $164-17$.

3 Ríus, III, 342 . innegable que nuestro autor deja traslucir no leve dosis de broma y escepticismo en todo este asunto de ánimas y apariciones $^{1}$; no menor que la revelada por la pregunta que en La guarda cuidadosa dirige Solórzano a cierto sujeto que demandaba «limosna para la lámpara del aceite de señora Santa Lucía». Dice Solórzano: «Pedís para la lámpara o para el aceite de la lámpara? Que como decís limosna para la lámpara del aceite, parece que la lámpara es del aceite, y no el aceite de la lámpara» ${ }^{2}$

Un género de farsa religiosa criticado abiertamente hallamos en los ermitaños: "No son los que agora se usan como aquellos de los desiertos de Egipto, que se vestían de hojas de palma y comían raíces de la tierra ${ }^{3}$. Y no se entienda que por decir bien de aquéllos no 10 digo de aquéstos [he aqui el rasgo cauteloso], sino que quiero decir que al rigor y estrecheza de entonces no llegan las penitencias de los de agora; pero no por esto dejan de ser todos buenos: a lo menos, yo por buenos los juzgo» ${ }^{4}$. Pero el disimulo es aquí burdo, tanto más cuanto que en Persiles dice concretamente de los ermitaños: «Ni nos ha de admirar que un pobre que en la ciudad muere de hambre se recoja a la soledad, donde no le ha de faltar el sustento. Modos hay de vivir que los sustenta la ociosidad y la pereza, y no es pequeña pereza dejar yo el remedio de mis trabajos en las ajenas, aunque misericordiosas manos» ${ }^{5}$. Cuando la Contrarreforma no ataba las plumas, he

1. Para Erasmo y las ánimas (exorcismos, etc.), véase Pineau, $O b$. cit., pág. 206. Ya hablé antes (pág. 65 n.) de cómo, en El rufián dichoso, echaba Cervantes sobre la crónica que seguía la responsabilidad las maravillas que acontecen a Fr. Cristóbal de Lugo.

2 IV, 64 .

3 II, 24; RM, V, $I_{3}$.

4 Clemencin ba 13.0 miedo en Lepanto, lo tuvo de lo que acababa de decir acerca de diferencia que había entre los ermitaños de su tiempo y los de la la baida, y quiso ponerse en salvos (edic. $1836, \mathrm{~V}, 8$ ).

Rivad., I, 620 b. 
aquí cómo se expresaba Torres Naharro acerca del ermitaño Teodoro:

\section{¡Pese el diablo comigo \\ con estos putos de padres!}

Siempre tienen mil comadres

doquiera hallan abrigo,

y al monesterio, si digo,

siempre van por los cabellos,

que no tienen todos ellos

que no tienen todos ellos

otro mayor enemigo...

disimuladas serpientes,

sacos llenos de placeres,

salvación de las mujeres,

mal francés entre las gentes ${ }^{1}$

Pero cien años más tarde esta explosión ingenua no era posible, no tendría sentido: los temas cándidos se recubren de abigarramiento, e inician una mueca barroca, capciosa y socarrona. Erasmo habla a menudo de las peregrinaciones, de la falta de piedad de los peregrinos, de su superstición ${ }^{2}$; en Persiles leemos: «Desde allí, prosiguió la peregrina, no sé qué viaje será el mío, aunque sé que no me ha de faltar donde ocupe la ociosidad y entretenga el tiempo, como lo hacen, como ya he dicho, algunos peregrinos que se usan. A lo que dijo Antonio el padre: "Paréceme, señora peregrina, que os da en el rostro la peregrinación.» «Eso no - respondí́ ella - , que bien sé que es justa, santa y loable, y que siempre la ha habido y la ha de haber en el mundo; pero estoy mal con los malos peregrinos, como son los que hacen granjería de la santidad y ganancia infame de la virtud loable..., y no digo más, aunque pudiera” ${ }^{3}$.

Al comenzar el estudio de lo que la Contrarreforma había puesto en Cervantes, senté como principio que la disi-

1 Comedia Serafina en Propaladia, edic. Menéndez Pelayo, I, 148

2 STomaré mucho pasatiempo, e darle he a mis amigos con el aparejo que terné de mentir sin miedo cuando contare mi peregrinaje en ejo que terne de lontir sing la, IV, 172; véanse 173 y 162)

3 Rivad., I, $634 a$ y $b$. mulación estaba en la base de aquel movimiento ideológico en lo religioso y lo moral. En cuanto llevamos tratado ha podido observarse que la técnica consiste en dar medio paso hacia adelante y uno hacia atrás; pero queda la huella del avance; como en ciertos cuadros de Velázquez permanece visible la huella de lo rectificado por el artista; Cervantes está lleno de estos «arrepentimientos». Un velo de moralidad ${ }^{1}$, de ortodoxia absoluta, recubre todos los salientes y aristas que produce el razonar independiente del autor. A veces la pluma corre indiscreta, y entonces la rectificación es de violenta crudeza. Ya vimos el caso del rosario y las Avemarías de Don Quijote (pág. 264); recordemos también (pág. 243) las dos redacciones de aquel pasaje de El Celoso extremeño cuando la protagonista yace, adúlteramente, entre los brazos de Loaysa. Cervantes escribe primero lo que piensa, es decir, que la joven es adúltera sin atenuación alguna; pero una vez dicho, surge el recuerdo de la moral, de Trento, de lo que prescriben las poéticas; actúa, en suma, el ambiente compresor de la Contrarreforma, no sólo de la Inquisición y de los jesuítas, sino de la sociedad en aquel momento histó rico; y Cervantes se rectifica, se enmascara como sabía hacerlo su espíritu complejísimo.

Se comprende, hasta cierto punto, que gentes poco equilibradas hayan querido buscar en Cervantes claves y misterios, y que hayan tratado de leer en él no sólo entrelíneas, sino al trasluz; yo creo ahora que basta con poner Cervantes de acuerdo con su tiempo, e intentar ver las cosas un poco como él podía verlas. Y llegamos así a resultados tan distantes de la ingenuidad como de la insensata fantasía.

1 Véase cómo se refleja este espíritu en una Poética coetánea: «L materia de religión, por ser della no parece tan bien en imitación; y Ja materia de amores, solamente no es razón que lo parezca; mas cuando fueren tan graves los escritores de la amorosa materia como los tres sobredichos [Museo, Eliodoro y Aquiles Tacio], bien se pueden admitir» (Pinciano, Filosofía antigua poética, edic. cit., pág. 452.) Por eso - ya lo hemos notado - fué escrito Persiles en competencia con Eliodoro. 
Por eso me abstengo de formular opinión sobre el tan mencionado elogio que en el Coloquio hace Cervantes de la enseñanza jesuítica ${ }^{1}$. Puede tratarse de un sincero elogio, recuerdo de estudios hecho por el autor en Sevilla ${ }^{2}$; puede tratarse de una de tantas fórmulas de obsecuencia a las ideas oficiales.

\section{¿TOLERANCIA O INTOLERANCIA?}

Como en otros aspectos acaecía, también aquí las opiniones son contrarias. La intimidad de Cervantes se desliza al querer asirla, y es difícil formular respuestas que supongan categóricos juicios. Como otras veces, habremos de procurar plegarnos al movimiento psíquico del autor, y acompañarlo. en su sinuosa trayectoria.

ulius Klein ${ }^{3}$ pensaba que Cervantes, "este gran alienista, no ha podido efectuar la curación radical, puesto que dejó subsistir intacta la demencia religiosa, específicamente española, la fantástica hereticofobia de la fe loca y el fanatismo religioso, los cuales, como sagrados, compartía con su pueblo... En materia de quemar herejes, Cervantes era una salamandra tan inquisicionófila como Lope de Vega, como Calderón». Morel-Fatio ${ }^{4}$ lo juzga asimismo intolerante: «Acerca de los moriscos, ha tenido ocasión de hablar repetidas veces... y siempre lo ha hecho con desprecio y odio. [Nada de contemplaciones con esa canalla, que es nuestra ignominia!» Esta idea es la generalmente admitida: que en el Quijote no hay la menor ironía al tratar de los moriscos ${ }^{5}$. No

1 «La solicitud y la industria con que aquellos benditos padres y maestros enseñaban a aquellos niños.... porque no torciesen ni tomasen mal siniestro en el camino de la virtud» (edic. Amezúa, pág. 307 y nota 132 ).

2 Rodríguez Marín, Cervantes estudiante en Sevilla (1564-1565), Sevilla, 1905

Geschichte des spanichen Drama's, 1872 . Véase Rius, III, 325 y 329. 4 Ob. cit., pág. $14 \mathrm{I}$.

5 También Schack, en su prólogo a la traducción de Calderón porIV. von Schlegel y J. D. Gries, Stuttgart, 1883. obstante, en el prólogo anónimo a la traducción alemana de 1837 , al cual sigue el bello estúdio de Heine, se acentúa que Cervantes «velaba sus más secretos pensamientos para despistar a los sabuesos inquisitoriales» (pág. xxxix). Más precisamente opina F. Scheichl ${ }^{1}$, acerca del episodio de Ricote en el capítulo LIV de la Segunda parte del Quijote, «que es indudable que el autor expresó con estas palabras su propia opinión sobre la libertad religiosa». Muchos años antes había dicho Clemencín, que tan asiduamente convivió con el espíritu de Cervantes, que «a pesar de ciertas expresiones y salvas, puede sospecharse que Cervantes no"era partidario de la expulsión» ". Prescindo de citar juicios apasionados de quienes tratan de presentar a Cervantes como a un enemigo de la Iglesia, defensor de herejes, etc., y procedo al examen directo de los textos. Una furiosa diatriba contra los moriscos se halla en el Coloquio ${ }^{3}$ : «iOh, cuántas y cuáles cosas te pudiera decir, Cipión amigo, desta morisca canalla, si no temiera poderlas dar fin en dos semanas!» Les saca, como culpa, ser trabajadores, ahorrativos, fecundos: «entre ellos no hay castidad, ni entran en religión ellos ni ellas...; róbannos a pie quedo, y con los frutos de nuestras heredades, que nos revenden, se hacen ricos... Pero celadores prudentísimos tiene nuestra república, que considerando que España cría y tiene en su seno tantas víboras como moriscos, ayudados de Dios hallarán a tanto daño cierta, presta y segura salida» 4 .

Según han demostrado Morel-Fatio y Amezúa ${ }^{5}$, tales acusaciones eran lugares comunes que corrían por libros y escritos de todas clases; el hecho es innegable. En este punto, la opinión de Berganza es la del país, que se basaba tanto

1 En un artículo, cuyo título promete más que da: Zur Geschichte des Toleranzoedankens in der spanischen Dichtung, en los «Monathefte der Comenius- Gesellschaft», I896, V, 121-142.

2 Tomo VI, 1839, páa. 106.

3 Edic. Rodríguez Marín, Clás. Cast., pág. 317

4 Pienso, con Rodríguez Marín, que esto se escribió después de

4609, fecha de la expulsión, y no antes, como quiere Amezúa.

5 Bulletin Hispanique, 1902, pág. 64; y edic. del Coloquio, pág. 131. 
o más que en motivos de fe en causas de otra índole: incomprensión, rivalidad económica, daño político. Cervantes habla aquí de los moriscos como un blanco del Sur de los Estados Unidos lo hace respecto de los negros, o como se habla hoy de los judíos en Alemania o en los Estados Unidos ${ }^{1}$.

En Persiles vuelven a aparecer las mismas razones, aún con más intensidad: "Vayan arrojadas a las contrarias riberas las zarzas, las malezas y las otras hierbas que estorban el crecimiento de la fertilidad y abundancia cristiana; que si los. pocos hebreos que pasaron a Egipto multiplicaron tanto, que en su salida se contaron más de seiscientas mil familias, ¿qué se podrá temer destos, que son más y viven más holgadamente, no las esquilman las religiones, no las entresacan las Indias, no las quintan las guerras, todos. se casan, todos o los más engendran, de do se sigue y se infiere que su multiplicación y aumento ha de ser innumerable?» ${ }^{2}$. Conventos, Indias, guerras e infecundidad eran, pues, causas de pobreza y ruina para la España de los cristianos viejos; los moriscos se libraban étnicamente de tales azotes y por eso... estaba bien echarlos fuera. ¿No se ve en ello alguna complicación? Refiriéndose a este lugar de Persiles, los Sres. Schevill y Bonilla observan : «Ya en el Coloquio de los perros, Cervantes había manifestado su odio a los moriscos y su contento por el decreto de expulsión» (II, I3I). Sin decir yo que esto no pueda apoyarse en los textos, creo esencial añadir que la proposición contraria podría hallar el mismo sostén en las páginas cervantinas; como tantas veces, aquéllas lanzan destellos en opuesto sentido, y el lector no extrañará

1 Cervantes censuraba a los moriscos por su sobriedad, su ahoro, etc. en periódico universitario de Norteamérica se echa en cara mo, etc; en peró a los judios su alejaco uento del deporte y su excesiva consagración a aenas intelectales, gracias a lo cual superan a sus companeros; el número de estudiantes judíos está limitado en algunas Universidades, etc. La psicología nacional de Norteamérica semeja en algún aspecto (más formal que de contenido, claro está) a la de España en el siglo xvı.

2 Rivad., I, $646 a$ que también en esta ocasión empleemos el método que venimos usando en este libro, consistente en abandonar nuestros criterios unilaterales y en adaptarnos al especial punto de vista del autor. Es improcedente que, porque el siglo xix se haya dividido entre reaccionarios y liberales, hayamos de colocar la religiosidad de Cervantes en uno u otro de esos apartados, cuando lo necesario es ver cómo su alma prismática refractaba la realidad del momento, cuya sencilla contemplación ofrecía ya al observador un aspecto distinto del que hoy al pronto imaginaríamos. Nos hace aquí falta algo de geometría literaria con múltiples dimensiones; y un poco de Pirandello no deja tampoco de tener su utilidad.

Pues sí: Cervantes dice que han hecho bien en echar a los moriscos, y dice también que eso es una absurda crueldad. Es la única solución razonable frente a las opiniones opuestas de los que sostienen la intolerancia o la tolerancia de Cervantes; no basta con decretar que están locos quienes admiten su liberalismo, ni que son rezagados los contraopinantes. Me parece de rigor una postura comprensiva, y no despectiva, ante unos y otros. Lope, Calderón y Tirso no han dado que hablar en esa forma; cuando sobre Cervantes se enzarzan personas cultas e inteligentes (no son los necios quienes dieron el tono a esta vieja polémica), cabe pensar que nos hallamos ante un "geminus Janus».

Un erudito de corte tan tradicional como el Sr. Amezía dice en su sabio libro acerca del Coloquio de los perros: "Creóse una atmósfera de decidida e implacable enemiga contra aquella raza proterva... que respiraron sin excepción alguna los escritores todos..., Cervantes entre ellos, como uno de tantos hijos de su siglo. No solamente así se justifica la severidad de sus juicios y la dureza extremada de sus epítetos, no atenuados ni contradichos, aunque otra cosa se quiera, en la parte II del Quijote» (pág. 133). Hay aquí, por lo menos, una alusión a posibles contradicciones, a las que el comentarista se opone de modo dogmático, pero que no destruye con razones. (RM, VI, I05, soslaya la cuestión que allí se plantea.) 
Para mí, la contradicción se presenta de este modo: el punto de vista oficial es que los moriscos son ladrones, cizaña, etc.; pero, ¿y el punto de vista de los moriscos? Ambos están expuestos: el primero, envuelto en el espíritu que vengo llamando de Contrarreforma; el segundo, matizado por notas de delicada humanidad. Habla Ricote (II, 54): «Con justa razón fuimos castigados con la pena del destierro, blanda y suave al parecer de algunos, pero, al nuestro, la más terrible que se nos podía dar.» $\mathrm{Y}$ continúa en tono de tan honda emoción, $\tan$ sobria, tan basada en objetividad, que sin vacilar podemos atribuir a astuta concesión lo que antes ha dicho el morisco: «Me parece que fué inspiración divina la que movió a su Majestad a poner en efecto tan gallarda resolución.» Porque Ricote dice: «Doquiera que estamos lloramos por España; que, en fin, nacimos en ella y es nuestra patria natural; en ninguna parte hallamos el acogimiento que nuestra desventura desea...; es el deseo tan grande que casi todos tenemos de volver a España, que los más de aquellos (y son muchos) que saben la lengua como yo, se vuelven a ella, y dejan allá sus mujeres y sus hijos desamparados...; agora conozco y experimento lo que suele decirse: que es dulce el amor de la patria.» ¿Puede hacerse hablar de esta manera a gente que infama la patria presencia? ¿Se expresa así la gente infame y proterva? En el capítulo LXIII surge Ana Félix, la hija de Ricote: «De aquella nación más desdichada que prudente, sobre quien ha llovido estos días un mar de desgracias, nací yo, de moriscos padres engendrada»; es cristiana, pero «no me valió con los que tenían a cargo nuestro miserable destierro, decir esta verdad", etc. $Y$ no se diga que este tono comprensivo y apiadado se usa por ser cristianos y no moriscos, ya que Ricote ha dicho: «La Ricota, mi hija, y Francisca Ricota, mi mujer son católicas cristianas, y aunque yo no lo soy tanto...» ${ }^{1}$.

Con tal antecedente, véase ahora este pasaje de Persiles:

1 RM, VI, 107
«Ven ya, joh venturoso mozo y rey prudentel, y pon en ejecución el gallardo decreto deste destierro, sin que se te oponga el temor que ha de quedar esta tierra desierta y sin gente, y el de que no será bien desterrar la que en efecto está en ella bautizada; que aunque estos sean temores de consideración, el efecto de tan grande obra los hará vanos, mostrando la experiencia dentro de poco tiempo, que con los nuevos cristianos viejos que esta tierra se poblare, se volverá a fertilizar y a poner en mucho mejor punto que agora tienen» ${ }^{1}$. ¿Pensaba Cervantes en serio que llevando cristianos viejos de una región a otra se evitaba con ventaja el inconveniente de que la tierra quedara «desierta y sin gente»? En eso de los nuevos cristianos viejos hay no leve ironía; recordemos las observaciones hechas antes (pág. 255) sobre tal clase social ${ }^{2}$; la espesa enjundia de ranciosa cristiandad no resolvía el problema. Pero Cervantes prosigue: "Con los nuevos cristianos viejos... tendrán sus señores, si no tantos y tan humildes vasallos, serán los que tuvieren católicos, con cuyo amparo estarán estos caminos seguros, y la paz podrá llevar en las manos las riquezas, sin que los salteadores se las lleven.»

En resolución, veamos claramente cómo se presenta el asunto: los moriscos son españoles, están en su patria natural, están bautizados, son la base de la riqueza agraria, los oponen a los cristianos viejos, han de casarse entre sí, no van a los conventos ni a la guerra ${ }^{3}$. Todo esto lo dice Cervantes; pero dice también, que son incompatibles con España y que han

\footnotetext{
1 Rivad., $645 b$.

2 Clemencín ( 1839 , VI, 107 ) ha escrito palabras discretas: $« \mathrm{~L}$ legislación, que pudo retardar o neutralian los efectos det pimer error tim error tirando la nación, tomó el camino contrario, y apoyando los estatutos de limpieza de sangre, $y$ otras preocupaciones del orgullo, poco conformes al cristianismo, concentró más y más a los moriscos, de suerte que, como se ve por esta misma relación de Ricote, sólo se casaban ellus entre sí, lo cual facilitó que se perpetuase secretamente de padres a hijos el odio al gobierno y a los cristianos,"
}

3 Comp. Clemencín, VI, 104. 
hecho perfectamente en expulsarlos. Sobre tal conflicto surge como dolorosa armonía la humana piedad que fluye de las palabras del morisco Ricote: «es dulce el amor de la patria».

Creo que conviene separar la animosidad de Cervantes. frente a los moros de Argel, y no superponerla a su opinión acerca de nuestros moriscos. Los turcos argelinos nada tenían que ver con España, ni en lengua ni en nacionalidad; eran el Islam, a la sazón bárbaro, frente al cristianismo civilizador. Cervantes suspiraba por una acción bélica contra tales salteadores de naves. $\mathrm{Y}$ tan distinta de la africana era la cuestión morisca, que repetidas veces nos habla de que África y nuestros moriscos son incompatibles: «En Berbería, y en todas las partes de África donde esperábamos ser recebidos, acogidos y regalados, allí es donde más nos ofenden y maltratan» (Quijote, II, 54); «Pasamos a Berbería, y el lugar donde hicimos asiento fué en Argel, como si le hiciéramos en el mismo infierno» (II, 63). En Persiles, los moriscos que se van con los turcos $(645 b)$, en cuanto se acercaron a los que creían sus libertadores, "comenzaron a sentir la pobreza que les amenazaba su mudanza, y la deshonra en que ponían a sus mujeres y a sus hijos». Y poco antes: "Piensan estos desventurados que en Berbería está el gusto de sus cuerpos y la salvación de sus almas, sin advertir que de muchos pueblos que de allá se han pasado casi enteros, ninguno hay que dé otras nuevas. sino de arrepentimiento, el cual les viene juntamente con las. quejas de su daño» $(645 a)$.

La cuestión morisca debía resolverse europea no africanamente. La noble frente de Cervantes debió inclinarse meditabunda ante la misma pregunta que ha mortificado a los. españoles más reflexivos, desde el siglo xvi: ¿Por qué no hemos aplicado las soluciones europeas a los casos mayores de la vida nacional? Cervantes veía con abierta claridad que el problema morisco era netamente español: África sería solución para el pueblo aplebeyado que carecía de sensibilidad, más no para él, egregio, humano y aristocrático pensador. Había otras soluciones para los moriscos, nada quimé- ricas ni de arbitrista, que Europa aplicaba: «Salí, como digo, de nuestro pueblo [dice Ricote], entré en Francia, y aunque allí nos hacían buen acogimiento, quise verlo todo. Pasé a Italia, y llegué a Alemania, y allí me pareció que se podía vivir con más libertad, porque sus habitadores no miran en muchas delicadezas ${ }^{1}$; cada uno vive como quiere, porque en la mayor parte de ella se vive con libertad de conciencia» ${ }^{2}$. Yo no sé si Cervantes pensaba que esa libertad debía utilizarse para audaces finalidades; sí sé que gustaba de la libertad existente más allá de la frontera como medio sencillamente de poder ser cristiano, cosa imposible a un morisco que aspirara a serlo en España: "Lo que me tiene admirado es no saber por qué se fué mi mujer y mi hija antes a Berbería que a Francia, adonde podía vivir como cristiana” ${ }^{3}$. Sin duda alguna, tal afirmación implica la contraria respecto de España. Frente a esto resultan irónicas las frases del morisco en Persiles: "Cuándo llegará el tiempo que tiene profetizado un abuelo mío, famoso en el astrología, donde se verá España de todas partes entera y maciza en la religión cristiana, que ella sola es el rincón del mundo donde está recogida y vene-

1 Corrección obligada, para no ir demasiado lejos (véase antes pág. 291); esto de la libertad de Alemania se refería a la libertad religiosa, sin duda posible; comp.: "No quiso el rey darnos campo en en prohibe; disb) (V́se mi estudio en Homenaje a Menéndez Pidal, III, 577). Había, pues, que salir del dominio católico (es decir, espaňol), para tener libertad, dno es esn? Se alude en general a la libertad de Italia en El Licenciado Vidriera: ‘Puso las alabanzas en el cielo de la vida libre del soldado y de la libertad de Italias (edic. Schevill-Bonilla, pág. 76).

2 II, 54 ; RM, VI, 106. - La frase slibertad de conciencia» era usada por oto cot́n por otros coetan en lo que piensa de sicon ajos verion. gentileza decula de de conciencia en materia de sujeción La viuda valenciana, Rivad., XXIV, 67).

3 II, 54; RM, VI, 108. Es algo parecida la actitud de Espinel en Marcos de Obregón ( 1618$)$, edic. Clás. Cast., $\mathrm{II}, 63$. 
rada la verdadera verdad de Cristo!» ${ }^{1}$. Con lo cual queda acentuada la diferencia entre España y los otros países europeos, lo mismo que antes cuando el morisco habla en sentido recto ${ }^{2}$

El arreglo de la dificultad morisca hubiera debido ser algo humano y razonable; Cervantes, enemigo de la violencia en frío, de la venganza, hubo de revestir la máscara para escribir estas palabras de Ricote: «El gran D. Bernardino de Velasco..., como él vee que todo el cuerpo de nuestra nación está contaminado y podrido, usa con él antes del cauterio que del ungüento que molifica... ¡Heroica resolución del gran Filipo Tercero, y inaudita prudencia en haberla encargado al tal D. Bernardino de Velasco!» ${ }^{3}$.

\section{5 a.}

2 Otra vez en el capítulo LXIII repite Ricote: «Yo salí de mi patri a buscar en reinos extraňos quien nos albergase y recogiese, $y$ habiéndole hallado en Alemania..., - La marcha a Berbería de la hija de Ricote con sus tíos debe compararse con la huída de todo un pueblo de moriscos en Persiles, 645 ; al barrunto de la expulsión, era natural que los moriscos intentaran escapar con más tiempo para salvar sus bienes. Para conocer el asunto de los moriscos nada mejor que $A$ history of the Inquisition of Spain, de H. Ch. Lea, 1922, III, estaban de tal modo fundidos con la vida espaǹ imposible trazar la línea entre los cristias verde los francamente musulmanes. Su caso en diferes y en 1493 . es 1493 . Thar los moriscos vueitos a Castilla a pesar de la expulsión. Dice bien Lea: 4.a insana determinación de purificar el país de toda huella de sangre morisca, la confusión de los procesos, hicieron que muchos católicos, tan sinceros como sus perseguidores, fuesen arrojados a toricos, infieles, (III, 404).

3 II, 65; RM, VI, 315. Me parece que los calificativos de sheroicas e «inaudita» se usan tan sinceramente como estos otros, aplicados a la vida pastoril: «Querían renovar e imitar a la pastoral Arcadia, pensamiento tan nuevo como discreto" (II, 57; RM, VI, 334). Con buena discreción anota Clemencín: «El elogio que se hace aquí del conde de Salazar me parece harto impropio en boca de uno de los moriscos expulsados por su diligencia.» Que la expulsión era para algunos un desatino se deduce indirectamente de estas palabras de Súrez de Figueroa (Pasajero, 1617): :Escribe un moderno... a este propósito
Prescindiendo ahora de la expulsión de los moriscos, hállanse en otros casos algunas alusiones a la tolerancia o intolerancia religiosa. En Los baños de Argel dialogan Vivanco y Ossorio:

Oss. Argel es, según barrunto, arca de Noé abreviada :

aquí están de todas suertes oficius y habilidades, disfrazadas calidades.

Viv. Y aun otra cosa, si advierles, que es de más admiración, y es que estos perres sin nos dejen, como se ve, guardar muestra religion. Oue digastra Que digamos nuestra misa nos dejan, aunque en secreto.

Oss. Mas de una vez, con aprieto se ha celebrado y con prisa que una vez desde el altar, al sacerdote sacaron revestido, y le llevaron por las calles del lugar arrastrando ${ }^{1}$.

Los cristianos gozaban, pues, en Argel de la libertad de su culto, cosa que admiraba; lógicamente debían haber hecho lo que los españoles hacían con ellos. Claro es que el principio de la tolerancia iba acompañado de actos ocasionales de

[de la despoblación de España], haber observado castellanos y portugueses cierta razón de Estado en todo opuesta a la de donde procedió el poder y arandeza de los romanos. Viendo no hallarse cosa tan dió el poder y gande de los ron necesaria para las gandes conquistas como la muchedumbre de gen te, pusieron sumo cuidado no sólo en propagarse y multipicar su número con matrimonios, sino también con las colonias y tales socorros. En esta conformidad admitieron en sus ciudades hasta los propios enemigos... Al contrario, castellanos y portugueses - ya que requiriéndose, por la inmensidad de países y distancias de conquistas, grandísimo número de gente - sólo se valen de la de su nación, que es no de las más numerosas de Europa: causa de irse continuamente debilitando» (Edic. «Renacimiento», pág. 24).

$$
\text { I. I, } 3 I_{4} \text {. }
$$


violencia ${ }^{1}$. Cervantes dista de creer que sea de natural evidencia el que otras religiones toleren la católica; lo juzga una virtud digna de admirar.

En La española inglesa la reina Isabel de Inglaterra, escudo del protestantismo, tolera y favorece junto a sí a la católica Isabela; una camarera dice a la reina «que Isabela era católica, y tan cristiana, que ninguna de sus persuasiones, que habían sido muchas, la habían podido torcer en nada de su católico intento. A lo cual respondió la reina, que por eso la estimaba en más, pues tan bien sabía guardar la ley que sus padres la habían enseñado» ${ }^{2}$ Se ha dicho que Cervantes revela ignorancia absoluta de la vida cortesana al presentar como lo hace a Isabel de Inglate$\mathrm{rra}^{3}$; pero le atribuye la más alta calidad que él concebía: la de comprender el ajeno punto de vista. No nos importa la irrealidad histórica de la reina que Cervantes forja, y quizá a él tampoco; pero sí el hecho de que el autor haya proyectado sobre la reina la idea de la comprensiva y señoril tolerancia, y haya puesto, en cambio, en boca de la camarera - pueblo, escaleras abajo - este pobre discurso, como disculpa de su intento de asesinar a Isabela: «Mandó la reina prender a su camarera y encerrarla en un aposento como su delito merecía, puesto que ella se disculpaba diciendo que en mata a Isabela hacía sacrificio al cielo, quitando de la tierra a una católica.»

Moros y protestantes, por consiguiente, aparecen usando la tolerancia y la barbarie, y Cervantes está naturalmente con la primera. Esa tolerancia, según él, existe en Francia, en Italia, en Alemania, en la reina de Inglaterra, hasta entre los moros; pero no en España, donde los moriscos, españoles y bautizados, se ven forzados a buscar aquella virtud donde la hay. No puede tampoco pasarse en silencio el que Cervantes

1 En principio el musulmán tolera junto a sí otras religiones; la prueba es la existencia de judíos en el Norte de África, que viven allá desde hace siglos.

2 Edic. Schevill-Bonilla, pág. 45.

3 F. A. DB ICAzA, Las novelas ejemplares de Cervantes, 1915, pág. 156 se refiera a crueldades de los moros como represalias de las cometidas en España contra los moriscos; cierto que él dice aprobar lo que se hace en España; aunque el lector tiene ya bastantes informes para decidir sobre la sinceridad de su opinión. En El trato de Argel hablan dos cautivos, con gran dolor, de la muerte fiera que ha recibido un cristiano:

Leonardo. Deja el llanto, amigo, ya:

que no es bien que se haga duelo

por los que se van al cielo,

sino por quien queda acá..

Mide por otro nivel

tu llanto ', que no hay paciencia

que las muertes de Valenci

se venguen acá en Argel.

Muéstrase allá la justicia

en castigar la maldad;

muestra acá la crueldad

cuánto puede la injusticia..

Bastábanos ser cautivos,

sin temer más desconciertos,

pues si allá queman los muertos,

abrasan acá los vivos ${ }^{2}$.

Usa, Valencia, otros modos

en castigar renegados:

no en público sentenciados

mueran a tóxico todos ${ }^{3}$.

El pasaje es importante; si en Valencia insisten en dar suplicio a los moriscos, preferible es que los envenenen a

1 Es decir: «Llora más bien por otra causa.»

2 La Inquisición solía ahorcar al condenado antes de quemarlo. Se refiere Cervantes al suplicio en Argel de Fr. Miguel de Aranda, en 1577 . Dos cautivos españoles, caballeros, estuvieron a punto de ser quemados en Argel en represalia de los moros que lo habían sido en España. (P. PAstor, Documentos cervantinos, I, 334; SchrVILL-Bonilla, Obras de Cervantes. Comedias, V, 222.)

3 La edición Schevill-Bonilla, V, 32, puntúa mal este pasaje:

$$
\begin{aligned}
& \text { Usa Valencia otros modos } \\
& \text { en castigar renegados } \\
& \text { no en público sentenciados; }
\end{aligned}
$$

Imueran a tóxico todos! 
todos sigilosamente; eso siquiera no acarreará las venganzas de allende el mar. ¿No se percibe la dolorosa ironía? Porque ¿qué base hay en toda la obra de Cervantes para pensar que él fuese partidario de crueldades de esa laya? Su moral - ya lo veremos - no admite nada parecido. Podrá algún personaje realizar un acto violento; pero nadie practica la doctrina del asesinato inquisitorial que se desprendería de estas líneas, si fuésemos a tomarlas en sentido literal.

Los judíos aparecen alguna vez. Sancho cree que «debían los historiadores tener misericordia de mí y tratarme bien en sus escritos» aunque sólo fuese por «creer, como siempre creo, firme y verdaderamente, en Dios y en todo aquello que tiene y cree la Santa Iglesia Católica Romana, y el ser enemigo mortal, como lo soy, de los judíos» ${ }^{1}$. Clemencín observó el tono de broma en esta observación: "Cervantes, a un mismo tiempo, pinta y ridiculiza las groseras ideas del vulgo, entonces comunes...; llegaron hasta creer que los judíos tenían rabo» ${ }^{2}$

Cervantes ha visto a los judíos en Argel y en Italia. En Los baños de $\mathrm{Argel}^{3}$ un sacristán se divierte en molestar a un hebreo, e intenta que le lleve su barril en sábado. El israelita da razones:

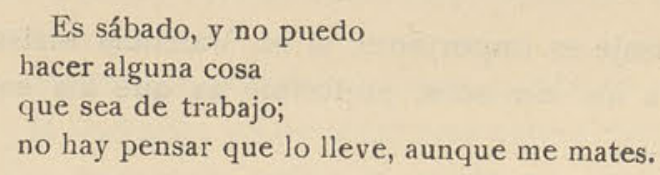

El sacristán cristiano lo maltrata; pero el hebreo defiende su fe:

iAy, ay, mísero y triste!

Por el Dío bendito,

que si hoy no fuera sábado,

que lo llevara. ¡Buen cristiano, basta!

\footnotetext{
1 II, 8; RM, IV, ${ }_{175}$

21835, IV, 139.

3 I, 285.
}

$\mathrm{Y}$ entonces interviene un viejo, uno de esos personajes cervantinos dotados de sensibilidad, que a vueltas de unos duros calificativos para los judíos, libra al desdichado:

$$
\begin{aligned}
& \text { A compasión me mueve. } \\
& \text { Oh gente afeminada, } \\
& \text { infame y para poco! } \\
& \text { Por esta vez te ruego que le dejes. } \\
& \text { Pies y manos te beso, } \\
& \text { señor, y el Dío te pague } \\
& \text { ei bien que aquí me has hecho. }
\end{aligned}
$$

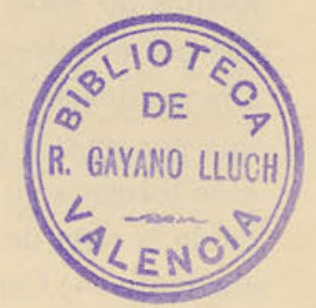

Según el viejo libertador,

$$
\begin{aligned}
& \text { La pena es esta de aquel gran pecado. } \\
& \text { Bien se cumple a la letra } \\
& \text { la maldición eterna } \\
& \text { que os echó el ya venido, } \\
& \text { que vuestro error tan vanamente espera }{ }^{1 .}
\end{aligned}
$$

En La gran Sultana hay otra escena de crueldad de que son víctimas unos judíos: échanles tocino en la comida, escúpenles, etc. El griego Andrés expresa un juicio sobre los hebreos parecido al del viejo en Los baños de Argel:

$$
\begin{aligned}
& \text { ¿Oh gente aniquilada! } \mathrm{Oh} \text { infame, oh sucia } \\
& \text { raza, y a qué miseria os ha traído } \\
& \text { vuestro vano esperar, vuestra locura } \\
& \text { y vuestra incomparable pertinacia! }
\end{aligned}
$$

Al final de Persiles hallamos en Roma algunos judíos de los establecidos allá: «Tenemos por oficio adornar casas de todo lo necesario, según y cómo es la calidad del que quiere habitarlas» ${ }^{2}$. Luego el judío Zabulón interviene en tercerías amorosas, y su mujer actúa de hechicera ${ }^{3}$.

En resumen, las poco numerosas alusiones a los israelitas son desfavorables para ellos. Cervantes los presenta como

1 El mismo sacristán comete otras crueldades con el judío: le roba su comida en sábado (págs. 299-300); le roba su hijo (ṕ́g. 330 ), que le devuelve por orden del rey, pero el judí le ha de pagr 40 dsperos por la devolución.

$$
2665 a \text {. }
$$

$3669 a, 671 b$. 
raza muy inferior, por bajo de los musulmanes de África, y ni por asomo les hace hablar como a los moriscos españoles. Las burlas crueles de que son objeto en dos de sus comedias no están suficientemente condenadas ni contrapesadas por el autor, que por dos veces atribuye tales desdichas a la pertinacia hebraica. No veo, pues, base sino para afirma que por unas u otras razones - antijudaísmo de español, opinión formada en Argel, donde el judío era un pobre ser, blanco de la saña de moros y cristianos, concesión a la opinión corriente - Cervantes aparece como lo que hoy llamaríamos un antisemita. De cualquier forma la cuestión es meramente incidental dentro de su obra ${ }^{1}$.

No creo posible, a menos de forzar los textos, ver ataques a la Inquisición ${ }^{2}$. Creo sí que hay datos suficientes para sostener que Cervantes pone acento personal en la cuestión de los moriscos, aun admitiendo que en su espíritu - en épocas iguales o diferentes - hubiese tenido cabida la opinión favorable a la expulsión o a la no expulsión; la no expul sión era la idea, un anhelo de belleza moral, como la de $G a$ latea o Don Quijote, como la de la justicia, en cuyo nombre

1 Judíos, moros y cristianos aparecen una vez en parangón:

$$
\begin{aligned}
& \text { Gasta en Pascuas el judio } \\
& \text { su hacienda; en bodas el moro; } \\
& \text { el cristiano a su albedrio, } \\
& \text { sigue en esto otro decoro, } \\
& \text { de todo gusto vacio, } \\
& \text { porque en pleitos le da cabo. } \\
& \text { (Baños de Argel, I, 334.) }
\end{aligned}
$$

2 Se ha interpretado como sátira de los autos de fe el capítulo LXIX de la Segunda parte del Quijote; así, Antonio Puigblanch, La Inquisición sin máscara, I8I I; pero no se ve la sátira por ninguna parte. Se menciona a la Inquisición en Persiles (pág. 602), con motivo de la bruja Cenotia; en el Quijote, cuando D. Antonio Moreno quita de su casa la cabeza encantada, y en I, 4 I (RM, III, 254), cuando un renegado quiere reducirse «al gremio santísimo de la Iglesia». Eso es todo, al menos que yo sepa. Pero que algo llevaba dentro el autor se desprende de la relación que establece entre saber leer e ir a la hoguera (pág. 78). Comp. D. Luis de Góngora diciendo a su obispo, en I588, ra (pág. 78). Comp. D. Luis de Góngora diciendo a su obispo, en r58, nado por liviano que por hereje» (M. Artigas, Góngora, pág. 64 ). se da suelta a los galeotes; lo demás era el hecho, el morisco de que se hablaba, que hacía estas o las otras cosas molestas para el vulgo, a quien no importaban los motivos ni los puntos de vista. Para mí es indudable que la conciencia de Cervantes, su ser más íntimo, se inclina hacia la idea, y que la opinión del vulgo está recubierta de sátira y de ironía. En último término, reconozcamos que el tema aparece tratado en forma «impresionista», tan esencial en el arte y en la ideología del autor.

\section{EL CRISTIANISMO DE CERVANTES}

Cervantes siente hondamente el valor de las virtudes cristianas, en cuanto amor y comprensión del prójimo. Su cristianismo se basa más en la conducta que en las aparentes ceremonias. La caridad y el perdón de las injurias mueven su pluma con expresiva elocuencia. Ánimas del purgatorio, oraciones, sermones, reliquias, santos, milagrería supersticiosa, ceremonias religiosas, conducta antievangélica de frailes, ermitaños y eclesiásticos, todo ello da lugar a zumbas y ataques más o menos penetrantes; en cambio, se ensalza a menudo la heroica sumisión de las pasiones al imperativo cristiano, que en nuestro autor se resuelve en categoría moral ${ }^{1}$.

Mas en esta zona viva de la conducta el pensamiento cervantino no olvida tampoco su ley fundamental, que es la de la armonía y la «composibilidad»; y en virtud de tal principio, las realidades morales se nos muestran condicionadas limitadas, como vimos que acontecía con los fenómenos psicológicos y los meramente físicos. Los estímulos morales, sancionados por la religión, hallan su límite en otros impulsos vitales basados en la naturaleza. Así vimos que acontecía a Leonora en El Celoso extremeño, a D. ${ }^{2}$ Lorencica en El

1 Erasmo había escrito: «Tienen en más las ceremonias que la verdadera religión, las leyes de los hombres que no las de Cristo, la máscara que no la persona, la sombra que no lo firme, lo tempora que lo eterno" (Silenos de Alcibiades, edic. 1555 , fol, ro $r$ ). 
Viejo celoso, a Luisa en Persiles, a Camila en El curioso impertinente. Todas esas mujeres infringen la fe jurada a sus esposos y, por ello, nada les acontece; la pluma cervantina las sostiene con enérgica resolución, y eleva el plano de su moral mucho más arriba de lo que toleraría la preceptiva de la Iglesia. Que la actitud del autor es desde luego consciente resulta de lo expuesto en esparcidos lugares de su obra: Ricaredo «determinó de posponer al gusto de enamorado el que tenía de ser católico» ${ }^{1}$, y está así dispuesto a embestir unas naves católicas, porque «tal vez las leyes del gusto humano tienen más fuerza que las de la religión» ${ }^{2}$. Y frente a posibles escrúpulos de conciencia, Cervantes echaría mano de un salvoconducto digno de la más fina moral de los casuístas:

$$
\begin{aligned}
& \text { Misericordia tuvo y tiene Cristo } \\
& \text { con que perdona siempre las ofensas } \\
& \text { que por necesidad pura le hacen }{ }^{3} \text {. }
\end{aligned}
$$

Excusado es decir que Cervantes no expone dogmáticamente ese concepto de la necesidad, ni nos da su límite. Se contenta con señalar la existencia de la relatividad moral.

1 Española inglesa, edic. Schevill-Bonilla, pág. 19.

2 Persiles, pág. 563 a. Comp.: «Doy yo al diablo al amor y al bellaco que me lo enseñó; y es lo peor que lo conozco, y determino ser soldado debajo de su bandera, porque no siento fuerzas que se opongan a las que hace el gusto con los que poco saben (Ibid., 657 b).

3 Trato de Argel, VI, 70 . Prescindiendo de esto, Cervantes alude en forma interesante a la infinitud de la divina misericordia, armonía sublime de amor $y$ comprension

$$
\begin{aligned}
& \text { En dos pecados se ha visto } \\
& \text { que Judas quiso extremarse, } \\
& \text { y fué el mayor ahorcarse } \\
& \text { que el haber vendido a Cristo. } \\
& \text { (Ruffian dichloso, II, 76.) } \\
& \text { Que más pecó en ahorcarse } \\
& \text { Judas que en vender a Cristo. } \\
& \text { (Gran Sultana, III, 184.) }
\end{aligned}
$$

Me parece que el pensamiento ha sido expresado con anterioridad, pero no recuerdo o no conozco sus antecedentes.
Hemos creído hallar a veces cierta dilección por la sencillez de los actos religiosos, frente al complicado aparato del rito y la ceremonia. En eso descubriríamos una vez más la honda influencia de Erasmo en la ideología del autor. Grisóstomo dispuso que lo enterraran «en el campo, como si fuera moro, y que sea al pie de la peña..., adonde él la vió [a Marcela] la vez primera. Y también mandó otras cosas, tales, que los abades del pueblo dicen que no se han de cumplir ni es bien que se cumplan, porque parecen gentiles» ${ }^{1}$. El entierro de Grisóstomo se verifica como él ordenó, y su sepultura se cava en una peña. Hay, sin duda, en este pasaje ecos de lo pastoril ${ }^{2}$; pero la escena está rodeada de ambiente realista (en el Quijote nada es plenamente de novela caballeresca o pastoril), tal como la intervención de los abades del lugar, inconcebible en la Galatea, cuyas escenas tienen muy otro carácter.

Debe compararse acto tan sencillo, que lleva la plena aprobación de Don Quijote, con la aventura del cuerpo muerto (I, I9), en que el Caballero deshace y maltrae la fúnebre y aparatosa comitiva de «los señores clérigos del difunto, que pocas veces se dejan mal pasar». La oposición que insinúo entre ambos casos cobrará más sentido si se tienen en cuenta textos como éste del erasmista Mal Lara: "Siempre entre cristianos fué estimada en mucho la pompa funeral, como cosa piadosa y necesaria al socorro de los difuntos. Pero hase de hacer de tal suerte, que en ella se pretenda la gloria de Dios y bien de las ánimas, y que no pare en sólo lo exterior... Los gentiles tenían locura que si no enterraban acá sus cuerpos y no les hacían ciertas solemnidades, que andaban allá sus almas errando y en pena, según lo trae Vergilio en el libro VI, Eneida; pero aquella fué ceguedad de hombres sin lumbre de fe. Nosotros creemos que como haya

\section{I, $12 ; \mathrm{RM}, \mathrm{I}, 360$.}

2 .Erastro hizo una sepultura..., y dándole el último svale», le pusieron en ella, y no sin compasión de su desdichado caso, se volvieron a sus ganados» (Galatea, edic. cit., I, 14). 
muerto el justo en buen estado, ora tenga buena sepoltura, ora esté en el disierto a ser manjar de aves, que el señor Dios nuestro tiene cuidado de nosotros» ${ }^{1}$.

Lo cual es pura doctrina erasmista : ni pompa funeral ni sufragios, sino vida justa y cristiana y muerte cándida : «Padre mío, entiérrame como enterrarías a un cristiano de los más ínfimos e bajos... Ni tampoco me doy mucho del lugar donde deposites este corpecillo, pues que doquiera que lo pusieres ha de ser hallado igualmente en el último día del juicio. La pompa e fausto del entierro tampoco me perturba nada, e por eso no debemos tardar en hablar en ella» ${ }^{2}$.

Consideremos ahora las opiniones de Don Quijote acerca de aquellos santos, cuyas imágenes tiene ocasión de contemplar en la apacible aventura del capítulo LVIII de la Segunda parte. Recuerde el lector. Aparecen allá San Jorge, San Martín, Santiago y San Pablo; cada uno de ellos va acompañado de breve caracterización. San Jorge, "fué uno de los mejores. andantes que tuvo la milicia divina; llamóse don San Jorge y fué además defendedor de doncellas». San Martín «también fué de los aventureros cristianos»; y su acto de partir la capa da lugar a un malicioso chiste (véase antes pág. 267). Santiago "se llama San Diego Matamoros; uno de los más valientes santos y caballeros que tuvo el mundo y tiene agora el cielo»; y más adelante ironiza el autor sobre la veracidad de sus portentos (véase pág. 258). Pero al llegar a San Pablo cambia el tono; Cervantes se torna grave y elocuente, y no hay sombra de ironía en sus palabras: "Caballero andante por la vida, y santo a pie quedo por la

1 Filosofia vulgar, 1568, fol. 94. Debe citarse el sencillo entierro de la doncella Taurisa, y los rasgos de Contrarreforma que lo acompala doncella Taurisa, y los rasgo de Contrarreforma que lo acompaňan: «La piedad y honestidad cristiana no consintió que la desnudasen.s Los dos caballeros muertos en desafío quedan sin sepultura •Los marineros no quisieron, como católicos, que se hiciese ninguna a los muertos en el desafíos (Persiles, 587 a).

2 Erasmo, De la manera del morir, en Origenes de la Novela, IV $244 b$. Compárese el entierro del mundano, Ibid., 24I $a$. muerte [es decir, que no sigue dando mandobles desde el cielo como Santiago], trabajador incansable en la viña del Señor, doctor de las gentes, a quien sirvieron de escuelas los cielos, y de catedrático y maestro que le enseñase el mismo Jesucristo" ${ }^{1}$. Capítulos antes hay también una referencia a San Pablo ${ }^{2}$, y la cita de una de sus epístolas ocurre en un momento de grave emoción: "Con todo eso, digo que ha de tener mucho de Dios el que se viniere a contentar con ser pobre, si no es de aquel modo de pobreza de quien dice uno de sus mayores santos: "Tened todas las cosas como si no las tuviésedes» ${ }^{3}$. Parecería, pues, razonable esta deducción : que nuestro autor toma más en serio a San Pablo que a esos otros santos, y que se inclina con más reverencia ante un «doctor» de Cristo, que actuó con el espíritu más que con la espada, y cuya vida no andaba envuelta en fábulas ${ }^{4}$. $\mathrm{Y}$ es imposible no volver a citar a Erasmo: « ¿No habéis observado que cuando celebra la Iglesia la fiesta de alguno de esos santos poéticos y novelescos, por ejemplo, de San Jorge, de San Cristóbal, de Santa Bárbara, suele desplegarse una pompa y una devoción bastante mayor que la usada para festejar a San Pedro y San Pablo, y aun al mismo Redentor? ${ }^{5}$.

\footnotetext{
II, $58 ; \mathrm{RM}, \mathrm{VI}, 157$

II, 44 ; RM, V, 390 .

Corintios, I, 7, 31 .

Santiago el Mayor desempeña escaso papel evangélico comparado con San Pablo; su celebridad viene de ser el primer Apóstol mártir (Hechos, XII, 2), no de su doctrina y predicación; y sobre todo del caudal de fábulas novelescas que en la Edad Media le dotaron de nueva personalidad, como aconteció a Virgilio, a Trajano y a otros ente dudaba el P. Mariana de la venida a España del cuerpo de aquel apóstol.

5 Elogio de la locura, edic. cit., pág. 75. San Pablo es santo prefeido de Erasmo, y le cita a cada paso: «En este libro están las epístolas de San Pablo, las cuales tú, Eulalio, sé yo que traerás de buena gana siempre contigo, pues siempre traes al autor de ellas en la boca (Coloquios, en Origenes de la Novela, IV, 199). Escribe Pineav, Erasme, pág. I09: ‘Siguiendo el ejemplo de John Colet, Erasmo cita a San Pablo muy frecuentemente. San Pablo es el mayor nombre teológico del cristianismo.»
} 
Proyectando ahora en más amplia perspectiva las ideas cristianas de Cervantes, hallamos que, según observé anteriormente, los problemas de conducta son para él esenciales. A menudo se establece estrecha correlación entre el proceder de la persona y el hecho de ser cristiano:

¿Cristiano soy y he de vivir cristiano! $\mathrm{Y}$ aunque a términos tristes conducido dádivas o promesa, astucia o arte, no harán que un punto de mi Dios me aparte ${ }^{1}$.

Dorotea confiaba en que D. Fernando habría de «caer en la cuenta de que era cristiano, y que estaba más obligado a su alma que a los respetos humanos» ${ }^{2}$. «Estando vos obligada a ser [buena] por ser cristiana» ${ }^{3}$. «Esta santa ley nos enseña [dice Antonio a su hijo] que no estamos obligados a castigar a los que nos ofenden, sino a aconsejarlos la enmienda de sus delitos», etc. ${ }^{4}$.

Esto último no es en Cervantes una máxima abstracta: en su eficiencia práctica hallaríamos una diferencia esencial entre nuestro autor y quienes, en su época, prodigan tal principio como tópico en escritos sacros y profanos. Por razones a la vez filosóficas y cristianas, la venganza está excluída de las acciones cervantinas, si no se trata de algún violento impulso ${ }^{5}$ que inhibe la reflexión: «No pude vengarme por estar enfrenado entonces, y después, a sangre fría, no qui-

\section{Trato de Argel, III, 72 .}

2 I, $28 ;$ RM, II, 403

3 Fuez de los divorcios, IV, 14.

- Persiles, 607 a. Comp.: $\alpha_{i}$ Muerto me has, moro fingido, Y cristiano mal cristiano! (Gallardo español, I, I I8). «Aunque ventero, todavía no mal cristiano!s (Gallardo español, I, 1 18). «Aunque ventero, todavía soy cristiano» (I, 32). «Hermano, si sois cristiano..., os ruego que enca-
minéis luego esta carta al lugar y a la persona que dice el sobrescritos (I, 27 ; RM, II, ${ }_{360}$ ). $\propto \mathrm{En}$ buen entendimiento y cristiana conciencias (I, 46). Véase además: RM, II, 412 ; III, I 21,127 , etc.

5 *El ardor de la cólera acrecienta el ánimo, y la injuria reciente despierta la venganzas (Señora Cornelia, Rivad, I, 216 a) Asi es cono

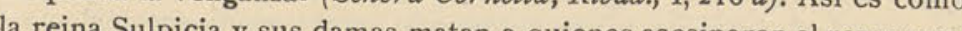
la reina Sulpicia y sus damas matan a quienes asesinaron al rey y que-
rían ofender la castidad de ellas (Persiles, Rivad., I, $6 \mathbf{I}_{2} \mathbf{b}$ ).

se: que la venganza pensada arguye crueldad y mal ánimo» ${ }^{1}$. Mediante esa reflexiva purificación del ímpetu pasional, llegamos a momentos de estoica sublimidad. El cristianismo se torna así en fuerte y austero estoicismo; y Cervantes viene a incorporarse de esa suerte a la tan española tradición senequista, que Petrarca y Erasmo avivan durante nuestro Renacimiento:

D. Fuan. ¡Por Dios, que mentís!

Vozmediano. Estoy preso y soy cristiano, y así no os respondo nada ${ }^{2}$

Sobre tal fondo de ideas vienen a situarse esos dramáticos episodios en que las venganzas se ahogan, severamente aprisionadas por impulsos humanos de signo contrario. En tales casos, ni cándida sensiblería de santoral ni frío silogismo de Calderón; como nunca destaca en tales momentos el ademán señoril y aristocrático de Cervantes, cuyo sentido pleno se nos revelaría si nos atreviésemos a prolongar el gesto del personaje en una de esas manos divinas que el Greco imaginó para expresar lo inefable: «¿Dónde está vuestra discreción, señor don Pedro Tenorio? ¿Cómo y es posible que vos mismo queráis confesar vuestra ofensa? ¿No veis que estos agravios, antes que la pena, traen la disculpa consigo?» 3 . Esas palabras esenciales impiden que Feliciana de la Voz sea víctima de la cólera de sus familiares; Feliciana, guiada por el amor y la naturaleza, se había entregado a Rosanio, a fin de no desposarse con Luis Antonio, que ella no amaba. Sobre tal hecho hace Cervantes un gran signo comprensivo, y la venganza paterna se desvanece: "Ganó fama de prudente el padre, de prudente el hijo, y los amigos de discretos y bien hablados." Maravillosa, vitalmente «bien hablados" salen de la mano de Cervantes estos pleitos de moral y de humanidad.

1 Coloquio, edic. Clás. Cast., pág. 328.

2 Gallardo español, I, 122.

3 Persiles, pág. 6326 . 
Comprendemos que la atención de nuestro egregio artista se proyectara con redoblada intensidad sobre las páginas de los Hecatommithi ( 565 ), de Giraldo Cintio, al llegar a la sexta novela de la sexta década en que se narra cómo una madre acoge al asesino de su hijo. Para desarrollar ese tema estaba previamente dispuesto su espíritu; y muy cervantinamente se nos hablará en Persiles de «el valeroso y nunca visto ánimo cristiano y admirable proceder de D. ${ }^{a}$ Guiomar de Sosa», dama portuguesa que concede hospitalidad, sin saberlo, a quien por desventura acababa de dar muerte a su hijo. La justicia aparece; la madre conoce entonces a quién ha dado albergue, y el afán de venganza brota en su corazón: «Ay venganza, y cómo me estás llamando a las puertas del almal» Mas la reacción heroica reduce el instinto : «La afligida madre... respondió llena el alma de generoso ánimo y de piedad cristiana: «Si ese tal hombre ha entrado en esta casa no a lo menos en esta estancia; por allá le pueden buscar, aunque plegue a Dios que no le hallen, porque mal se remedia una muerte con otra, y más cuando las injurias no proceden de malicia» ${ }^{1}$. El matador puede escapar en salvo. Cervantes ha sido más discreto que Giraldo Cintio; éste hace que la madre adopte como hijo a quien la privó del suyo. Nos hallaríamos entonces ante maravillas de santoral, y Cervantes sabe justamente dónde caen los límites del arte en esa zona peligrosa que linda con la ética.

Rasgos como el anterior son típicos en Erasmo. Leemos en los Apotegmas ${ }^{2}$ :

Deste sabio [Pitaco] se cuenta un ejemplo maravilloso de piedad, yes que estando un hijo suyo, 1 lamado Tirreo, en la ciudad de Cods y es que cstando un he sub has sentado en una tienda de un barbero, lleg barda le dió un golpe en la cabeza y lo mató. Los cumanos prendieron luego a este hombre y entregáronselo a Pitaco para que él tomase la venganza que quisiese; mas el filósofo, conocida la causa, lo soltó luego y perdonó, diciendo que mejor era el perdón que la venganza.

1 Rivad., I, 635.

2 Amberes, 1549 , fol. 261

La imitación de Giraldo Cintio no es, pues, ocasional; así se deduce de cuanto llevamos dicho, y también de otras situaciones análogas. En La española inglesa, Ricaredo solicita el perdón para la envenenadora de Isabela, su amada; en Persiles ${ }^{1}$, un conde, herido por la espalda, habla estas palabras: «Perdono a mi matador y a todos aquellos que con él tuvieron culpa» ${ }^{2}$. Por todo ello hay que admitir que al excusarse Sancho, medroso como siempre, de entrar en pelea con los cómicos de las "Cortes de la Muerte», expresa humorísticamente un pensamiento muy del autor de su personalidad: «No hay para qué, señor, tomar venganza de nadie, pues no es de buenos cristianos tomarla de los agravios» ${ }^{3}$.

Cristianismo es, pues, obras y no meras palabras:

$$
\begin{aligned}
& \text { De cristianos juramentos } \\
& \text { está preñada la tierra, }
\end{aligned}
$$

lleno el mar, densos los vientos 4 .

«Bien predica quien bien vive - respondió Sancho y yo no sé otras tologías». "Ni las has menester, dijo Don Quijote» ${ }^{5}$. Pasaje que debe concordarse con este otro de Los baños de Argel (I, 28I):

Viejo.

\section{Ya vos}

tenéis ancha la conciencia, ya coméis carne en los días ya coméi
vedados.

Sacristan

$$
\text { ¿Qué niñerías! }
$$

1 Rivad., I, 640 b.

2 La venganza no se realiza en algún caso por motivos puramente vitales, no de razón. La hermosa Ruperta va a matar a Croriano, hijo del asesino de su esposo (cuya cabeza llevaba en su equipaje para mantener vivo su afán vindicador); pero la belleza del joven, que contempla dormido, suspende su ánimo; en lugar de matarlo acaba compartiendo su lecho (Persiles, Rivad., I, 654).

3 II, I I; RM, IV, 242 .

4 Gallardo español, I, ı06. Comp.: «Cuán admirable fué la verdad de los que antes con un sí o con un no eran creídos; no agora, que pensamos cuando más juramentos hacen mienten más? (MAL LARA, Filosofia vulgar, edic. 1568 , fol. ${ }_{3} \mathrm{I} r$ ).

5 II, 20; RM, IV, 419 . 
mi amo.

Viejo. ¡Mal os hará!

Sacristán. Oue no hay aqui teologias

El pasaje es de la mayor importancia, sobre todo por lo que sigue. El Viejo recuerda al Sacristán a aquellos Macabeos que

por no comer grosura

se dejaron hacer piezas.

Y responde el Sacristán:

Si empiezas,

en viéndome, a predicarme,

por Dios que he de deslizarme

en viéndotc.

Viejo.

¿Ya tropiezas?

Que no caigas, plega al Cielo

Sacristán. Eso no, porque en la f

Soy de bronce.

Viejo.

Yo recelo.

que si una mora os da el pie,

deis vos de mano a ese celo.

Sacristin.

más de dos lo que quiź

tro no lo desechara?

Nuestro Sacristán afirma, pues, que su fe es de bronce; que ha observado la castidad, no obstante las solicitaciones de que le ha hecho objeto más de una mora; que la abstinencia de carne es una «niñería» y «teologías». Erasmo, basándose en San Pablo (Corintios, IV, 8 y IO): «omnia licent», había declarado: «En las cuales palabras da a entender que no hay unas viandas lícitas e otras defendidas para los cristianos» ${ }^{1}$.

Por diversos caminos llegamos siempre al mismo resultado: el cristianismo de Cervantes es esencialmente erasmista. Sancho y el Sacristán coinciden en entender por teologías ${ }^{2}$

1 Coloquios, en Origenes de la Novela, IV, 1876 .

2 No sería lícito identificar el sentido que claramente ofrece aquí teologia con el que presenta en la frase «meterse en teologias" = 'me- prescripciones formalistas que poco tienen que ver con la vida cristiana. Cervantes habría leído lo que el erasmista Castiglione dice en El Cortesano ${ }^{1}$ : "Muy pocas veces se hallaba teólogo que fuese buen cristiano.» De ellos había dicho Erasmo en el Elogio de la locura, «que ni aun tienen tiempo de leer una sola vez el Evangelio o las Epístolas de San Pablo. $\mathrm{Y}$ lo mejor del caso es que mientras garrulean en sus escuelas se imaginan estar defendiendo la Iglesia ${ }^{2}$. Y con tono más grave en los Silenos de Alcibiades ${ }^{3}$ : «Llaman herejía si alguno dijere o escribiere algo que en alguna manera no concierte con las proposiciones que llaman magistrales o con la gramática, y no llaman ni tienen por herejía si alguno alabe o tenga en mucho... aquello que el mismo Cristo en toda su doctrina manda menospreciar, el que ordena alguna orden de vida muy contraria a los mandamientos evangélicos y a los establecimientos apostólicos» ${ }^{4}$.

Entre las virtudes cristianas, las que más destacan, las que sin duda pone Cervantes en primer plano, por entender que son la base de la armonía de amor predicada en el Evangelio, son la humildad ${ }^{5}$ y la caridad: "No puede ninguno de nosotros [los diablos] alabarse que ha visto en el infierno

erse en honduras', que ocurre en Rinconele (védse edic. Rodríguez Maín, 1920, pág. 380). En estos citados pasajes del Quijote y de Los baños de Argel, lo teológico se contrapone, como un enredo teórico, a la conducta sencillamente honesta y cristiana.

1 Edic. cit., pág. 24I. Eran muy frecuentes las críticas a los teólogos: «I filosofi e i teologi e tutti gli altri che scrivono le cose sopra natura $o$ che non si veggono, dicono mille pazzie; perchè in effetto gli no (in the ha (Guicciardin, Ricordi politici e civili, núm, cxxv).

2 Edic. cit., pág. 100.

3 Edic. ${ }_{555}$, fol. $13 r$.

No es, pues, exacto Busson, Sources du rationalisme, pág. xıv, al decir: «Budé, Erasme... attaquent les moines, le célibat ecclésiastique, mais non la théologie.»

5 eLa humildad es la basa y fundamento de todas virtudes, y que sin ella no hay alguna que lo sea, (Coloquio de los perros, edición Clás. Cast., pág. 234). 
algún caritativo» ${ }^{1}$. Sancho, es sabido, posee en alto grado el don de conmoverse ante el dolor ajeno; así, en el episodio del galeote viejo: «Túvole tanta compasión, que sacó un real de a cuatro del seno, y se lo dió de limosna» ${ }^{2}$. Sancho es también el ministro de esa virtud con aquel pobre rapaz, doble víctima de la bestialidad de Haldudo y de la insania de Don Quijote. Y, aparte de esto, son frecuentes los rasgos de delicada humanidad en todas las obras cervantinas ${ }^{3}$; y tanta im. portancia concedía el autor a la caridad, que llega a escribir: "Las obras de caridad que se hacen tibia y flojamente no tienen mérito ni valen nada» ${ }^{4}$. El pasaje fué tachado por la Inquisición (véase pág. 263, nota).

Erasmo en el Elogio de la locura (pág. I06) hace que Cristo responda a los monjes el día del supremo juicio: «De que país viene esta nueva casta de judíos? ¿No he dado a los hombres una sola ley?... Claramente y sin parábolas prometí la herencia de mi padre no a las cogullas, ni a las oracioncillas ni a las abstinencias, sino a las obras de caridad (caritatis officiis).» $\mathrm{Y}$ en los Coloquios ${ }^{5}$, al exponer los preceptos cristianos: «La tercera [cosa], que tengamos caridad; esto es, que en todo cuanto pudiéremos, hagamos bien a todos.»

Los textos citados, lo expuesto antes al tratar de la Contrarreforma, las numerosas concomitancias que en diversos lugares de este libro se han establecido entre Cervantes y Erasmo, todo ello nos obliga a aceptar como hecho evidente que las ideas cristianas de Cervantes cuadran bien con su filiación renacentista. Esa aspiración a la sencillez rústica de la naturaleza que hemos puesto de relieve en el capítulo $V$, está en lógica correlación con esta idea de un cristianismo más simple y más ingenuo, no recargado por cuanto los hombres añadieron a la prístina pureza del Evangelio: San

\footnotetext{
Rufiain dichoso, III, 90.

I, 22; RM, II, 200.

«Propia y natural condición de mujeres principales, enternecerse de los sentimientos y trabajos ajenos» (Dos doncellas, Rivad., I, 204a).
}

4 II, $36 ; \mathrm{RM}, \mathrm{V}, 247$

Origenes de la Novela, IV, 152.
Pablo y no Santiago Matamoros; castidad y caridad y no abstinencias ni teologías. Levantada cuidadosamente esa cubierta de prudencia, tejida por la cautela del momento (la Contrarreforma), llegamos a la intimidad del pensamiento de Cervantes, nótese bien que sin hacer conjeturas, sin tocar a claves ni a misterios, sino colocando pulcramente unos textos después de otros, y dándoles el sentido que tenían para un español esclarecido en el siglo xvi, que había leído los libros que corrían en romance, al alcance de quien tuviese empeño en pasar sus páginas.

La ideología renacentista está obsesionada por ese retorno a los orígenes de las formas de cultura, de la moral, de la justicia, de la religión ${ }^{1}$. Habría querido el Renacimiento hacer una edición crítica del Universo. En el terreno religioso, cristiano, el problema consistía en volver a las Escrituras, al Evangelio, a la soñada pureza de los primeros tiempos, al texto hebreo mejor que al latino, a lo más próximo, en suma, de la inalterable esencia que se aspiraba a encontrar. Erasmo es el máximo representante de esa inquietud, de ese afán inquisitivo, que en él es método y no contenido cerra-

«El Renacimiento y la Reforma son épocas de dirección idealista del espíritu; en todas partes se esfuerzan por transformar la situación y por acomodar todas las actividades según el ideal de un pasado muy remoto, en cuya segura existencia se cree, que se reconstruye científicamente y al cual se asigna absoluta validez. Hoy reconocemos que aquellos hombres se mecían en una autoilusión, que aquella Edad Media seguí perviviendo de hecho, no obstante ser considerada como deformación y oscurecimiento del ideal antiguo. (a) continuidad historica aparece claramente en los mismos que niegan aquella edad; pero esto no obsta para que tal convicción fuese el más poderoso impulso y la más fecunda fuente de energía para los humanistas, los artistas y los reformadores. El «ritornar al segno», de Maquiavelo, la vuelta a la fuente original, de la que se esperaba purificación y remozamiento, como de una verdadera fuente de juventud, puede valer como principio general. La vuelta a la Biblia supone sencillamente aplicación de ese principio del Renacimiento al dominio religioso» (E. GotHers, Staat und Gesellschaft des Zeitalters der Gegenreformation, en Kultur der Gegenwart, II, V, I, 1908, pág. I39). 
do ${ }^{1}$; por eso repugnará las soluciones dogmáticas, tanto las de los teólogos católicos como las de los protestantes; por eso será odiado y perseguido en ambos campos. Pero ha dejado a lo largo del siglo, a la vez que mística emoción, una estela de criticismo y de insatisfecha inquietud; de exigencia racio nal y de espíritu de protesta. Sin Erasmo, Cervantes no habría sido como fué.

De ahí que fallen todos los intentos de hacer a Erasmo católico, protestante, librepensador u otra cosa. Su espíritu va por donde le
lleva el libre juego de su inteligencia y de su cultura, sin miedo a los resultados. A todo inteligencia y de su cultura, sin miedo a sinuosas y opuestas vertientes de su espíritu discurren, al mismo tiempo, las remotas fuentes germinales de Rousseau y de Voltaire. 
los Ensayos de Montaigne, los tratados de Justo Lipsio y otras obras semejantes. No ocurre eso porque hay una abundante literatura científica que se ha encargado de fijar las fuentes y el alcance del pensamiento de Montaigne; sobre Cervantes, en cambio, apenas si existen estudios que supongan en él ideas dignas de ser notadas. Cervantes alardeó constantemente de sencillez, de desdén por el pedantismo y el tono magistral; a veces el señor de alta alcurnia y gran caudal ostenta despego elegante hacia sus timbres, y se allana, no sin afectación, a alternar con gente de menor cuantía; pero será, por lo menos, rudo de ingenio quien contemple tal hecho sin la debida inclinación irónica.

Vamos a demostrar que la moral de Cervantes es en su última raíz de carácter esencialmente filosófico, puramente natural y humana, sin ingerencia activa de principios religio$\operatorname{sos}^{1}$. El autor no se propone pensar en contra de la religión; pero discurre por senda aparte, sin preocuparse de la orientación teológica. El núcleo de esta moral es el naturalismo, a cuyo estudio hemos consagrado un capítulo. Con ese naturalismo se combinan, además, elementos de razón y de análisis que vienen derechamente del estoicismo renacentista. A este último punto, por no haberlo estudiado antes, vamos a consagrarle ahora cierta atención.

Sabe el lector que el neoestoicismo es la doctrina moral que en el siglo xvr trat $\delta$ de conciliar, en lo posible, el rigor del estoicismo clásico (fatalista y, en el fondo, panteísta y negador de la inmortalidad del alma) con las exigencias del dogma cristiano o católico. Uno de sus representantes más notables es el belga Justo Lipsio, contemporáneo de Cervantes $(1547-1606)^{2}$. No tengo motivos para decir que Lipsio influyera en Cervantes ni hace falta esa hipotesis, ya que el

Eso no impide que en el desarrollo de la conducta nos encontremos con virtudes cristianas que son a la vez filosóficas, o en todo caso no contradicen éstas.

2 Una buena exposición de sus doctrinas en L. ZanTa, La renaissance du stö̌cisme au XVI0 siècle, 1914. siglo xvi, en Italia y en España, está lleno de pensamiento estoico ${ }^{1}$; lo hago notar sencillamente para establecer la normalidad histórica de la moral cervantina. Creo, además, que Cervantes se preocupa mucho menos que Lipsio de las consecuencias teológicas de la moral que infunde a sus personajes, entre otras razones porque la fábula artística quitaba aspereza y rigor a doctrinas que no habrían podido vivir en España presentadas en forma directa y dogmática. Aun así, Cervantes acudirá a veces a cautelosas ambiguiedades de lenguaje.

No puedo abordar aquí las complicadas cuestiones relacionadas con el desarrollo de las doctrinas estoicas en España, desde que comienzan a revivir las humanidades en torno a D. Juan II hasta la época de Cervantes y Quevedo. Libro atil y fecundo sería el que se ocupase en tal asunto ${ }^{2}$. He de

1 Antes que Pomponazzi, Averroes había considerado inmorales las recompensas ultraterrenas; ambos coincidían en que hay hombres perfectamente morales que rechazan todas esas ficciones, y que, en virtud, no van a la zaga de quienes las admiten. Nota Busson que ese "elevado estoicismo que el filósofo quiere implantar en vez de la moral cristiana fué adoptado por todo el elemento serio del Renacimientos (Sources et développement du rationalisme, publicado por la «Société d'Histoire Ecclésiastique de la France», 1922, pág. 39).

Las traducciones de Cicerón y Séneca debieran ser uno de los puntos de arranque. Alonso de Cartagena, obispo de Burgos, por mandado del rey de Castilla, traduce y recopila varias obras de L. A. Séneca a mediados del siglo xv (véase AMȦDor DE los Ríos, Historia critica, VI, 33 y 303), incluyendo algún tratado que no era de Séneca. Se publica esa traducción en Sevilla, 1491, por Ungut y Polono (Cinco libros de L. A. Séneca. I: De la vida bienaventurada. II: De las siete artes liberales. III: De los preceptos y doctrinas, IV: De la providencia de Dios. $\mathrm{V}$ : De la misma providencia de Dios), y las notas señan ya el can. V: De la gelo a cel cas Evangelio. Conozco ediciones de Toledo, ${ }_{15} 10$; Alcalá, ${ }_{53}$; Amberes, 1551. Las Epistolas (Summa de filosofia moral) se editan en Toledo, 1502, 1510; Alcalá, 1529; Amberes, 1551. Las Fiores, de Séneca, traducidas por el erasmista Juan Martín Cordero, salen en Amberes, 1555 Para la influencia concomitante de Petrarca, véase el eruditísimo trabajo de A. FARINELLI, Sulla fortuna del Petrarca in Ispagna nel Quarocento, Giornale Storico, XLIV, 1904; comp. Revista de Filologia Es pañola, 1916, pág. 383 . 
limitarme a exponer las ideas que más directamente influyen: en el tema moral cervantino.

El Renacimiento hubo de aprehender con vehemencia ciertos aspectos de la doctrina estoica, que hacía al hombre centro del cosmos, miraba la razón como principio autónomo, identificaba la providencia con el orden fatal del universo (mas sin atribuir aquélla a la persona de Dios) ${ }^{1}$, y en armonía con la metafísica neoplatónica, divinizaba la naturaleza, casi en un monismo panteísta. Véanse algunos textos. característicos de nuestro Séneca en la forma que ofrecían en el siglo xvi: "Del buen varón a Dios no hay diferencia sino en tiempo, porque su discípulo es, y seguidor de sus. carreras y su verdadero hijo...; Dios, que es padre muy gravey riguroso, demandador de las virtudes, críale duramente como hacen los padres rigurosos... Mas no puede cosa de mal acaescer al buen varón, porque no se abaja ni se muda por las cosas contrarias... La fuerza de las cosas adversas no mueve el corazón del varón fuerte; antes está firme en su estado, y cualquier cosa que le venga tórnala de su color. Porque es más poderoso que todas las cosas que fuera le acaescen. No digo yo que no las siente, mas digo que las vence» ${ }^{2}$. El mal que nos aflige lo es sólo en apariencia, puesto que tiende a realzar nuestro ser interior a manera de disciplina pedágogica; el mal verdadero surgirá si el buen varón se deja oprimir por la adversidad. No hay otro programa moral que el de obedecer a la naturaleza, «sequere naturam», no entendiendo por tal los simples estímulos vitales (empirismo naturalista de Montaigne), sino el curso inexorable del destino, forma del orden fatal del universo, al que hay que plegarse: « ¿ $Y$ qué piensas que pertenesce al buen varón? Yo te lo diré: Darse y obedescer al hado. Gran consuelo es ser hombre arrebatado con todo lo que hay en el mundo; que esto (como quier que ello sea) a que llamamos hado, que nos mandó así vivir y morir, por esa misma necesidad ligo

1 ZANTA, Ob. cit., pág. 103

2 Traduc, de Alonso de Cartagena, edic. Amberes, ${ }_{15} 5$ I, fol. 83. a los dioses. Y este curso y movimiento traen sin revocación alguna las cosas humanas y divinas. Porque aquel mismo criador y regidor de todas las cosas escribió los hados» 1 Locura será para los más finos espíritus del siglo xvı alzarse contra ese hado, dentro del cual conviven Dios y el hombre, parcela de Dios, según Séneca. Mas el cristianismo no podía aceptar tales supuestos, ya que su concepto de que el hombre sea hijo de Dios, no quiere decir que con el tiempo aquél se haga Dios, ni que la criatura finita venga nunca a participar de la esencia infinita de la divinidad ${ }^{2}$. Mucho menos aceptaría el catolicismo esa fatal predestinación, grata a protestantismo. No obstante, tales doctrinas flotaban en el ambiente renacentista, las difundía Erasmo (a pesar de sus ocasionales ataques al estoicismo en el Elogio de la locura), y hallarán eco en pensadores de Italia y Francia, y en Cervantes. No se intentaba generalmente hacer resaltar la contradicción que con las verdades de la fe presentaban esos sistemas de moral naturalista y puramente humana. Es raro el caso de Justo Lipsio que emprende una adaptación sistemática e interesante del antiguo estoicismo a la moral católica, renovando los procedimientos de los Padres de la Iglesia ${ }^{3}$. Lo frecuente es que tales ideas bogasen libremente por el campo de la literatura, protegidas por fórmulas ambiguas de lenguaje, en apariencia ortodoxas, o a favor del flexible recurso de la doble verdad (que el lector conoce), resucitado por Pomponazzi en el siglo xvi para comodidad de los espíritus inquietos durante la época de la Contrarreforma.

1 SÉneca, De la providencia de Dios, traduc. cit., fol. $96 \%$.

2 «Dios viene al hombre. Ningún entendimiento hay bueno sin Dios. En los cuerpos humanos est́́ desparcida la simiente divina la mano de Dios. Ia cul, si el ho tabre la sabe tratar, y como labra la buenn la ejercita, lo que nace es conforme y semejante a la semiente, y igual a aquello de lo cual ha nacido» (Flores, de Séneca, traduc. de J. M. Cordero, Amberes, ${ }_{1555}$, fol. $57 v$ ).

Nuestro Quevedo en esta vía, pese a otras dotes espléndidas de su genio literario, no logro resultados muy originales como moralista. Véase E. Mérimée, Francisco de Quevedo, 1886, pág. 256. 
Tanto más fácil era esto en el caso del estoicismo cuanto que las concomitancias que existen entre aquella filosofia y el cristianismo eran efectivas y bien conocidas. Ya había dicho San Agustín de los estoicos paganos: «Han hecho por la patria de la tierra lo que no hacemos por la patria del cielo... Avergoncémonos si el amor por la gloriosa ciudad de Dios. no nos lleva a la práctica de la verdadera virtud» ${ }^{1}$. Ese era el grave problema. El estoico no pensaba en otro mundo; le bastaba la gloria terrena, y lógicamente Pomponazzi negaba la inmortalidad del alma (como filósofo, no como cris tiano), y juzgaba inmoral hacer el bien pensando en premios ultraterrenos y no en la práctica desinteresada de la virtud. La moral se independizaba de la teología.

Vengamos ahora a nuestro Cervantes. Al examinar el papel asignado al error, hubimos de ver cómo la sanción de las culpas (aplicada aun cuando éstas fuesen leves) no se basaba en normas externas de carácter religioso o social. Cervantes no nos habla de que la justicia de los hombres o de Dios, en virtud de sus leyes, intervenga en los castigos que frecuentemente ocurren. La fuerza pública no actúa nunca en forma respetable, y si alguien va a la cárcel es para poner de relieve los defectos y yerros de tal procedimiento. Las san ciones (ya lo vimos en la página I44) son mera consecuencia de la culpa: "Naturalis est punitio culpae.» Compárese la muerte de D. Tello en El mejor alcalde el rey, de Lope, o de D. Juan en El Burlador, de Tirso, con cualquiera de las cervantinas; en los dramaturgos hay un principio de justicia trascendente (la realeza o la divinidad) que domina los actos de los personajes. En El alcalde de Zalamea, se acude a la autoridad del magistrado municipal. En Cervantes, por el contrario, la misma puerta, que indebidamente queremos cerrar, es quien nos coge los dedos (Grisóstomo, Anselmo, Rosamunda, etc., etc.). La concepción de la naturaleza comoun orden inmanente, es, pues, la base de la mo ral cervantina, moral en absoluto impopular y aristocrática

1 Ciudad de Dios, V, 18 . como lo era la estoica), que no habría podido sostenerse sobre la escena. ¿No se ve aquí otra razón de la esencial discrepancia entre Cervantes y Lope de Vega, y cuán imposible era que nuestro mayor autor escribiese famosas comedias al uso? Ya hemos visto su repugnancia por las venganzas; en ese punto estoicismo y cristianismo iban de la mano.

Como Montaigne, sin declararlo directamente, Cervantes maneja sus creaciones artísticas como si no existieran penas y recompensas fuera de este mundo, lo que puede ser compatible con la más fervorosa creencia en las cosas ultraterrenas. Más que la calificación moral de la conducta, le interesa la presentación objetiva de los seres humanos, prestos a re correr la senda, recta o torcida, que su natural estructura les marque. Los desastres surgirán por el choque de los puntos de vista, por la marcha fatal de los sucesos ${ }^{1}$, no porque se infrinjan normas exteriores previamente trazadas.

El mal, en tanto que imputable al hombre ${ }^{2}$, tiene para

1. A Luisa, casadla o no la caséis, séase ella libre y desenvuelta como un cernícalo, que el toque no está en sus desenvolturas, sino e sus sucesos, según lo hallo yo en mi astrologías (Persiles, $636 b$ ).

2 El malobjetivo, el no imputable al hombre, es explicado por pexta Dice así en el Coloquio: ‘Todas las desgracias que vienen a las gentes, a los reinos, a las ciudades y a los pueblos..., en fin, todos los maes que llaman de daño, vienen de la mano del Altísimo y de su voluntad permitente, y los daños y males que llaman de culpa vienen y se causan por nosotros mismos. Dios es impecable, de do se infiere que nosotros somos autores del pecado... (Clás. Cast. páina 300$)$ Los comentaristas no explican aqu nada y deben hacero ( or an Agustín llama culpa al mal que causamos, y pena (daño), al que sufrimos. En este punto dió Santo Tomás su gran ataque al maniqueísmo, que admitía un principio divino para el mal. Dice Santo Tomás: «El mal de culpa no puede venir de Dios, mas puede Dios querer que el mismo bien divino, o cualquier otro bien inferior, se quitado a alguien... para que nada tenga aquello que no es digno de tenerlo. Esa privación de bien increado, o de cualquier otro bien en tavel que es indigo de ́b tiene la razón de la pena (daňo). Dioses,

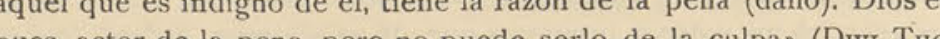
pues, actor de la pena, pero no puede serlo de la culpas (Divi Tно- 
Cervantes dos causas mayores: o la inclinación vital e invencible de la persona o su errrado proceder. Claro es que la perseverancia en este áltimo arguye disposición incontrastable en el individuo: «La costumbre del vicio se vuelve en naturaleza, y este de ser brujas se convierte en sangre y carney (Coloquio). En «sangre y carne» se convierten muchas formas de conducta, frente a cuyo desarrollo sólo cabe la actitud de espectador de sí mismo.

Ante el ritmo inexorable de la vida, Cervantes conserva un gesto grave e impasible: "Quedóse el delito sin castigo, el muerto se quedó por muerto, quedaron libres los prisioneros.... ${ }^{1}$. Sin posible arreglo quedan en el Quijote las desventuras del niño Andrés y del viejo padre de Zoraida, para no citar sino los casos de más extremada emoción. Por estas zonas de la obra cervantina se filtra un hilo de glacial fatalismo ${ }^{2}$ Establecidas las condiciones que han de influir en la marcha

cumo Cervantes acepta la doctrina del hado y asiente a los principio de la inexorabilidad natural, tanto subjetiva como objetiva, lo únic que cabe es admitir ahora, y una vez más, que Cervantes es providen cialista católico al teorizar en este caso, y fatalista como pensado imbuido de filosofía estoica al organizar la vida de sus principales personajes. La doctrina vulgar en tiempos de Cervantes es que el mal procedía del pecado de Adán y Eva: sueno es Dios y buenas hio todas las cosas. Pues de dónde procelio el malor Y prosigue: cLa laz de religión cristiana mastra de la verdad, nos saca destas perplejide ta religion cristiana, maestra de la verdad, nos saca destas perplejidade y errores... El origen y principio de todos estos males es el pecado original en que todos somos concebidos." Así dice Luis de Granada citando a San Agustín, en el Simbolo de la fe, Rivad., VI, $403 a$.

1 Persiles, 631 $a$.

2 Ya citamos antes: «La suerte fatal, que según la opinión de los que no tienen lumbre de la verdadera fe, todo lo guía (I, 23; RM, II, 226). Comp. :Porque quiere y permite Dios que tenga (L, 23; RM, pre ve . Comp.: c Porque quiere y peras pre verdugos que nos castiguen" (I, 39, RM, 111,176$)$. El autor oscila entre la opinión fatalista de quienes sno tienen lumbre de la verdade ra fe» y la providencialista: «Permisión fué del cielo el haberle atro pellado» (Fuerza de la sangre, Rivad., I, i 70a). «No fué pequeño el miedo de los que en la nave iban...; mas cuando de esto estaban más temerosos, la suerte, que mejor nos la tenía guardada, o el cielo. que escuchó los votos y promesas que alli se hicieron, ordenó que el maestral se cambiase en un mediodías (Galatea, edic. cit., II, II5). de los sucesos humanos, los resultados se producen con automática seguridad ${ }^{1}$. Antes de morir reconoce Anselmo, en El curioso impertinente que «no estaba ella obligada a hacer milagros, ni yo tenía necesidad de querer que ella los hiciese». Y leemos en el Fuez de los divorcios: "No está obligado ningún marido a tener ['detener'] la velocidad y corrida del tiempo, que no pase por su puerta y por sus días."

Los caracteres individuales son a su vez realidades inmutables; cada persona dará aquellos frutos que están en armonía con su naturaleza (pág. I68), en lo cual Cervantes está de acuerdo con la doctrina de la inmutabilidad del carácter individual que claramente formula Telesio: «Utique et virtutes vitiaque non consuetudine comparari, sed natura inesse existimandum videtur» ${ }^{2}$. De esta concepción de los caracteres deriva lógicamente que cada uno deba permanecer, según Cervantes, en la condición que por naturaleza le corresponde (pág. 169): el canónigo de los duques sin meter-

1 Se comprende ahora el valor metódico de que Cervantes piense que la Astrología pudiera predecir la marcha preestablecida del fatum humano? En teoría, tal supuesto era congruente con la moral estoica:

- Los estoicos decían que hado es un concierto y orden de las causas naturales que obran sus efectos con una necesidad forzosa... Est orden inevitable según su parecer de algunos y aun casi de todos, procede de la fuerza que tienen para influir las estrellas en los cuerpos humanos... Ni hay hado ni hados, sino sólo la imaginación que los gentiles tuvieron dellos, que un buen cristiano en ninguna manera del mundo ha de atribuir su ventura o desventura ni sus inclinaciones malas ni buenas, ni los sucesos dellas a sus hadoss, etc. (AN

2. «Ciertamente parece que las virtudes y los vicios no se adquiere por la costumbre, sino que son inherentes a la naturalezas (De rerim natura, lib. IX, cap. xxxı). Lo que a su vez es derivación del estoi cismo: $\varsigma$ Los vicios naturales del cuerpo y del ánimo con ninguna sabiduría se pueden perder; pero lo que nasció con nosotros puédese refrenar, aunque no pueda perderse ni arrancarses (Flores, de Séneca, traduc. de J. M. Cordero, Amberes, ${ }_{555}$, fol. $8 r$ ). Véase luego página $34 \mathrm{I}$ y nota 2. Me parece que los que estudian a Telesio (Gentile, Blanchet, Troilo) no dan bastante importancia a la influencia estoica en su moral. 
se aleccionar príncipes; Sancho siendo lo que es; Don Quijote en su locura, el que es para poco sin rebasar su esfera: Rosamunda en su lubricidad; el viejo sin procurar ser joven casándose con frescas mozuelas, etc. El espectador de la vida debe saber que las cosas son así y abstenerse de intentar transformaciones:

el mundo hemos de dejar

del modo que le hallamos

Temería que algún lector pensara que rasgos parecidos a éstos pueden ocurrir en otras obras literarias; para evitarlo haré observar que lo que atribuyo a Cervantes no es la exclusividad de crear seres con firme contextura y perfil inconfundible. Pedro Crespo, Don Juan, Guzmán de Alfarache, el Caballero de Olmedo, Peribáñez, Lazarillo, Segismundo, Calixto, Melibea y cien más discurren con vida propia y perenne por los Campos Elíseos de nuestras letras, y acuden solícitos a nuestra fervorosa evocación. Lo singular, en las figuras plenamente delineadas por Cervantes, es ostentar como esencial característica el designio afanoso de mantene inalterable su persona y la necesidad de obrar en los casos. decisivos en la forma que lo hacen, pese a todos los obstáculos. El carácter cervantino abre polémica acerca de sí mismo.

Pedro Crespo es un maravilloso ser que forjaron de consuno la mítica popular y el genio de Calderón como el más puro símbolo del honor español; sus actos responden a ese ideal en modo perfecto, pero nadie pone en litigio que él deba, en efecto, ser o dejar de ser Pedro Crespo. Problemas. de esa índole no se plantean más que en la obra de Cervan tes. Aparecen allí unas personas cuyo primordial menester consiste en sostener que en verdad son como son, y que no han de apartarse de su ser aunque vinieren a rogárselo todos los capuchinos descalzos. En otros autores no acontece que los personajes polemicen sobre su misma naturaleza literaria, ni que el autor haga patente la fatal necesidad de que aqué-

1 Laberinto de amor, II, 266 lla sea como es. Segismundo, por ejemplo, es así porque su padre hubo de obstinarse en convertirlo en un bárbaro encadenado; sus desatinos en el palacio provienen de aquella mala crianza, que el Príncipe corrige en cuanto las circunstancias vienen en su ayuda. Segismundo no nos dice que él es esen cialmente Segismundo, y que no puede ser otra cosa. Por el contrario, uno de los esenciales rasgos de Don Quijote es su esfuerzo para no dejar de serlo. Es en verdad imposible acumular más valladares contra el intento de nuestro buen Hidalgo de no apartarse de su naturaleza; la sociedad de altos y chicos está coligada contra él; sus conterráneos no se satisfacen con que dé de mano a sus aventuras: quieren que se convierta en otra persona, que abandone su nombre. No querían saber que Don Quijote tenía seco el "celebro» y sublime el alma, y que lo único conseguible, de empeñarse mucho en la disputa, era que se muriese, mas no que abandonara su indeclinable estructura.

¿Y Sancho? «Sancho nací, y Sancho pienso morir» (II, 4), pese a todas las ínsulas y a las interpretaciones de los historiadores. Es inútil querer sacarle de sus casillas con el halago del gobierno, que él desempeña sanchescamente. Y si la proximidad de su señor le trastorna algo el seso, y llega a senti algún impropio deseo, el autor, vigilante, hará que alguien lo traiga inmediatamente al lugar que por naturaleza le corresponde (véase pág. I39).

¿A qué insistir? Ningún autor, antes ni después de Cervantes, ha concebido así la vida de sus creaciones. Consecuencias de ese procedimiento no se han sacado en realidad hasta Pirandello. En el siglo xvir no veo sino un caso que, de lejos, podría parangonarse en la técnica de su estructura con los de Cervantes: el Don Juan, de Tirso. Pero aun admitiendo el parangón, habría que decir que las semejanzas son superficiales. Todo se reduciría a la frase "Tan largo me lo fiáis con que el Burlador responde a su criado. Don Juan es audaz, desafía al Cielo, pero no tiene la conciencia de su fatal carác ter como los personajes cervantinos. $\mathrm{Y}$ en todo caso, y procediendo con rigor histórico, cuanto acontezca después de 
Cervantes estará, en principio, bajo la posible acción de su inmenso influjo, más latente que expreso, pero no menos real y positivo.

La conciencia literaria del personaje cervantino se manifiesta en doble forma: expresamente en los casos máximos de Don Quijote y Sancho; indirectamente al intentar hacer que alguien abandone la senda de su fatal destino. Ya sabemos lo que acontece: quien emprende esa peligrosa aventura no consigue nada, y él se estrella (Grisóstomo y Marcela, el Polaco y Luisa, el padre de Zoraida frente a su hija, etc., etc.) En suma, los personajes secundarios viven, ni más ni menos, como sus paradigmas, Don Quijote y Sancho. La frase

el mundo hemos de dejar

del modo que le hallamo

no es, pues, un lugar común, sino un pensamiento revelador de la íntima y profunda ley arquitectónica de la obra cervantina.

Piénsese en las consecuencias morales de tal actitud. Si el carácter y su secuela la conducta son inmutables, la razón podrá darse cuenta de ese estado, pero no lo podrá variar. La moralidad se convertirá en un hecho positivo, que en lo sensible nos contentará o nos amargará, pero que, en realidad, no merecerá censura ni elogio; el individuo experimentará automáticamente los resultados de su conducta. Lo moral deja de estar gobernado por el ideal religioso y trascendente, y se torna un producto casi biológico; «el mundo es ansî", y es inútil querer variarlo. El Quijote es la gran prueba de esa verdad. No quisiera excederme una línea en la escrupulosa interpretación de los textos cervantinos que voy a someter al lector: "Yo tengo una de estas almas que te he pintado: todo lo veo y todo lo entiendo; y como el deleite me tiene echados grillos a la voluntad, siempre he sido y seré mala» ${ }^{1}$. En cambio, «la nobleza del linaje pone

Coloquio, Clás. Cast., pág. 302. Y este otro significativo ejemplo: *Doy yo al diablo al amor y al bellaco que me lo enseñó; y es lo peo alas y esfuerza el ánimo a levantar los ojos adonde la humilde suerte no osara jamás levantarlos» ${ }^{1}$. Son los mismos estímulos naturales los causadores del mal: «El amor no es otra cosa que deseo... Este deseo es aquel que incita al hermano a procurar de la amada hermana los abominables abra zos, la madrastra del alnado, y, lo que peor es, el mesmo padre de la propia hija» ${ }^{2}$. Rosamunda es un ser necesaria mente malo: "Desde el punto que tuve uso de razón, no la tuve, porque siempre fuí mala... Como los vicios tienen asiento en el alma, que no envejece, no quieren dejarme» ${ }^{3}$. Relacionados con los anteriores, estos otros textos vienen a corroborar su sentido: «Huir el mal que el cielo determina es trabajo excusado» ${ }^{4}$. "Haga el cielo lo que ordenado tiene, pues nuestra diligencia no lo puede excusar» ${ }^{5}$. Los cuales, si aisladamente podrían pasar inadvertidos, agrupados con los restantes vienen a querer decir esto :

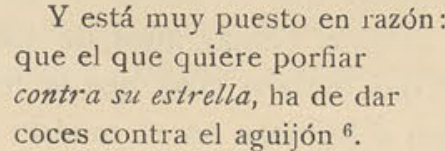

Como en ocasiones anteriores, hallamos un sistema de principios, vivificados en los personajes y razonados luego por el autor.

Quienes, desde Bowle en el siglo xvin, notaron que Cervantes era entusiasta partidario del libre arbitrio, se fijaron en determinados textos en que el autor manifiesta dogmáti-

que lo conozco, y determino ser soldado debajo de su bandera, porque no siento fuerzas que se opongan a las que hace el gusto con los que poco saben» (Persiles, $657 b$ ). De ahí la imposibilidad de luchar contra el amor, y la absolución general que cubre a todos los pecadores por amor.

Galatea, edic. cit., I, 22.

2 Ibid., II, 47

3 Persiles, pág. 587 a

4 Baños de Argel, I, 239.

5 Persiles, pág. $582 b$.

6 La Entretenida, III, 29 
camente su fe en la eficacia de la libre voluntad. Podría ser que así fuese, en vista de las vacilaciones y contradicciones que por múltiples causas se dan en Cervantes y en otros pensadores contemporáneos. Traigamos, empero, a examen los pasajes en cuestión. Los tres que cita Bowle ${ }^{1}$ se refieren a la hechicería: «Bien sé que no hay hechizos en el mundo que puedan mover y forzar la voluntad, como algunos simples piensan; que es libre nuestro albedrío y no hay yerba ni encanto que le fuerce. Lo que suelen hacer algunas mujercillas simples y algunos embusteros bellacos es algunas misturas y venenos, con que vuelven locos a los hombres, dando a entender que tienen fuerza para hacer querer bien, siendo, como digo, cosa imposible forzar la voluntad» ${ }^{2}$. «Quién [quitará] al amante desdeñado que no quiera, si puede, reducir a ser querido del que le aborrece? Puesto que ['aunque'] en mudar las voluntades, sacarlas de su quicio, como esto es ir contra el libre albedrío, no hay ciencia que lo pueda ni virtud de yerbas que lo alcance» ${ }^{3}$. «Dió a Tomás unos de estos que llaman hechizos, creyendo que le daba cosa que le forzase la voluntad a quererla, como si hubiese en el mundo yerbas, encantos ni palabras suficientes a forzar el libre albedrío» ${ }^{4}$. Todo lo cual guarda íntima conexión con la crítica que vimos hacía Cervantes (pág. 150), del episodio de la Diana, de Montemayor, en que el agua encantada cambia las inclinaciones amorosas. Añádanse aún: «Estos señores bien pueden entregarte mi cuerpo, pero no mi alma, que es libre y nació libre, y ha de ser libre en tanto que yo quisiere» ${ }^{5}$. Que es lo mismo que decía Marcela : «Yo nací libre, y para poder vivir libre escogí la libertad de los campos» ${ }^{6}$.

Nos hallamos, pues, con que libre albedrío significa con-

Y a los que alude Rodríguez Marín, II, 199.

2 I, 22; RM, II, 199.

3 Persiles, pág. $602 b$.

4 Licenciado Vidriera, edic. cit., pág. 24.

5 Gitanilla, edic. Schevill-Bonilla, pág. 22.

- I, I4; RM, I, 425. Véase antes pág. 327, nota I. cretamente para Cervantes libertad de amar ${ }^{1}$, es decir, derecho a perseverar en la fatal inclinación o repugnancia que liga o separa a una mujer y a un hombre. En suma, que teóricamente se expuso aquí lo mismo que vitalmente ejemplarizan todos los personajes que han desfilado en nuestro capítulo sobre «El error y la armonía como temas literarios».

Fijémonos bien: Cervantes no dice que sea potestativo el rumbo que un individuo tomó en la vida, y que lo mismo que escogió uno pudo seguir otro; en todo caso, no es eso lo que le interesa poner de relieve en sus obras ni en los textos citados $^{2}$. Dice en cambio muy claramente que cada ser tiene su trayectoria propia, marcada por la naturaleza, y que es locura apartarnos de ella o intentar que los demás la abandonen, o cruzar violenta e inarmónicamente nuestra órbita con la de los demás. "Libre albedrío» en los textos anteriores significa ‘derecho a seguir sin entorpecimiento su destino', y la voluntad resulta ser así el estímulo vital que nos incita a determinarnos según nuestro carácter y naturaleza propios ${ }^{3}$. Quien

1 «Sola una voluntad, ;oh Persiles!, he tenido en toda mi vida, y esa habrá dos años que te la entregué, no forzada, sino de mi libre albedrío, la cual tan entera y firme está agora como el primer día que te hice señor della» (Persiles, pág. 66ı $a$ ).

2 No se opone a esto el que Cervantes admita como un hecho el libre albedrío o libertad de indiferencia. Recuérdese la respuesta de aquel mozo al Gobernador de la ínsula: «Con todo esto, si yo no quiero dormir, y estarme despierto toda la noche sin pegar pestaña, ¿será v. m. bastante con todo su poder para hacerme dormir, si yo no quierois (II, 49; RM, V, 492). Pero, en el fondo, la resolución libre vendrá condicionada por la naturaleza de la persona.

3 Si el libre albedrío fuese en esos casos lo que solemos entender por tal, no habría para qué alarmarse tanto cuando alguien intenta variar el rumbo de una voluntad. I a libertad serí justamente la posibilite de ra su aimo a Gerera su ánimo a Grisóstomo. Esto pasa en el teatro, donde los desdenes se tornan amores. He ahí otra diferencia profunda entre la comedia y Cervantes. Éste nos presenta acondiciones» humanas, que nada ni nadie hará variar, como no se varía la forma geométrica de un cristal. Véase de cuán distinto modo entiende el libre albedrío Luis de 
quiera forzar con hechizos la voluntad de amar en otra persona es tan necio como Sansón Carrasco queriendo sacar de sus andanzas a Don Quijote, artificiosa y violentamente. Y no necesitará más ejemplos quien tenga presentes las páginas de este libro:

$$
\begin{aligned}
& \text { el mundo hemos de dejar } \\
& \text {. del modo que le hallamos. }
\end{aligned}
$$

Henos, pues, ante un sistema de moral autónoma. El individuo no desenvuelve su conducta en vista de motivos que trasciendan de su ser más íntimo, ni luchando con éste (según manda la religión), sino en dócil armonía con ese ser. Los caracteres más firme y detalladamente trazados por Cervantes son como saetas que se encaminan a un blanco, salvando abismos, a costa de la propia vida, en bastantes casos.

Dentro de semejante sistema, admitido el fatum, las nociones de fortuna y azar no tienen cabida en la marcha de los sucesos humanos. Todo acontece como debe acontecer. Por encima de ese curso necesario de nuestra vida, la razón debe estar vigilante para comprender y soportar con sabiduría cuanto venga sobre nosotros. Es esta una de las formas supremas de virtud: la serena intelección, la cual nadie puede menguarnos.

Así, pues, si objetivamente no hay fortuna ni azar, porque todo obedece a una razón, subjetivamente tampoco puede haberla para el varón sabio, que erige contra ella una inaccesible fortaleza. Esa virtud interior, creada heroicamente, es en absoluto autónoma; está protegida por una muralla

Granada: «Primeramente se dice ser el hombre imagen de Dios, porque tiene libre albedrío y entendimiento como Dios y como sus ángeles. Porque ninguna de las otras criaturas tiene esta libertad, ca todas son agentes naturales que no pueden dejar de hacer aquello para que tienen facultad; y así, el fuego no puede dejar de quemar, ni el sol de alumbrar, etc. Mas el hombre es libre y señor de sus obras, y así puede hacer y dejar de hacer lo que quisieres (L. DE Granada, Simbolo de la fe, Rivad, VI, 264 a). de altivez contra toda posible invasión. El estoicismo es el más orgulloso de los sistemas morales ${ }^{1}$.

En las postrimerías de la maravillosa novela, dialogando Don Quijote y Sancho, se contrapone la opinión vulgar del Escudero, para quien la causa de nuestros desastres es la diosa Fortuna («mujer borracha y antojadiza, y, sobre todo, ciega, y así no ve lo que hace, ni sabe a quién derriba ni a quién ensalza ${ }^{2}$ ), y el contrario parecer del Hidalgo, que sostiene la aristocrática doctrina de los filósofos del Pórtico : «Lo que te sé decir es que no hay fortuna en el mundo, ni las cosas que en él suceden, buenas o malas que sean, vienen acaso, sino por particular providencia de los cielos, y de aquí viene lo que suele decirse: que cada uno es artífice de su ventura ${ }^{3}$.

1 Era esa una de las esenciales discrepancias con el cristianismo. Ya decía San Agustín, refiriéndose a los estoicos: «La rigidez no es 1 rectitud; la insensibilidad no es la saluds (Ciudad de Dios, XIV, 9). «Los ciudadanos de la ciudad de Dios, temen y desean, sufren y se alegran» (Ibid.).

2 II, 66; RM, VI, 318. Como lugar común, sin hondo sentido, se sobrepone el saber a la fortuna en Guzmán de Alfarache, Rivad., III, 230a: «En los pasos peligrosos, en los casos graves de fortuna, el sabio se tiene y pasa, y el simple en lo llano tropieza y cae... Preguntarásme: đdónde va Guzmán tan cargado de ciencia?... Por mi fe, her. mano mío, a dar con ella en un esportón.

3 Está inspirado este texto en la Silva de Pero Mejía: «Todas la cosas que pasan y se hacen en el mundo... provienen y manan de la providencia y sumo saber de Dios; no hay fortuna ni acaescimiento; todo tiene causa y orden admirable... muchos de los antiguos gentiles no dejaron de atinar a esta verdad. Salustio dice que cadh uno es of tante bacer notar $c$ tante hacer notar que nuestro autor se atiene al texto de Pero Mejía, $\sin$ duda por preferirlo, ya que Antonio de Torquemada, leído y muy imitado por Cervantes en otros casos, le brindaba doctrina distinta. Véase una vez más cómo Cervantes no está a merced de sus fuentes, sino al contrario. El Fardin de fores curiosas, de Torquemada (edic. Lérida, 1573 , fols. $164-165$ ), trata en detalle de la fortuna, pero no menciona el capital texto de Salustio («cada uno es oficial de su fortuna): ¿Ninguna cosa es hecha por Dios sin causa, y no se bace nath por casos fortuito cono las per Dios sin casa y no se hace nada po cosos nin guna la temeridad de la fortuna ciega; de donde podemos entender 
El pasaje es por demás abstruso, y es natural que los comentaristas hayan cavilado para entenderlo y hallarle sentido congruente. Hay en él una primera parte: las cosas de este mundo no obedecen al azar, acontecen porque tienen que acontecer; como dice, con razón, Rodríguez Marín : «De lo que antecede no se deduce sino que lo que ha de ser está escrito.» Hay, en efecto, según Cervantes, un orden preestablecido y fatal, dado sin duda en la presciencia divina, pero nacido de condiciones inmanentes en la naturaleza (véase pág. 329). Al hablar aquí de la "particular providencia de os cielos», acude el autor a una fórmula tradicional y bien vista, pero tras de la cual se percibe la misma idea que tantas veces ha ocurrido en el curso de este libro: «Las cosas pasan porque tienen que pasar.» Cervantes no podía expresar crudamente su pensamiento; no podía decir en forma dogmática, aunque filosóficamente lo pensara, que el curso de los sucesos humanos pende de la naturaleza, «mayordomo de Dios», y no de la misma providencia divina. Destino y providencia parecen fundirse aquí en un mismo concepto $^{1}$.

Lo que ningún comentarista del Quijote explica es la segunda parte del citado pasaje: «De aquí viene lo que suele decirse: que cada uno es artífice de su ventura.» Hay que to-

que... no hay más fortuna que la voluntad y providencia de Dios, que todo lo rige y gobierna... El buen cristiano no ha de decir cuando le sucede alguna prosperidad, sesto hízolo mi fortunas..., sino «esto Dio lo hizo, o Dios lo permitió, o fué la voluntad de Dios»... La fortuna y a voluntad de Dios es una mesma cosa, y que no hay otra fortuna.y Torquemada piensa con Aristóteles que: «La fortuna es causa accidental en aquellas cosas que por algún propósito se hacen para accifin , lo cual supone que salimos al encuentro de la fort que nos alejamos bastante de las ideas estoicas, dentro de las que nos alejamos bastante de las ideas estoicas, dentro de las que se mueven Cervantes y Pero Mejía.

1 Justo Lipsio, De constantia, cap. XIX, hubo de corregir la idea stoica del orden fatal (al que los mismos dioses estaban sometidos) admitiendo que la providencia es la fuerza creadora que reside en Dios, y el destino es lo realizado en virtud del orden marcado en Dios.
FORTUNA Y VENTUR

mar una de estas dos posiciones: o Cervantes era un alocado cuya pluma corría, a veces, sin ton ni son, o aquí existe, como en tantos otros casos, una complicación de pensamiento de expresión que demanda ser aclarada. Opto sin vacilar por esto último. El enrevesado pasaje tiene un pensamiento incidental que desorganiza el conjunto («las cosas suceden por particular providencia de los cielos»), y que le hace estar mal construído estilísticamente; el pensamiento central es éste: no hablemos de la fortuna como de un elemento exterior, azaroso y fortuito que caprichosamente va dando origen a la ventura individual; tienen razón quienes dicen que cada uno se labra su ventura.

En términos análogos vuelve a decirse en La fuerza de la sangre ${ }^{1}$, aunque en forma más llana, que la fortuna no tiene acceso a ese reducto autónomo e invulnerable en donde se labra la sabiduría y la virtud: "Como si la sabiduría y la virtud no fuesen las riquezas sobre quien no tienen jurisdicción los ladrones ni la que llaman fortuna.» Esta autonomía de nuestras determinaciones racionales ${ }^{2}$ es de puro abolengo estoico. Mal Lara conoce semejante punto de vista «Sentencia era de los filósofos estoicos, y opinión fuera de vulgo, que los griegos llaman paradoxon, según lo trae Tulio, que sólo aquel es rico que es sabio: Quod solus sapiens dives est... Decían los estoicos que la virtud no puede ser robada ni hecha menos parte de ella, que no se pierde por tormenta de naos, ni por fuego se acaba ${ }^{3}$.

\footnotetext{
1 Rivad., I, $169 a$.

- La virtud y el buen entendimiento siempre es una y siempre es uno, desnudo o vestido, solo o acompanado. Bien es verdad que puede padecer acerca de la estimación de las gentes; mas no en la realidad verdadera de lo que merece y vale» (Coloquio, edic. Clás. Cast., pág. 339).

3 Filosofia vulgar, edic. 1568 , fol. 1о $r$. Tradición, en efecto, estoica y renacentista, opuesta a la aristotélica y medieval. Dante es aún plenamente medieval, según se ve por este pasaje del Convivio: $₫ \mathrm{La}$ loro imperfezione (de la riqueza) primamente si può notare ne la indiscrezione del loro avvenimento, nel quale nulla distributiva giustizia risplende... più volte a li malvagi che a li buoni la celate riccher-
} 
Va apareciendo claro el pensamiento cervantino. El juego fatal del universo puede llevarnos de acá para allá, como piezas que somos dentro de ese orden de la naturaleza, cuyos embates experimentamos; pero de nosotros mismos puede también elevarse un modo de regulación que se sobreponga a las acciones objetivamente naturales. En un sentido doble podemos, pues, ser "artífices de nuestra ventura»: como agentes portadores de una fatal proclividad (Rosamunda, Don Quijote, Anselmo, Carrizales, etc.), que va determinando nuestra vida, la cual brota del individuo como la hoja del árbol; o somos también «artífices de nuestra ventura», cuando merced a un acto racional nos aislamos de nuestro fatum y nos. erguimos sobre él. Se produce así una escisión entre el sujeto sensible y el racional, y en la esfera de este último podemos labrarnos una cristalina «ventura» que nadie ni nada.

ze' che si truovano o che si ritruovano si rappresentanos (IV, II). Y en Inferno, 67-69, la Fortuna aparece encargada por Dios,

$$
\begin{aligned}
& \text { Che permutasse a tempo li ben vani } \\
& \text { di gente in gente e d'uno in altro sang } \\
& \text { oltre le difension de senni umani. }
\end{aligned}
$$

Petrarca señala el momento del giro fundamental que encamina hacia nuevos horizontes; siguiendo a Séneca dirá en De remediis utrius que fortunae, II, I: «Sola virtus fortunae legibus libera est, atque illa obluctante clarius nitet.s Y tras él se precipita el humanismo renaciente. Dice León Bautista Alberti (1407-1472) en Della Famiglia: «Ma se alcuno, con diligenza qui vorrà investigare qual cosa molto estolla e accresca le famiglie... costui apertamente vedrà gli uomini a versi d'ognisuo bene cagione e d'ogni suo male. Non èpotere della fortuna; non è, come alcuni sciocchi credono, cosi facile vincere chi non voglia esser vinto. Tiene giogo la fortuna solo a chi sè gli sottomette, En igual forma, aún más brillante y enér icn, se presa Maquiavelo: Si può statuire, la fortuna essere ingan, se expres. bolissima a rapirci qualunque nostra minima virtù, etc. (Compárese para estos últimos textos G. Gentile, Il concetto dell' uomo nel Rinascimento, en Giordano Bruno e il pensiero del Rinascimento, 1920, página 151.) Más citas aduciremos al hablar del honor; con lo notado basta para que se perciba con plena claridad cuál es la génesis y la trayectoria que han seguido las ideas morales que Cervantes manifiesta cerca de la inanidad de la fortuna frente a la inconmovible e interior grandeza del ser humano. podrá empañar. Es la fórmula clásica del estoicismo, que en toda su pureza nos da Cervantes en este pasaje de Persiles: «La baja fortuna jamás se enmendó con la ociosidad ni con la pereza; en los ánimos encogidos nunca tuvo lugar la buena dicha: nosotros mismos nos fabricamos nuestra ventura, y no hay alma que no sea capaz de levantarse a su asiento; los cobardes, aunque nazcan ricos, siempre son pobres; como los avaros, mendigos» ${ }^{1}$.

¿Piensa Cervantes que esta actitud racional puede modificar el yo sensible, la conducta de la persona o su carácter? En teoría y en principio, con grandes salvedades, nos dice que sí, como en el caso de Roque Guinart ; en la práctica sin embargo, los mayores personajes cervantinos intentan labrarse esa superior «ventura», debida al conocimiento y a la victoria sobre sí mismos, cuando los desatinos de la propia vida produjeron ya sus máximas y necesarias consecuencias. Los héroes cervantinos más bellos y más nobles mueren conscientes, aspirando a inhibir su ser superior de aquel torbellino que les arrastra, pero melancólicamente entregados a un sino fatal.

Los textos adquieren luz más clara mediante esta compleja y doble interpretación que hemos dado a la sentencia según la cual es cada uno «artífice de su ventura»: «De los pecados que se cometen, nadie ha de echar la culpa a otro sino a sí mismo» ${ }^{3}$.

1 Rivad., I, 6oga.

2 \&El principio de la salud está en conocer la enfermedad...; los pecadores discretos están más cerca de enmendarse que los simples. El cielo, o Dios, por mejor decir, que es nuestro médico, le aplicará medicinas que le sanen, las cuales suelen sanar poco a poco, y no de repente y por milagro» (II, 60; RM, VI, 227).

3 Persiles, $611 a$. Persiles dice a Segismunda, en un momento de exaltación amorosa: "Mira, señora, cómo no es posible que ninguno fabrique su fortuna, puesto que ['aunque'] dicen que cada uno es el artífice della desde el principio hasta el cabo; así yo no puedo responlerte a do que haremos despés que la buena suerte nos ajunte (66, b). Persiles, desce su punto de vista, analiza con esperitu prér 
En ese maravilloso capítulo IV del Viaje del Parnaso, donde tantas hondas observaciones sobre sí mismo hace el autor, volvemos a hallar la célebre frase, aplicada al fatal devenir del individuo, en este caso el mismo Cervantes:

Tú mismo te has forjado tu ventura,

y yo te he visto alguna vez con ella;

pero en el imprudente poco dura;

mas si quieres salir de tu querella

alegre, y no confuso, $y$ consolado,

dobla tu capa, y sientate sobre ella ${ }^{1}$.

Para Cervantes, como para sus máximas criaturas, no hay, pues, opción entre la fortuna venturosa y la desdichada; única salida que resta es «sentarse sobre la capa» de la propia vida y dominar ésta con aire comprensivo, consolado y melancólico. Contemplamos, a nuestra vez, llenos de reverente amor este noble espíritu de Cervantes, de cuyos más íntimos. afanes brotaron, como esencial emanación, las supremas figuras de su fantasía. ¡ $Y$ hubo quienes se atrevieron a escribir que él era un inconsciente hombre de la calle!

La grave aunque necesaria consecuencia que se desprende de semejante moral es que el concepto de responsabilidad se reduce meramente a imputabilidad, a atribuir a la propia persona la paternidad de la culpa, y a presentar sus fatales resul tados, nocivos para el causante o para el prójimo. Pero sin considerar que las cosas hubiesen podido seguir distinta trayectoria. De ahí la impresión de glacial fatalismo que a veces nos invade leyendo a Cervantes. En las postrimerías de la genial novela exclama Sancho: "Muy bien dice v. m.; porque según opinión de discretos, la culpa del asno no se ha de a la albarda; y pues deste suceso v. m. tiene la culpa, castí-

su suerte inmediata; pero Cervantes, creador del personaje, sabe muy bien que Persiles ha de ir, sin poder hacer otra cosa, a fundir su existencia con la de Segismunda. La variedad de planos en la obra cervantina produce estos efectos, ya familiares para nosotros.

Edic. Schevill-Bonilla, pág. 56 . guese a si mesmo, y no reviente sus iras por las ya rotas y sangrientas armas, ni por las mansedumbres de Rocinante» ${ }^{1}$. "¿Qué hace aquí este Arnaldo..., llorando acá, suspirando acullá, lamentándose amargamente de la fortuna que él mismo se fabrica ? $^{2}$. "El príncipe, justa razón es que viva seguro entre sus vasallos, que el temor de las traiciones nace de la injusta vida del principe» ${ }^{3}$. Hay que resignarse a las consecuencias de nuestra fatal conducta. En Rinconete, cuando el arriero engañado en el juego por los dos mozalbetes quiere ir tras ellos, «sus compañeros le detuvieron y aconsejaron que no fuese, siquiera por no publicar su inhabilidad y simplezas ${ }^{4}$.

No hace falta aducir otros casos para probar que nos hallamos ante un arraigado pensamiento cervantino; ni cabe tampoco la menor duda sobre la filiación de tal doctrina moral, de evidente carácter estoico, según creemos haber demostrado. Cervantes, como en ocasiones anteriores, sigue aquí las ideas de su siglo. El humanismo había hecho pie firme en una moral que concedía a la razón poder y autonomía cuasi divinos. La razón debe disponernos para la desgracia, y en ella, sólo en ella debemos tener confianza; Séneca hace que su amigo Lucilio rompa las pasiones y desprecie el dolor, hasta llegar a la perfecta impasibilidad. Erasmo dirá: «Es exacta la definición de los estoicos, que el sabio es aquel que vive según las reglas de la razón, y loco, por el contrario, el que se deja ir a la rastra de sus pasiones» ${ }^{5}$. Para Castiglione la prudencia razonable debe gobernar la vida de su Cortesano, «de tal arte, que cualquier obra suya salga hecha y compuesta de todas las virtudes juntas, conforme al oficio, según dicen los estoicos, del hombre sabio» ${ }^{6}$. Y así habla el Cura a D. Fernando: «En los casos inremediables era suma cordura,

\section{II, 66; RM, VI, 322 \\ 2 Persiles, $597 a$.}

3 Ibid., 5846 .

4 Clás. Cast., pág. 152.

5 Elogio de la locura, edic cit pág. 26.

6 Cortesano, pág. 147 . . 
forzándose y venciéndose a sí mismo, mostrar un generoso pecho" ${ }^{1}$. Otros personajes cervantinos dominan a menudo los impulsos pasionales por motivos de razón. Cardenio está a punto de hacer un desatino durante el casamiento de Luscinda, "pero mi suerte... ordenó que en aquel punto me sobrase el entendimiento». Más adelante se resigna serenamente a su desastrada vida: "Que yo no siento en mí valor $n$ fuerzas para sacar el cuerpo desta estrecheza en que por mi gusto he querido ponerlo" ${ }^{2}$. Dorotea, por su parte, aparece animada de análogo espíritu: «Si algo le había dejado bueno la fortuna, era el ánimo que tenía para sufrir cualouier bueno tre que le sobreviniese» ${ }^{3}$. Con la misma estoica disposición presenta Sancho al noble Hidalgo, retornando a su pueblo, una vez concluído el ciclo de sus aventurs: tu hijo Don Quijote, que si viene vencido de los brazos ajenos, viene vencedor de sí mismo; que, según él me ha dicho, es el mayor vencimiento que desearse puede» 4 .

Esa suprema conformidad resume en nota esencial la inquieta y turbulenta vida del héroe; Don Quijote fracasa en e empeño de suprimir en la tierra las fuentes del mal, pero logra la única victoria que no era quimérica para la filosofía moral del Renacimiento: la victoria de sí mismo ${ }^{5}$. En su tra tado De la providencia nos presenta Séneca al joven Faetón, inconmovible en su propósito grandioso de conducir el carro del Sol, no obstante las razones con que su padre intent arredrarle. Séneca se complace en reproducir las palabras de aquel egregio mancebo: «Porque estas cosas en que me piensas espantar, más me avivan. $\mathrm{Y}$ allí me place estar donde mismo Sol ha miedo. Porque al hombre bajo y para poco, per-

1 I, 36; RM, II, 126.

2 I, 27 ; RM, II, 370 y 373

3 I, $28 ; \mathrm{RM}, \mathrm{II}, 392$.

4 II, $72 ; \mathrm{RM}, \mathrm{VI}, 416$.

5 A veces anduvo el

A veces anduvo el caballero muy lejos de aquel ideal. En la aventura de la mano cogida en la cuerda, el Hidalgo «bramaba como un toros (I, 43; RM, III, 292). Maravilloso claroscuro, que priva creación artística de àstracto y frío convencionalismo. tenesce buscar lo seguro. Por lo alto va la virtud» ${ }^{1}$. No piensa así Don Quijote? Anhelo máximo y caída en él superada por el vencimiento de sí mismo. Razonando por esa vía, llegaríamos al ideal perfecto, en el que Spinoza hará consistir la libertad suprema. Esa región de sublime pureza bordeaba Cervantes al escribir:

Con mi corta fortuna no me ensaño, aunque, por verme en pie como me veo y en tal lugar, pondero así mi daño...

Que tal vez suele un venturnso estado,

cuando le niega sin razón la suerte, honrar más merecido que alcanzado 2 .

Erraríamos, sin embargo, si pensáramos que la dirección moral de Cervantes es mero calco de la de Séneca. La distinta índole de la obra literaria imponía ya esenciales diferencias. La compresión a que el estoicismo sometía al individuo habría hecho imposible el interés novelístico. Además Cervantes, personalmente, no cree que la vida sea una preparación para la muerte, ni que deba renunciarse a los goces y placeres que la naturaleza nos brinda. Don Quijote emprende su áspero ministerio, que implica renuncia al placer de los sentidos ${ }^{3}$, porpue así lo requiere su carácter de héroe que ha de vivir en el ámbito del «universal poético»; no obstante lo cual, sueña con honores y galardones, con triunfos terrenos; ansía el aplauso, conoce la jactancia y la vanidad; en casa de los duques se pavonea en forma que habría sonrojado a un estoico. Sancho no querría desperdiciar ninguna grata sensación; su epicureísmo es tan importante para el autor como la inmaterialidad quijotesca. Y allí está la casa de don Diego de Miranda, apacible y codiciadera, de cuya molicie se zafa Don Quijote, y que Sancho no querría abandonar nunca. Aquella casa, en sí, no supone para Cervantes ninguna

Cinco libros, traduc. de A. de Cartagena, edic. Amberes, 1551 , fol. 97 v.

2 Viaje del Parnaso, edic. cit., pág. 56.

3 «Por no parecer bien que los caballeros andantes se den muchas horas al ocio y al regalos (II, 17 ; RM, IV, 374). 
inmoralidad. Es una manera de vivir la de D. Diego tan estimable y $\tan$ explicable como la de Don Quijote o la de Sancho. Y si a esto se añaden los casos placenteros en que abundan todas las obras cervantinas, goces de amor y de fortuna, habremos de concluir que la vida no es para Cervantes entrenamiento que deba avezarnos al dolor y disponernos para la muerte. En este sentido, Cervantes no es estoico. El bien es para él algo más que la rígida y áspera virtud dictada por la razón esquemática. La naturaleza y la vida han creado muchos bienes apetecibles: "Una de las cosas en que ponían el sumo bien los antiguos filósofos, que carecieron del verdadero conocimiento de Dios, fué en los bienes de la naturaleza, en los de la fortuna, en tener muchos amigos y en tener muchos y buenos hijos» ${ }^{1}$. Si la Edad de Oro fuese actualizable, no habría más que pedir; la armonía y el buen acuerdo reinarían por doquier, y tendríamos así entre nosotros un reflejo de aquel «summum bonum» de la antigua filosofía. Desorra mente el hado no ha querido que la armonía y la discreta concondancia rijan siempre nuestras relaciones con la naturaleza. objetiva :

\section{Naturaleza compuso \\ la suerte de los mortales}

entre bienes y entre males ${ }^{2}$.

Estos males - lo hemos visto - vienen a menudo de no concordar nuestros propósitos con la realidad, ni con nuestro ser íntimo: "Condición de la naturaleza humana, que puesto. que Dios la crí́ perfecta, nosotros, por nuestra culpa, la hallamos siempre falta, la cual falta siempre la ha de haber, mientras no dejáremos de desear» ${ }^{3}$. Falla a veces el engrane entre los deseos y las posibilidades, entre nuestra razón y la realidad ${ }^{4}$, y así se produce el error, cuyas consecuencias recaen

1 II, $16 ;$ RM, IV, 323

2 La Entretenida, edic. cit., pág. 71 .

3 Persiles, 595 .

- El racionalismo propiamente dicho, llegado el siglo xvir, no conocerá más realidad que la inserta en el ámbito de las fórmulas racionales. sobre el causante o sobre cualquier otra persona. Y entonces es cuando Cervantes recurre al estoicismo, como actitud que a posteriori hemos de adoptar: «Sufra y calle el que se atreve a más de a lo que sus fuerzas le prometen» ${ }^{1}$. «Si a su tiempo tuviera yo esos veinte ducados..., hoy me viera en mitad de la plaza de Zocodover, y no en este camino, atraillado como galgo; pero Dios es grande, paciencia $y$ basta» ${ }^{2}$.

Recuérdese asimismo la forma de resignación imperturbable en que mueren los condenados por Cervantes a la muerte post errorem. Ese buen conformar lo hallamos también en la vida de Sancho, que resume así su actitud íntima: ${ }_{*} \mathrm{Si}$ cuando era gobernador estaba alegre, agora que soy escudero de a pie, no estoy triste» ${ }^{3}$.

La moral de Cervantes es, pues, bastante compleja. Si quisiéramos aprisionarla en una fórmula, diríamos que la moral naturalista, a base de espontaneidad, aparece fuertemente matizada de elementos estoicos. Erasmo y Montaigne se enfrontaron con ese problema y lo resolvieron de forma distinta a Cervantes. En Erasmo predomina sin duda la concepción naturalista de la vida, y hay censuras acres contra el estoicismo: "Los estoicos alejan del sabio cualquier perturbación del ánimo, considerándola como verdadera enfermedad... Séneca, dos veces estoico, despoja a su sabio de toda suerte de pasiones. |Valiente obra maestra ha sacadol Este sabio ciertamente ya no es un hombre, sino una especie de Dios, que no ha existido nunca y que jamás podrá existir. Hablemos más claro: ha hecho una fría estatua de mármol, carente en absoluto de sentido humano» 4.

1 II, 44; RM, III, 309.

2 I, 22; RM, II, 192. Como rasgo típicamente estoico se subraya la resistencia del pícaro en el tormento: «Tantas letras tiene un no como un sis, frase que ocurre en el Quijote y en Rinconete. Sentencia de “escritores moralistas», dice con acierto Rodríguez Marín, Quijote, II, 190 , nota.

3 II, 66; RM, VI, 318

4 Elogio de la locura, edic. cit., págs. 44-45. 
Montaigne, por su parte, emprendió también la vía naturalista, como expresa reacción contra el método estoico, por el que se dejó seducir en los primeros ensayos, compuestos hacia 1572 . Las exigencias vitales del yo impulsan a Montaigne a rechazar las reglas estoicas. Del conocimiento de sí mismo surge una especie de moral psicológica y empírica, muy tocada de utilitarismo, a base de compensaciones entre el placer y el dolor. La virtud vendrá a consistir, en suma, en el desarrollo armónico de las facultades del individuo, en un sensualismo templado por la razón ${ }^{1}$.

Cervantes adoptó en moral una postura más comprensiva de los elementos contrarios que integran al hombre. Se renueva en este punto el conflicto que, cruzando todo el siglo xvi, llegó a Cervantes, lo mismo que a Montaigne y a Justo Lipsio, en demanda de solución apremiante: racionalismo abstracto y universalizador, vitalismo sensible e individualista. En el terreno puramente artístico ya vimos con claridad cómo libraban batalla esas dos tendencias esenciales, que son la medula del humanismo, y cómo nuestro novelista logró efectos maravillosos oscilando, sin espíritu doctrinario, de uno a otro campo, usando una técnica impresionista, «el engaño a los ojos», la reducción irónica de cada uno de esos mundos mediante la contraposición del opuesto. Cervantes no era un genio científico y no creó un método racional como Descartes; pero inventó el método de la novela, no menos fecundo en arte de lo que fué en ciencia el admirable principio de Cartesio. Ahora bien: si nuestro autor hubiese reunido en un haz doctrinal sus preocupaciones morales, no sé cuál habría sido la trascendencia de su creación; pero sí que en ningún modo habría sido inferior su ética a la de Montaigne, Lipsio o cualquier otro gran moralista del Renacimiento. Pero Cervantes tenía horror a la abstracción y a la didáctica pura; las ideas se revestían para él de contornos animados y las sus-

No insisto en ello por haber excelentes libros sobre este punto. Véase, por ejemplo, VitLey, Sources des Essais de Montaigne, tomo II, cap. III. tancias éticas se le tornaban sensibilidad y arte. No poseemos unos «Ensayos» cervantinos, aunque de cuanto va dicho se desprende que en el espíritu del autor existía una concepción ética que aspiraba a ser armónica e integral, síntesis de las direcciones que a la sazón se daban en las mentes más exquisitas.

Hemos visto cómo en más de un caso Cervantes corrige la ideología entusiasta basada en la espontaneidad natural y vital, no obstante atraerle con violencia esos principios naturalistas; la ideología opuesta, basada en razonamientos generalizadores, le interesa también no menos profundamente. En la moral humanista este dualismo puede rotularse con alternativo título: estoicismo razonador o naturalismo sensualista El «debe ser» que Don Quijote ha sacado de un arsenal de razonamientos, está frente al «es así» que Sancho intuye mediante la impresión de sus sentidos. La respuesta de Cervantes, en lo que atañe a la moral, creo que es ésta: ambas posiciones son legítimas, con tal que ponderemos y limitemos su zona de acción; es posible una suprema y muy grave armonía.

Bien está la espontaneidad natural, fuerza eterna y divina, anterior a las leyes y a los razonamientos. Ojalá nuestros inpulsos volitivos fueran coincidentes con el concepto de virtud y supusiesen la realización de un bien. Sobrarían entonces las leyes y quién sabe si las preceptivas religiosas. En Las dos doncellas, Leocadia y D. Rafael no necesitan nada externo ni racional para cumplir el bien de poseerse mutuamente: «Dadme, señor don Rafael, la mano de ser mío, y veis aquí os la doy de ser vuestra, y sirvan de testigos los que vos decís, el cielo, la mar, las arenas y este silencio... Diciendo esto, se dejó abrazar, y le dió la mano, y D. Rafael le dió la suya, celebrando el nocturno y nuevo desposorio solas las lágrimas que el contento, a pesar de la pasada tristeza, sacaba de sus ojos» ${ }^{1}$. Por esa senda caminaríamos a la Edad de Oro, sede

Rivad., I, 209 b. Es innegable que a Cervantes le encanta este amor libre y espontáneo, sin fórmulas legales ni religiosas, que, laxa- 
de todas las concordancias vitales. Mas si las cosas no acontecieren en esa forma perfecta, si los instintos y los deseos nos llevaren a fracasar, ¿qué haremos entonces? Debemo

mente, podría cubrirse con el derecho canónico anterior a Trento. Lo malo es que el matrimonio solemne y eclesiásticamente atornillado era un tema de Contrarreforma, pues el Concilio de Trento había prohibido en 1563 los matrimonios clandestinos, y declaró nulo írrito el llamado matrimonio presunto, contraído sin el párroco. No obstante, siempre que se pueda, hay que casarse actuando el instint certero como ministro, a reserva de hacer luego unas afectadas reverencias. Lo que a Cervantes le gusta, de verdad, es que las cosas ocurran como en el citado ejemplo de Las dos doncellas, o, mejor todavía como en este otro: «Dame esos brazos, respondió Ruperta y verás, señor, cómo éste mi cuerpo no es fantástico, y que el alma que en te entrego es sencilla pura $y$ verdader. Testigos fueron de en abrazos y de las manos que por esposos se dieron, de abrazos y de las manos que por esposos se dieron, los criado de Croriano, que habían entrado con las luces; triunfó aquella noche la blanda paz desta dura guerra, volviéndose el campo de la batalla en tálamo de desposorio...; amaneció el día, y halló a los recién des. posados cada uno en los brazos del otros (Persiles, $655 a$ ). Feliciana de la Voz logra igualmente un marido a su gusto - no por cierto que le brindaban sus padres - y se entrega át sin más rodeos, considerándose desposada : Destas juntas y destos hutos anos, consiacortó mi vestido y creció mi infamia, sies que se prede llanorosos, se acortón vere la conver sacion de los desposados amantes (Ibid., 628 a). Según esta moral naturalista e independiente, aquí, en efecto, no hay infamia, sino virtud. A veces, a nuestro buen Cervantes le entran temores por tan excesivo naturalismo, y toma precauciones realmente cómicas. Véase qué casamiento: «Si va a decir la verdad, señores alcaldes, tan marida es Mari-Cobeña de Tozuelo, y él marido della, como lo es mi madre de mi padre, y mi padre de mi madre: ella est́ enci ta, y no está para danzar ni bailar. Ć́sentos, y váy el diablo enara ma y no está para iños las manos, si niños las manos, si es que no se las han dado hasta agora, y queden para en uno, como lo manda la Santa Iglesia, nuestra Madre [!], y vamos con nuestro baile al olmos (Persiles, 638 b). Pero ¿̨qué había de mandar eso la Santa Iglesia? Menéndez Pelayo se creyó en el caso de explicar la moralidad del matrimonio de Amadís y Oriana, por haber sido escrita la obra dos siglos antes de que el Concilio de Trento declarase nulos los matrimonios clandestinos: eSi esta doctrina no hubiese enteramente ortodoxa, la Inquición no la bubiese dejado past to tánose de matera tratándose de materia tan delicada.s (Origenes de la Novela, I, ccxv.) hacer este doble razonamiento: los acontecimientos y sucesos de este mundo proceden en virtud de una trabazón infinita de hechos, cuyo curso pende de la fatalidad inmanente en la na-

pero se hacía el distraído. En cien lugares estaba explicado cómo había que casarse: «Aquí quiero avisar que en todo caso se deben
evitar los casamientos clandestinos, sin los padres, o los que tienen evitar los casamientos clandestinos, sin los padres, o los que tienen
lugar de padres, y sin ministro eclesiástico (como lo ordena y manda lugar de padres, y sin ministro eclesiástico (como lo ordena y manda el sagrado Concilio tridentino, ses. 24, cap. I, que sea presente e cura u otro de su comisión y licencia, con dos testigos), porque no será válido; y se han de hacer primero las amonestaciones. Y amonesta el Santo Concilio, que antes de recibir las bendiciones en la iglesia, ni cohabiten ni se junten» (L. DE Granada, Doctrina Cristiana Rivad., XI, $166 b$ b). Estas prescripciones eran acatadas por Cervantes como católico (sestando ya el sacerdote a punto para darles las manos y hacer las católicas ceremonias que se usan", Persiles, $606 a$ ), e infringidas como filósofo, porque el matrimonio pretridentino era para él el ayuntamiento de un hombre y una mujer que amorosamente se disponían a vivir juntos, forma de nupcias que prefería. Veremos, empero, cómo Cervantes se cubre astuciosamente contra posibles observaciones. Al final de La fuerra de la sangre. ${ }^{2}{ }^{2}$ Estefanin dijo al curacio luego desposa a su hijo con Leocadia; hizo ansí, que por haber sucedido este caso en tiempo cuando con sola la voluntad de los contrayentes, sin las diligencias y prevenciones justas y santas que ahora se usan, quedaba hecho el matrimonio, no hubo dificultad que impidiese el desposorios (Rivad., I, 172 a). Por eso, cuando el autor se acuerda de que hay que proceder con cautela, casa a la gente de muy distinta forma: «Hallóse presente el obispo o arzobispo de la ciudad, y con su bendición y licencia los llevó al templo $y$ dispensando en el tiempo, los despo en el mó puntor (El a parte liberal, edic. Schevill-Boilla, pág. 206). En Perso puntos (El amante liberal, edic. Schevill-Bonilla, pág. 206). En Persiles, Isabela Castrucho y Andrea Marulo se dan las manos, sy con dos síes quedaron indubitablemente casados.s ¿Y Trento? Como llovidos del cielo, «dos sacerdotes que se hallaron presentes dijeron que era válido el matrimonios; y por si no era bastante, de alli a dos días, Isabela y Andrea fueron a la iglesia a casarse (Rivad., I, 660 b). En La Gitanilla las disposiciones del Santo Concilio sirven como ardid en la trama novelesca, pues las amonestaciones ins dibles sirven para aplazar indefinamente la conclena de D. Junn de Cárcano. Dice el teniente cura al corregior: cLso no podrey Cárcamo. Dice el teniente cura al corregidor: «Lso no podré yo hacer, si no preceden primeramente las circunstancias que para tal caso se requieren; ‘dónde se han hecho las amonestacionesł; ‘adónde está la licencia de mi superior para que con ella se haga el desposorio? 
turaleza: cada cosa y cada persona es y hace lo que puede, en virtud de su íntimo ser. Respetemos ese orden natural, pleguemos a él nuestra sensibilidad y nuestra razón (hasta aquí Cervantes va con Montaigne), porque sólo así podremos tropezar con la felicidad posible en esta vida. Ahora bien: hay un ideal superior al que nos propone esta actitud hedonista. Que procedamos en esta vida guiados por las pasiones o por el razonamiento, el ideal es que al final realicemos un supremo esfuerzo de conocimiento, para que atribuyendo los efectos a las causas, aneguemos las pasiones en un mar de prudencia. La ira y la venganza están excluídas. Siendo víctimas, podemos tornarnos señores y maestros de la vida mediante ese acto de suprema comprensión, única manera para Cervantes de llegar a la libertad. No existe la «fortuna»; «cada uno es artífice de su ventura», porque cada uno está cruzado $y$ atravesado por la encadenada causalidad que informa la vida; y a quien vencen brazos ajenos, le queda el supremo recurso de tornarse "vencedor de sí mismo».

Viene, pues, a combinarse el neoestoicismo del Renacimiento con el inmanentismo naturalista, y el resultado es un sistema ético que no le cede en belleza a los de Montaigne, Lipsio o cualquier otro moralista del siglo xvi. Porque el coronamiento de este sistema es que el ser humano, en los. casos más ejemplares y característicos que ha ideado Cervantes (los casos de tragedia moral), puede llegar a un momento de conciencia suprema que le otorga autonomía intelectual y buena conformidad frente a ese devenir inexorable. Pero esa victoria de sí mismo no es sino un destello entre dos tinieblas, siendo así que el individuo ve inmediatamente destruirse su existencia, minada en su base por la propia conducta. Lo biológico sume así sus raíces en lo moral, y la vida

Más adelante sabremos que «concedió licencia el arzobispo, para que con una sola amonestación se hiciese» la boda (edic. Schevill-Bonilla, págs. 127 y 130). Raro habría sido que los trámites canónicos se cumpliesen en realidad; basta con el ademán respetuoso. Eso nos autorizará a que en otros casos mandemos a tálamo parejas amorosas, ungidas no más que por el sacramento de la voluntad marital. errada de los héroes cervantinos lleva necesariamente al aniquilamiento de su mismo ser físico. Quien yerra gravemente, el infractor de las armonías naturales, es, ni más ni menos, como un árbol falto de savia, que pronto o tarde ostentará al viento su ramaje inerte. La diferencia sería que Cervantes concede al hombre equivocado un punto, si no de contrición, al menos de lucidez para levantar acta de lo que allí acontecio: «Un necio e impertinente deseo me quitó la vida.» El castigo es inmanente e indisoluble de la culpa : "Seco ogni colpa è doglia», que dirá Campanella, arribando, por su cuenta, a orillas próximas a las cervantinas.

En último término, acaba por dominar en Cervantes la concepción naturalista e inmanente de la vida. Las pasiones y la conducta florecen o se resuelven en seca hojarasca, como si pertenecieran a un reino de la naturaleza. El espíritu humano comprende y tiene conciencia de esas realidades en la forma que lo admite la filosofía estoica. Pero he aquí una Gltima y capital divergencia: el estoico cuando no puede o no quiere seguir soportando el fardo de las humanas peripecias, se abre-las venas, mediante severo y frío cálculo; en Cervantes, la razón sirve sólo para espectar y contemplar; no propone suicidios ${ }^{1}$; esa misión aniquiladora fué confiada por nuestro genial autor a algo que él consideraba la única fuerza efectiva y actuante: a la Naturaleza, mística e infinita divinidad que revive en las mentes neoplatónicas del Renacimiento.

A fin, ahora, que no pueda imaginarse que ni por un momento nos hemos perdido en generalizaciones al formular estos resultados, vamos a considerar de nuevo una de las catástrofes morales más características en la obra cervantina, tratando de poner en cada frase del texto los contenidos que inmediatamente demandan. Si éstos coinciden con la teoría

1 Pero no preocupa la muerte: «Con qué prodigiosas señales [dice Auristela] me va mostrando el cielo mi desventura, que si se remator con acabarse mi vida, pudiera llamarla dichosa; que los males que tie nen fin en la muerte, como no se dilaten y entretengan, hacen dichosa la vida» (Persiles, 587 a). Véase adición final a la pág. 282. 
formulada, habremos llegado a una exactitud científica. Vea el lector cómo habla Carrizales en El Celoso extremeño, en aquellos graves momentos que preceden a su muerte:

«Habéis visto, señores, cómo llevado de mi natural condición, y temeroso del mal de que sin duda he de morir..., quise guardar esta joya, que yo escogí y vosotros me disteis, con el mayor recato que me fué posible... Mas como no se puede prevenir con diligencia humana el castigo que la voluntad divina quiere dar a los que en ella no ponen del todo en todo sus deseos y esperanzas ${ }^{1}$, no es mucho quede defraudado en las mías, y que yo mismo haya sido fabricador del veneno que me va quitando la vida... La venganza que pienso tomar desta afrenta no es ni ha de ser de las que ordinariamente suelen tomarse; pues quiero que, así como yo fuí extremado en lo que hice, así sea la venganza que tomare, tomándola de mí mismo, como del más culpado en este delito... Yo fui el que, como el gusano de seda, me fabriqué la casa donde muriese.»

Carrizales hace testamento, $\mathrm{y}$ «al seteno día le llevaron a la sepultura». Y es notable que añada Cervantes: «Sólo no sé qué fué la causa que Leonora no puso más ahinco en disculparse y dar a entender a su celoso marido cuán limpia y sin ofensa había quedado en aquel suceso» ${ }^{2}$. Olvidó, sin embar-

1 En una exégesis minuciosa habría que decir que vuelve a usar í Cervantes una de sus fórmulas convencionales, de sentido ambiaqui Cervantes una de sus for guo, que no anula la idea reiterad convencios elaboró fatalmente el veneno que habla de matarle), y que se explica dentro de su concepción naturalista. ¿Qué quiere decir entonces que Carrizales no puso sus esperanzas en la voluntad divina? Esto: que confió en que sus artificiosas precauciones serían poderosas a torcer el curso del instinto natural en Leonor, fuerza invencible. Es un caso más de «disparidad, que no hace consonancia» (pág. $2 \mathrm{r}$ ). La «voluntad divinas es aquí el principio infinito que ordena $y$ anima la vida natul: cu es aqui el principio infinto que orena y anima la vida a naturaleza, es indudable pro divina voluntad.

2 Véase antes pág. 243. En la primera redacción faltan, como es lógico, estas ladinas palabras. La conducta de Leonora está de acuerdo con el texto de esa primera redacción, porque habría roto la estructura de la novela el ponerla de acuerdo con la segunda. go, nuestro autor hacer dar al triste viejo los santos sacramentos, circunstancia que no descuida en el caso de Don Quijote. Este detalle podría mirarse como secundario; lo que no lo es, lo que hace que esta moral sea extracristiana, es que todo transcurre como si no existiesen premios y castigos supernaturales. Carrizales va natural y fatalmente lanzado por un ignoto destino, que le hace creador de la misma sustancia corrosiva que ha de disolverlo. Es un proceso inmanente, un círculo concluso en el ámbito humano. ¿Qué papel desempeña la religión en la conducta y desastre del protagonista? Porque Carrizales no es un malvado; no lo es quien da muestras de tan noble y serena elevación interior; es, sin duda, un héroe moral, pero de una moral puramente racionalista. Recuerda a los mártires de la filosofía estoica, que serenamente perdían la vida, sin estar sostenidos por la esperanza en bienes ultraterrenos, infinitamente más valiosos. Esa era la diferencia capital que los separaba del mártir cristiano, y esto era lo que les echaban en rostro los Padres de la Iglesia. A su vez Carrizales se distingue del mártir estoico en que no aspira tampoco a la gloria mundana: se disuelve oscuramente en el caos cósmico, porque así debía ser, y él sólo sabe que así sucede. La vida futura no desempeña aquí el menor papel. No ha partido Cervantes de la base de que las desdichas de nuestra vida proceden del pecado original o de nuestra libre conducta frente a los mandatos divinos, y que la religión estaba allí para salvar esas deficiencias en un mundo superior, donde reinaba la más comprensiva dulzura. Si nuestros teólogos no hubiesen embotado su perspicacia al leer a Cervantes, no habrían dejado de reprocharle lo que el cristianismo no puede mirar sino como seca y fría crueldad, inadmisible dentro del Evangelio. dY cómo no ver además que los casos de muerte post errorem no descansaban sobre supuestos cristianos, sino en un sentimiento estoico del destino? ¿Ni qué pecados han cometido, en general, los condenados por Cervantes a la extinción vital? Son sencillamente reos natos de lesa naturaleza.

Cervantes se asimiló, en modo que sorprende, las doctrinas morales del siglo xvr, difundidas fuera de España. Está 
en la corriente derivada de Pomponazzi ${ }^{1}$, para quien las penas. y las culpas son fatales, y las virtudes y los vicios llevan en sí mismos sus sanciones, todo dentro del plano del naturalismo. inmanente ${ }^{2}$; se halla, en el fondo, en la misma postura moral que Telesio o Campanella.

Ahora bien: pese al interés que ofrece para la historia del pensamiento español el hecho que Cervantes participe de las nuevas ideas morales de su siglo, es fuerza reconocer que por ese solo camino no habría llegado a la suprema región a que le condujo su arte. Moralista, aun admitiendo que en España hubiese hallado Cervantes medio hábil de dar curso a su filosofía moral, poseeríamos hoy en él un escritor comparable en ese punto a Lipsio, a Montaigne, a Telesio en su ética: es decir, en el terreno científico, una obra de epigono o de precursor. No era posible otra cosa antes de los grandes sistemas racionalistas iniciados, como se sabe, por Descartes, y que fueron muy distintos del práctico razonar del siglo xvı, limitado en moral a servirse del principio estoico de la universalidad de la razón. El racionalismo científico estaba en ciernes antes de Descartes; la bruma ideológica de la Edad Media envolvía aún las mentes mucho más de lo que pensaba el humanismo. A pesar, pues, de la interesante combinación que Cervantes formó con el naturalismo neoplatónico y el estoicismo, fué realmente genial que decidiera usar ese embrionario sistema del mundo como medio y no como fin. Si hubiese sido moralista puro, a Cervantes no le habría interesado sino el perfil ético de la conducta, su abstracto análisis, su valoración; como artista de genio se lanzó a presentarnos el dramático devenir de los

1 Véase De fato, lib. I, cap. XI.

2 Quod ridiculosum est, oportet dicere hoc [la diversidad mo2 "Quod riciculos moral y de todo genero] provenire ex natura universi, et non ex Dei in justitia (De fato, lib. II, cap. VII). Tan necesario al universo es el bien como el mal (véase antes, pág. 346 , y comp. ZaNTA, La renaissance du stö̈cisme..., págs. 44-45). Pomponazzi acaba por admitir la sucesión de mundos que permita la reencarnación, y el restablecimiento del orden perturbado en este que vivimos. Ni cielo ni infierno. Claro que al vulgo, dice Pomponazzi, hay que hablarle de otra vida. pecados y las virtudes naturales, en medio del torbellino vital, dentro de un sistema de moral autónoma. Con serena grandeza discurren las creaciones de Cervantes por el universo de las pasiones y de los destinos. Entre esos seres, los hay que tienen ante sí un porvenir esplendoroso; otros, en cambio, contienen en su seno elementos destructores que les harán sucumbir desastradamente. A su vez, toda esta concepción de los destinos vitales ha sido circunscrita en el Quijote por una actitud intelectual - tan propia de la época de la Contrarreforma, como lo es la moral cervantina - , que eleva aún más el plano de la obra artística. ¿Es este mundo «el engaño a los ojos»? ¿Dónde está la verdad o el error? ¿Infringe Don Quijote el sistema de las concordancias naturales, o es que deberíamos superar esta moral (casi física y biológica) que percibimos con tanta evidencia, y lanzarnos a inventa otras dimensiones? Quedan vibrando en el ánimo los ecos del problema - claros, patentes - , que se nos brinda como un campo de infinitas experiencias artísticas e intelectuales. Por eso podemos recorrerlo sin fatiga una y cien veces, penetrar en él por cualquiera de sus lados, laborarlo insistentemente en busca de renovadas cosechas. Sus cultivadores son legión ostentan el más vario estilo, y entre ellos los hay tan preclaros como Flaubert y Pirandello.

Las consecuencias de la moral cervantina son importantes en el aspecto intelectual y en el histórico. En el aspecto ideológico nos lleva al terreno de la experiencia humana, desde el momento que las faltas y las virtudes se valoran en vista de sus consecuencias vitalmente afirmativas o negativas; queda así excluída la norma abstracta preestablecida, escolástica o religiosa, que califica y moldea el contorno ético del hecho humano. Así como la nueva ciencia interpreta los hechos en vista de lo que se deduzca de la observación directa y de las nuevas leyes físicas que lógicamente los explican (dejando a un lado la Biblia y los Santos Padres), de la misma suerte Cervantes considera la conducta en vista de la experiencia sensible y de acuerdo con su sistema de armonías e incon- 
gruencias vitales. De ahí que sus pecados no sean siempre los del Catecismo; pecados que para el católico serían venialísimos, son para nuestro autor merecedores de la extinción vital (el error, la necedad pertinaz, obstinarse, por ejemplo, en amar a quien no nos ama); en cambio, el adulterio, en los casos que lo presenta, es en sí un hecho natural y justificable. Nunca se da el caso de que una adúltera reciba penas y castigos por su deshonestidad. Ya lo ha visto el lector: una mujer es o no fiel a su marido en virtud del juego natural de las pasiones. Camila, en El curioso impertinente, va al adulterio porque la virtud suya no pendía de un acomodamiento abstracto a tales. o cuales mandatos de la moral religiosa, sino de una serie de condiciones positivas, del hecho de encontrarse en un plano de concordancias amorosas. Se rompen esas armonías por causa de Anselmo, y surgen en seguida otras simpatías amorosas, que Cervantes censura por fórmula ${ }^{1}$, pero por las cuales. no castiga a Camila. Si esta muere luego, no es por el pecado de su adulterio, sino por la pena que le produce la muerte de su amante: "Camila estaba casi en el término de acompañar a su esposo en aquel forzoso viaje, no por las nuevas del muerto es poso, mas por las que supo del ausente amigo» ${ }^{2}$. El lector conoce ya otras situciones, que no he de recordar ahora.

Bajo toda aquella discreción a que obligaba la Contrarreforma ${ }^{3}$, se descubre bien clara una moral nueva y revolucionaria en su tiempo. Si tal semilla no fructificó plenamente en la literatura y el pensamiento de España, eso ya no fué culpa de Cervantes. Sus resultados se perciben más en Francia que entre nosotros, ya que en este punto Molière continúa el arte moralizador de Cervantes ${ }^{4}$. No sé cómo no se dice que

1 Bien sabe que, para Dios, es aquello un pecado: piensa Lotario aque si así tuviera disculpa para con Dios, como para los hombres, de lo que pensaba hacer, que no temiera pena por su culpas $(I, 33)$. 2 I, 35, final.

3 No se olvide cómo se regocija Cervantes con el adulterio en $E l$ Viejo celoso, cómo protege a Luisa en Persiles, etc., etc.

4 Molitre a profondentent igorele chis ginale de la morale chrétienne c'est la résistence à la nature. On ne la
L'École des femmes y L'Ecole des maris responden a ideas expresadas en España a principios del siglo xvir, y no proceden tan sólo de intrigas de comedia; habrá que tener presente ese sistema moral metódicamente aplicado por Cervantes; nadie ha expuesto con tanta profundidad ideal y artística la doctrina de la libertad de amar en la mujer.

Nó puedo ahora perseguir a lo largo de nuestro siglo xvII la huella de Cervantes en la novela y en la comedia. En esa

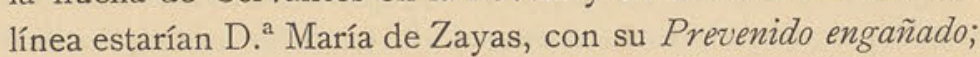
Rojas Zorrilla ${ }^{1}$, con Don Lucas del Cigarral; Antoniò Hurtado de Mendoza, con El marido hace mujer, y muchos más que en una $u$ otra forma han sufrido la influencia cervantina ${ }^{2}$. Pero es innegable que la parte central de aquella moral, los gérmenes poderosos que contenía para el progreso y renovación de nuestro pensamiento, quedaron tan enterrados, que hasta ahora realmente no se destacan esas ideas a primer plano, a la luz de la cultura renacentista de fines del siglo xvi.

LOS CONSEJOS A SANCHO

El prurito de moralización se manifiesta una vez más en las dos series de consejos que Don Quijote da a su escudero. Los consejos en sí nada tienen de insólito, en cuanto a las ideas, y su mayor interés reside en los reflejos que provocan en Sancho y en el ambiente de ironía y buena gracia que envuelve el diálogo. La causa de que nos fijemos en ellos, incidentalmente, es el propósito de ponerlos en relación con

trouve pas chez Molière... Combattre la nature est folie: on est ridicule de le faire et malheureux; car la nature a le dessus; elle se retourne contre celui qui veut la forcer ou la détruires (Lanson, Hist. litt.frang., I912, pág. 586).

1 Véase nuestro estudio de Rojas en Teatro Antiguo Español, II, 1917 , págs. 185 y sigs.

2 Habría que deslindar cuidadosamente lo que la comedia del siglo de oro pueda deber al influjo de Cervantes, de lo que proceda directamente de la tradición naturalista del siglo xvi. La dama boba de Lope $\left(161_{3}\right)$ me parece hallarse en este último caso. 
otras obras del siglo xvi, de índole moral, para que se observe también en este detalle la filiación humanista de Cervantes. La idea de que éste conociese el Diálogo de Mercurio y Carón de Valdés ${ }^{1}$, me parece inadmisible no sólo por la diferencia que existe entre ambos textos, sino por lo inverosímil de que Cervantes conociese las obras de los Valdés entonces inéditas. Creo más probable que Cervantes manejara las trac ciones de Isócrates ${ }^{2}$, y las mismas obras de Séneca romanceadas, donde abundan consejos de carácter análogo a los dados a Sancho.

Sin que yo sostenga que Cervantes consultó necesariamente la Parénesis o exhortación a la virtud, de Isócrates, es cuando menos curioso establecer un cotejo entros, y comparar el análogo espíritu, y a veces la estrecha semejanza:

$$
\text { ISOCRATES }
$$

CERVANTES

Teme siempre a Dios (pág. 695). Primeramente, ioh hijo!, has de temer a Dios (II, 42; RM, V, 346).

Todo género de murmuración contra ti debes de evitar (Ibíd.).

Deben acompañar la gravedad del cargo... con una blanda suavidad que... los libre de la murmuración maliciosa (Ibíd., pág. 349).

En tu vestido has de procurar er pulido, limpio y bien adere zado (pág. 697).

No andes, Sancho, desceñido y flojo; que el vestido descompuesto da indicios de ánimo desmazalado (Ibíd., pág. $35^{8}$ ).

1 Menéndez Pelayo, Cultura literaria de Cervantes, págs. 16-17.

2 Diego Gracián tradujo y reunió en un volumen los. 17. obras: Isócrates, De la gobernación del reyno: A cargo de rey; Drón, De la institución del principe. Traducidos de la licio griegra en castellama, y dirigidos al onperador Mas huilhano de la lengua griega en castellana, y dirigidos al emperador Maximiliano II, por el se. Petario Diego Gracian, Salamanca, Mathias Gast, 1570.

Pedro Mexía tradujo: Parénesis o exhortación a la virtud, de Isócrates, antiquísimo orador y filósofo, a Demónico, su discipulo, traducida de griego en latín por el doctisimo varón Rodolfo Agricola, y de latin en castella no por Pero Mexia. Se encuentra al final de algunas ediciones de Silva de varia lección. Me sirvo de una tard́a, Wadrid, 1673 , nas $691-703$.
Entre las cosas que más debe huir es el beber vino sin orden ni templanza...; el hombre, turba da la razón y el juicio con el vino, hace muchos desatinos (pág. 698).

No vituperes ni menosprecies a ninguno por infortunio o desastre que le acontezca, porque todos estamos sujetos a las miserias de esta vida (pág. 697) ${ }^{1}$.

En conversar con los hombres muéstrate siempre afable $\mathrm{y}$ be. igno, y no altivo ni arsog igno, y no altivo ni arrogante, porque el fausto y fantasía de lo presuntuosos apenas lo puede sufrir sus mismos siervos (página 698).

Algunos consejos parecidos pueden verse en la Gobernación del reyno, de Isócrates: "Preciarte has en el atavío de tu cuerpo..., para que los que vieren tu presencia te juzguen por digno del reino» ${ }^{2}$. Otros varios podrían mencionarse, pero tal vez lo más interesante sea notar el aire de parentesco, que, en general, ofrecen los consejos a Sancho con las moralidades de Isócrates y los demás autores de los trataditos que Diego Gracián y Pedro Mejía pusieron en romance.

\section{EL HONOR}

$\mathrm{Va}$ a terminarse este libro justamente con el estudio del tema en que hace años percibí, por primera vez, una concreta relación entre Cervantes y el pensar renacentista ${ }^{3}$. Como el

El mismo espíritu muestra este otro consejo: «Procura asimismo ser con los hombres fácil y cortés, y en tus palabras blando y afable (pág. 697).

2 Edic. cit., pág. 14.

3 Véase Rev. de Filol. Esp., 1916, III, 357 y sigs. 
ambiente se halla mal dispuesto para este género de investigaciones, lo que entonces dije no fué recogido ni comentado por nadie; el desarrollo metódico de aquellas observaciones permitió, sin embargo, llegar a los resultados contenidos en este volumen. Se ha seguido hablando de que Cervantes era escritor de ideas vulgares y corrientes, a lo sumo de ánimo más humanitario y compasivo en cuanto a las venganzas por causa de honra ${ }^{1}$.

La doctrina del honor cervantino no es sino un aspecto de su moral. Siendo ésta autónoma e inmanente, también lo será el concepto de la dignidad del hombre, que no pende de circunstancias externas (fama, opinión, galardones), sino de la intimidad de la virtud individual. El honor es atributo de la virtud; pero ésta existe y vale, no obstante la actitud que los demás observen: "La virtud y el buen entendimiento siempre es una y siempre es uno: desnudo o vestido, solo o acompañado. Bien es verdad que puede padecer acerca de la estimación de las gentes; mas no en la realidad verdadera de 10 que merece y vale» ${ }^{2}$. El honor es un mero apéndice de la virtud, que no vale por sí mismo, en tanto que signo externo, como acontece en la doctrina tradicional y popular de la honra, profesada por todo el mundo en tiempo de Cervantes, reflejada en el teatro, y frente a la cual él se yergue: «El honor y la alabanza son premio de la vir-

1 Hay un interesante artículo de conjunto de G. T. Northup, Cervantes' attitude toward honor, en Modern Philoloory, 1924, párs. 397-421. Resume así sus conclusiones: ¿Cervantes era demasiado de su tiempo para condenar el duelo in toto; no obstante, su actitudera bastinte propara conder el due gresivas, era un espiritu noble, caballeresco, humano y compasivo: *his charity for women is allembracings (pág. 426). Esa piedad y simpatía son la causa de que sea el único de sus contemporáneos que se haya hecho escritor universal. Northup explica, pues, por el temperamento del autor, lo que yo atribuyo ante todo a formas especiales de la cultura de la época. Ya hemos visto que Cervantes, cuando así lo exige su concepción de la vida, es cruel e implacable. Las mujeres le merecieron a menudo juicios poco caritativos (véase pág. I 26).

2 Coloquio de los perros, Clás. Cast., pág. 339 . Compárese la doctrina sobre la verdad, pág. 88 , nota 1 . tud que, siendo firme y sólida, se le deben; más no se le debe a la ficticia y hipócrita... La alabanza es premio de la virtud» ${ }^{1}$. «La virtud se ha de honrar dondequiera que se hallare» ${ }^{2}$. Lo sustantivo es, por consiguiente, la virtud, como íntima e inalterable sustancia, basada, según la filosofía estoica, en el uso de la razón, y según Cervantes, en el uso discreto de esta razón de acuerdo con las armonías que postula la naturaleza. El honor o el ultraje no afectan a aquella esencia virtuosa. Ya hemos visto la actitud de Cervantes ante la injuria, la venganza y la responsabilidad individual, que supone aquiescencia a la doctrina estoica, la cual entre nosotros mostró reflejos preclaros en las traducciones de Erasmo y en Luis Vives: «La sentencia que nadie es ofendido sino de sí mismo..., en todos los negocios del mundo es verdadera, e tal se hallaría si los hombres se quisieren desengañar y entender en qué consisten verdaderamente las ofensas» ${ }^{3}$. "No os puede todo el mundo hacer injuria... cuando no os tocan en el ánimo, al cual ninguno puede dañar sino vos mesmo» ${ }^{4}$ $\mathrm{Ni}$ el bien ni el mal pueden venirnos de fuera; y así dirá Cervantes: «Las venganzas castigan, pero no quitan las culpas; las que en estos casos se cometen, comola enmienda no proceda de la voluntad, siempre se están en pie» ${ }^{5}$. La culpa de la adúltera es, pues, su voluntad de serlo, y no conseguiríamos nada suprimiendo su vida, sino intentando cambiar esa voluntad culpable (lo que es por cierto difícil, si no imposible). Y por de contado, la fama u opinión públicas son incapaces de producir ni injuria ni merma en el honor ${ }^{6}$.

\footnotetext{
1 Persiles, $597 a, 582 a$.

2 II, 62; RM, VI, 252 .

3 Erasmo, Coloquios, en Origenes de la Novela, IV, 187 a

4 L. Vives, Introducción a la sabiduria, Amberes, 155 I, fol. $27 r$.

5 Persiles, 637 a.

6 Téngase en cuenta la doctrina de Bervardivo Tesesio, De rerum natura, IX, vi y xxil, sobre la «sapientias (que nos sugiere el mejor método de conservación personal) y la «sublimitas» («apex omnium virtutum») que nos enseña a no situar el honor en el juicio más o menos exacto o predispuesto de la opinión pública, sino en los bienes
} 
El concepto de honra se manifiesta aquí tanto teóricamente como proyectado en la acción vital de las personas. Hay en La fuerza de la sangre un pasaje esencial. El lector recuerda cómo Leocadia, cierta noche, sufrió atroz violencia y tornó a su casa hollada en lo más íntimo de su recato. Su padre le dirige este razonamiento:

"Advierte, hija, que más lastima una onza de deshonra pública, que una arroba de infamia secreta. Y pues puedes vivir honrada con Dios en público, no te pene de estar deshonrada contigo en secreto: la verdadera deshonra está en el pecado, y la verdadera honra en la virtud. Con el dicho, con el deseo y con la obra se ofende a Dios; y pues tú ni en dicho, ni en pensamiento, ni en hecho le has ofendido, tente por honrada, que yo por tal te tendré, sin que jamás te mire sino como verdadero padre tuyo» ${ }^{1}$.

Como la culpa procede de la razón y la voluntad, y la de Leocadia no intervino en aquella aventura, el honor de esta mujer sigue inmaculado, aunque ella, siendo célibe, dé al mundo un hijo. Esta es la posición estoica. Pero Cervantes es algo más que un estoico y un abstracto moralista. En la intimidad de nuestra conciencia o de nuestro hogar pensamos como el padre de Leocadia; pero vivimos en Toledo, por cuyas callejas y plazuelas discurren, de hecho, conceptos plebeyos acerca de la honra, que positivamente causan sufrimiento y pesar ${ }^{2}$. Cervantes no piensa (ya lo vimos) que el

interiores, en el testimonio de la conciencia, que es preferible a todo. (Véase Charbonner, Le pensée italienne au XVIe siècle, pág. 456). Ya había insistido Castiglione en el peligro de tomar como criterio la opinión para juzgar de la nobleza de una persona: «Realmente tienen por cierto que esas opiniones universales se fundan siempre sobre verdad y nacen de causas razonables, etc.» (Cortesano, pág. ${ }^{6} 6$ ).

Rivad., I, $\mathrm{I} 686$.

2 De ahí «que las infamias mejor es que se presuman y sospechen que no que se sepan de cierto y distintamentes ( $L a$ señora Cornelia Rivad I 2 16a). Claro que Cervantes es incapaz de convertir esa circund, $\mathrm{I}$ a). Claro que Cervantes es incepaz de convertir esa cir cunstancia de hecho (cuyo valor reconoce) en una idea constructiva, como hizo Calderón en $A$ secreto agravio, secreta venganza, o Lope de Vega en El castigo sin venganza. No vale la pena insistir más sobre ello. placer y el dolor son inexistentes; cuenta con ellos, lo mismo que Montaigne; trata de evitarlos si es posible; pero supera ese plano de la sensibilidad, y se eleva, en último término, al puro dominio del «deber ser».

La honra vulgar, la que rige la comedia lopesca, existe en la vida, y constituye, sin duda, un elemento social de ingente significación ${ }^{1}$. Hallamos ecos precisos de ese punto de vista:

\section{Marcela. La desventura mayor,
más espantosa y temida, es la de perder la vida.}

Don Antonio. Primero es la del honor ${ }^{2}$.

«De los bienes que reparten los cielos entre los mortales, los que más se han de estimar son los de la honra, a quien se posponen los de la vida» ${ }^{3}$.

Puede acontecer además que la honra o la infamia dadas por la opinión correspondan a valores esenciales: la discreción de Cervantes no olvida ningún aspecto del problema. Por ese motivo hay casos en que «una onza de buena fama vale más que una libra de perlas, y esto no lo puede saber sino el que comienza a gustar de la gloria que da el tener buen nombre. El pobre, a quien la virtud enriquece, suele llegar a ser famoso; como el rico, si es vicioso, puede venir y viene a ser infame» ${ }^{4}$.

Es lo que Lotario quiere hacer comprender a Anselmo en $\mathrm{El} \mathrm{Cu}$ rioso impertinente: «Mira que todo el honor de las mujeres consiste en la opinión buena que dellas se tiene» (I, 33; RM, III, 27 ). «Vuesa merced, señora mía, no grite, que las voces que diere serán pregoneras de su deshonra...; no por mi muerte dejará de quedar en opinión vuestra famas (La ilustre fregona, Rivad., I, 197b). Más ejemplos puse en Rev. de Filol. Esp., 1916, III, 364 .

2 La Entretenida, edic. cit., pág. 45. Comp.: «Dice Horacio que 2 La Entretenida, edic. cit., pág. 45 . Comp.: «Dice Horacio que
mayor mal viene de la fama que de la hacienda perdidas (MAt Lara, mayor mal viene de la fama que de Filosofia vulgar, cent. VI, refr. 61).

3 Persiles, 593 a y 617 b. Comp. Rev. de Filol. Esp., 1916, III, 23. Para el rey dando honra, véase Persiles, $588 b$ : "por la [honra] que debes hacer como rey que eres».

4 Persiles, 612a. 
Lo sustantivo del concepto cervantino del honor, lo que reflejan las vidas de los personajes en los momentos supremos, es la idea moral del humanismo, el concepto de la pura dignidad humana, basada en virtud racionalmente autónoma, independiente de fama, casta y linaje: "Cada uno es hijo de sus obras» ${ }^{1}$. Al concepto de honor que florece en la Edad Media, como exponente de determinado grupo social, sustituye el humanismo un honor que si por un lado tiende a realzar al individuo aislado, de otra parte contempla aspectos universales de la conciencia; lo humano queda así abstraído en una categoría, en análisis racional, ajeno al momento y al lugar. Individualismo y socialismo pueden aspirar igualmente a tener aquí sus puntos de arranque.

Véanse unos expresivos textos: «A esto puedo decir que Dulcinea es hija de sus obras, y que las virtudes adoban la sangre, y que en más se ha de estimar y tener un humilde virtuoso que un vicioso levantado" ${ }^{2}$. "La honra puédela tener el pobre, pero no el vicioso» ${ }^{3}$. Estas ideas venían desde hacía tiempo incorporadas a la tradición estoica en lengua española. He aquí cómo habla Séneca: «Dice Platón que ningún rey hay que no sea venido y haya tenido su principio de muy bajos, y ningún bajo tampoco que no haya descendido de hombres muy altos. Pero la variedad del tiempo to ha todo mezclado, y la fortuna lo ha abajado y levantado ¿Quién, pues, es el noble? Aquel a quien naturaleza ha hecho para la virtud» 4 .

Por la misma senda camina Petrarca: «La opinión no muda la virtud... Por ningún camino se va más aína al error $\mathrm{y}$ al despeñadero que por las pisadas del vulgo» ${ }^{5}$. Y Erasmo: "Aquella sola es honra, la cual se hace a alguno por su virtud

\section{I, 4; RM, I, 168.}

II, $32 ; \mathrm{RM}, \mathrm{V}, \mathrm{I} 7 \mathrm{O}$

3 Quijote, Prólogo, Segunda parte, RM, IV, $36-37$.

4 Flores, de Séneca. Traduc. de J. M. Cordero, Amberes, 1555 , fol. $32 r$.

De los remedios contra próspera y adversa fortuna, Sevilla, 1534 , fol. $8 r$. Otros pasajes, en Rev. de Filol. Esp., 1916, III, 383. propia... Te hago saber que yo no estimo a uno por hombre diferente del vulgo, habiendo respeto al lugar y preeminencia que posee, sino al corazón que veo que tiene.... ${ }^{1}$. «Después de las riquezas tienen en mucho la nobleza que llaman de linaje (joh nombre vano y de burla si no te acompaña virtud!). Tienen por un medio Dios al que se dice venir de linaje de Codro, rey de Atenas, o de Bruto el Troyano, que por ventura nunca fué en el mundo» ${ }^{2}$.

Muy representativa es la opinión de Torres Naharro, en la dedicatoria de su Propalladia al marqués de Pescara: «Y aun estoy por decir qu'es la menor parte que en vos cabe [el tener noble ascendencia], como quiera que vuestro pensamiento más se funda en comenzar linaje que en allegar linajes, esperando más gloria de la virtud propia que de la apelativa, y más claridad de sus ojos que de los ajenos» ${ }^{3}$.

Concuerda con Erasmo nuestro Luis Vives ${ }^{4}$ : "La verdadera y firme nobleza nace de virtud... Las que ordinariamente se llaman dignidades, ¿̨cómo se podrán llamar así si vienen a personas indignas, que no las mereciendo, las ganaron con engaño...? ${ }^{5}$. Gloria es tener buen renombre por hechos virtuosos. Honra es ser acatado por nuestra virtud propia.»

1 Enquiridion del caballero cristiano, Amberes, 1555 , fols. 16 I y I 10 .

2 Silenos de Alcibiades, Valencia, ${ }_{5} 529$, fols. $h j$.

3 Edic. Libros de antaño, I, 3 .

4 Introducción a la sabiduria, Amberes, $155 \mathrm{I}$, fols. 5, 6, 3 .

5 Véase cuán de otro modo opinaba la Edad Media: «Al súbdito bueno se le debe en sí mismo mayor reverencia; pero se le debe mayor al superior malo, atendiendo a la razón de su superioridads (SaNто Tомís, Summa Theologiae, 3 Dist., IX, q. 2, $a .3$ ad 3. Comp. Rev. de Filol. Esp., 1916, III, 47). Luis Vives, sin embargo, tórnase escolástico y tradicional al decir más adelante: «La verdadera honra que nace de buena reputación y acatamiento del ánimo dala solamente a los buenos; y a los que tienen ofio público de justicia, annue no sean tales, che pesads, que as lo quiere Dios, porque den cosas recias y graves y pesadas, que así lo quiere Dios, porque haya sosiego en la república (Introducción a la sabiduria, fol. 44v). La diferencia está en que Vives llega a este resultado por extrínsecos motivos de oportunismo. Castiglione será, en cambio, tajante: $\varangle \mathrm{E}$ cosas injustas no debemos obedecer a nadie» (Cortesano, pág. 174). 
Y llegamos así a Mal Lara, quien, como siempre, responde a su filiación humanista. Glosando el refrán «Dejemos padres y abuelos, por nosotros seamos buenos», nos dice que «Sócrates, gran músico, siéndole dado en cara ser de bajos padres, respondió: Pues por eso soy digno de más honra, porque de mí comienza mi linaje» ${ }^{1}$. Y más adelante: "Los padres tienen muchas veces la culpa en ataviar antes a sus hijos de seda que de buenas costumbres y de virtud, que es la verdadera hidalguía... La virtud del hombre es la que se ha de estimar; al que la tiene, no hay para qué buscarle linaje» 2 .

A fines del siglo (I596) dirá el Pinciano en su Poética: "La honra está fundada en virtud» ${ }^{3}$. Para él hay nobleza basada en fortuna y en virtud, y adopta esta ecléctica opinión: "Quiero más la nobleza nueva de la virtud ganada con mi persona, y más la nobleza antigua de la riqueza ganada con sudor de mis mayores». Queda, sin embargo, manifiesto que la nobleza por virtud no se hereda.

En presencia de tales antecedentes cobra pleno sentido histórico la célebre frase de Cervantes: "Cada uno es hijo de sus obras», así como estos expresivos pasajes: «Haz gala, Sancho, de la humildad de tu linaje, y no te desprecies de decir que vienes de labradores... Préciate más de ser humilde virtuoso que pecador soberbio... Innumerables son aquellos que de baja estirpe nacidos han subido a la suma dignidad pontificia e imperatoria.» «La virtud vale por sí sola lo que la sangre no vale» ${ }^{4}$. "La verdadera nobleza consiste en la virtud.» "Más [honrado] lo era él por la virtud que tenía que por la riqueza que alcanzaba» 5 .

$\mathrm{Y}$ entre buenos es fuero que valga la virtud más que el dinero ${ }^{6}$.

1 Filosofia vulgar, edic. 1568 , fol. 183 .

2 Ibid., cent. VII, refr. 34; cent. X, refr. 45

3 Edic. r894, pág. 53.

II, 42 ; RM, V, 349-350.

I, 36 y 5 I; RM, III, I 22 y 443.

6 Pedro de Urdemalas, edic. cit., pág. 132.
La doctrina cervantina del honor descansa sobre precedentes de alta significación en el Renacimiento; forma, además, un conjunto armónico con la moral antes expuesta, y en lo que atañe al honor matrimonial encontramos reflejos exactos de la ideología naturalista que sobrepone los estímulos vitales a las convenciones de la sociedad coetánea. El concepto del honor descansa, por tanto, en la nueva concepción del hombre que formula el Renacimiento ${ }^{1}$. En la Edad Media, el hombre era considerado principalmente como un portador de exponentes que trascendían de él, religiosos o sociales; la definición del hombre se hacía desde fuera. Para D. Juan Manuel podía uno ser «defensor, orador o labrador». Cervantes tomará, en cambio, puntos de vista intrínsecos, humanos: "Una de las difiniciones del hombre es decir que es animal risible» ${ }^{2}$. Otro modo de consideración puede ser el de su dinámica finalidad, atendiendo a los caminos que conducen a la gloria: armas o letras. El hombre es definido, en suma, en vista de su presente y futuro humanos.

Al contemplar al hombre en su ser inmanente, se le convierte en centro, al que todo lo demás se subordina. El acto de conocimiento se mira como una creación ${ }^{3}$, de la cual es ministro la razón humana, característica del hombre, que 10 acerca a Dios y lo coloca por encima de los restantes seres terrenos. El tema de la dignidad del hombre como ser dotado de entendimiento constituye uno de los polos del humanismo renaciente. En él se reflejan las alternativas y la lucha de 10 medieval y lo moderno ${ }^{4}$. Hallo, por ejemplo, este texto de D. Juan Manuel, que refleja a maravilla el punto de

1 Supongo presente en el lector mis estudios sobre el honor, publicados en la Revista de Filologia Española, 1916.

2 Persiles, $596 a$.

3 Recuérdese el capítulo XIII, 3, de la Theologia platonica, del Ficino: «Et qui propter ingenii similitudinem discernit is certo posset easdem constituere, postquam agnovit, modo non deesset materia, (texto en G. GeNTILE, Giordano Bruno, pág. 144).

4 Reunió excelentes materiales de los siglos xvi y xvII A. REXES, Un tema de "La vida es sueños, en Rev. de Filol. Esp., 1917. 
vista medieval: "Pues es cierto que la ley de naturaleza muy mejor usan della las animalias que los homes, de balde hobieron los homes entendimiento e razón, lo que no han las animalias; demás que los homes han alma, que es cosa espiritual que nunca ha de fallescer, e que habrá gualardón e pena desque se partiere del cuerpo...; e esta alma non se puede salvar sinon guardando la ley que le fuere acomendada» ${ }^{1}$. Véase cómo el hombre no conserva frente a los animales otra superioridad sino la de su destino sobrenatural, más allá de la experiencia humana. $\mathrm{Y}$ vengamos ahora, bruscamente, a los antípodas de esa actitud, leyendo a Luis Vives, inspirado por la nueva visión del mundo: «Mira que por más crecidas que sean [las fuerzas] no igualarán con las de un toro o elefante, al cual con el ingenio y virtud llevas ventaja... En nuestro ánimo hay dos partes: una superior, que podemos llamar entendimiento...; desta parte somos hombres semejantes a Dios, y somos más excelentes que todos los otros animales» ${ }^{2}$.

Sería largo cuento describir la trayectoria de este tema durante el siglo $\mathrm{xvI}^{3}$. No hemos de hacerlo, porque Cervan-

1 Libro de los estados, Rivad., LI, $292 a$.

2 Introducción a la sabiduria, ${ }_{55} \mathrm{I}$, fols. 7 y 13.

3 Es conocido el bello Diálogo de la dignidad del hombre, del maestro Pérez de Oliva (Rivad., LXV), del cual daremos algún día una edición. Aprovecha elogios de la grandeza del ser humano hechos por los latinos (Ovidro, Metamorfosis, I, 76; Cickrón, De legibus, I, 9, De natura deorum, II, 56); Pérez de Oliva hace una maravillosa descripción de la mano, lo mismo que otros esclarecidos humanistas; en Ma Lara encontramos una alusión: «Por menudo, Galeno describe al hombre cuando elocuentemente disputa del uso de las partes humanas, que bien se aprovechó y se dilató Coelio Rhodigino [Lectionum antique bien se apX quartm libri XXX] en el tercero libro, por muchos capitulos, principalmente en el cuarto libro, de la excelencia de la manos (Filosofía vulgar, 1568 , fol, 2r). Isócrates, en la traducción de Diego Gracián exponía las mismas ideas gratas al Renacimiento: «Siendo como es la razón a la verdad causa de todos los más bienes que hay en la naturaleza de los hombres, porque en los otros dotes que tenemos no diferimos nada de los brutos animales, antes en muchos somos infe-

tes no consagró atención especial a la cuestión de si el hombre era superior o no a los otros seres de la naturaleza. En el Quijote (II, I2) se alude, con otro propósito, a las enseñanzas que de las bestias han recibido los humanos, idea que sigue dirección opuesta a la que ahora nos interesa, y que, como sabemos ya, responde al naturalismo místico, que en busca de lo primitivo y espontáneo llegaba hasta los brutos ${ }^{1}$.

Este concepto del honor fué considerado por estrictos pensadores simplemente como secuela de la noción de virtud, de la cual es premio. Las obras ilustres deben ser hechas sin perseguir ninguna finalidad exterior: $* \mathrm{El}$ propio fin de la

riores, y menos que ellos, como en la ligereza y en las fuerzas y otras cosas» (Isócrates, De la gobernación del reyno, Salamanca, 1570, página 25 ).

1 Por cierto que los comentaristas del Quijote (Clemencín y Bowle) mencionan a Plinio y Pulci como fuente de este pasaje. Sin negar que eso pudiera ser así, juzgo más probable que el autor recordara la Silva de varia lección de Pero Mejía, donde aparecen agrupadas, y no dispersas, muchas de esas noticias, hasta con coincidencias verbales:

$$
\begin{aligned}
& \text { QUIOTE } \\
& \text { (II, I2). }
\end{aligned}
$$

De las bestias han recebido muchos advertimientos los hombres y aprendido muchas cosas de importancia, como son: de las cigüeñas, el cristel; de los perros, el vómito y el agradecimiento; de as grullas la vigilanciar de las hormigas, la providencia, etc.

$$
\text { SILVA DE VARIA LECCIÓN }
$$$$
\text { (II, } 4 \mathrm{r} ; \mathrm{III}, 28 \text { ). }
$$

Como los brutos animales mostraron y dieron avisos a los hombres de muchas medecinas y propiedades de cosas... El ave llamada ibis... con su propio pico se purga..., dize Plinio que cle aqu deprendieron los hombres los cristeles. jos peros provocas cristeles...; los perros provocan el vómito...; la fe $\mathrm{y} . .$. agradecimiento mostrarnos lo ha... la lealtad de los perros...; el cuidado y solicitud de la hormiga, como se... provee en verano para el invierno, etc.

Recordaría también Cervantes lo que refiere Antonio de Torquemada, Fardin de fores curiosas, lib. IV, donde habla de las abejas, de las hormigas y de las grullas, sque para poder dormir las noches seguras, queda una despierta velando a las otrass (edic. Lérida, I573, fol. 158 v). 
pura honestidad no puede consistir en la opinión de los: hombres que ponen la honra y gloria en la memoria de las. historias que conservan la fama, y menos debe consistir en el fantástico deleite que el glorioso toma de la gloria y el famoso de la fama. Estos son premios que debidamente deben conseguir los virtuosos, pero no el fin que les haya de mover a hacer las obras ilustres» ${ }^{1}$.

No obstante esas filosóficas restricciones, si hay un estímulo grato al Renacimiento es, sin duda, el de la gloria humana. Para el hombre renacentista, su virtud y valor no penden del reconocimiento y valoración externas; cada cual siente en sí la potencia y el ardor creadores del hecho ilustre; pero el campo de la fama es el ambicionado teatro donde las hazañas han de cumplirse. En la comedia calderoniona, e hombre honrado se siente esclavo de la opinión; el héroe renaciente aspira a señorearla con su esfuerzo. «Hay hombres - dice Nebrija en el Prólogo al Diccionario latino (I492) que no solamente hacen bien; más aún, según la sentencia de nuestro Salvador, obran el manjar que nunca perece; e pues que les es negado vivir mucho tiempo, dejan alguna obra por donde muestran que vivieron. Y querer yo contar en el número de éstos, aunque de hombre poco modesto e que destempladamente usa de su deseo, quiero agora confesar esta mi liviandad: que ninguna cosa tuve más delante mis ojos que traer al común provecho de todos mis velas e trabajos, porque después de muchos merecimientos en nuestra república alcanzase gloria inmortal.»

Y nota L. Hebreo: «El honor legítimo, como es premio de las virtudes honestas..., su deleite se mezcla con lo honesto; por lo cual, y también por ser el sujeto suyo la sin medida fantasía, sucede que, después que se ha ganado, se ama y su aumento se desea con insaciable deseo, y no se contenta la fantasía humana de alcanzar la honra y gloria para toda la vida, sino que también la desea y largamente la procura para después de la muerte, la cual propiamente se

1 L. Hebreo, Diálogos, en Origenes de la Novela, IV, $295 a$. dice fama» ${ }^{1}$. Por igual senda discurre Castiglione: «Qué hombre hay en el mundo tan bajo y de tan vil espíritu que leyendo los hechos de César, de Alexandre, de Scipión, de Anníbal y de otros muchos, no se encienda en un extraño deseo de parecelles, y no tenga en poco esta nuestra breve vida de dos días por alcanzar la otra de fama perpetua, la cual, a pesar de la muerte, nos hace vivir mientras más va con más honra?» ${ }^{2}$.

Sancho desdeña esa gloria ${ }^{3}$ y esa fama: "No se me da un higo que digan de mí todo lo que quisieren.» Don Quijote, a tan bajo desdén, opone largo razonamiento, rematado con estas ardientes frases: "Quiero decir, Sancho, que el deseo de alcanzar fama es activo en gran manera. ¿Quién piensas tú que arrojó a Horacio del puente abajo, armado de todas armas, en la profundidad del Tibre?», etc. ${ }^{4}$. En otras ocasiones vuelve el Hidalgo a semejante tema: "Una de las cosas que más debe de dar contento a un hombre virtuoso $\mathrm{y}$ eminente es verse, viviendo, andar con buen nombre por las lenguas de las gentes impreso y en estampa» ${ }^{5}$. El camino «de la virtud, angosto y trabajoso, acaba en vida y no en vida que se acaba, sino en la que no tendrá fin, y sé, como dice el gran poeta castellano nuestro, que

$$
\begin{aligned}
& \text { Por estas asperezas se camina } \\
& \text { de la inmortalidad al alto asiento, }
\end{aligned}
$$$$
\text { do nunca arriba quien de allí declina» } 6 \text {. }
$$

1 Diálogos, edic. cit., pág. 295 a

2 Cortesano, edic. cit., pág. 109.

3 De la que dice Mal Lara: «La gloria temporal, según dice Aristóteles..., es el mayor bien de los bienes que son fuera del alma cuerpo (Filosofia vulgar, edic. 1568 , fol. $27 r$ ).

4 II, 8; RM, IV, 177-179. Cfr. Pero Mejía, Silva de varia lección: «Hablando de moral y humanamente, dos cosas son principales, las que mueven y levantan a los hombres a hacer grandes y señalados hechos en la guerra y en la paz: la primera es bonra y fama, y la segechos en la guerra y en la paz: la prinera es honra $y$ fama, y la segunda $e$ provecho e interese. Los magnánimos y gr. palmente cubdician lo primeros, etc. (lib. III, cap. xxix, edic. Lyon, : 556 , pág. 485 ).

5 II, $3 ;$ RM, IV, 86.

6 II, 6; RM, IV, I49. 
Ahora bien: lo mismo que acontecía con otros motivos renacentistas, el tema de la gloria no se yergue en el Quijote firme y lozano como un siglo atrás; el héroe que lo soporta es punto de quiebra y refracción para cuanto roza su compleja naturaleza; y con la ironía se cruza el tono melancólico de la Contrarreforma, que proyecta un desengañado «para qué?» sobre el entusiasmo y la exuberancia: «Todas estas y otras grandes y diferentes hazañas son, fueron y serán obra de la fama, que los mortales desean como premio y parte de la inmortalidad que sus famosos hechos merecen puesto que ['aunque'] los cristianos católicos y andantes caballeros más habemos de atender a la gloria de los siglos venideros ${ }^{1}$, que es eterna en las regiones etéreas y celestes, que a la vanidad de la fama que en este presente y acabable siglo se alcanza; la cual fama por mucho que dure, en fin se ha de acabar con el mismo mundo, que tiene su fin señalado asi, joh Sancho!, que nuestras obras no han de salir del limite que nos tiene puesto la religión cristiana que profesamos ${ }^{2}$. Pocos pasajes hay tan hondamente expresivos del espíritu de época que refleja el Quijote, obra expuesta, sin el genio de Cervantes, a caer en el tono elegíaco y desconsolado. Hay en torno al I 600 español como un lejano destello del milenario, que presta tonos lívidos a las más espléndidas invenciones del Renacimiento: Felipe II aspira a instalar en El Escorial un negociado magno de reliquias; el Greco, en el Entierro del conde de Orgaz, orienta el mayor prodigio de la técnica y fantasía pictóricas hacia el mundo de ultratumba, causa final que razona y justifica aquel derroche de valores humanos; y Don Quijote dirá : «Así, joh Sancho!, que nuestras obras no han de salir del límite que nos tiene puesto la religión cristiana que profesamos.»

Por dicha para nosotros, la melancolía no dió lugar a tesis negativas; se resuelve más bien en problemas que, lejos de negar el Renacimiento, sirven para deducir de él consecuen-

$1 \mathrm{La}$ «vita venturi saeculis de que habla el credo.

2 II, $8 ;$ RM, IV, 180. cias fecundas. De ese terremoto que padecen las construcciones humanas durante la Contrarreforma, algunas de ellas quedan inconmovibles para Cervantes, según vimos con respecto a ciertos puntos de la moral; otras experimentan crisis, como el concepto de gloria, al combinarse lo poético universal con el particular histórico. En suma, el autor no destruye ni derriba, y se limita a presentarnos el proceso íntimo de sus dudas, sacando el máximo partido artístico al tema de «el engaño a los ojos». Por eso nunca podremos averiguar científicamente - gracias a Dios - si Don Quijote obtuvo realmente la gloria debida al hombre virtuoso y eminente, 0 si sus nobles hazañas sólo fueron ilusión de una triste manía. "Così è, se vi pare», que dirá Pirandello, resucitando tres siglos después - con original talento - el método artístico de Cervantes ${ }^{1}$.

Aquel concepto de honor exaltado por Guicciardini y Rabelais ${ }^{2}$, independiente de toda casta - pura dignidad humana - es utilizado como alto estímulo en las creaciones literarias del Renacimiento. Si cada uno es hijo de sus obras, cada uno puede aspirar a ser cabeza de linaje; y el afán de gloria será necesaria consecuencia de la mirada entusiasta hacia un porvenir conquistable. Es característico de este tiempo el desarrollo sin medida de la literatura de caballerías, salida derechamente de la épica medieval, pero que adquiere otros sentidos al contacto de la nueva sensibilidad. El Amadís fué «código del honor que disciplinó a muchas generaciones» 3; el regidor Garci-Ordóñez de Montalvo, que lo corrigió y enmendó en I 508 , se propuso, entre otros fines, animar «los corazones gentiles de mancebos belicosos que con grandísimo afecto abrazan el arte de la milicia corporal,

1 Traté de Cervantes y Pirandello en La Nación, de Buenos Aires 16 de novembre de 1924 ) y en una conferencia dada en la «Union Intelectuelle», de París, en diciembre de 1924.

2 BURCKHARDt, Ob. cit., II, 192.

3 Meń́ndez Pelayo, Orígenes de la Novela, I, ccxxiv. 
avivando la inmortal memoria del arte de caballería, no menos honestísimo y glorioso».

Esta aspiración gloriosa ${ }^{1}$, dinámica y ascendente, fué sometida a crítica por Cervantes, como vimos que acontecí́ con otros puros temas del I 500 . Y no sólo ocurre así con la gloria que sueña en el alto vuelo, sino con el simple afán de la honra quietamente poseída. La mirada vigilante del autor está siempre pronta a reprimir lo que pudiere haber de exceso en tales aspiraciones, que fácilmente llevan a desarmonías y desmesuras, olvidan lo real por lo quimérico y, sobre todo, pueden confundir los valores humanos. Cierto que se nos presentan con amor actos de honrosa caballerosidad, como se ve en La señora Cornelia; pero juzgo más característicos de Cervantes rasgos como el siguiente. ¿Por qué son más rápidas y eficaces las galeras de los corsarios turcos que las de los cristianos españoles? La razón se nos da en El trato de Argel, una de las más antiguas comedias del autor (jhacia I580?). En los casos de peligro para el navío turco:

El soldado más lucido,

el más flaco y más membrudo

luego se muestra desnudo

y del bogavante asido.

Pero allá tiene la honra

el cristiano en tal extremo,

que asir en un trance el remo

le parece que es deshonra:

y mientras ellos alla

en sus trece estan honrados,

nosotros, dellos cargados,

venimos sin honra aci ${ }^{2}$.

El honor, como dinamicidad y afán de gloria (armas y letras), cruza la obra de Cervantes; pero recibe ora una melancólica interpretación de Contrarreforma, ora el dardo directo de su crítica razonadora. Y mucho más severos y penetrantes son los juicios del autor cuando surge el drama de

1 «Las [cosas] que se intentaban por Dios y por el mundo juntamente son aquellas de los valerosos soldados que..., llevados en vuelo de las alas de volver por su fe, por su nación y por su rey, se arrojan intrépidamente. Estas cosas son las que suelen intentarse, y es honra, gloria y provecho intentarlas" (Quijote, I, 33).

2 Edic. Schevill-Bonilla, V, 37. Comp. lo dicho antes (pág. 221) sobre los españoles y el hidalguismo. honra, provocado por el sentimiento de su pérdida. Si difícil es alardear de honor, lo es bastante más reconocer que una persona ha sido deshonrada por un acto ajeno. Dado el sistema moral antes expuesto, el honor no puede perderse por actos externos. Los casos más significativos son los relacionados con la vida matrimonial, porque en torno a ellos tejió a literatura lo más tupido de la dialéctica del honor. La reacción de Cervantes sabemos ya que es diametralmente opuesta a la del teatro coetáneo: se pasa sobre la ofensa y se rechaza la venganza ${ }^{1}$.

Conviene dar una ojeada de conjunto a este importante tema, ya que Cervantes se ha interesado en él de modo singularísimo. Hablamos antes de sus ideas acerca de la mujer en general y de la forma de matrimonio que prefería. La dama escogida para esposa no debiera ser linda, si pensáramos en las posibles consecuencias de ese hecho:

\section{Quien casa con mujer bella, de su honra se descasa si no lo remedia el cielo ${ }^{2}$.}

El consejo, puramente teórico, no impide que Cervantes haya casado a sus personajes con bellísimas mujeres; porque "pensar que un rostro feo, que se ha de tener a todas horas delante de los ojos, en la sala, en la mesa y en la cama, pueda deleitar, otra vez digo que lo tengo por casi imposible» ${ }^{3}$.

1 Véase pág. 3ł3.

2 Rufián dichoso, edic. cit., pág. 19.

3 La fuerza de la sangre, Rivad., I, I71 $a$. Era éste un asunto muy tratado por los moralistas: «En lo que toca a la hermosura y gesto de la mujer, Favorino, filósofo, según escribe Aulo Gelio, decía que el hombre debía de casar con mujer que ni sea muy hermosa, ni tampo co fea, sino de mediano y razonable gesto. Lo cual él decía, respondiendo a otro filósofo que quería fundar que no se deben los hombres casar..., diciendo...: «El hombre se ha de casar con mujer fea o con hermosa, si con hermosa es andar a peligro y tener mujer para otro;

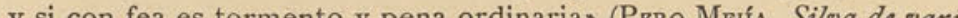
y 100 I mosa que mate, etc.) (MaL Lara, Filosofía vulgar, edic. 1568 , fol. $109 r$ ) 
Cierto es que los tremendos conflictos de honra familiar son, en efecto, causados por lindísimas jóvenes.

$\mathrm{Al}$ estudiar el error como tema literario, hablamos ya de la proporcionalidad exigible entre los cónyuges: «Pues el del matrimonio es ñudo que no le desata sino la muerte, bien será que sus lazos sean iguales y de unos mismos hilos fabricados» ${ }^{1}$. Cuando esta proporcionalidad parece evidente, las uniones suelen realizarse con gran presteza, como acontece con el Cautivo, con D. ${ }^{a}$ Clara (la hija del Oidor), etc. cuando se duda de la realidad de esa armonía, Cervante exagera la reflexión y la mesura. Dos años de plazo pone la Gitanilla a Andrés "para que tantees y ponderes lo que será bien que escojas o será justo que deseches... Como yo no pienso hacer cosa que llame al castigo, no quiero tomar compañía que por su gusto me deseche». El summum de esta preparación matrimonial sería el prolongado y accidentadísimo noviazgo de Persiles y Segismunda.

El matrimonio, como acabamos de ver en La fuerza de la sangre, es nudo que no se desata sino con la muerte; la Gitanilla dirá á su vez: "Yo no me rijo por la bárbara e insolente licencia que estos mis parientes se han tomado de dejar las mujeres o castigarlas cuando se les antoja» ${ }^{2}$. «En otras religiones, que en la cristiana, entre las cuales los matrimonios son una manera de concierto y conveniencia, como lo es el de alquilar una casa, u otra alguna heredad; pero en la religión católica el casamiento es sacramento que sólo se desata con la muerte» ${ }^{3}$.

Hay, pues, que llevar a esa unión prudencia y paciencia, ya que Cervantes, lo mismo que Erasmo, reconoce la grave dificultad del divorcio. El asunto está tratado cómica, pero hondamente, en el entremés de El Fuez de los divorcios, en el fondo, una prédica acerca de la buena inteligencia marital:

$$
\text { Entre casados de honor, }
$$

cuando hay pleito descubierto

1 Fuerza de la sangre, Rivad., I, $170 b$.

2 Gitanilla, edic. Schevill-Bonilla, pág. 82

3 Persiles, pág. $637 a$. más vale el peor desconcierto

que no el divorcio mejor ${ }^{1}$.

Y poco antes dice el Juez: «Pluguiese a Dios que todos los presentes se apaciguasen como ellos» ${ }^{2}$.

Ocasiones hay, sin embargo, en que Cervantes no insiste en salvar la posible convivencia de los casados, como acontece cuando la mujer abandona al marido para marchar en pos de quien ella prefirió: «Preguntóle uno que qué consejo o consuelo daría a un amigo suyo que estaba muy triste porque su mujer se le había ido con otro. A lo cual respondió: Dile que dé gracias a Dios por haber permitido le llevasen de casa a su enemigo» ${ }^{3}$. "Dad gracias a Dios, señor Campuzano, que fué prenda con pies, que se os ha ido, y que no estáis obligado a buscarla» ${ }^{4}$. $\mathrm{Y}$ así aconseja Periandro a Ortel Banedre : "Al enemigo que huye, puente de plata, y el mayor que el hombre tiene suele decirse que es la mujer propia... No os aconsejo por esto a que perdonéis a vuestra mujer para volvella a vuestra casa, que a esto no hay ley que os obligue; lo que os aconsejo es que la dejéis, que es el mayor castigo que podréis darle... La ley del repudio fué muy usada entre los romanos ${ }^{5}$; y puesto que sería mayor caridad per-

1 Es la doctrina desarrollada en el Coloquio de Erasmo, llamado Mempsigamos: «Antiguamente, para las discordias que no tenían cura el último remedio era el divorcio; mas agora de todo punto este remedio es quitado; es por fuerza que todos los días de tu vida él sea tu marido y tú su mujer. Tú ya no has de tener pensamiento de divor. cion (Ortenes de la Novela, pags. 203 y 208). Comparese el admirable en tormentos (Filosofia vulgar, IV, 36, edic. ${ }_{5} 568$, fol. 85).

2 Edic. cit., pág. 19.

3 Licenciado Vidriera, edic. Schevill-Bonilla, pág. 89.

4 Casamiento engañoso, Clás. Cast., pág. 198.

5 Quizá recordaba el autor este pasaje de Polidoro Virgilio: «Los romanos también tenín buena orden en el casamiento, si no usaran del repudio, que era desechar $y$ apartar de sí la mujer por cualquie del repucho, que era desechar y apurtar de si la mujer por cualquier causa y cuando querian, lo cual que para guardar la castidad más firmemente era provechoso, con todo eso no se permite en la religió cristiana» (Los inventores de las cosas, Amberes, ${ }_{15}^{\circ}$, fol. $12 r$ ). 
donarla, recogerla, sufrirla y aconsejarla, es menester tomar el pulso a la paciencia, y poner en un punto extremado a la discreción, de la cual pocos se pueden fiar en esta vida.» Tan mesuradas razones alejan el impulso vengativo de Ortel Banedre: «Un ángel te ha movido la lengua, con la cual has ablandado mi voluntad» 1 .

Esta resignación cristiana y estoica a la vez responde a la tradición que Cervantes representa: «Yo tengo por bueno - dice Mal Lara - aquel que si le tocan... en la honra, ruega

1 Persiles, $637 b$. Se trata de una fórmula cervantina: «Fué socorri do de algún ángel que no consintió que con su sangre sacase la mancha de mi agravio" (Señora Cornelia, Rivad., I, 216a). Nótese que e episodio de Persiles (v. antes pág. I30) debe estar inspirado en un cuento del Patrañuelo, de Juan de Timoneda (Rivad., III, I42b), toma do del Orlando furioso; el rey y Octavio encuentran en un mesón una linda moza, sque ya Siriaco, un mancebo, era fama que babia babido lo mejor de ella». En Persiles,

PATRAÑUELO

Pidámosla al huésped, ofreciendo por ella su dote...; dieron parte de ello al mesonero. El cual, viendo su presencia y la liberalidand de ellos, fué contento en ha. cello, con que depositasen luego
el dote en su poder. Depositado, el dote en su poder. Depositado, y muy bien aderezado de ropas... fué otorgada en sus poderes.

La moza del Patrañuelo burla a sus dos señores con su antiguo amante, no obstante haber tomado éstos la precaución de hacerla dormir entre ambos; la de Persiles huye con su novio y abandona al polaco. Es natural que Cervantes no conservara nada del obsceno desenlace de Timoneda. Timoneda no hace sino copiar al Ariosto $(O r$. lando, XXVIII); pero Cervantes sigue más de cerca la copia de Timoneda que el original italiano. Compárese Orlando, III, 53, que coresponde al trozo que transcribimos de Timoneda, y se ver que

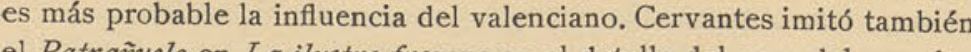
el Patrañuelo en La ilustre fregona en el detalle del asno del aguador y la disputa sobre el rabo (véase Gallardo, Ensayo, IV, 738 ). a Dios por el que lo deshonra» (Filosofía vulgar, fol. 8.) Ya sabemos que Cervantes no llega, en la práctica, a esa casi sobrehumana pureza; pero tampoco opina con Mal Lara que la adúltera "hace un crimen, por donde meresce ella gran castigo> (fol. $77 v$ ). Su actitud íntima es la revelada en el pasaje ya comentado de La fuerza de la sangre (pág. 364); el ideal sería que las gentes mirasen al marido engañado con «lástima, viendo que no por su culpa, sino por el gusto de su mala compañera, está en aquella desventura»; pero esto no acontece, entre otras razones, porque «como la carne de la esposa sea una mesma con la del esposo, las manchas que en ella caen, o los defectos que se procura, redundan en la carne del marido, aunque él no haya dado, como queda dicho, ocasión para aquel daño» ${ }^{1}$. Así razona Lotario con su amigo Anselmo en El curioso impertinente; considerado el matrimonio como unidad, cabe dentro de esa teoría la sentencia de que nadie es ofendido sino de sí mismo. No obstante, fijémonos bien: Cervantes no ha presentado nunca un caso de adulterio cuya responsabilidad no caiga de lleno sobre el marido, y eso demuestra, por lo menos, que no le interesaba desarrollar de hecho la cuestión de si podía el marido ser ofendido por la esposa. Lotario hace ese bíblico razonamiento a Anselmo, el cual está aherrojado a su invariable propósito, única causa del futuro adulterio de Camila ${ }^{2}$. La disquisición de Lotario

\section{I, 33; RM, III, 33.}

2 Anselmo, al partir de ese abstracto concepto de virtud, piensa como un estoico; sus argumentos son los de Séneca: «En el Tractado de la limpieza y castidad, en el libro cuarto de los Beneficios, dice que no debe ser dicha casta la que por temor es casta. No llamaré del todo casta a la que desecha el amador por temor de su marido o de todo casta la que desecha el por ter por temor de su mo a pena de la ley, y no sin razón se debe poner en el cuento de las que pecan aquella que no dió la castidad a sí mesma, mas dióla al temor» (SÉnzca, Cinco libros, De la providencia de Dios, traduc. A. de Cartagena, edic. Amberes, ${ }_{55}$ I , fol. $115 v$ ). De aquí procede la actitud racionalista de Anselmo. Cervantes, por el contrario, admite que la virtud puede florecer plenamente dentro de las armonías vitales. Este es el aspecto del estoicismo a que Cervantes se opone, juntamente con Erasmo y Montaigne. 
sobre el honor matrimonial debe mirarse, pues, como un punto de vista de la sociedad, del mismo tipo que las frecuentes generalizaciones acerca del honor como reputación ${ }^{1}$. El autor no tenía para qué ignorar la existencia de las ideas corrientes en su tiempo, ya que no aspiraba él a escribir abstractas fantasías; su pensamiento propio va, como siempre, implícito en la conducta de los personajes, sobre todo en los momentos trágicos.

En resolución, el honor relacionado con el matrimonio aparece en manifiesto contraste con las doctrinas vulgares en los casos justamente en que se le juzga perdido; también entonces es cuando el teatro define con precisión máxima lo que es honor. La renuncia a castigar a la adúltera es el rasgo mís característico de Cervantes. El alférez Campuzano podrá

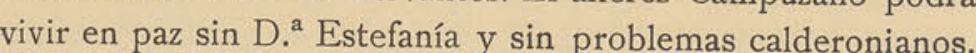
Pero lo frecuente es, como sabemos, que los errores de los maridos les hagan incurrir en el castigo capital. Esto hace que, como siempre, lo estricto cervantino sea de profunda complicación, y que no podamos resumir su actitud hacia los problemas de honor diciendo meramente que fué más piadoso, cristiano y comprensivo con las mujeres que los demás escritores de su época. La mujer es para Cervantes el más tremendo imperativo vital, contra el que suelen estrellarse los poco avisados; lo femenino o da lugar a dulce y apacible armonía ${ }^{2}$,

1 Cité ejemplos, señalando su secundaria importancia, en Revista de Filologia Española, 1916, III, 363-364. Nop I923, XXI, 400, reune algunos más, y celebro que piense quilogy, generalisations are insignificant,

2 Merece recuerdos la preocupación cervantina por los celos:

$$
\begin{aligned}
& \text { Yo he compuesto romances infinitos, } \\
& \text { y el de los celos es aquel que estimo } \\
& \text { entre otros que los tengo por malditos. }
\end{aligned}
$$

Así dice en el Viaje del Parnaso, aludiendo a su conocido romance. Hay muchas alusiones en Persiles (590 $a, 591 a, 600 a)$ : La muerte borra los celos, «téngase por dicho que puede lo imposibles; en $L a G i$ borra los celos, «téngase por dicho que puede lo imposibles; en $\mathrm{La} \mathrm{Gi}$ -
tanilla (edic. Schevill-Bonilla, págs. 59, 93); en la Galatea (edic. Schevill-Bonilla, I, 228): «No son los celos señales de mucho amor, sino de mucha curiosidad impertinente», etc., etc. Habrá en esto mucho de tópico literario, pero la insistencia es signo de preocupación por o es término funesto y desastrado. Para Cervantes no son ellas únicamente seres blandos y suaves necesitados de la protección masculina. La mujer es un temible problema.

Para terminar, una palabra sobre el honor en relación con los duelos y desafíos. Como es natural, ocurren éstos alguna vez; pero, como ha notado Northup ${ }^{1}$, los desafíos innecesarios son evitados por Cervantes ${ }^{2}$. Me remito a la docta exposición del hispanista norteamericano. Un punto, sin embargo, he de poner de relieve. Algunos comentaristas del Quijote (II, 32) y Persiles (III, 9) han notado que hay contradicción entre lo que en ambos lugares se dice acerca de la «afrenta» y el «agravio» ${ }^{3}$. Una debilidad más de razonamiento atribuída a Cervantes. Pero la verdad es que ha habido, como casi siempre, mala interpretación de los textos, que Northup aclara bien. Antonio, en el desafío de Persiles, se sintió «agraviado» y no «afrentado», porque «la luz de las armas quita la fuerza a las palabras»; lo que no está en contradicción con lo dicho en el Quijote. Como observa Northup, «era un principio admitido, que luego que un caballero había desenvainado la espada, cualquiera cosa que dijese no contaba como afrenta que exigiese ser vengada» ${ }^{4}$.

tema. ¿Un detalle más para insistir sobre la relación amorosa concebida como dramática lucha, en la que se bordeaban todos los peligros? 1 Modern Philology, 1923, XXI, 403.

2 Ya dijo Castiglione: «No sea liviano en venir fácilmente a estos desafíos, excúselos cuanto pudiere» (Cortesano, pág. 64).

3 Véase Persiles, edic. Schevill-Bonilla, II, 307.

4 Mal LARA, Filosofia vulgar, edic. I568, III, 32 , fol. $58 v$, ya hace Mal Lara, Filosofía vulgar, edic. 1568 , III, 32, fol. 580 , ya hace
diferencia entre la afrenta efectiva y el agravio de palabra, y cita a Alciato, De la manera del desafio, que, como es sabido, tradujo J. Martín Cordero, Amberes, $155^{8}$ : «Cuando la afrenta, que llamaban baldón, viene de persona que tiene poder sobre otro, como de señor a esclavo, de amo a criado, de marido a mujer, no es afrenta de tal naturaleza que quede el otro afrentados, etc. 
biésemos deseado, por su tono apologético y superficial, por carecer de la ponderada comparación con la ciencia coetánea en otros países; los prejuicios político-religiosos de aquel gran crítico ponían además una valla a la libre marcha de sus in dagaciones. Por lo demás, en ninguna parte dijo Menéndez Pelayo claramente en qué consistiese la nueva concepción de la vida que el Renacimiento trajo a nuestra España; se daba por supuesto aquello que debía ser probado.

Se originó así una estéril polémica entre quienes decían

Si el lector ha tenido paciencia para recorrer este largo estudio, habrá visto que Cervantes encierra problemas ideológicos muy complejos. No sé si mis razones persuadirán a todo el mundo. Me contentaría con que se reconociese que frente a los juicios tradicionales sobre nuestro mayor escritor se imponen otras posiciones. Nuestro trabajo ha consistido no más que en prolongar histórica e idealmente los temas de Cervantes, caminando por la senda de que son natural punto de partida. Nunca se dijo que en Cervantes existiera una flora temática, determinada por el clima histórico en que su obra crece y por la especial visión del mundo de su autor. Se pensaba que el genial artista era un producto de ocasionales aunque sublimes intuiciones; se ignoró siempre su formidable poder de selección. Los mismos estudiosos alemanes, tan afanados en torno a las menores particularidades ideológicas de Calderón, no pensaron en escribir una: "Cervante's Weltanschauung». Y todo ello ha sido causado por un prieto haz de desfavorables prejuicios, no sometidos a contraste.

Sería necesario escribir otro libro para exponer con método el origen y la amplitud de todos los malos prejuicios proyectados sobre Cervantes, verdadero «caper emissarius» de nuestras desventuras. España adquirió fama de lega en el trato de las naciones, y lego fué llamado el más excelso de sus hijos, que ha padecido y padece persecución a causa de pecados en que no él participó. Todos hemos creído que en la España del siglo xvi no hubo alta cultura del espíritu, sino arte piadoso o de fantasía.

Las reivindicaciones de la ciencia española intentadas por Menéndez Pelayo no fueron siempre todo lo eficaces que huque España había participado del movimiento renacentista, y sus contradictores que lo negaban. Lo curioso es que de la primera actitud participaban los tradicionalistas y de la segunda los liberales. No sabíamos a qué atenernos quienes hace veinte años comenzábamos a interesarnos en el estudio del pasado español. Siguiendo la moda, hube de escribir, hacia 1909, que el Renacimiento no había influído en la esencia de nuestra literatura clásica. Tal postura me parece hoy absurda y fruto de una pertinaz indolencia.

Muy lejos estaba de creer que Cervantes ofreciera en armónico y grandioso despliegue los más finos temas del Renacimiento italiano. Conocía los juicios agrupados en la introducción de este libro, y pensaba que Cervantes no era sino el maravilloso creador del Quijote, el artista de estilo único, etc. Comencé a vislumbrar otras posibilidades en I9I6, al estudiar el honor en dos artículos de la Revista de Filología Española; vi que Cervantes reaccionaba de modo opuesto a los dramaturgos, y cómo su actitud no obedecía meramente a espíritu compasivo y cristiano, sino a estar imbuído de ideología renacentista. Por primera vez hallaba una conexión concreta entre Cervantes y el humanismo italiano. El hecho pasó sin comentario en pro ni en contra. Como no se trataba de un documento de archivo que revelara alguna desconocida andanza del autor, el cervantismo ni aprobó ni rechazó mis ideas. Habría sido preciso revisar el concepto de Cervantes «ingenio lego», y el ambiente no es nada propicio a esa busca de pan de trastrigo. Por mi parte no tuve sino caminar por la senda percibida en I9I6 para llegar naturalmente al final del 
presente estudio. España participó de las corrientes renacentistas; y con Cervantes, en forma originalísima.

Una de las causas primordiales del menosprecio intelectual hacia nuestro mejor escritor ha sido la triste circunstancia de que el cervantismo no haya conocido de su vida sino aspectos insignificantes o lamentables: cobranzas de alcabalas, prisiones, cautividad, vida familiar, orlada Dios sabe de qué miserias (ambiente de Valladolid descubierto por el proceso con motivo del asesinato de Ezpeleta; manejos inconfesables de Cervantes y su hija cuando ésta se casa viviendo en la calle de la Montera, etc.). Un hombre así, hambriento y casi mendicante, incita a que se le hable de tú; sus ideas serían cualquier cosa, a lo sumo las vulgares y corrientes: «no había tiempo ni afición para formarse otras», como perentoriamente decidió Menéndez Pelayo. Decían que razonaba mal, y además le achacan renuncios, olvidos y contradicciones en que nunca incurrió. Mucho más nos habría valido que, como en el caso de Shakespeare, se discutiera si realmente él fué el autor de esas obras admirables.

El cervantismo se aferró a los archivos de protocolos (cuya utilidad no niego, por propia experiencia), y a la erudición lingüística, y no pensó en la formación intelectual del escritor, intensificada durante los años de Italia. Un hombre como Cervantes, ¿pudo pasar allá año tras años sin hacer otra cosa que jugar a quínolas y vaguear? Los archivos callan sobre este punto; pero los libros suyos, ¿para qué sirven? La estancia en Italia fué el más trascendental hecho en la carrera espiritual de Cervantes.

Otro de los grandes prejuicios que han gravado la memoria de Cervantes ha sido el esoterismo. Ahora me explico ese extravagante hecho. Los hombres serios y de estudio sostenían que en Cervantes no había sino fantasía y humorismo, a lo sumo espíritu jovial, satírico y mordaz, heredado de los erasmistas. Pero aconteció que al leer a Cervantes se notaba algo, no se sabía bien qué; el espíritu del autor hacía a veces contorsiones extrañas, parecía como si quisiese decir lo que no decía. Ignorando el concepto de Contrarreforma, se lan- zaron muchos a desbarrar. Obstruída la normal salida histórica de aquellas inquietudes de Benjumea y compañía, vino el estallido. Y así nació el Cervantes anticlerical, republicano, místico, lleno de anagramas. La locura.

Contra los esoteristas cerraba la crítica aburguesada y tradicional. Por entre los resquicios de la batalla había que intentar una salida, llevando a Cervantes a su época y ordenando con técnica filológica los hechos que nos presenta. Gracias a este método hemos visto la poderosa unidad de la concepción ideal de Cervantes, la armonía y concordancia de sus partes. Las bases de sus caracteres literarios son quintaesencia del naturalismo y el estoicismo de su siglo. La psicología de sus personajes - empirismo, relativismo y "engaño a los ojos» - nos lleva a los estados de espíritu más exquisitos dentro del Renacimiento precartesiano. La moral naturalista y estoica da en él frutos originales. La religiosidad es igualmente la que hallamos en otros grandes genios de su época.

Salía de mi plan estudiar el estilo. Quizá algún día emprenda su análisis. En una época en que la razón no ofrece base segura a la ciencia (que está en ciernes y sin cuajar), la gente se refugia en los sentidos. Se duda de la validez de los juicios, y las sensaciones e impresiones adquieren valor eminente: "Lo que veo y columbro no es sino un hombre.» Pero la sensación puede ser falaz: de ahí relativismo (yelmo, bacía y baciyelmo) y también «engaño a los ojos». El impresionismo de Cervantes es, pues, algo muy hondamente enraizado dentro de su sistema ideal; no menos que el del Greco, cuya comparación con Cervantes sería fecunda ${ }^{1}$. El impresionismo de ambos, lo mismo que el barroquismo del pintor $^{2}$, son floraciones típicas de la época de la Contrarrefor-

1 Ya escribió M. B. Cossío: «Por los mismos años se concebían, en la misma amplia y soleada llanura castellana; se engendraban, a la vista uno de otro, la novela y el cuadro, las dos fuentes de vida más intensa, las dos más armónicas y originales conjunciones de idealismo y realismo que en el arte español se han producido» (El entierro del conde de Orgaz, 1914, pág. 29).

2 Véase el citado libro de Weissbach. 
$\mathrm{ma}^{1}$. El Renacimiento puso en cuarentena las definiciones dogmáticas, dentro de las cuales se reinstala la Contrarreforma algo incómodamente. Los grandes ingenios saben que la verdad no puede nacer sino de la crítica de la experiencia. Cervantes, por lo pronto, presentará sus figuras envueltas y resueltas en la impresión que suscitan en cada observador, en puntos de vista. De ahí el impresionismo.

Un gran contemporáneo de Cervantes, Miguel de Montaigne, sintió con acuidad ese problema de la relatividad de nuestros juicios y estuvo a punto de caer en un mar de escepticismo; su salvación estuvo en refugiarse en el sentido práctico, en el-fondo sensaciones e impresiones (si comemos mucho, nos dolerá el estómago). Cervantes deja abierto y patente el problema, y con rara genialidad lo lleva íntegro al centro de su arte, que al mismo tiempo supone una profunda visión del mundo, visión reflexiva de los magnos hallazgos y construcciones del Renacimiento, cuya existencia reconoce Cervantes, pero ante cuya eficiencia sonríe melancólico. Las realidades se estremecen ante nuestra crítica y acaban por resolverse, intelectualmente, en impresión de relatividad; moralmente, en enérgica resignación, en melancólica victoria sobre nosotros mismos, ya que fuera de ese reducto de la conciencia, en las trágicas crisis, todo es inseguro y problemático.

A lo largo de nuestro siglo xvi hemos podido seguir la marcha de los temas humanistas. Visto así, aquel siglo se nos ofrece con estructura más metódica, y aparece más próximo a las literaturas coetáneas de Italia y Francia. Cervantes se nos muestra plenamente como una de las más espléndidas floraciones del humanismo renacentista. Podemos al mismo tiempo apreciar con nuevos elementos el desarrollo de su rara originalidad.

1 ¿Deberá recordarse que el impresionismo del siglo xix nace también después de una época de sensacionismo, de positivismo y de lescón despés de un desconfianza en la idea? Inútil es decir que no prolongo la comparación

\section{ADICIONES}

Pág. 64, nota 2. - Antonio de Torquemada, Fardín de flores curiosas, Salamanca, I570, fol. 6, dice que el llamar las cosas milagrosas o sobrenaturales viene de «las mesmas cosas, que como por dificultosas y nunca por nosotros vistas, por la grandeza dellas las llamamos milagros..., porque no las suele hacer la naturaleza (o por mejor decir, el mesmo Dios) muchas veces».

Pág. 71. - Con posterioridad a Cervantes dice Espinel en el Marcos de Obregón: «Yo, como iba historiando mi vida, no advertí que podría cansarse de oírme hablar tan difusamente» (edic. Clás. Cast., II, I 5).

Pág. 87. - A la relatividad de los juicios alude también B. Varchi, L'Ercolano, Venecia, I570, pág. 17: «Non pure un' huomo medesimo ha altro giudizio da vecchio, che egli non haveva da giovane... ma molti uomini d' una età hanno diverso giudizio in quelle medesime cose, che non haveano molti huomini d' un' altra età.»

Pág. 89. - En la nota 3 téngase presente: L. Blanchet, Les antécédents historiques du Fe pense donc je suis, París, Alcan, I920.

Pág. 95. - El vuelo en manta es un tema frecuentemente tratado; se halla también en el fardín de flores curiosas de A. de Torquemada, Salamanca, I 570, fol. I 50v: «Tendiendo un manto grande que llevaba, de manera que no quedó arruga ninguna en él», fueron varias personas a Granada desde Castilla. Ya notó esta fuente De Lollis, Cervantes reazionario, pág. I77.

Pág. 101, nota 3.- Comp.: Las brujas «se untan con algunos ungüentos que las hacen perder el sentido, pareciéndoles que se convierten en aves o animales» (A. de Torquemada, Fardin de flores curiosas, Salamanca, I 570, fol. I 54). 
Pág. 126, nota. - Comp. "¿Quién hay en el mundo que se pueda alabar que ha penetrado y sabido el confuso pensamiento y condición mudable de una mujer? Ninguno, por cierto» (I, 27; RM, II, 363).

Pág. 129. - El texto de Erasmo, citado al final, debe completarse por el principio con estas palabras de Pánfilo a María: "Yo muero por ti, y tú eres la causa, y, por el consiguiente, yo el muerto y tú el homicida.»

Pág. 133. - El duque de Nemours quiere buscar mujer a su gusto, "porque dice que los reyes bien pueden dar la mujer a quien quisieren de sus vasallos, pero no el gusto de recibilla» (Persiles, 649a).

Pág. 140. - Añádase el caso de quien compró un caballo por menos de su valor, lo pierde y le suceden otras desdichas: "Casi todos se holgaban de que la codicia de mi amo le hubiese rompido el saco» (Coloquio, Clás. Cast., pág. 276).

Pág. 159. - Cristóbal de Villalón, en la Ingeniosa comparación entre lo antiguo y lo presente (I534), habla de la creación del hombre como de un hecho puramente natural, prescindiendo de la explicación bíblica: «En la primera edad andaban los hombres hechos salvajes por las montañas... Después, como naturaleza los criase para ayuntamiento y generación, ingerió en sus corazones (como dice Hesíodo), un amor, sin el cual dice que era el mundo un caos o confusa masa sin forma ni ser. E por este amor se vinieron los hombres a comunicar con las mujeres, y así a engendrar... Platón dice que juntamente nació con nosotros amor, e que nos. crió naturaleza a cada uno dos uncidos por las espaldas... Presumo yo que fuese a todos en esta edad la mesma lengua y habla común, etc. ... Después, como fuese cresciendo el amor entre ellos, fué cresciendo por el contrario la enemistad, porque cuando naturaleza hace una cosa, cría su contrario» ${ }^{1}$ (Biblióf. Esp., XXXIII, I58). Los humanistas,

\footnotetext{
1 Véase arriba, pág. 346 .
}

como se ve, sustituían la explicación bíblica por otras que ellos juzgaban más racionales, de acuerdo con la posible evolución histórica del hombre.

Pág. 162, nota. - Creo más bien que Cervantes imitó en este caso el Fardín de flores curiosas de A. de Torquemada: «De Apolonio Tianeo se escribe que también él las entendía [las aves]. Yo os diré lo que cerca de esto he leído... Estando Apolonio con otros amigos suyos en el campo, y debajo de unos árboles, vino un pájaro volando, y comenzó a chirriar o cantar con otros que estaban en los mesmos árboles, los cuales juntos todos comenzaron a hacer muy grande estruendo con sus voces, y con una manera de regocijo, disparan y se van camino de la ciudad. Apolonio se comenzó a reír...; sus compañeros le fatigaron que les dijese de qué tenía aquella risa...; él les respondió que... aquel pájaro que había venido trajera nuevas a los otros que en el camino, cerca de la ciudad, viniendo un molinero con un costal de trigo cargado encima de un asno, se le había caído, de manera que el costal se reventó y se había vertido muy gran parte del trigo... Los otros pájaros le habían dado las gracias, y iban todos a comer del trigo» (edic. Lérida, I573, lib. V, pág. 217). Cervantes tenía muy en la memoria este libro de Torquemada. Los editores de Persiles no han dicho de dónde procede el siguiente pasaje: «Según lo aconsejan aquellos antiguos versos castellanos que dicen:

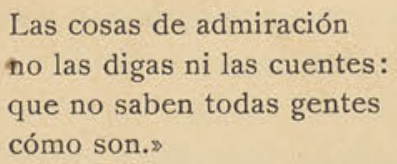

Pensaríamos que la fuente es Santillana, cuyos son estos versos:

\section{Los casos de admiración non los cuentes: \\ ca non saben todas gentes cómo son.}

Proverbios, edic. Amador de los Ríos, pág. 52. ) 
Pero Cervantes no tomó el texto directamente de Santillana, sino a través de Torquemada, que ya lo había alterado un poco en su memoria:

«Conforme a lo que dijo el marqués de Santillana:

$$
\begin{aligned}
& \text { Las cosas de admiración } \\
& \text { no las cuentes: } \\
& \text { que no saben todas gentes }
\end{aligned}
$$$$
\text { cómo son.» }
$$

(fardin de flores curiosas, Salamanca, 1570, fol. 3 v.)

Pág. 166. - Antonio de Torquemada (Fardín de flores curiosas, Salamanca, I570, fol. $4 r$ ) no admite una naturaleza operante distinta de Dios: «Pues que nosotros todo 10 que tratáremos ha de ser cristianamente, dejemos los autores y filósofos gentiles y sigamos solamente a los cristianos, entre los cuales me parece que el que mejor ha acertado fué Levino Lenio, el cual, siguiendo a Santo Tomás, dejando las opiniones antiguas como cristiano..., dice que la naturaleza no es otra cosa sino la voluntad o razón divina, causadora de todas las cosas engendradas... Según esto, este nombre o vocablo naturaleza (de que comúnmente usamos) no sirve de más de representarnos la voluntad y mente de Dios... Bien sé que no faltarían filósofos que... dijesen que hay una "natura naturans», y que ésta es el mesmo Dios, y que otra es «natura naturata», la cual es el efecto natural que por su voluntad se hace y obra en las criaturas, mas yo no quiero que nos detengamos en esto, sino mirar el fundamento de donde todo procede, que es Dios.»

El asunto preocupaba también a Quevedo, que prefiere se hable de Dios directamente y no de su intermediaria la naturaleza: "La tierra... no puede dar habilidad a las plantas, ni instinto a los animales, ni razón a los hombres, porque nadie puede dar lo que no tiene. Dirás que todo eso da la naturaleza, y si ésta lo recibió de otro daremos proceso infinito, y éste ninguno le concedió. Si a la naturaleza llamas principio de todo, sin principio, necesariamente confiesas que hay un Dios. Pónesle nombres, mas no le niegas; llámasle como quie- res, no como debes» (Providencia de Dios, Rivad., XLVIII, I94a).

Pág. 183. - Muy distinta era la opinión de Luis de Granada: "Vemos en la edad tierna de los muchachos, antes que puedan pecar, las semillas destos males (porque entonces comienza a descubrirse la ira, la insidia, el odio, la rabia, el deseo de venganza y otras semejantes pasiones, las cuales no vienen por pecados propios porque aún no los tienen); por lo cual habemos de confesar que pues todos los hombres nacen con estas malas inclinaciones, y no por pecados propios actuales, que algún pecado hubo en algún hombre, que fué principio de toda la generación humana» (Símbolo de la fe, Rivad., VI, 403b).

Pág. 212. - El odio al vulgo fué violentamente expresado por Cosme de Aldama, Invectiva contra el vulgo y su maledicencia, Madrid, I59I (Rivad., XLIV, 495). Empieza:

Querría, vulgo, morir; querría sin vida
o verme o verte. ¡Ay, que no sé dezillo!
Tramposo, desleal, gente abatida,
gente, manjar de horca y de cuchillo, etc.

Pág. 219. - Las «armas y las letras» son anuncio de la importancia que adquieren la cultura y la razón frente a la vida de tipo tradicional. El intelectual, armado de razón teórica se apresta a intervenir en los destinos de Europa. Creo que podría compararse la situación moral y ocasional, de que es índice ese tema, con lo acaecido en épocas similares de la historia de Grecia y Roma. (Comp. J. Ortega Gasset, El tema de nuestro tiempo, I923, págs. I 86 y sigs., y 2 I 2 y sigs.)

Pág. 246. - Para el pesimismo causado por el triunfo del luteranismo, véase este curioso texto: «Bernardo. - Entendido habemos que la cristiandad es mayor de lo que pensábamos si estuviésemos todos los cristianos conformes en conocer y obedecer a la Iglesia católica, y estar debajo del amparo della, y no como muchos que tienen solamente el nombre de cristianos y son miembros apartados por obedecer a otras Iglesias, y seguir nuevas opiniones y herejías. 
¡Plega a Dios que con todo esto veamos cumplida aquella profecía: «Et erit unum ovile et unus pastor!»

»Luis. - Que lo veamos, decís. Eso es prometeros muy más larga vida que ninguna de la que ayer referimos, que sola la mala cristiandad de los luteranos y su pertinacia, sin haberse querido someter al santo Concilio que se celebró en Trento, basta para tener estragado el mundo mucho tiempo» Antonio de Torquemada, Fardin de flores curiosas, Lérida, I 573, fol. $95 \mathrm{v})$.

Págs. 272 y 281. - «Aun aquellas cosas que los antiguos con sola lumbre de sus juicios alcanzaron, aun nosotros con dejárnoslo escrito en sus libros, ansí amasado y aparejado, aún no podemos con nuestro cotidiano estudio entender» (C. de Villalón, Ingeniosa comparación entre lo antiguo y lo presente (I 534), en Biblióf. Esp., XXXIII, I37).

Págs. 281 y 282. - El preferir la muerte súbita es rasgo típicamente erasmista: «Todos aborrecen la muerte súbita y improvisa. Por cada rincón oirás estas voces: «Líbranos, Señor, de muerte súbita.» No sé qué demandan éstos. ¿Es por ventura abominable toda muerte súbita? No en verdad, porque Salomón dize que de cualquiera muerte que muera el justo, estará en refrigerio. No puede ser mala muerte, aunque más súbita sea, si la vida precedente fué buena. Pues dpor qué no rogamos assí: De la mala vida, líbranos tú, Señor?» (Erasmo, Preparación y aparejo para bien morir, traduc. del maestro Bernardo Pérez, Amberes, I 553 , fol. 20, verso.) Hay que recordar también que en otro lugar del Quijote se alude a lomismo: «La [muerte] que se recibe repentina presto acaba la pena; mas la que se dilata con tormentos siempre mata, sin acabar la vida» (I, 27; RM, II, 370).

Pág. 308. - Cervantes hace decir al Cura: «Cuando se cumplen las fuertes leyes del gusto, como en ello no intervenga pecado, no debe de ser culpado el que las sigue» (I, 36 ; RM, III, I 27).

Pág. 317. - «Pues si nos venimos a comparar con los teólogos de aquel tiempo dados a la lectura de la Escriptura Sagrada, Hierónimo, Augustino..., ¿̇qué diríamos de los deste tiempo?... Los teólogos de agora (ןoh Dios inmortal, que no lo puedo decir sin lágrimas!), que lo primero que hacen es desnudarse de Jesucristo, del cual primero se habían de vestir, porque agora dicen que el teólogo que sirve a Dios, no suele tener de comer» (C. de Villalón, Ingeniosa comparacion entre lo antiguo y lo presente (I534), en Biblióf. Esp., XXXIII, I46).

Pág. 354. - Dado mi propósito de perseguir ahora en Cervantes más la idea que la forma, he de prescindir del estudio de las fuentes de El Celoso extremeño. Cervantes conocería estos o los otros relatos, escritos u orales, pero lo específico y original de la novelita y su sentido es inútil buscarlo en sus precedentes. Véase ahora el erudito estudio de A. González Palencia, Un cuento popular marroqui y «El Celoso extremeño", de Cervantes, en Homenaje a Menéndez Pidal, 1925, I, 4I7. En ese cuento se trata de un padre y una hija, no de un marido y una mujer. Palencia cita la bibliografía del asunto. 


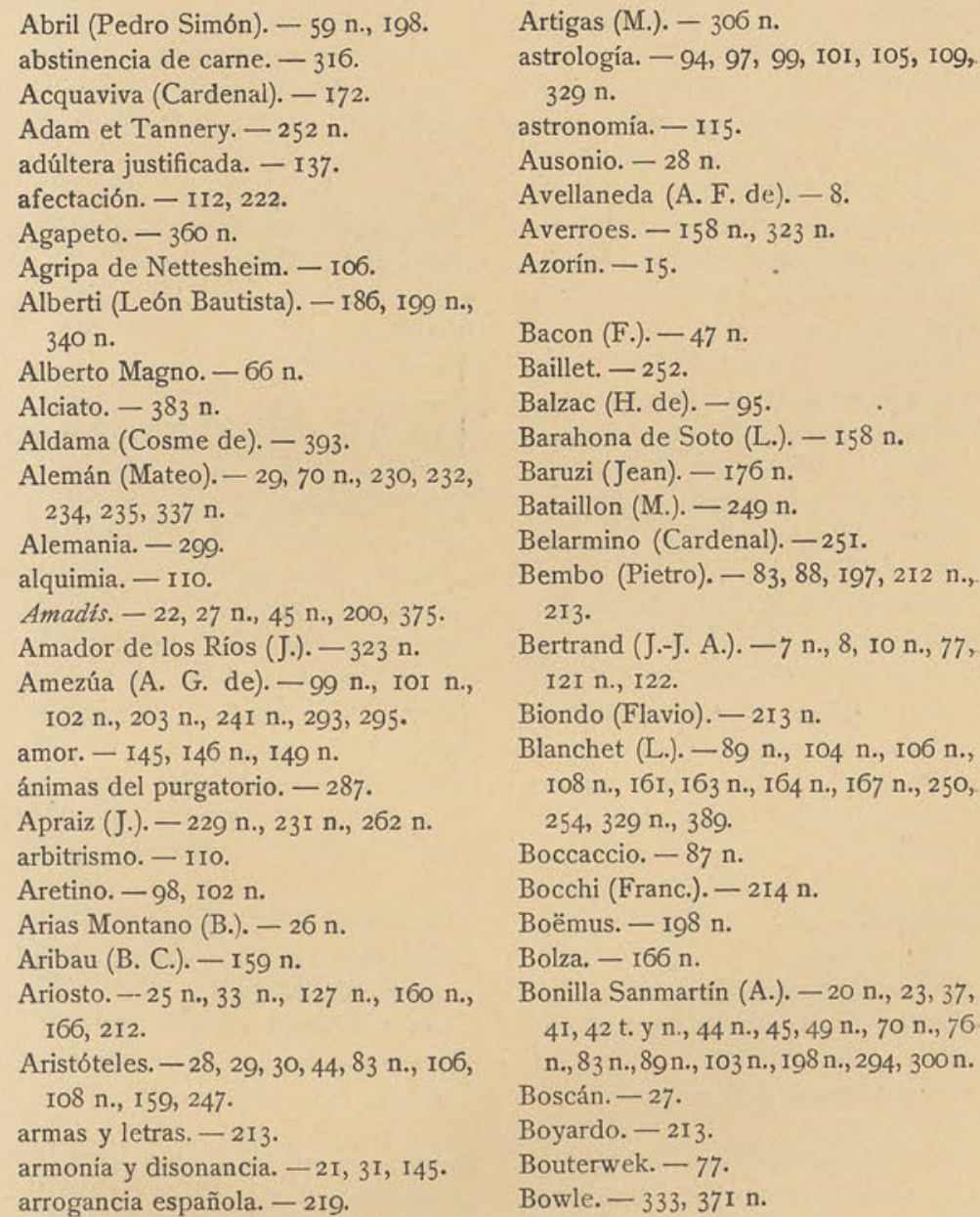

Los números se refieren a las páginas; la negrilla indica que se trata de 
brujeria. -98 , гог.

Cintio (Giraldo). - 314, 315

(G.). -144 n., I60, I6I, 212, $\operatorname{Cirot}(\mathrm{G}$.). $-284 \mathrm{n}$.

$\begin{array}{cl}\text { 247, 250, 251, 252, } 253 . & \text { Ciruelo (P.). }-103 \mathrm{n} ., 104,105 \mathrm{n} ., 106 \mathrm{n} . \\ \text { Burckhardt. }-186 \mathrm{n} ., 215 \mathrm{n} . & \text { Clemencin. }-9,17,25, \text { IOI, II } \mathrm{n} .,\end{array}$

247 n., 317 n., $323 \mathrm{n}$.

caballerías (libros de). - 22, 26, 47 .

"cada uno es hijo de sus obras". -

366,368 .

Calderón. - 65 n., 283 n., 292, 295,

$313,330,364,384$.

Campanella. $-45,104$ n., I06, 107

I08, I44, I6I, 163, 247, $25025 \mathrm{I}, 252$

Canalejas (F. de Paula). - Io n.

Cánovas del Castillo (A.). -49

Caperán (L.). -273 n., 275 .

Capriano (Giovanni Pietro). - 3I

Cardano. - I58 n., 167

Caro (Rodrigo). - I91.

Carranza (G.). -60 .

Carreras Artau (T.). $-15 \mathrm{n}$.

Cartagena (Alonso de). $-323 \mathrm{n}$., $324 \mathrm{n}$,

$38 \mathrm{I} \mathrm{n}$.

casamiento desacorde. - 129, 133 .

Casamiento engañoso (El) - I 39 , 238

Cascales (F.). -22 .

Castañega (Fr. M. de). $-65,66 \mathrm{n}$.

Castelvetro. -28

Castiglione (B.). $-6 \mathrm{I}, 87,88, \mathrm{125}$,

I26 n., I36, I37, I44, I46 n., I48,

I54 n., I55, I58 n., I63, I73, I74 n.,

180, 202, 213, 214 n., 217, 223, 224

225 n., $317,343,367,373,383$ n.

Castro (Guillén de). - I 27 .

Castro Guisasola (F.). -20 n., 2 II

catalanes. -228 .

Cautivo (Historia del). -146

Celestina ( $(\mathrm{La})-24,35, \mathrm{I59}, 2 \mathrm{II}$

celos. $-382 \mathrm{n}$.

Celoso extremeño $(E l) .-242$

Celso. $-273 \mathrm{n}$.

ceremonias eclesiásticas, -265 .

Cervantes de Salazar (F) - -26

ian (V.) $-87,126 \mathrm{n}, 199 \mathrm{n}$,

Cicerón, $-64,113$.

$216 \mathrm{n} ., 275,370 \mathrm{n}$.
I2I, I4I n., 150, 196, 205 n., 206, 240 , 282, $300 \mathrm{n} ., 37 \mathrm{I} \mathrm{n}$.

Clemente (Alejandrino). $-274 \mathrm{n}$

comedia lopesca. $-22,53$.

concilio de Trento. $-26,27,29,254$ 259, 277, 349 n., 350 .

contrarreforma. $-26,27,28,35,45,46$, $65,78,167,177,244$ n., 29I, 374. 323 n., 325 n., 329 n., 366 n., 383 n. Córdoba (Sebastián de). $-27 \mathrm{n}$. Cortehoevius (Teodorico). -280 n. cortes de Valladolid. $-26 \mathrm{n}$. Cossío (M. B.). -387 .

Coulange (L.). $-277 \mathrm{n}$.

Crawford (J.P. Wickhersham). -224 n crisopeya. - 1 IO.

cristianismo de Cervantes. $-307,316$ cristianos viejos. -255 n., 297.

crítica humanista. -269 .

crítica romántica. - I0.

criticismo. $-75,88$.

Croce (B.). $-19,25 \mathrm{n}$

cuadratura del círculo. - IIO.

Cueva (Juan de la) $-22,93$

cultura de Cervantes. - I8, I9, III

curiosidad ilimitada. - II

Curioso impertinente $(E l) .-73$, 121

Cusa (Nicolás de). - I55, I59 n., I6I.

Chandler (F. W.). $-23 \mathrm{I}$ n.

Charbonnel (J.-R.). - 104 n., 108 n., 109 n., 167 n., 252 n.

on (Pierre). -204.

. $-8,143$ n. $190 \mathrm{n}$

Dante. $-7,17,159$ n., 273,339

Dejob (Ch.). $-244 \mathrm{n}$.

Denzinger $-274 \mathrm{n}$.

Descartes. $-20,45,46,8 \mathrm{I}, 89,103$,

242 n., 247, 252, 253, 254 n., 348 . determinismo. - 169 (v. fatalismo)
Cordero (Juan Martín). - 198, 203
Díaz de Benjumea (Nicolás). - 9 , I23, I29.

dignidad del hombre. -369 .

Dión. - $360 \mathrm{n}$.

disimulo. -24 r.

doble verdad. -42

Don Juan. - 33r.

duelos y desafios. -383 .

eclesiástica (vida). -287 .

Edad de Oro. - I67, 177 .

Elena y María. $-2 \mathrm{I} 4 \mathrm{n}$.

Engaño a los ojos $(E l) .-79$.

Entremés de los romances. - 148

Entretenida (Ja). - 50 n., 5 I.

erasmismo. -263 .

Erasmo. - 24, 25, 63 n., 85, 88, III n. I29, I 33 t. y n., I 58 n., 163, I64, I65 n., I67 n., I68 n., I69, I72, I74, I80, I8I, I83 n., I91, I92, 195, 197, 198, 199, 2II, 2I6, 223, 245, 248 n., 254, 263, 267 n., 268 n., 269 n., 270 n., 275 , 279 n., $280,281,283$ n., 285 n., 289 n., 290, 307 n., 309, 310 n., 3II, 314. $316,318,320,325,347,363$ n., 366 367 n., 379, 390, 394

ermitaños. -289 .

error. - II7, I18, 120, I24.

Escalígero. -29 .

esgrima. -60 .

esoterismo. - IO, 386 .

España. - 230.

Española inglesa $(L a),-302$.

españoles. - 2I9.

Espinel (Vicente). - 232, 237, 299 n.$$
389 .
$$

estilo. $-57, \mathrm{II} 2,38 \%$

estoicismo - 337,34 .

Etchegoyen (G.). - I75 n.

Etienne (Henri). -133 n. 280 n.

exámenes. -59 .

experiencia. $-89,9$

Farinelli (A.). $-323 \mathrm{n}$.

fatalismo. $-\mathrm{I} 69,328,329,333,336$

Felipe II. - 374

Fernán González (poema de). -34

Fernández de Navarrete $(M)-8$

$$
\text { II3 } \mathrm{n} \text {. }
$$

Fernández de Oviedo (G.). -26 n., $27 \mathrm{n}$., $200 \mathrm{n}$.

Ficino (Marsilio). - 24, 66 n., 155, I6I, I63.

Fiorentino. $-158 \mathrm{n}$

fisica. - 115 .

Fitzmaurice-Kelly. -8 , II.

Flamini. $-16_{3} \mathrm{n}$.

Flandes. -226 .

Flaubert. $-69 \mathrm{n}$

Folengo. $-170 \mathrm{n}$.

Fonseca (arzobispo de Toledo).-24

fortuna y ventura. -337

Fox Morcillo. $-83 \mathrm{n}$.

frailes. -285 .

Francia. $-228,299$.

Fuentes (Alonso de). $-26 \mathrm{n}$

fuentes de Cervantes. -20 .

fuerza del sino. - 333 (v. fatalismo).

Galatea $(L a) .-37$ t. y n., 38,39 .

Galicia. -230

Galileo. $-20,46,103,104$ n., 247, 251 .

Gallardo (B. J.). $-380 \mathrm{n}$.

gallegos. -229

Gálvez de Montalvo. - 36, $39 \mathrm{n}$.

Ganivet (Angel). -13

Garci-Ordoñez de Montalvo. - 375 .

García Calderón (V.). -47

Garcilaso. - 27, I62, I65.

Gentile (G.). - I 44 n., I 160 n., 163 n., I64

$369 \mathrm{n}$.
gentiles.

gent., 273 .

Giglio. - $198 \mathrm{n}$.

Gil Polo. -36

gloria. -375 .

Goleta (La). -226 .

Gómara (F. L. de). -205

Góngora (Luis de). $-306 \mathrm{n}$

González (J. A.). - 214.

González Palencia (A.). -395

Gothein (E.). -244 n 319 .

Gracián Dantisco -203 n.

Gracián (Diego). $-26 n$ n 27,360 n.

Granada (L de) $-26 n$, $78 n$, I57 n 
176 n., 272, 274 n., 278,328 n., 336 n., justicia. - 59, 204. 349 n., 35 I n., 393.

grandeza española. -227

Greco (El). $-374,387$

Gregorio XIII. - 26 .

Guadalupe (Santuario de). -25 .

Guadalupe (Satha de). -259 .

Guevara (Fr. A. de). -26 n., 186, 18

Guicciardini. -317 n., 375

Haan (F. de). $-23 \mathrm{I}$ n.

Hadriani Junii. $-178 \mathrm{n}$

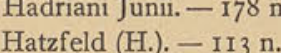

hechicería. $-94,97$.

Hechiceria. - 10, 16, 240, 293.

Keplero. - I04 $\mathrm{n}$

Klein (J.). - 49, 5 I n., 288, 292.

La Fayette (Mme. de). $-69 \mathrm{n}$.

Lafranchino (Cristóforo). $-214 \mathrm{n}$.

(G.). $-47 \mathrm{n}, 359 \mathrm{n}$

Laredo (Bernardino de). $-175 \mathrm{n}$.

Larra. 228.

(si Cervantes lo sabía). - II2.

Lazarillo de Tormes. $-24,25,221 \mathrm{n}$.

(2)

Lea (H. Ch.). $-300 \mathrm{n}$

lengua vulgar. -195 Heliodoro, Historia eizopica. - I6 n., León Hebreo. - 22, 23, 24, 31 n., 40, 22,35 n., 44, 45 t. y n., 69 n. $\quad 43,8 \mathrm{r}, 117, \mathrm{I} 44, \mathrm{I} 45$ n., I 48,149 , Herder. -77 .

Herodoto. -29 .

hidalguismo. $-145 \mathrm{n}$., 221, 125

Höffding (H.). $-250,252 \mathrm{n}$.

Honigswald (R.). - I44 n., 160, I6r.

honor. - I30 n., 36I, 38

Horacio. $-87,202 \mathrm{n}$

Horozco (S. de). -24 .

Huerta (Gerónimo de). - I59 n.

humanismo. -269

Hurtado de Mendoza (Antonio). -

$$
\text { II } 3 \text { n., } 359 \text {. }
$$

Icaza (F. A. de). -15 n., I8, II 3 n.

idealismo renacentista. -42 .

impresionismo. -38

influencia italiana sobre Cervantes. 28.

singenio lego.$-\mathrm{II}_{3}$.

Inquisición. - 158, 264, 291, 306

intolerancia. -30

Isócrates. $\mathbf{- 3 6 0}, 360$ n., $36 \mathrm{I}, 370 \mathrm{n}$.

Italia. - 228, 299.

151 t. y n., I54 n., I55, 158 n., I63,

$172,212,372 \mathrm{n}$.

Levitico. - I $122,103 \mathrm{n}$.

libertad de conciencia. -229

libre albedrío. -335

licantropia. -102.

Lipsio (Justo). - 322, 323, 325, 338 n., 348.

Lofraso (Antonio de), La fortuna de amor. $-16 \mathrm{n}$.

Lollis (C. de). - I6 n., 26 n., 35 n., 44 n., 45 n., 69 n., 75, 76, 94, 95, 102 n., IO3, IIO n., II2, 23I n., 389. Lope de Vega. - 11, 23, 35 n., 47, 49, 50, 54, 66, 70 n., I12, II5 n., I95, $226,232,253,254,270,283$ n., 292, 295, 299 n., 327, 359 n., 364 n. López de Mendoza (f́ñigo). - (Véase Santillana.)

Loreto (Nuestra Señora de). -259 . Lucano. -45

Luciano, Dialogos. -25 .

jesuítas. - 29I.

Maeztu (Ramiro de). - I5.

Maggi. - 29 .

magia. - I06.
Máinez (J. L.). -8 n., I22.

Jofreu (Pedro Antonio). - I04 n., I05 n. Mal Lara. - 28 n., I16, I25, I33, I36,

Juan Manuel (Don). - 214.

judios. -304 .

I63, $168 \mathrm{n} ., 174,175,179,180 \mathrm{n}$. ,

I83 n., 185 n., 189, I9I, 193, 194 t. y

n., $195,204,205,216,224,225,272$;
299, 309, 315 n., 339, 368, 370 n., Moratin (L. F. de). $-48,55$ n. 373 n., 377 n., 379 n., 380,383 n. $\quad$ Morel-Fatio (A.). -8 , 12, 13 n., 18, 206 Malón de Chaide. $-26 \mathrm{n}$. Manrique (Inquisidor general). $-245 . \quad$ morisc Marcial. -28 t. y n. Marden (C.). $-34 \mathrm{n}$ Mariana (P.). -258 n., 284 n.. 31 II. Marti (Juan). - $106 \mathrm{n}$ Martinez de Burgos (Fr. Juan). - 206 . matrimonio. -377

matrimonio solemne. $-349 \mathrm{n}$

medicina. - 108 , II5.

Mejia (Pero). -26 n., I16 n., I32, 163, I 83 n., I99 n., 212, 216.337 n., 360 n, 36r, 371, 373 n., 377 melancolía. -177 .

Melchor Cano. $-26 \mathrm{n}$.

Mena (Juan de). -206

Méndez de Silva (Rodrigo). - II3 n

Mendizábal (Rufo). $-17 \mathrm{n}$.

Menéndez Pelayo. - 8, 9 n, II, 12, 13 I4, 16, 20,21, 22, 23, 24 n, $26 \mathrm{n}$ $36,37,39,4$ I t. y n., $45,49,55 \mathrm{n}$ $75,77,82$ n., 83 n., 84 n., 86 n., 94 I1 13 n., I 48 n., I5O, I56 n., I62 n., I88, I0I, 199 n., 200 n., 212 n., 230 , $231 \mathrm{I}, 245,262,263,28 \mathrm{I}, 350 \mathrm{n}$ 360 n., 375 n., 385 .

Tenéndez Pidal (R) - $-9,143$ n., 48 n, $214 \mathrm{n}$.

Mérimée (E.). $-325 \mathrm{n}$.

Tersenne (P) $-25 \mathrm{n}^{2}$

Mersenne (1.). -252.

milagros, $-64,65,258 \mathrm{n}, 28 \%$

.

Milhaud (G.). $-103 \mathrm{n}$.

Viríndo (Pico de

$163,176,275,276 \mathrm{n}$.

(Pietro Lauro). -

358,359 .

ontaigne. $-20,65,108 \mathrm{n}, 1113 \mathrm{n}$.,

I15, I27 n., 156, I57 n., 181, 182 n.

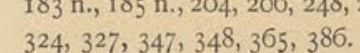

Nontemayor, Diana. $-36,70$ n., 126 n.

150, I51 n., I88, 190, 334 .

Mora (Domenico). - 2I4

moral. $-55,137,32 \mathrm{I}$.

Morales (Ambrosio de) - 201

muerte «post errorem». - I27, 128 , I31, 347.
mujer. - I68.

mujer ses animal imperfectox, - 126 .

smutatio capparum. $-265 \mathrm{n}$.

Muzio (Girolamo). - 43, 214 n.

Nasarre (B.). $-5 \mathrm{I} \mathrm{n}$.

naturaleza. $-156,158 \mathrm{n}$

Navarro Ledesma (F.). -234 .

Navarro Tomás (T.) - I65

Nebrija (A. de). - I99.

neoestoicismo. $-322,325$.

(160.

no conformismo. -261 .

Nolhac (P. de). $-108 \mathrm{n}$.

Northup (G. T.). -362 n., 382 n., 383 .

Novalis. -77 .

novela (género literario). -76

novela naturalista. $-\mathrm{I} 62$.

novela pastoril. -39 , 187 (v. Montemayor).

novela picaresca. $-25,230$.

novelas intercaladas. -12

Núñez (Hernán). - Ig1.

Núñez de Castro (Alonso). - II 3 n.

Núñez de Velasco (Francisco).-214 n.

ocultismo. - 106, 107

Ordónez (D. Alonso). $-29 \mathrm{n}$

orientación literaria. - 18, 24 .

Origenes. $-273 \mathrm{n}$.

Ortega y Gasset (J.). $-9,34$ n., 74 n.,

77 n, 95 n., 232 n., 24 I n., 393.

ortodoxia (alarde de). -254 .

Osuna (rrancisco de). $-264 \mathrm{n}$.

Ovidio. - $179,370 \mathrm{n}$

Palmireno (L.). -199 .

Paracelso. - I06.

particular histórico. $-23,27$.

patriotismo. -57

Pastor de Filida (El). - 39:

pastoril (v. novela pastoril). 
Pazzi.-28.

pedanteria (ausencia de). -112

peregrinaciones. -290

Pereyra (P.). -277 .

.

Pérez de Oliva (H.). -201
Pérez Pastor (C.) -303 n.

Persiles. - 39, 44, 45, 147, 148, 363 .

Petrarca. -108 n., 125,159 n., 166 n.,

I86, 211,340 ก., 366 .

picaresco. $-24,39,230$

Piccolomini. $-28,30$.

Pinciano (Alonso López). - 22, 23, 30

33 n., 34 n., 35 t. y n., 4 I, 43,44 t. y 291 n., 368.

Pineau (J.-B.) -167 n., 245 n., 279 n.

280 n., 285 n., 286 n., 289 n.,

Pirandello. $-295,33 \mathrm{I}, 375 \mathrm{n}$.

Platón. $-27,32,83$ n., 192, 193.

Plattard. -20 .

Plinio. - 66 n., 159, 190, $37 \mathrm{I} \mathrm{n.}$

Plotino. - I6I

Plutarco. -26 .

poesía (concepto de). $-22,45,47$.

Polidoro Virgilio - $100 \mathrm{n}, \mathrm{II}, 379$

Poliziano (Angelo). - I85.

Pomponazzi (P.). $-28,64,65,78$ n.,

$163,323 \mathrm{n}$.
Porfirio. -32.

Porta (Della). - 107.

portuguesa (lengua). -220

preceptismo. -63 .

Proaza (Alonso de). - $199 \mathrm{n}$

providencia divina. -338 .

Puigblanch (Antonio) - 306

Pulci, Morgante. - 24.

punitiva (técnica). -221

punitiva (técnica). -

Quevedo. - II $3,234,235$ n., 237 n., 238,252 n., 254,258 n., 278,325 n., 238,

Rabelais. - 20, I13 n., 176, 375 .

Racine. - IO2 $\mathrm{n}$.

riocinal frente a vital -6

racional frente a vital. -6

racionalismo. $-46,55$ realidad (crítica de la). $-68,88$.

refranes. -190

regulación literaria. $-46,47$.

religión. -240 .

Renacimiento. $-23,24,26,28,29,6 \mathrm{I}$, I93.

Renier (R.). - I23.

Rennert (H. A.). -54 n., 188 n., $190 \mathrm{n}$. Revilla (Manuel de la). - I6 $\mathrm{n}$.

Reyes (Alfonso). $-369 \mathrm{n}$

rezos. -287 .

(6) $\mathrm{n}, 162 \quad \mathrm{n}$,

Ríos (Amador de los). $-323 \mathrm{n}$

Rius (L.). -8 , $10 \mathrm{n}$., $\mathrm{I} 3, \mathrm{I} 6, \mathrm{I} 13 \mathrm{n}$

Robortelli. $-28,32$ t. y n., 33 n., 43 n. Rodriguez Marin (F.). - 9, II, I5, I7, I 8,21 n, I2I, I26 n., I50, 153 n $158 \mathrm{n}, 206 \mathrm{n}, 24 \mathrm{I} \mathrm{n}, 242 \mathrm{n}, 284 \mathrm{n}$, 286 n., 292 n., 338 . Rojas (Fernando de). -162 . Rojas Zorrilla (F.). - II5 n., 359 . Romancero general. $-\mathrm{I} 57 \mathrm{n}$.

romerias. -260

Rosenkranz (K.). -55 n.

Rossi - I88 n.). -5 .

Roussean. - I 8 I, 320.

Ruiz de Alarcón (Juan). - 49.

San Agustin. - 274 n., 275, 337 n.

San Jorge. - 310.

San Justino. $-273 \mathrm{n}$.

San Martin. - 310.

San Pablo. $-164,165,273$ n. 310, 311 ,

Sannazaro, La Arcadia. -24, 176, $188 \mathrm{n}$.

Sansovino (M. Fradia.-24, 176,188

Santa Cruz (Melchor de).

Santa Teresa. $-175 \mathrm{n}$

Santiago (apóstol). $-258,310$

Santillana (Marqués de). $-22,45$, II 3

n., 39 r.

Santo Tomás. $-275,327$ n., 367 n.

santos. -287 .

antos milagreros, -267 santuarios. -269 .

Savj-Lopes. - 8, I4, 2I n., 75 n.

$103 \mathrm{n} ., 23 \mathrm{I} \mathrm{n}$.

Sbarbi (J. M.). $-262 \mathrm{n}$.

Schack (Conde de). $-22,49,292 \mathrm{n}$.

Scheichl (F.). -293 .

Schevill (R.). $-8, I_{4}, 16$ n. 20 n., 37 , 42,44 n., 49 n., 70 n., 76 n., 103 n., I12 n., 122, I27 n., I79 n., 23I n., $303 \mathrm{n}$.

Schlegel (G. de). - I22.

Séneca. - 176 n., 211 n., 324, 325, $320 \mathrm{n}, 340 \mathrm{n}, 343,345,366,381 \mathrm{n}$. Sepúlveda (Ginés de). -277 .

Shakespeare. -7 , 10, 20, 102 n., 253. sobriedad. - II2.

Sócrates. - 197, 275

Solalinde (A. G.). -75

Solger. - I22.

Spingarn. -30 n., 43 n., 46 n.

Spinoza. -345

Suárez de Figueroa (C.). - 220, 300

sueños. - I02, I03
Suetonio. -282 .

sujeto (análisis del). $-68,70$.

superstición. -287 .

Tamayo de Vargas (Tomás) Tasso. $-28,29,35,249,252$ n., 253 .

dramática), 53.

Telesio (Antonio). $-\mathrm{I} 63 \mathrm{n}$

Telesio (Bernardino). - 104 n., $106 \mathrm{n}$.,

I63, 164, 247, 329, 329 n., 363 n.

«teologias. -316

Thámara (Francisco). - 198

Tieck. - Io n., I22 t. y n.

tierra (inmovilidad de la). $-103 \mathrm{n}$.

Timoneda (Juan de). $-\mathbf{3 8 0}$ n., $381 \mathrm{n}$.

Tirante el Blanco. - 39

Tirso de Molina. - 65 n., 17 I n., 227 n.

254, 295.

Toffanin (G.). $-9,27,28,29$ n., $30 \mathrm{t}$

y n., 32 n., 35 n., 46 n.

de). $-99 \mathrm{n}$,

37 ก., 371 n., 389 ,

$391,392,394$. anzas. -257

Torres Naharro. -24 n., 290, 367

Troilo (E.). - 106 n., I63 n., 329

Turguenef. -10

urismo. - II4.

Unamuno (M. de). - I5, 12

universal poético. $-23,27$.

Valbuena (Ángel). $-282 \mathrm{n}$.

Valdés (J. de). -26 n., I97, 198, 200,

alencia (C.). -229.

Valera (Juan). - I3, I4.

Valla (Lorenzo) $-28,155,158 \mathrm{n} ., 159$

n., 177

Vanegas (Alejo). -26 n., 198 .

Varchi (Benedetto), -29, 16I n., $162 \mathrm{n}$ 389

vascuence. -229 .

elázquez. - 29 .

Velasco (A.). -212

venganza suprimida. -313 .

Vergara (J. de). -199

verosímil. - 36, 37, 39, 4I, 43 . Viejo (Luiso. - I3.

Vis 242

de). -127 n., 197 , I98, 390, 394, 395

(P.). -20 , 109 n., I27 n., I8 3 n.

Viñaza (Conde de la). $-198 \mathrm{n}$

Virgen (culto de la). -289 .

Virgilio. - 25, 32, 186

Virués (C. de). -22

(L.). -26 n., 30 n., 83, 88, 99 n II3, 211,363 n., 367 t. y n., 370

.

vizcainos. -229 .

vulgo y sabio. -210

Weisbach (Werner) $-246 \mathrm{n}, 26 \mathrm{I}$

Zanta (L.). -322 n., 324 n.

Zayas (Maria de). -359 .

winglio -278 
ÍNDICE GENERAL

INTRODUCCIÓN.............................

I. La ORIENTACIÓN LITERARIA..................... Is

Armonía y disonancia................... 20

Lo universal poético y lo particular histórico... 23

Lo verosímil.................... 36

Regulación literaria y racionalismo............ 46

II. Análisis del sujeto $x$ CRítica de La REalidad ......... 68

El punto de vista en los personajes........... 68

El putido critico.......

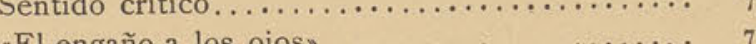

.El engaño a los ojos.......................... 79

Crítica de la realidad........................

Astrología y hechicería.................... 94

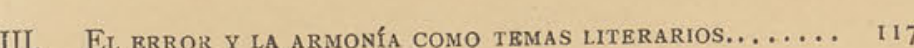

La doctrina del error..................... 117

La armonía y el acierto...................... 145

IV. La Naturaleza COMO PRINCIPIO Divino E INMANENTE, .... 156

$\begin{array}{ll}\mathrm{La} \text { edad de oro } \ldots \ldots \ldots \ldots \ldots \ldots \ldots \ldots \ldots \ldots \ldots \ldots & { }_{177}\end{array}$

Lo pastoril........................... ${ }_{187}$

Los refranes.......................... 190

La lengua vulgar....................... ${ }^{195}$

La justicia............................. 204

V. Otros temas ............................ 21

El vulgo y el sabio...................... 210

Las armas y las letras................... 213

Los españoles........................... 219

Lo picaresco ............................. 230

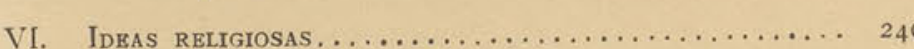

Contrarreforma........................ 244

Alarde de ortodoxia ................................. 244 
No conformismo .................... 26 Crítica humanista....................... 26 Tolerancia o intolerancia?........................ El cristianismo de Cervantes.............. 307

VII. La moral......................... 321

Los consejos a Sancho.................. 359 El honor............................ 36

VIII. Conclusión............................. ${ }_{3} 8_{4}$

Adiciones............................... ${ }^{28}$

Indice de autores y materiales citados........ 397

Adiciones hispanicas al Diccionario etimológico de W. Mever-Lübke, en Revista de Filologia Española, 1918 y 1919.

Unos aranceles de aduanas del siglo XIII (estudio lexicográfico), en Ibidem, 1921 a 1923.

Une charte léonnaise intéressante pour l'histoire des mours, en Bulletin Hispanique, 1923.

Disputa entre un cristiano y un judio, en Revista de Filologia Espa. ñola, 1914 .

Sobre «-tr-s $y$ «-dr-» en español, en Ibidem, 1920.

La pasiva refleja en español, en Hispania, de California, 1918 .

-Mozos e ajumadoss (etimología), en Revista de Filologia Española, 1914.

- Muchachos, en Ibidem, 1916.

"Boquirrubios, en Ibidem, 1916 y 1910.

"Hacer la salva", en Mélanges $A$. Thomas, 1926.

Algo sobre celtismo, en Revista de Libros, 1919.

Don Federico Hanssen, en Ibidem, 1919.

Fueros leoneses, tomo I (en colaboración con F. de Onís), Madrid, 1916 (Centro de Estudios Históricos).

Traducción anotada de la Introducción al estudio de la lingriuistica romance, de W. Meyer-Lübke, Madrid, 1914 (Centro de Estudios Históricos. Segunda edición en prensa).

Reseña de la Gramática histórica, de F. Hanssen, en Revista de Filo. logia Española, 1914.

La enseñanza del español en España, Madrid, V. Suárez, 1922.

Lengua, enseñanza y literatura, Madrid, V. Suárez, 1924.

El movimiento científico en la España actual, en La Rassegna, de Florencia, 1919 (reproducido en Hispania, de California, 1920, y en Spanien, de Hamburgo, con adiciones, 1920, Der Fortschritt der Wissenschaft im heutigen Spanien).

Observaciones acerca del concepto del honor en los siglos XVI y XVII, en Revista de Filologia Española, 1916.

Sobre el teatro clásico español, en Nosotros, de Buenos Aires, 1923 Don Juan en la literatura española (conferencia), Buenos Aires, Imprenta del fockey Club, 1924 . 
Alusiones a Micaela Lujain en las obras de Lope de Vega, en Revista de Filologia Espaĩola, 1918.

Una comedia de Lope de Vega condenada por la Inquisición, en Ibidem, 1922

El autógrafo de "La corona merecida", de Lope, en Ibidem, 1919. Datos para la vida de Lope de Vega, en Ibidem, 1918.

Vida de Lope de Vega, Madrid, Hernando, I 919 (en colaboración cón H. A. Rennert).

Obras mal atribuidas a Rojas Zorrilla, en Revista de Filologia Española,

"Cada qual lo que le toca» $y$ «La viña de Nabot», de Francisco de Rojas Zorrilla [dos obras inéditas, con un estudio de las ideas del autor en materia femenina], Tealro Antiguo Español, II, IgI7 (Centro de Estudios Históricos)

«El Vergonzoso en Palacio»y \&El Burlador de Sevilla», de Tirso de Molina [con un estudio sobre el teatro del siglo xvrn], Madrid, Clásicos Castellanos, 1022.

Les grands romantiques espagnols, París, La Renaissance du Livre,

Acerca de "El Diablo Mundo", de Espronceda, en Revista de Filología Española, 1920.

Reseña de la edición del Quijote por F. Rodríguez Marín, 1916, en Ibidem, 1917.

Cervantes pensador; en Revisla de Occidente, 192

fuan de Mal Lara y su "Filosofia vulgar", en Homenaje a Menéndez Pidal, 1925.

\section{EN PREPARACIÓN}

El judeocspañol de Marruecos (Centro de Estudios Históricos). 


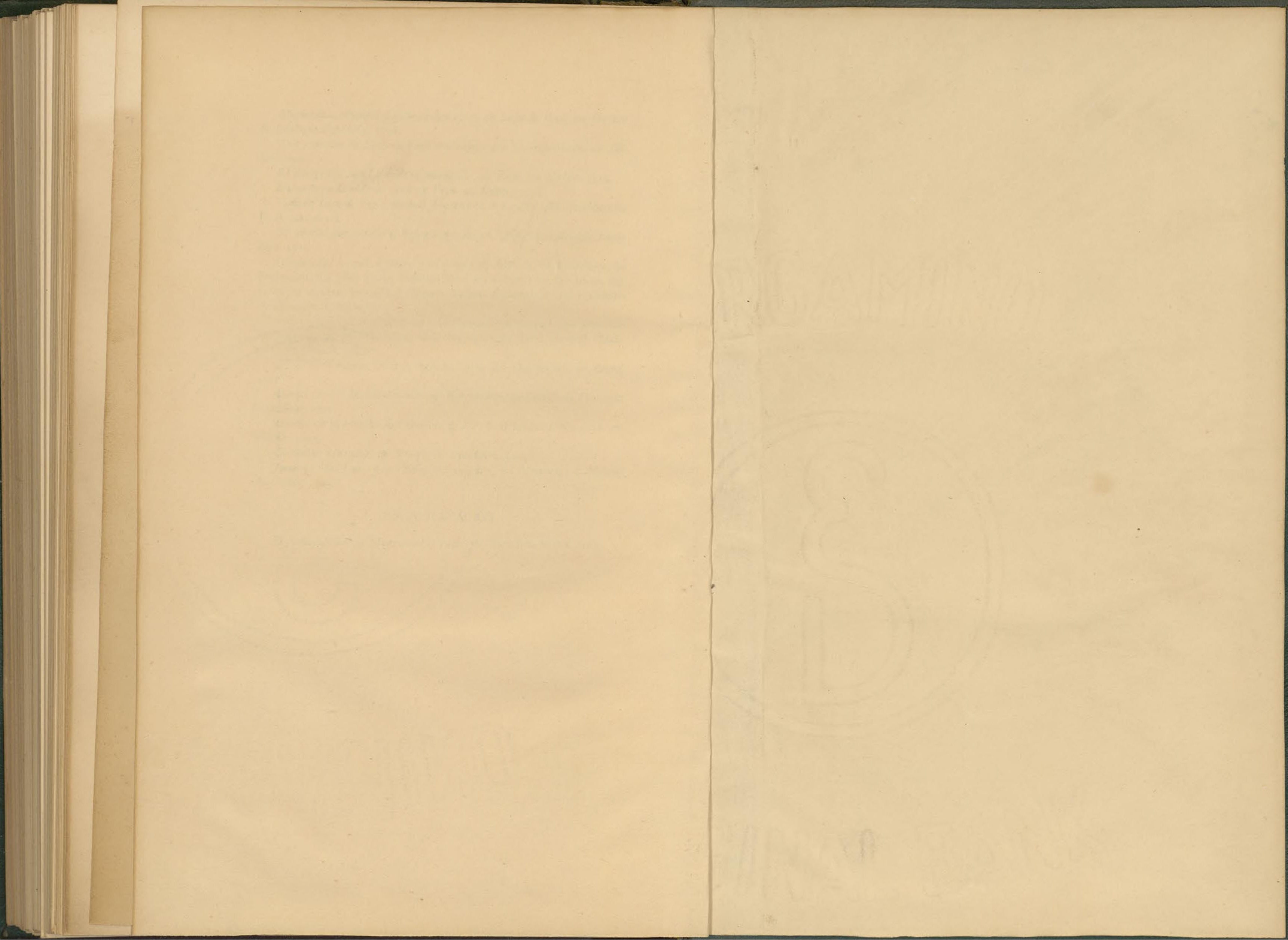




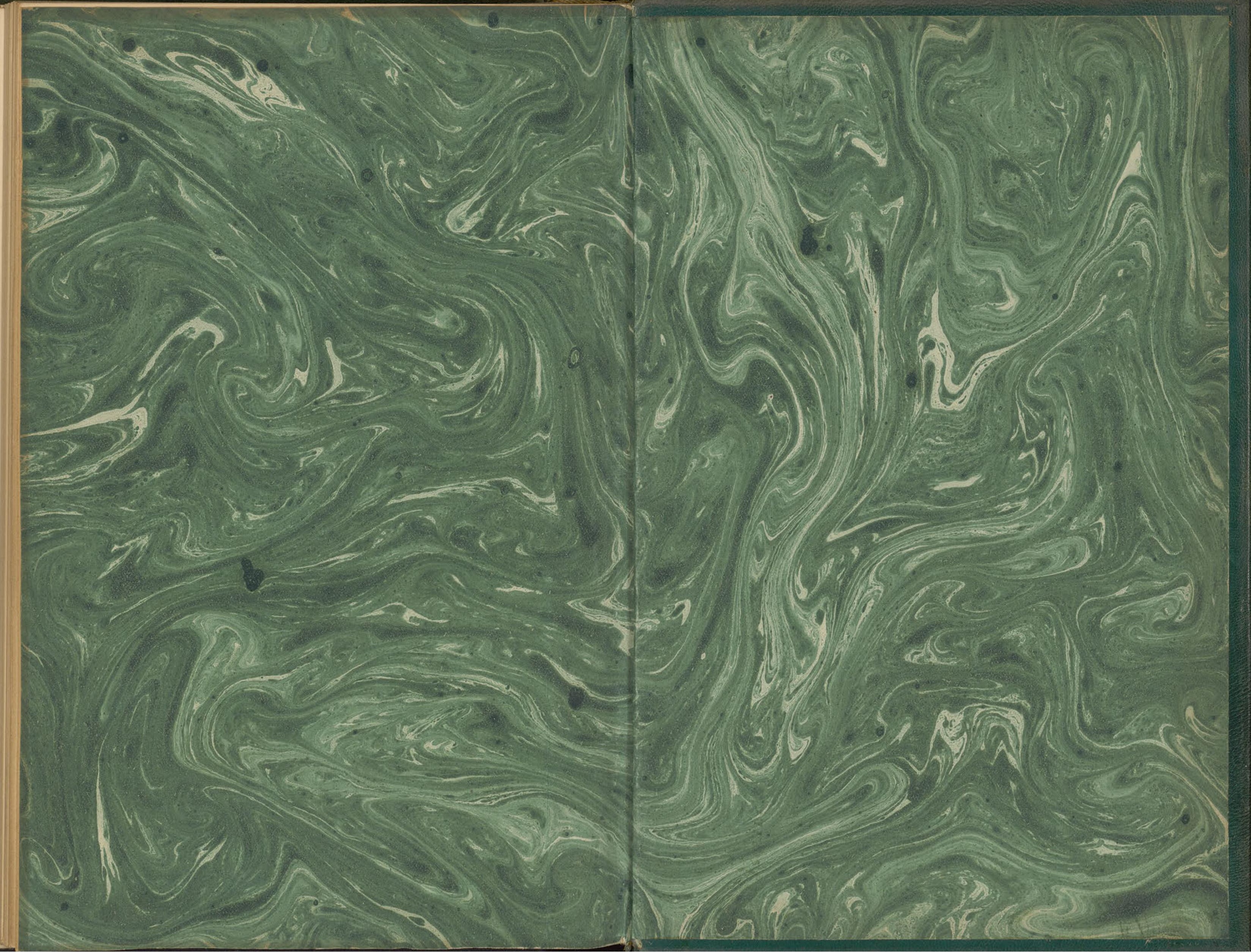

